DEPARTMENT OF THE INTERIOR

UNITED STATES GEOLOGICAL SURVEY

GHORGE OTIS SMITH, DIRECTOR

BULLetin 585

SHCLLED,

\title{
USEFUL MINERALS OF THE UNITED STATES
}

\author{
COMPILED BY \\ SAMUEL SANFORD \\ AND \\ RALPH W. STONE
}

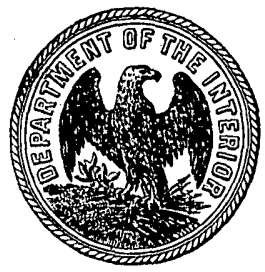

WASHINGTON

GOVERNMENT PRINTING OFFICE

1914 



\section{USEFUL MINERALS OF THE UNITED STATES.}

Compiled by Samuel Sanford and Ralph W. Stone.

\section{INTRODUCTION.}

By Edward W. Parker.

The final chapters of two of the earlier volumes of the Geological Survey's annual report entitled "Mineral Resources of the United States" (the volumes for 1882 and 1887) consist of lists of the useful minerals in the United States. No similar lists have been published by the Survey in the last quarter of a century. During that period, however, the mineral resources of the United States have been enormously developed, the value of the total production having increased from $\$ 500,000,000$ to over $\$ 2,000,000,000$, and the investigations made by the United States Geological Survey and the State geological surveys have added immensely to the knowledge of the natural resources of the country. It is therefore believed that the present publication is timely. It gives concisely the location, by States, of the principal deposits of useful minerals and includes a glossary showing the composition and character of each mineral and the location of its principal deposits.

Many changes other than increase in production have taken place during the last quarter of a century. Aluminum was not made in the United States in 1887, so that the deposits of bauxite, now the source of material that maintains a great industry, were untouched and were not included in the Survey's lists. Twenty-five years ago the imports of Portland cement were four times the domestic production, and the total quantity consumed was about $1,250,000$ barrels. The production of natural rock cement was five times the combined production and imports of Portland cement. To-day the Portland cement industry is distributed generally over the United States, and the production amounts to more than $80,000,000$ barrels. The production of natural rock cement and the imports of foreign cement are so small as to be negligible. These are only examples of notable changes in the mineral production of the United States and of correlated changes in the appraised value of some of the mineral deposits.

In this list, as in the earlier lists, it has not been deemed necessary to make the references very detailed. A general statement may give a clearer and more comprehensive view of the occurrences than 
a minute and specific enumeration of the known deposits; indeed, to state all the localities at which some minerals are found would make the lists too bulky for convenient reference, and they would be useful principally to the professional mineralogist rather than to the miner or manufacturer or the student of economic conditions. The principal localities at which most of the minerals are found are clearly indicated, but the more extensive deposits of some others, such as clay, coal, and iron ore, are mentioned only in general terms.

One material difference will be found between this list and the earlier lists. The form of the earlier lists was twofold, a separate group of items showing the substances "mined" and "not mined" in each State, whereas this list only indicates whether the deposits are, have been, or are not mined or worked. The material in this bulletin is in two distinct parts. In the first part, which consists of lists of the occurrence of minerals in each of the States, the State lists begin with Alabama and end with Wyoming. Under each State the minerals found there are given in alphabetic sequence. The second part is a glossary of more than 425 names. Each definition is followed by a list of the States in which the mineral occurs. It is therefore virtually an index to the first part. In connection with the localities given the reader may find it helpful to refer to Survey Bulletin 507, "The mining districts of the western United States," and to the chapter entitled "Mineral products of the United States" in the report Mineral Resources of the United States for 1912 or later years. Details of occurrence, development, utilization, and market conditions are given in the annual volumes of Mineral Resources of the United States and in the bulletins and other publications of the Survey.

The intention has been to present a list of localities at which minerals occur in sufficient quantity to be of present or possible future value, but the existing literature is very defective in statements of the quantities available at many localities. It may be, therefore, that at some of the localities listed the mineral occurs in quantities so small that it is of scientific interest only, or, if it was once abundant, it may have been completely exhausted by mining or quarrying. Deposits of minerals of wide distribution, such as quartz and calcite, have been omitted, except those that by some unusual feature, such as occurrence in fine crystals or in very pure form or in remarkably large quantity, are of especial interest or value. Some minerals, such as the copper ores of Pennsylvania, are included in the list not because they occur in sufficient quantity to warrant mining for their usual products but because they furnish excellent museum specimens. Some mineral aggregates, as clay, granite, limestone, sand, and sandstone, are included, because they constitute a very considerable part of the mineral production of the country. 
This list-does not contain discoveries or development later than January 1, 1913, excepting uranium ores. Any corrections of errors or any information concerning deposits not listed will be gratefully received by the authors and will be incorporated in a later edition of the list.

The list was first compiled by Samuel Sanford. Upon Mr. Sanford's transfer to the Bureau of Mines the work was put into the hands of Frank L. Hess, under whose supervision the final revision has been made by Ralph W. Stone. Acknowledgments are due to the following State geologists and others who have cooperated in compiling this list by revising the statements regarding their respective States:

Alabama........ Dr. Eugene A. Smith, University.

Arkansas..........Dr. A. H. Purdue, Nashville, Tenn.

California........Mr. William H. Storms, San Francisco.

Prof. A. F. Rogers, Stanford University, Palo Alto.

Colorado......... Prof. R. D. George, Boulder.

Connecticut. ..... Prof. William N. Rice, Middletown.

Prof. H. E. Gregory, Sheffield Scientific School, New Haven.

Delaware.........Prof. B. L. Miller, Lehigh University, South Bethlehem, Pa.

Florida............Dr. E. H. Sellards, Tallahassee.

Georgia..........Dr. S. W. McCallie, Atlanta.

Illinois............Mr. F. W. DeWolf, Urbana.

Indiana............. Edward Barrett, Indianapolis.

Iowa.............. Prof. George F. Kay, Iowa City.

Kansas............ Prof. Erasmus Haworth, University of Kansas, Lawrence.

Kentucky.........Mr. J. B. Hoeing, Frankfort.

Mr. J. H. Gardner, Lexington.

Louisiana.........Prof. Gilbert D. Harris, Baton Rouge.

Maine............. C. Vey Holman, Bangor.

Maryland.......... Prof. E. B. Mathews, Johns Hopkins University, Baltimore.

Michigan..........Mr. R. A. Smith, Lansing.

Dr. A. C. Lane, Tufts College, Mass.

Minnesota........ Prof. W. H. Emmons, University of Minnesota, Minneapolis.

Mississippi ....... Prof. E. N. Lowe, Jackson.

Missouri.........Dr. H. A. Buehler, Rolla.

Nebraska.........Prof. E. H. Barbour, University of Nebraska, Lincoln.

Nevada........... Dr. W. S. Tangier Smith, Berkeley, Cal.

New Jersey........Dr. H. B. Kümmel, Trenton.

New York.........Mr. D. H. Newland, State Museum, Albany.

North Carolina. . . Dr. Joseph Hyde Pratt, Chapel Hill.

North Dakota. ... . Dr. A. G. Leonard, Grand Forks.

Ohio........... Prof. John A. Bownocker, Columbus.

Prof. G. D. Hubbard, Oberlin College, Oberli)

Oklahoma........ Prof. D. W. Ohern, Norman.

Oregon.............Prof. A. J. Collier, Eugene.

Pennsylvania......Mr. R. R. Hice, Beaver.

Prof. Florence Bascom, Bryn Mawr.

Rhode Island.... . Prof. Charles W. Brown, Providence.

South Carolina. . . Dr. Earle Sloan, Charleston.

South Dakota. . . .Prof. E. C. Perisho, Vermilion. 
Tennessee.........Mr. George H. Ashley, Washington, D. C.

Texas...........Dr. William B. Phillips, Austin.

Vermont...........Prof. George H. Perkins, Burlington.

Virginia...........Dr. Thomas L. Watson, Charlottesville.

Washington........Prof. Henry Landes, Seattle.

West Virginia.... Dr. I. C. White, Morgantown.

Wisconsin..........Prof. W. O. Hotchkiss, Madison.

Wyoming..........Mr. C. E. Jamison, Cheyenne.

Those members of the United States Geological Survey who have assisted in the compilation are Adolph Knopf, D. B. Sterrett, J. B. Umpleby, E. L. Jones, jr., G. S. Rogers, H. G. Ferguson, and G. F. Loughlin.

Mr. Stone acknowledges his great indebtedness to Frank L. Hess for his cordial and efficient cooperation in bringing the work to its present form, and to all other members of the United States Geological Survey who have assisted in any way in its compilation.

\section{ATABAMA.}

Aluminum. See Bauxite and Halloysite.

Asbestos. Tallapoosa County, with corundum deposits near Dudleyville; not found in commercial quantity or quality.

Asphalt. Colbert County, small quantity has been shipped from near Leighton; has been obtained also from Russellville and Moulton valleys.

Barite (heavy spar). Very pure and white in residual clays at following localities: Bibb County, Pratts Ferry; Calhoun County, near Tampa; Clay County, T. 20, R. 7 E.; Jefferson County, at Elyton; Lee County, at Chewacla lime works; St. Clair County, at Greensport; Shelby County, near Whiting Station and Calera; Talladega County, in several places.

Bauxite. Cherokee County, mined near Rock Run; known also in Dekalb County, and occurring southward along narrow belt from Georgia State line near Rock Run to Jacksonville, Calhoun County.

Beryl. Coosa County, crystals suitable for gems have been found near Rockford.

Brown iron ore. See Limonite.

Cemert material (Portland). Portland cement manufactured near Demopolis, Leeds, Ragland, and St. Stephens. Mississippian and Pennsylvanian shales and residual clays, Ordovician and Mississippian limestones abundant in northern Alabama; Cretaceous and Tertiary limestones in southern Alabama.

Chalcopyrite (copper pyrites). Clay County, with pyrite in T. 21, R. 6 E., and near Ashland. Cleburne County, with pyrite in mica schist at Wood's mines and Smith's mines. Tallapoosa County, in T. 23, R. 22 E. Occurs at many localities in Clay, Coosa, Randolph, and Talladega counties and has been mined at some places.

Chalk. Soft, argillaceous, quarried in Dallas County, at Selma; Breene County, at Eutaw; Marengo County, at Demopolis; Sumter County, at Epes; and other localities.

Chert. Calhoun County, at Anniston and Jacksonville. Jefferson County, extensive quarries near Birmingham and Bessemer. Talladega County, several quarries.

Clay (brick). Pits at one or more places in 38 counties. Value of product reported in 1911, $\$ 708,903$.

Clay (china). Cherokee County, suitable material not worked, occurs as soft white clay atRock Run. Colbert County, good white ware clay at Pegram. Dekalb County, white, fine sandy at Fort Payne; pits working in pure white clay at Eureka 
mine 4 miles northeast of Valley Head. Etowah County, white, good ball clay at Gadsden. Marion County, white, fine grained at Chalk Bluff; hard, porous, gritty, adapted to highest grade ware at Pearces Mills. Talladega County, hard, white, micaceous clay, suitable for white tile or earthenware at Kymulga.

Clay (fire). Mined at the following places: Bibb County, at Ashby, Bibbville, and Woodstock. Blount County, at Lehigh, burns buff. Calhoun County, coarse, sandy near Anniston and at Oxanna. Colbert County, black, gritty, burning white at Pegram. Dekalb County, coarse, sandy at Kaolin and Valley Head. Iefferson County, at Littleton, Mabel and Hoagland mines. Marion County, white at Pearces Mills. Russell County, at Girard. Tuscaloosa County, at Hulls Station.

Clay (flint). Abundant in many localities in Choctaw, Clarke, Conecuh, Monroe, and Washington counties.

Clay (porcelain). Dekalb County, dug near Valley Head, hard, white, close to halloysite, used for chinaware.

Clay (pottery). Autauga County, at Edgewood, smooth, plastic, and sandy. Barbour County, was formerly mined for red crockery at Mineral Springs. Cherokee County, occurs at Rock Run. Elmore County, at McLean pottery, burns bluish. Marion County, at Chalk Bluff, reddish, fine grained, and burns red. Pickens County, occurs at Roberts Mill.

Coal (bituminous). Three fields: Cahaba, Coosa, and Warrior; coals all of Pottsville age.

Cahaba field.-Bibb, Shelby, St. Clair, and Jefferson counties, about 290 square miles, 40 coal beds, half workable, some only locally; mined at Acton, Aldrich, Blocton, Coalmont, Garnsey, Glen Carbon, Hargrove, Henryellen, Margaret, Marvel, Maylene, Piper, Sanie, and elsewhere; excellent domestic and steam coals.

Warrior field.-Jefferson, Tuscaloosa, and Walker counties, and southern end of Blount County, 7,800 square miles. Four groups of beds-Black Creek, Brookwood, Mary Lee, and Pratt coal groups. Black Creek coal group mined at Bradford, Coaldale, Empire, Indio, Kimberly, Seloca, Warrior, Wigan, and elsewhere. Brookwood coal group mined at Brookwood, Kellerman, and Searles. Mary Lee coal group mined at Abernant, Adger, Bessie, Davis Creek, Johns, Lewisburg, Littleton, Mulga, Newcastle, Sayre, Sayreton, Sumter, and Yolande, extensively throughout Walker County. Pratt coal group mined at Pratt mines west of Birmingham, Blossburg, Brookside, Cardiff, and Mineral Springs.

Coosa field.-Shelby and St. Clair counties, about 300 square miles; 20 beds; mostly of small area; mined at Coal City and Ragland.

Coal (lignite). Brown coal, wood coal. Occurs in Tertiary of southern and southwestern parts of State at Horse Creek, and at many places eastward in Barbour, Choctaw, Clarke, Marengo, Monroe, Pike, Wilcox, and other counties. Also in Cretaceous, mostly as lignitized trunks, in Greene, Pickens, and other counties. Some of the Tertiary lignites have recently been tested, with satisfactory results, in the clarifying of sugar, and also at the University of Alabama, in gas producer and gas engine.

Copper. Along eastern flank of Talladega Mountain from Chilton County to Georgia State line, small production. See Chalcopyrite, Covellite, and Melaconite.

Corundum (emery). Found in various places in gold region, including Coosa County, near Mount Olive and Hanover; Tallapoosa County, near Alexander City and Dudleyville. No deposits of commercial value.

Covellite (indigo copper). Clay County, small quantities with pyrite in sec. 24, T. 19, R. 7 E.

Dolomite. See Marble. 
Feldspar. Coosa County, mined at Hissop.

Flagstone. Yellow sandstones of Red Mountain, Bucksville to Georgia State line; sandstones of Pennsylvanian series ("Coal Measures") at Plank Shoals on North River. Thin bedded limestone in Mississippian and Ordovician rocks. Gneisses and mica schists of metamorphic region. Quarries at Tallassee Falls in Elmore County.

Galena. Calhoun County, occurs 5 miles west of Jacksonville, was worked during Civil War; Madison County, near New Market; Marshall County, near Guntersville.

Gold. In metamorphic rocks, Chilton, Clay, Cleburne, Coosa, Elmore, Randolph, Talladega, and Tallapoosa counties; for most part, free milling and associated with limonite, resulting from oxidation of pyrite; below water level both free and with pyrite. Chilton County, Blue and Rock creeks. ' Clay County, Idaho district. Cleburne County, Arbacoochee, Chulafinnee, Kemp Mountain. Coosa County, Rockford and Parsons mines. Elmore County, on Peru Branch. Randolph County, Goldberg, Pinetucky district. Talladega County, near Waldo. Tallapoosa County, Goldville, Hog Mountain district, Silver Hill; cyanide plant at Hog Mountain. Placer mining in Clay, Cleburne, Randolph, and Talladega counties.

Granite. Not much quarried, but occurs in great quantities in Chambers, Chilton, Clay, Cleburne, Coosa, Elmore, Lee, Randolph, and Tallapoosa counties. Quarried in Coosa County about Rockford, and in Randolph County at Wedowee. Thick bedded gneisses quarried in Chambers County at Milltown; Coosa County, Bradford, and Rockford; Lee County, Auburn; Macon County, Notasulga; Randolph County, Blakes Ferry; Tallapoosa County, Tallassee.

Graphite (plumbago). Chilton County, flake graphite mined along Mountain Creek. Clay County, at Ashland, Quenelda, and Stockdale. Coosa County, near Rockford and Goodwater. Randolph County, was formerly mined at Christiana. Tallapoosa County, at Blue Hill and Gregory Hill.

Gypsum. Choctaw, Clarke, and Dallas counties, found in small quantities; not of commercial importance.

Halite. See Salt.

Halloysite. Dekalb County, mined at Sulphur Springs for pottery. Jackson County, found near Stevenson. Shelby County, near Calera.

Hematite (Clinton, dyestone, fossil, oolitic, red iron ore). Most important iron ore of State; 1 to 5 beds. Greatest mining district, Jefferson County between Bessemer and Birmingham; also mined in Blount County at Village Springs; Cherokee County, Gaylesville and Round Mountain; Dekalb County, Fort Payne and Valley Head; Etowah County, Attalla and Gadsden; St. Clair County, Springville. Has been mined formerly in Shelby County at Columbiana, and in Tuscaloosa County south and east of Dudley; occurs also in Bibb, Clay, Coosa, Jackson, Marshall, Talladega, and Tallapoosa counties, and in other places.

Hematite (gray iron ore). Talladega County, with variable proportions of magnetite in narrow belt; mined at Emauhee and Mesabi, ore of two types, quartzitic and slaty.

Iron. See Hematite, Limonite, Magnetite, Pyrite, Pyrrhotite.

Infusorial earth (tripolite). At many localities in recent and Tertiary formations, including swamp deposits near Mobile and at Montgomery.

Kaolin. In weathered portion of coarse-grained granite veins in Piedmont Province from alteration of feldspar. In Calhoun County, near Jacksonvi'le. Coosa County, at Socopatoy. Randolph County, Louisa. Also found in Chilton, Cleburne, Clay, Elmore, Lee, Macon, and Tallapoosa counties.

Lead. See Galena. 
Limestone (building stone). Quarried in Blount County, near Blount Springs and Bangor; Calhoun County, at Anniston; Franklin County, at Rockwood. Used in construction of locks on Tennessee River, and at Greenport and other sites on Coosa River. Quarried also in Etowah County at Lagarde, and in Bibb, Colbert, Dekalb, Jefferson, Marshall, Shelby, St. Clair, and Talladega counties.

Limestone (crushed stone). Quarried for macadam, riprap, in Blount County at Chepultepec; Clarke County, Coffeeville; Etowah County, Lagarde; Franklin County, Rockwood and Darlington; Jackson County, Bridgeport; Jefferson County, Gate City; Madison County, Huntsville; Morgan County, Guntersville; Tuscaloosa County, Dowdle between Vance and Bibbville; Washington County, St. Stephens.

Limestone (lime). Quarried and burned in Blount County near Chepultepec; Calhoun County, Anniston; Colbert County, Dennis kilns; Dekalb County, Fort Payne; Etowah County, Rock Springs; Jackson County, Bridgeport; Lee County, Chewacla kilns; Morgan County, New Decatur; Shelby County, about Calera, Keystone, Longview, Newala, Saginaw, and elsewhere; Tuscaloosa County, Dowdle between Vance and Bibbville. See also Chalk, Flagstone, Flux, and Lithographic stone.

Limonite. Mined in Bibb and Tuscaloosa counties near Woodstock; Blount County, near Champion; Calhoun County, near Anniston, Jacksonville, Piedmont; Cherokee County, Baker Hill, Bluffton, Langdon City; Franklin County, Russellville; Jefferson County, Birmingham district. Principal ore used in Colbert, Lamar, and Marion counties. Occurs also in Clay, Cleburne, Coosa, and other counties, as gossan of pyritiferous ore; also in concretionary masses.

Lithographic stone. Jackson County, quarried on small scale.

Magnetite (gray iron ore). Chambers County, occurs with hematite near Fredonia and Oak Bowery; Clay County, near Kennedys and Millerville; Coosa County, T. 24, R. 20 E.; Randolph County, Wedowee; Talladega County, Ogdens Mill, Pope Mountain, Mesabi, and Emauhee.

Manganese ore. Manganiferous limonite mined in Bibb County at Woodstock; Calhoun County, near Anniston. See also Manganite, Psilomelane, and Pyrolusite.

Manganite. Blount and Etowah counties, occurs in Murphrees Valley; Cherokee County, near Piedmont; Cleburne County, in residual clays near Borden Springs.

Marble (crystalline). Crystalline or statuary along west border of metamorphic rocks from northwest part of Coosa County, through Talladega County into Calhoun County, one-fourth mile wide, 60 miles long; Talladega County, best stone; pure white and white clouded marble near Sylacauga and at Carrara near Talladega. Crystalline dolomite found along east foot of Talladega Mountain range in Chilton and Coosa counties; in Clay County, near Elder post office; and in Lee County at Chewacla quarry, near Opelika.

Marble (noncrystalline). Variegated marble has been quarried in Shelby County, southeast of Calera; in Bibb County, near Pratt Ferry. Marble has been taken also in Colbert County at Dickinson, and in Shelby County, south of Shelby

1 Springs. It occurs also in Franklin, Lauderdale, Lawrence, Madison, and other counties in the northern part of the State. Quarried near Birmingham for flux.

Marl (greensand). Occurs in Autauga, Barbour, Bullock, Butler, Choctaw, Clarke, Coffee, Conecuh, Crenshaw, Elmore, Greene, Hale, Macon, Marengo, Monroe, Perry, Pickens, Pike, Russell, and Wilcox counties.

Marl (shell). Occurs in Butler, Clarke, and Monroe counties.

Melaconite (black copper, black oxide of copper). Cleburne County, was mined with other copper ores at Woods' copper mine.

Mica. See Muscovite. 
Millstone. Madison County, "Millstone grit" of the Pennsylvanian series ("Coal Measures") quarried for millstones at many points on sides of anticlinal valleys, as near Huntsville; Marion County, ferruginous conglomerate (probably from Lafayette formation) quarried and used; Butler, Choctaw, Clarke, Crenshaw, Monroe, Pike, and Wilcox counties, as buhrstone.

Mineral paint. See Barite and Ocher.

Muscovite. Chilton County, mined in T. 22, R. 16; Clay County, in T. 20, R. 6, and near Bowden; Cleburne County, prospected near Micaville; Randolph County, mined in Wedowee, and prospected at Pinetucky mine.

Natural gas. Occurs in scattering wells in Franklin County, at Russellville; Madison County, at Huntersville and Hazelgreen; Walker County, Jasper; Winston County, Haleyville. Largest well in State at Fayette, Fayette County; yielded 4,500,000 cubic feet a day. Natural gas also issues in small quantities from many salt wells in Baldwin, Clarke, Mobile, and Washington counties.

Niter. Obtained in limestone caves, principally in Tennessee River valley, during Civil War, for making gunpowder.

Ocher. Red ocher mined in Etowah County, at Attalla, and found at many other places. Yellow ocher, mined in Autauga County, and in Elmore County, at Coosada station; found also in Fayette, Marion, and Tuscaloosa counties.

Petroleum. Show of oil in wells in northwestern part of State, but no producing wells.

Phosphate rock. Dark and light rock phosphate extends several miles into State from Tennessee along Elk River; in Limestone County, small quantity mined 1 mile west of Veto. Phosphatic greensand, with phosphate nodules, at base of Selma chalk, through or near Eutaw, Greensboro, Hamburg, Marion, Montgomery, Prattville, and Selma.

Potash. See Marl and Niter.

Psilomelane (black manganese). Found in several localities in Bibb, Blount, Calhoun, Cherokee, Cleburne, and Tuscaloosa counties.

Pyrite. Clay County, formerly mined and shipped from near Pyriton for sulphuric acid. Randolph County, small quantity at Pinetucky mine, carries gold, and at other gold mines. Occurs with copper ores also in Clay County, and in Cleburne County at Smith's and Wood's copper mines; in Limestone County, abundant at Elkmont.

Pyrolusite (manganese dioxide). Occurs in Blount and Etowah counties, in Murphrees Valley; in Bibb and Tuscaloosa counties; in Cherokee County, north and northwest of Piedmont, and in Cleburne County, in residual clays near Borden.

Pyrrhotite. Cleburne County, was mined at Wood's copper mine near Stonehill; Talapoosa County (auriferous), at Hog Mountain.

Quartz. Friable quartz rock in Chambers, Chilton, Lee, Macon, Randolph, Tallapoosa, and other counties. Fine silica from cherty limestone in Tennessee Valley, may be suited for glass sand; not used.

Quartz (sand). Monroe County, near Claiborne.

Road metal. See Chert and Limestone.

Salt. Made from waters of salt wells in Clarke and Washington counties during Civil War.

Sand (building). Dug in Calhoun County, at Anniston; Clarke County, Jackson; Dallas County, Plantersville; Elmore County, Coosada, Grandview, and Jones; Escambia County, Pollard; Etowah County, Alabama City and Gadsden; Jefferson County, Irondale and Truesville; Montgomery County, Montgomery.

Sand (glass). Glass sand from crushed sandstone in Jefferson County, at Gate City, carries 99 per cent $\mathrm{SiO}_{2}$; also in Etowah County, at Gadsden. 
Sand (molding). Dug in Clarke County, at Jackson; Elmore County, at Coosada, Grandview, and Jones; Etowah County, at Alabama City and Gadsden; Jefferson County, at Truesville; St. Clair County, at Cooks Springs.

Sandstone. Quarries: Calhoun County, at Anniston; Colbert County, Cherokee; Cullman County, Cullman; Tuscaloosa County, Tuscaloosa; Walker County, Jasper, and elsewhere. Fayette County, rough stone; Jefferson County, flagstone of Clinton formation used at Birmingham.

Shale. For jetties and ballast, quarried $2 \frac{1}{2}$ miles east of Berry and at Ledule. Quarried for making brick in Blount County, at Lehigh; Jefferson County, at Alton, Coaldale, Graves, Lovick, and Shale; Marion County, at Bexar, Glen Allen, and Pearces Mills.

Sienna. Cherokee County, found at Oxford.

Silver. Recovered in refining gold in three deep mines and three placers.

Slate. Promising beds of slate occur in Calhoun County, near Anniston; in Clay County, T. 19, R. 7; in Shelby County, at Buxahatchee Creek; in Talladega County, T. 21, R. 3; also in Chilton, Cleburne, and Coosa counties. Not worked anywhere since the Civil War.

Soapstone. Greenish schistose rock mined in Chambers County, at Oak Bowery for lining kilns, near Dudleyville for hearth stones, T. 22, R. 25, for headstones. Old excavations in Coosa, Lee, and Tallapoosa counties.

Sphalerite (zinc blende). Cleburne County, near Wood's copper mine.

Sulphur. See Pyrite and Pyrrhotite.

Tripoli (rotten stone). Largest deposits in Calhoun, Lauderdale, and Talladega counties. Shipments have been made from Talladega County.

Tripolite. See Infusorial earth.

Wavellite. St. Clair County, important deposits 5 miles northeast of Coal City, on Coosa River, undeveloped.

Zinc. See Sphalerite.

\section{ARIZONA.}

Alabaster. Occurs in Superstition Mountains; near Pueblo Viego; near Sulphur Springs; in La Gila Range, and elsewhere.

Andradite. See Garnet.

Anglesite (sulphate of lead). Gila County, at Lost Gulch mine, near Globe; Mohave County, in Mineral Park; Pima County, in Mammoth mine, Schulz; Yavapai County, in ores of Bradshaw Mountains; common in silver veins.

Antimony ores. See Jamesonite and Stibnite.

Argentite (silver glance). Mohave County, in pre-Cambrian granite gneiss in Chloride, Mineral Park, and Stockton Hill districts. Pinal County, at Silver King; Santa Cruz County, at Montezuma and Empress of India mines, Tyndall district; Yavapai County, in ores of Bradshaw Mountains.

Arsenopyrite (mispickel, arsenical pyrite). Mohave County, in pre-Cambrian granite gneiss in Chloride and Mineral Park districts; Minnesota-Connor, Windy Point, and Queen Bee mines; carries gold and silver; not mined for arsenic. Yavapai County, in veins of Bradshaw Mountains; carries gold and some silver at McCabe mine.

Asbestos (chrysotile). Coconino County, associated with serpentine in limestone at Grand View and Bass Camp, Grand Canyon. Gila County, fine specimen found on Ash Creek, 35 miles northeast of Globe.

Azurite. Cochise County, was abundant at Copper Queen mine, Bisbee district. The finest specimens of azurite in many museums have come from this mine. Gila and Pinal counties, rare in Globe district. Greenlee County, large masses in Longfellow, Manganese Blue, and Shannon mines. Yavapai County, in ores of Bradshaw Mountains. 
Azurmalachite. Cochise County, blue azurite and green malachite, an ornamental stone in copper mines of Bisbee district. Mohave County, as impregnation of porphyry at John Kay mine, Mineral Park.

Bismuth. See Tetradymite.

Bornite (peacock ore). Cochise County, small quantity in quartz veins in Whetstone Mountains. Mohave County, at Altata and Pinkham mines, Chloride district. Pima County, occasional in Mammoth mine. Pinal County, in Silver King mine. Santa Cruz County, small quantity at Line Boy prospect, near Duquesne. Yavapai County, common in copper veins; in ores of Bradshaw Mountains carries free gold.

Brochantite. Cochise County, small quantities often associated with malachite in Bisbee district; also with cuprite in Copper Queen and in Calumet and Arizona mines. Greenlee County, common with malachite in Clifton-Morenci district; mined at Shannon, Metcalf, Copper Mountain, and Montezuma mines. Yavapai County, United Verde mine, Jerome.

Brongniardite. Associated with other argentiferous ores.

Brown iron ore. See Limonite.

Carnotite. Navajo Reservation.

Cement material. Occurs in many places, as at Flagstaff, and near Phoenix. Utilized at Roosevelt Dam.

Celestite. Maricopa County, occurs at Gila Bend.

Cerargyrite (horn silver, chloride of silver). Mohave County, in pre-Cambrian granite gneiss in Chloride, Cerbat, and Stockton Hill districts; mined at Distaff mine, Chloride district. Yavapai County, Bradshaw Mountains district; common in silver veins.

Cerusite (lead carbonate). Cochise County, impure sandy form in Hendricks Gulch, Bisbee district. Greenlee County, mined for gold values at Hormeyer mine, Morenci. Mohave County, in Mineral Park district; Tyler mine. Pima County, in Greaterville placer deposits; silver and gold values. Pinal County, Haley claims, $2 \frac{1}{2}$ miles east of Ray. Santa Cruz County, Morning and Flux mines.

Chalcanthite (bluestone). Greenlee County, small quantities mined at Copper Mountain, Clifton-Morenci district. Yavapai County, considerable quantity formerly in United Verde mine, Jerome district.

Chalcedony. Greenlee County, in limestone in Clifton-Morenci district; also loose on Shannon Mountain. Mohave County, gray, white, and purplish on western slope of River Range, and other localities. Santa Cruz County, Grosvenor Hills. See also Chrysoprase.

Chalcocite (copper glance). Common below oxidized zone in most copper mines of the State. Cochise County, formerly most important sulphide near Bisbee; in Copper Queen, Calumet, Arizona, and other mines, but chalcopyrite has succeeded it at greater depth; abundant in massive form in Shattuck mine, Bisbee. Gila and Pinal counties, the essential constituent of the disseminated ores in schist and porphyry at Ray and Miami; in the Old Dominion mine, near Globe; with bornite forms rich ore of Queen mine at Superior. Greenlee County, principal copper mineral in Clifton district; in Ryerson and other mines. Mohave County, in Chloride district. Pima County, occurs in Cobriza mine, Cababi district. Yavapai County, in copper-silver veins of Bradshaw Mountains. Yuma County, in prospects at Cinnabar, 8 miles southwest of Quartzsite.

Chalcopyrite (copper pyrites). Found in nearly all of the copper mines of the State. Cochise County, in massive form in Bisbee district; mined at Copper Queen, Calumet, Arizona, and other mines. Gila and Pinal counties, abundant with specularite in Gibson mine as vein in schist, Globe district. With pyrite 
in veinlets and in disseminated form in so-called "primary ore" of mines at Miami and Ray. Greenlee County, small proportion in copper ore bodies in Clifton-Morenci district. Mohave County, primary ore of Chloride district, in Pay Roll and Redemption mines; primary ore, Mineral Park district, in Keystone, Windy Point, and other mines; Cerbat district, in Cerbat and Alpha mines; Stockton Hill district, in Banner Group and Treasure Hill mines; Helvetia and Silver Bell districts. Pima County, important copper ore at Old Boot, Leader, and Ridley mines; occurs also in quartz veins at McCleary prospects, 10 miles south-southwest of Helvetia. Santa Cruz County, in Tyndall district at American Boy mine. Yavapai County, in ores of Bradshaw Mountains and United Verde mine, Jerome district; auriferous and argentiferous.

'Chrysocolla (silicate of copper). Cochise County, Bisbee district, Calumet and Arizona mines, 3 miles north of Dragoon; not abundant. Coconino County, in sandstone of White Mesa of Navajo Indian Reservation. Gila and Pinal counties, formerly a more important ore than at present; in Globe district, abundant in Live Oak, Keystone, Black Warrior, Geneva, and Black Copper mines. Graham County, common, but not important, in Clifton-Morenci district. Yavapai County, in Bradshaw Mountains district, common in outcrops of copper veins; not important.

Chrysolite. See Olivine.

Chrysoprase (blue-green chalcedony). Gila County, "blue chrysoprase," copperstained chalcedony at Live Oak and Keystone mines, near Miami. Mohave County, true chrysoprase on west slope of River Range.

Chrysotile. See Asbestos.

Cinnabar. Gila County, reported at Rye. Yavapai County, reported at Skull Valley. Yuma County, sparsely distributed in veins at Cinnabar, 14 miles from Ehrenberg; has been mined on small scale.

Clay (brick). Cochise County, clay made into common and front brick at Benson, Douglas, and Naco; Coconino County, at Williams and Flagstaff; Maricopa County, at Alhambra and Tampa. Navajo County, small quantity dug at Snowflake; Pima County, at Tucson; Pinal County, at Florence; Santa Cruz County, at Nogales; Yavapai County, at Mayer and near Prescott.

Clay (china). See Kaolin.

Clay (fire, graphitic). Cochise County, mined in Whetstone Mountains, near Benson; burns white; used for lining converters; used also for manufacture of pressed brick.

Coal (bituminous). Pinal County, Deer Creek field, at the eastern end of the county, 35 miles southeast of Globe, and east of Winkelman; area 30 square miles; two workable beds, 24 to 30 inches; block, coking.

Coal (subbituminous). Apache, Coconino, and Navajo counties, Black Mesa field, in Moqui and Navajo Indian reservations; area approximately 5,920 square miles; coal in two main groups of beds, appears to be in thin benches alternating with layers of shale and bone.

Copper (native). Cochise County, Bisbee district, with cuprite in Calumet \& Arizona, Copper Queen, and other mines. Gila and Pinal counties, Globe district, in quartzite, Old Dominion mine. Greenlee County, with other copper ores in Metcalf mines, Clifton-Morenci district, not important. Yavapai County, in ores of Bradshaw Mountains district; not important.

Copper minerals. Ores of copper are of chief importance in the following districts: Cochise County, Courtland, Dragoon, Huachuca, Johnson, and Warren (Bisbee); Coconino County, Francis, Grand Canyon, and Jacobs Lake; Gila County, Black Warrior, Christmas, Globe, Lost Gulch, Miami, and Pinto Creek; Graham and Greenlee counties, Bunker Hill, Clark, Greenlee (Metcalf), Morenci, and 
Lone Star; Maricopa County, San Domingo; Mohave County, Bentley and Hualpai; Pima County, Ajo, Amole, Helvetia, Old Baldy, Pima, Rincon, Santa Rosa, and Silver Bell; Pinal County, Bunker Hill, Mineral Creek, Mineral Hill, Pioneer, and Vekol; Santa Cruz County, Patagonia and Washington; Yavapai County, Agua Fria, Black Hills, Copper Basin, and White Picacho; Yuma County, Harcuvar, Planet, Plomosa, Swansea, and Vicksburg. See Azurite, Azurmalachite, Bornite, Bournonite, Brochantite, Chalcanthite, Chalcocite, Chalcopyrite, Chrysocolla, Covellite, Cuprite, Malachite, Melaconite, Stromeyrite, Tenorite, and Tetrahedrite.

Coronadite (manganite of lead). Greenlee County, Clifton-Morenci district, fairly abundant near Coronada vein, three-quarters of a mile west of Horseshoe; stated to contain some gold; has been mined.

Covellite (indigo copper, blue copper). Greenlee County, rare in Clifton-Morenci district; in Ryerson and Montezuma mines.

Crocoite (chromate of lead, red lead). Maricopa County, in some of the mines of the Vulture district; occasionally met with in other lead ores.

Cuprite (red oxide of copper). Cochise County, abundant and important ore of Bisbee district; in Calumet, Arizona, and Copper Queen mines. Gila and Pinal counties, in Continental and Buffalo mines, Globe district; Greenlee County, in Clifton; Morenci, and Metcalf mines; Yavapai County, Bradshaw Mountains district; not important.

Descloizite (vanadate of lead). Cochise County, Lucky Cuss mine, Tombstone, Castle Dome district; Mammoth mine in Catalina Mountains, and Old Yuma mine in Tucson Mountains. Pinal County, Dripping Spring Range, 4 miles east of Kelvin, with vanadinite and wulfenite.

Dufrenoysite (arsenical lead ore). Mohave County, associated with other ores of lead, zinc, and silver; mined when argentiferous; Mineral Park.

Dyscrasite (antimonide of silver). Associated with other ores of lead and silver.

Embolite (chlorobromide of silver). Cochise County, especially abundant in Pearce district; occasionally found with other silver ores.

Fluorspar (fluorite). Cochise County, small quantity in quartz veins, 4 miles north of Dragoon; has been mined. Mohave County, gangue mineral of Black Mountain. Yavapai County, gangue mineral of Bradshaw Mountains district.

Freieslebenite (antimonial sulphide of silver). Yuma County, mined at Castle Dome; small quantities shipped. With other argentiferous ores.

Gadolinite. Mohave County, in pegmatite 20 miles south of Hackberry.

Galena. Invariably argentiferous and sometimes slightly auriferous. Gila and Pinal counties, sparingly in Globe and Ray districts; Greenlee County, in Metcalf ores of Clifton-Morenci district, gold bearing (?) in Copper King mine, carries considerable silver in Stevens group. Mohave County, Chloride district; mined at Tennessee, Elkhart, Hercules, and other mines; principal ore of Mineral Park district; mined at Tyler; Lady Bug, and Queen Bee mines; Cerbat district, Idaho and Alexander mines; Stockton Hill district. Pima County, Mammoth mine, argentiferous; Ridley mine, near Helvetia. Yavapai County, common silver mineral of Bradshaw Mountains district; also gold values; Senator and other mines; occurs also in Cochise, Santa Cruz, and Yuma counties.

Garnet. Greenlee County, large masses on western slope of Modoc Point at Morenci, and on top of Shannon Mountain at Metcalf; massive garnet occurs in many of the mining districts; as yellowish to dark brown andradite at Clifton. Yavapai County, common in schists of Bradshaw Mountains. Navajo Reservation, gem pyrope ("Arizona ruby") in extreme northern part of the State, and with peridot 10 miles north of Fort Defiance. 
Glauberite (sulphate of soda and lime). Yavapai County, associated with thenardite, halite, and mirabilite, Verde Valley.

Gold (lode). Principal producers are Cochise County, Warren and Tombstone districts; Mohave County, San Francisco district; Yavapai County, Big Bug, Martinez, Tiger, and Verde districts; Yuma County, Kofa district.

Gold (placer). Pima, Yavapai, and Yuma counties are the largest producers. Other counties yielding appreciable quantities are Cochise, Coconino, Gila, Greenlee, and Santa Cruz. Dredges have been erected on Lynx Creek, in the Walker district, Yavapai County, and in French Gulch, a small tributary of Hassayampa River. Other important placers are in Pima County at Greaterville; Yavapai County, at Canada del Oro, Catalina Mountains, and Weaver placers.

Granite. Quarried in Cochise County, at Lee Station; Gila County, at Globe; and Maricopa County, at Phoenix; building and monuments.

Granite (quartz diorite). Gila County, Pinal Range, not used. Yavapai County, Bradshaw Mountains; would make handsome building stone; not used.

Graphite. Pure graphite has not been found. See Clay, graphitic.

Gypsum. Cochise County, quarried at Douglas. Navajo County, used for manufacture of plaster in Fort Apache Reservation, Woodruff, and Snowflake. Pima County, occurs in Santa Rita Mountains, Sierrita Mountains, and Santa Catalina Mountains; quarried near Tucson. Cochise and Pinal counties, used for manufacture of plaster in San Pedro Valley. See also Alabaster and Halite.

Halite (common salt). Gila County, occurs in headwaters of Salt River and in Tonto Basin. Yavapai County, occurs in Verde Valley associated with glauberite, gypsum, mirabilite, and thenardite; used to a small extent for cattle; too impure for table use.

Hematite. Occurs in gossan of copper deposits at many localities; in Santa Cruz County, at Pluto, Isabella, and other claims; in Yuma County, at Palmer \& Wharton claim. Occurs as contact mineral in Cochise County in magnetite on croppings of Black Diamond copper mine, Dragoon; Greenlee County, Clifton-Morenci district; and at Manganese Blue mine. Gila County, mined with copper ores in Globe district.

Hematite (micaceous). Yavapai County, reported from Willcox and Briggs.

Hematite (specular). Gila County, with chalcopyrite in Old Dominion, Superior \& Boston, Gibson, and other mines of Globe district. Mohave County, common in Black Mountain and Cerbat Range, Chloride district. Pinal County, occurs near Mammoth. Santa Cruz County, at Line Boy, near Duquesne.

Hubnerite. Cochise County, in veins and placer deposits near Dragoon; the placers are mined. Pima County, in quartz veins cutting granite at Arivaca; mined.

Iron minerals. See Arsenopyrite, Hematite, Limonite, Magnetite, Pyrite, and Pyrrhotite.

Jamesonite. Yavapai County, in ores of Bradshaw Mountains; carries free gold.

Jasper. Mohave and Yuma counties, brilliant red, orange to yellow, with chalcedony in petrified forests. Mohave County, dark red and brown on west slope of River range 20 miles west of Mineral Park.

Kaolin (china clay). Gila County, occurs at Globe. Greenlee County, not uncommon at Copper Queen, Morenci, and Metcalf, Clifton-Morenci district; as veinlets in quartz in Humboldt, Ryerson, and other mines; mined at Longfellow mine for converter lining. Pinal County, in Vekol mines.

Lead minerals. See Anglesite, Cerusite, Coronadite, Crocoite, Dufrenoysite, Galena, Jamesonite, Leadhillite, and Pyromorphite. Ores of lead are of chief importance in the following districts: Cochise County, California (Paradise); Graham County, Aravaipa; Mohave County, Cedar Valley and Stockton Hill; Pima County, Empire; Yuma County, Castle Dome and Silver.

Leadhillite. Pinal County, rare; occurs with other lead ores at Schulz. 
Iimestone. Cochise County, quarried for building or lime at Lee Station. Coconino County, at Flagstaff. Gila County, quarried during construction of dam at Roosevelt. Greenlee County, gray Modoc limestone quarried at Morenci. Yavapai County, at Wekon.

Limonite (brown hematite, brown iron ore). Cochise County, Copper Queen mine at Bisbee. Gila and Pinal counties, mined for contained copper in old Dominion mine, Globe district. Greenlee County, abundant in CliftonMorenci district, valuable as flux. Mohave County, common in Black Mountains and Cerbat Range, Chloride district. Pima County, coating quartz veins at McCleary prospects near Helvetia. Yavapai County, in ores of Bradshaw Mountains.

Magnetite (magnetic iron ore). Cochise County, Black Diamond mine, Dragoon Range. Greenlee County, Clifton-Morenci district; mined for flux in Manganese Blue and Arizona Central mines. Yavapai County, in ores of Bradshaw Mountains; carries free gold.

Malachite (green carbonate of copper). Cochise County, mined at Bisbee, Copper Queen, and other mines; wonderfully beautiful specimens have been obtained from the Copper Queen mine and placed in various museums. Greenlee County, common in irregular deposits in limestone in Clifton-Morenci district; mined at Detroit, Manganese Blue, Longfellow, and Standard mines. Gila and Pinal counties, abundant in Globe district; associated with copper ores but not itself an important ore constituent. Mohave County, in granite-gneiss, Mineral Park district. Yavapai County, in ores of Bradshaw Mountains.

Manganese. Cochise County, manganese oxide abundant in oxidized ores of certain mines of the Tombstone district. Ore mined for silver in these mines is principally pyrolusite and wad, with some psilomelane. See also Coronadite, Psilomelane, Pyrolusite, and Wad.

Marble. Cochise County, medium-grained crystalline, pure white with pinkish tones, beautiful color, suitable for decorative purposes near Fort Bowie; white, pinkish or grayish white, also gray, dove-color, or blue, handsome decorative marble near Emigrant Canyon; coarsely crystalline, granular white, excellent building stone near Whitetail Canyon. Pima County, black marble in Tucson Mountains. Pinal County, white statuary marble at northern end of Catalina Mountains, near Condon mine. Yavapai County, light green to white, weathering producing yellow and red banding, near Mayer, Bradshaw Mountains, deposit $\frac{3}{4}$ mile by $\frac{1}{2}$ mile, maximum thickness 25 feet, decorative stone; has been quarried; little shipped; onyx marble.

Melaconite (black oxide of copper). Of common occurrence in many mines with other ores of copper.

Mica. See Muscovite.

Mineral paint. Hematite near Parker on California side of river; also in Yuma County, 30 miles northeast from Quartzsite, and at Bouse's Well.

Mirabilite. Yavapai County, associated with thenardite, glauberite, and halite, Verde Valley.

Molybdenum. See Molybdenite and Wulfenite.

Molybdenite. Gila County, in disseminated ores at Miami. Greenlee County, in copper ores of Clifton-Morenci district. Mohave County, primary ore of Chloride district in granite-gneiss; with copper in Hualpai Mountains, Maynard district. Pima County, in Madera Canyon, 10 miles southwest of Helvetia; in limestone and quartz at Leader and Ridley mines, Helvetia; in workable quantities only at Leader mine; with copper ores at Vail. Pinal County, in ores at Ray and Kelvin mines as original mineral. Santa Cruz County, sparingly in granite at Providencia Canyon, 5 miles west of Washington; also at Duquesne and San Antonio Canyon. 
Muscovite (mica). Several deposits, none developed, value unknown. Occurs in Coconino County, on north side of Grand Canyon, and in Maricopa County, White Horse Tank Mountains, southwest of Phoenix.

Obsidian. Occurs in regions of Tertiary volcanic rocks; small quantities cut for jewelry.

Olivine (chrysolite, Job's tears). Apache County, beautiful green, yellowishgreen, brownish-green, and brown gems are found 10 miles north of Fort Defiance, in the Navajo Indian Reservation; and in Gila County in basaltic rocks near Rice, in the San Carlos Indian Reservation.

Onyx marble. The most important locality in Arizona is in Yavapai County near Mayer, about 26 miles from Prescott. Occurs also in Maricopa County, at Cavecreek, 45 miles north of Phoenix; Pima County, at Greaterville, Kirkland Valley, and Oak Creek; Yavapai County, at Big Bug Creek.

Opal (cacholong, and hyalite). Pinal County, Picket Post; Yavapai County, several localities.

Platinum. Yavapai County, occurs in black sands near Columbia.

Polybasite. Pinal County, fine specimens were found at Silver King mine; occasionally with other argentiferous ores.

Proustite (light ruby silver). Occurs with other argentiferous ores at many places.

Psilomelane (manganese ore). Cochise County, with pyrolusite and wad in Carboniferous limestone at Tombstone; mined for silver contents.

Pyrargyrite (ruby silver). Mohave County, secondary ore of Chloride, Mineral Park and Cerbat districts; large quantities were found in upper levels of Stockton Hill district; mined at Minnesota-Connor, Golden Star, and Paymaster mines. Yavapai County, in silver ores of Bradshaw Mountains.

Pyrite (iron sulphide). Common and widely distributed, generally in close association with copper sulphides. Cochise County, with copper ore of Bisbee, Copper Queen, Calumet \& Arizona, and other mines. Gila and Pinal counties, abundant in unenriched parts of nearly all copper deposits near Globe, Miami, and Ray. Greenlee County, important ore of Clifton-Morenci district; large masses in Joy, Ryerson, Morenci, and other mines. Mohave County, primary ore of Chloride, Mineral Park, and Cerbat districts; mined at Tennessee, Schuylkill, Keystone, Windy Point, Vanderbilt, and Idaho mines; carries gold values. Pima County, important ore in Mammoth mine; also in Leader and Ridley mines. Santa Cruz County, in granite at Providencia Canyon, 5 miles west of Washington; also at Duquesne. Yavapai County, in ores of Bradshaw Mountains, carries free gold; also with chalcopyrite and sphalerite mined at United Verde mine, Jerome district, for copper, gold, and silver.

Pyrolusite (black oxide of manganese). Cochise County, at Tombstone, mined for silver content only; formerly used for flux. Greenlee County, in CliftonMorenci district; mined for flux. Yavapai County, secondary mineral in ores of Bradshaw Mountains; unimportant; not mined.

Pyromorphite (phosphate of lead). Occasionally found with other lead ores; occure in Yuma County, at Iber-Plumosa mine, Bouse; reported in Pima County, at Cerro Colorado mine, and in Santa Cruz County, at Constitution mine.

Pyrope. See Garnet.

Pyrrhotite (magnetic pyrite). Yavapai County, in ores of Bradshaw Mountains; mined for gold values.

Quartz. Cochise County, gold bearing; formerly mined at Easter Sunday mine, for use as converter lining.

Quartzite. Greenlee County, quarried for converter lining, near Metcalf, CliftonMorenci district.

Salt. See Halite.

$29123^{\circ}-$ Bull. 585-14-2 2 
Sand. Widespread and abundant; reported dug for building in Cochise County, 18 miles west of Douglas, and in Mohave County, at Yucca.

Sandstone. Excellent quality in great abundance in many places; as red, brown, so-called blue, and white sandstone of good quality, in Grand Canyon region. Quarried for rough building in Yavapai County, at Kirkland, and $2 \frac{1}{2}$ miles northwest of Prescott, and for flagging and rubble in Cochise County, at Douglas.

Scheelite. Cochise County, small quantity in quartz veins cutting granite about 4 miles north of Dragoon. Pinal County, mined for gold and silver content at Maudina mine, Old Hat district, Santa Catalina Mountains. Santa Cruz County, small quantity mined as tungsten ore with wolframite, $7 \frac{1}{2}$ miles north of Nogales.

Serpentine. Greenlee County, pure vellow, translucent, west of Morenci; darkgreen with magnetite at Thompson mine.

Silver. Large quantities produced generally with various proportions of gold, copper, and lead, at the following places: Cochise County, Tombstone, Herschell, Bunker Hill, Royal Guard, Calumet \& Arizona, and Copper Queen mines; Gila County, Old Dominion, Arizona-Commercial, Warrior, Keystone, Globe Consolidated, and other mines; Greenlee County, Detroit, Arizona-Copper, Shannon, Silver King, Gold Bar, Capote, Silver Bonanza, and other mines; Mohave County, Grand Gulch, Bentley district; Gold Road and Tom Reed, San Francisco district; Banner, Champion, and Tennessee, Wallapai district; Pima County, Pima and Silver Bell districts; Yavapai County, Big Bug, Martinez, Tiger, Verde, and Walker districts. Small quantities of silver are produced in Pinal, Santa Cruz, and Yuma counties. See also Argentite, Cerargyrite, Dyscrasite, Embolite, Freieslebenite, Polybasite, Pyrargyrite, and Stromeyerite.

Silver (native). Native silver in beautiful specimens has been found in Gila County

- in a placer 12 miles north of Globe; in Pinal County, at Silver King mine; in Yavapai County, at McMillanville, at the Tiger mine; and in other counties.

Slate. Maricopa County, fair grade of roofing slate, bluish gray, $6 \frac{1}{2}$ miles north of Phoenix; undeveloped.

Smithsonite (zinc carbonate). Greenlee County, in Shannon Mountain, CliftonMorenci district; unimportant.

Specularite. See Hematite.

Sphalerite (zinc blende). Cochise County, Tombstone district. Greenlee County, accompanies copper ores in Clifton-Morenci district. Mohave County, occurs in Chloride district, Tennessee and Towne mines; Mineral Park district, Keystone mine; Cerbat district, Vanderbilt and Flores mines; Stockton Hill, Union Pass, and Golconda districts. Pima County, occurs with silver ores at Mammoth and many other mines and with copper ores at Ridley mine. Pinal County, Globe district, Bobtail mine, on north side of Mineral Creek. Santa Cruz County, occurs at many mines; shipped from Patagonia district. Yavapai County, common in Bradshaw Mountains district; carries free gold at Crown King and other mines, and gold and silver at United Verde mine, Jerome district.

Stibnite (sulphide of antimony). Mohave County, in Cerbat district, at Vanderbilt mine. Yavapai County, common in silver veins; in ores of Bradshaw Mountains carries free gold; mined.

Stromeyerite. Pinal County, Silver King mine, with other cupriferous and argentiferous ores.

Tenorite. Cochise County, unimportant copper ore; occurs in Lowell and Copper Queen mines, Bisbee, and elsewhere.

Tetradymite (telluride of bismuth). Yavapai. County, small quantity in Montgomery mine, at Minnehaha, and near Bradshaw City. 
Tetrahedrite (gray copper). Pinal County, Heintzelman and Silver King mines. Santa Cruz County, Tyndall district, Alta mine, Treasure Vault mine, and others. Yavapai County, in ores of Bradshaw Mountains district; also in copper-silver veins.

Thenardite (verde salt). Yavapai County, Verde Valley, 3 miles southwest of Old Camp Verde, occurs in large beds with rock salt, glauberite, and mirabilite.

Tungsten minerals. See Hübnerite, Scheelite, and Wolframite.

Turquoise. Cochise County, near Gleason; has been mined at Turquoise Mountain. Maricopa County, occurs 12 miles east of Morristown. Mohave County, several mines worked near Mineral Park yield large quantities of gem material.

Vanadinite. Occurs at numerous places associated with lead ore: Cochise County, near Fairbanks; Gila County, Globe district, at Lockwood claim, Clark \& Stewart claims near Old Dominion mine; Pima County, Old Yuma mine, 14 miles northwest of Tucson; Pinal County, Mammoth mine at Schultz, Royal Dane claim, 7 miles southwest of Oracle, Black Prince mine, Pioneer district, and at Kelvin; Yavapai County, near Silver Belt mine, Big Bug district; Yuma County, Red Cloud mine.

Vanadium ores. See Descloizite, Vanadinite, and Volborthite.

Verde salt. See Thenardite.

Volborthite (vanadate of copper). Occasionally met with in other copper and lead ores.

Wad (manganese ore). Cochise County, occurs at Tombstone; mined for silver content only.

Willemite (silicate of zinc). Greenlee County, small grayish crystals in Modoc open cut on Modoc Mountain, Clifton-Morenci district.

Wolframite (tungstate of iron and manganese). Cochise County, Whetstone Mountains, 12 miles south of Benson; Maricopa County, Cave Creek, 30 miles north of Phoenix; Mohave County, 80 miles southeast of Kingman in Aquarius Mountains, mines 17 miles east of Yucca; Pima County, with gold and quartz in Arivaca district; Santa Cruz County, 7 miles north of Nogales; Yavapai County, Tip Top mine, Bradshaw Mountains.

Wood (silicified). Apache County, large quantities obtained at Adamana and cut for ornamental purposes.

Wulfenite (molybdate of lead). Occasionally found with other lead ores; nearly always present with silver ore of Tombstone, Cochise County, in small quantity; occurs also in Gila County, at Troy; Pima County, Old Yuma mine, 14 miles northwest of Tucson; Pinal County, Mammoth mine, Schultz; Yavapai County, Bradshaw Mountains; Yuma County, at Castle Dome.

Zinc. Principal production of zinc in the State is in Mohave County; small quantity in Santa Cruz. See also Smithsonite, Sphalerite, and Willemite.

\section{ARKANSAS.}

Agate. Montgomery County, finely variegated; has been mined.

Antimony ore. See Stibnite.

Asphalt. Pike' County, in Lower Cretaceous sandstones (Trinity sand), $2 \frac{1}{2}$ miles southeast of Pike City; has been used to a small extent. Also occurs in Madison County.

Azurite (blue carbonate of copper). Searcy County, copper mines at Tomahawk; not worked as ore.

Barite (heavy spar). Montgomery and Polk counties, in seams or pockets.

Bauxite. Pulaski and Saline counties, in area 20 miles long and 5 to 6 miles wide, south and southwest of Little Rock; principal producing area of United States in 1912 . 
Braunite (manganese ore). Independence, Izard, and Sharp counties, mined with psilomelane in Batesville district.

Brown iron ore. See Limonite.

Calamine (zinc silicate). Lawrence County, in Bath and Koch mines. Marion County, in zinc mines of Sugar Orchard region; has been mined.

Celestite (strontium sulphate). Pike County, occurs at White.

Cement material (Portland). L Little River County, large cement plant at Whitecliffs. Limestone suitable for Portland cement occurs in many counties in northwestern part of the State.

Cerusite (lead carbonate). Howard County, with galena and coating it in mines in northern Arkansas.

Clay (brick). Ashley County, alluvial clay used at Hamburg. Arkansas County, common brick made from red surface clay at Stuttgart. Benton County, pits at Bentonville, Rogers, and Siloam Springs. Boone County, at Harrison. Bradley County, at Warren. Clark County, at Gurdon. Clay County, at Pratt. Cleveland County, pressed brick made at Kingsland. Columbia County, surface clays used at Magnolia and Waldo. Craighead County, common and pressed brick made at Jonesboro. Cross County, loess and surface clay used near Wynne. Drew County, alluvial clays used near Monticello. Faulkner County, buckshot clays used at Conway. Greene County, loess used at Paragould and Gainesville. Hempstead County, surface clay used at Hope, Doyle, and Spring Hill. Hot Spring County, alluvial clay used for common and pressed brick at Malvern; white plastic for white front and paving at Malvern. Howard County, at Nashville. Jefferson County, alluvial and surface clays used at Pine Bluff and Redfield. Lawrence County, white surface clay used at Walnut Ridge; yellow or reddish clay at Black Rock, residual clay at Imboden. Lee County, red brick from loess of Crowleys Ridge at Marianna. Lonoke County, at Lonoke and Cebat, red surface clays used. Miller County, Tertiary clays used at Texarkana for pressed and common brick. Mississippi County, alluvial clay used for common brick and tile at Blytheville. Monroe County, at Brinkley. Nevada County, at Emmet and Prescott, common brick and building tile. Phillips County, loess used at Helena. Poinsett County, reworked loess used at Harrisburg, common brick and draintile. Pope County, residual clay and shale used at Mena and Atkins. Prairie County, red surface clay used at Devall Bluff. Pulaski County, surface clay used at Little Rock. Randolph County, at Pocahontas, common and front brick. St. Francis County, brick clay and yellow loess on and near Crowleys Ridge, burns solid red; mined at Forrest City. Saline County, surface clays used at Benton. Sebastian County, Carboniferous shales used at Fort Smith and Mansfield for common and paving brick; alluvial clay near Fort Smith, burns bright red, soft brick, repressed for front brick, uniform good color. Union County, red surface clay used at Felsenthal. Washington County, at Prairie Grove, common brick and drain tile. White County, argillaceousshales of Round Mountain suitable for sewer pipe and paving brick; surface clay mined at Beebe, Searcy, and Judsonia. Woodruff County, surface clay used at Cotton Plant. Yell County, alluvial and surface clay, mined at Dardanelle.

Clay (fire). Crawford County, disintegrated Carboniferous shales in vicinity of Van Buren; make good yellow ware; used to line kilns at Fayetteville; occurs also in Dallas, Hempstead, Pike, Sebastian, and White counties.

Clay (kaolin). Dallas County, white kaolin of fair refractoriness outcrops on Kilmer land. Ouachita County, in large quantity on Sandy Branch. Pike, Pulaski, and Saline counties, beds of variable color on Vaughn Creek. Pulaski County, white pisolitic kaolin in various places in Fourche Mountain region, burns white, glazes well. 
Clay (pottery). Ashley County, Tertiary clays suitable for common pottery near Hamburg. Bradley County, near Alga Bluff, Crawfords Bluff. Calhoun County, supply on Champagnolle Creek, Moro Creek, and large streams. Cleveland County, near New Edinburg, Mount Elba, etc. Columbia County, near Mount Holly and Magnolia. Dallas County, abundant and excellent quality along streams. Faulkner County, buckshot clays, abundant over flood plains of streams. Franklin County, strong dark-red earthenware, residual clays abundant. Hempstead County, Tertiary clays used for jug ware, etc., at Spring Hill. Hot Spring County, at Perla switch, near Malvern, burns light cream common pottery. Jefferson County, white Bluff on Arkansas River. Johnson County, soft shale sagger clay in Felker mine, Coal Hill. Lafayette County, leached pottery clays along Red River. Logan County, Pennsylvanian clay abundant. Miller County, Tertiary clays used at Texarkana for jugs, churns, and jars; burns solid cream colored. Ouachita County, abundant along Ouachita Valley: Pulaski County, red and yellow surface clay used in Little Rock district for making flower pots. Saline County, Tertiary clays used for jugs, crocks, jars, etc., at pottery near Benton. Sebastian County, red and blue has been mined in NE. $\frac{1}{\mathrm{sec} .}$ 20, T. 10 N., R. 26 W.; abundant at Fort Smith and elsewhere; light yellowish surface clay used at Comby's pottery. Union County, abundant. Yell County, Carboniferous shale formerly used in SE. $\frac{1}{4}$ sec. 12 , T. 6 N., R. $21 \mathrm{~W}$.

Coal. Arkansas coal varies from bituminous to semianthracite; coal-bearing rocks belong to Pennsylvanian (upper Carboniferous); three beds worked, Hartshorne, Charleston, and Paris; Hartshorne most important. Crawford County, Charleston coal, 9 to 18 inches on north side of river near Alma, semibituminous, mined. Franklin County, Paris coal mined at Potato Hill; west of Potato Hill worked for local supply. Franklin and Johnson counties, Coal Hill, Denning district, Hartshorne coal 1 to 5 feet thick; mined from Coal Hill to Denning; semibituminous. Johnson County, Spadra district, Hartshorne coal, 3 feet thick, mined near Spadra, anthracite; Philpot district, Charleston coal 18 to 22 inches, mined at Ozark, semibituminous. Logan County, Paris seam 2 to 3 feet; mined in vicinity of Paris; semibituminous. Pope County, Russellville district, Hartshorne coal 40 to 46 inches in Shinn Basin, mined; semianthracite. Scott County, Hartshorne coal 4 feet in Bates-Coaldale district; mined near Bates. Sebastian County, Bonanza-Jenny Lind district, Hartshorne coal 3 to 6 feet; also 2 to 6 feet in Greenwood-Huntington district. Charleston bed outcrops between Charleston and Fort Smith, mined near Central, 20 inches thick. Yell County, Atoka coal $1 \frac{1}{2}$ to 3 feet thick in vicinity of Dardanelle; has been mined. See also Lignite.

Copper ore. See Azurite.

Diamond. Pike County, two peridotite dikes near Murfreesboro; white, brown, and yellow stones; more than 1,200 found.

Fuller's earth. Area of about 3 square miles between Hot Springs and Benton; 2,563 tons produced in 1910. Only two plants operating in 1911, at Fairplay and Klondike.

Galena. Has been mined in northern Arkansas fields, in Benton, Carroll, Boone, Marion, Washington, and other counties. In western Arkansas it has been found sparingly and mined occasionally in: Garland County, small crystals occasionally found in quartz near Blakely Creek; Montgomery County, in quartz at Rubicon mine, near Virginia City, and at Waterloo mine; Pulaski County, Kellogg mines; Sevier County, New Discovery shaft, near Conboy, and elsewhere.

Gas, natural. See Natural gas.

Gypsum. . Pike County, was mined at Tokie. 
Greenockite. Marion and other counties; occurs with sphalerite.

Hydrozincite (zinc carbonate). In zinc and lead regions, Baxter, Lawrence, Marion, and Searcy counties.

Kaolin. See Clay.

Iignite. Beds, possibly of workable thickness, underlie parts of several counties south and southwest of Little Rock; workable beds near Camden, Ouachita County.

Limestone (building). Carroll County, quarried at Eureka Springs; Independence County, oolitic limestone, ornamental, has been quarried at Batesville; Izard County, quarried at Guion; Lawrence County, quarried at Imboden, for building and crushed stone.

Limestone (hydraulic). Occurs in Saline County, and many counties in northern part of State; not used.

Limestone (lime). Benton County, quarried and burned near Rogers; Montgomery County, Cedar Glades; Stone County, east of Sylamore; Washington County, Farmington, Johnson, and elsewhere.

Limonite. Small quantity in nearly every county; has been mined near Berryville, Carroll County.

Magnetite (magnetic iron ore). Hot Spring County, in loose fragments at Magnet Cove; not mined.

Manganese ore. See Psilomelane, Pyrolusite, Wad.

Marble. Marble region includes Benton, Boone, Marion, and parts of Baxter, Independence, Izard, Searcy, Stone, and Washington counties. Marbles and limestones belong to the Mississippian series and the Ordovician system of rocks. -

Marble (black). Fine black, suitable for ornamental purposes at Jamestown, in southern part of Independence County; reported shipped.

Marble (gray). Gray (Boone limestone), finest quality in Boone, Marion, Newton, and Searcy counties; coarsely crystalline; good polish.

Marble (onyx). Onyx marble in numerous caves and through limestone in northern Arkansas.

Marble (oolitic). Independence County, oolitic marble quarried near Batesville, for monuments.

Marble (St. Clair). Light gray to chocolate-brown, highly crystalline, 2 to 4 feet thick in irregular belt running across central part of northern Arkansas in east and west direction from Hickory Valley, Independence County, to Mount Hersey, Newton County; valuable building stone.

Marble (St. Joe). Widely distributed north of Boston Mountains. Light pink to dark chocolate, spotted white, gray, or pea-green, varies in texture; in Buffalo River and Crooked Creek basins in Newton, Boone, Carroll, Marion, and Searcy counties.

Marl. Calcareous and shell marls in Clark, Greene, Hempstead, Jefferson, Lonoke, Madison, Pike, and St. Francis counties; gypseous marls in Greene and Pike counties; have been mined.

Mica (muscovite). Hot Spring County, Magnet Cove; not mined.

Natural gas. One hundred and ten productive wells in State in 1911, all near Fort Smith.

Niter (saltpeter). Occurs in niter earth of limestone caves of northern Arkansas, Marion, and Newton counties; not mined.

Novaculite. White novaculite forms ridges in Hot Spring, Garland, Howard, Montgomery, Pike, Polk, Pulaski, and Saline counties; many quarries. Whittington's on Quarry Mountain ships to all parts of country; used by engravers; surgeons, etc.; also for wheels, and for finishing and polishing powder. Called Arkansas stone and Washita stone.

Oilstone. See Novaculite. 
Phosphate rock. Independence County, mined near Batesville; occurs near Hickory Valley, 12 miles north of Batesville. Searcy County, Garvin tract, near St. Joe.

Psilomelane (manganese ore). In the manganese mines of Batesville district, Independence, Sharp, and Izard counties; occurs with pyrolusite in novaculite in belt extending from Pulaski County, through Saline, Garland, Hot Spring, Pike, Montgomery, and Polk counties.

Pyrolusite (manganese ore). Important ore of manganese; in small quantities with psilomelane in Pulaski, Saline, Garland, Hot Spring, Pike, Montgomery, and Polk counties; has been mined at Cushman, Independence County; and near Little Rock, Pulaski County.

Quartz. Hot Spring County, clear crystals at many localities; used for ornaments and lenses; smoky quartz in small quantities about Magnet Cove, used for jewelry; Madison County, clear, limpid quality at Delaney; Montgomery County, crystals have been mined near Crystal Springs.

Reddle (red chalk). Abundant in many localities; probably useful in paint manufacture; not mined.

Rutile. Hot Spring County, abundant in several places about Magnet Cove, often with brookite; not mined; good museum specimens.

Sand (building). Dug at many places: Boone County, Harrison; Clark County, Arkadelphia; Greene County, Paragould; Izard County, Guion; Jefferson County, Pine Bluff; Pulaski County, Little Rock; Saline County, Benton; Sebastian County, Fort Smith.

Sand (glass). Dug in Izard County, at Guion; Jefferson County, in small quantity at Pine Bluff; St. Peter sandstone along valley of White River from Batesville nearly to Fayetteville, probably will make excellent glass sand.

Sand (molding). Johnson County, brown sandy loam suitable for molding sand in vicinity of Coal Hill; Pulaski County, dug at Little Rock.

Sandstone (building and crushed stone). Quarries are located at the following places: Benton County, Siloam Springs; Boone County, Alpena Pass; Cleburne County, Heber; Conway County, Morrillton; Garland County, Hot Springs; Independence County, Batesville; Johnson County, Clarksville; Polk County, Eagleton, near Mena; Sebastian County, Greenwood; Washington County, Fayetteville; White County, Bald Knob and Russell; and Yell County, Dardanelle.

Silver. Pulaski County, in galena, chalcopyrite, and sphalerite in Kellogg mines; Sevier County, with lead ores in Stewart lode near Antimony City.

Slate. Gray, black, green, and red slates along uplift west of Little Rock; slate area includes parts of Saline, Garland, Montgomery, and Polk counties. Garland County, worked in small way at several points near Hot Springs; not shipped at present. Montgomery County, dark red quarried for switchboards at Slatington. Polk County, several quarries; Missouri Mountain slate, red and green, suitable for laundry tubs, wainscoting, switchboards, extensively prospected near Board Camp Creek; slate, blue to black, in Stanley shale, extensively prospected in southeastern part of county.

Smithsonite (zinc carbonate). Most valuable and next to sphalerite most abundant ore of zinc in Arkansas; "turkey fat," a cadmiferous variety of smithsonite, mined in limited quantity.

Soapstone. See Talc.

Sphalerite (zinc blende). Most important and abundant zinc mineral in northern Arkansas; in Boone County mines; Lawrence County, calamine and smithsonite in Bath and Koch mines; Marion County, in limestone at Wood's mine; Pulaski County, Kellogg mines; and mines in Saline, Sevier, and Sharp counties. 
Stibnite (antimony sulphide). Sevier County, was mined for silver in Bob Wolf mine; also found in Pike County.

Sunstone. Hot Spring County, pink or gray, occasionally found in Magnet Cove; cut for ornaments.

Syenite. Hot Spring County, elæolite syenite quarried at Diamond Jo quarry in Magnet Cove region; suitable for ornamental interior use. Saline County, occurs in large masses, light gray, pinkish, or buff; quarried.

Talc (soapstone). Pulaski County, at Wallis's soapstone quarry. Saline County, has been quarried between Little Rock and Hot Springs; no production in 1911.

Tripoli (polishing powder). The porous siliceous residue resulting from decay of siliceous limestone occurs in zinc region. Montgomery County, T. 4 S., R. $26 \mathrm{~W}$., reported good quality. Marion County, reported abundant at Lees Mountain; not used. Occurs as decomposed novaculite in Hot Spring, Garland, Montgomery, Polk, Pike, and Howard counties.

Variscite. Montgomery County, translucent and transparent, emerald to bluish green; not mined.

Vesuvianite. Hot Spring County, yellowish-green to olive-green crystals in Magnet Cove; not mined.

Wad (bog manganese). Izard County, north fork of White River. Marion County, about Dodd City; unimportant. Common but of no particular value in northern Arkansas.

Whetstone. See Novaculite.

Zinc. In plateau portion of Ozark uplift, including parts of Baxter, Boone, Marion, Newton, and Searcy counties; mines scattered; deposits chiefly in Ordovician rocks. See Smithsonite and Sphalerite.

\section{CATIFORNIA.}

Agalmatolite (pyrophyllite). San Diego County, near Encinitas.

Agate, moss. San Bernardino County, jaspery agate in San Bernardino Mountains, not mined.

Alabaster. Riverside County, in Palen Mountains; San Luis Obispo County, at Arroyo Grande; Santa Barbara County, has been mined at Point Sal, occurs in eastern part of county.

Alum salts. See Kalinite.

Alunite. Mariposa County, occurs in Tres Cerritos Buttes, southwest of Indian Gulch.

Amalgam. Mariposa County, gold amalgam quoted by Dana.

Amblygonite. San Diego County, was mined at Stewart mine near Pala.

Andalusite (chiastolite). Madera County, fine specimens at Daulton; Mariposa County, Moores Hill, and on Chowchilla River; Riverside County, opaque pink at Cahuilla.

Anglesite. Inyo County, found in oxidized zone of Cerro Gordo mines.

Anhydrite. Shasta County, Rising Star mine.

Antimony. Kern County, has been mined in San Emigdio Canyon, and near Havilak; Riverside County, occurs near Corona. Is obtained in antimonial lead as a by-product in smelting gold-lead-silver ores of the State. See also Stibnite.

Apatite (asparagus stone). San Bernardino County, east end of Kingston Range; San Diego County, Dos Cabezas mine near Jacumba; not mined.

Ápophyllite (fish-eye stone). Plumas County, white to gray at Buckeye mine near Orion Valley; San Francisco County, found rarely at Fort Point; San Mateo County, near La Honda; Santa Clara County, at New Almaden quicksilver mines.

Arsenic. See Arsenopyrite. 
Arsenopyrite. Kern County, mined for gold in Sunshine and La Crosse mines southeast of Randsburg. Placer County, common in Ophir gold-silver veins. Madera County, often associated with coarse gold as at Gambetta mine; Sierra County, Fightner mine, and in many mines of the Mother Lode. Common in gold mines of East Lode.

Asbestos (chrysotile). Reported from northwestern border of serpentine belt extending from Plumas County south through Sierra, Nevada, Placer, Amador, and Calaveras counties; prospects; was mined in Butte and Riverside counties, and near Auburn, Placer County.

Asphalt and bituminous rock. Considerable deposits of asphaltic sandstone in following counties: Kern County, in the McKittrick and Sunset oil fields; Mendocino County, near Point Arena; Monterey County, southeast of Metz, northeast of King City, west of San Ardo, and west of Bradley; San Luis Obispo County, south of San Luis Obispo; Santa Barbara, along the coast west and east of Santa Barbara, and in the Santa Maria district in the Casmalia Hills, on Graciosa Ridge, east of Sisquoc, and in the Purisima Hills; Santa Cruz County, north of Santa Cruz; Ventura County, in the Ojai Valley. Also numerous small deposits of maltha and asphalt scattered through the Coast ranges.

Axinite. Eldorado County, Consumnes copper mine near Fairplay; Inyo County, occurs at several places in Death Valley; Riverside County, in quarry near Riverside; San Bernardino County, Funeral Range and Owl Mountains; San Diego County, mined near Bonsall.

Azurite (blue carbonate of copper). Eldorado County, with other copper ores in Alabaster Cave mine near Newcastle; Inyo County, in Ubehebe district. Also in copper ores in Calaveras, Modoc, Monterey, San Bernardino, and Shasta counties.

Basalt. Used extensively for road metal.

Bauxite. Riverside County, near Riverside; Yuba County, 2 miles southeast of Smartsville, white and red.

Benitoite. San Benito County, in southeastern part, 35 miles northwest of Coalinga; associated with serpentine.

Bentonite. Kern County, 4. miles north of Randsburg.

Beryl. San Diego County, aquamarine variety mined intermittently at Pala, Rincon, Mesa Grande, and Ramona.

Bismuth. San Bernardino County, southeast of Banning, in veins; San Diego County, Pala, Rincon, in pegmatite.

Bismutite. San Diego County, Pala, Rincon, in pegmatite.

Bitumen. See Asphalt.

Bloodstone. San Bernardino County, south end of Brown Mountain, Death Valley region, cut for gems.

Borax. Has been produced from the waters of Borax and Hachinhama lakes in Lake County. Deposits of the màrsh type were formerly extensively worked at numerous localities in Inyo, Kern, and San Bernardino counties. Deposits of the calcium borate mineral, colemanite (which see), are now being worked in Ventura, Los Angeles, and Inyo counties, and similar deposits have formerly been worked in San Bernardino County. See Colemanite and Ulexite.

Bornite. Del Norte County, with other copper ores in Low Divide district; Eldorado County, mined at Cosumnes copper mine and Pioneer mine; occurs at Alabaster Cave and Pioneer mines; Nevada County, Mineral Hill, California mines; Shasta County, Bully Hill, Afterthought mines; Plumas County, Shoofly and Peters mines; San Bernardino County, occurs at Tiptop mine, Lava Beds district.

Brown iron ore (limonite). Calaveras County, common in mines southeast of Campo Seco, near Valley Spring, Esmeralda, and Murphy; Placer County, 
has been mined with magnetite at Hotaling iron ore deposits 6 miles north of Auburn; Riverside County, San Bernardino County, prospects in Cave Canyon area north of Scott Station, at Eagle Mountain, and near Dale; San Luis Obispo County, occurs in secs. 1 and 6, T. 31 S., Rs. 10 and 11 E., and in Jurassic shale and limestone in Perfumo Canyon about 5 miles south of west from San Luis Obispo; Shasta County; with magnetite in numerous prospects, at Gossan, Iron Mountain, near Keswick; mined as iron flux for Bully Hill smelter; Siskiyou County, occurs in sec. 10, T. 46 N., R. 10 W.

Californite. See Vesuvianite.

Calaverite. Calaveras County, Stanislaus mine.

Caledonite. Inyo County, found in oxidized zone at Cerro Gordo mines.

Cassiterite (tin ore, tin stone). Riverside County, small occurrence in Cajalco mine, 7 miles east of Corona, in tourmaline rock; San Diego County; found at Pala, of mineralogic importance only.

Celestite. San Bernardino County, occurs near Silver Lake.

- Cement material (Portland). Seven Portland cement companies are operating in the State at the following places: Contra Costa County, Cowell, using travertine and shaly clay; Kern County, Monolith, using limestone and clay; San Bernardino County, Colton, using marble; Napa County, Napa Junction, using two grades of limestone; Riverside County, Riverside, using limestone and clay; Santa Cruz County, Davenport, using crystalline limestone, clay, and diatomaceous shale; Solano County, Cement, near Suisun, using travertine and clay.

The principal deposits of suitable material are in the following places: Contra Costa County, travertine from Mount Diablo to Pinole; Kern County, limestone at Tehachapi; Los Angeles County, shell limestone near Mission San Fernando; San Benito County, limestone west of Hollister; Orange County, shell limestone at San Fernando and on mesa toward Orange and toward San Juan; San Diego County, chalklike limestone near Pacific coast at Jamul; Santa Cruz County, limestone near the coast in vicinity of Santa Cruz associated with shale and clay; Shasta County, limestone in abundance in the copper-bearing district, east of Furnaceville, Brock Mountain, north of Lillienthals, near Kennett, and elsewhere; Solano County, travertine from Vallejo to Goodyear; Sonoma County, limestone reported 6 miles northeast of Geyserville on Little Sulphur Creek.

Cerargyrite (horn silver, silver chloride). Placer County, Gold Blossom, California, Mina Rica, and other mines in Ophir region; San Bernardino County, Calico district, and Grapevine mine near Barstow.

Chalcanthite (blue vitriol, sulphate of copper). Alameda County, Leona Heights. Shasta County, was mined at Peck and other mines. Trinity County, with copper and iron ores in New River district.

Chalcedony. Del Norte County, handsome varieties at Pebbly Beach, Crescent City; Fresno County, near Panoche; Kern County, Kane Springs; Los Angeles County, Redondo, in lava near Acton, abundant in rhyolite in Jawbone canyon; Placer County, in gold veins in Ophir district; San Bernardino County, beautiful chalcedony containing vermilion-red cinnabar and resembling St. Stephen stone variety, in granitic rocks near Ash Hill, 15 miles east of Indian Springs; blue chalcedony 38 miles east of Johannesburg and 2 miles east of Leadpipe Spring; San Mateo County, at Pescadero.

Chalcocite (copper glance). Calaveras County, Penn Chemical Co. mines, Campo Seco; Del Norte County, Low Divide district; Inyo County, Bluejay and Sanger mines, Ubehebe district; Mariposa County, Green Mountain mines; Plumas County, Peters and Duncan mines, mined for gold and silver; Shasta County, Afterthought and Bully Hill mines; Tuolumne County, Oak Hill copper mine. 
Chalcopyrite (copper pyrites). Calaveras County, Penn Chemical Co. mines west of Campo Seco, said to carry some gold in places, mined for gold and silver in "Foothill Copper Belt"; Del Norte County, Low Divide district; Eldorado County, Alabaster Cave mine, with gold and silver; Fresno County, Fresno copper mine and Copper King mine; Inyo County, Chloride Cliff prospects; Madera County, was mined at Buchanan mine; Mariposa County, Green Mountain mines; Merced County, Jose copper claims, sec. 4, T. 14 N., R. 9 E.; Nevada County, California mine, gold and silver, Spenceville copper mine; Placer County, 2 miles east of Valley View, was worked for gold, was also mined at Hotaling; Riverside County, Vulture Crag, 14 miles east of Capis: trano, little gold; San Benito County, Lewis Creek claim, 16 miles from King City; San Diego County, prospects 18 miles east of Encinitas and 12 miles northeast of Lakeside; San Luis Obispo County, near Cayucos, carries gold and silver; Shasta County, mined at Mountain Copper, Bully Hill, Balaklala, and other mines in Shasta district; Siskiyou County, Blue Ledge mine in Elliot district, carries gold and silver; Trinity County, Lambert claims, South Fort district; Tulare County, Tule River, about 20 miles above Porterville; Tuolumne County, was mined at Washington and other mines.

Chromite (chromic iron ore). Alameda County, 15 and 20 miles southeast of Livermore, has been mined at several mines; Amador County, near Jackson and Mount Spring House; Calaveras County, has been mined at Valley Springs, and is found at Campo Seco and Murphy; Del Norte County, found in Rattlesnake Mountain from Bald Hill to Klamath River, French Hill and Low Divide mines; Eldorado County, numerous deposits; Fresno County, has been mined near Sentinel; Glenn County, at Black Diamond mine near Newville; Lake County, in Jerusalem Valley, 8 miles east of Middletown and near Bradford; Los Angeles County, with magnetite near Langs Station, Soledad Canyon; Marin County, $7 \frac{1}{2}$ miles west of San Rafael, reported from Maillard Ranch; Mendocino County, several localities in hills west of Russian River Valley; Monterey County, near San Benito River; Napa County, in Pope and Chiles valleys east of St. Helena; Nevada County, near Nevada City, at Washington on Deer Creek, and Coyote Diggings; Placer County, has been mined 2 miles east of Flagstaff Hill, 7 miles east of Iowa Hill, and near Alabaster Cave; Plumas County, 2 miles west of Spanish Ranch and south of Clear Creek, near Meadow Valley; San Benito County, at Emmet and Idria; San Luis Obispo County, near San Luis Obispo, in Santa Lucia Mountains, and near Santa Margarita, and elsewhere; Santa Barbara County, near Santa Ynez; Santa Clara County, near Livermore, San Jose, and elsewhere; Shasta County, deposits have been worked to small extent on Shotgun Creek; Sierra County, occurs along Goodyear Creek and at Howland Flat, near Downieville; Siskiyou County, is found in Forest Mountains and is mined at Chromite Station and Dunsmuir; Solano County, Fairfield; Sonoma County, occurs near Geyersville and Litton Springs, and has been mined at Cloverdale; Tehama County, was mined on north fork of Elder Creek; Trinity County, vicinity of Hayfork and north fork of Trinity River; Tulare County, Deep Creek near Plano and Portersfield; Tuolumne County, northwest of Mountain Pass, about 8 miles southwest of Sonora and elsewhere. Found also in other counties, usually in serpentine areas.

Chrysocolla (hydrous silicate of copper). Eldorado County, with other copper ores at Consumnes copper mine, sec. 25, T. 9 N., R. 12 E., reported to carry gold and silver; Inyo County, found at Darwin and other places; Mariposa County, John Dias mine, sec. 12, T. 6 S., R. 16 E., carries gold; shipped; Mono County, Goleta mines on Copper Mountain, mined for gold and silver; Plumas County, with copper ores in Engels copper mine, Light Canyon; San Bernardino County, claims in Ord Mountain copper group, Hixon mine near Barnwell. 
Chrysoprase. Tulare County; mined at Venice Hill, 10 miles east of Visalia; on Deer Creek, 8 miles southeast of Porterville; near Lindsay; at Stokes Mountain, and other localities. Used for jewelry and ornamental. work.

Chrysotile. See Asbestos.

Cinnabar. Colusa County, has been mined at Manzanita mine; Contra Costa County, near Mount Diablo; Del Norte County, prospecting on Diamond Creek, near northern boundary of county; Eldorado County, has been mined near Latrobe; Fresno County, Mexican mine in northwest branch of Cantua Creek, also Providential group; Lake County, Abbot mine and Anderson prospects in Mayacmas district; Máriposa County, occurs near Horseshoe Bend; Monterey County, Cholame Parkfield mine, 6 miles from Parkfield, has been mined on Arsenal Creek, east of Table Mountain, and at Table Mountain 13 miles from Parkfield; Dutro mine, in the San Carpojo district; Napa County, Boston Mine, Cathill mine, and other places; San Benito County, New Idria and Stayton mine; Santa Barbara County, was mined at Los Prietos mines; Santa Clara County, New Almaden mine and Guadaloupe mines near Los Gatos; Shasta County, 30 miles northeast of Redding; Siskiyou County, near Oak Bar in northern part of county; Solano County, was mined at St. John mine; Sonoma County, Boston Group, Cloverdale mine, Culver-Baer mine, and various other mines; Yolo County, New England and Harrison mines, Knoxville district.

Clay (brick). Ninety-two operators reported a production of brick and other clay products in 1911 valued at $\$ 4,915,866$; yards at the following places:

Alameda County, Alameda, East Oakland; Amador County, South Carbondale near Jane; Butte County, Biggs; Contra Costa County, Antioch, Eckley, Point Richmond; Del Norte County, Elk Valley; Fresno County, Fresno and vicinity; Humboldt County, Eureka and Fortuna; Imperial County, Holtville and Inglewood; Kern County, Bakerfield and Kern; Kings County, Hanford; Lassen County, Susanville; Los Angeles County, Garvanza, Long Beach, Los Angeles, and elsewhere; Marin County, McNear and. San Rafael; Mendocino County, Ukiah; Merced County, Merced; Monterey County, Salinas; Orange County, Fullerton, La Balsa, and Huntington Beach; Placer County, Lincoln; Riverside County, Corona and Hemet; Sacramento County, Sacramento and Riverside; San Bernardino County, Redland and San Bernardino; San Diego County, San Diego; San Francisco County, San Francisco; San Joaquin County, Roberts Island, Carnegie, and on San Joaquin River; San Luis Obispo County, San Luis Obispo; San Mateo County, South San Francisco; Sonoma County, Glen Ellen and Hilton; Santa Barbara County, Santa Barbara and Santa Maria; Santa Clara County, San Jose, Pleasanton, Mount View, and elsewhere; Shasta County, Anderson and Redding; Solano County, Vallejo; Stanislaus County, Modesto; Tulare County, Milo; Ventura County, Montalvo and Ventura.

Clay (fire). Los Angeles County, has been mined at Palates Ranch; Orange County, mined at Gypsum Switch; Placer County, at Lincoln; Riverside County, at Alberhill.

Clay (pottery). Amador County, white clay mined northwest of Ione, and about Carbondale; Eldorado County, has been mined at Michigan Bar; Placer County, at Lincoln.

Coal (lignite). Alameda County, Corral Hollaw, includes area on both sides of divide between Livermore and San Joaquin valleys; Eocene age; has been mined. Amador County, Ione field, 4 miles northwest of Ione, underlies valley between Ione and Carbondale; Miocene age; bed 6 to 24 feet thick, has been mined for local use. Orange County, Santiago Canyon, small beds in Trabucco Canyon mined for local use. Riverside County, Elsinore field, bed 3 to 10 feet thick, 
has been mined for local use. Trinity County, Hyampom Valley, T. 3 N., R. $6 \mathrm{E}$., bed 17 feet thick, not mined. Is found in small quantity in several other counties, but not mined.

Coal (bituminous). Monterey County, has been mined in Stone Canyon, sec. 14, T. 22 S., R. 13 E., near middle of Mount Diablo Range; San Benito County, Trafton mine, sec. 21, T. 17 S., R. $10 \mathrm{E}$.

Cobalt. See Erythrite.

Colemanite (borate of lime). Inyo County, mined at Lila C. mine, Death Valley; Los Angeles County, Lang; Ventura County, Griffin; San Bernardino County, has been mined in Calico district, Lone Star, and other places.

Copper (native). Del Norte County, Diamond Creek district; Humboldt County, Horse Mountain district; with other copper ores in Amador, Calaveras, Napa, Plumas, Riverside, San Bernardino, and Shasta counties.

Copper. Copper is the principal metal produced in the following districts: Alameda County, Alma (Leona Heights); Calaveras County, Campo Seco and Copperopolis; Fresno County, Big Dry Creek and Pollasky; Inyo County, Furnace Creek, Gold Belt, Harrisburg, and Ubehebe; Kern County; Rademacher and Woody; Madera County, Buchanan and Daulton; Mariposa County, Green Mountain, White Rock; Nevada County, Spenceville; Plumas County, Genesee Valley and Taylorsville; San Bernardino County, Bullion, Dry Lake, Ivanpah, Kane Springs, Monument Park, Shadow Mountains, Signal, and Stedman; San Diego County, near Encinitas; Shasta County, Afterthought, Bully Hill, Kennett, Keswick; Tehama County, Tom Head; Tulare County, Portersville. It is of subordinate importance in many other districts. See also Azurite, Bornite, Chalcanthite, Chalcocite, Chalcopyrite, Chrysocolla, Cuprite, and Malachite.

Corundum. Los Angeles County, in drift at San Francisquito Pass; Plumas County, near Meadow Valley; San Bernardino County, in syenite in western part of county.

Cuprite (red oxide of copper). Calaveras County, mined in Copperopolis; Humboldt County, Horse Mountain district; Mono County, Copper Mountain; Napa County, near St. Helena; San Bernardino County, Ord Mountain copper group; Shasta County, Bully Hill mine.

Diamond. Amador County, at Rancheria and Volcano; Butte County, found at Cherokee Flat; Eldorado County, in auriferous gravels at Webber Hill, Placerville and White Rock; Nevada County, at French Corral, and elsewhere.

Diopside. Pink diopside found near San Francisco, cut for gems. Eldorado County, occurs in limestone and serpentine near Mud Springs and at Consumnes copper mine.

Electrum. Placer County, alloy of gold and silver intergrown with sulphides in Ophir mines.

Erythrite (red cobalt ore). Los Angeles County, Kelsey mine, 4 miles north of Azusa; Maripośa County, Josephine mine, Fremont grant.

Feldspar. Kern County, near Woody; Monterey County, mined at Chualar; San Bernardino County, mined at-Saratoga Springs; San Diego County, occurs in quantity at Dehesa and Lakeside; Tulare County, near Porterville and Visalia.

Fluorspar (fluorite). Los Angeles County, Glendora; San Diego County, Palomar Mountain, Oak Grove.

Gabbro (norite). Placer County, dark, coarse-grained, quarried near Penryn, for building stone.

Galena. Inyo County, mined in Cerro Gordo, Chloride Cliff, Darwin, Independence, Lookout, and other districts, argentiferous; Placer County, abundant at Booth, Gold Blossom, and other mines in Ophir region, argentiferous; also in Butte, Mono, Plumas, San Bernardino, and Shasta counties. 
Garnet. Calaveras County, almandite occurs at Bald Point, Mokelumne River; Eldorado County, grossularite in copper ore in Rodgers mine in eastern part of county; Fresno County, grossularite, 35 miles east of Selma; Inyo County, with datolite at San Carlos; Plumas County, Good Hope mine; Riverside County, essonite in tourmaline district near Coahuila; San Diego County; essonite mined for gems at Hercules, Lookout, Prospect, Little Three, and Surprise mines in Ramona district.

Gold. Gold is the predominant metal produced in 307 of the 413 mining districts of the State. The annual production of gold is about $\$ 20,000,000$, of which about $\$ 9,000,000$ comes from placers.

Gold (lode). The mining districts in which gold derived from lodes is the chief metal produced are too numerous to mention. They can be found in United States Geological Survey Bulletin 507, Mining districts of western United States.

Gold (placer). Gold derived from placers has been the principal metal produced in the following districts, many of which, once great producers, havelong been idle: Amador County, Lancha Plana, Middle Bar, Oleta, Pine Grove, and Volcano; Butte County, Bangor, Cherokee, Magalia, Nimshew, and Oroville; Calaveras County, Jenny Lind, Mokelumne Hill, Railroad Flat, and Vallecito; Del Norte County, Crescent City; Eldorado County, Indian Diggings, Newtown, and Pacific; Humboldt County, Blocksburg, China Flat, Hoopa, Klamath, Orick, Orleans, and Weitchpec; Kern County, Goler, Red Rock, and Summit; Los Angeles County, Arrastre Canyon; Mono County, Dogtown Diggings; Nevada County, Lowell Hill, North Bloomfield, and You Bet; Placer County, Damascus and Ralston Divide; Plumas County, Elizabethtown, Laporte, Lights Canyon, Sawpit Flat, and Spanish Ranch; Sacramento County, Folsom; San Luis Obispo County, La Panza; Shasta County, Bayles, Jerusalem Creek, and Redding; Sierra County, American Hill, Brandy City, Church Meadows, Eureka, Indian Hill; Siskiyou County, Cottage Grove, Deadwood, Etna, Forks of Salmon, Gilta, Gottville, Hamburg, Happy Camp, Knownothing, O'Mears, Sawyers Bar, Somes Bar, and Summerville; Stanislaus County, Knights Ferry; Trinity County, almost every one of the 24 mining districts; Tuolumne County, Columbia; Yuba County, Brownsville, Camptonville, Marysville, Smartville, and Wheatland. Placer gold is produced in many other districts, but is subordinate to lode gold or some other metal.

Granite (building). Amador County, quarried 4 miles northeast of Jackson; Eldorado County, Placerville; Fresno County, various shades, blue, gray, and black granite quarried in sec. 13, T. 12 S., R. 22 E:; Madera County, large quarries at Raymond; Nevada County, Grass Valley; Placer County, Loomis Station, Lincoln, Penryn, and Rocklin; Riverside County, Riverside, Temecula, and elsewhere; Sacramento County, Folsom; San Bernardino County, Oro Grande and Victorville; San Diego County, San Diego, Foster, Santee, and Sweetwater; Tulare County, Rocky Point quarry, sec. 8, T. 19 S., R. 27 E.; Tuolumne County, Porterville, Phoenix Lake quarry 7 miles northeast of Sonora.

Granite (crushed stone, paving stone, road material). Alameda County, quarried at Berkeley, Leona Heights, and Newark; Butte County, Oroville; Contra Costa County, Richmond and elsewhere; Humboldt County, Arcata; Imperial County, Hanlon Junction; Los Angeles County, Duarte and Hollywood, and stream bowlders crushed in San Fernando Valley and near Azusa; Marin County, San Rafael; Napa County, Napa; Riverside County; Corona; Sacramento County, Fairoaks and Folsom; San Benito County, Logan; San Bernardino County, Victorville; San Francisco County, San Francisco; Santa Clara County, San Jose; Solano County, Cordelia; Sonoma County, Allison, Santa Rosa, and Sonoma. 
Graphite (plumbago, black lead). Mendocino County, has been quarried in sec. 8, T. 12 N., R. 15 W.; Sonoma County, quarried 10 miles south of Healdsburg, for mineral paint; Tuolumne County, Morgan graphite mine near Columbia. Undeveloped deposits near Los Angeles and Santa Cruz and in San Bernardino and Siskiyou counties.

Gypsum. Widely distributed; reported from Butte, Colusa, Fresno, Kern, Los Angeles, Riverside, San Benito, San Bernardino, San Luis Obispo, Santa Barbara, Tulare, and Ventura counties. Quarried in Fresno County, at Coalinga and Mendota; Kern County, near McKittrick, Bakersfield, and Dudley; Los Angeles County, Palmdale and Los Angeles; Monterey County, King City; Riverside County, Corona; San Bernardino County, Amboy; Santa Barbara County, at Casmalia, as alabaster. Occurs, but not quarried: Kern County, near McKittrick and elsewhere in West Side oil field; Kings County, $5 \frac{1}{2}$ miles northeast of Dudley; Riverside County, extensive beds in Palen Mountains; San Benito County, efflorescent deposit at numerous places on southwest flank of Temblor Range, east of Carrizo Plain, poor grade.

Halite. See Salt.

Hematite (red iron ore). Amador County, large deposit in Ione formation, 2 miles west of Ione, also in Calaveras formation; Eldorado County, Pioneer mine and other places; Madero County, Minarets; Riverside County, Eagle Mountain; San Bernardino County, near Kane Springs, Cima, Silver Lake, and Leastalk, and prospects in Cave Canyon area north of Scott Station; Shasta County, abundant; Sonoma County, large deposit at Noble's ranch. Found in small quantity at various places in Alameda, Alpine, Butte, Del Norte, Inyo, Napa, Nevada, Placer, and Sierra counties.

Hübnerite. Inyo County, reported from Tin Mountain; San Bernardino County, with pyrite and chalcopyrite in quartz veins 5 miles from Barnwell, also near Vontrigger, and at Clark Mountain.

Infusorial earth. Los Angeles County; has been dug on Santa Catalina Island, occurs at Wilmington; Monterey County, has been dug in sec. 4, T. 24 S., R. $10 \mathrm{E}$., and occurs from Santa Lucia Range to Arroyo Seco; Orange County, occurs on Alisos Creek, south of El Toro; San Benito County, has been dug at San Benito and occurs at Hernandez; San Luis Obispo County, occurs at Rancho Corral de los Mulos, in gulch from Oak Flat to Adelaide; Santa Barbara County, has been dug at Lompoc; Shasta County, occurs at Pit River near Hat Creek.

Iron. Iron ore has been produced in the following districts: Calaveras County, Murphy (Esmeralda); Del Norte County, Low Divide and Rattlesnake Divide; Eldorado County, Flagstaff Hill and Latrobe; Madera County, Minarets; Placer County, Hotaling; San Bernardino County, Cave Canyon, Garlic Spring, Iron Mountain, Kelso, Kingston Range, West Lava Beds, and Owl Holes; San Luis Obispo County, Perfumo Canyon and San Luis Obispo; Santa Clara County, Los Gatos; Shasta County, Baird and Shotgun Creek; Siskiyou County, Gazelle; Sonoma County, Cloverdale, and Geyserville; Tehama County, Newville. See also Brown iron ore, Chromite, Hematite, Magnetite, Ocher, Pyrite, and Pyrrhotite.

Jasper. Gem quality, found: Calaveras County, red, brown, and yellow, at Murphy; Los Angeles County, red, white, and bluish, near Acton; Marin County, 1 mile south of Sausalito; Plumas County, west of Meadow Valley; San Francisco County, near Lands End Station; Santa Clara County, reported; Shasta County, near Hart.

Kalinite (alum). Alpine County, efflorescence in Silver Mountain district; Inyo County, Caso Springs; Napa County, Howell Mountain; not mined. 
Kaolin. San Bernardino County, occurs near Calico; San Diego County, at Jamul. Kunzite (lilac spodumene). Riverside County, at Fano mine near Coahuila; San Diego County, lilac and greenish colored crystals have been mined at Pala Chief, Caterina, and Stewart mines near Pala and at the Mack mine near Rincon.

Lapis lazuli. San Bernardino County, north slope of South Fork of Cascade Canyon, $1 \frac{1}{2}$ miles east of Hogback Mountain, 12 miles from' Upland.

Lazulite. Inyo County, occurs in a vein cutting schist in Breyfogle Canyon, Death Valley. The lazulite is confined to a few patches in the vein which can be traced several miles. Mono County, near Bodie.

Lead. Lead is the predominant metal produced in the following districts: Inyo County, Lookout, New Coso, Russ, Saratoga, Swansea, and Union; Orange County, Trabuco Canyon (very little); San Bernardino County, Silver Lake. It is of minor importance in several other districts in other counties. 'See also Galena.

Lepidolite (lithia mica). Riverside County, found with tourmaline in Coahuila Mountains. San Diego County, has been mined as a source of lithia and for ornamental purposes at Stewart mine near Pala; occurs with tourmaline, kunzite, etc., at Pala Chief, Naylor-Vanderburg, Caterina, Tourmaline King, Tourmaline Queen, and other places near Pala; at the Mack and Victor mines near Rincon; in the gem mines of the Ramona district.

Limestone (building). Well distributed over State, chiefly used for lime. Quarried for building, crushed stone, and road metal. Amador County, 4 miles east of Ione; Modoc County, Cedarville; San Bernardino County, Colton; Santa Cruz County, Santa Cruz; Shasta County, Redding.

Limestone (lime). Burned for lime at: Alameda County, Alvardo; Amador County, near Ione; Calaveras County, Vallecito and Camp Seco, in sec. 20, T. 16 N., R. 5 W.; Colusa County, Manzanita; Contra Costa County, near Concord, Oil Canyon, and near Antioch; Eldorado County, at Marble Valley, New Castle, and other places; Kern County, at Tehachapi, Keene, and Sparda; Monterey County, at Davenport; Riverside County, at West Riverside and San Jacinto; in several places in San Benito County; San Joaquin County, at Carnegie; San Luis Obispo County, near Lomon Pelon, Arroyo Grande, and elsewhere; Santa Barbara County, at Lompoc and Batteravia; Santa Clara County, at Black Mountain, 9 miles from Mount View; Shasta County, at Kennett; Siskiyou County, at Callahan and Gazelle; Tuolumne County, at Sonora; Ventura County, at Oxnard; and at other places in other counties.

Iimonite. See Brown iron ore.

Linarite. Inyo County, Cerro Gordo mine.

Magnesite. Many deposits scattered along the Coast Range from Mendocino County to Los Angeles, and few along foothills of the Sierra Nevada; deposits generally occur as veins in serpentine. Fresno County, mined at Kings River, 10 miles east of Sanger; Kern County, development work has been done on deposits intercalated with sandstone and shale at Bissell, 11 miles east of Mohave; Napa County, has been mined in Chiles and Pope valleys; Placer County, mined at Iowa Hill; Riverside County, mined at Winchester; San Benito County, development work has been done at the Sampson claims between the forks of Larious Creek in Diablo Range; Santa Clara County, has been mined near Livermore; Sonoma County, has been mined near Cloverdale; Tulare County, is mined at Tule River, 9 miles east of Porterville, and has been mined at Harker deposit, 4 miles northeast of Porterville.

Magnetite (magnetic iron ore). Has been mined: Alameda County, at Cedar Mountain; Los Angeles County, at Russ Station and near Acton (very little); Placer County, 6 miles north of Auburn, in Hotaling district; San Bernardino County, with hematite near Dale; Shasta County, numerous mines and prospects, mined as flux for Bully Hill smelter. 
Malachite (green copper carbonate). Eldorado County, occurs in Alabaster Cave and Pioneer mines; Inyo County, Wisconsin and Kingman claims; Los Angeles County, in prospects 23 miles northeast of Acton and 3 miles southeast of Little Rock Creek; Madera County, has been mined at Joe Wagner mine, secs. 2 and 35, Ts. 8 and 9 S., R. 18 E.; Mariposa County, mined with other copper ore in Caven Milling Co. mine; Mono County, has been mined with cuprite in Copper Mountain; Riverside County, has been mined in Homestake group, Mount King, and on other claims; San Bernardino County, mined at Copper World mine with other copper ores, occurs in many places; Shasta County, mined with other copper ores at Bully Hill mine.

Manganese minerals. See Psilomelane, Pyrolusite, Rhodonite, and Wad.

Marble. Quarried: Amador County, at Carrara quarry, sec. 29, T. 7 N., R. 12 E.; Butte County, at several places; Calaveras County, Vallecito; Mono County, Topaz; Placer County, at several places; San Bernardino County, several quarries on Slover Mountain, beautiful green brecciated variety 11 miles southwest of Barstow, also east of Oro Grande; Tulare County, dark bluish gray at Porterville, for ornamental and monumental use; Tuolumne County, near Columbia.

Meerschaum. Santa Clara County, has been found in Arroyo de San Jose de Gracia. Mercury (native). In small and variable quantity in all quicksilver mines. Has been mined in Colusa, Eldorado, Fresno, Lake, Monterey, Napa, San Benito, Solano, Sonoma, San Luis. Obispo, Santa Clara, Stanislaus, Trinity, and Yolo counties. See also Cinnabar, Metacinnabarite, and Quicksilver.

Metacinnabarite. Has been found: Fresno County, in New Idria mine; Lake County, Baker mine; Monterey County, Cholame Parkfield mine, 6 miles from Parkfield; San Benito County, Picachos mine. Was important ore: Napa County, in Redington mine, Knoxville; Santa Clara County, New Almaden mine; Yolo County, Reed mine.

Mexican onyx. See Onyx, marble.

Mica (muscovite). Small sheets have been found: Kern County, at Tehachapi; Lassen County, Susanville; Plumas County, Gold Lake; San Bernardino County, Ivanpah; Ventura County, scrap mica has been mined in secs. 12, 13, and 24, T. 17 N., R. $20 \mathrm{~W}$.

Mimetite. Inyo County, found in Cerro Gordo mines. .

Millerite. Common in small quantities in quicksilver mines.

Mineral paint. See Ocher and Sienna.

Molybdenite. Kern County, found frequently in gold region near Havilah; Placer County, abundant in small scales in Golden Stag veins in Ophir region; Riverside County, small quantity in granite quarry near Corona; Shasta County, found at Lamoine.

Natural gas. At depths of a few hundred to a few thousand feet in the Tertiary strata in all the oil fields of the State (see Petroleum), especially in the Midway field and the Buena Vista Hills, western Kern County, locally used for fuel, for lighting, and for conversion into gasoline, or wasted; Sacramento County, occurs at Sacramento; San Joaquin County, in the Quaternary filling of the San Joaquin and Sacramento valleys, near Stockton; Sutter County, at Marysville Buttes; in Solano County, and elsewhere.

Nickel (native). Reported in minute grains in gravel in several counties, but has not been found in sufficient quantity for mining. See Millerite.

Niter. Inyo County, beds in upper part of canyon on both sides of Amargosa River and Willow Creek, and at Tecopah; San Bernardino County, beds in the side of the lower part of Amargosa River canyon, Saratoga, and elsewhere; not mined.

$29123^{\circ}-$ Bull. 585-14-3 
Obsidian. Occurs in regions of Tertiary volcanic rocks; small quantities cut for gem purposes.

Ocher (mineral paint). Has been mined: Calaveras County, near Valley Springs; Napa County, near Calistoga; Nevada County, Spenceville; Riverside County, near Corona; Sonoma County, at Ochre and 10 miles south of Healdsburg; Stanislaus County, Knights Ferry, near Kenglas. Mineral paint occurs in quantity also in Butte, Los Angeles, Placer, Siskiyou, Trinity, and Yuba counties.

Onyx, marble, California onyx, Mexican onyx. Quarried: Glenn County, northwest corner sec. 21, T. 18 N., R. 6 W.; Inyo County, white variegated, yellow and black, between Keeler and Lone Pine, about 5 miles north of Keeler; Kern County, various colors were quarried in sec. 2, T. 9 N., R. 17 W.; Plumas County, large deposits in southwest part of county; San Diego County, gray, black, and white on Coyote Mountain, Colorado Desert; San Luis Obispo County, in sec. 9, T. 32 S., R. 15 E., and 5 miles north of Musick; Siskiyou County, 6 miles south of Berrydale, all colors, principally pure white, in secs. 16, 19, 20, and 21, T. 43 N., R. 12 E.; Solano County, Suisun and Vacaville; Sonoma County, Healdsburg.

Opal. Lake County, transparent variety hyalite has been found 30 miles northwest of Mount Diablo; Modoc County, good opal reported from vicinity of Fort Bidwell; San Bernardino County, in seams, veins, and pockets 25 miles northwest of Barstow, amber yellow and other colors, good stones cut; Siskiyou County, fire opals at Dunsmuir; Tulare County, yellow opal has been found at Yøkohl and Venice Hill, near Visalia, and "chrysoprase opal" has been mined with chrysoprase at Venice Hill and near Lindsay.

Petroleum. Petroleum is the most important mineral product of California, the leading State in the 1912 production of oil. The principal districts in order of importance are the Temblor Range district, western Kern County, including the Midway, McKittrick, Maricopa, Sunset, and other fields; Coalinga district, Fresno County; Kern River district, central Kern County; Puente Hills district, Los Angeles and Orange counties; Santa Maria district, northern Santa Barbara County; Los Angeles district in the county of that name; Lost Hills district and Belridge, northern Kern County; Santa Clara River diatrict, Ventura and Los Angeles counties; Summerland district (now small), southern Santa Barbara County. Production in those districts in 1911 was $81,000,000$ barrels, value $\$ 38,700,000$, from about 6,000 wells. Also numerous indications of oil and prospects in Devils Den, Kreyenhagen, and Kettleman Hills districts, Kern, Kings, and Fresno counties; San-Emigdio district, southern Kern County; southern San Luis Obispo County; Parkfield and Loneoak districts, and west of Bradley, western Monterey County; San Antonio River district, southern Monterey County; Sargent and Moody Gulch districts, Santa Clara County; western San Mateo County; Vallecitos district, San Benito County; Livermore district, Alameda County; western Contra Costa County; Colusa County; southern Humboldt County.

Petzite. Tuolumne County, Norwegian mine, near Tuttleton, Bonanza and Sugarman mines, Sonara.

Platinum. Was recovered in 1911 at dredges in Butte, Calaveras, Merced, Sacramento, and Yuba counties. A few ounces recovered annually at placers in Del Norte, Humboldt, Siskiyou, and Trinity counties. Found also in black sands of Placer, Plumas, San Bernardino, and Shasta counties; in black sands in Kern County at Kane Springs; Nevada County, at Rough and Ready, and Relief Hill; Riverside County, at Holcomb.

Potash. See Niter.

Priceite. See Borax. 
Psilomelane (manganese ore). Alameda County, near Tesla, and formerly mined on Cedar Mountain, 10 miles east of Livermore; Plumas County, in Calaveras formation, 3 miles southwest of Meadow Valley; Riverside County, in the Maria Mountains, northeastern part of county; not mined.

Pumice. Abundant in Mono, Modoc, Lake, San Diego, and San Francisco counties. Many deposits in the Sierra Nevada counties; not worked. Deposit near San Francisco formerly utilized.

Pyrargyrite (ruby silver). Napa County, associated with quicksilver at Calistoga. Pyrite. Alameda County, mined at Leona Heights, Oakland, and shipped to acid works; also at Fruitdale; Amador County, with copper ore at Newton mine; Calaveras County, "Foothill Copper Belt," at Campo Seco and Union mine, Copperopolis, carries gold and silver, disseminated in gold quartz veins throughout the country; Eldorado County, Pioneer mine, carries gold and silver, with copper ores; Fresno County, with galena and zincblende in Fresno copper mines, argentiferous; Inyo County, Chloride Cliff district; Kern County, Butte mine, Randsburg quadrangle, mined for gold; Madera County, disseminated in gold quartz veins; Mariposa County, Cavan Mining \& Milling Co. mine, and Pocahontas mine, with copper ores; Nevada County, was mined at Spenceville with copper ore at Meadow Lake, and in all gold mines of county; Placer County, abundant in veins of Ophir district, auriferous, also in Dairy Farm district; Shasta County, Mountain Copper, Balaklala, Trinity mines, etc., in copper district, carries gold and silver; Siskiyou County, Blue Ledge in Elliott district, carries gold and silver; Tuolumne County, with copper ores in Oak Hill copper mine, carries gold and silver, also disseminated in gold quartz veins.

Pyrolusite (manganese oxide). Alameda County, Cedar Mountain; Calaveras County, occurs, but is not mined, with quartz in mica schists of Calaveras formation 2 miles northeast of San Andreas; Colusa County, prospects in jasper on east flanks of St. John Mountain, near Little Stony; Marin County, on east slope of mountains north of Golden Gate, west of Sausalito; Placer County, reported from foot of Cape Horn Bluff near Colfax; Plumas County, near Meadow Valley and elsewhere; San Bernardino County, with silver ores; San Francisco County, in veins in jasperoid rock; San Luis Obispo County, was mined 5 miles west of San Luis Obispo; Tuolumne County, 2 miles north of Sonora, and small quantities in auriferous gravel near Columbia.

Pyrophyllite. See Agalmatolite.

Pyrrhotite (magnetic pyrite). Del Norte County, has been mined with copper ores in Low Divide district; Fresno County, Fresno copper mines; Mariposa County, Green Mountain mines; Shasta County, with pyrite, chalcopyrite, and zinc in Iron Mountain mine, at Gray Rocks and other copper mines. Common in gold ores in granite of East Lode.

Quartz (cat's-eye). Humboldt County, quartz-actinolite cat's-eyes have been found at Eureka; San Diego County, quartz cat's-eye at Point Loma; San Mateo County, at Pescadero Beach.

Quartz (crystals). Calaveras County, from Green Mountain mine, 2 miles south of Mokelumne Hill; have been shipped to New York and cut for ornamental purposes.

Quartz (rose). Tulare County, 9 miles north of Lemon Cove, and Parson claim, 8 miles southeast of California Hot Springs, near the Kern County line; reported at several other places.

Quicksilver. Quicksilver (mercury) is the predominant metal produced in the following districts: Colusa County, Sulphur Creek; Contra Costa County, Mount Diablo (Ryne); Fresno County, Mexican; Lake County, Baker, Mayacmas, and Sulphur Bank; Monterey County, Dutro and Table Mountain; Napa County, Bella Union, Knoxville, La Joya, and Mayacmas; San Benito County, 
Central Benito, New Idria, and Stayton; Santa Clara County, New Almaden mine, and Guadalupe mine near Los Gatos; San Luis Obispo County, Adelaida, Oceanic, Ocean View, and Rinconada; Santa Barbara County, Los Prietos; Siskiyou County, Beaver Creek; Solano County, St. Johns; Sonoma County, Guerneville and Pine Flat; Trinity County, Altoona; Yolo County, Knoxville. See also Cinnabar and Mercury.

Rhodonite. Plumas County, occurs at Peters near Taylorsville; Siskiyou County, Wheeler prospect, 9 miles north of Happy Camp; Tulare County, near Ward ranch, 3 miles north of Lemon Cave; Tuolumne County, with manganese oxide, 2 miles north of Sonora; and at many other localities.

Road metal (macadam, rubble, and concrete). Various materials have been quarried, as listed below: Alameda County, trap, chert, sandstone, basalt, and jasper; Colusa County, sandstone; Contra Costa County, sandstone, and gravel; Los Angeles County, sandstone; Marin County, sandstone, chert, and siliceous shale; Napa County, tuff; Riverside County, granite, and gneiss; Sacramento County, diorite, and granite; San Benito County, granite; San Francisco County, sandstone; San Joaquin County, chert, and sandstone; Santa Clara County, siliceous shale; Santa Cruz County, limestone; Shasta County, limestone; Solano County, basalt; Sonoma County, basalt; Ventura County, limestone.

Rubellite (red tourmaline). See Tourmaline.

Salt. Evaporated from sea or lake water: Alameda County, at Alvarado, Newark, Mount Eden, Oakland, and Russell; Imperial County, Salton Lake, northwest part of county, works no longer exist owing to flooding of Salton Basin; Inyo County, at Owens Lake, Saline, and Salt Wells Valleys; Los Angeles County, Long Beach; San Diego County, La Punta; San Mateo County, Redwood City and Leslie. About 90 per cent of the State's production of salt is made in Alameda County.

Sand (building). Dug in Alameda County, at Centerville and Niles; Contra Costa County, Antioch; Los Angeles County, Los Angeles, Long Beach, and Puente Largo; Monterey County, Lake Majella and Seaside; Napa County, Napa; San Diego County, Coronado, Lakeside, and San Diego; Sonoma County, Healdsburg; Yuba County, Marysville. Sand is dug in small quantity at many other places and occurs in great abundance in dunes along the coast.

Sand (glass). Dug in Alameda County, at Tesla; Los Angeles County, Palmdale; Monterey County, Lake Majella, near Pacific Grove; San Joaquin County, near Stockton.

Sand (molding). Dug in Alameda County, at Centerville and Decoto; Monterey County, Lake Majella; Orange County, Horseshoe Bend; San Diego County, San Diego.

Sandstone. Quarried: Amador County, 6 miles south of Ione; Calaveras County, Valley Springs; Colusa County, near Sites; Contra Costa County, near Martinez; Kern County, 6 miles south of Tehachapi; Los Angeles County, Chatsworth; Marin County, McNear's Point; Monterey County, Tassajara Springs; Napa County, near Monticello, near Napa, and in Maxwell Canyon, 15 miles from Rutherford; Orange County, Santiago Canyon; Sacramento County, along Consumnes River, fine white to yellow, quarried near Michigan Bar; San Bernardino County, in sec. 7, T. 1 S., R. 1 W.; San Luis Obispo County, Arroyo Grande; Santa Barbara County, Santa Barbara, Mission Canyon, Santa Maria, Santa Ynez; Santa Clara County, Graystone, and 10 miles from Los Gatos; Shasta County, secs. 7 and 18, T. 32 N., R. 4 W., and sec. 29, T. 31 N., R. 5 W.; Siskiyou County, Yreka and Henley; Ventura County, near Brownstone; Yolo County, Putah quarry, 9 miles from Winters; and in small quarries at several other places. 
Sapphire. Los Angeles County, have been found in drift in San Francisquito Pase.

Satelite (gem stone). Tulare County, variety of serpentine associated with asbestos at Venice Hill; put on the market in 1908.

Scheelite. Kern County, small production from Winnie vein, Stringer district; San Bernardino County, Atolia field, $4 \frac{1}{2}$ miles east of Randsburg, largest individual producer in the United States; mixed scheelite and wolframite shipped from vicinity of Nipton.

Serpentine. Amador County, has been quarried 2 miles west of Plymouth, and near Sugar Loaf.

Sienna. Colusa County, secs. 29 and 32, T. 17 N., R. 6 W.

Silver (native). Placer County, Gold Blossom and California mines, Ophir region.

Silver. Silver is the predominant metal produced in the following mining districts: Alpine County, Silver Mountain; Inyo County, Cerro Gordo, Daylight, Deep Springs, Independence, Panamint, and Wildrose; Kern County, Amalie; Mono County, Castle Peak, and Cloverpatch; San Bernardino County, Brightwood, Calico, and Cima. Of minor importance in many other districts. See also Cerargyrite, Electrum, Petzite, Pyrargyrite, and Stromeyerite.

Slate. Eldorado County, large quarry roofing slates at Slatington, near Placerville; Mariposa County, has been quarried at Chili Bar, 4 miles north of Placerville, and in sec. 6, T. 6 S., R. 16 E.; Merced County, quarry opened in 1912 about 11 miles east of Planada.

Smithsonite. Inyo County, found in Cerro Gordo mines.

Soapstone. See Talc and soapstone.

Soda. Inyo County, mined at Owens Lake; Mono County, occurs at Long Valley Hot Springs, and elsewhere in the county; San Luis Obispo County, at Soda Lake, Carriso Plain.

Sphalerite. Fresno County, with galena and pyrite in Fresno copper mines; Placer County, Moore mines and elsewhere in Ophir region; Shasta County, important ore of Shasta district, rich in gold and silver, Mammoth, Bully Hill, Trinity, and other mines; Siskiyou County, small amount with sulphides and oxides of iron and copper in Blue Ledge mine, Elliott district; carries gold and silver.

Spinel. A few crystals were found in Mack mine, near Rincon, San Diego County, and gems of good quality near San Luis Obispo, San Luis Obispo County.

Spodumene.(hiddenite). See Kunzite.

Stibnite (gray antimony ore). Found with cinnabar in Colusa County, at Manzanita mine; Kern County, was mined at San Emigdio Canyon; Napa County, at Manhattan mine; Riverside County, near Corona; San Benito County, at Stayton mine.

Stromeyerite. Inyo County, found near Panamint, in Panamint Range; San Bernardino County, has been found at Silver King mine, Calico.

Sulphur. Kern County, at Mariposa; Lake County, has been mined at Sulphur Bank mine; Shasta County, found also in fumeroles near Lassen Butte.

Talc and soapstone. Amador County, has been quarried at Jackson; Shasta County, occurs near Castella; Tulare County, is quarried 8 miles east of Lindsay; occurs in large quantities in Calaveras, Eldorado, Fresno, Kern, Los Angeles, Marin, Nevada, Placer, Tuolumne, and Yuba counties.

Tetrahedrite (gray copper). Inyo County, with malachite and cuprite in Ulida prospects, Ubehebe district; Placer County, with other sulphurets at Boulder, Gold Blossom, Pine Tree, and Golden Stag mines, Ophir region; Shasta County, carries gold and silver in Afterthought mine, Ingot; sparingly in few mines of Mother Lode in Mariposa and Tuolumne counties.

Tin. See Cassiterite.

Topaz. San Diego County, mined $2 \frac{1}{2}$ miles northeast of Ramona. 
Tourmaline. Fine gems, red and pink (rubellite), blue (indicolite), green (Brazilian emerald), and other colors, mined in Riverside and San Diego counties. Riverside County, in the Coahuila Mountains and San Jacinto Range; San Diego County, Himalaya and other mines near Mesa Grande; Pala Chief, Caterina, Naylor-Vanderburg, Tourmaline King, Tourmaline Queen, Stewart, and other mines near Pala; Mack and Victor mines near Rincon; Little Three, Surprise, Hercules, Daggett, and other mines near Ramona.

Trona (carbonate of soda). Obtained at salt lakes in Inyo, Mono, and San Bernardino counties.

Trap rock. Alameda County, quarried at Berkeley, Oakland, and elsewhere, mostly andesite; Butte County, Oroville; Contra Costa County, Richmond; Napa County, Napa City; Sacramento County, Dredge; San Francisco County, San Francisco; Solano County, Cordelia; Sonoma County, Santa Rosa, Mellita, Penn Grove, and Petaluna. See also Road metal.

Tufa (calcareous). San Luis Obispo County, quarried at Creston, for fireplaces and furnaces. Has been used locally for making cement in Kern, Mono, Santa Cruz, San Luis Obispo, and Shasta counties.

Tuff. Calaveras County, massive rhyolite tuff has been quarried at Mokelumne Hill, Angels, and elsewhere; Eldorado County, near Placerville; San Luis Obispo County, near Los Bevios; Sonoma County, near Santa Rosa, Sebastopol, and Sonoma; Sutter County, near Sutter City; Tehama County, 20 miles west of Red Bluff, and in sec. 12, T. 24 N., R. 6 W.

Tungsten. See Hübnerite, Scheelite, and Wolframite.

Turquoise. Fresno County, Bluish-green turquoise has been found at Taylor's ranch, Chowchilla River; San Bernardino County, about a dozen mines have been worked in the northeastern part of county for gems, ornamental stones, and beads.

Gexite (borate of lime). Inyo County, occurs at Bennett's Wells at the bottom of Death Valley, Furnace Creek, and elsewhere; Kern County, Cane Springs; San Bernardino County, Cave Springs, Willow Springs Lake, Calico district.

Vesuvianite (californite). Butte County, mouth of Feather River near Oroville; Fresno County, found near Selma and Watts Valley, 32 miles east of Fresno City; Riverside County, Crestmore; Siskiyou County, south fork of Indian Creek, 10 miles west of north of Happy Camp and 90 miles from Yreka; Tulare County, near Exeter and Lindsay.

Verde antique (marble). San Bernardino County, large quarry in sec. 28, T. 7 N., R. 2 W., between Victorville and Barstow.

Wad (bog manganese). Tuolumne County, found in few places in limestone and shale near Columbia.

Wolframite. Madera County, small quantity in tungsten-bearing vein near Raymond; Mariposa County, in quartz vein about 12 miles north of Raymond; San Bernardino County, with scheelite near Nipton, Clark district.

Wood (silicified). Sonoma County, occurs at The Geysers.

Zinc. See Smithsonite and Sphalerite.

\section{Cotorado.}

Acanthite. Clear Creek County, small quantity with other silver ores; Dolores County, Enterprise mine, Rico.

Agate. Fremont County, mined at Garden Park 7 miles north of Canon City and at Curio Hill $6 \frac{1}{2}$ miles south of Canon City. Occursalso at many other places.

Alabandite (manganese sulphide). Park County, Quartzville; Summit County, Queen of the West mine, argentiferous, with rhodochrosite.

Almandite. See Garnet.

Altaite (telluride of lead). Boulder County, Gold Hill district, argentiferous and auriferous; has been mined. 
Alunite. Custer County, Knickerbocker Hill; Hinsdale County, San Cristobal quadrangle.

Amalgam (natural). Boulder County, several mines; La Plata County, Neglected mine, 15 miles from Durango.

Amazon stone. Douglas County, Devils Head Mountain; El Paso County, Pikes Peak region and Crystal Park near Manitou Springs; Fremont County, near Canon City, in vicinity of Royal Gorge; Jefferson County, Elk Creek; Teller County, 4 miles north of Florissant.

Amethyst. Has been mined at the following localities: Fremont County, 12 miles northwest of Canon City, 1 mile south of Twelve-mile Park; Gilpin County, Nevada; Gunnison County, Elk Mountains; Hinsdale County, Henson Creek; Las Animas County, Animas Range; Mineral County, at Amethyst, near Creede; Saguache County, Carners Creek.

Anglesite (lead sulphate). Chaffee County, Monarch and Garfield area; Clear Creek County, Georgetown mines; Fremont County, occurs in croppin of of Sedalia mine; Hinsdale County, near Lake City; Lake County, in silver-lead mines at Leadville; Ouray County, Red Mountain; Summit County, Breckenridge. Occurs also in many other places.

Antimony. See Stibnite.

Aquamarine. Chaffee County, Mount Antero; Clear Creek County, near Georgetown; Fremont County, reported from vicinity of Royal Gorge, 5 miles northwest of Canon City; Jefferson County, near Creswell; Park County, Buffalo Mountain.

Argentite (silver glance). Clear Creek County, Silver Plume and Georgetown mines; Dolores County, Newton Hill mine, Rico district; Hinsdale County, near Lake City; Lake County, silver-lead mines at Leadville; Montrose County, Cashin mine; San Miguel County, Marshall Creek, in quartz veins with tetrahedrite, galena, sphalerite, and some silver; Summit County, Montezuma district. Occurs in many other mines in small quantity all through the Sulphide Belt.

Arsenopyrite (mispickel). Gilpin County, of rare occurrence, sometimes highly argentiferous, but of no great economic value; occasionally auriferous. Gunnison County, near Ruby Camp, with proustite, argentiferous. San Miguel County, Mount Wilson, argentiferous, with tetrahedrite.

Asbestos. Boulder County, Allens Park, Mont Alto Park, etc.; Chaffee County, near Maysville; Fremont County, occurs in Sedalia mine, no production. Rio Grande County, near Jasper.

Azurite (blue carbonate of copper). Fremont County, occurs in Red Gulch copper district; Routt County, Hahns Peak, prospected; San Juan County, occurs in ore bodies of Bear Creek.

Barite. Boulder County, many places in mining area; also vein of considerable size near Boulder. Pitkin County, gangue mineral of Aspen district; common in many veins. San Miguel County, occurs 2 miles north of Placerville in veins 2 to 7 feet wide.

Bauxite. Chaffee County, reported from near Buena Vista.

Beryl. Boulder County, near Glendale. Chaffee County, occurs near top of Mount Antero; color varies from light blue to deep aquamarine green; fine gems, worked intermittently. Clear Creek County, Georgetown. Fremont County,

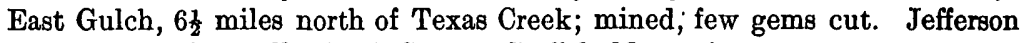
County, near Creswell. Park County, Buffalo Mountain.

Bismuthinite (bismuth sulphide). Boulder County, several mines; Chaffee County, occurs at Granite; Grand County, occurs at Cummins City, North Park; Jefferson County, Guy Hill; Lake County, Leadville district, Highland Mary and other mines; La Plata County, California district, Comstock mine; Larimer County, Big Thompson River; Ouray County, Red Mountain district, Indiana mine. 
Bornite (peacock ore). Larimer County, occurs at Pearl; Moffat County, with vanadium deposits on Blue Mountain; Montrose County, in ore bodies of Cashin mine; Pitkin County, occasionally found in Aspen district; small quantities of ore found in many other places.

Brochantite. Chaffee County, was mined in Monarch minė.

Brown iron ore (limonite, brown hematite). Mined for flux, also for silver. Fremont County, Sedalia mine; Gunnison County, occurs in irregular masses along Tomichi Creek, Whitepine district; Hinsdale County, occurs near Lake City; Lake County, mined in silver-lead mines at Leadville; mostly manganiferous. Pitkin County, common in Aspen district mines; Saguache County, large body interbedded with limestone at Orient; was extensively worked; still producing few thousand tons annually. Summit County has been mined for flux; occurs in thousands of vein cappings.

Calaverite. Boulder County, several mines; Teller County, mined in Cripple Creek district, at Raven mine, Prince Albert mine, and C. O. D. mines. Principal gold mineral of Cripple Creek mines.

Calciovolborthite. Montrose County, found in crevices in sandstone near Uranium post office. See also Volborthite.

Carnotite. Dolores County, reported from points along Rio Dolores; Eagle County, carnotite stains are found on silver and vanadium bearing sandstone on Brush Creek; Moffat County, found on Blue Mountain near Skull Creek, 15 miles north of Rangely, Rio Blanco County; Mesa County, found as an impregnation in sandstone along the Rio Dolores, 40 miles southwest of Gateway; Montrose County, found as an impregnation in sandstone along Roc, La Sal, and Paradox creeks, and in other places; Rio Blanco County, prospects near Coal Creek, 14 miles northeast of Meeker; San Miguel County, near Cedar, along Disappointment Creek, and in adjacent territory, near Placerville in small quantity with roscoelite.

Cement material (Portland). · Boulder County (see also Larimer County). Fremont County, Mississippian and Cretaceous limestone west and east of Front Range, suitable for Portland cement; cement plants at Portland and Concrete, east of Florence; limestone of Niobrara group used. Larimer County, Niobrara limestone from La Porte to 8 miles west of Longmont, Boulder County, suitable for Portland cement; only very narrow band, $10-20$ feet in Niobrara at this point; widens southward into Boulder County. Good limestone occurs at several points in Pennsylvanian east of range and in Carboniferous in Chaffee, Gunnison, and other counties west of range.

Cerargyrite (horn silver). Custer County, Illinois mine, Schanck Hill near Silver Cliff; Eagle County, a silver mineral reported to be cerargyrite occurs in vanadiferous sandstone on Brush Creek; Lake County, common in oxidized ores of silver-lead mines at Leadville; Summit County, occurs near Breckenridge, in small quantities impregnating a rhyolitic rock.

Cerusite (lead carbonate). Clear Creek County, Georgetown area produced considerable quantity; Custer County, has been extensively mined at Silver Cliff; Fremont County, small quantity in Sedalia mine; Hinsdale County, occuis near Lake City; Lake County, mined in silver-lead mines at Leadville; Pitkin County, principal ore of upper zones of Aspen district; Routt County, Hahns Peak region, Tom Thumb mine only producer; occurs also in greater or less quantity with galena ores of Chaffee, Eagle, Summit, and other counties.

Chalcanthite (bluestone). In Clear Creek County and in adjacent parts of Summit County, in considerable quantities in veins, with tetrahedrite, galena, chalcopyrite, sphalerite, barite, etc.; San Juan County, Silver Pick and Special mines. 
Chalcedony. Grand County, Willow and Corral creeks, near old salt works, South Park; Park County, Thirty-one Mile Mountain, west of Guffey, blue chalcedony; occurs also at several localities in surface gravels of Gunnison, Logan, Morgan, Ouray, Rio Grande, Saguache, and Weld counties.

Chalcocite (copper glance). Clear Creek County, occurs near Idaho Springs; Chaffee County, near Poncha Springs; Fremont County, Gem mine; Larimer County, occurs at Pearl; Montrose County, rich ore at Cashin mine, La Sal Creek, carries silver; Ouray County, has been mined at Ironton, argentiferous, massive; Routt County, seen at few places; San Miguel County, occurs with siderite and small crystals of sphalerite; argentiferous. Also in sandstone with matrix of calcite (argentiferous); common at other mines.

Chalcopyrite (copper pyrites). Found in small quantities in nearly every camp in Sulphide Belt. Clear Creek County, in mines northwest of Idaho Springs; carries gold and silver. Dolores County, not abundant in Rico district; small amount in Newman, Silver Swan, and other mines. Gilpin County, occurs with uranium in Wood, Kirk, Belcher, and German mines near Central City. Gunnison County, Blistered Horn, Tincup district, Sandy Hook and Gold Links, Gold Brick district, and elsewhere; gold and silver values. Hinsdale County, occurs near Lake City; Larimer County, occurs at Pearl; Pitkin County, Aspen district; Routt County, occurs at Hahns Peak; Sản Juan County, Monticello lode, Silverton district, carries gold; also in Bear Creek district, carries gold and silver. Summit County, in veins of Montezuma district. Common in other places.

Chrysocolla (silicate of copper). Custer and Saguache counties, Sangre de Cristo Mountains; undeveloped. Jefferson County, Pine Grove and Bear Creek; Lake County, Leadville.

Cinnabar. Boulder County, in small quantity at several points; La Plata County, in sandstone; said to be rich; undeveloped. Several small finds in southern part of State.

Clay (brick). Dug at the following places: Boulder County, Boulder, Trilby; Conejos County, Alamosa; Denver County, Argo and Denver; Douglas County, Parker; El Paso County, Colorado City, Colorado Springs, and Subburbs Springs; Fremont County, Canon City and Florence; Garfield County, Glenwood Springs and Rifle; Hinsdale County, Lake City; Jefferson County, Golden and Hall; Kit Carson County, Burlington; La Plata County, Bell Spur; Larimerer County, Fort Collins and Fossil Creek; Las Animas County, Trinidad; Mesa County, Grand Junction; Moffat County, Craig; Montrose County, Montrose; Morgan County, Brush and Fort Morgan; Otero County, La Junta and Fowler; Prowers County, Lamar; Pueblo County, Pueblo; Rio Grande County, Monte Vista; Teller County, Cripple Creek; Weld County, Greeley; Yuma County, Wray and Yuma.

Clay (fire). El Paso County, Colorado City and De Wit Ranch, 4 miles from Colorado Springs; Fremont County, Canon City; Garfield County, plastic clay from Dakota sandstone near Glenwood Springs; has been mixed with crushed quartz and made into bricks for coke ovens at Cardiff; Jefferson County, Golden.

Clay (stoneware). Jefferson County, Golden; burns white, red, and buff.

Coal (anthracite). Gunnison County, mined at Crested Butte; coal-bearing area is about 25 square miles. Pitkin County, has been mined at Crystal City; Routt County, Yampa coal field; small local areas of good coal; not mined yet.

Coal (bituminous and subbituminous). Book Cliffs, Canon City, Durango, Grand Hogback, Grand Mesa, Raton, and South Platte are the principal coal fields.

Book Cliffs field, Mesa and Garfield counties.-There are about 360 square miles of workable, medium grade bituminous coal. The 4 important mines are: 
Cameo (8-foot bed), Palisade (6-foot bed), and Book Cliff (7-foot bed), in Mesa County, and Carbonera (7-foot bed), in Garfield County.

Canon City field, Fremont County.-There are about 22,400 acres of high-grade noncoking bituminous coal. The average thickness of beds is 3 to 6 feet. Mining for domestic trade is extensive.

Colorado Springs field, El Paso County.-A good quality of subbituminous coal occurs in 3 beds of 1 to 2 feet in thickness. There are 12 mines in operation.

Danforth Hills field, Rio Blanco and Routt counties.-The workable coal in 10 beds has a minimum thickness of 73 feet. There are about 159,700 acres of workable noncoking bituminous coal. Mined for local use.

Durango field, La Plata and Archuleta counties.-There are 3 beds, 3, 4, and 6 feet thick, of excellent coking bituminous coal, all of which are mined. There are also several workable beds of bituminous coal.

Glenwood Springs field, Garfield and Pitkin counties.-There are 9 beds mined, having a total thickness of about 96 feet. It is a good grade of bituminous coal, noncoking in Garfield County, but coking in Pitkin County.

Grand Hogback field, Rio. Blanco and Garfield counties.-There are about 41,720 acres of workable coal land. The 7 beds mined have a total thickness of from 105 to 108 feet. The coal is noncoking bituminous. Mining is rather extensive.

Grand Mesa field, Gunnison, Delta, and Mesa counties.-There are about 550 square miles of workable bituminous coal, some of which is of coking quality. The field is divided into the Palisades district containing 11 feet of workable coal beds, the Rollins district containing 15 feet of workable coal beds, and the Somerset district containing 65 feet of workable coal beds. Of these the Somerset is the most important, producing most of the coal shipped.

Lower White River field, Rio Blanco, Routt, and Moffat counties.-A good grade of bituminous coal is mined in small quantities for local use.

North Park field, Jackson County.-There are about 75,000 acres of possible subbituminous coal land. The 2 beds mined have average thicknesses of 10 and 50 feet. One mine is shipping coal and six are mining for local use.

Raton Mesa (Trinidad) field, Las Animas and Huerfano counties.-About 1,115 square miles of high-grade bituminous coal. There are three series of beds, of which the lower is the most important; average thickness of beds is 6 feet; coal in the southern part of the area is largely consumed in the manufacture of coke. It is the most important coal field in Colorado, producing 62 per cent of the total annual tonnage.

South Park field, Park County.-There are 3 beds 5, 6, and 8 feet in thickness, which were formerly mined; the mines have all been abandoned.

South Platte field (including Denver Basin and Boulder districts).-This field extends from below Denver to near the Wyoming line, covering parts of Douglas, Elbert, Arapahoe, Jefferson, Adams, Morgan, and Weld counties. The coal is of subbituminous grade. Mining is extensive in Boulder County. Beds mined vary from 2 to 15 feet in thickness.

Yampa field, Routt County. - Workable coal area is estimated at 1,200 square miles of bituminous coal. The northern part of the field contains many thick beds of subbituminous grade. The coal is mined for local use at Craig, Hayden, Pool, and Eddy.

Cobalt. See Erythrite and Smaltite:

Columbite. Fremont County, near Canon City; Jefferson County, Turkey Creek; Teller County, several points in Pikes Peak region.

Copper (native). Dolores County, California prospect near head of Iron Draw; Jefferson County, near Golden; Montrose County, has been mined and shipped from Cashin mine; Park County, Handcart Gulch; Routt County, in veins near Columbine, Hahns Peak region. Occurs also at many other places. 
Copper minerals. Copper is the predominant metal produced in the following districts: Chaffee County, Cleora and Sedalia; Fremont County, Canon City, Cotopaxi, Red Gulch; Grand County, Harmon; Huerfano County, Huerfano (Malachite); Jackson County, Pearl; Jefferson Ccunty, Evergreen; Larimer County, Empire and Steamboat Rock; Mesa County, Unaweep; Montrose County, La Sal; Ouray County, Red Mountain; Routt County, Copper Ridge, Elkhorn, Oak Creek, Rock Creek, Spring Creek; Teller County, East Beaver, 8 miles south of Rosemont. Of minor importance in many other districts. See also Azurite, Bornite, Brochantite, Chalcocite, Chalcopyrite, Chrysocolla, Covellite, Cuprite, Enargite, Malachite, Melaconite, Tennantite, and Tetrahedrite.

Cordierite. Fremont County, found 6 miles from Canon City.

Corundum. Chaffee County, occurs in crystals at Calumet; Clear Creek. County, occurs in Saxon Mountain near Georgetown.

Cosalite. La Plata County, several mines, including Comstock mine near Parrott City; Ouray County, Gladiator and other mines.

Covellite. Montrose County, rich ore at Cashin mine, La Sal Creek; carries silver. Rio Grande County, Summitville; San Juan County, several small finds.

Cuprite. Chaffee County, near Poncha Springs, mined at Lily mine near Garfield. Fremont County, Sedalia mine; Jefferson County, Bear Creek and Pine Grove; Montrose County, occurs in ores of Cashin mine, La Sal Creek; Pitkin County, in oxidized ores of Aspen district. . Mined also in many other places.

Cryolite. El Paso County, occurs at St. Peters Dome, Pikes Peak district.

Embolite (chlorobromide of silver). Lake County, near Leadville; of frequent occurrence, chiefly in a siliceous iron ore in cavities and on fissure planes.

Enargite. Clear Creek County, small quantities occur; Gilpin County, has been mined at Russell Gulch, particularly at Powers mine; argentiferous; with pyrite and fluorite. Gunnison County, small quantities in several mines; Ouray County, several mines; Rio Grande County, Summit district; both auriferous and argentiferous; often carries free gold; with pyrites only, in quartz matrix. San Juan County, has been mined on Red Mountain; argentiferous, with tetrahedrite and galena in quartz veins.

Epidote. Chaffee County, Calumet, fine crystals; Fremont County, occurs near Canon City; Gunnison County, occurs on Italian Mountain.

Erythrite. Gunnison County, Tercelli Mountain.

Ferberite. Boulder County, Nederland, ị veins cutting granite, pegmatite, and gneiss; mined. Clear Creek County, small finds reported. Gilpin County, northern part; mined.

Fluorspar (fluorite). Boulder County, mined at Jamestown, and shipped; Chaffee County, at Mount Antero; Clear Creek County, at Georgetown; Custer County, has been mined at Rosita; Dolores County, abundant gangue mineral in Blackhawk mine and prospects of Silver Creek, Rico region; Douglas County, at Devils Head; El Paso County, in quantity at Elk Creek, near Cheyenne and Pikes Peak; mined at Duffields. Gilpin County, in Gregory and Russell districts; Gunnison County, in lead ores near Sherrod; Jefferson County, mined at Evergreen, and shipped; Mineral County, mined at Wagon Wheel Gap; Park County, in northern part of Halls Valley; shipped from Jefferson. San Juan County, in quartz veins in Poughkeepsie Gulch; San Miguel County, in Telluride district; Teller County, Cripple Creek, with gold tellurides.

Freieslebenite. Gunnison County, on Augusta Mountain.

Fuller's earth. Chaffee County, low grade near Salida.

Gadolinite. Douglas County, mined on Devils Head Mountain.

Galena (argentiferous auriferous lead ore). Boulder County, in small quantity in tungsten-bearing veing of Boulder district; Chaffee County, in Alpine, Chalk 
Creek, and Cottonwood districts; Clear Creek County, in mines 6 miles southwest of Idaho Springs; carried gold and silver. Dolores County, important ore mineral of Rico district, abundant in Enterprise mine, also Union, Carbonate, and Newman mines; argentiferous. Eagle County, in Red Cliff (Battle Mountain) district. Fremont County, at Cotopaxi. Gilpin County, reported with uranium in Wood, Kirk, and other mines near Central City. Gunnison County, mined at Blistered Horn, Tincup district; Sandy Hook and Gold Links, Gold Brick district, and elsewhere; Elkhorn and Timichi districts, carries gold and silver. Hinsdale County, Galena district, 5 miles west of Lake City. Lake County, important ore at Ohio mine; carries silver and gold; also in silver-lead mines at Leadville. Park County, Horseshoe district, 7 miles west of Garo, on easterly slope of Mosquito Range. Pitkin County, common silver-bearing ore in Aspen district; Mollie Gibson and other mines. Routt County, mined in Slavonia district and at Columbine and near Hahns Peak (Minnie D. and Tom Thumb mines); carries gold. Summit County, in veins of Montezuma district. Teller County, in small quantities in many mines of Cripple Creek district. Occurs in many other mines.

Garnet. Chaffee County, on Ruby Mountain, east side of and across Arkansas River from Nathrop; spessartite variety in rhyolite at Nathrop; large brilliant crystals near Salida; worked intermittently. Fremont County, Grape Creek, 2 miles southwest of Canon City; almandite variety; handsome gems cut; occurs also at Sedalia mine. Gunnison County, grossularite variety on Italian Mountain.

Gas, natural. See Natural gas.

Gold (lode). Predominant metal produced in the following districts: Boulder County, Central, Gold Hill, Grand Island, Magnolia, Sugarloaf, and Ward; Chaffee County, Granite, Riverside, and Turret; Clear Creek County, Argentine, Idaho Springs, Lincoln, and Upper Union (Empire); Conejos County, Ute (Platoro), 45 miles southwest of Monte Vista; Dolores County, secondary importance in Lone Cone and Pioneer (Rico) districts; Eagle County, Fulford and Holy Cross; Fremont County, White Horn, 26 miles northeast of Salida; Gilpin County, Central City, Independence, and Pine; Grand County, Grand Lake (Wolverine) and La Platte; Gunnison County, Box Canyon, Cebolla, Cochetopa, Gold Brick, Tincup, and White Earth; Hinsdale County, Park (Sherman); Huerfano County, La Veta; Lake County, Twin Lakes, minor importance at Leadville; La Plata County, California, Needle Mountains (Florida); Montezuma County, East Mancos; Ouray County, Imogene Basin (Camp Bird), Sneefles, Uncompahgre; Park County, Buckskin, ConsolidatedMontgomery, Hartsel, Mosquito, Tarryall; Rio Grande County, Decatur, Embargo, Summitville; Routt County, Hahns Peak; Saguache County, Baca Grant (Crespone); San Juan County, Animas (Silverton), Eureka; San Miguel County, Iron Spring (Ophir), Lower San Miguel, Upper San Miguel (Telluride); Summit County, Breckenridge, Frisco, Swan River; Teller County, Cripple Creek, from reduction of tellurides. See also Amalgam, Calaverite, and Petzite.

Gold (placer). Produced in the following districts: Chaffee County, Granite; Clear Creek County, Lincoln; Costilla County, Greyback and Plomo; Eagle County, Holy Cross (Eagle River); Jefferson County, Golden; Lake County, Twin Lakes, 9 miles northwest of Granite; Moffat County, Lay (Jackrabbit); Park County, Monquetto and Tarryall; Routt County, Hahns Peak; San Miguel County, Lower and Upper San Miguel (Placerville and Telluride); Summit County, Breckenridge, Swan River. Produced in minor quantity in several other districts.

Grahamite. Grand County, near Granby. 
Granite. Chaffee County, quarried at Salida and Turret; Clear Creek County, quarried at Silver Plume; Fremont County, quarried at Cotopaxi and Texas Creek; Gunnison County, fine granite at Aberdeen quarries; State capitol built from it. Jefferson County, quarried at Stone Spur and Buffalo Creek; Larimer County, at Masonville and other points; United States mint at Denver built from Masonville quarry.

Graphite. Chaffee County, good quality amorphous graphite, mined near Turret; originally coal, metamorphosed by igneous intrusion. Gunnison County, occurs $3 \frac{1}{2}$ miles north of Pitkin; branches of Quartz Creek; impure; in quartz veins $2 \frac{1}{2}$ feet thick. Las Animas County, occurs near Trinidad. This is carbonate from coking coal by igneous intrusion.

Greenockite. Reported with zinc ores at Leadville, Park City, and elsewhere.

Grindstones. Gunnison County, Gunnison.

Gypsum. Custer County, occurs near Arkansas River; Delta County, west side of Grand Canyon of Gunnison River, into Montrose County; Dolores County, as gangue mineral, Rico region, and elsewhere; Eagle County, at Ruedi; worked recently; occurs along Grand and Eagle rivers. El Paso County, has been worked extensively near Perry Park and near Colorado City; Fremont County, Coaldale and Canon City; Jefferson County, opened near Mount Morrison; Larimer County, worked extensively at Arkins near Loveland; thick bed at Owl Canyon and on Sand Creek east of Boxelder, and at several other localities. Montrose County, several places.

Hematite (red iron ore). Gunnison County, prospects near Whitepine and north of Iola Station; Lake County, has been mined at Breece iron mine, Breece Hill, near Leadville; very pure ore; large irregular deposits in porphyry. Pitkin County, very common in mines of Aspen district. Occurs at many other places in State.

Hessite (telluride of silver). Boulder County, Goldhill district, important ore; Eagle County, Redcliff; La Plata County, occasionally important, has been mined; Hinsdale County, Hotchkiss mine. .

Hinsdalite. Hinsdale County, Golden Fleece mine, near Lake City.

Huibnerite. Ouray County, Royal Albert vein, Uncompahgre district; mined. San Juan County, several mines near Silverton and Gladstone; has been mined.

Infusorial earth. Denver County, small bed at West Denver; not mined.

Iron. Chaffee County, predominant metal in South Arkansas district. Sce also Brown iron ore, Hematite, Magnetite, Marcasite, Pyrite, Pyrrhotite, and Siderite.

Jet. Las Animas County, Wet Mountain valley, Trinchera Mesa.

Kaolin. Occurs in thousands of mines as gouge, as at Durango Girl mine, on east slope of Lewis Mountain La Plata County. Deposits are known near Silver Cliff, Parkdale, Salida, Newcastle, etc., but quality and extent are not known.

Krennerite. Teller County, Cripple Creek.

Lead. Lead is the predominant metal produced in the following districts: Chaffee County, Alpine, Chalk Creek, Cottonwood; Clear Creek County, Trail, 6 miles southwest of Idaho Springs; Custer County, Spaulding, 14 miles southwest of Florence; Gunnison County, Elk Mountain, Tomichi; Hinsdale County, Galena, 5 miles west of Lake City; Lake County, California (Leadville); Park County, Horseshoe, 7 miles west of Garo; Pitkin County, Columbia, Frying Pan, Roaring Fork (Aspen); Routt County, Slavonia, 40 miles north of Steamboat Springs; Saguache County, Blake (Kerber Creek); Summit County, Montezuma (Snake River). Lead is produced but is less important in many other districts. See also Altaite, Anglesite, Cerusite, Cosalite, Galena, Massicot, Minium, and Pyromorphite.

Limestone. Chaffee County, limestone quarried atGarfield and Newett;Boulder and Larimer counties, limestones of Lykins, Morrison, and Niobrara formations 
burned for lime along foothills of northern Colorado. Douglas County, has been quarried at Silica for lime; El Paso County, Manitou, for lime; Fremont County, quarried at Canon City and Calcite for crushed stone; Jefferson County, quarried at Mount Morrison; La Plata County, at Rockwood; Larimer County, at Ingleside, for sugar refining; Pitkin County, burned for lime at Thomasville; Pueblo County, quarried at Lime near Pueblo. Abundant in many counties.

Limonite. See Brown iron ore.

Magnetite (magnetic iron ore). Chaffee County, has been mined in Arkansas Hills, 9 miles from Salida; Costilla County, interbedded with limestone at Grayback Gulch, 5 miles from Placer station; Dolores County, with chalcopyrite in Magnet and Eagle prospects; has been mined for flux. Fremont County, on Iron Mountain near Pine Creek; titaniferous. Gunnison County, prospects on Saguache Mountains and in Cebolla district; Pitkin County, prospects in Elk Mountain divide, 6 miles south of Ashcroft.

Malachite (green copper carbonate). Occurs in hundreds of places, among them: Fremont County, mined at Sedalia mine; Montrose County, in ores of Cashin mine, La Sal Creek; Routt County, prospects on Hahns Peak; San Juan County, in Bear Creek district.

Manganese. Eagle County, considerable manganiferous silver ore mined at Iron Mask mines, Gilman; Lake County, large output from lead-silver mines of Leadville district. See also Alabandite, Psilomelane, Pyrolusite, and Rhodochrosite.

Marble. Boulder County, small deposits; Chaffee County, near Salida, Calumet, Monarch, and Mayville; Gunnison County, quarried at Marble and along Yule Creek; Larimer County, small beds west of Fort Collins; Pitkin County, quarried at Crystal City; also in other localities.

Marcasite. Occurs in hundreds of mines, as in Routt County, in veins of Hahns Peak district; San Juan County, in ore bodies in Bear Creek district.

Massicot (oxide of lead). Occurs in many mines. Dolores County, with galena ores near Rico; argentiferous; Lake County, at Leadville, and elsewhere. Sạ Miguel County, with galena in upper San Miguel region; argentiferous.

Melaconite. Pitkin County, thin coatings in Aspen district mines.

Mimetite. Chaffee County, Monarch and Garfield district.

Minium. Lake County, Leadville; Pitkin County, in oxidized ores of Aspen district, and at other places; San Miguel County, Telluride.

Molybdenite (sulphide of molybdenum). Chaffee County, small quantities near Buena Vista and other places. Gunnison County, 2 miles from Pitkin in quartz veins; possible source of molybdenum. Lake and Summit counties, Fremont Pass; promising. San Juan County, near Silverton. Teller County, in Cripple Creek district; occurs also at many other places.

Monazite. Chaffee County, in black sands at Buena Vista; Costilla County, in San Luis Valley; Routt County, at Timber Lake.

Mica (muscovite). Clear Creek County, reported from Idaho Springs; Fremont County, mined near Canon City and at Micanite; Jefferson County, at Morrison; Larimer County, on Buckhorn Creek; Mesa County, has been mined 8 miles south of Grand Junction.

Natural gas. Boulder County, considerable quantity produced from Boulder field; Costilla County, near Mosca and other places in San Luis Valley; Delta County, occurs in oil shales of Green River formation on head of Muddy Fork; Fremont County, considerable quantity produced from Florence field; Pitkin County, "blowers" in middle Cretaceous shales at Coal Basin; undeveloped; natural flow limited. Pueblo County, Nepesta.

Niccolite. Custer County, small quantity at Silver Cliff; Fremont County, occurs at Gem mine, Grape Creek Canyon; in dolomite, with bornite, and rarely with native silver. 
Nicholsonite. New zinc mineral found in some quantity at Leadville.

Opal. Opal of inferior quality is found at several places: Buffalo Peaks, Cripple Creek, Idaho Springs, Ute Creek.

Petroleum. Boulder County, Boulder oil field, 3 miles northeast of Boulder; highgrade light illuminating oil. Fremont County, south of Florence, field 10-20 square miles. Mesa County, small wells near De Beque. Routt County, Yampa field; used as lubricant. Rio Blanco County, Rangely oil district. Petroleum has been found also in Archuleta, Pueblo, and Moffat counties.

Petroleum (oil shales). Delta and Garfield counties, extensively developed, geologically, constituting the greater part of the rocks of the Green River formation (Eocene). In the Book Cliffs, the richer rock occurs in bands, about 50 in number, from 2 to 15 feet thick. Destructive distillation gives from 15 to 35 per cent of condensed hydrocarbons, and 10 to 20 per cent of gas. Prospective source of lubricating oil.

Petzite (telluride of gold and silver). Found in many mines in Colorado in Boulder, Clear Creek, Gunnison, and Hinsdale counties. San Juan County, most valuable ore in Gold Bug and other mines in Bear Creek district.

Phenacite. Chaffee County, occurs at Mount Antero. El Paso County, occurs in Crystal Park, 2 miles southwest of Manitou; has been mined at Pikes Peak; gem stone. Teller County, near Florissant.

Pitchblende. Clear Creek County, Jo Reynolds mine. Gilpin County, mined in Kirk, Wood, German, Calhoun, and Belcher mines, near Central City; reported in small quantity in other places.

Platinum. Chaffee County, occurs in black sands of Buena Vista; Clear Creek County, Centennial mine, Georgetown; Pitkin County, Aspen; Saguache County, Liberty; San Miguel County, Telluride, in small quantities.

Polybasite. Clear Creek County, mines at Georgetown and Silver Plume. Dolores County, considerable quantity at Newman Hill mine, Rico region. Ouray County, Yankee Girl mine; Pitkin County, in Molly Gibson and Smuggler mines, Aspen district; San Juan and San Miguel counties, occurs in Red Mountain district. San Miguel County, Marshall basin; occurs in quartz veins with pyrargyrite, sphalerite, and stephanite; not uncommon in Mendota mine.

Proustite (ruby silver, light). Dolores County, Newman Hill mine, Rico district; Gunnison County, small quantity with arsenopyrite in Ruby district; Ouray County, at Yankee Girl mine; Routt County, in veins of Hahns Peak district; San Miguel County, at Sheridan mine; occurs also in many other Colorado mines.

Psilomelane. Chaffee County, small quantity near Garfield; Custer County, occurs south of Round Mountain, at Silvercliff.

Pyrargyrite (ruby silver, dark). Clear Creek County, in Georgetown mining district; Dolores County, reported from Newman Hill mine; Gilpin County, rare near Central City; Gunnison. County, in Ruby district; Hinsdale County, near Lake City; Ouray County, in Sneffle's district; Routt County, in Hahns Peak region; San Miguel County, in Marshall Creek basin; Summit County, in Montezuma mining district.

Pyrite. Pyrite is found in nearly every county along the Rocky Mountains: Boulder County, in Ward district; Clear Creek County, in Georgetown mining district; gold-silver ore. Dolores County, important ore of Rico district; carries small quantities of gold and silver; mined at Enterprise, Union, Carbonate, and other mines. Fremont County, mined at Sedalia mine for gold. Gilpin County, abundant; important gold ore. Gunnison County, in quartz at Sandy Hook and Gold Links mines; carries gold. Hinsdale County, near Lake City. Lake County; mined at silver-lead mines, Leadville. La Plata County, Neglected mine, 15 miles from Durango. Larimer County, at Pearl. Ouray County, in mines along Uncompahgre River, between mouth of Dexter Creek 
and Ouray; contains gold and silver; common in other places. Pitkin County, original sulphide of Aspen district ore bodies; mined for silver. Rio Grande County, in Summit district. Routt County, common vein mineral of claim on Farwell Mountain, Hahns Peak region. San Juan County, Silverton district; mined at Ohio mine; common at many mines. San Miguel County, common.

Pyrolusite (black oxide of manganese). Gunnison County, occurs in Steuben Valley, 6 miles southwest of Gunnison, and in Cebolla Valley; Hinsdale County, occurs near Lake City.

Pyromorphite. Lake County, occasionally in oxidized ores of Leadville district, silver-lead mines.

Pyrrhotite (magnetic iron pyrites). Chaffee County, Monarch and Garfield area; Jefferson County, Malachite mine, and many other places; San Juan County, has been mined in Needle Mountains in limited quantity; auriferous.

Quartz. Jefferson County, mined from veins in foothills near Golden, and used in manufacture of fire bricks at Golden.

Quartz (moss agate, silicified wood, and smoky quartz). Very common and much used in the manufacture of jewelry, ornaments, etc. Smoky quartz occurs near Pikes Peak, and is known in trade as "smoky topaz" or "cairngorm stone."

Quartz (rose). Fremont County, 6 miles north of Texas Creek; some mined as gems. Jefferson County, Floyd Hill, Bear Creek, etc. Larimer County, large body in granite 25 miles west of Fort Collins; cut as gem stone.

Quicksilver. Boulder County, occurs in Magnolia district. La Plata County, Ruby claim south of Cumberland Peak. See also Amalgam and Cinnabar.

Rhodochrosite. Boulder County, Ward district; Dolores County, gangue mineral of Newman Hill and Enterprise mines, Rico region; Lake County, Alicante; Summit County, Peru district.

Roscoelite. Boulder County, sparingly in gold veins; Rio Blanco County, reported to occur along Coal Creek, near Meeker; San Miguel County, large deposits at Newmire and Placerville.

Rutile. El Paso County, occurs near St. Peters Dome, Pikes Peak district.

Sand (building). Dug at many places; Denvet County, Denver; Fremont County, Canon City; La Plata Courty, Animas City and Durango; Pueblo County, Pueblo; Rio Grande County, Monte Vista.

Sand (molding). Dug at Denver and Pueblo.

Sandstone. Sandstone is quarried at Boulder County, Boulder and Lyons; Delta County, Montrose; Douglas County, Castle Rock; El Paso County, Colorado City; Fremont County, Canon City; La Plata County, Durango; Larimer County, Arkins, Stout, and other places; Pueblo County, Pueblo; Rio Grande County, Del Norte; Routt County, Steamboat Springs.

Sandstone (asphaltic). Grand County, Upper Willow Creek, sec. 24, T. 4 N., R. $77 \mathrm{~W}$.

Scheelite. Boulder County, small quantities occur with ferberite in the Boulder district; Lake County, Golden Queen mine; San Juan County, near Silverton and Gladstone with hübnerite.

Serpentine. Gunnison County, occurs near Gothic; Park County, occurs in Buckskin Gulch, a mottled rock, largely calcite, but deeply colored by true serpentine; prospective use as ornamental stone.

Siderite. Gunnison County, occurs with magnetite and hematite in Cebolla Valley, near Powderhorn. Jefferson County, occurs near Bear Creek; zinciferous. Pitkin County, occurs in iron ore near Ashcroft, Taylor Peak district.

Silver. Predominant metal produced in the following districts: Chaffee County, La Plata, Monarch-Garfield; Clear Creek County, Georgetown, Jackson, Montana; Custer County, Hardscrabble (Rosita, Silver Cliff); Dolores County, Lone Cone and Pioneer (Rico); Eagle County, Battle Mountain (Red Cliff); Gunnison 
County, Quartz Creek, Rock Creek, Ruby; Hinsdale County, Lake (San Cristobal); Mineral County, Sunnyside (Creede); Park County, Halls Gulch and Sacramento; Pitkin County, Lincoln; Saguache County, Crystal Hill; San Miguel County, Mount Wilson; Summit County, Peru, Tenmile (Kokomo). Silver is of minor importance in many other districts. See also Acanthite, Amalgam, Calaverite, Cerargyrite, Embolite, Hessite, Petzite, Polybasite, Proustite, Pyrargyrite, Stephanite, Stromeyerite, and Sylvanite.

Silver (native). Boulder County, occurs in Caribou mine and Up-to-Date property, and mines of Ward district, especially the White Raven; Clear Creek County, small quantity of wire silver found in Georgetown district; Dolores County, reported from Enterprise and Puzzle mines; Gunnison County, occurs in Ruby district and near Gothic; Hinsdale County, in Galena district; Lake County, occasionally found in silver-lead mines at Leadville. La Plata County, occurs along Bear Creek, usually with galena, tetrahedrite, and stephanite; Montrose County, Cashin mine, La Sal Creek; Pitkin County, irregular wires and masses of silver in Molly Gibson and Smuggler mines, Aspen district; Teller County, in small quantities in many mines of Cripple Creek district.

Smaltite (gray cobalt ore). Gunnison County, occurs near Gothic in calcite gangue, associated with small quantities of erythrite and native silver.

Sphalerite (zinc blende). Chaffee County, Monarch and Garfield area; Clear Creek County, Georgetown and Silver Plume mines, Idaho Springs district; carries silver. Dolores County, with galena and chalcopyrite in Rico district; abundant in Newman Hill silver ores and Sambo mines; mined for zinc alone in $\Lambda$ tlantic Cable mine. Fremont County, Sedalia mine; Gilpin County, a common mineral usually argentiferous, sometimes highly so, and occurring associated with pyrite, chalcopyrite, galena, and tetrahedrite; has been mined for silver. Gunnison County, Blistered Horn, Tincup district; Sandy Rock and Gold Links, Gold Brick district, and other mines; carries gold and silver. Hinsdale, La Plata, Ouray, and San Miguel counties, a very common, usually argentiferous mineral; common associate, galena; frequently with chalcopyrite, tetrahedrite, or pyrargyrite. Jefferson County, Malachite mine. Lake County, silver-lead mines at Leadville. San Juan County, in ores of Ohio mine near Whitecross; mined for gold and silver; also mined at other places. Found also in other mining counties.

Spinel. Fremont County, occurs at Sedalia mine.

Stephanite (brittle silver). Clear Creek County, frequently associated with other silver-bearing minerals; Dolores County, reported from Newman Hill mine, Rico region; Gunnison County, mined at Red Jacket; Hinsdale County, limited quantity in. Galena district; Ouray County, occasionally found in Sneffle and Uncompahgre districts; Summit County, occurs in Montezuma mining district. Mined also at other places.

Stibnite (antimony sulphide). Not known in commercially valuable deposits, though small quantities are found in many mining districts, as Boulder County, in several mines; Clear Creek County, Alice mine; Grand County, Lost Lakes; San Juan County, North Star mine; Teller County, in Cripple Creek district.

Stromeyerite (copper and silver sulphide). Boulder County, Grand Lode. Clear Creek County, occurs with bornite, tetrahedrite, etc., at Plutus mine, Idaho Springs; occasional. Ouray County, in quantity in Yankee Girl mine; has been mined.

Sulphur. Gunnison County, has been mined at Vulcan. Mineral County, occurs 25 to 30 miles southwest of Creede. Several other deposits are reported.

Sylvanite. Boulder County, associated with tungsten ore at mines in Boulder district. La Plata County, occurs at Durango Girl mine on east slope of Lewis $291.23^{\circ}-B u l 1.585-14-4$ 
Mountain. Teller County, important gold ore of Cripple Creek district. Occurs also at other places.

Tennantite. Much of the so-called tetrahedrite of the sulphide ores of Colorado is tennantite. Clear Creek County, occurs in silver-bearing ores at Georgetown and at Silver Plume mines. Gilpin County, in large number of mines. Pitkin County, very common in Aspen district, Molly Gibson, and other mines. Also in mines of Ouray, Hinsdale, and San Juan counties.

Tetradymite (bismuth telluride). Boulder County, Red Cloud mine. Fremont County, occurs near Whitehorn.

Tetrahedrite (gray copper ore). Clear Creek County, mined for silver in Georgetown and Silver Plume mines. Dolores County, silver-bearing in Rico district, Enterprise, and Rico-Aspen mines. Gilpin County, reported with uranium in Wood, Kirk, and other mines near Central City. Gunnison County reported from Ruby district. Hinsdale County, has been mined near Lake City. Ouray and San Miguel counties, very abundant in silver ores. Pitkin County, very common in Aspen district, Molly Gibson, and other mines. San Juan County, important ore of Ohio mine, near Whitecross; mined for silver; Bear Creek district, Gold Bug, and other mines; gold and silver bearing. Teller County; mined in Cripple Creek district.

Topaz. Chaffee County, Mount Antero and Ruby Mountain; on east side of Arkansas River, near Nathrop. El Paso County, Crystal Park, 2 miles southwest of Manitou Springs. Teller County, occurs at Pikes Peak, and mined intermittently at Crystal Peak, 4 miles north of Florissant.

Tourmaline. Fremont County, 2 miles north of Royal Gorge and 5 miles northwest of Canon City; opaque but colored. Gilpin County, near Blackhawk; Larimer County, Estes Park; Teller County, Rhyolite Mountain.

Trona. Deposits estimated at 100,000 tons or more exist in the soda lakes of the San Luis Valley; a little development has been done.

Tungsten. Sce Ferberite, Hübnerite, and Scheelite.

Turquoise. Conejos County, 13 miles east of La Jara; Eagle County, Mount of Holy Cross; Mineral County, Last Chance mine, Creede; Saguache County, near Villa Grove.

Uranium minerals. See Carnotite and Pitchblende.

Vanadium. Found in many localities as carnotite, roscoelite, calciovolborthite, and possibly volborthite (which see). Custer County, 7 or 8 miles southeast of Silver Cliff, reported to occur as in Huerfano County. Eagle County, with silver ores in sandstone on Brush Creek, form of mineral unknown. Huerfano County, in an unidentified mineral near head of Pass Creek, south of Malachite. Montrose County, found in the Paradox Valley country as calcium vanadate; possibly two forms; unnamed, awaiting future investigation.

Volborthite. Huerfano County, near head of Pass Creek, south of Malachite. The mineral has not been definitely identified, but is probably either volborthite or calciovolborthite, or both. La Plata County, Boren Gulch, vanadium occurs in a quartz vein in a mineral which is probably volborthite or calciovolborthite, and probably also in an amorphous yellowish-green mineral. Park County, reported from Garo.

Volcanic ash. Exists in enormous quantity in several of the eastern counties; in Huerfano County, near Cripple Creek and Durango; Yuma County, has been shipped from Wray for scouring powder.

Wolftonite. Lake County, a new zinc mineral found in considerable quantities in Leadville; it is a magnetic oxide of zinc and manganese with trace of iron.

Wood (opalized). El Paso County, has been obtained in eastern part of county with jasperized wood; Bijou Basin. Silicified wood is very common.

Zinc. Fremont County, predominant metal in Currant Creek (Micanite) district. See also Sphalerite, 


\section{CONNECTICUT.}

Agate. Hartford County, at Farmington; New Haven County, at East Haven; Litchfield County, at Woodbury; has been cut for seal stones. In various localities in amygdules in the trap.

Amethyst. Occurs occasionally in amygdules in trap at Meriden.

Aquamarine. Middlesex County, some of gem quality has been found in Portland and Haddam.

Arsenopyrite (arsenical pyrite). Fairfield County, in lead mine in Wilton and at Lanes mine, Monroe; Middlesex County, in small quantities at the old CobaltNickel mine, in Chatham; New Haven County, in mine at Derby, and in Oxford and Bethany.

Asbestos (actinolite). Litchfield County, at New Hartford and Barkhamsted.

Azurite (blue carbonate of copper). Hartford County, in small quantities at Rocky Hill near Hartford; also at other copper deposits.

Barite. New Haven County, in Triassic sandstone in Cheshire, and in small quantities elsewhere. The Cheshire barite was formerly mined to mix with whitelead paint.

Beryl. Fairfield County, at Branchville; Litchfield County, at New Milford; Middlesex County, at several quarries in Middletown, Portland, Chatham, and Haddam; abundant in many of the pegmatite dikes; some aquamarine of gem quality has been found in Portland and Haddam; New Haven County, moderately abundant in Southford quarry.

Bismuth (native). Fairfield County, small quantities associated with arsenopyrite, pyrite, wolframite, etc., in quartz vein at Monroe.

Bismuthinite. Middlesex County, with chrysoberyl in minute quantities at Haddam, and sparingly at a small feldspar quarry formerly worked in Portland.

Bornite (variegated copper). Hartford County, at Bristol copper mine, Bristol; Iitchfield County, with chalcocite and malachite at Wolcottville, and elsewhere; occurs in quartz veinlets in Rocky Hill, quarry at Winsted; New Haven County, occurs with diabase at Mount Carmel, Hamden.

Brown iron ore (bog iron ore, limonite). Litchfield County, mined at Davis and Orehill mines, near Lakeville; large deposits at Sharon and Salisbury; has been mined; New London County, occurs at Colchester; Tolland County, bog iron mined and smelted in Stafford and Hebron townships; Windham County, at Woodstock.

Calamine (silicate of zinc). Fairfield County, with galena at Brookfield.

Cassiterite (tin ore). Middlesex County, few crystals found at Haddam.

Cement material. Outcrops of suitable limestone are small and few.

Cerussite (lead carbonate). Fairfield County, on galena at Brookfield.

Chalcocite (copper glance). Hartford County, was mined in very small quantity at Simsbury mine, Granby; splendid crystals formerly obtained in Bristol mine at Bristol; Tallwaa mine, Hampden; Litchfield County, with bornite and malachite, Wolcottville; New Haven County, occurs in southeastern part of Cheshire and in Hamden.

Chalcopyrite (copper pyrite). Fairfield County, in various places in Trumbull; Hartford County, in granite gneiss, Bristol; Litchfield County, with pyrrhotite at Mine Hill; Middlesex County, in Middletown lead mine; New Haven County, near Lamberts mine, Orange, and in small quantities at other places.

Chrysoberyl. Middlesex County, crystals at Haddam, little of gem quality. Locality has been inaccessible in recent years.

Clay (brick). Occurs abundantly; has been used in following districts: Berlin, Clayton, Cromwell, Elmwood, Hartford, Kensington, Middletown, Milldale, New Haven, Parkville, Quinnipiac, South Windsor, Thompsonville, and Windsor. 
Clay (fire). Litchfield County, has been dug 2 miles south-southwest of Boardmans Bridge.

Clay (kaolin, porcelain). Fairfield County, has been found at Sherman; Hartford County, at Granby; Litchfield County, dug at West Cornwall and shipped to potteries outside of State; occurs also at New Milford and Kent.

Columbite. Hartford County, with feldspar, near Glastonbury; found in several feldspar quarries in Middletown, Portland, and Haddam. A large quantity found some years ago at one quarry in Portland no longer worked.

Copper (native). Hartford County, small quantities at Farmington; New Haven County, occasionally found in Triassic sandstone or trap, Hamden.

Copper minerals. See Azurite, Bornite, Chalcocite, Chalcopyrite, Cuprite, and Malachite.

Cordierite. Middlesex County, has been found at Haddam Neck.

Corundum. Litchfield County, found near Barkhamsted; with talc and pyrite at Litchfield; London County, sparingly, with sillimanite near Norwich; not mined.

Cuprite. Hartford County, Simsbury mine, Granby, very small quantity.

Diabase. See Trap rock.

Dolomite. See Marble.

Feldspar (orthoclase or microcline). Fairfield County, occurs at Branchville, ground and shipped out of State for manufacture of porcelain; Hartford County, Howe quarry, 2 miles south of South Glastonbury; numerous quarries, large and small, worked for longer or shorter times, in the pegmatites of Middletown, Portland, Haddam, and Chatham; New Haven County, mined near Southford.

Flagstone. Fairfield County, near Bridgeport; Hartford County, red sandstone, quarried at Enfield; Litchfield County, at Roxbury; Middlesex County, gneiss quarries on Connecticut River, at Middletown, Chatham, and Haddam; New London County, large flags quarried in Lebanon; Tolland County, mica schist of Bolton Mountain, extensively quarried; Windham County, micaceous quartzite quarried at Killingly.

Fluorspar (fluorite). Farifield County, in topaz vein in Trumbull, used for flux; Litchfield County, at Plymouth; Middlesex County, Haddam Neck, and at the old lead-silver mine, Middletown; Windham County, in gneiss at Willimantic. Nowhere in considerable quantity, except at Trumbull.

Galena. Fairfield County, in limestone at Brookfield, in quartz veins at Monroe; Hartford County, at Chatham; Middlesex County, with sphalerite, chalcopyrite, and pyrite at Middletown; and several other localities. Was mined for lead in Colonial and Revolutionary times; for a few years, about 1860, mined for silver.

Garnet. Hartford County, quarry near South Glastonbury; Litchfield County, was mined at Roxbury as abrasive; Middlesex County, small garnets in pegmatite at Andrews' quarry, Portland, and in Eureka quarry; New Haven County, in Southford quarry. In larger or smaller quantities at most of the pegmatite (feldspar) quarries.

Gneiss. Quarried for foundation stone at many places. Hartford County, Glastonbury; Middlesex County, at Haddam, quarried for curbstone; New London County, at quarries on Thames River above New London; Tolland County, at Union; Windham County, at Plainfield, Willimantic, and Putnam.

Granite (building, structural). Quarried at Branford, Bristol, Greenwich, Groton, Guilford, Lyme, Middletown, Norfolk, Roxbury, Stonington, and Torrington. Much of the granite quarried is a granite gneiss.

Granite (curbing and trimming). Quarried at Ansonia, Bolton, Bridgeport, Cornwall, East Litchfield, Glastonbury, Norwalk, Roxbury, Seymour, Sterling, Torrington, Waterford, and Willimantic. 
Granite (inscriptional, monumental). At Center Groton, East Lyme, Groton, Lyme, Stonington, Thomaston, and Waterford.

Granite (paving). At Guilford and Sterling.

Granite (riprap). At Sachem Head, Guilford; Mason Island, Stonington.

Granite (road material). At Bridgeport Jail; Danbury; Torrington; Town Hill.

Graphite. Fairfield County, at Danbury and Redding; Litchfield County, found in western part of Cornwall; New Haven County, in northern part of Bethany; Windham County, has been quarried in northwest corner of Ashford.

Grindstone. Hartford County, fine-grained quartzose mica slate was quarried in Marlborough; not now produced.

Iron minerals. See Brown iron ore, Magnetite, Pyrrhotite, and Siderite.

Lead minerals. See Cerussite, Galena, and Pyromorphite.

Lepidolite. Middlesex County, fine granular masses in pegmatite at Haddam and Middletown; larger plates or crystals in pegmatite at Portland and Haddam.

Limestone (crushed stone). Litchfield County, quarried at Canaan.

Limestone (flux). Litchfield County, was quarried at East Canaan.

Iimestone (hydraulic). Hartford County, near Berlin in Southington; in thin strata, compact, earthy, and somewhat bituminous; Northford, a gray limestone.

Limestone (lime). Fairfield County, magnesian limestone burned near Redding, Brookfield, Ridgefield, and Danbury; Litchfield County, at Canaan.

Limonite. See Brown iron ore.

Magnetite (magnetic iron ore). Fairfield County, was mined and smelted in small quantities at New Preston and at Redding; Litchfield County, in Sharon Township; Middlesex County, near Haddam; New Haven County, northwest of Madison; Winchester County, in northwest corner.

Malachite (green carbonate of copper). Hartford County, principal ore at Simsbury mine, Granby, but not abundant. Disseminated through sandstone.

Marble. Litchfield County, old quarries in East Canaan and Marbledale. Dolomite: Iitchfield County, abundant; was quarried at New Preston.

Mica (muscovite). Found in large plates at Middletown, Portland, Haddam, and elsewhere in pegmatites; the large plates are too irregular and too much flawed to use as isinglass. Recently it has been torn into shreds for an insulating material. Muscovite sometimes associated with biotite or lepidolite in the same crystal. Also found in the topaz veins at Trumbull.

Mineral paint. Fairfield County, soapstone ground at Greenwich; asbestos rock at Stamford, talcose slate at Wilton; Litchfield County, soapstone ground at sarkhamsted.

Molybdenite (sulphide of molybdenum). Hartford County, in pegmatite at South Glastonbury; Middlesex County, in gneiss quarries at Haddam.

Monazite. Middlesex County, crystals in pegmatite at Andrews's quarry, Portland (no longer worked). New London County, in small crystals with sillimanite at Norwich. Nowhere in commercial quantities.

Pitchblende. See Uraninite.

Pyrite. Fairfield County, at Newtown; Hartford County, in slate at Windsor; Litchfield County, at Winchester; New Haven County, near North Madison. Small quantities in other localities; not now produced.

Pyromorphite (green lead ore). Fairfield County, with galena at Brookfield.

Pyrrhotite. Fairfield County, small quantity mined at New Fairfield; Litchfield County, occurs with chalcopyrite and pyrite at Prospect Hill, Bradleyville. Middlesex County, in small quantities in pegmatite at Portland and elsewhere.

Quartz. Litchfield County, at Long Hill and Lantern Hill, North Stonington; New London County, 2 miles east of Roxbury station, and 3 miles north of Litchfield; New Haven County, quarried near Southford. The pegmatites of Portland and other places are worked chiefly for feldspar, but the quartz is also 
ground and used for various purposes. Rose quartz has been found in pegmatite at Portland and Chatham.

Road metal. See Granite, Limestone, and Trap rock.

Rutile. Fairfield County, at North Greenwich; has been mined in small quantities at Monroe; Hartford County, at Granby; Litchfield County, at Plymouth.

Sand (building). Hartford County, at Plainville, New Britain, and Windsor Locks. Dug in small quantity at other places.

Sand '(molding). Hartford County, New Britain, and Windsor Locks.

Sandstone. Varies from nearly white to brick red and dull brown; Hartford County, at Buckland; Middlesex County, at Portland; New Haven County, at East Haven; and at other localities in the Triassic area. This area extends along both sides of the Connecticut River from northern boundary of State to Middletown; thence it extends southwestward to New Haven.

Sapphire (asteriated). Litchfield County, at Litchfield.

Scheelite (tungsten ore). Fairfield County, has been mined at Trumbull.

Serpentine. New Haven County, has been quarried at Milford.

Siderite (spathic iron ore). Litchfield County, has been mined at Mine Hill, Roxbury.

Slate. Tolland County, quarried in Stafford for local use.

Sphalerite (zinc blende). Fairfield County, Lane's mine, Monroe, and at Brookfield; Middlesex County, Middletown lead mine; in small quantity in pegmatite at Portland and elsewhere.

Spodumene. In pegmatite at Branchville. Crystals often very large; sometimes altered to cymatolite. Associated with numerous rare minerals.

Tin. See Cassiterite.

Topaz. Fairfield County, found at Trumbull; Windham County, at Willimantic.

Tourmaline. Fairfield County, occurs at Monroe; Middlesex County, mined with feldspar at Strickland's quarry, Portland; green. Some of it is of gem quality. Mined at Haddam Neck quarry, Haddam; small gems cut; considerable gem material obtained; quarry no longer worked. New Haven County, intergrown with quartz at Southford quarry; black. Black tourmaline found in nearly all the pegmatite quarries.

Trap rock. Fairfield County, quarried at Bridgeport; Hartford County, near Newington, Rocky Hill, and Plainville; Middlesex County, Middlefield, New Haven County, Branford, East Haven, Meriden, Milford, New Haven, and Westville.

Tremolite. Litchfield County, in dolomite at Canaan.

Uraninite (pitchblende). Fairfield County, at Branchville; Middlesex County, at Andrews's quarry and Strickland's quarry, Portland; Windham County, at. Willimantic. At the two quarries in Portland it occurs in amorphous grains, and in octahedral crystals, some more than one-half inch in diameter. Occurs nowhere in commercial quantities; only as mineralogic specimens.

Whetstone. Tolland County, mica schist formerly quarried at Bolton and Vernon; Windham County, at Woodstock.

Wolframite (tungstate of iron). Fairfield County, at Lane's mine, Monroe, and in topaz-quartz vein at Trumbull.

\section{DELA WARE.}

Asbestos. - Newcastle County, in serpentine at feldspar quarries northeast of Wilmington; no production.

Brown iron ore (brown hematite, bog iron ore, limonite). Kent County, at East Dover; Newcastle County, Iron Hill, and Chestnut Hill near Newark, has been mined; Sussex County, Little Creek, 2 miles south of Laurel; near Georgetown; Collins's ore bed on Green Meadow Branch of Deep Creek; Green Branch, 10 miles west of Millsboro; Burtons Branch, 1 mile west of Burton. 
Cement material (Portland). Limestone suitable for cement occurs in extreme north part of State, but outcrops are small. Greensand marl may be used.

Clay (brick). Dug at the following places: Kent County, near Dover, Houston, Smyrna, and Wyoming; Newcastle County, at Blackbird, Elsmere Junction, Newark, and elsewhere; Sussex County, Blades, Bridgeville, Dagsboro, and elsewhere.

Clay (fire). Newcastle County, Newcastle, dug and shipped, used for fire pots and crucibles.

Clay (kaolin). Newcastle County, dug at Hockessin and 4 miles north of Newark. Clay (pottery). Newcastle County, was dug at Christiana.

Corundum. Newcastle County, small quantity near Chandlers Follow.

Cyanite. Delaware County, Darky Creek.

Feldspar. Newcastle County, Tucker's quarry near Wilmington; Tweed's quarry, $2 \frac{1}{4}$ miles north of Newark near Pleasant Hill; and Hockessin pits.

Gneiss. Quarried in northern part of State.

Granite. Gneiss and granite are quarried for ballast, building, curbing, concrete, road making, rubble, riprap, at many places in northern part of State.

Infuso-ial earth. Somewhat impure; abundant in Calvert formation; not used; outcrops on southern tributaries of Appoquinimink Creek and valley of Ftangmans Run.

Kaolin. See Clay.

Limestone. Newcastle County, has been quarried at Jeane's, on Pike Creek; Klair's, 2 miles west of Centerville; Bullock's, on Brandywine, near Pennsylvania line.

Iimonite. See Brown iron ore.

Marble. Newcastle County, small exposures.

Marl (greensand). Newcastle County, dug at many localities; occurs in Cretaceous deposits at St. Georges Hundred, St. Georges; Middletown, 3 miles west, on Bohemia Creek, at head of tidewater; Cantrell's bridge, north side of Appoquinimink; Silver Run; Dwyers Run; Noxentown Branch of Appoquinimink; Port Penn; Latman's mill on branch of Dwyers Creek; Scotts Run.

Ocher. Sussex County, with limonite.

Quartz. Newcastle County, white granular quartz has been quarried $2 \frac{1}{2}$ miles north of Newark and ground at Tweed's mill, near Newark.

Road metal. Gravel is abundant in many localities. See also Gneiss, Granite, and Trap rock.

Serpentine. Newcastle County, occurs 6 miles northwest of Wilmington.

Sand (building). Unlimited quantity of good quality at many places.

Sand (glass). Newcastle County, dug at Christiana.

Sand (molding). Newcastle County, dug at Christiana.

Trap rock. Newcastle County, quarried at Wilmington.

\section{DISTRICT OF COLUMBIA.}

Clay (brick). Occurs in extreme eastern and southern portion of Washington and at intersection of Bladensburg Road and Florida Avenue, in Potomac and Columbia formations. Washington is supplied by large brickyards on west side of Potomac River in Virginia.

Clay (terra cotta). Worked extensively for terra-cotta tile at Lamond, Terra Cotta, and University station, on Metropolitan Branch of Baltimore \& Ohio Railroad. Many large masses east of Anacostia River.

Diorite. Has been quarried near Georgetown but is so tough and difficult to work that little is used; was quarried at east end of Connecticut $\Lambda$ venue Bridge for concrete used in bridge.

Granite. Has been quarried on Broad Branch of Rock Creek. 
Gneiss. Granite gneiss has been quarried at east end of Chain Bridge and at the receiving reservoir near Chain Bridge.

Quartz. Vein quartz abundant in northwestern part of District; has been crushed for concrete and road material.

Road metal. Granite, diorite, and granite gneiss are abundant and have been crushed for road material. See also Sand and gravel, and Quartz.

Sand (building). Principal supply dredged from Potomac River. Deposits of Potomac formation have been worked at number of places in Washington and vicinity. Old pit one-half mile south of Anacostia; new pit at Benning. Sand under clay at Terra Cotta is used for tempering clay. Dug near Lamond and made into sand-lime brick.

Sand and gravel. For road material and concrete; have been dug at many localities and dredged from Potomac River. Gravel dug at Benning is shipped for Maryland roads.

\section{FIORIDA.}

Brown iron ore. See Limonite.

Cement material. Limestone suitable for cement covers large part of northern Florida; not utilized.

Clay (brick). Dug at Alachua County, Campville; Clay County, Black Creek, B. P. Landing, and Green Cove Springs; Columbia County, Lake City; Duval County, Jacksonville and St. Nicholas; Escambia County, Brent Station, Dolores, Quintette, and elsewhere; Gadsden County, Lawrence; Hillsboro County, Tampa; Holmes County, Eleanor; Lake County, Sorrento and Whitney; Leon County, Tallahassee; Nassau County, Callahan; Walton County, Glendale; Washington County, near Chipley. Occurs but not used in Hamilton County, near Marion, and on Suwannee River at White Springs; Leon County, 18 miles southwest of Tallahassee.

Clay (fire). Escambia County, dug at Brent Station.

Clay (pottery). Lake County, dug at Yalaha, Okahumpka, and Richmond; Putnam County, at Edgar, Johnson, and McMeekin.

Coquina (limestone). Brevard County, St. Augustine quarries, Rock Ledge on Indian River; used for building stone. St. John County, Anastasia Islands and other points near ocean; used as building stone and road metal.

Fuller's earth. Gadsden County, dug at Jaimeson and Quincy, large deposits; Manatee County, at Ellenton. Occurs in following places but is not mined: Alachua County, Gainesville; Columbia County, High Falls, 8 miles southeast of Lake City; Leon County, 13 miles west of Tallahassee, sec. 26, T. 1 N., R. 3 W.; Liberty County, Rock Bluff and along headwaters of Rock and Sweetwater creeks; 27,658 tons produced in 1911.

Gypsum. Sumter County, 6 miles west of Panasoffkee with limestone. Not used. Infusorial earth. Lake County, near Eustis, mined to some extent.

Lignite (brown coal). On Suwannee River; has been mined.

Limestone. Alachua County, has been quarried at Gainesville; Dade County, Miami oolite quarried at Miami for serveral large buildings, and used also as road metal; De Soto County, occurs at Charlotte Harbor; Hillsboro County, Fort Brooke; Jackson County, from Campbellton to Marianna; Manatee County, Manatee River; Marion County, Kendrick, Ocala, and Silver Springs; Monroe County, oolite at Key West; Orange County, Rock Spring; Wakulla County, St. Marks. Occurs-also in Hernando, Holmes, Leon, Walton, and Washington counties.

Iimestone (lime). Marion County, burned at Ocala and Kendrick.

Iimonite (bog iron ore). Duval County, found around Beauclerc; Volusia County, 12 miles east of Seville, and at several points on the Florida East Coast Railway. 
Malachite (green carbonate of copper). Suwannee County, reported 5 miles southeast of Dowling Park.

Marl. Occurs very generally skirting the eastern and southern edges of the limestone ridge traversing the axis of the State. Isolated deposits have been noted at Jacksonville and on Fort George Islands, Duval County. The marl is used locally on many orange groves on the St. Johns River, particularly at Sanford, Orange Bend, and Lanier.

Mineral paint. Lee County, Estero Bay, not developed.

Peat. Extensive deposits throughout the State. "Machine peat" has been made at Orlando, Orange County.

Phosphate rock. In 1911, production was 2,436,248 long tons of land pebble and hard rock phosphate, quarried in Alachua County, at Clark, Newberry, and elsewhere; Citrus County, Floral City, Hernando, and Istachatta; Columbia County, Fort White; Hernando County, Bay City; Hillsboro County, Plant City; Marion County, Anthony and Dunellon; Polk County, near Bartow, Fort Meade, Mulberry, and elsewhere; was formerly mined at Hull, De Soto County, and Buda, Orange County.

\section{GEORGIA.}

Abrasive. See Burrstone and Novaculite.

Agate. Fulton and Jones counties; not mined.

Aluminum. See Bauxite and Halloysite.

Amethyst. Rabun County, Ledbetter mine near Rabun Gap, stones of good color; North Georgia Co.'s mine 4 miles northwest of Clayton, good gems reported; Wilson prospect 4 miles southeast of Clayton. Reported also in Cobb and Oglethorpe counties.

Arsenopyrite. Cherokee County, at Canton mine and other places; Forsyth County, at Charles mine.

Asbestos. Habersham County, occurs at Hollywood; Hancock County, occurs at Sparta and many other places; Rabun County, has been mined at Hicks mine; White County, mined at Sall Mountain, near Nacoochee, shipped from Clarkesville.

Barite (heavy spar). Bartow County, present in nearly all ocher deposits of Cartersville district; mined at Cartersville, Emerson, and near Allatoona; Murray County, mined at Eton.

Bauxite. Occurs in northwestern part of the State, chiefly in Bartow and Floyd counties, and deposits are known extending from near Summerville or Adairsville to the Alabama State line. Cave Spring and vicinity have long been the center of the industry. Deposits are worked in the central part of the State near McIntyre, Wilkinson County, and have been discovered recently in Sumter County, near Andersonville.

Beryl. Rabun County, Beck beryl mine 7 miles east of Clayton. Large flawed crystals in pegmatite contain clear portions suitable for cutting.

Braunite. Bartow County, Cartersville district, mined with other manganese ores; Floyd County, small quantity in Cave Spring district.

Brown iron ore (limonite). Bartow County, extensively worked near Hermitage and other places in Barnsley district; Fannin County, Blue Ridge; Floyd County, extensive deposits in Cave Spring district, mined at Atkinson mine; Murray County, large deposits in sandstone ridges north of Cohutta Springs; Polk County, extensively mined near Cedartown, Ledbetter and Reed mines; Pulaski County, deposit at Hawkinsville; Whitfeld County, openings near Tunnel Hill; reported in Gilmer, Gordon, Hall, Haralson, Milton, Whitfield, and other counties.

Burrstone (millstone). Bullock, Burke, Early, Jefferson, and Screven counties; has been quarried. 
Cassiterite (tin ore). Lumpkin County, small quantity in placer gold near Dahlonega.

Cement material. Bartow County, limestone of Conasauga formation quarried for natural cement at Cement, 2 miles north of Kingston; Polk County, Rockmart and Davittes, Portland cement, limestone and slate used; Walker County, Chickamauga limestone used; natural cement at Rossville.

Chalcocite (copper glance). Cherokee County, Canton mine; other localities with chalcopyrite, not mined.

Chălcopyrite (copper pyrites). Cherokee County, Canton mine; Lincoln County, Phelps and Seminole mines; McDuffie County, Columbia mine and Landers prospect; has been mined in other localities in Carroll, Fannin, Fulton, Greene, Haralson, Lincoln, Lumpkin, Murray, Paulding (at Dallas), and Towne counties.

Chromite (chromic iron ore). Towne County, disseminated in minute crystals through chrysolite at Hog Creek near Hiawassee; fine exposures in Heard and Fayette counties; not mined.

Clay (brick). Extensive deposits in all parts of the State. Dug at many places. The production of common brick in 1911 was valued at $\$ 1,692,610$.

Clay (paper). Glascock County, deposits near Gibson; Randolph County, Moyce property, $5 \frac{1}{2}$ miles north of Cuthbert; Richmond County, Hephzibah, 9 miles southwest of Augusta; Taylor County, Butler clay mine, $2 \frac{1}{2}$ miles west of Butler, shipped to northern markets; Twiggs County, near Dry Branch, Georgia kaolin mines; Wilkinson County, 1 mile west of Lewistown.

Clay (pottery). Developed deposits: Columbia County, pits at Groveton; Crawford County, Williams Mill, 6 miles east of Roberta; Hall County, small potteries at Oakwood and Gillsville operated at times; Oconee County, Bogart; Polk County, small quantity near Aragon; Twiggs County, Georgia kaolin mines near Dry Branch; White County, number small potteries operated at times. Undeveloped deposits: Chattooga County, small deposit near Menlo; Clarke County, 5 miles west of Athens; Glascock County, near Gibson; Washington County, Gilmore property, 10 miles north of Oconee; Wilkinson County, 3 miles northwest of McIntyre.

Coal (bituminous). Chattooga County, small area in northern part of county, not mined; Dade County, 3 workable seams in Lookout sandstone (Dade, Rattlesnake, and White Ash), mined near Cole City and in limited quantity near Rising Fawn; Walker County, coal confined to Pigeon Mountain, and east side Lookout Mountain, in Walden sandstone and Lookout sandstone, mined at Durham mine, 12 miles south of Chattanooga, Tenn.

Copper. See Chalcocite, Chalcopyrite, Covellite, and Malachite.

Corundum. Found in quantity at only few places. Prospecting as follows: In Cobb County, 2 miles south of Powder Springs; Forsyth County, 1 mile north of Sheltonville and elsewhere; Habersham County, Aleck Mountains; Hall County, in stream 1 mile west of Gainesville; Heard County, in magnesian rocks at Centralhatchee; Lumpkin County, 1 mile southeast of Porter Springs; Paulding County, has been mined in northeastern and southeastern corners of county; Rabun County, at Stone mine and Laurel Creek mine; Towns County, Bell Creek, Foster, and other mines (17th-18th districts); Troup County, sparingly near West Point; Union County, Track Rock mine; Upson County, 8 miles southwest of Thomaston; Walton County, near Monroe.

Covellite (indigo copper). Cherokee County, at Canton mine, with chalcopyrite and chalcocite, not mined.

Diamond. Four-carat diamond was found in Clayton County. Few finds in Hall and White counties.

Diopside. Pickens County, Southern marble quarries. 
Fuller's earth. Columbia County, near Groveton, not mined; Decatur County, mined at Attapulgus; Twiggs County, mined at Pikes Peak.

Galena (sulphide of lead). Gwinnett County, abundant in Piedmont mine, argentiferous; Lincoln County, in small quantities at Ramsey property, abundant in Paschal and Phelps mines; McDuffie County, Columbia mine and Landers prospect.

Garnet. Lumpkin County, near Dahlonega. Abundant in garnet schists, and in gangues of some gold ores in Cherokee, Lumpkin, and other counties.

Genthite (nickel silicate). Towns County, with millerite, not mined.

Gneiss (biotite). Troup County, quarried 1 mile west of Mountville for macadam.

Gneiss (hornblende). Meriwether County, Tignor quarry.

Gold (placer). Bartow County, old placer mines on Gold Branch; Campbell County, Camp property, 8th district; Cherokee County, Cherokee, Kellogg, Sixes, and other mines; Cobb County, old placer mines; Coweta County, Bingham and Hill properties; Dawson County, old mines, Harris Branch and others; Douglas County, limited amount of mining at Roach mine; Elbert County, along stream courses within few miles of Bowman; Fannin County, Rantze Hill mine near Noontootly Creek, found about 12 miles southeast of Blue Ridge; Forsyth County, Faver mine; Gilmer County, White Path mine, 6 miles northeast of Ellijay, worked at intervals; Gwinnett County, considerable placer work was done on Richland Creek and tributaries; Habersham County, little work near Chattahoochee River in southeastern part of county, Nicholas mine 6 miles east of Clarkesville and few places along Soque River; Hall County, old prospects along creek emptying into Chattahoochee River in vicinity of Gainesville; Haralson County, old mines in 8th district; Hart County, small placer deposits mined on Red Hollow Road about 4 miles from Bowersville; Lumpkin County, Etowah, Josephine, and other mines were worked; Madison County, small deposits on Smith property, Webb, etc.; Meriwether County, small mine on Post property; Milton County, old mines; Murray County, Cohutta mine 4 miles east of Chatsworth; Newton County, 7 miles southwest of Covington; Paulding County, Austin mines 7 miles southeast of Dallas, Yorkville and Dunaway mines irregularly worked; Rabun County, considerable mining on Pages Creek and Lawground Branch; Towns County, Hightower Creek belt in vicinity of Visage northeast to near Georgia-North Carolina line, mining confined to Hightower Creek; Union County, extensive mining along Coosa Creek; Walton County, Malcome, Smith, and other mines have been worked; White County, Longstreet, Loud, and other mines, extensively worked.

Gold (lode). Bartow County, was mined at Glade mine; Cherokee County, Cherokee mine worked at times, Franklin mine near Creighton large producer, other mines; Cobb County, was mined at Mason mine 8 miles northeast of Dallas, and at Freeman mine near Acworth; Coweta County, prospecting on Clarke property near Hollingsworth Ferry; Dawson County, at Harris Branch, Magic, and other mines; Douglas County, at Pine Mountain; Forsyth County, at Strickland mine and elsewhere; Green County, about 6 miles northeast of Union Point; Gwinnett County, important mining operations in vicinity of Buford; Habersham County, Royal mine near Walkers Creek, 3 miles southeast of Tallapoosa, old prospects near Clarkesville, and near Chattahoochee River, in southeastern part of county, and at Hood and Nichols mines; Hall County, Odum and Potosi mines worked at intervals; Hart County, Brown mine, 6 miles south of Bowersville; Lincoln County, Paschal mine; Lumpkin County, Findley, Hedwig, Lockart, Preacher, Singleton, Whim Hill, and other mines, free and in quartz, mined at several points in Dahlonega and Auraria districts, and on Yahoola Creek and Chestatee River; McDuffie County, Columbia mines and others worked; Meriwether County, was mined at Wilkes 
and Lone Oak mines; Milton County, prospecting 4 miles from Sheltonville; Oglethorpe County, Buffalo, Guarantee, and Morgan mines-last worked; Paulding County, free gold reported from Sheffeld property near Huntsville; Rabun County, Lamar, Moore, and other mines; Towns County, Greater Pittsburg and Nancy Brown mines; Union County, Legal Tender; White County, Loud mine, 4 miles southwest of Cleveland, many old mines worked at intervals; Wilkes County, Latimer mine (free gold) and Stone Ridge mine worked at intervals.

Granite (building and monumental). Bibb County, quarried at Macon; Campbell County, fine-grained medium light-gray biotite granite was quarried near Fairburn; Cobb County, Austell; Coweta County, several quarries in vicinity of Newnan; Dekalb County, dark blue-gray biotite granite, Congress and Lithonia quarries, and at many quarries on Stone Mountain; Elbert County, medium light-gray biotite granite in Elbertson area, several quarries; Fayette County, near Fayetteville, coarse-grained biotite granite; Hancock County, near Sparta; Heard County, Flat Rock at Wynn quarries near Franklin, finegrained biotite granite; Madison County, Brown \& Deadwyler quarries; McDuffe County, near Thomson, fine-grained biotite granite; Meriwether County, dark blue-gray medium-fine biotite granite quarried near Greenville; Oglethorpe County, dark blue-gray and light-gray fine, even-grained biotite granite quarried near Lexington; Oglethorpe and Madison counties, Oglesby area, superior fine-grained dark-blue biotite granite, 6 quarries; Putnam County, massive, fine, evengrairned dark blue-gray biotite granite quarried near Eatonton; Spalding County, medium coarse-grained 'light gray, at Griffin and Turner.

Granite (crushed stone). Henry County, quarried for crushed stone at Stockbridge; Stephens County, 3 miles from Toccoa; Troup County, Hogansville.

Granite gneiss. Clark County, quarried at Athens; Dekalb County, Rock Chapel Mountain quarries near Lithonia and Floyd quarry near Redan; Gwinnett County, Sawyer quarry; Jackson County, Saunders and Stanton quarries near Winder; Meriwether County, Odessa quarry near Greenville; Newton County, Freeman quarry near Covington; Oglethorpe County, extensive exposures coarse to fine-grained $3 \frac{1}{2}$ miles northeast of Lexington, suited for road work and masonry; Richmond County, biotite granite gneiss quarried near Augusta, rough work; Rockdale County, Powell, Turner, and other quarries; Walton County, near Loganville.

Granite porphyry. Columbia County, undeveloped, near Appling; Greene County, extensive body about 10 miles south of Greensboro; Lumpkin County, several exposures near Dahlonega; Morgan County, few outcrops, principal one on Hard Labor Creek, 5 miles northwest of Madison; Pike County, granular to porphyritic granite, dark gray, 9 miles west of Zebulon; also in Muscogee and Wilkes counties.

Graphite (plumbago). Bartow County, extensive deposits of graphitic slate for fertilizer filler mined near Emerson; Cobb County, was mined at Powder Springs. Occurs in Carroll, Cherokee, Clarke, Douglas, Elbert, Habersham, Hall, Heard, Madison, Paulding, Pickens, Rabun, and Spalding counties.

Halloysite. Chattooga County, $4 \frac{1}{2}$ miles northeast of Gore, extensively prospected; Dade County, near Rising Fawn, was mined and shipped; Floyd County, scattered through bauxitic clay in Holland Spring bank; Fulton County, near Lakewood, Atlanta; in Catoosa, Cherokee, and Walker counties, not mined.

Fematite (red ore, fossil ore). Bartow County, in minable quantities between Emerson and Etowah rivers, also near Warford, not mined; Catoosa County, abundant as float ore in Dicks Ridge, also occurs in Taylors Ridge and White Mountain; Chattooga County, mined along base of Lookout Mountain and $3 \frac{1}{2}$ miles east of Summerville, also on Dirtseller Mountain; Dade County, mined 
on Johnson Creek; Polk County, occurs north of Rockmart; Walker County, mined at West property, tenth district; has been mined also in Floyd and Whitfield counties.

Hematite (specular iron ore). Cherokee County, occurs in Allatoona hills, along Etowah River, extensive deposits; also in valley of Etowah River, in Bartow, Cass, Cobb, Fannin, Floyd, Gilmer; Lumpkin, Milton, Murray, Paulding, Pickens, Towns, and Union counties.

Hyalite. See Opal.

Iron. See Brown iron ore, Chromite, Hematite, Magnetite, Ocher, and Pyrite.

Itacolumite (flexible sandstone). Hall County, Chattahoochee Ridge; Meriwether County, near Warm Springs.

Kaolin (true and plastic). Developed: Bartow County, Sheet mine, 3 miles south of Adairsville; Greene County, small quantity mined 4 miles northeast of Union Point; Houston County, small mine on Yancey property 2 miles northwest of Perry; Richmond County, in clay bed at Hephzibah, 9 miles southwest of Augusta; Twiggs County, Georgia kaolin mine, 2 miles southeast of Dry Branch, and other mines. Undeveloped: Columbia County, deposits located 1 mile east of Grovetown; Glascock County, large deposit near Gibson; Hancock County, Carrs Station; Jones County, Griswoldville, 11 miles east of Macon; McDuffie County, 3 miles southwest of Dearing; Paulding County, prospecting at old Turner mica mine, 5 miles north of Dallas; Pickens County, in vicinity of Jasper; Polk County, Ledbetter mine; Taylor County, Butler.

Kaolin (porcelain clay). Undeveloped deposits in Baldwin, Cherokee, Fulton, Heard, and other counties in the crystalline area.

Lead. See Galena and Pyromorphite.

Lazulite. Lincoln County, Graves Mountain, not mined.

Limestone (building). Catoosa County, quarried at Graysville; Walker County, Chickamauga and Rossville.

Limestone (crushed stone). Bartow County, quarried at Cartersville and Clifford; Catoosa County, Graysville; Walker County, Chickamauga.

Limestone (flux). Walker County, quarried at Chickamauga.

Limestone (lime). Bartow County, quarried at Cartersville; Catoosa County, Graysville; Hall County, Gainesville; Walker County, Rossville.

Limonite. See Brown iron ore.

Magnetite (magnetic iron ore). Cherokee County, found in marble at Mabel station, 6 miles northeast of Canton; Carroll County, near Villa Rica, no well defined vein. Occurs also in Cherokee, Cobb, Dekalb, Gilmer, Greene, Gwinnett, Habersham, Hall, Lumpkin, and other counties; not mined.

Malachite (green carbonate of copper). Fannin County, mines of Ducktown, Tenn., belt.

Manganese ore. Occurs with brown and manganiferous iron ores in area of Paleozoic rocks which includes 10 northwestern counties of State. Bartow County, mined in Cartersville district; Fannin County, small deposits were mined at Blue Ridge; Floyd County, mined in Cave Springs district; Habersham County, has been mined at Mount Airy; Haralson County, small deposits in Draketown district; Hart County, mined $1 \frac{1}{2}$ miles east of Bowersville; Murray County, occurs with iron-ore deposits 4 miles north of Cohutta Springs; Paulding County, has been mined in Draketown district; Polk County, mined in Cave Springs district; Whitfield County, mined in vicinity of Tunnel Hill. See also Braunite, Manganite, Psilomelane, Pyrolusite, Rhodochrosite, and Wad.

Manganite. Bartow County, associated with psilomelane and pyrolusite in Cartersville mines, not mined.

Marble. Cherokee County, extensive exposures of dark-colored marble near Mabel Station and on Longswamp Creek; Gilmer County, extensive exposures, pink and white, quarried at Marble Bluff; Pickens County, white marble, quarried 
at Tate and at Southern Marble quarries, Marble Hill, Kenesaw, Piedmont, and other quarries 4 miles east of Tate; Polk County, white marble near Van Wert, not quarried; Whitfield County, dark chocolate grayish marble in northwestern corner of county; colored marbles in Bartow, Catoosa, Chattooga, Floyd, Gordon, Polk, and Walker counties.

Marl. Occurs in Bibb, Bullock, Burke, Charlton, Chatham, Chattahoochee, Clay, Crawford, Effingham, Emanuel, Houston, Jefferson, Pulaski, Quitman, Randolph, Screven; Stewart, Thomas, and Washington counties; not mined.

Mica (muscovite). Cherokee County, occurs in marble near Mabel Station 6 miles northeast of Canton; Elbert County, has been mined at Elberton; Fannin County, found near junction of Cutcane and Hempton creeks; Hall County, has been mined near Gainesville; Lumpkin County, mined near Tworun; Pickens County, common in marble; Rabun County, 10 miles east of Clayton; Union County, mined near Blairsville and 9 miles from Dahlonega; has been mined at Gaddistown, Quebec, and Ward Gap; also occurs in Carroll, Gwinnett, Heard, Towns, and Warren counties.

Millstone. See Burrstone.

Mineral paint. See Ocher.

Nickel. See Genthite.

Novaculite (oilstone). Undeveloped beds in Heard, Lincoln, McDuffie, Meriwether, Oglethorpe, and Troup counties.

Ocher (mineral paint). Bartow County, mined extensively near Cartersville, large plants.

Oilstone. See Novaculite.

Opal. Fire opal is found in Bullock and Washington counties; hyalite in Burke, Rabun, and Screven counties.

Psilomelane. Bartow County, important ore of Cartersville district; mined near Cartersville, Emerson, and Rowland Spring.

Pyrite. Bartow County, occurs in quartzite in Cartersville district; Carroll County, mined near Bremen, at Reids Mountain, and at Villa Rica; Cherokee County, mined at Ball Ground and near Creighton; Cobb County, mined at Acworth; Dawson County, occurs in large quantities on Shelton property; Greene County, small quantities in east part of county; Haralson County, mined near Westbrook, Draketown district; Lumpkin County, mined 6 miles northeast from Dahlonega; McDuffie County, occurs in considerable quantities in Columbia mine and Landers prospect; Murray County, occurs near Cohutta; Oglethorpe County, occurs in large quantities in quartz in Guarantee and Morgan mines; Paulding County, has been mined near Hiram; White County, occurs in large quantities in Blake mine.

Pyrolusite (black manganese oxide). Bartow County, important ore in Cartersville district, mined near Cartersville, Emerson, and Rowland Spring; Catoosa County, occurs but not mined; Fannin County, occurs with brown iron ores 10 miles northeast of Blue Ridge; Floyd County, important ore of Cave Spring district, mined in several places; Paulding County, occurs in residual mica schist clay in Draketown district; Whitfield County, occurs but not mined.

Pyromorphite. Lincoln County, at few points in Seminole mine; McDuffie County, occasionally found in oxidized vein of Columbia mine, not mined.

Quartz (rock crystal). Gem quality, occurs in Franklin, Forsyth, Fulton, Jones, Rabun, and Wilkes counties.

Rhodochrosite. Polk County, in iron mines near Cedartown; Towns County, in - small quantity lining cavities several miles west of Hiawassee, not mined.

Road metal. Suitable material in northern part of State consists of the Knox dolomite and the Chickamauga and Bangor limestones. Chert deposits of Knox and Fort Payne formations. Granite, gneiss, diorite, schist, quartzite, and trap rock widely distributed, 
Ruby. Rabun County, Laurel Creek mine; Towns County, Hiawassee mine; Union County, near Caldwell.

Sapphire. Rabun County, Laurel Creek mine.

Sand (building). Dug in Cobb County, Oakdale; Crawford County, Zenith; Floyd County, Rome; Fulton County, Bolton; Habersham County, Demorest; Henry County, Stockbridge; Monroe County, Popes Ferry; Muscogee County, Columbus; Taylor County, Howard; Telfair County, Lumber City; Walker County, Flintstone; Whitfield County, Dalton.

Sand (glass). Dug in Crawford County, Zenith; Montgomery County, Lumber City; Taylor County, Butler.

Sand (molding). Dug in Catoosa County, Ringgold; Gilmer County, Ellijay; Frabersham County, Demorest; Newton County, Almon; Taylor County, Howard; Walker County, Flintstone; Whitfield County, Dalton.

Sandstone (flexible). See Itacolumite.

Serpentine. Cherokee County, quarried at Verde Antique Marble Quarry, Holly Springs. Occurs also in Rabun, Towns, and Union counties; not quarried.

Shale (brick). Catoosa County, occurs near Ringgold; Chattooga County, small quantity 3 miles west of Lyerly, mined and shipped; Floyd County, mined near Rome; Gordon County, mined at Calhoun; Murray County, Chatsworth; Walker County, Mission Ridge; Whitfield County, Conasauga shale, 3 miles southeast of Dalton, not used.

Silver. Small quantity recovered from placer and lode gold in Cherokee, Hall, Lumpkin, Paulding, and White counties.

Slate. Bartow County, quarried near Fairmount; Polk County, several producing quarries near Rockmart; was formerly quarried near Van Wert.

Soapstone. See Talc.

Sphalerite (zinc blende). Lincoln County, Seminole mine; not mined.

Sulphur. See Pyrite.

Talc (soapstone). Cherokee County, occurs ncar Ball Ground and Holly Springs; Fannin County, has been mined near Blue Ridge; Murray County, good grade of talc for burners and crayons, lower grade for grinding; mined at several places near Chatsworth. Undeveloped in Clayton, Cobb, Dekalb, Elbert, Fannin, Fulton, Gilmer, Hall, Habersham, Jasper, Paulding, Union, and White counties.

Tin. See Cassiterite.

Tourmaline. Rabun County, Laurel Creek corundum mine; Towns County, Hog Creek corundum mine near Hiawassee.

Tremolite. Fannin County, Park property near junction of Cutcane and Hampton creeks; Pickens County, Southern Marble quarries, near Tate.

Tripoli. Has been mined in Chattooga County, near Lyerly; Murray County, at Chatsworth and Spring Place; Whitfield County, near Dalton.

Verde antique. See Serpentine.

Wad. Bartow County, associated with psilomelane and pyrolusite in Cartersville manganese mines; not mined.

Zinc. See Sphalerite.

\section{IDAHO.}

Anglesite (lead sulphate). Found in surface ores of some of the argentiferous lead mines in Blaine County, at Sawtooth, Vienna, and Wood River; Custer County, at Bay Horse; Lemhi County, at Texas, and in other districts.

Antimony ore. Shoshone County, reported in ores of Stanley mine, near Burke, in the Cour d'Alene district. Character not known. See also Cervantite and Stibnite.

Argentite. Occurs at the following places: Blaine County, Silver King and Vienna mines; Custer County, Bay Hoṛe and Yankẹe Fork disțịctsts; Elmore County, 
Yuba City, Monarch mine at Atlanta and Banner mines; Idaho County, Warren district; Owyhee Oounty, Black Jack, Trade Dollar, and other Silver City mines.

Arsenopyrite. Common in many mining districts; has been mined in the following places: Ada County, Black Hornet (Shaw Mountain) district, 8 miles east of Boise; Blaine County, mined for gold at North Star, Red Cloud, and Croesus mines; argentiferous near Ketchum; Boise County, mined for gold and silver at Gold Hill, Checkmate, Good Friday, and other claims in Willow Creek district; Bonner County, near Granite; Elmore County, Neal and Rocky Bar districts; Idaho County, Warren district; Washington County, Mineral district.

Asbestos (amphibole). Lewis County, has been mined 14 miles southeast of Kamiah.

Azurite. Blaine County, has been mined with lead ore in Wood River district; Custer County, has been mined with other copper ores; Elmore County, in Tahoma mine, Atlanta district; Oneida County, has been mined at Blackstone mine; Shoshone County, occurs in gangue of silver-lead ores near Mullan; abundant in Hunter; less so in Morning mine, and other mines and prospects.

Bornite. Bannock County, Moonlight property near Pocatello; Kootenai County, prospects on the east side of Lake Pend Oreille; Lemhi County, Copper Queen mine; Shoshone County, Snowstorm and Copper King mines, Cœur d'Alene district; Washington County, Weiser district; mined for gold and silver in Seven Devils district.

Brown iron ore (limonite). Common in outcrops of lode deposits in many mining districts; not mined for iron; used as flux at Muldoon, Blaine County.

Cassiterite. Occasionally found in Jordan Creek and other streams, Bitterroot Mountains; in Lemhi County, on Panther Creek; and in Shoshone County, in the Cœur d'Alene district.

Cerargyrite (horn silver). Has been mined in the following places: Blaine County, surface ore in Wood River district; Custer County, Bay Horse district; Elmore County, surface ore of Monarch lode, Atlanta, and Smoky district; Idaho County, Warren district; Lemhi County, districts in the southeastern part of the county; Owyhee County, De Lamar and Silver City districts. Reported from other districts.

Cerusite (lead carbonate). Common oxidized ore in silver-lead mines of: Blaine County, Wood River district; Custer County, Bay Horse and other districts; Lemhi County, Junction, Nicholia, Spring Mountain, and Texas Creek districts; Shoshone County, Cœur d'Alene district.

Cervantite (antimony ocher). Blaine County, has been mined in Wood River district.

Chalcanthite. Washington County, Mineral district, and in copper mines in other districts.

Chalcedony. Custer County, occurs in Yankee Fork district; Lemhi County, Gravel Range and Parker Mountain districts; Owyhee County, Silver City.

Chalcocite. Bannock County, Moonlight mine near Pocatello; Bear Lake County, in Triassic rocks near Montpelier; Fremont County, Sedalia mine; Shoshone County, mined for gold and silver in the Snowstorm mine, and in small quantity in the Park, Reindeer, and Carney copper prospects, Cœur d'Alene district; Washington County, Seven Devils district.

Chalcopyrite. Blaine County, mined for gold at Argent and Jay Gould mines, Wood River district. Boise County, rare in Willow Creek district. Custer County, chief ore of White Knob copper mine; auriferous in Lost Packer mine. Idaho County, Big Buffalo, Monte Cristo, and Jumbo mines, Buffalo Hump district; prospects near Harpster and Mount Idaho; carries gold and silver: Kootenai County, prospects east of Pend Oreille Lake. Owyhee County, mined for gold and silver at Black Jack and Trade Dollar mines, Silver City. Shoshone County, chief copper ore in Monitor mine, and many prospects of St. 
Joe basin and Cour d'Alene district; subordinate part of ore in Snowstorm mine. Washington County, Mineral and Seven Devils districts.

Cinnabar (sùlphide of mercury). Custer County, in gold-bearing gravel, Willis placers, on Stanley Creek; Elmore County, stringers of cinnabar in granite are reported in the Pine mining district about 40 miles north of Mountain Home; Idaho County, Pringle-Smith prospect on Sugar Creek, 10 miles east of Roosevelt.

Clay (brick). Dug in the following places: Ada County, at Boise; Adams County, Meadows; Bannock County, Pocatello; Bear Lake County, Paris; Bingham County, Idaho Falls; Bonner County, Sandpoint and Albany Falls; Canyon County, Caldwell, Emmett, and Payette; Cassia County, Oakley; Fremont County, St. Anthony; Idaho County, Grangeville and Keuterville; Kootenai County, Cœur d'Alene and Huetter; Latah County, in Genesee, Hendrick, and elsewhere; Nez Perce County, in Ilo, Kippen, Lewiston, and elsewhere; Oneida County, Preston; Washington County, Weiser.

Coal. Bituminous coal has been mined in the eastern part of Bonneville and Fremont counties in an extension of the Sublette field of Wyoming. Lignite has been mined in the ridges between Horseshoe Bend and Jerusalem, Boise County, and near Salmon City, Lemhi County.

Cobalt. Lemhi County, occurs near Blackbird. See also Erythrite.

Copper. The predominant metal produced in the following districts: Adams County, Seven Devils district; Bannock County, Fort Hall; Bear Lake County, Bear Lake; Bonneville County, Mount Pisgah; Blaine County, Hamilton; Bonner County, East Shore (Clark Fork); Custer County, Alder Creek; Fremont County, Skull Canyon and Camp Howard; Lemhi County, Blackbird; Shoshone County, Bald Mountain and Black Prince; Washington County, Heath. Of minor importance in many other mining districts. See also Azurite, Bornite, Chalcanthite, Chalcocite, Chalcopyrite, Covellite, Cuprite, Malachite, Melaconite, and Tetrahedrite.

Copper (native). Shoshone County, rare in Snowstorm mine, Cœur d'Alene district.

Corundum (sapphire). Adams County, in concentrates from Rock Flat gold placer near Meadows. Clearwater County, various shades of blue and green in gravel deposits near Pierce, especially along Rhodes and Orofino creeks.

Covellite. Bear Lake County, small quantity near Montpelier; Shoshone County, in Last Chance mine of Cœur d'Alene district.

Cuprite (copper oxide). Shoshone County, in Snowstorm and Monitor mines, Cœur d'Alene district; Washington County, occurs in Weiser district; argentiferous at River Queen copper deposit, one-half mile above Ballards.

Dufrenoysite. Blaine County, with lead ores in considerable quantity in Wood River district; has been mined; Bonner County, occurs in Crown Point mine.

Erythrite. Lemhi County, near Blackbird.

Freibergite (argentiferous tetrahedrite). Blaine County, has been mined in Columbia, Pilgrim, and other mines in the Sawtooth district.

Galena. Blaine County, the principal ore of Wood River district, mined for lead and silver near Hailey, and elsewhere; Boise County, Checkmate, Good Friday, and other claims in Willow Creek district; mined for gold and silver; Bonner County, occurs with gold at Buckhorn mine, east of Mooyie River; Custer County, Bay Horse district; extensively mined, also in copper ores of White Knob mines; Elmore County, mined in Neal district for gold and silver; Idaho County, Little Giant, Rescue, and other mines in Warren district, for gold and silver; Big Buffalo and Monte Cristo mines, Buffalo Hump district; Kootenai County, mines and prospects on south and west sides of Lake Pend Oreille argentiferous; Snowshoe mine, near Troy; Lemhi County, Texas Creek,

$29123^{\circ}-$ Bull. $585-14-5$ 
Junction, Spring Mountain, and Nicholia districts; extensively mined; Owyhee County, South Mountain, Black Jack, and Trade Dollar mines, Silver City; Shoshone County, chief ore of silver-lead mines, Cœur d'Alene district; associated with gold in Golden Chest and other mines near Murray; prospects in St. Joe basin; Washington County, mined for gold and silver in Mineral district, Blue Mountain gold belt.

Garnet (spessartite). Washington County, with bornite and powellite in Peacock claim, Seven Devils district.

Gold (lode). Predominant metal produced in the following districts: Ada County, Black Hornet and Boise (McIntire); Blaine County, Camas, Little Smoky, and Rosetta; Boise County, Highland Valley, Idaho City, Quartzburg, Summit Flat, and Westview; Bonner County, Mooyie Yaak, Blacktail, and Pine Creek; Cassia County, Connor Creek; Clearwater County, Musselshell Creek, and Pierce; Custer County, Loon Creek, Seafoam, Stanley Basin, Washington Basin, and Yankee Fork; Elmore County, Atlanta, Black Warrior, Neal, Pine Grove, and Rocky Bar; Idaho County, in nearly every district; Lemhi County, in nearly every district; Owyhee County, De Lamar and Mammoth; Shoshone County, Eagle (Murray), St. Regis, and Summit.

Gold (placer). The predominant metal produced in the following districts: Ada County, Snake River; Adams County, Meadows, 16 miles northeast of Evergreen; Bingham County, Snake River at Blackfoot, Rich, and Otis; Blaine County, Soldier and Snake River, near Wampi; Boise County, Moore Creek, Deadwood, Gold Fork, Payette River, and Twin Springs; Cassia County, Snake River; Clearwater County, Burnt Creek, Moose Creek; Elmore County, Highland Valley; Idaho County, Crooks Corral, Maggie, Salmon River, Kootenai County, Camas Cove; Latah County, Gold Creek and Moscow; Lemhi County, Kirtley Creek, Leesburg, Mackinaw, and Pratt Creek; Owyhee County, gravels of Snake River; Shoshone County, St. Joe, 25 miles west of Iron Mountain, Mont.

Granite. Boise County, quarried at Boise and elsewhere.

Hematite. Widespread in outcrops of lode deposits.

Hübnerite. Lemhi County, mined on Patterson Creek, Blue Wing district.

Iron. See Brown iron ore, Hematite, and Magnetite.

Lead (native). Blaine County, reported in Wood River district.

Lead minerals. Lead is the predominant metal in the following districts: Bear Lake County, St. Charles; Blaine County, Dome, Elkhorn, Galena, Muldoon, and Mineral Hill; Bonner County, Priest Lake; Custer County, East Fork, 24 miles west of Mackay; Fremont County, Little Lost River, 25 miles northeast of Arco; Lemhi County, Junction, Spring Mountain, and Texas Creek; Owyhee County, South Mountain, 46 miles south-southwest of Murphy; Shoshone County, Beaver, Evolution, Hunter, Leland, Pine Creek, Slate Creek, Wallace, and Yreka; Washington County, Mineral, 29 miles north-northeast of Huntington, Oregon. See also Anglesite, Cerusite, Galena, Massicot, and Pyromorphite.

Iignite. Boise County, has been mined near Horseshoe Bend; Cassia County, occurs in Goose Creek field; Lemhi County, has been mined near Salmon City.

Iimestone (building). Quarried in Blaine County, at Ketchum and Arco; Fremont County, Rexburg; and Oneida County, Franklin.

Limestone (lime). Bannock County, burned at Pebble; Cassia County, Burley; Clearwater County, Orofino; Fremont County, Rexburg and Teton; Kootenai County, at Squaw Bay on Pend Oreille Lake.

Limonite. See Brown iron ore.

Magnetite (magnetic iron ore). Blaine County, occurs in Wood River country; Shoshone County, rare in ores of Cœur d'Alene district; Washington County, occurs in Mineral district, Blue Mountain gold belt. 
Malachite (green carbonate of copper). Has been mined with other copper ores in Blaine County, Wood River district; Idaho County, Warren district; Washington County, Mineral and Seven Devils districts.

Marble. Cassia County, small quantity quarried at Little Basin.

Marcasite. Has been mined for gold and silver: Blaine County, in Wood River district; and Owyhee County, in Trade Dollar mine, Silver City.

Massicot. Shoshone County, oxidized lead ore in Cœur d'Alene district; Hercules, California, and other mines.

Melaconite. Washington County, was mined with other copper minerals in Seven Devils district.

Mica. Adams County, was mined 15 miles from Council; Cassia County, prospecting 30 miles from Albion; Idaho County, prospecting at Pardee; Latah County, prospecting at Avon and Troy.

Monazite. Ada County, occurs in black sands at Boise and Boise Basin; Adams County, Meadows, Snake River, and John Day Creek; Boise County, in black sands at Placerville, Idaho City, and elsewhere; Canyon County, Payette River; Clearwater County, Orofino, Dent, and elsewhere; Lemhi County, at Leesburg; Lincoln County, at Minidoka; Owyhee County, at Oreana.

Nickel ore. Lemhi County, deposits at Blackbird.

Phosphate rock. Bannock County, occurs in many parts of the county; Bear Lake County, near Georgetown, Montpelier, and Paris; Bingham County, along Snake River; Bonneville County, on Pine Creek and along the State line; Fremont County, along the State line southeast of St. Anthony.

Platinum. Found in small quantity (no production reported in 1910 and 1911) in black sands of Boise, Idaho, and Shoshone counties, and also in the following localities: Ada County, Payette River; Bingham County, Snake River; Clearwater County, Pierce City district; Elmore County, Rocky Bar; Idaho County Elk City district; Nez Perce County, North Fork, Clearwater River.

Polybasite. Owyhee County, occurs at Silver City.

Proustite (light ruby silver). Blaine County, associated with pyrargyrite in Sawtooth and other districts; Elmore County, in Monarch and Buffalo mines, Atlanta; Owyhee County, has been mined at Silver City; Shoshone County, in Cour d'Alene district.

Pumice. Oneida County, has been mined at Rockland.

Pyrargyrite. Blaine County, has been mined in Wood River district; Boise County, has been mined in small quantity for gold and silver in Banner silver veins; Idaho County, in Warren district; Owyhee County, in De Lamar district.

Pyrite. Boise County, mined for gold and silver at Checkmate, Gold Hill, and other veins in Willow Creek district; Custer County, important ore of White Knob copper mine; Elmore County, in Neal district; Idaho County, at Big Buffalo and Jumbo mines in the Buffalo Hump district; Lemhi County, at Gibbonsville and elsewhere; Shoshone County, found in all deposits of Cœur d'Alene district; mined for gold at Golden Chest mine, north of Littlefield; Washington County, at Mineral silver mines, Blue Mountain region.

Pyromorphite. Shoshone County, Cœur d'Alene district; mined at Idaho Giant and other prospects.

Pyrrhotite. Blaine County, has been mined in Croesus, Camas, and Tip Top mines, Wood River district; Lemhi County, in ores of Blackbird and Indian Creek districts; Shoshone County, Cœur d'Alene district, and in copper veins of St. Joe Basin.

Salt (brine). Bannock County, Stump Creek and Tygee valleys, west of Star Valley.

Salt (rock). Bannock County, mined on southeast side of Crow Creek valley, 38 miles northeast of Montpelier; Bear Lake County, mined on Crow Creek.

Sand and gravel. Ada County, dug at Boise and Idaho Falls. 
Sandstone. Quarried in the following localities: Ada County, at Boise and Table Rock; Bonneville County, at Elva, Idaho Falls, and Willow Creek; Fremont County, at Sunnydell.

Scheelite. Blaine County, small quantity reported from North Fork mining district, northeast of Ketchum; Idaho County, has been mined for gold and silver in the Warren mining district; Lemhi County, found as secondary mineral in Bluewing district; Shoshone County, found in Golden Chest and Golden Winnie mines, near Murray.

Silver. The predominant metal produced in the following districts: Blaine County, Antelope, Lava Creek, Sawtooth, and Warm Springs; Boise County, Banner; Bonner County, Kootenai, 40 miles northwest of Iola; Custer County, Bay Horse and Sheep Mountain; Kootenai County, Lakeview and Medimont; Lemhi County; Bluewing and Parker Mountain; Owyhee County, Carson and Flint. Silver is of only less importance in many other districts. See also Argentite, Cerargyrite, Polybasite, Proustite, and Pyrargyrite.

Silver (native). Shoshone County, associated with cerusite in Last Chance mine, Cour d'Alene district; rare; and in oxidized portion of many lodes in the State but nowhere is an abundant ore.

Specularite. Idaho County, streaks through ore at Peacock claim, Seven Devils district.

Sphalerite (zinc blende). Blaine County, mined for gold and silver at Silver King and Vienna mines; Boise County, Gold Hill, Good Friday, Checkmate, and other veins in Willow Creek district; Custer County, occurs with lead-silver ores; Elmore County, small quantity in Neal district; Idaho County, Monte Cristo, and other mines in Buffalo Hump district, and Little Giant, Rescue, and other mines in Warren district; Lemhi County, occurs with lead-silver ores; Owyhee County, Silver City and South Mountain; Shoshone County, associated with galena, etc., in some mines in the Cœur d'Alene district, save at Success and Morning mines; Washington County, Mineral district.

Stibnite. Blaine County, occurs in Wood River district; Boise County, occasionally found at Gold Hill; Elmore County, occasionally found in the Neal district; Shoshone County, has been mined in George Gulch, 1 mile from Burke; carries gold.

Sulphur. Bannock County, sulphur springs deposit near Soda Springs; has been mined.

Tetrahedrite (gray copper ore). Has been mined in the following localities: Blaine County, intergrown with galena in number of mines in the Wood River district; Custer County, great deposits in Bay Horse district; Elmore County, small quantity in Banner mines; Idaho County, mined for gold and silver at Big Buffalo, Jumbo, and other mines in Big Hump district, and at Little Giant, Rescue, and other mines in Warren district; Owyhee County, small quantity at Flint, Silver City; Shoshone County, at some lead-silver mines in the Cour d'Alene district; Washington County, at Mineral silver mines, Blue Mountain gold belt.

Tin. See Cassiterite.

Tungsten. See Hübnerite and Scheelite.

Zinc. See Sphalerite.

\section{ILLINOIS.}

Cement material. Large deposits suited for development. Those developed are: Clark County, "Lower Magnesian" (Ordovician) limestone mined for natural cement near Utica; Cook County, blast-furnace slag and crushed limestone used for Portland cement at Chicago; La Salle County, Pennsylvanian ("Coal 
Measures") limestone quarried for Portland cement material at Oglesby and east of La Salle; Lee County, "Trenton" limestone quarried at Dixon for Portland cement.

Cerusite (carbonate of lead). Jo Daviess County, secondary mineral of lead-zinc mines.

Clay (brick). Clay suitable for brickmaking is dug at one or more places in practically every county in the State. The value of common brick produced in Illinois in 1911 was $\$ 6,129,911$. Total clay products were valued at over $\$ 14,500,000$.

Clay (fire). Dug in Alexander County, at Elco; Calhoun County, Golden Eagle; Fulton County, Avon; Green County, 21 miles northeast of Whitehall, and at Drake; Grundy County, at Coal City; La Salle County, near Streator, Utica, and Ottawa; Livingston County, $1 \frac{1}{2}$ miles south of Streator; McDonough County, 1 mile north of Macomb; Pope County, on branch of Robustle Creek; Rock Island County, at Carbon Cliff; Scott County, Alsey; Union County, Kaolin and Jonesboro; Warren County, Monmouth; Winnebago County, Rockton.

Clay (kaolin). Pope County, has been dug at Raum; Union County, dug at Kaolin. Clay (paper). Pulaski County, occurs at Pulaski.

Clay (pottery). Pits in Green County, at Drake (ball clay also dug); La Salle County, Lowell; Massac County, Round Knob; McDonough County, Colchester; Pulaski County, Yates Landing and near Lockharts Landing; Rock Island County, Carbon Cliff; Warren County, Monmouth.

Coal (bituminous). Nearly three-fourths of the State is underlain by productive coal measures, the total area being estimated at 35,600 square miles. Fifty-one counties reported some coal production in 1911. Sangamon and Williamson counties produced over 5,000,000 short tons each; Macoupin County exceeded 4,000,000 tons; and five other counties, Franklin, Madison, St. Clair, Saline, and Vermilion, produced over $3,000,000$ tons each. The total production of the State in 1911 was $53,679,118$ short tons, valued at $\$ 59,519,478$.

Flagstone. Alexander County, Thebes; Madison County, Alton; Monroe County, Columbia and Monroe; Wayne County, Fairfield; Will County, Joliet, TwelveMile Grove, and Wallingford; in Calhoun, Hamilton, Pike, Scott, Wabash, White, and other counties.

Fluorspar. Hardin County, mined in Rosiclare and Hicks district, at Cave-in-Rock, Fairview Landing, and elsewhere; Pope County, mined at Pittsburg, McClellan, and other mines.

Galena. Hardin County, occurs in small bunches in fluorspar at the Fairview mine, also in Empire mine; Jo Daviess County, occurs in numerous mines. Produced as by-product in cleaning fluorspar at Empire, Rosiclare, and other mines.

Geodes. Hancock County, abundant in shale at Warsaw.

Lead. See Cerusite and Galena.

Limestone (building). Quarried in Adams County, at Front, Jefferson, and Quincy; Boone County, Belvidere; Carroll County, Savanna; Cook County, at Lemont, Sag Bridge, and elsewhere; Jersey County, Grafton; Jo Daviess County, Galena and near Woodbine; Kane County, Batavia; Kankakee County, Momence; La Salle County, La Salle; McHenry County, Marengo; Madison County, Alton; Monroe County, Maeystown and Millstadt Junction; Ogle County, Mount Morris; Randolph County, Menard; Will County, near Lemont, and Joliet; Winnebago County, Rockford and Pecatonica.

Limestone (crushed stone). Quarried in Adams County, at Quincy; Boone County, Belvidere; Carroll County, Savanna; Cook County, Bellwood, Chicago, Summit, and elsewhere; Dupage County, Elmhurst; Hancock County, near Niota; Jersey County, Elsah and Grafton; Kane County, Batavia and South Elgin; 
Kankakee County, Kankakee and Momence; La Salle County, La Salle; Lee County, Dixon; McHenry County, Marengo; Madison County, Alton; Monroe County, Millstadt Junction; Montgomery County, Hillsboro; Ogle County, Rochelle; Pike County, Valley; Randolph County, Menard; Rock Island County, Port Byron and Moline; St. Clair County, Belleville, Falling Springs and Stolle; Union County, Anna; Whiteside County, Fulton and Sterling; Will County, Elwood and Joliet; Winnebago County, Rockford and Rockton.

Limestone (fertilizer). Good limestone for fertilizer occurs in Alexander County, along river bluff one-half mile south of Thebes; Coles County, near Charleston; Hardin County, Rosiclare; Johnson County, Belknap; Pulaski County, near Ullin; Union County, Anna.

Limestone (flux). Quarried in Adams County, at Quincy; Cook County, Chicago; Jersey County, Elsah; Monroe County, Millstadt Junction; Vermilion County, Fairmount; Will County, Joliet.

Limestone (lime). Quarried in Adams County, at Marblehead and Quincy; Cook County, many points in vicinity of Chicago; Jo Daviess County, Stockton; Kankakee County, Kankakee; Madison County, Alton; Monroe County, New Hanover; Rock Island County, Port Byron; Whiteside County, Fulton; Will County, Joliet; Winnebago County, Rockford.

Natural gas. Gas was produced in 1911 in the following counties: Bond, Bureau, Champaign, Clark, Crawford, Cumberland, De Witt, Edgar, Lawrence, Lee, Logan, McHenry, McLean, Macoupin, Morgan, and Pike. There were 458 productive wells at the close of the year.

Peat. Occurs in Boone County, Boone Township; Bureau County, Gold Township; Cook County, in several localities; Kane County, Carpentersville, Hampshire and Rutland; La Salle County, west of Utica; in Lee, Lake, and McHenry counties; Ogle County, Monroe; Stephenson County, Florence; Whiteside County, in Cattail Slough, very large body. In glacial drift 50 to 90 feet below surface, of variable quality, most commonly only a soil rich in humus.

Petroleum. The principal oil-producing counties in 1911 were: Clark, with 60 square miles of productive territory; Crawford, 110 square miles; Cumberland; Lawrence, 40 square miles. There are small fields at Carlisle, Clinton County; Centralia and Sandoval, Marion County; Carlinville, Macoupin County; and other places. Up to the close of 1911 about 16,000 wells had produced oil. The yield for 1911 was $31,317,038$ barrels.

Pyrite. Hardin County, occurs in small quantities in Fairview, Empire, and other mines; Jo Daviess County, with galena and sphalerite in lead-zinc mines.

Sand (building). Dug in Alexander County, at Cairo; Bond County, Greenville; Boone County, Belvidere; Bureau County, Buda and Wyanet; Carroll County, Savanna; Cook County, Lake Michigan and Worth; Dekalb County, Genoa; Dupage County, Warrenville; Henderson County, Gladstone; Jo Daviess County, East Dubuque; Kane County, Aurora, Carpentersville, and elsewhere; Kendall County, Millington; Lake County, Antioch, Beach, and elsewhere; La Salle County, La Salle, Ottawa, and Wedron; Lee County, Dixon; Logan County, Kickapoo Creek and Lincoln; McHenry County, Algonquin and Cary Station; Madison County, Alton; Mercer County, Keithsburg; Ogle County, Hazlehurst and Woosung; Peoria County, Peoria; Piatt County, Hammond; Rock Island County, Moline; Tazewell County, Pekin; Whiteside County, Galt, and near Sterling; Will County, Joliet, Millsdale, and Plainfield; Winnebago County, Rockford and South Beloit; and at other places.

Sand (glass). Bond County, pits at Greenville; Calhoun County, Cap au Iris; Kendall County, Millington; La Salle County, important quarries in St. Peter sandstone at Ottawa, Utica, and Wedron; Lee and Ogle counties, occurs along Rock River. 
Sand (molding). Pits in Alexander County, at Cairo; Bond County, Greenville; Bureau County, Wyanet; Fayette County, Vandalia; Hancock County, Niota; Henderson County, Gladstone; Kane County, Aurora, Batavia, and Elgin; Kendall County, Millington; La Salle County, Ottawa, Utica, and Wedron; Lee County, Pit; McHenry County, Algonquin; Madison County, Collinsville and East Alton; Jackson County, Cora; St. Clair County, East St. Louis and French Village; Shelby County, Cowden; Tazewell County, Pekin; Whiteside County, Round Grove; Will County, Joliet; Winnebago County, Rockton.

Sand and gravel. Abundant and used in many counties for making concrete.

Sandstone. Quarried in Alexander County, at Elco; Carroll County, Savanna; Clay County, Xenia; Fulton County, Lewistown and Marietta; Henry County, Colona; Lee County, Ashton; Union County, small quantity 6 miles east of Anna. Was formerly quarried in Jackson County, Drury Creek; Peoria County, Kickapoo River; Rock Island County, Andalusia; St. Clair County; Sangamon County, west of Springfield; Warren County, Berwick and Greenbush.

Siderite (iron carbonate). Crawford County, Palestine; Edwards County, T. 1 S., R. 10 E.; Hardin County, Sellers Landing; Schuyler County, Sugar Creek, T. 2 N., R. 1; Wayne County, at several localities. These and other localities in Pennsylvanian ("Coal Measures") rocks; beds from 1 to 2 feet thick, generally poor.

Silica (amorphous). Alexander County, mined near McClure; Union County, mined near Jonesboro, Reynoldsville, and Wolf Lake.

Silver. Hardin and Pope counties, recovered from lead concentrates in fluorspar district.

Smithsonite. Jo Daviess County, mined in Galena district.

Sphalerite (zinc blende). Jo Daviess County, principal ore of Galena district. Hardin and Pope counties, small quantities are obtained as a by-product in cleaning fluorspar, though none has been marketed from this region.

Tripoli. Union County, large production from Anna, Jonesboro, and Westlake; refineries at Jonesboro and near Westlake; lesser occurrences elsewhere.

Zinc. See Smithsonite and Sphalerite.

\section{INDIANA.}

Abrasive. See Grindstone, Oilstones, and Whetstones.

Asphalt. Gibson County, bed several feet thick in deep well near Princeton; also seeps into bottom of a coal mine in considerable quantity at same place.

Brown iron ore (bog iron ore, limonite). Clay County, Harmony and in T. $10 \mathrm{~N}$., R. $6 \mathrm{~W}$.; Daviess County, several localities; Greene County, vicinity of Cincinnati and along creeks; Lawrence County, a few workable deposits; Martin County, south of Shoals near Coal Hollow, extensive deposits near Baltimore \& Ohio Southwestern Railroad have been mined; Monroe County, small deposits along Indian Creek, formerly used infurnaces; Noble County, Ore prairie; Orange County, in many hills; Vermilion County, Nortons Creek and Hilton prairie; occurs also at several localities in Jasper, Kosciusko, La Porte, and St. Joseph counties but is not mined.

Cement material (Portland). Plants are operating on local deposits of marl in Lagrange County, at Stroh; and in Kosciusko County, at Syracuse; on limestone in Lawrence County, at Mitchell. Limestone worthy of consideration as source of cement material occurs in three geologic divisions: Cincinnatian series (Upper Ordovician), only in southeastern Indiana, occupying all or part of Dearborn, Fayette, Franklin, Jefferson, Ohio, Ripley, Switzerland, Union, and Wayne counties. Mississippian series (lower Carboniferous), in belt 20 miles wide from Harrison County on Ohio River northwest to Benton County. 
Pennsylvanian series ("Coal Measures" or upper Carboniferous), in southwestern part of State; 14 counties underlain, and some coal found in 12 others. See also Marl, which is suitable for Portland cement.

Cement material (natural). Clark County, Devonian hydraulic limestone quarried. and burned for natural cement at Sellersburg, Belknaps, Speeds, Watson, and Charlestown.

Clay (brick). Indiana ranked seventh in brick produced in the United States in 1911; practically every county in the State has at least one brickyard.

Clay (fire). Common occurrence associated with coal beds in 14 counties in southwest part of State; mined in Clay County, at Brazil; Dubois County, Huntingburg; Vermilion County, West Montezuma; and in many other places.

Clay (kaolin). Greene County, occurs near Newark; Lawrence County, has been mined near Huron, and $2 \frac{1}{2}$ miles west of Shoals; Martin County, large deposit near Indian Springs Hotel; occurs at other places in Lawrence and Martin counties.

Clay (pottery). Productive localities: Clay County, Brazil and Center Point; Dubois County, Huntingburg; Owen County, high-grade, pinkish red 1. miles southwest of Freedom; Parke County, at Bloomingdale; Spencer County, at Lincoln City; Wayne County, alluvial deposits along Whitewater River. Slip clay mined at Elkhart, Elkhart County. Good quality clay, not mined at present, occurs at following places: Clark County, formerly mined near Port Fulton; Daviess County, near Washington, Cannelburg, Montgomery, and elsewhere; Fountain County, superior quality along bottoms of Coal Creek; also found near Shawnee Creek; Green County, good grade one-fourth mile east of Cincinnati and near Mineral City, was mined at Owensburg; Jefferson County, southeast of Dupont; Knox County, Enterprise mine near Bicknell; Martin County, Burns City pike, Little Boggs Creek, and elsewhere; Miami County, fine deposit on Weasaw Creek near Denver; Owen County, occurs in vicinity of Cataract, was mined at Spencer; Putnam County, superior quality near Cloverdale; Sullivan County, was mined at Pleasantville; Switzerland County, was mined at Vevay; Vanderburg County, was mined at Inglefield; Vermilion County, near Hillsdale; Vigo County, at Coal Bluff and elsewhere; Warrick County, in vicinity of Folsomville.

Coal (bituminous). Indiana ranked seventh in United States in 1912, producing over $15,000,000$ tons. Coal area about 6,500 square miles in 26 different counties in southwestern part of State; 8 workable beds 3 to 10 feet thick. Produced commercially in following 19 counties: Clay, Daviess, Dubois, Fountain, Gibson, Greene, Knox, Martin, Owen, Parke, Perry, Pike, Spencer, Sullivan, Vanderburg, Vermilion, Vigo, Warren, and Warrick. "Brazil Black," peculiar to northeastern part of Clay County, has special value as furnace fuel; bed approaching exhaustion.

Dolomite. Cass County, quarried at Kenneth for flux. The Niagara limestone quarried along Wabash River is all dolomite.

Diamond. Found in panning gravels of glacial drift in Brown and Morgan counties; largest stone weighed 2.28 metric carats.

Flagstone: Decatur County, large quantities quarried at Greensburg and St. Paul; Franklin County, at Laurel; several quarries; Orange County, near Paoli; Putnam County, large quantity quarried at Putnamville; Wabash County, Wabash and vicinity; other localities for local use.

Gold (placer). Occurs very sparingly in glacial drift; washed from sands and gravel along streams in Brown and Morgan counties in small quantity; few flakes found in other counties.

Grindstone and scythestones. Have been quarried in Harrison County at Leavenworth; Lawrence County, at Huron; Warren County, at Redwood Creek. See also Oilstones and Whetstones. 
Halite (common salt). In most deep borings or wells more or less salt water is found; not utilized. Salt was made from brines on small scale years ago in Harrison County, at Glen Fort salt works.

Hematite (red iron ore). Greene County, along Ore Branch, Richland Creek, and vicinity of Cincinnati; Lawrence County, sec. 28, T. 5 N., R. 2 W.; Martin County, south of Shoals; not used.

Kaolin (indianaite). Lawrence County, best known deposit at Huron; also found in Martin and Owen counties; has been mined.

Limestone (building). Quarried in Adams County, at Decatur and Linn Grove; Bartholomew County, Elizabethtown and Hartsville; Crawford County, Marengo and Milltown; Decatur County, Harris City, Letts, New Point, and St. Paul; Delaware County, Yorktown; Franklin County, Laurel; Grant County, small quantity quarried at Marion; Howard County, Kokomo; Huntington County, Huntington; Jennings County, Queensville and Scipio; Lawrence County, Bedford, Buff Ridge, and Wallner; Monroe County, Bloomington, Clear Creek, and Ellettsville; Shelby County, small quantity quarried at Waldron; Vanderburg County, at Evansville. Laurel limestone (Niagaran) quarried from extensive beds in Decatur County, at New Point, St. Paul, and Westport; Franklin County, Laurel; Ripley County, near Osgood; Wabash County, similar stone quarried near Wabash. Oolitic limestone, principal quarries: Harrison County, Corydon; Lawrence County, Bedford, Dark Hollow, and Oolitic; Monroe County, Bloomington, Ellettsville, Sanders, and Stinesville; Owen County, near Romona.

Limestone (crushed stone). Grant County, crushed at Marion and near Roseburg; Wabash County, on river bluff, near Wabash.

Iimestone (flux). Quarried in Cass County, at Trimmer; Franklin County, Laurel; Lake County, Indiana Harbor; Lawrence County, Bedford; Monroe County, Bloomington and Ellettsville.

Limestone (lime). Has been or is burned in Carroll County, at Delphi; Cass County, Keesport; Clark County, near Utica; Crawford County, Milltown; Franklin County, near Laurel; Huntington County, Huntington; Jay County, Portland; Lawrence County, Mitchell; Madison County, near Ingalls; Ripley County, near Napoleon; Washington County, Salem.

Iimestone (road metal). Quarried in Adams County, at Decatur, Geneva, and Lenn Grove; Blackford County, Montpelier; Carroll County, near DDelphi; Cass County, Trimmer; Clark County, Jeffersonville and Sellersburg; Decatur County, small quantity quarried at Clarksburg; Delaware County, Muncie and Yorktown; Floyd County, Edwardsville; Fountain County, Davis Township; Franklin County, Brookville, Derbyshire Falls, and Laurel; Grant County, Liberty Township (Fairmount); Hamilton County, small quarries southwest of Fishersville; Harrison County, Corydon; Howard County, Kokomo; Huntington County, Huntington and Warren; Jasper County, Rensselaer; Jay County, Portland; Jennings County, North Vernon and Queensville; Lawrence County, 2 miles northeast of Mitchell, Williams, and elsewhere; Madison County, west part of Alexandria; Montgomery County, Waveland; Newton County, in vicinity of Kentland; Owen County, Spencer; Putnam County, Cloverdale and Greencastle; Pulaski County, Francesville; Randolph County, Farmland and near Ridgeville; Ripley County, Nolton; Rush County, New Salem; Shelby County, Waldron; Vanderburgh County, Inglefield, Evansville, and Howell; Wabash County, Wabash; Wells County, abundant in central part; White County, quarried at Bluffton, near Monon.

Limestone ("rock wool"). Madison County, upper layers Niagara lipuestone used at Alexandria for mineral or "rock wool" by melting and blowing into threads.

Limonite. See Brown iron ore. 
Marl. Calcareous marl in glacial lakes in Elkhart, Fulton, Kosciusko, Lagrange, Lake, Marshall, Noble, St. Joseph, Starke, Steuben, and Whitley counties; minor deposits in Cass, Clinton, Laporte, Miami, Randolph, Vermilion, and White counties; largest marl bed is in Lake Wasassee, 1,700 acres, and thickest is 45 feet in Turkey Lake, Lagrange County.

Mineral paint. See Ocher.

Natural gas. There were 2,633 producing wells at close of 1911 in the following counties: Adams, Bartholomew, Blackford, Daviess, Decatur, Delaware, Grant, Hamilton, Hancock, Henry, Howard, Jay, Madison, Miami, Marion, Martin, Pike, Randolph, Ripley, Rush, Shelby, Spencer, Sullivan, Tipton, and Wayne.

Niter. Crawford and Harrison counties, occurs in caves, not mined.

Ocher (mineral paint). Dearborn County, deposits near Dillsboro; Dubois County, excellent quality has been mined near Ferdinand; Greene County, occurs near Washington; Martin County, has been extensively worked 1 mile west of Dover Hill; Miami County, in several places near Denver and in large quantities in vicinity of Chili; Vigo County, has been mined in Pierson Township.

Oilstones. Orange County, produced at Bonds, French Lick, and Orleans.

Peat. Peat bogs in Allen, Dekalb, Elkhart, Fulton, Jasper, Kosciusko, Lagrange, Lake, Laporte, Marshall, Miami, Newton, Noble, Porter, Pulaski, St. Joseph, Starke, Steuben, Wabash, White, and Whitley counties. Plant operating at Lakeville, St. Joseph County, makes fertilizer filler and briquets.

Petroleum. Production in 1911 was 1,695,289 barrels. Producing wells in the following counties: Adams, Blackford, Delaware, Gibson, Grant, Greene, Hamilton, Huntington, Jay, Perry, Pike, Randolph, Sullivan, Vigo, and Wells.

Pyrite. Knox County, has been mined at Bicknell; Parke County, Coxville; Vigo County, mined with coal at Terre Haute and Macksville.

Road metal. See Limestone (road metal).

Salt. See Halite.

Sand (building). Dug in Allen County, at Fort Wayne; Clark County, Jeffersonville and near New Albany; Clay County, Brazil; Daviess County, Washington; Floyd County, New Albany; Fountain County, Attica, Covington, and Silverwood; Hancock County, near Mohawk; Jefferson County, Madison; Lake County, Liverpool and Miller; Laporte County, Michigan City; Marion County, Indianapolis; Parke County, Montezuma; Porter County, Crisman and Willow Creek; Posey County, New Harmony; Randolph County, Farmland, Modoc, and Winchester; St. Joseph County, Mishawaka and South Bend; Sullivan County, Merom; Tippecanoe County, Lafayette; Vanderburgh County, Evansville; Vermilion County, Clinton; Vigo County, Terre Haute; Warren County, Kickapoo; Wells County, Liberty Center.

Sand (glass). Friable sandstone is quarried and crushed in Martin County, Loogootee; Parke County, at Coxville; White County, near Wolcott. Occurs in Blackford County, Montpelier; Floyd County, New Albany; Fountain County, near Hillsboro; Greene County, Johnson; Hamilton County, Lapel; Harrison County, Depauw; Madison County, bed has been quarried near Pendleton.

Sand (molding). Dug in Clark County, at Jeffersonville and near New Albany; Clay County, Aurora and Brazil; Jackson County, Brownstown and Seymour; Laporte County, Michigan City; Marion County, Indianapolis; Martin County, Loogootee; Morgan County, Centerton; Parke County, Coxville; Porter County, Crocker, McCool, and 4 miles southeast of Valparaiso; Spencer County, Rockport; St. Joseph County, South Bend; Wayne County, Fort Wayne.

Sand and gravel. Very abundant in many counties on bluffs and flood plains of streams. 
Sandstone (building). Quarried in Clay County, at Brazil; Fountain County, at Riverside and Independence; Orange County, at West Baden and Paoli; Parke County, Coxville; Perry County, at Cannelton; Putnam County, near Raccoon and Bainbridge; Spencer County, at Rockport; Vermilion County, at Worthy. Occurs in Dubois County, at St. Anthony; Parke County, at Judson and elsewhere; Warren County, at Green Hill, Williamsport, and elsewhere.

Sapphire. Morgan County, bronze-colored sapphires are found in small number in gold placers.

Siderite. Fountain County, reported as occurring on Coal Creek and Wabash River; Martin County, south of Shoals near Coal Hollow; Monroe County, Indian Creek township; Putnam County, formerly mined at Eaglesfield; Scott County, lean manganiferous ores in Vienna and Finley townships; Vermilion County, Browntown Branch and Big Vermilion River; Vigo County, Terre Haute and Brouillets Creek; about 3,000 acres in Cass, Jasper, Starke, and White counties in beds 1 to 3 feet thick.

Tripoli (polishing powder). Dubois County, has been extensively worked near Ferdinand; Jackson County, deposits near Mooney; Lawrence County, Bedford; Sullivan County, near Merom; Washington County, near Bartle. "Drift marl" found in quantity in Clay County, near Carbon and Rushville; Owen County, near Gosport; Porter County, at Boone Grove.

Whetstones. Indiana ranks second among States in production of whetstones. Dubois, Martin, and Orange counties, Carboniferous sandstones (Pennsylvanian and Mississippian) afford abundant good grindstone "grit." Floyd County, have been quarried at Floyds Knobs; Orange County, have been quarried at Bonds, French Lick, Orleans, Paoli, and West Baden.

\section{IOWA.}

Brown iron ore (limonite). Allamakee County, Iron Hill; Clayton County, in lead and zinc regions; Dubuque County, in lead and zinc regions; Henry County, a lean ore on Skunk River; Jackson County, not in workable quantity; Webster County, in limited quantities.

Cement material. Shales and clays suitable for cement abundant in many parts of the State; calcareous constituent may be obtained from limestone, chalk, and marl, which see. Cement plants operating at Des Moines and Mason City.

Cerusite (lead carbonate). Allamakee County, at Lansing mine (abandoned); Dubuque County, found throughout Dubuque lead region but not in sufficient quantity to be valuable as an ore, except as mined with galena.

Chalcedony. Story County, near Ames, not used. In the geodes of southeastern Iowa.

Chalk. Associated with Cretaceous deposits of northwest Iowa; outcrop confined mainly to valley of Big Sioux River, between Sioux City and Hawarden; bed 30 to 50 feet thick.

Chert. Abundant in the Mississippian rocks in southeastern Iowa; also found associated with the Silurian rocks.

Clay (brick). Abundant in many counties; has been or is dug at one or more places in nearly every county in the State.

Clay (fire). Blackhawk County, has been used at Waterloo; Hardin County, Eldora; Montgomery County, Red Oak. Material suitable for refractory wares occurs in Clay, Des Moines, Henry, Jefferson, Polk, Van Buren, and Wapello counties.

Clay (gumbo). Cedar County, abundant; Decatur County, has been burned at Davis City; Monroe County, Selection; Pottawattamie County, on flood plains; used for railroad ballast: 
Clay (pottery). Delaware County, has been dug and used in Colesburg; Des Moines County, ncar Parrish; Lee County, Donaldson; Mahaska County, 3 miles north of Eddyville, black ware only made; Montgomery County, Red Oak; Muscatine County, Fairport, mined and shipped; Polk County, Pennsylvanian ("Coal Measures") clay of Des Moines group, used for coarser grades of pottery; Van Buren County, Vernon; Webster County, Fort Dodge; Wapello County, Ottumwa. Occurs, but not used: Johnson County, thin seams near Iowa City; Monroe County, has been mined near Attica; Woodbury County, extensive deposits in lower part of the Benton or upper part of the Dakota at Sioux City.

Coal (bituminous). Coal-bearing formations occupy area of about 20,000 square miles in central and southern part of State; thin beds, noncoking. Mined in 21 counties as follows: Adams, Appanoose, Boone, Dallas, Greene, Guthrie, Jasper, Jefferson, Keokuk, Lucas, Mahaska, Marion, Monroe, Page, Polk, Taylor, Van Buren, Wapello, Warren, Wayne, and Webster.

Dolomite. Quarried extensively in Dubuque, Jackson, and other counties. Fine crystals in cavities: Lee County, Keokuk; Webster County, near Fort Dodge. It is prevalent in the Paleozoic rocks of the State.

Galena. Allamakee County, mined at New Galena; Clayton County, mined near Guttenberg and Buena Vista; Dubuque County, the important lead ore of Dubuque region.

Geodes. Lee County, abundant around Keokuk; sold for museum specimens.

Gold (placer). In drift in small quantities in Des Moines, Fayette, Keokuk, and Lee counties; no importance.

Granite. Bowlders in drift in several counties; locally used.

Gravel. Abundant in glacial deposits and river terraces. Used for road metal in Buchanan, Ida, Palo Alto, Pocahontas, Sac, Scott, and other counties; Polk County, dug for ballast along Fourmile Creek.

Gypsum. Extensive deposits quarried in Appanoose County, at Centerville; Webster County, Fort Dodge.

Hematite. Allamakee County, principal ore body at Iron Hill; widely distributed through shales and sandstones of the Pennsylvanian ("Coal Measures"); Jasper County, has been mined near Monroe for manufacture of metallic paints.

Lead minerals. See Cerusite and Galena.

Limestone (building, crushed stone). Quarried at one or more places in more than half the counties in the State.

Limestone (lime). Has been burned at several places in Benton, Blackhawk, Bremer, Cedar, Cerro Gordo, Clayton, Clinton, Davis, Des Moines, Henry, Humboldt, Jackson, Johnson, Linn, Mills, Mitchell, Monroe, Montgomery, Plymouth, Scott, Union, and other counties.

Limonite. See Brown iron ore.

Lithographic stone. Floyd County, occurs in Devonian; Mitchell County, southwest of Osage.

Marble. Not at present quarried in State. Floyd County, at Charles City, fossiliferous marbles were formerly used for mantels and table tops; Van Buren County, occurs at Chequest Creek, known to the trade as Chequest marble, white. The Bonaparte (gray) marble of the trade occurs near Bonaparte:

Marcasite. Des Moines County, abundant in Pennsylvanian ("Coal Measures") rocks; not mined.

Marl. Calcareous marl occurs in many small lakes in north-central part of State; no beds of importance yet discovered.

Mineral paint. See Hematite, Ocher, and Shale. 
Natural gas. Small quantities in glacial drift. Dallas County, wells 100-115 feet deep produced small quantity of gas for several years; used for light and heat, few homes. Guthrie County, shallow wells near Bagley had several pounds' pressure; shut in, not used. Louisa County, wells about 100 feet deep near Letts and Wapello; gas from 4 wells has been used in owners' houses. Muscatine County, small showings of gas in shallow wells in southern part of county, not used.

Ocher (mineral paint). Allamakee County, deposits at Iron Hill and various points along Paint Creek; Jasper County, has been quarried at Fairview Township; Keokuk County, undeveloped deposit near Hayesville; Monroe County, deposits near Hamilton; Webster County, mined at Fort Dodge.

Petroleum. Nowhere discovered in commercial quantity, but rather widely disseminated as shown by traces in wells; found near Fort Madison, Lee County, in very small quantity.

Pyrite. Clayton County, associated with galena and sphalerite in lead-zinc mines; Dubuque County, in lead mines of Dubuque.

Quartz. Widely distributed; crystals in geodes near Keokuk, Lee County, and in mines of Des Moines County, exceptionally fine; sought for museum specimens.

Quartzite. Lyon County, valuable for building purposes, not utilized.

Road metal. Dallas County, gravel beds at Redfield and Van Meter worked extensively for railroad ballast; Dubuque County, dolomite quarried at Dubuque for macadam; Johnson County, stone crushed north of Coralville for railroad ballast, products of Iowa City also used; Madison County, large quantities of limestone crushed for use in Des Moines; Montgomery County, limestone in this county would make excellent macadam; Polk County, gravel beds at Des Moines extensively worked for railroad ballast.

Sand (building). Large supply of good building sand along streams and in sand hills of Benton, Cedar, and Jackson counties; at various points along river in Humboldt County. Pits are worked in the following counties: Appanoose, Audubon, Blackhawk, Buena Vista, Butler, Cherokee, Clinton, Des Moines, Dickinson, Dubuque, Emmet, Fayette, Grundy, Hardin, Howard, Ida, Johnson, Jones, Kossuth, Lee, Linn, Lyon, Mahaska, Marion, Montgomery, O’Brien, Osceola, Palo Alto, Plymouth, Polk, Sac, Scott, Sioux, Story, Van Buren, Wapello, Webster, Woodbury, and Wright.

Sand (glass). Allamakee County, glass sand is abundant in St. Peter sandstone, but is not used; Clayton County, pits worked near Clayton; Johnson County, River Junction; Linn County, Cedar Rapids.

Sand (molding). Dug in Appanoose County, at Centerville; Audubon County, Kimballton; Cherokee County, Cherokee; Linn County, Cedar Rapids; Lyon County, Doon; Marshall County, Marshalltown; Polk County, Des Moines and Valley Junction.

Sand and gravel. Large quantities in stream and drift deposits of Des Moines, Franklin, Lee, Marshall, Muscatine, and other counties.

Sandstone. Sandstone has been quarried in Allamakee County; Clay County, at Garnavillo; Dallas County, Redfield; Davis County, Carbon, local use; Des Moines County, Danville; Dubuque County, Spechts Ferry; Guthrie County, quarried at many points for local use; Hardin County, Eldora and near Steamboat Rock; Jackson County, several small quarries; Jasper County, near Lynnville; Jefferson County, at many points; Jones County, Olin; Lee County, very small quantity quarried at Franklin Township; Marion County, large supply at Red Rock quarry; Muscatine County, along Mississippi River from Scott County to 3 miles west of Muscatine, also quarries on West Branch of Pine Creek in Montpelier Township; Polk County; Scott County, small quantity quarried at Buffalo; Webster County, Washington Township; Woodbury County, near Sioux City. 
shale. Webster County, ground for use as pigments at Fort Dodge.

Silver. Dubuque County, in minute quantities in lead ore at Dubuque; not recovered.

Smithsonite. Clayton County, in lead mines near Buena Vista and Guttenberg; Dubuque County, a common zinc ore at Dubuque mines.

Sphalerite. Allamakee County, mined 5 miles west of Lansing; Clayton County, associated with galena in flatcrevices and fissures in galena limestone; Dubuque County, mined near Dubuque.

Tripoli (polishing powder). Des Moines County, abundant, not used.

Zinc ore. See Smithsonite and Sphalerite.

Abrasive. See Pumice.

KANSAS.

Calamine (zinc silicate). Cherokee County, secondary mineral of zinc ore mined at Galena.

Cement materials. Limestone and shale used for Portland cement in Allen County, at Iola and Concreto; Anderson County, at Mildred; Bourbon County, Fort Scott; Ellis County, Yocemento; Montgomery County, Independence and Le Hunt; Wilson County, Neodesha and Fredonia; Wyandotte County, Bonner Springs. In great abundance generally in eastern two-thirds of State.

Cerusite (lead carbonate, "dry bone"). Cherokee County, secondary mineral of lead ores mined at Galena.

Clay (brick). Dug in the following counties: Allen, Atchison, Bourbon, Chautauqua, Cherokee, Clay, Cloud, Crawford, Douglas, Elk, Franklin, Hamilton, Labette, Leavenworth, Linn, McPherson, Marshall, Miami, Montgomery, Nemaha, Neosho, Phillips, Saline, Shawnee, Wilson, and Wyandotte.

Clay (fire). Fire clay in Pennsylvanian ("Coal Measures") rocks, in Bourbon County, at Fort Scott, under the coal; Douglas County, Lawrence; Leaven"worth County, near Leavenworth; Mill Creek; in all the eastern counties as far west as Manhattan; not pure.

Coal (bituminous). About 20 workable beds, from a few inches to 5 feet thick; essentially steam coals, mined in Atchison County, near Atchison; Cherokee County, Cherokee coal, 18 inches to 5 feet thick, mined at Scammon, excellent quality; Crawford County, Frontenac, Pittsburg, and elsewhere; Franklin County, near Ransomville; Leavenworth County, Leavenworth; Osage County, Osage seam 20-22 inches, along Santa Fe Railway; and many other places. Southeastern part of the State, south of the Kansas River and east of the Shawnee, has workable beds in nearly every county, and beds crop out in Allen, Bourbon, Brown, Coffey, Doniphan, Douglas, Franklin, Greenwood, Jackson, Jefferson, Miami, Nemaha, Neosho, Osage, Shawnee, Wabaunsee, Woodson counties.

Galena. Cherokee County, most abundant lead ore at Badger-Peacock, Galena, and Lawton districts.

Gypsum. Gypsite (gypsum earth), found in low swampy ground in central Kansas forms basis of greater portion of plaster manufacture; mined in Barber County, at Kline; Butler County; Clay County, at Longford. Rock gypsum, mined in Barber and Comanche counties, in Medicine Lodge area; Dickinson County, at Hope; Marshall County, Blue Rapids; Saline County, near Gypsum City. In comparative abundance at numerous places in the Permian rocks of Kansas; in smaller quantities along Smoky River, Ellsworth County, and McPherson County; Tertiary formations in southwestern part of Meade County and Seward County, often in fine crystals. Nearly all gypsite beds in Kansas are exhausted.

Halite. See Salt. 
Hydrozincite. Cherokee County, with calamine and smithsonite, Galena district. Lead. See Cerusite and Galena.

Iignite (brown coal). Extensive beds in the Cretaceous strata, and sparingly in Tertiary, Smoky Hill Valley; beds of good brown coal over large part of western Kansas, range from 1 to 3 feet thick; few beds in Dakota (Cretaceous) strata, always of inferior quality; most important seam 10 to 36 inches thick, is traceable for 170 miles from the northern boundary southwestward across the State, and is found in Barton, Cloud, Ellsworth, Lincoln, McPherson, Mitchell, Ottawa, Republic, Rice, Saline, Washington, and perhaps other adjoining counties.

Limestone (building). Quarried in following places: Atchison County, Atchison; Bourbon County, Fort Scott; Brown County, Hiawatha; Butler County, Augusta and Eldorado; Chase County, Cottonwood Falls; Chautauqua County, Sedan; Cowley County, Silverdale and Winfield; Douglas County, near Lawrence; Franklin County, Ottawa; Greenwood County, Madison; Jackson County, Delia; Jewell County, Randall and near Formosa; Johnson County, Olathe; Labette County, one-half mile south of Parsons; Leavenworth County, Leavenworth; Lyon County, Admire, and near Americus and Emporia; Marion County, Florence and Marion; Marshall County, Irving, Frankfort, and Marysville; Miami County, Paola; Neosho County, Chanute and Erie; Ness County, Bazine; Phillips County, Logan Township; Pottawatomie County, Emmett and Wamego; Riley County, Manhattan and vicinity; Rush County, Alexander; Russell County, Russell; Shawnee County, Topeka; Sumner County,

Caldwell; Wabaunsee County, Alma; and Wyandotte County, Quindaro.

Limestone (crushed stone). Atchison County, Atchison; Brown County, Fairview and Hiawatha; Butler County, Augusta and Eldorado; Chase County, Cottonwood Falls; Chautauqua County, Sedan; Cowley County, Silverdale and Winfield; Douglas County, Lawrence; Elk County, Moline; Franklin County, Ottawa and Wellsville; Greenwood County, Hilltop and Madison; Jackson County, Delia; Johnson County, Olathe; Labette County, one-half mile south of Parsons; Leavenworth County, Leavenworth; Lyon County, near Allen and Americus; Marion County, Florence; Marshall County, Beattie, Irving, Frankfort, and elsewhere; Miami County, Paola; Morris County, Dwight; Neosho County, Chanute and Erie; Pottawatomie County, Emmett; Riley County, Manhattan; Russell County, Russell; Saline County, Salina; Shawnee County, Topeka; Wyandotte County, Loring, Quindaro, and vicinity.

Limestone (lime). Burned for lime: Bourbon County, at Fort Scott; Chautauqua County, at Sedan; Elk County, at.Moline; Shawnee County, at Topeka.

Iimestone (hydraulic, water lime, cement rock). Bourbon County, magnesian limestone occurs at Fort Scott, to some extent hydraulic. Manufactured at Fort Scott.

Marcasite. Cherokee County, abundantly associated with lead and zinc ores at some mines in Galena district. Requires roasting and electric treatment to remove from ore.

Natural gas. Wells in Allen County, Iola, La Harpe, Moran, Savonburg, and Humboldt; Chautauqua County, Peru, Sedan, and many points in southern half of county; Franklin County, Rantoul; Johnson County; Spring Hill; Linn County, Pleasanton, local use; Miami County, Paola and Osawatomie; Montgomery County, Cherrydale, Coffeyville, Independence, Caney, Havana, Jefferson, and Dearing; Neosho County, Chanute, Erie, and Thayer; Wilson County, Altoona, Benedict, Buffalo, Fredonia, Neodesha, New Albany, and Vilas; Wyandotte County, Bonner Springs and Kansas City. 
Petroleum. Producing wells in Allen County, vicinity of Moran and Humboldt; Chautauqua County, Sedan, and southern part: Miami County, high-grade oil, Paola; Montgomery County, Coffeyville, Wayside, and elsewhere in Bolton field; Neosho County, Chanute; Wilson County, in vicinity of Benedict, Neodesha, and Buffalo; Woodson County, vicinity of Toronto. Occurs at numerous other places in State. About 1,800 producing wells in 1910.

Pumice. Dug in Gove County, Quinter; Meade County, Meade; Phillips County, Woodruff; and has been found in many other places.

Pyrite. Cherokee County, associated with lead and zinc ores in Galena district; also abundant in many coal mines of the State.

Salt (brine). Brines obtained from Cherokee and other shales throughout the oil and gas fields. Manufacturers of evaporated salt in Ellsworth County, Ellsworth; Reno County, Hutchinson; and Rice County, Sterling.

Salt (rock). Mined in Ellsworth County, at Ellsworth and Kanopolis; Harper County, Anthony; Kingman County, Kingman; Rice County, Sterling and Lyons.

Sand (building). Dug in Douglas County, at Lawrence; Leavenworth County, at Leavenworth; Reno County, at Hutchinson; Sedgwick County, at Wichita; Shawnee County, at Topeka; Wyandotte County, at Armourdale and Kansas City.

Sandstone. Quarried in Bourbon County, at Fort Scott, Hiattville, and Redfield; Chautauqua County, Chautauqua Springs; Elk County, Howard; Labette County, Parsons; Linn County, Pleasanton; Montgomery County, Independence; Pawnee County, Larned; Pottawatomie County, Onaga; Woodson County, Yates Center.

Siderite (spathic iron ore). Bourbon County, occurs in Pennsylvanian ("Coal Measures") rocks on Marais des Cygnes, near Fort Scott; also on the Neosho and many other streams, interstratified with beds of good coal. Not sufficiently abundant for use.

Smithsonite (zinc carbonate). Cherokee County, mined in Galena district.

Sphalerite (zinc blende). Cherokee County, principal ore of zinc in Badger-Peacock, Galena, and Lawton districts.

Zinc. See Calamine, Hydrozincite, Smithsonite, and Sphalerite.

\section{KENTUCKY.}

Asphalt. Bituminous sandstones are found in the following places: Breckinridge County, quarried 2 miles southwest of Garfield and 2 miles southeast of Harned; Carter County, prospected at Soldier; Edmondson County, small tar springs and many deposits of bituminous sandstone in Bee Spring region, quarried at Pittsburg Landing on Green River; Grayson County, prospect 3 miles south and 9 miles north of Leitchfield, large abandoned quarry at Tar Hill, 9 miles northeast of Leitchfield; Logan County, quarry 5 and 6 miles northeast of Russellville; Rowan County, prospected near Morehead; Warren County, two quarries at Youngs Ferry.

Barite. Anderson County, at Lawrenceburg; Bourbon County, has been mined at Millersburg and near Paris; Boyle County, mined near Danville; Caldwell County, was mined at Fredonia, and shipped; Fayette County, mined and shipped from near Lexington; Franklin County, gangue mineral of Clerk vein near Kissinger; Gerrard County, 4 miles west of Lancaster; Harrison County, in Ordovician limestone, 3 miles southeast of Cynthiana, at Lair Station and vicinity; Henry County, Lockport, and other points, mined and shipped; Jessamine County, 1 mile northeast of Ambrose; Mercer County, was mined near Harrodsburg; Owen County, Gratz mine and other points; Scott County, gangue 
mineral of Johnson vein $1 \frac{1}{2}$ miles from Duvall Station and other points; Woodford County, with galena and sphalerite at Shyrock Ferry, Shropshire, Prewitt, and other prospects; at points in Garrard, Jessamine, Lincoln, Madison, and Russell counties.

Brown iron ore (limonite, brown ore). Bath County, mined at Preston ore banks; occurs in Red River iron region, between Licking and Kentucky rivers, ores at base of Pennsylvanian series ("Coal Measures"); Hanging Rock region, embracing whole or parts of Boyd, Carter, Greenup, Johnson, and Lawrence counties in northeastern gart of State. Iron made from these ores noted for its excellence for castings. In abundance from Ohio River southward to southern part of Carter County; Cumberland River iron region, embracing whole or parts of Caldwell, Crittenden, Livingston, Lyon, and Trigg counties in western part of State; occurs in clay and chert above Mississippian limestones, irregular shape and uncertain extent, but aggregate of ore immense; most extensive deposits are between the Tennessee and Cumberland rivers, and of excellent quality. Nolin district, in Butler, Edmonson, Grayson, Muhlenberg, and Ohio counties; ores occur near base of the Pennsylvanian rocks ("Coal Measures"). "Oriskany" ore on north slope of Pine Mountain, Bell County, has been mined.

Calcite. Fayette County, in vicinity of Morton's Mill, and 6 miles north of Lexington; Livingston County, Spees mine, was mined; Mercer County, is mined and milled at Chinn mine on Kentucky River at mouth of Shawnee Run; Owen County, gangue mineral in Gratz mine; Woodford County, with sphalerite at Shyrock Ferry. Most abundant mineral associated with fluorite in western Kentucky.

Cement material (Portland). Jefferson County, only plant in State in 1912 at Kosmosdale; oolitic limestone from Meade County used. Limestones suitable for Portland cement are abundant in north-central and western part of State. Cement plants are proposed in Campbell County, at Mentor; Kenton County, at Ludlow; Powell County, at Stanton; Rockcastle County, Pine Hill; and a plant was being built in January, 1913, near Livingston, Rockcastle County. Large quantity of pure clay suitable for Portland cement in counties of the Jacksons Purchase region in west Kentucky, west of Tennessee River.

Cement rock (natural). Jefferson County, cement rock first discovered in Central States in digging canal at Louisville. Quarried for natural cement. Similar materials in Lewis and other counties along western border of eastern coal field.

Clay (brick). Widely distributed; used in nearly all counties of the State.

Clay (fire). Flint and plastic clay in Boyd, Carter, Greenup, Lewis, Powell, Rockcastle, Rowan, Wolfe, and other counties of east Kentucky. Siliceous refractory clays in counties west of Tennessee River and also in Crittenden and Livingston counties.

Clay (pottery). Ballard County, thin beds of white plastic clay from Laketown southward and in a few places in eastern part of county; Calloway County, at Potterton; Fulton County, large quantity in bluffs at Hickman, and southward to Tennessee line; Graves County, white, ball, and sagger clay mined at Clay Switch; Hart County, near Bonnieville; Hickman County, pottery clay near Columbus; Madison County, Waco and Bybeetown; McCracken County, in eastern and middle portions and 5 miles south of Paducah; Marshall County, near Scales, west of Benton, and near Palma; was mined at Scale and Hardin.

Coal (bituminous). Pennsylvanian ("Coal Measures") rocks occupy the eastern and western parts of the State. Twelve or more beds which range from 2 to 8 feet in thickness are identified in the eastern field. Most coals hard bituminous, semiblock, excellent for steam and domestic purposes. High-grade coking coals in Big Sandy Valley. The coal-producing counties of eastern Kentucky

$29123^{\circ}-$ Bull. 585-14-6 
are: Bell, Boyd, Breathitt, Carter, Clay, Elliott, Floyd, Greenup, Harlan, Jackson, Johnson, Knott, Knox, Laurel, Lawrence, Lee, Leslie, Letcher, Magoffin, Martin, Morgan, Owsley, Perry, Pike, Pulaski, Rockcastle, Wayne, Whitley, and Wolfe. The coal-producing counties of western Kentucky are: Butler, Christian, Crittenden, Daviess, Edmonson, Grayson, Hancock, Henderson, Hopkins, McLean, Muhlenberg, Ohio, Union, Warren, and Webster.

Dolomite. Ordovician, excellent building material, found along Kentucky River in Clark, Fayette, Franklin, Jessamine, and Woodford counties; a buff and cream colored dolomite, convenient to transportation; "Corniferous" limestone in Bullitt and Nelson counties, of excellent quality and in vast quantities; quarried to some extent.

Fluorspar. Caldwell County, near Princeton and other points; Crittenden County, at Crayne, Marion, and Mexico; Fayette County, in Ordovician limestone in vicinity of Morton's Mill; Jessamine County, south of Ambrose on north side of McKenna branch; Livingston County, Salem and other points; Mercer County, with calcite and barite around bend of Kentucky River and Two Chimneys and Fantail mines; Trigg County, at Gracey; Woodford County, at Faircloths Ferry, below Brooklyn and elsewhere, and was mined at Withrow vein near Spring Station.

Galena. Bourbon County, prospects at Paris and vicinity; Caldwell and Crittenden counties, with fluorspar at Asbridge, Glendale, Tabor, and other mines; Fayette County, Russell Cave and elsewhere; Franklin County, large masses at Kissinger; Harrison County, was prospected near Cynthiana and Lair Station; Livingston County, Evening Star mine; Owen County; Gratz mine; Scott County, Johnson vein about $1 \frac{1}{2}$ miles from Duvall Station; Woodford County, with barite at Withrow vein near Spring Station. Other points in central Kentucky barytes district.

Garnet (pyrope). Elliott County, in peridotite dike on Ison Creek.

Gravel. Ballard County, mined at Wyckliffe; Hickman County, thick beds in bluffs around Columbus; McCracken County, Paducah; abundant in region west of Tennessee River along Ohio River and in regions bordering coal fields, from conglomerate sandstone. Abundant at a number of other points in the Jackson Purchase.

Hematite (red iron ore). Bath County, mined near Owingsville; Graves County, small quantity in gravel beds $2 \frac{1}{2}$ miles south of Hard Money; was mined in Fleming County; Marshall County, small quantity near Birmingham.

Iignite. Ballard County, Fort Jefferson bluff and near Blandville; Graves and Hickman counties.

Limestone. Widely distributed. Used in many counties. Quarried: Boyle County, at Danville and.Perryville; Fayette County, Lexington; Jefferson County, Florida Heights, Louisville, and Tucker; Jessamine County, Nicholasville; Kenton County, Covington and Latonia; Pendleton County, Ivor and near Carntown; Warren County, Bowling Green and Hadley. Has been quarried: Barren County, near Glasgow Junction; Caldwell County, near Princeton and Leitchfield; Púlaski County, near Somerset; also in Grayson, Meade, Simpson, Todd, Wolfe, and other counties.

Limestone (flux). Quarried: Boyd County, at Ashland; Carter County, Lawton and Limestone; Kenton County, Covington; Rockcastle County, Burr; occurs at many other points.

Limestone (lime). Quarried: Christian County, at Hopkinsville; Hardin County, Elizabethtown; Meade County, near Battletown and Cedar Branch; Rockcastle County, Mount Vernon; Union County, Mississippian limestone was burned near Morganfield. 
Limestone (oolitic). Large quarries in Warren County. The oolite outcrops around eastern and northern edge of western coal field and across from there to western edge of eastern coal field.

Lithographic stone. Most important quarry in United States at Bradensburg, Meade County. Found in Bath, Estill, Pulaski, Rowan, Warren, and Wayne counties.

Marble. Barren County, pink and yellow varieties quarried near Cave City; Warren County, near Bowling Green; also in Bath and Rowan counties.

Marl. Bullitt and Spencer county line, in Ordovician; Garrard, Lincoln, Madison, Marion, Nelson, and Washington counties, in Silurian shales. In the Chester group of the Mississippian series in many counties is a marly shale, containing 4 to 6 per cent of potash, 1 or 2 per cent of phosphoric acid, and 15 per cent of lime. Worked near Leitchfield, Grayson County.

Mineral paint. See Ocher.

Natural gas. Barren County, small quantity near Glasgow; Boyd County, at Ashland and near Catlettsburg; Breckenridge County, number of wells in Mississippian limestone at Cloverport; excellent illuminant gas, also domestic fuel to town; Clay County, near Manchester; Estill County, near Irvine; Hardin County, at Elizabethtown; Knox County, large flow was obtained from Big Injun sand near Barbourville; Lawrence County, in Berea sandstone in Horsford well; Logan County, near Diamond Springs; Martin County, large fielc: near Eden; Meade County, most important gas district of western Kentucky, a number of wells in vicinity of Brandenburg and Rock Haven in Devonian shale; Menifee County, "Corniferous" limestone source of large supply of gas; wells on Gay, Mynhier, and other forms near Frenchburg; piped to Mount Sterling, Winchester, and Lexington. Morgan County, Caney sand at Caney, source of high-pressure gas; little development; also on Licking River, supplies West Liberty. Warren County, near Bowling Green, no economic value; Wayne County, large producing wells at Pisgah; Wolfe County, near Campton and near Hazel Green.

Ocher. Ballard County, yellow ocher was mined in the bluffs of creeks near Laketon and in ravine east of Wyckliffe; Calloway County, near Murray; Carlisle County, was mined near Laketon; Crittenden County, 5 miles southwest of Marion; McCracken County, mined 3 miles east of Paducah; Marshall County, on banks of Tennessee River at Highland Landing.

Onyx marble. Barren, Hart, and Edmonson counties, found in limestone caverns.

Petroleum. Oil-producing areas: Barren County, near Glasgow; Bath County; Breathitt County, Frozen Creek; Cumberland County, near Burkville; Estill County, near Irvine; Floyd County, Right Beaver, Salt Lick, and Middle creeks near Prestonburg; Knox County, vicinity of Barbourville; Lawrence County, Busseyville; Logan County, Diamond Springs; Menifee County; Morgan County, Caney and West Liberty; Ohio County, near Hartford; Rowan County, Triplet Creek; Wayne County, number of wells; Webster County, Lebree; Whitley County, near Williamsburg; Wolfe County, near Campton. Oil shows reported in Allen, Boyd, Breckenridge, Caldwell, Carroll, Carter, Christian, Clark, Clinton, Harrison, Hart, Jefferson, Johnson, Knott, Lawrence, McLean, Magoffin, Martin, Meade, Montgomery, Oldham, Pike, Pulaski, Rockcastle, Russell, and Warren counties.

Phosphate rock. Woodford County, mined at Midway; occurs in thin plates and finely comminuted débris from weathering of phosphatic limestone beds at the top of the Lexington limestone and base of the Winchester limestone (Ordovician).

Salt. Salt brines found in gas and oil wells in Breckenridge, Clay, Estill, Hancock, Henderson, Jefferson, Meade, Union, and other counties. May be utilized as source of salt. 
Sand (building). Dug: Boyd County, at Ashland; Campbell County, Dayton; Jefferson County, Louisville and Shively; McCracken County, Paducah; Rockcastle County, Dudley and Withers; Warren County, Bowling Green.

Sand (glass). Dug: Calloway County, in hills bordering Beechy Creek; Carter County, Lawton; Hardin County, at Tip Top, 28 miles southwest of Louisville; Kenton County, Ludlow.

Sand (molding). Dug: Boyd County, at Ashland; Kenton County, Covington and Visalia; Warren County, Bowling Green.

Sandstone. Quarried: Bell County, at Pineville; Breckenridge County, near Garfield; Knox County, Barbourville; Logan County, near Russellville; Muhlenberg County, South Carrollton; Rockcastle County, Langford and Wilfie; Rowan County, Bluestone, Farmers, Freestone, and Morehead. Occurs in many other counties of the State.

Siderite. Boyd, Carter, and Greenup counties, original mineral of Hanging Rock iron ores; Butler, Edmonson, Grayson, Hart, and Muhlenberg counties, occurs in Nolin River district near base of the Pennsylvanian series ("Coal Measures"), largely undeveloped; Whitley County, near Cumberland Falls.

Silver. Crittenden County, recovered from lead concentrates separated from fluorspar.

Smithsonite (zinc carbonate). Crittenden County, mined and shipped from old Jim, Brown, Hodge, Columbia, and other mines.

Sphalerite (zinc blende, blackjack). Crittenden County, mined at Old Jim and Columbia mines; Livingston County, Evening Star mine; occurs in many other mines, usually associated with fluórspar and galena, as accessory mineral in central Kentucky barytes district, and in veins in Lewis County.

Sulphur. Sulphur springs are common all over the State.

Tripoli. Fulton County, in gray silt in top of Hickman bluff and southward, and at several points in eastern parts of Calloway and Marshall counties; not used.

\section{IOUISIANA.}

Brown iron ore (brown hematite, limonite). In Tertiary sands in Bienville, Bossier, Caddo, Claiborne, Lincoln, and Union parishes; not used.

Clay (brick). Abundant throughout the State; dug in following parishes: Ascension, Assumption, Avoyelles, Caddo, Calcasieu, De Soto, East Baton Rouge, East Feliciana, Franklin, Grant, Iberia, Harvey, Lafourche, Lincoln, Livingston, Natchitoches, Ouachita, Pointe Coupee, Rapides, Richland, St. Landry, St. Martin, St. Mary, St. Tancmany, Tangipahoa, Vermilion, Webster, and West Feliciana.

Clay (pottery). Numerous outcrops of very pure white clay called "chalk" in Caddo Parish, near Spring Ridge church, Chalk Hills, and elsewhere; Catahoula Parish, in north-central part of parish; La Salle Parish, has been mined at Rosefield; Natchitoches Parish, lignitic clay near Robeline; Rapides Parish, pure white potter's clay reported in "Grand Gulf" rocks near Lena; and Sabina Parish, 10 miles southeast of Fort Jesup.

Gravel (road metal). Extensive deposit in hills of south Rapides Parish; also in Catahoula, Claiborne, Grant, Sabine, St. Landry, Washington, and Winn parishes; largely used.

Gypsum. Bienville Parish, with limestone at Rayburns salt works; Calcasieu Parish, large quantity in sulphur deposits at Lake Charles; Caldwell Parish, selenitic clays 85 feet thick at Grand View, on Ouachita River; St. Landry Parish, at Pine Prairie.

Hematite. Occurs in Bienville, Grant, Natchitoches, Rapides, Red River, Sabine, Winn, and other parishes; not used. 
Iron. See Brown iron ore and Hematite.

Lignite. Bienville Parish, occurs in eastern part; Caddo Parish, West Shreveport; Caldwell Parish, near Columbia; Claiborne Parish, near Homer; De Soto Parish, northwestern part; Sabine Parish, Coalkill Creek, 6 miles east of Fort Jesup.

Limestone (building). St. Landry Parish, small outcrops; good building stone.

Limestone (crushed stone). Winn Parish, produced at Winnfield.

Limestone (lime). Natchitoches Parish, was burned locally 5 miles from Natchitoches; Sabine Parish, Rocky Spring; St. Landry Parish, Pine Prairie, and on Bayou Chicot.

Limonite. See Brown iron ore.

Marl. Occurs in Catahoula Parish, at Sicily Islands; Claiborne Parish, in vicinity of Homer and Lisbon; Grant Parish, near Montgomery, "Zeuglodon marl" contains glauconite; Natchitoches Parish, phosphatic and greensand marl in bluff at Natchitoches, calcareous.

Natural gas. Caddo Parish, large production from Caddo field near Shreveport; Calcasieu Parish, considerable quantities at Welsh oil wells; De Soto Parish, abundant at Mansfield and Naborton; East Baton Rouge Parish, occurs in several gas pockets in well at Deerford; Grant Parish, in well at Colfax; Iberia Parish, abundance on Bayou Bouillon, 30 miles northeast of New Iberia; La Fourche Parish, small production; Sabine Parish, in salt spring near mouth of Bayou Negrett; St. Martin Parish, above oil in Anse-La-Butte field, and considerable quantity from "Natural Gas Spring," $2 \frac{1}{4}$ miles from Breaux Bridge; St. Mary Parish, Belle Isle; Terrebonne Parish, common occurrence in Quaternary areas.

Petroleum. Caddo Parish, Caddo field important producer; Calcasieu Parish, Vinton gushers in 1911, numerous wells 6 miles northeast of Jennings in Quaternary and Miocene beds, best lubricating oil in southern region in wells near Welsh; Cameron Parish, small quantity of oil from wells on Hackberry Islands; Iberia Parish, small quantity in wells at Bayou Bouillon 30 miles northeast of New Iberia; St. Landry Parish, Pine Prairie, gusher 1912; St. Martin Parish, in coarse shallow sands at Breaux Bridge, Anse-La-Butte district.

Salt (brine). Bienville Parish, Rayburn's salt works, and Kings; Lafayette Parish, salt brines in wells of Anse-La-Butte oil field, and other oil fields, and artesian boring for brine, T. 12 N., R. 5 W.; Natchitoches Parish, old salt works.

Salt (rock). Evangeline Parish, occurs at Pine Prairie, not mined; Iberia Parish, large quantities mined from shafts on Weeks and Avery Islands; North Bienville Parish, has been mined on Saline Bayou and about 8 miles from Bienville; Sabine Parish, has been mined near Coal Bluff and near mouth of Negrett Bayou. Occurs also at Belle Isle, and Jefferson's Island, but is not mined.

Sand (building). Dug: Caddo Parish, at Shreveport; St. Tammany Parish, Bayou Lacomb, and Covington; Webster Parish, Lanesville; West Baton Rouge Parish, Baton Rouge.

Sandstone. Catahoula Parish, small quarries in "Grand Gulf" sandstone near Harrisonburg; Sabine Parish, quarried on Bayou Toro, canal and railroad construction; Winn Parish, best in small exposure at Coochie Brake.

Sandstone (ballast). Iberia Parish, occurs in Iron Mine Run on Petite Anse; Rapides Parish, "Grand Gulf" sandstone quarried between Boyce and Lena.

Sulphur. Calcasieu Parish, obtained from wells in extensive deposit about 3 miles from town of Sulphur; sulphur and associated beds are some hundreds of feet thick; sulphur, associated with limestone above gypsum, melted by superheated water and pumped out by Frasch process. 


\section{MAINE.}

Amethyst. Oxford County, gem crystals found on Deer Hill in town of Stow, and on Pleasant Mountain, in the town of Denmark.

Apatite. Androscoggin County, in transparent pink, purple, blue, and green crystals, at Apatite Hill, Wade, and Pulsifer quarries in town of Auburn, Berry quarry, town of Poland; Oxford County, at Hebron.

Argentite (silver glance). Hancock County, reported from Sullivan silver mine.

Arsenopyrite (arsenical pyrite). Franklin County, Titcombs Hill, Farmington; Hancock County, occurs in Blue Hill and Brooksville copper mines, and Sullivan silver mines, was prospected on Verona Island; Knox County, occurs at Owls Head, South Thomaston; Oxford County, occurs at Corinna, Greenwood, Rumford, and at Mount Rubellite in town of Hebron; Waldo County, occurs in veins in schist at Fort Point; York County, Bonds Mount and Newfield, and accompanying silver ores at Lebanon and Acton.

Beryl. Aquamarine.-Kennebec County, at Winslow with mica and fluorite in cassiterite vein; Oxford County, French Mountain, town of Albany; Dunton mine, town of Newry; Mount Mica, town of Paris, associated with corundum, town of Greenwood; Sugar Hill and Harndon Hill, town of Stoneham.

Golden beryl.-Oxford County, Edgecomb Mountain, town of Stoneham, and Speckled Mountain, town of Peru.

Cæsium beryl.-Androscoggin County, Berry quarry, town of Poland; Oxford County, town of Hebron; on Dudley farm, town of Buckfield.

Opaque varieties common in pegmatites, notably: Androscoggin County, Apatite Hill, town of Auburn; Hancock County, in cassiterite-bearing granite at Catharine Hill; Oxford County, Noyes mine, town of Greenwood.

Bornite (purple copper ore). Hancock County, has been mined in Ellsworth schist at Blue Hill; Washington County, Lubec lead mine and Pembroke copper prospects; not abundant.

Brown iron ore (bog iron ore). Lincoln County, occurs on Pemaquid Ledge; Oxford County, at Rumford; Piscataquis County, Dover, several deposits of large size; Somerset County, Skowhegan, several large deposits; York County, New Limerick and Newfield.

Brown iron ore (brown hematite, limonite). Aroostook County, occurs at Houlton and Linneus; Hancock County, most abundant oxidized mineral in Blue Hill and Brooksville district; Piscataquis County, has been mined at Katahdin mines; Washington County, has been mined at Trescott and at Lubec lead mine, at latter place trace of gold, some silver.

Cassiterite. Kennebec County, occurs in 1-inch vein at Winslow; Oxford County, occasional specimens at Mount Mica and Greenwood.

Cement material. Knox County, limestone near Rockland suitable for Portland cement.

Cerargyrite (silver chloride). Hancock County, reported from Sullivan silver mine. Chalcocite (copper glance). Hancock County, sparingly on chalcopyrite at Blue Hill copper mines, at Douglas mine carries gold and silver.

Chalcopyrite (copper pyrites). Hancock County, important mineral of Blue Hill; has been mined at Douglas, Twin Lead, and other mines for gold and silver; Somerset County, has been mined at Robinson mine; Washington County, occurs in old mines at Cooper; has been mined at Cherryfield and Lubec lead mine for gold and silver, at Pembroke copper prospect.

Clay (brick). Knox County, deposits and brick works at Thomaston, South Thomaston, and Rockland. Dug: Androscoggin County, at Danville, Durham, Leeds Junction, and elsewhere; Aroostook County, Masardis and Presque Isle; Cumberland County, Brunswick, North Yarmouth, and Portland; Hancock County, 
East Sullivan, Ellsworth, Orland, and elsewhere; Kennebec County, Augusta, Waterville, and Winslow; Oxford County, East Bethel; Penobscot County. Bangor, Brewer, and Howland; Piscataquis County, Abbot Village and East Dover; Sagadahoc County, Bath, Topsham, and Woolwich; Somerset County, Madison; Washington County, Calais and Lubec; York' County, Eliot, Kennebunk, Saco, and elsewhere.

Columbite. Androscoggin County, sparingly in pegmatite at Apatite Hill, town of Auburn; Cumberland County, town of Standish; Oxford County, Mount Mica, town of Paris; Sagadahoc County, Harndon Hill, town of Stoneham; Mount Ararat and Willes feldspar quarry, town of Topsham.

Copper. See Bornite, Chalcocite, and Chalcopyrite.

Epidote. Sagadahoc County, occurs at Phippsburg.

Essonite. Sagadahoc County, Phippsburg; Oxford County, found at several places.

Feldspar. Extensively quarried from pegmatite deposits. Androscoggin County, quarried at Apatite Hill, town of Auburn; Berry quarry, town of Poland; Lincoln County, has been quarried in town of Edgecomb; Oxford County, has been quarried at Hibbs quarry and Mills quarry, town of Hebron, at Mount Mica, town of Paris; Piscataquis County, has been quarried at Brownsville; Sagadahoc County, quarried at Golding's quarry, Georgetown, Willes quarries, town of Topsham; has been quarried at Mount Ararat and at Fisher's quarry, town of Topsham.

Flagstone. Mica schist suitable for flagging occurs in Kennebec County, at Winthrop; Sagadahoc County, at Phippsburg; York County, Acton and Lebanon; and at other localities; also sandstones in northern part of State.

Galena. Hancock County, occurs in Ellsworth schist near Blue Hill and Brooksville; Oxford County, in granite at Mount Glines; Penobscot County, in thin veins near Hampden and Corinna; Piscataquis County, at Dover; Somerset County, abundant at Bingham mine, small quantity at Robinson mine has been mined; Washingtọn County, Cherryfield, Lubec lead mine, and Pembroke copper prospect.

Garnet. See Essonite.

Gold. Franklin County, associated with pyrite-bearing slates at Strong; Hancock County, has been mined in granite with molybdenite at Catharine Hill, is sparingly present with sulphides in Blue Hill mines, and in some river gravels and crevices in underlying rocks; Oxford County, has been found in some river gravels; Somerset County, occurs at Moscow, and in some river gravels; Washington County, in quartz veins at Bailey, Baring, and Cutler, and in some river gravels and in crevices in underlying rocks.

Granite. Quarried: Cumberland County, at Brighton, Brunswick, Portland, Pownal, Westbrook, and Woodfords; Franklin County, North Jay; Hancock County, Blue Hill, Brooksville, Dedham, Franklin, and elsewhere; Kennebeck County, Augusta, Hallowell, and Mainstream; Knox County, Long Cove, Pequoit, Rockland, South Thomaston, St. George, and elsewhere; Lincoln County, Round Pond and Waldoboro; Oxford County, Fryeburg and Oxford; Penobscot County, Lincoln, black granite at Hermon Hill; Piscataquis County, Guilford; Somerset County, Canaan and Norridgewock; Waldo County, Frankfort, Searsport, and Swanville; Washington County, Addison, Baileyville, Calais, Jonesboro, Marshfield, and Millbridge; York County, Alfred, Biddleford, and Kennebunkport.

Graphite (plumbago). Cumberland County, occurs in pegmatite dike near Yarmouth; Franklin County, in schist near Madrid; Hancock County, in pegmatite and schists near Blue Hill and Brooksville; Kennebec County, at Gardiner on the Kennebec River; Oxford County, sparingly in granite and mica schist in towns of Paris, Rumford, and Woodstock; Sagadahoc County, has been mined 
at Georgetown and Phippsburg; Waldo County, occurs at Belfast, disseminated through clay slate.

Hematite (red iron ore). Aroostook County, occurs at Curriers; Piscataquis County, has been mined at Katahdin mines.

Infusorial earth. Hancock County, was mined at Blue Hill and Surry; Washington County, was mined at Beddington.

Iron. See Brown iron ore, Hematite, and Magnetite.

Kunzite (spodumene). Oxford County, lilac-colored, occurs in regmatite in town of Andover.

Lead. See Galena.

Lepidolite. Androscoggin County, in pegmatite deposits at Apatite Hill, and in the Wade and Pulsifer quarries, town of Auburn; Oxford County, at the Dunton quarry in the town of Newry, and at Mount Mica, iown of Paris; Mount Rubellite, town of Hebron.

Limestone (lime). Knox County, extensively guarried and burned in vicinity of Rockland, Rockport, Thomaston, and West Warren.

Iimonite. See Brown iron ore.

Magnetite (magnetic iron ore). Aroostook County, occurs at Linneus, impregnating slaty rock; Cumberland County, Raymond, in thin sheets in epidotic gneiss; Hancock County, in schist at Douglas, Twin Lead, Owen, and other mines near Blue Hill and Brooksville, and on Marshall Island; Knox County, Union; Oxford County, Buckfield.

Mica (biotite). Common in many pegmatite deposits of the State.

Mica (muscovite). Abundant in all of the pegmatite deposits. Oxford County, small quantities have been mined at Mount Mica, town of Paris, Bennett and Pingree farms, town of Albany, Hibbs quarry, town of Hebron, southwest part of town of Waterford.

Molybdenite (sulphide of molybdenum). Cumberland County, occurs in granite in close connection with pegmatite at a number of places in Brunswick; Hancock County, under similar conditions at Catharine Hill on Long Island in Blue Hill Bay; Washington County, Cooper, 22 miles southwest of Calais, with fluorspar and bismuth in narrow pegmatite dikes cutting granite along joints, and impregnations in granite.

Ocher. Androscoggin County, has been mined at Lisbon; Cumberland County, occurs at Bridgton, Naples, and Sarmonite.

Platinum. Knox County, in peridotite, East Union; Penobscot County, at Hermon; Piscataquis County, in pyrrhotite ores.

Pollucite. Oxford, found in pegmatite at Buckfield and Hebron.

Pyrargyrite (ruby silver). Hancock County, occurs at Sullivan, Franklin, and Hancock, with galena, native silver, silver glance, pyrite, chalcopyrite, etc., sparingly.

Pyrite. Hancock Countý, Douglas, Twin Lead, Blue Hill, and other mines in Blue Hill and Brooksville district, and in granite at Catharine Hill; Oxford County, in granite at Mount Glines; Somerset County, has been mined at Robinson mine; Washington County, Cherryfield, has been mined at Lubec lead mine.

Pyrrhotite. Hancock County, Douglas, Twin Lead, Monmouth, and other mines, have been mined; Knox County, Miller farm, East Union; Piscataquis County; Somerset County, Robinson mine.

Quartz. Abundant in all pegmatite deposits. White quartz: Androscoggin County, mined with feldspar at Apatite Hill, town of Auburn; Cumberland County, has been mined near Cumberland Mills. Rose quartz: occasionally used as a gem. Oxford County, Tubbs ledge and French Mountain, town of Norway; Mount Mica, town of Paris. Smoky quartz: Androscoggin County, occurs at Apatite Hill, town of Auburn; Oxford County, Blueberry Hill, town of Stoneham. 
Rhodonite. Hancock County, was mined on Osgood farm, Blue Hill, when furnace of Katahdin Iron Works was in blast.

Sand (building). Dug at many places throughout State.

Sand (glass). Knox County, Camden, abundant; not mined; Waldo County, Liberty, pure, granular quartz.

Sandstone. Washington County, Devonian sandstone mostly unsuited for building purposes occurs near Perry.

Silver (native). Hancock County, reported from Eggemoggin and Sullivan mines See also Argentite, Cerargyrite, Pyrargyrite, and Stephanite.

Slate. Piscataquis County, slate region in central part of State, quarried at Barnard plantations, Blanchard, Brownville, Monson, and Williamsburg; Somerset County, prospect in southwest corner of town of Forks.

Sphalerite (zinc blende). Hancock County, occurs sparingly in Blue Hill copper deposits, argentiferous in Gouldsborough mine, has been mined; also found in Eggemoggin, Deer Isle, and other mines, and at Harborside; Somerset County, has been mined at Robinson mine; Washington County, has been mined at Cherryfield, also occurs at Pembroke copper prospect.

Stephanite (silver glance). Hancock County, reported from Sullivan mine.

Talc (soapstone). Hancock County, Harpswell, Jaquish, Deer Isle; Kennebec County, Ovis Island, bed 14 feet wide; Vassalboro.

Tin. See Cassiterite.

Topaz. Oxford County, Harndon Hill, town of Stoneham.

Tourmaline. Colored tourmalines of gem quality. Androscoggin County, mined at Apatite Hill, town of Auburn; has been mined at Wade and Pulsifer quarries, town of Auburn, Berry quarry, town of Poland; Oxford County, mined at Mount Mica, town of Paris; has been mined in town of Greenwood, at Mount Rubellite, town of Hebron, Mills quarry, town of Hebron, Dunton quarry, town of Newry; Sagadahoc County, Willes feldspar quarry, town of Topsham.

Tripolite (diatomaceous earth, "fossil meal"). Hancock County, occurs abundantly in all the pond bottoms near the coast, mined to some extent. A very white, fine variety occurs in Blue Hill ponds in beds from 4 to 6 feet thick.

Wad (bog manganese). Occurs in Aroostook County, at Hodgdon; Hancock County, at Blue Hill; Knox County, at Thomaston, on Dodges Mount; Oxford County, at Sumner; Piscataquis County, at Dover; York County, at Mount Agamenticus.

Zinc. See Sphalerite.

\section{MARYLAND.}

Asbestos (chrysotile). Baltimore and Harford counties, small, inferior deposits of fibrous serpentine have been quarried at several places; Cecil County, at West Nottingham.

Barite. Carroll and Frederick counties, lens-shaped bodies have been found.

Bornite (peacock copper). Carroll County, occurs at Mineral Hill, 7 miles southwest of Finksburg and near New Windsor; Frederick County, mined at Liberty mine between Union Bridge and Libertytown, occurs in Linganore copper region.

Brown iron ore (brown hematite, limonite). Was formerly mined more or less extensively at the following places: Allegany County, Nicholas Mountain and Shriver Ridge; Baltimore County, near Bosley, 2 miles west of Cockeysville, 2 miles west of Glencoe, near Lutherville, Stevenson, and Towson; Carroll County, at Avondale, Bachman Mills, Ebbvale, Lineboro, Melrose, and Westminster; Frederick County, east foot of Catoctin Mountains near Thurmont, near Feagaville, Frederick Junction, Unionville, and Washington Junction; 
Harford County, at Hess, and 2 miles southwest of Jarrettsville; Washington County, 1 mile south of Boonsboro, 3 miles north and 4 miles southwest of Clear Spring, 1 mile and 3 miles northwest of Harpers Ferry, near Green Spring, 2 miles northeast and 1 mile southeast of Indian Spring, 1 and 2 miles south of Pondsville.

Brown iron ore (bog iron ore). Found at several localities in small quantity. Was mined and made into pig iron many years ago at Federalsburg, Caroline County, and on Nassawango Creek, Worcester County, latter locality producing as high as 700 tons in one year.

Calamine (zinc silicate). Carroll County, zinc mine near New Windsor, with sphalerite and smithsonite, not worked.

Cement (natural). Allegany County, Silurian limestone used for natural cement at Cumberland and Potomac; Baltimore County, Cockeysville and Texas; Carroll County, vicinity of Union Bridge; Washington County, at Cavetown, Cayuga, Chewsville, Hagerstown, Hancock, and Tonoloway station.

Cement (Portland). Allegany County, has been quarried at Cumberland and Pinto; Frederick County, Ordovician limestone suitable for $\$$ Portland cement lies along Monocacy River in east-central part of county; Washington County, same rock in two belts, one north and south through center and one in east third of county, has been quarried at Round Top.

Chalcocite (copper sulphide). Carroll County, has been mined at Mineral Hill mine and Roop farm; Frederick County, mined occasionally at Liberty mine, occurs at Bare Hill and Dolly Hyde mines.

Chromite (chromic iron ore). Baltimore County, has been mined at Bare Hills and Soldiers Delight; Carroll County, occurs in a belt from near New Lisbon, through Montgomery County, nearly to Potomac River; Cecil County, formerly mined in small way along State line near Rock Springs; Harford County, was mined at several points in serpentine; Montgomery County, near headwaters of Seneca Creek in serpentine.

Chrysocolla (copper silicate). Carroll County, sparingly in red sandstone between Middleburg and Big Pipe Creek.

Chrysotile. See Asbestos.

Clay (brick and tile). Clay suitable for the manufacture of brick and tile are of common occurrence throughout the State. Common brick are made from sedimentary clays of the Coastal Plain, residual clays of the Piedmont region, and shaly deposits of the Appalachian region. There are 67 brick, tile, and terra-cotta works in the State, including 4 at Baltimore, 2 at Cambridge, 5 at Hagerstown, 3 at Salisbury, 3 at Westminster, and one or more at many localities in 16 different counties.

Clay (fire). Allegany County, worked at Cumberland, Frostburg, and Mount Savage; Baltimore County, Pleistocene and residual clays of Algonkian, worked at 4. places; Cecil County, 4 yards near Northeast; Frederick County, 1 yard at Frederick; Wicomico County, 1 yard at Salisbury.

Clay (kaolin). Cecil County, residual, white, derived from feldspathic gneisses, is used chiefly in manufacture of paper.

Clay (pottery). Anne Arundel County, important outcrops along western shore of Chesapeake Bay from Bodkin Point southward; Cecil County, found at many places in Patapsco formation; pottery clay is worked near Baltimore, Catonsville, Cumberland, Frederick, and Hagerstown.

Coal (bituminous). Occurs in five basins, known as Castleman, Georges Creek, Upper Potomac, Lower Youghiogheny, and Upper Youghiogheny, all in Allegany and Garrett counties; Pittsburg principal seam, mines from Frostburg to Midland; Ocean, Union, and Carlos largest mines; lower beds of Allegheny formation extensively mined from Moscow to Westernport, at Loar- 
ville, Barrellville, and along west bank Potomác River on east border of Garrett County; Lower Kittanning coal (in Allegheny formation), 6 feet, mined North Potomac Valley; Mercer coal bed (in Pottsville formation), 2-4 feet, mined for firing brick at Mount Savage, also mined to slight extent near Westernport; Pittsburg coal (in Monongahela formation), 5-20 feet, extensively mined in Georges Creek district; high-grade steam and blacksmith coal.

Copper (native). Frederick County, Catoctin Mountain, specimens only.

Copper ores. See Bornite, Chalcocite, Chrysocolla, and Malachite.

Diabase. See Road metal.

Dolomite. Quarried in Baltimore County, and near Hagerstown, Washington County.

Feldspar. Baltimore County, orthoclase and microcline mined near Woodstock, Granite, and Hollofield, and across the line in Howard County; Montgomery County, 4 miles west of Laurel, microcline mined; Cecil County, soda feldspar, albite, mined near Conowingo.

Flagstone. Frederick County, Catoctin Mountain, Emmitsburg, High Knob, near Frederick.

Flint. See Quartz.

Fluorspar (fluorite). Allegany County, occurs near Cumberland.

Gabbro. Baltimore County, quarried at Dickeyville and Woodberry; Harford County, near Havre de Grace; Howard County, Savage. See also Road metal.

Galena (lead ore). Baltimore County, traces in Jones Falls quarries; Carroll County, with limestone in western part of Carroll and eastern part of Frederick County; Montgomery County, has been mined for gold in Maryland mine at Great Falls.

Gneiss. Quarried at Baltimore; and in Baltimore County, at Loch Haven, Pikesville, Phoenix, Stevenson, and opposite Ellicott City.

Gold. Baltimore County, found in quartz veins at Catonsville; Carroll County, found in small quantity at Mineral Hill; Montgomery County, was mined with pyrite, galena, etc., at Great Falls.

Granite. Cecil County, quarried extensively at Port Deposit.

Hematite (Clinton oolite). Allegany County, was stripped many years ago on west side of Wills Mountain, near Roberts and near Cumberland; it occurs in three areas, Wills Mountain, Evitts Mountain, and Tussey Mountain.

Hematite (specularite). Carroll County, was formerly mined at Springfield and Carroll mines near Sykesville, Mineral Hill mine near Louisville, and Patapsco mines at Finksburg.

Infusorial earth. Bed 30 feet thick at base of Miocene has been traced from Herring Bay on the Chesapeake to Popes Creek on the Potomac, across Anne Arundel, Calvert, and Charles counties; has been dug for polishing powder; chief production at Lyons Creek on Patuxent River, Anne Arundel County.

Iron ores. See Brown iron ore, Chromite, Hematite, Magnetite, Pyrite, Pyrrhotite, and Siderite.

Limestone (building). Very little limestone is quarried for dimension building stone; small quantities are taken at a few places for local use.

Limestone (crushed stone). Quarried: Allegany County, at Cumberland; Baltimore County, Baltimore, Glyndon; Frederick County, Catoctin Furnace, Frederick, Lime Kiln; Washington County, Cavetown, near Hagerstown, at Maugansville, Pinesburg, and elsewhere.

Limestone (lime). Quarries where stone is or formerly was procured to burn for lime: Allegany County, Cumberland, and near Allegany Grove; Baltimore County, Butler, Dover, Glyndon, and Texas; Carroll County, Avondale, Linwood, Uniontown, Union Bridge, near Westminster, and elsewhere; Frederick County, Buckeystown, Catoctin Furnace, Daysville, Mount Pleasant, Mount Savage, and elsewhere; Howard County, Clarkville, Fulton, and Highland; Washington County, Cavetown, Cayuga, Chewsville, Clear Spring, Hagerstown, Pinesburg, and elsewhere. 
Iimonite. See Brown iron ore.

Linnæite (siegenite, cobalt pyrites). Carroll County, Mineral Hill copper mines, Finksburg, in small quantities with copper ores in chlorite schist.

Magnetite. Baltimore County, was mined 1 mile southeast and $2 \frac{1}{2}$ miles northeast of Whitehall; Frederick County, 15,000 or more tons of ore were taken on hill southwest of Catoctin Furnace, near Thurmont; Harford County, small quantity was mined 1 mile southeast of Minefield. Besides these places where magnetite has been mined, there are several mines and prospects where it has been found in very small quantity or might be found by driving through the limonite cap.

Malachite (green carbonate of copper). In Blue Ridge district and crystalline rocks of Frederick, Carroll, Howard, and Baltimore counties; Liberty mine, Frederick County, only producer.

Manganese ore. Reported in small quantities in Cambrian and Ordovician rocks at following localities: Allegany County, Keysers Ridge and Bear Creek, Youghiogheny Valley; Frederick County, New Market, associated with copper; Montgomery County, at Brookville and Mechanicsville; Washington County, north shore of Potomac, 3 miles north of Harpers Ferry; pyrolusite has been mined.

Marble. Baltimore County, at Cockeysville, fine dolomitic marble quarried for - building and decorative purposes; at Texas, coarse-grained, quarried for flux and lime; Carroll County, a few miles south of Union Bridge, variegated marble suitable for decoration; development work begun; Frederick County, Liberty, New Market, Sams Creek, variegated; east slope Catoctin Mountain, "Potomac or calico marble"; valley of Monocacy River; Washington County, Eakles Mills and Boonsboro, cream-colored and variegated, has been quarried; Benevola and Hagerstown, quarried.

Marl (greensand). Glauconitic, occurs abundantly in Anne Arundel, Charles, Kent, and Prince Georges counties.

Marl (shell). Occurs abundantly in Calvert, Caroline, Queen Annes, St. Marys, and Talbot counties. Caroline County, deposit in bank of Choptank River, near Denton, has been used for road material.

Mica (muscovite). Baltimore County, with quartz and feldspar in quarry near Hollofield Station; Howard County, has been quarried $1 \frac{1}{2}$ miles north of Scaggsville and near Woodstock; Montgomery County, prospects 4 miles northwest of Laurel on south side of Patuxent River.

Ocher. Anne Arundel and Prince Georges counties, was formerly mined from Patapsco and Arundel formations; Frederick County, considerable shipments from Catoctin Furnace pits.

Pyrite. Anne Arundel County, in Magothy formation on Magothy River, was roasted for sulphuric acid; Montgomery County, abundant in quartz at Maryland mine near Great Falls; Prince Georges County, Oxon Creek, was mined for gold.

Pyrolusite. Frederick County, near Point of Rocks; Montgomery County, Brookville, abandoned mines; Washington County, was mined on north shore of Potomac, 3 miles north of Harpers Ferry.

Pyrrhotite. Howard County, in small quantities with hornblende near Woodstock.

Quartz. Baltimore County, quarried at Glen Morris and Woodstock; Carroll County, Louisville; Harford County, Flintville, Deer Creek, and $1 \frac{1}{2}$ miles west of Conowingo (Cecil County); Howard County, Marriotsville; all ground for use in pottery manufacture; Montgomery County, mined 4 miles west of Laurel with mica and feldspar. 
Road metal. Gabbro, extensive in Baltimore, Cecil, Harford, Howard, and Montgomery counties; diabase, long narrow outcrops in Baltimore and Howard counties, more extensive in Frederick and Montgomery counties; marble, limestone, and sandstone, extensive in valleys north of Baltimore City, and in Frederick and Hagerstown valleys; gravels and marls, Anne Arundel, Calvert, Cecil, Charles, Kent, Prince Georges, Queene Annes, and Talbot counties.

Sand (building). Anne Arundel and Baltimore counties, dug and dredged near Baltimore; Prince Georges County, Farmington; Washington County, Hancock.

Sand (glass). Anne Arundel County, dug at Robinson; has been worked on both banks of upper part of Severn River. Allegany and Washington counties; occurs in Silurian and Devonian deposits.

Sand (molding). Anne Arundel County, dug at Magothy River; Baltimore County, Catonsville; Washington County, Rock Forge. Found also in Cecil, Harford, and Kent counties.

Sandstone (building). Quarried in small quantity in Allegany County, at Cumberland; Carroll County, at Taneytown; Montgomery County, near mouth of Seneca Creek.

Sandstone (crushed stone). Allegany County, quarried at Cumberland; Garrett County, Bloomington.

Serpentine. Baltimore County, quarried at Bare Hills and Reistertown; Cecil County, forms wall rock at West Nottingham quarry; Harford County, quarried at Dublin, has been quarried at Broad Creek, near Cambria, at Coopstown, and Deer Creek.

Siderite (spathic iron ore). Confined to Cretaceous deposits of Coastal Plain; found in Anne Arundel, Baltimore, Cecil, and Prince Georges counties; ore occurs in lenses in clay. A large number of ore banks are found on a line from Poplar, through Baltimore, Eldridge, Annapolis Junction, Murkirk, to Branchville.

Silver. Frederick County, Catoctin Furnace, in sphalerite and galena.

Slate. Frederick County, has been quarried at Ijamsville and Bennett Creek, near Thurston; Harford County, quarried for roofing in Peachbottom area, Cardiff; Montgomery County, occurs at Hyattstown.

Smithsonite (carbonate of zinc). Carroll County, zinc mine near New Windsor, with sphalerite and calamine; has been mined.

Soapstone. Small quantity sawn into slabs, more ground for acid and fireproof paints. Carroll County, quarried from extensive deposit northwest of Marriottsville; small quantity ground near Westminster; Cecil County, Patersons on west branch of Northeast River; New Leeds on Little Elk; Harford Co'ınty, soapstone occurs but quarrying abandoned; Montgomery County, near Cloppers Mills, Rockville, and Smells Bridge.

Sphalerite (zinc blende). With crystalline limestone in west part of Carroll County, and east part of Frederick County.

Stibnite. Frederick County, Middletown Valley.

Talc (French chalk). Cecil County, Rock Springs, in serpentine; Montgomery County, 6 miles from Rockville on Darnestown road.

Tetradymite. Montgomery County, has been mined with gold in Great Falls mines.

Tourmaline. Montgomery County, chrome tourmaline near Etchison.

Verde antique. See Serpentine.

Zaratite (emerald nickel). Cecil County, small quantity in chrome ore mine in northern part of county.

Zinc. See Calamine, Smithsonite, and Sphalerite. 


\section{MASSACHUSETTS.}

Alum. Dukes County, lignitic clays in vicinity of Gay Head and elsewhere on Marthas Vineyard, once shipped to Salem for alum.

Anthracite. See Coal.

Aquamarine. Found at Royalston and Fitchburg. See also Beryl.

Asbestos. Berkshire County, was mined in connection with talc at Dalton; Hampshire County, mined near Pelham.

Beryl. Worcester County, at Royalston, best locality in State, blue and yellow gem quality, worked intermittently. Found also in Franklin County at Northfield; Hampden County, Blandford; Hampshire County, Chesterfield, Goshen, and Norwich.

Beryl (emerald). Hampshire County, reported specimens found at Chesterfield and Goshen.

Brown iron ore (limonite, bog iron ore). Dukes County, deposits in swamps and in Tertiary rocks in Marthas Vineyard; Hampden County, formerly worked near Brimfield.

Brown iron ore (brown hematite). Berkshire County, numerous and extensive beds in Richmond, has been mined to some extent; Bristol County, large quantities at Dartmouth and Easton, has been mined at West Stockbridge.

Chalcopyrite (copper pyrites). Essex County, with galena, pyrite, etc., middle vein, Newburyport lead mines; Franklin County, occurs in very small quantity at Davis, Greenfield, Leverett, Montague, and elsewhere, was shipped from Davis mine; Hampshire County, Loudville and Southampton; Worcester County with siderite in mica slate at Sterling.

Chiastolite. Worcester County, good specimen locality in argillaceous slate at Westford and Lancaster; abundant gem quality, some cut.

Chromite (chromic iron ore). Hampden County, in serpentine at Chester, three outcrops 5 to 18 inches wide; 1,200 pounds of ore once obtained.

Clay (brick). Dug in following places: Barnstable County, at West Barnstable; Berkshire County, Braytonville; Bristol County, near Taunton; Dukes County, Gay Head; Essex County, Danvers, Danversport, Salisbury, and elsewhere; Franklin County, Turners Falls, Montague City, and elsewhere; Hampton County, Springfield, West Brimfield, and Williamsette; Hampshire County, Amherst, Easthampton, Northampton, and elsewhere; Middlesex County, Belmont, Cambridge, and Medford; Plymouth County, Bridgewater, Middleboro, Plymouth, and elsewhere; Suffolk County, Chelsea and Revere; Worcester County, East Brookfield, South Fitchburg, Still River, and elsewhere.

Clay (fire). Dug in Bristol County, at Fall River; Dukes County, Chilmark, Gay Head, and Mahonikey.

Clay (kaolin). Berkshire County, occurs 4 miles south of Clayton; Dukes County, occurs at Gay Head and elsewhere; Hampden County, dug at Blandford.

Clay (plastic). Barnstable County, occurs at Truro on Cape Cod; Dukes County, abundant in southeastern part of Chilmark and at Gay Head, Marthas Vineyard; Nantucket County, Nantucket; Plymouth County, beneath sands at Duxbury.

Clay (pottery). Dukes County, underlies district from Tisbury Brook westward to cliffs at Gay Head, Marthas Vineyard, mined at Gay Head; Essex County, mined at Danvers, shipped, not used locally.

Coal (anthracite). The Rhode Island coal field extends northeast into this State and small quantities of coal were mined years ago in Bristol County, at Mansfield; Norfolk County, at Wrentham; Plymouth County, at Middleboro and West Bridgewater. The coal is graphitic and not suitable for domestic fuel. The so-called coal at Worcester is graphitic phyllite and that on the bank of Agawam River at West Springfield is of somewhat the same character. See also Lignite. 
Corundum (emery). Hampden County, has been mined in vicinity of Chester, at Sacket, Wright, and other mines, and with asbestos at Pelham.

Cyanite. Hampshire County, Chesterfield.

Diabase. See Trap rock.

Feldspar. Hampden Coun'ty, small quantities quarried near Blandford.

Flagstone. Berkshire County, Washington; Franklin County, Montague, red micaceous sandstone was quarried.

Fluorspar. Franklin County, occurs at Conway, Deerfield, and Northfield; Hampshire County, occurs in Southampton lead mine, near Northampton, and West Springfield.

Fuller's earth. Worcester County, produced in 1904 at Lancaster.

Galena. Hampden County, was formerly mined at Montgomery; Hampshire County, argentiferous galena in masses to more than 1 foot in diameter were found in Southampton lead mine.

Garnet. Franklin County, many stones almost suitable for cutting on Northfield Mountain; Hampden County, fine crystals at Chester and Russell, large quantity was obtained from Russell.

Gneiss. Franklin County, has been quarried at Montague; Hampden County, Wilbraham and Monson; Worcester County, Boylston, Dudley, Milbury, Westboro, and Uxbridge.

Granite. Quarried at following places for building, monuments, paving, etc.: Berkshire County, Becket; Bristol County, Dartmouth and Fall River; Essex County, Lynn, Peabody, and Rockport; Franklin County, Warwick; Hampden County, Chester and Monson; Hampshire County, Pelham; Lowell County, Westford; Middlesex County, Dunstable, Grantsville, Hopkinton, and Westford; Norfolk County, East Weymouth, Milton, Quincy, and Wrentham; Plymouth County, East Hingham; Worcester County, Fitchburg, Milford, Oxford, and elsewhere. Principal quarrying centers are Becket, Milford, Quincy, and Rockport.

Graphite. Franklin County, impure bed about 5 feet wide reported at Charlemont; Worcester County, in gneiss at Sturbridge; has been mined.

Grindstones (millstones). An argillaceous slate suitable for grindstones found at Charlestown, Malden, and Quincy. Berkshire County, millstone produced at Washington.

Hematite. Franklin County, has been mined in small way at Bernardston, Montague, and Warwick; Hampshire County, at Hawley.

Infusorial earth. Middlesex County, has been mined at Framingham.

Jade. Middlesex County, has been obtained at Framingham; possibly williamsite and not true jade.

Jasper. Essex County, Saugus; Franklin County, in mica slate at Conway; Middlesex County, has been mined at Framingham.

Lead. See Galena.

Lignite (brown coal). Dukes County, Marthas Vineyard, 50 tons mined in 1908, none since.

Limestone (building). Berkshire County, quarried at North Adams; Middlesex County, Acton, Carlisle, Chelmsford, Littleton, and Stoneham; Worcester County, has been quarried at Bolton.

Limestone (lime). Berkshire County, burned at Adams, Cheshire, and elsewhere. Limonite. See Brown iron ore.

Magnetite (magnetic iron ore). Franklin. County, considerable quantity of iron sand at Montague; Hampden County, large quantity impure at Warwick, considerable quantity has been mined at Sacket mine, Chester; Hampshire County, small bed at Plainfield. 
Marble. Berkshire County, quarried at Ashley Falls, Lee, and North Adams; Hampden County, at Westfield.

Marl. Berkshire County, occurs at Lenox, Pittsfield, and Williamstown; Plymouth County, considerable quantity at Duxbury.

Mica (muscovite). Worcester County, at Beryl Hill, Royalston; has been prospected recently.

Mineral paints. Berkshire County, ocher and sienna were once worked at Williamstown; Franklin County, at East Whately.

Novaculite. Middlesex County, in beds of argillaceous slates at Malden; Norfolk County, Quincy; Suffolk County, Charlestown; not used.

Peat. Numerous deposits in swamps and bogs principally in eastern and central parts of State.

Psilomelane. Franklin County, in quartz veins at Conway; Hampshire County, with slate near Plainfield; not mined.

Pyrite (iron pyrites). Franklin County, Davis mine near Rowe, cupriferous, shipping; Worcester County, mined for copperas at Hubbardston.

Pyrolusite. Franklin County, in quartz veins at Conway; Hampshire County, in beds 3 feet thick at Plainfield.

Pyrrhotite. Franklin County, in veins in gneiss at Charlemont; Hampden County, in Chester emery mine.

Quartz. Berkshire County, quarry near Cheshire.

Rhodonite. Berkshire County, at Sheffield; Franklin County, Conway and Hawley; Hampshire County, fine material in Silurian schist at Cummington; has been mined for ornaments.

Road metal. See Granite and Trap rock.

Sand (building). Dug in following places: Berkshire County, at Williamstown and North Adams; Essex County, Lawrence and Methuen; Middlesex County, Watertown; Norfolk County, Walpole; Plymouth County, East Bridgewater and East Wareham; Suffolk County, Boston and Brighton; Worcester County, Worcester; and at many other places.

Sand (glass). Berkshire County, large supply from granular quartzite at Cheshire and Washington; Dukes County, Tertiary sands abundant at Gay Head and vicinity Marthas Vineyard, probably suitable for glass making.

Sand (molding). Dug in Berkshire County, at Cheshire; Plymouth County, East Bridgewater; Worcester County, Worcester.

Sandstone. Hampden County, quarried at East Longmeadow and Holyoke; Suffolk County, Boston, Brighton, and Jamaica Plains, building and crushed stone; Franklin County, has been quarried at Deerfield; Hampshire County, Granby.

Schist. Hampshire County, mica schist was quarried at Chesterfield and Goshen.

Serpentine. Beds extend across State from Rowe to Granville. Berkshire County, occurs at Windsor; Franklin County, on north side of Deerfield River in Zoar; Hampden County, in west part of Westfield; Hampshire county, Middlefield and Hoosac Mountain; Middlesex County, Chelmsford and Littleton.

Siderite (spathic iron ore). Berkshire County, at West Stockbridge, with limonite ore; Dukes County, Gays Head, Marthas Vineyard, in clay; Essex County, Newburyport, with galena at the silver-lead mine in middle vein in small quantities; Worcester County, in mica slate in Sterling and Worcester.

Slate. Franklin County, Connecticut River slate quarried at Bernardston; Middlesex County, has been quarried at Somerville; Norfolk County, argillaceous slate extensively quarried at Quincy; Suffolk County, Charlestown, for gravestones, flagging, etc.; Worcester County, Harvard, Lancaster, Pepperell, and Shirley; has been quarried at Lancaster for roofing and gravestones. 
Soapstone. Berkshire County, has been quarried at Windsor; Hampden County, Blandford; Hampshire County, fine bed associated with serpentine in northeast part of Middlefield; Middlesex County, Groton; Worcester County, Worcester.

Sphalerite (zinc blende). Essex County, has been mined at Newburyport lead mines; Hampshire County, principal ore in vein at Northampton; Worcester County, considerable quantity in mica slate at Sterling.

Spinel (ruby, pleonaste). Middlesex County, in limestone at Littleton and Boxboro; Worcester County, specimen once found at Bolton.

Talc. Berkshire County, mined near Hoosac tunnel and Dalton; Franklin County, mined and milled at Rowe and Zoar; Hampshire County, has been mined in Middlefield. Occurs in small quantity in several other places associated with serpentine.

Tetrahedrite (gray copper ore). Essex County, in lead mine, Newburyport, in small quantities with galena, pyrite, chalcopyrite, and siderite.

Tourmaline. Berkshire County, has been found in limestone at Dalton; Hampden County, at Sacket mine near Chester; Hampshire County, Huntington and asbestos mine at Pelham.

Trap rock. Quarried in Essex County, at Beverly, Methuen, Salisbury, and elsewhere; Franklin County, East Deerfield; Hampden County, Westfield and West Springfield; Hampshire County, Amherst; Middlesex County, Medford, Newton, Weston, and elsewhere; Norfolk County, Brookline and North Stoughton; Suffolk County, Franklin Park and Roxbury; Worcester County, Sterling.

Verde antique. Berkshire County, occurs at Becket; Essex County, at Newbury; Hampden County, at Westfield. See Serpentine.

Wad. Berkshire County, occurs at Sheffield; Franklin County, Conway, Leverett, and Whately; Hampshire County, Chesterfield and Plainfield.

Whetstone. Hampshire County, mica schist quarried at Enfield and Huntington; Norfolk County, extensive quarries in northeastern part of Bellingham.

Wulfenite (molybdate of lead). Hampshire County, found in Manhan lead mine, Loudville, and in Southampton.

Zinc. See Sphalerite.

\section{MICHIGAN.}

Agate. Amygdules and pebbles found at many places along shore of Lake Superior are polished for jewelry. Agates from Petoskey are mainly polished limestone corals.

Amethyst. Occasional good specimens in trap rock of Keweenaw Point.

Anhydrite. Salt shaft at Oakwood, South Detroit; very widespread according to drillings.

Bromine. Produced from brine in Crawford County at Grayling; Gratiot County, St. Louis (idle); Huron County, Harbor Beach; Isabella County, Mount Pleasant; Midland County, Midland; Saginaw County, St. Charles and Saginaw. Up to 2,000 parts per million in deep copper mine waters.

Cement material (Portland). Limestone for Portland cement quarried at Alpena County, Alpena; Eaton County, Bellevue; Emmet County, Petoskey; Monroe County, Dundee; Newaygo County, Newaygo; and Wayne County, Sibley and Bellevue, near Trenton. Suitable limestone also occurs at Arenac County, Omer; Charlevoix County, Bayshore and Charlevoix; Huron County, Bayport and Sebewaing; Cheboygan County, Afton; Jackson County, near the Portage River 5 or 6 miles north of Jackson; Presque Isle County, Onaway; but is not used.

Marl more largely used in cement manufacture, obtained from a large number of localities distributed over the entire State. The more important localities

$29123^{\circ}$-Bull. 585-14_7 
are in Alpena, Antrim, Branch, Crawford, Genesee, Hillsdale, Jackson, Lenawee, Livingston, Mason, Ogemaw, St. Joseph and Washtenaw counties.

Shale is quarried for cement manufacture in Alpena County, 7 miles north of Alpena; Branch County, at Coldwater, near Union City and (formerly) at Bronson; Eaton County, Bellevue; Newaygo County, Newaygo. Suitable shales are found, but not used at present, on the shores of Thunder Bay and at several localities in Charlevoix County.

Chrysocolla. Keweenaw County, at Allouez mine; Ontonagon County, Algomah mine at Lake Mine.

Chlorastrolite. Keweenaw County, collected and cut as gem stone at Isle Royale and occasionally found near Porcupine Mountain and Mandan.

Clay (brick). Obtained from small local deposits over greater part of State. Important localities are: Eaton County, Grand Ledge; Huron County, Sebewaing; Ingham County, Lansing; Ionia County, Ionia; Jackson County, Jackson; Kalamazoo County, Kalamazoo; Shinawassee County, Corunna; Wayne County, Detroit; Wexford County, Harriette. Clay suitable for sewer pipe, vitrified brick, in connection with Saginaw Valley coal mines, especially in Bay County, at West Bay City; Eaton County, large pits at Grand Ledge; Genesee County, at Flushing. See also Cement material and Shale.

Clay (fire). Eaton County, mined at Eaton for sewer pipe and fireproof tile; Jackson County, Spring Arbor coal mines at Batcheldor Place; was formerly mined at Jackson.

Clay (pottery). Ionia County, glacial drift used for pottery at Ionia; Jackson County, 5 miles west of Jackson, not worked; Washtenaw County, glacial drift used for pottery at Ann Arbor; Wayne County, at Detroit; Wexford County, at Harriette, not worked.

Clay (slip). Ontonagon County, mined at Rockland.

Coal (bituminous). Coal basin covers an area of approximately 11,000 square miles. Principal developments in the eastern portion of the field and in a line from Bay City, Bay County, south to Jackson, Jackson County. More important operations in Bay, Greene, and Saginaw counties, though coal also mined in Clinton, Eaton, Jackson, Shiawassee, and Tuscola counties. All of the coal produced is of the noncoking, bituminous variety.

Copper (native). Large quantity mined in Houghton, Keweenaw, and Ontonagon counties, Lake Superior region. Nuggets in glacial drift of both peninsulas, more or less changed to carbonates.

Datolite. From copper mines of the northern peninsula; cut as a gem.

Diamond. Berrien County, one found at Buchanan in glacial drift.

Flagstone. Jackson County, has been quarried at Napoleon.

Gold. Marquette County, Ropes mine, near Ishpeming, T. 48 N., R. 27 W., free gold with auriferous pyrite, chalcopyrite, etc. Also several prospects in T. $48 \mathrm{~N}$., R. $28 \mathrm{~W}$., colors reported in glacial drift.

Granite. Abundant in Upper Peninsula. Only small quantity quarried, and quarries idle since 1909.

Graphite. Baraga County, graphitic slate milled at L'Anse; Marquette County, mine between that place and Humboldt.

Grindstone. Huron County, quarried at Port Austin and Grind Stone City; Sanilac County, sandstone of Marshall formation quarried in Austin township for grindstone.

Gypsum. Iosco County, mined at Alabaster; Kent County, near Grand Rapids and Grandville. Occurs also in northern Arenac County and southeast Ogemaw County, not mined; Mackinac County, near Point Aux Chenes, 7 miles west of St. Ignace, and in the vicinity of St. Martins Bay, not mined at present. See Anhydrite. 
Hematite. The most important iron ore of the State; mined at the following places: Dickinson County, Iron Mountain, Loretto, Norway, Quinnesec, Randville, Vulcan, and Waucedah; Gogebic County, Bessemer, Ironwood, and Wakefield; Iron County, Amasa, Crystal Falls, Iron River, Mansfield, Stambaugh; Marquette County, Champion, Gwinn, Humboldt, Ishpeming, Michigamme, Negaunee, Palmer, Princeton, Republic.

Iron. See Hematite, Magnetite, and Marcasite.

Jaspilite. Marquette County, quarried for road metal at Ishpeming and Negaunee.

Limestone. Extensively quarried in Alpena County; Eaton County, at Bellevue; and Wayne County, Sibley, for use in sodium bicarbonate, soda ash, etc. See also Cement material.

Limestone (building). Quarries in Alpena County, at Alpena; Arenac County, Omer; small quantity quarried in Emmet County, at Petoskey; Huron County, Bay Port; Kent County, Grand Rapids; Menominee County, Menominee; Monroe County', Monroe and Maybee.

Limestone (crushed stone). Quarried and crushed in Alpena, Charlevoix, Cheboygan, Delta, Emmet, Huron, Mackinac, Menominee, Monroe, Oakland, Schoolcraft, and Wayne counties.

Limestone (flux). Quarried in Alpena, Emmet, Mackinac, Monroe, Presque Isle, and Schoolcraft counties.

Iimestone (lime). Quarried and burned in Alpena, Charlevoix, Eaton, Emmet, Huron, Jackson, Kent, Monroe, Sanilac, Schoolcraft, and Wayne counties.

Magnetite. Occurs in small quantities in metamorphosed iron formation in PehokeeGogebic Range.

Manganese ore. Manganiferous iron ore mined in Gogebic district; occurs near Copper Harbor, Keweenaw Point, not now mined.

Marble. Dickinson County, formerly quarried at Metropolitan.

Marcasite. Bay County, in several mines in Lower Verne coal bed; Huron County, abundant in coal mines of Sebewaing and in shales at Point Aux Barque lighthouse; formerly mined in connection with coal.

Marl. Antrim County, mined for polishing powder and burned for lime at Lake Wetzell and other places; Monroe County, was formerly mined for polishing powder north of Plaisance Creek. See also Cement material.

Natural gas. Macomb, Oakland, and St. Clair counties; local consumption.

Peat. Large deposits throughout the State, especially in northern peninsula. In southern peninsula has been utilized to slight extent in manufacture of fuel, paper, and peat litter. Peat fuel plant was operating at Kalamazoo in 1911.

Important localities are in following counties: Chippewa, Clare, Eaton, Jackson, Kalamazoo, Kent, Lenawee, Luce, Mackinac, Mecosta, Ottawa, St. Clair, St. Joseph, Sanilac, Shiawassee, Tuscola, Van Buren, and Washtenaw.

Petroleum. Near Port Huron, Saginaw, and Allegan; production unimportant:

Quartz. Marquette County, mined at Ropes mine, near Ishpeming for abrasive.

Quartzite. Marquette County, used for road metal, Marquette.

Road metal. See Jaspilite, Limestone, Quartzite, and Trap rock.

Salt. From natural brine at Bay City, Midland, Saginaw, and St. Charles. Dissolved from rock salt: Mason County, at Ludington; Manistee County, Manistee, Filer City, and Eastlake; St. Clair County, Marine City and Port Huron; Wayne County, Delray, Detroit, Ecorse, and Wyandotte. Rock salt mined only at Oakwood shaft, South Detroit, just outside city limits.

Sand (building). Abundant throughout the State.

Sand (glass). Monroe County, Sylvania sandstone member of Monroe formation quarried; shipped to Saginaw.

Sand (molding). Used in following places: Berrien County, at St. Joseph and Niles; Calhoun County, Battle Creek; Eaton County; Dimondale; Ingham County, 
Lansing; Jackson County, Jackson; and Tuscola County, Cass City. Occurs, but is not utilized, in Delta, Genesee, Kent, Marquette, and Wayne counties.

Sandstone. Has been quarried at Baraga County, numerous quarries in L'Anse; Calhoun County, Battle Creek; Eaton County, Grand Ledge; Genesee County, Flushing; Houghton County, Jacobsville; Huron County, Grind Stone City near Rush Lake; Jackson County, Springport, Parma, Sandstone, and Napoleon; Keweenaw County, Isle Royale; Marquette County, Marquette; Monroe County, Ottawa Lake.

Shale. Largely quarried for cement materials. Also quarried for manufacture of brick in Bay County, at Bay City; Charlevoix County, East Jordan; Genesee County, Flushing; Ionia County, Ionia; and Shiawassee County, Corunna.

Silver (native). Small quantity mined with copper in Houghton, Keweenaw, and Ontonagon counties, Lake Superior region. Formerly mined on Silver Islet. Associated with copper, made into so-called "half-breed" jewelry.

Slate. Baraga County, at Arvon; not quarried.

Specularite. Occurs with hematite. See Hematite.

Thomsonite. Keweenaw Point amygdules and Lake Superior pebbles; polished for jewelry:

Trap rock. Used for road metal, Marquette, Marquette County, and on Copper Range.

Whetstone. Huron County, quarried at Grind Stone City, Port Austin, and elsewhere; Ontonagon County, novaculite along Carp River between Jackson Forge and Teal Lake; was formerly quarried.

\section{MINNESOTA.}

Brown iron ore (limonite). St. Louis County, large production from Mesabi iron range, and Vermilion Range. Large quantities in contact plane of Cretaceous on Silurian and Devonian, as in Brown, Lesueur, Fillmore, and other counties; also in Cuyuna district.

Calcite. Houston County, large mass at sand quarry near Caledonia suitable for quicklime.

Catlinite (pipestone). Pipestone County, in many localities; largely worked into articles of use and ornament.

Cement material (natural). Blue Earth County, "Lower Magnesian" (Ordovician) limestone used at Mankato; and Mower County, Austin.

Cement material (Portland). Fillmore County, "Trenton" limestone in vicinity of Wykoff and Spring Valley; not used.

Chalcocite (copper glance). Chisago County, occurs in Taylors Falls, argentiferous, and at Pigeon Point; of little importance; Pine County, near Pine City on Snake River.

Chalcopyrite (copper pyrites). Itasca County, occurs in Rainy Lake region; St. Louis County, near Tower.

Clay (brick). Utilized in nearly every county in the State.

Clay (fire). Brown County, has been dug at New Ulm; Redwood County, Redwood Falls; Steele County, dug 1 mile east of Owatonna.

Clay (pottery). Dug in Blue Earth County, near Mankato; Brown County, New Ulm; Goodhue County, extensively dug at Red Wing; Hennepin County, Northtown; Steele Conty, 1 mile east of Owatonna. 'Itasca County, Cretaceous clays suitable for pottery, not used.

Copper. (native). Keweenawan series ("Cupriferous") extends into northeastern part of the State in Chisago, Cook, Pine, and St. Louis counties; of no commercial importance to date.

Copper minerals. See Chalcocite and Chalcopyrite. 
Feldspar. Lake County, considerable quantity quarried, ground at Duluth; St. Louis County, at Point Corundum near Duluth, and at Rices Point.

Flagstone. Blue Earth County, Mankato, on Minnesota River; Brown County, New Ulm; Lesueur County, Ottawa and Kasota; Nicollet County, Redstone; and valley of Minnesota (red quartzite); magnesian limestone on Mississippi, from Winona, Winona County, to Hastings, Dakota County, and thence to Stillwater, Washington County.

Galena. Itasca County, has been mined in Rainy Lake region. Small quantities here and there in "Trenton" limestone in southern part of State.

Gneiss. Redwood County, quarried at Redwood Falls.

Gold (lode). Beltrami County, occurs in many prospects in Archean rocks around Lake of the Woods and near Rat Portage; Itasca County, was mined in Rainy Lake region; St. Louis County, occurs near Vermilion Lake, in quartz in talcose slate, and with pyrite; workings abandoned.

Gold (placer). Fillmore County, small amounts in drift of Spring Valley and Jordan; Olmsted County, along streams; Wabasha County, Chester, and elsewhere.

Granite. Quarried in Benton County, at Sauk Rapids (syenite); Bigstone County, has been quarried near Ortonville; Itasca County, Giants Range north of Mesabi Range, also north of Net Lake and elsewhere; Kanabec County, Mora; Lac Qui Parle County, 3 miles southeast of Big Stone; in Redwood County; Renville County, Morton; St. Louis County, Duluth; Sherburne County, Haven; Stearns County, Rockville, and in vicinity of St. Cloud.

Hematite (red iron ore). St. Louis County, large quantity, many mines, in Mesabi, Vermilion, and Cuyuna ranges. Shipments amount to millions of tons annually.

Hematite (specular iron ore). Mined in Cook and Itasca counties.

Iron. See Brown iron ore, Hematite, Magnetite, and Pyrite.

Kaolin. Occurs in Cretaceous strata in Minnesota River valley; also in Itasca County. See also Clay (pottery).

Lignite. Itasca County, occurs in Rainy Lake region; of doubtful value.

Limestone (building). Cottonwood County, limestone was quarried at Selma and Delton for foundations and walls; Le Sueur County, magnesian limestone quarried at Kasota.

Limestone (crushed stone). Quarried in Anoka County, at Fridley; Blue Earth County, Judson and Mankato; Dakota County, Mendota, Farmington, and Lakeville; Dodge County, Mantorville; Fillmore County, Rushford; Goodhue County, Red Wing and Wanamingo; Hennepin County, Minneapolis; Houston County, Caledonia and Hokah; Le Sueur County, Kasota and Ottawa; Nicollet County, St. Peter; Olmsted County, Rochester; Ramsey County, St. Paul; Rice County, Cannon City; Scott County, Louisville; Sibley County, Faxon and Jessenland; Steele County, Clinton Falls near Owatonna; Traverse County, Austin; Wabash County, Minneiska; Washington County, Stillwater; Winona County, Minnesota City, Homer, Stockton, and Winona.

Limestone (hydraulic). Dodge County, Galena limestone at Mantorville, has properties of hydraulic limestone.

Limestone (lime). Limestones widely distributed and burned in many counties in the State.

Limonite. See Brown iron ore.

Magnetite (magnetic iron ore). St. Louis County, mined in Cuyuna, Mesabi, and Vermilion districts. Great quantities of lean magnetic iron-bearing rocks occur at east end of Mesabi Range, in Gunflint district, where Duluth gabbro cuts overlying formation.

Marl. Very frequently under the peat bog bordering many small lakes. Has been burned for lime. 
Mica. Itasca County, occurs in pegmatite dikes in Rainy Lake region.

Mineral paint. Redwood County, kaolinized gneiss and granite was used for paint at Reedwood Falls.

Natural gas. Small quantities found in Big Stone, Freeborn, and Waseca counties; no importance.

Nickel. Cook County, small quantity in gabbro.

Peat. Anoka County, Coon Creek, formerly manufactured into fuel; many other localities.

Pyrite (auriferous). Has been mined in Cook County, at Pigeon Point, Lake Superior, with chalcopyrite; Itasca County, Rainy Lake region; St. Louis County, Vermilion Lake.

Quartzite. Pipestone County, quarried near Pipestone City. Occurs in Brown County at New Ulm, and in Cottonwood, Pipestone, Rock, and Watonwan counties; a very hard and durable stone.

Sand (building). Dug in Dakota County, at South St. Paul; Goodhue County, Red Wing; Hennepin County, Minneapolis; Nicollet County, Courtland; Rice County, near Northfield; Rock County, Luverne; St. Louis County, Lake Superior, near Duluth; Scott County, Jordan; Washington County, Stillwater; and Winona County, Winona.

Sand (concrete and mortar). Dakota County, St. Peter sandstone furnishes sand for mortar in several places; Fillmore County, St. Peter and Jordan sandstones suitable for mortar sand and lime, mixed for concrete at Fillmore and Rushford; Houston County, St. Peter and Cambrian sandstones quarried near Caledonia and Union.

Sand (molding). Dug in Pine County, at Kerrick; Ramsey County, St. Paul; Rice County, near Northfield; St. Louis County, Duluth; Washington County, Stillwater.

Sandstone (building). Pine County, quarried at Sandstone on Kettle River; fine quality.

Sandstone (concrete, crushed stone). Quarried in Brown County, at New Ulm; Chisago County, at Taylors Falls; Hennepin County, near Fort Snelling; Pine County, Banning; Pipestone County, Jasper; Rock County, Luverne; St. Louis County, near Fond du Lac; Scott County, Jordan along Sand Creek; Winona County, Dresbach.

Silver. Cook County, small quantity found in Animikie rocks.

Slate (roofing). Has been quarried in Carlton County, at Thomson; St. Louis County, few miles west of Duluth. In favorable situations and large quantity at Vermilion Lake and other points in northeastern Minnesota.

Specularite. See Hematite (specular iron ore).

Sphalerite (zinc blende). Itasca County, was mined in Rainy Lake region; Washington County, Stillwater. Small scattered masses at several places in "Trenton" limestone in southeastern Minnesota.

Trap rock. Quarried in Chisago County, at Taylors Falls; and St. Louis County, at Duluth.

Tripoli (polishing powder). Washington County, occurs at Stillwater between bluffs of Browns Creek.

\section{MISSISSIPPI.}

Brown iron ore (limonite). Tishomingo County, Iuka Lake, not used; common in orange sand but unimportant.

Burrstone. Attala, Carroll, Leake, and Neshoba counties furnish hard quartzitic sandstone used locally for building stone.

Cement material. Suitable material for Portland and natural cement is found in the northeastern part of the State, in Alcorn, eastern Chickasaw, Clay, Itawamba, Lee, western Lowndes, western Monroe, Noxubee, Oktibbeha, Prentiss, 
and Tishomingo counties; and in a belt extending nearly east and west across the center of the State, including parts of Clarke, Hinds, Jasper, Rankin, Scott, Smith, Warren, Wayne, and Yazoo counties; none produced.

Clay. Clay is found in nearly every county in the State. "Buckshot" clay burned and used as road metal at Clarksdale and elsewhere, Coahoma County.

Clay (brick). Brick is made locally from clay found in the following counties: Adams, Alcorn, Amite, Attala, Chickasaw, Claiborne, Clarke, Clay, Coahoma, Copiah, Covington, De Soto, Forest, Franklin, Greene, Grenada, Hancock, Harrison, Hinds, Holmes, Jackson, Jones, Lafayette, Lamar, Lauderdale, Lee, Leflore, Lincoln, Lowndes, Madison, Monroe, Montgomery, Newton, Noxubee, Oktibbeha, Panola, Pike, Pontotoc, Prentiss, Quitman, Smith, Sunflower, Tallahatchie, Tate, Tippah, Tunica, Union, Warren, Washington, Wayne, Webster, Wilkinson, Winston, Yalobusha, and Yazoo.

Clay (fire). Fire brick is made in Jefferson County at Stonington; Marshall County, Holly Springs; Smith County, Taylorville.

Clay (pottery). Pottery is made from the clays in Harrison County, at Biloxi; Itawamba County, at Miston and vicinity; Jefferson County, at Stonington; Lauderdale County, at Lockhart and Lauderdale; Marshall County, Holly Springs; Tishomingo County, Lake Coma; Webster County, Mathiston; Winston County, western part. Excellent clays for pottery, stoneware, and terra cotta abundant at Oxford, Lafayette County; not used at present.

Gypsum. Rankin County, near Cato; also east and west of Rankin County, was formerly mined. Gypsiferous marls in Attala, Carroll, Hinds, Holmes, Leake, Madison, Rankin, and Scott counties.

Lignite (brown coal). Found over a large part of the State. Of possible future importance in Benton, Calhoun, Choctaw, Holmes, Itawamba, Kemper, Lafayette, Lauderdale, Monroe, Panola, Pontotoc, Scott, Tate, Webster, Winston, and Yalobusha counties. No production at present. Thickest beds are 20 inches near Reedsville, Itawamba County, and two beds each 5 feet thick, separated by less than 2 feet of clay, at Tchula, Holmes County.

Limestone. Quarried for building material for local use in Clarke, Jasper, Noxubee, Smith, and Wayne counties. Burned for lime in Jasper, Rankin, and Wayne counties.

Limestone (hydraulic). See Cement material.

Limonite. See Brown iron ore.

Marl. Marls suitable for local use as fertilizer are found in Attala, Carroll, Chickasaw, Claiborne, Clarke, Hinds, Holmes, Leake, Lowndes, Madison, Pontotoc, Rankin, Scott, Smith, Tippah, Tishomingo, Warren, and Wayne counties.

Millstone. See Burrstone.

Ocher (mineral paint). Tishomingo County, extensive beds of red ocher, some yellow ocher near Iuka; was formerly mined and shipped.

Road metal. Burned clay used at Clarksdale, Coahoma County. Clay suitable for this use found throughout the Yazoo delta region. Crushed limestone from Tishomingo County used locally. Also chert gravel and beds of fine chert near Tennessee River in northeastern Tishomingo and in Itawamba counties. Other suitable material is burrstone of Attala, Clarke, Grenada, Lauderdale, Leake, Montgomery, Neshoba, and Newton counties.

Sand (building). Dug in Carroll County, at Carrollton; Forest County, at Hattiesburg; Hinds County, Jackson; Warren County, near Vicksburg; Washington County, Greenville. Immense quantity at Oxford, Lafayette County, and in most of the north-central counties where the Wilcox formation outcrops.

Sand (glass). Hinds County, occurs at Byram and Jackson, and elsewhere along Pearl River; Tishomingo County, large deposit of fne-grained silica 1 mile from Tennessee River now worked; also in southern part of county, Horn Island. 
Sand (molding). Dug in Alcorn County, at Corinth; Hinds County, Jackson.

Sandstone. Attala, Carroll, Leake, and Neshoba counties, burrstone locally used; Claiborne County, sandstones of Grand Gulf region of inferior quality; Hinds

- County, has been quarried near Raymond; Lafayette, Marshall, Tippah, and Yalobusha counties, some stone suitable for building; Rankin County, quarried at Starr; Tishomingo County, along Big Bear Creek, Bay Spring, Gardner, on Rock Creek, and kelow Scott's mill.

Siderite. Notable deposits of iron carbonate have recently been discovered in Benton, Lafayette, Marskall, and Tippah counties.

\section{MISSOURI.}

Anglesite. Jasper County, Joplin district. In fine tabular crystals on galena in lead and zinc mines in southeast and southwest Missouri.

Asphalt (bitumen, mineral pitch). Barton County, occurs impregnating sandstone, and is quarried near Liberal; Lafayette County, in small quantity near Higginsville.

Azurite (blue carbonate of copper). Crawford, Dent, and Phelps counties, found in small quantities in many of the hematite deposits; Franklin County, at one time mined and smelted near Sullivan.

Barite (heavy spar). Cole County, mined at Eugene, Henley, and Hickory Hill; Franklin County, at Morrellton and St. Clair; Jefferson County; Miller County, at Etterville and Bagnell; Morgan County, at Versailles; St. Francois County, Blackwell; Washington County, Barytes, Cadet, Fertile, and elsewhere. Occurs as important gangue of central and southeastern lead regions.

Brown iron ore (limonite). Franklin County, mixed with ocher and chert in cavities at Bowlen Bank, Iron Hill, and Stanton Hill Bank, dug from pits near Moselle, and shipped; Howell County, Lamons mine, near West Plains, mined and shipped to lead smelters in Kansas City; Madison County, Mine La Motte, formerly used mainly for flux. Found chiefly in Cambrian limestones widely distributed over counties of the southern and central parts of the State; has been mined in numerous localities.

Calamine (silicate of zinc). Jasper County, mined in Joplin district; Lawrence County, at Aurora; Newton County, at Granby.

Calcite. Jasper County, occurs in Joplin district, museum specimens.

Cement (natural). Clinton County, shales and limestone suitable for natural cement in vicinity of Plattsburg.

Cement material (Portland). Ordovician and Devonian limestones and shales in narrow belt along eastern border of State from Ralls County on north to Cape Girardeau County on south. Mississippian limestones over extensive areas in northeast and southwest Missouri. Pennsylvanian ("Coal Measures") limestones and shales in northern and western parts of State best adapted for Portland cement. Plants at Cement City, east of Kansas City; Prospect Hill and Continental, near St. Louis; and Cape Girardeau.

Cerusite (carbonate of lead). Jasper County, mined in Joplin district; Newton County, Granby district; and in other mines in Dade, Greene, Lawrence, and Madison counties.

Chalcocite (copper glance). Occurs in subordinate quantity in Crawford County, in Sullivan mines; Shannon County, Slater and Tyrell mines near Eminence; Ste. Genevieve County, in Cornwall mines.

Chalcopyrite (copper pyrites). Franklin County, irregularly distributed through clay at Sullivan mine; Madison County, disseminated through limestone at Mine La Motte, and mined at Mine La Motte and Fredericktown; Shannon County, mined at Slater and Jerktail mines; Ste. Genevieve County, mined at 
Ste. Genevieve mines. Widely distributed in small quantities in Joplin district, Jasper, Lawrence, and Newton counties.

Clay (brick). Widely distributed and utilized in nearly every county of the State.

Clay (brick shale). Barry County, numerous beds of shale at Golden City and elsewhere; Camden County; Cape Girardeau County, in Pennsylvanian ("Coal Measures") rocks near Jackson City; Clay County, extensive Pennsylvanian shale along Missouri River bluffs at Liberty Landing and Wayne City; Dade County, near Everton and Lockwood; Daviess County, near Gallatin and elsewhere along streams; Greene County, near Springfield and Willard; Iron County, near Belleview and Kaolin; Livingston County, several Pennsylvanian shale beds along streams; McDonald County, Sugar Creek and Mill Creek, in southern portion of county; Mercer County, near Princeton; Platte County, in Pennsylvanian rocks along river; Polk County, near Humansville; Ralls County, Louisiana to Hannibal along Mississippi River bluffs; Saline County, Slater, near Marshall, and elsewhere; Scott County, near Oran, and Benton; Shelby County, near Lakenan; St. Louis County, Prospect Hill and Cheltenham; Sullivan County, near Milan; Webster County, near Marshfield; Wright County, near Mansfield.

Clay (fire). Mined in the following localities: Audrain County, at Mexico and Vandalia; Boone County, near Columbia; Callaway County, at Fulton; Crawford County, at Leasburg, flint clay; Franklin County, at Union and Washington; flint fire clays occur throughout the county; Gasconade County, at Canaan, Owensville, and Rosebud; Johnson County, at Knobnoster; Linn County, at Laclede; Montgomery County, at Jonesburg; Morgan County, at Versailles; Newton County, at Gregg; Shelby County, at Lakenan; St. Louis County, at Cheltenham and St. Louis; Stoddard County, near Dexter; Warren County, shipped from Truesdail and Pendleton.

Clay (fire, flint). Boone County, occurs near Columbia; Crawford County, extensive deposits near Wesco; Franklin County, old pit near Washington; Maries County, excellent white in Lanes Prairie district; Monroe County, near Stoutsville, and Clapper; Montgomery County, mined at Jonesburg; Osage County, excellent quality abundant in central and southern part; Phelps County has been extensively worked at Knobview, Rolla, and St. James; St. Clair County, small deposits occur near Baker and elsewhere on Osage River; St. Louis County, near Glencoe, and elsewhere.

Clay (fire, plastic). Monroe County, occurs in Pennsylvanian rocks covering nearly all of county; has been mined near Stoutsville for stoneware; Morgan County, excellent quality near Versailles; St. Charles County, has been mined near St. Charles.

Clay (kaolin). Bollinger County, mined at Bollinger, extensive deposits near Glen Allen not worked in 1912; Cape Girardeau County, large deposit near Jackson; Morgan County, mined near Versailles; Warren County, mined at Warren.

Clay (pottery). Cass County, dug near Harrisonville on Grand River; Cooper County, near Boonville; Franklin County, near Union; Henry County, Calhoun; Jasper County, near Webb City; Jefferson County, excellent ball clay mined at Rcgina; Johnson County, Knobnoster and Montserrat; Linn County, Kelsey and Laclede; Livingston County, near Chillicothe; Marion County, "pipe" clay on south side of New River, and elsewhere; Monroe County, abundant, mined at Stoutsville, and near Clapper; Ozark County, residual clay near Gainesville, mined to limited extent for local trade; Scott County, near Commerce, local use; Stoddard County, Dexter; Texas County, near Plato; Vernon County, near Deerfield. Pottery clay occurs in many other counties of the State. 
Clay (shale, plastic). St. Juouis County, from Pennsylvanian rocks, mined at Castello, Glencoe, and Prospect Hill.

Coal (bituminous). Coal found in the Des Moines group of the Pennsylvanian. Six . producing fields: (1) Bevier field occupies parts of Boone, Chariton, Howard, Macon, and Randolph counties; (2) Lexington field in clay, Lafayette, and Ray counties; (3) Southwestern field in Barton, Bates, Henry, and adjacent counties; (4) Novinger field in Adair County; (5) Marceline field in Linn County; and (6) Mendota field in northwestern Adair, Putnam, and Schuyler.

Cobalt. Linnæite, sulphide of cobalt and nickel, associated with chalcopyrite and pyrite in some of the mines of the southeastern district especially Fredericktown, Madison County; recovered from the copper matte made in smelting these ores.

Copper. See Azurite, Chalcocite, Chalcopyrite, Cuprite, and Malachite.

Cuprite (copper oxide). Ste. Genevieve County, subordinate quantity in Cornwall mines, has been mined.

Feldspar. Camden and Laclede counties, in pegmatite granite on border line between counties; Ste. Genevieve County, in granite near Jonca, was used in Belleville pottery.

Fluorspar. Madison County, Einstein silver mine near Iron Mountain; St. Louis County, in St. Louis limestone near St. Louis.

Galena. Large production from disseminated deposits in southeastern district in Franklin, Jefferson, Madison, St. Francois, and Washington counties; associated with zinc in southwestern region, in Jasper, Lawrence, and Newton counties; and in central region in Cole, Miller, Moniteau, and Morgan counties.

Granite. Carter County, quarried in Van Buren; Iron County, extensively quarried at Graniteville; Madison County, Skrainka, and La Motte; St. Francois County, Syenite, and Knob Lick; Ste. Genevieve County; and Wayne County, Granite Bend.

Greenockite. Occurs with sphalerite in Joplin district, Jasper, Lawrence, and Newton counties.

Grindstone. Johnson County, sandstone at Warrensburg, has been used in the manufacture of grindstones; St. Clair County, few made at Collins and Griessel.

Hematite (red iron ore). Crawford County, in sandstone at Craig mine; Dent County, Flank, Hawkins, and Sligo mines; Franklin County, at Leslie mine; Phelps County, at De Camp; Reynolds County, good quality in sandstone on west limit of Bee Fork of Black River in January mine; and also in Callaway, Cooper, Henry, Lincoln, and Saline counties.

Hematite (specular ore). In porphyry, mined in Pilot Knob and Iron Mountain districts in St. Francois and Iron counties; in sandstone, has been mined in Crawford, Dent, Franklin, Iron, Montgomery, Phelps, and other counties.

Iron. See Brown iron ore, Hematite, and Marcasite.

Kaolin. Bollinger County, large deposits near Glen Allen, mined and shipped for pottery; Cape Girardeau County, pure white near Jackson, mined and shipped for paints, etc.; Morgan City, in Buffalo lead mines near Versailles, mined and shipped for enameling purposes. Occurs also in Carter County, at Chilton; Cooper County, Clifton City; Howell County, near West Plains and Sterling, and near Willard Springs; Iron County, in old pits and prospects at Kaolin, 12 miles west of Iron Mountain; Madison County, near Fredericktown; Oregon County, near Thayer; Perry County, near Silver Lake; Reynolds County, near Centerville, and Lesterville; Ripley County, near Doniphan; Shannon County, near Winona, and old pits near Monteer; Texas County, in vicinity of Sargent and Wayne County, near Brunot.

Limestone (building). Limestones widely distributed over the State suitable for building purposes. Large quarries in Cape Girardeau County; Greene County, 
Phenix; and Jasper County, at Carthage. Many other quarries in eastern, northern, and western counties of the State.

Lead. See Anglesite, Cerusite, and Galena.

Limestone (crushed stone, road metal, etc.). Quarried extensively throughout the State, with the exception of counties in the south-central part.

Iimestone (flux). Lincoln County, quarried at Ellsberry; and St. Louis County, near White House.

Limestone (lime). Limestones excellent for lime making are burned at many localities in the State. Large plants are located at Ash Grove, Cape Girardeau, Glencoe, Glen Park, Hannibal, Louisiana, Mincke, Pierce City, Sarcoxie, Springfield, and Ste. Genevieve.

Limonite. See Brown iron ore.

Linnæite (sulphide of nickel and cobalt). Occurs in mines of southeastern Missouri, in Madison County, at Mine La Motte and Fredericktown, and in St. Francois County.

Malachite. Franklin County, mined near Sullivan; Shannon .County, mined at Jerktail, Slater, and other mines; Ste. Genevieve County, at Cornwall mines. Occurs with azurite in many hematite deposits of Crawford, Dent, and Phelps counties.

Manganese ore. Reported in porphyritic rocks around Pilot Knob, in Iron, Madison, and Reynolds counties.

Marble. Occurs in Cape Girardeau, Iron, Madison, and other southeastern counties; not quarried.

Marcasite. Franklin County, occurs in commercial quantity underneath hematite ores in central ore district, is mined at Leslie; Jasper County, occurs in abundance associated with lead and zinc ores in Joplin district, few carloads shipped.

Mineral paint. Iron ore, ferruginous shales, and limestones, lead ores and ocher are used.

Natural gas. Cass, Clay, Clinton, and Jackson counties, small quantities in shallow wells.

Nickel. Nickel and cobalt recovered from matte produced from ore from some of the mines of southeastern Missouri. See also Cobalt.

Ocher. Henry County, common in the Pennsylvanian rocks of western part of the State, near Calhoun; Johnson County, Knobnoster, many exposures in this vicinity. A red ocher at,Andrew County, Amazonia, and Jackson County, Hickman Mills. Others in Buchanan, Lafayette, and Ray counties. Produced to some extent in hematite mines of central Ozark County.

Onyx marble. Undeveloped commercial deposits in caves of Ozark region. Other localities in Atchison, Carroll, Daviess, Henry, Jackson, Lafayette, and Livingston counties.

Petroleum. Small quantity in shallow wells in northern Cass and southern Jackson counties.

Pyrite (iron pyrites). Franklin County, Leslie mine, principal producer; Jasper County, occurs in Joplin district; Madison County, disseminated through limestone at Mine La Motte; St. Francois and Washington counties, gangue mineral of Federal, St. Louis, and other mines. See also Marcasite.

Road metal. Andrew County, oolitic limestone was quarried at Schuster station; Clay County, Bethany Falls limestone was quarried near L.jiberty. See also Limestone (crushed) and Sandstone (crushed).

Limestone quarried at Andrew County, Amazonia; Daviess County, Gallatin; Jackson County, Kansas City, Independence, and other places; St. Louis County, St. Louis, and other places. Granite and porphyry quarried in Iron, Madison, and St. Francois counties. 
Sand (building). Inexhaustible supply can be dredged from Missouri and Mississippi rivers and their tributaries. Atchison County, dug at Rockport; Benton County, Warsaw; Buchanan County, St. Joseph; Callaway County, near Fulton; Carroll County, Carrollton; Christian County, Ozark; Cole County, Jefferson City; Cooper County, Boonville; Daviess County, Gallatin; Franklin County, Pacific; Gasconade County, Drake; Grundy County, Trenton; Jackson County, Kansas City; Jefferson County, Crystal City; Marion County, Hannibal; Phelps County, Jerome; St. Charles County, Klondike and St. Charles.

Sand (glass). St. Peter sandstone between Klondike, on Missouri River, and Crystal City, on Mississippi River. Important quarries in Atchison County, at Rockport; Franklin County, Becker, Gray Summit, and Pacific; Jefferson County, Crystal City and Silica; and St. Charles County, at Klondike.

Sand (molding). Number of small pits in Franklin County, at Gray Summit and Pacific; Kent County, Black Hills; St. Charles County, Klondike.

Sandstone (building, monuments, crushed stone, etc.). Barton County, quarried near Lamar and Liberty; Bates County, Butler and Rich Hill; Benton County, near Cole Camp; Carroll County, DeWitt and near Miami station; Clark County, near Kahoka, local use; Franklin County, near Union; Henry County, near Clinton; Johnson County, near Warrensburg; Saline County, near Miami; St. Clair County, near Collins. Bituminous sandstone quarried in Lafayette County, near Higginsville.

Silver. Recovered from the lead ores of southeastern Missouri in Jefferson, Madison, St. Francois, and Washington counties.

Smithsonite (carbonate of zinc). Jasper County, in quantity in many mines of the Joplin district; Newton County, at Granby; St. Francois County, principal zinc ore at Valle mines; occurs also in central district in Cole, Miller, Moniteau, and Morgan counties, and mined in Howell and Oregon counties.

Specularite. See Hematite (specular ore).

Sphalerite (zinc blende). Principal ore of the Joplin district, Jasper, Lawrence, and Newton counties; mined also in central district, Cole, Miller, Moniteau, and Morgan counties; has been mined at Frumet and at Valle mines, Jefferson County; occurs also in small quantity in the deeper disseminated lead ores of Madison and St. Francois counties.

Tripoli (polishing powder). Chariton County, quarried extensively at Dalton; Jefferson County, occurs at Hillsboro; Newton County, quarried extensively near Racine and Seneca, for filters; chips and waste used for polishing powder and scouring soap; occurs at Stella.

Wad. Found in connection with brown iron ore deposits in southeastern Missouri.

Zinc. Chief production from mines in Jasper County, about Alba, Carterville, Carthage, Duenweg, Joplin, Neck, Reeds, Sarcoxie, Thoms Station, and Webb City; Lawrence County, Aurora; Newton County, Granby, Spurgeon, and Wentworth. See also Calamine, Smithsonite, and Sphalerite.

\section{MONTANA.}

Ægirite. Lincoln County, vanadiferous ægirite occurs in quartz veins associated with sulphides of iron and copper in the Rainy Creek district, 4 miles southwest of Libby.

Agate, moss. Found along Yellowstone River, especially near Glendive.

Antimony. See Polybasite and Stibnite.

Argentite (silver glance). Cascade County, in Neihart district; Deer Lodge County, at Cable mine; Granite County, Granite-Bimetallic mine, Philipsburg; Jefferson County, Ruby mine, Boulder and Clancey; Silver Bow County, Butte mines.

Arsenic. Smelter by-product saved at the Washoe smelter, Anaconda, in smelting arsenical copper ores. 
Arsenopyrite. Deer Lodge County, in Cable mine; Granite County, GraniteBimetallic mine, Philipsburg, mined for silver and gold; Jefferson County, Corbin, Elkhorn, Warm Spring Creek, and Wickes (auriferous); Missoula County, Mineral Point mines, silver bearing; Powell County, Elliston; Lewis and Clark County, Tenmile district, formerly mined for gold contents near Gardiner, Sheep-eater mining district; Park County, abundant, massive, and gold bearing; not mined.

Azurite (blue carbonate of copper). Of mineralogic rather than economic interest. Found in small quantity in many mines and prospects; Deer Lodge County, Cable mine; Granite County, Granite-Bimetallic mine near Philipsburg; Jefferson County, in minute clusters in Elkhorn mine and in McClellan Creek district; Lewis and Clark County, Drumlummon mine, Marysville; and Silverbow County, Butte district.

Bentonite. Beaverhead County, near Glendale.

Bormite (peacock ore). Deer Lodge County, in small quantity at Cable mine, carries gold; Granite County, at Granite-Bimetallic mine; Jefferson County; Corbin; Silver Bow County, common ore mineral, Butte district.

Brown iron ore (limonite). Cascade and Meagher counties, found at a number of localities in Little Belt Mountain district; Chouteau County, occurs in oxidized ores of gold deposits near Landusky and Alabama; Deer Lodge County, at Cable mine; Fergus County, formerly mined in Judith Mountains, prospected at Woodhurst Mountain and in Little Belt Mountains; Jefferson County, at many places in Elkhorn and Wickes districts, mined at Elkhorn Peak iron mine.

Cement material. Chouteau County, suitable materials known to exist at Havre; Gallatin County, limestone and shale quarried for Portland cement at Trident; suitable material at other places but not used.

Cerargyrite (horn silver). Granite County, was important ore of Granite mine, $2 \frac{1}{2}$ miles southeast of Philipsburg; Silver Bow County, found in small quantity in Summit Valley (Butte) district and other mining districts.

Cerusite (lead carbonate). Jefferson County, has been mined in Elkhorn and Wickes districts; Meagher County, Castle Mountain district. Occurs in many other districts.

Chalcanthite (copper sulphate). Silver Bow County, minor ore of oxidized zone, Butte district.

Chalcocite (copper glance). Deer Lodge County, in small quantities at Cable mine; Silver Bow County, important ore of Butte mines. Occurs in many other districts.

Chalcopyrite (copper pyrite). Broadwater County, has been found in Beaver Creek and Crow Creek districts; Deer Lodge County, Cable mine carries gold; Granite County, Philipsburg; Jefferson County, with pyrite in Amazon, Clancey, Corbin, Elkhorn, McClellan Creek, Rimini, Warm Spring Creek, and Wickes districts; Lewis and Clark County, Drumlummon mine, Marysville (rare); Lincoln County, Troy, Grouse Mountain prospects carry silver and gold; Park County, abundant with galena, New World district near Cooke City and at many other places; Ravalli Oounty, Mineral Point, silver and gold bearing; Silver Bow County, minor ore in silver veins at Butte.

Chrysocolla (silicate of copper). Deer Lodge County, occurs in Cable mine; Granite County, Granite-Bimetallic mine near Philipsburg; Silver Bow County, in claims east of Butte along the fonthills of East Ridge.

Clay (brick). Oan be found abundantly throughout the State. Beaverhead County, dug at Dillon; Cascade County, Great Falls; Chouteau County, Havre; Custer County, Miles City; Flathead County, Kalispell and Whitefish; Gallatin County, Bozeman; Jefferson County, Boulder; Lewis and Clari County, Helena; Mis- 
soula County, South Missoula and Riddle Spur; Park County, Livingston; Powell County, Blossburg; Ravalli County, Stevensville; Rosebud County, Forsyth; Sanders County, Thompson; Silver Bow County, Butte and Williamsburg; Valley County, Glasgow; and Yellowstone County, Columbus.

Clay (fire). Cascade County, dug near Armington and at Fields; Deer Lodge County, Anaconda and Lost Creek; Jefferson County, Whitehall; Lewis and Clark County, Helena.

Coal (bituminous and subbituminous). Areas of workable coal are known to exist in the following counties: Carbon, Cascade, Chouteau, Fergus, Flathead, Gallatin, Madison, Missoula, Musselshell, Park, Rosebud, Teton, and Yellowstone. Coal is mined in the following places: Carbon County, Bear Creek, Bridger, Burgin, Carbon, Fromberg, Joliet, Red Lodge, and Washoe; Cascade County, Armington, Belt, Eden, Geyser, Sand Coulee, and Stockett; Chouteau County (Big Sandy), Chinook, Harlem, Havre, and Macton; Fergus County, Buffalo Creek, Giltedge, Lewiston, Stanford, Smith, Utica, and Windham; Gallatin County, Chestnut; Missoula County, Missoula; Musselshell County, Roundup; Park County, Cinnabar and Cokedale; Yellowstone County, Bull Mountains.

Coal (lignite). Areas of workable lignite are known to exist in Custer, Dawson, Rosebud, and Valley counties. Custer County, mined at Miles City and Stacey; Dawson County, Cohagen, Jordan, Glendive, and Wibaux; Valley County, Brockton and Culbertson; chiefly for local use.

Copper ores. See also Azurite, Bornite, Chalcocite, Chalcanthite, Chalcopyrite, Chrysocolla, Covellite, Cuprite, Enargite, Malachite, and Tetrahedrite. Copper is the predominant metal produced in the following districts: Beaverhead County, Beaverhead, Elkhorn, Utopia; Broadwater County, Hellgate; Meagher County, Copperopolis; Missoula County, Denemora, Wallace; Ravalli County, Mineral Point; Silver Bow County, Butte.

Copper (native). Deer Lodge County, small quantities in upper level of Cable mine at Cable; Silver Bow County, in oxidized zone of Butte.

Corundum. Gallatin County, was formerly mined at Bozeman, Salesville, and headwaters of Elk Creek for abrasive. No abrasive corundum is now mined in Montana.

Corundum (sapphire). Deer Lodge County, in gravel of Dry Cottonwood Creek; Fergus County, in dike near Yogo Gulch (blue gems only); Granite County, considerable quantity mined from placers on Rock Creek, 20 miles southwest of Philipsburg; Lewis and Clark County, mined in placers of Missouri River, east and northeast of Helena.

Covellite (indigo copper). Jefferson County, Boulder (rare); Silver Bow County, ore of minor importance in Butte mines.

Cuprite (red copper oxide). Silver Bow County, minor mineral in ore of Butte district.

Enargite. Silver Bow County, next to chalcocite, the most abundant copper mineral at Butte.

Galena (argentiferous). Beaverhead County, mined in Hecla and Trapper districts; Broadwater County, Argenta, Beaver Creek, Crow Creek, Indian Creek, Park, and Winston districts; Cascade County, Barker and Neibart districts; Chouteau County, Bearpaw Mountains; Deer Lodge County, Cable district (rare); Granite County; Philipsburg; Jefferson County, Amazon, Basin, Clancey, Elkhorn, Gregory; Lump Gulch, and Wickes districts; Lewis and Clark County, Bald Butte, Helena, Ottawa, Rimini, and Tenmile districts; Lincoln County, Troy, and Snowshoe; Meagher County, Castle Mountain; Missoula County, Iron Mountain; Park County, New World; Powell County, Elliston; Ravalli County, Hamilton (Curlew mine); Silver Bow County, sparingly in silver veins and in some of the later fault veins of the copper area, Butte. 
Garnet. Madison County, small quantity recovered from gold dredges at Alder Gulch and at Ruby; cut for jewelry.

Gold (lode). Widely distributed in southwestern quarter of the State. Principal districts that have produced are: Beaverhead County, Bald Mountain and Bannock; Broadwater County, Lone Mountain, Park, and Radersburg; Chouteau County, Landusky and Bearpaw; Deer Lodge County, Cable and Heber; Granite County, Philipsburg and Red Iron; Jefferson County, Cataract, Colorado, and Lump Gulch; Lewis and Clark County, Bald Butte, Helena, Marysville, and Rimini; Lincoln County, Cabinet, Fisher Creek; and Sylvanite; Madison County, Pony, Norris, and Whitehall; Missoula County, Clinton and St. Regis; Silver Bow County, Fleecer Mountain, German Gulch, and Fighland.

Gold (placer). Placer mining formerly very important, still carried on to some extent in Broadwater, Chouteau, Deer Lodge, Granite, Jefferson, Lewis and Clark, Lincoln, Madison, Missoula, Park, Powell, Ravalli, and Silverbow counties. Formerly in Beaverhead, Custer, and Meagher counties as well. Beaverhead County, dredged near Dillon; Deer Lodge County, dredged near Deer Lodge; Madison County, dredged in Alder Gulch; Missoula County, dredged in Cedar Creek.

Gold tellurides. Fergus County, formerly mined in Judith Mountains, Spotted Horse mine.

Granite. Abundant in western part of the State. Jefferson County, quarried at Welch and near Corbin; Lewis and Clark County, quarried at Baxendal, near Helena, also at Helena.

Graphite. Beaverhead County, mined near Dillon.

Grindstone. Yellowstone County, produced at Columbus.

Gypsum. Widely distributed throughout eastern flanks of the Rocky Mountains. Cascade County, mills located at Armington and Riceville; Carbon County, Bridger, on local deposits; Jefferson County, quarried near Limespur; Park County, occurs at Hunters Hotsprings.

Hematite (red iron ore). Deer Lodge County, found in Cable mine; Jefferson County, with magnetite, in mine on north side of Elkhorn Peak, Elkhorn district.

Hematite (specularite, turgite). Deer Lodge County, found at Cable mine, carrying gold; Granite County, mined for flux near Philipsburg. Occurs at many localities in Little Belt Mountains district, Cascade, Fergus, and Meagher counties, and prospected at Woodhurst Mountain; in small quantities at other places.

Hübnerite. Granite County, occurs at Philipsburg; Madison County, with silver ore in Potosi district, 8 miles southwest of Pony; Powell County, occurs at Sugarloaf Mountain; Silver Bow County, Birdie silver mine, and Gagnon and Leonard mines, Butte, small quantities mined.

Lead. See Cerusite; Galena, and Pyromorphite.

Lignite: See Coal.

Limestone (building). Abundant in western part of the State. Quarried in Flathead County, at Kalispell; and Lewis and Clark County, Helena.

Limestone (flux and lime). Cascade County, quarried at Albright and Logging Creek; Gallatin County, Bozeman; Jefferson County, Limespur; Lewis and Clark County, East Helena; Powell County, Elliston; and Silver Bow County, Divide.

Limonite. See Brown iron ore.

Magnetite. Chouteau County, with apatite and augite in Black Diamond prospect, Bearpaw Mountains, high grade, not mined; Deer Lodge County, was formerly mined for flux at Cable mine; Gallatin County, near Bozeman; Jefferson County, formerly mined with hematite in iron ores on Elkhorn Peak. 
Malachite. Chouteau County, found in small quantities in gold-bearing veins near Landusky; Deer Lodge County, at Cable mine; Granite County, GraniteBimetallic mine near Philipsburg; Jefferson County, small quantities in Elkhorn mine and McClellan Creek district; Silver Bow County, Butte district; and in many other places. Of more mineralogic than economic interest.

Manganese ore. Cascade County, manganiferous silver ore mined at Neihart; Deer Lodge County, carries gold and silver at Cable mine; Granite County, was mined in Granite-Bimetallic mine near Philipsburg; Madison County, prospected on Wigwam and Cherry creeks, 15 miles southeast of Virginia City; Silver Bow County, oxidized ore of Butte mines, silver bearing.

Marcasite. Deer Lodge County, carries gold at Cable mine; Lincoln County, found in Troy, Grouse Mountain prospects; Silver Bow County, common in Butte mines.

Molybdenite. Beaverhead County, occurs in quartz veins near Dillon; Fergus County, at Neihart; Jefferson County, at Homestake.

Monazite. Granite County, has been found in black sands at Princeton; Madison County, at Norris; Powell County, locality not reported.

Petroleum. Teton County, in northwest part; no production.

Phosphate. Granite County, good bed at Philipsburg; Madison County, thin beds in canyon of Jefferson River between Limespur and Cardwell; Powell County, good bed near Elliston, and 6 miles north of Garrison; Silver Bow County, Melrose; and elsewhere.

Pisanite. Silver Bow County, common in old drifts in Butte copper mines.

Platinum. Granite County, small quantity in black sands at Princeton, not mined.

Polybasite. Cascade County, intimately associated with galena and sphalerite in Neihart district; Lewis and Clark County, rich in silver, Drumlummon mine, Marysville.

Proustite. Granite County, sparingly scattered through ore in Granite-Bimetallic mine, Philipsburg.

Psilomelane. Silver Bow County, at Butte, common surface ore in many veins, usually contains silver.

Pyrargyrite (ruby silver). Cascade County, common in Neihart district, usually associated with polybasite; Deer Lodge County, known but not now mined; Granite County, Granite-Bimetallic mine near Philipsburg, with galena and sphalerite; Lewis and Clark County, Drumlummon mine, Marysville.

Pyrite. Common ore of gold, has been mined in the following districts: Broadwater County, Beaver Creek, Crow Creek, Indian Creek, Radersburg; Cascade County, Neihart; Chouteau County, Landusky, Alabama; Deer Lodge County, Cable; Fergus County, Ford Creek, Gilt Edge, Maiden; Granite County, Philipsburg; Jefferson County, near Basin, Boulder, Clancey, Elkhorn, Gregory, and Warm Spring Creek; Lewis and Clark County, Bald Butte; Lincoln County, Sylvanite; Madison County, Pony; Missoula County, Mineral Point, Mineral Hill; Powell County, Elliston; Silver Bow County, Butte (cupriferous).

Pyrolusite (black oxide of manganese). Chouteau County, with high-grade gold ores in mines near Landusky and Alabama; Granite County, mined for flux in Flint Creek (Philipsburg) district; Meagher County, large veins at Castle, carry small quantity of lead; Silver Bow County, common surface ore in many veins at Butte carrying rhodonite, etc.; usually contains silver, and is much sought for as flux for siliceous ores.

Pyromorphite (phosphate of lead). Cascade County, found in one mine in Narrow Gauge Gulch, Neihart district; Granite County, in Granite-Bimetallic mine, near Philipsburg.

Pyrrhotite (magnetic pyrites). Chouteau County, found in Bearpaw Mountains; Deer Lodge County, at Cable mine, carries gold; Jefferson County, Elkhorn district. 
Rhodonite (manganese silicate). Silver Bow County, gangue mineral of silver veins of Butte mines; cut as gem.

Sand (building): Dug at many places for local use.

Sandstone. Sandstone suitable for dimension stone is abundant. Cascade County, quarries at Field and Great Falls; Gallatin County, Salesville and Sappington, near Bozeman; Park County, Livingston; Yellowstone County, Billings and Columbus.

Sapphire. See Corundum.

Scheelite. Park County, has been mined at Jardine with gold.

Silver (native). Cascade County, in oxidized veins in Neihart district; Granite County, in upper levels of Granite-Bimetallic mine, Philipsburg; Jefferson County, at Clancey, Elkhorn, and Ruby mines; Silver Bow County, common in silver veins and oxidized portions of copper veins at Butte.

Silver. Predominant metal value in following districts: Beaverhead County, Dillon, Hecla, and Vipond; Cascade County, Neihart; Jefferson County, Elkhorn; Lewis and Clark County, Greenhorn; Park County, Cowles. See also Argentite, Cerargyrite, Polybasite, Proustite, Pyrargyrite, and Stephanite.

Sphalerite (zinc blende). Broadwater County, mined in Beaver Creek district; Cascade County, occurs with galena in all veins in Neihart district; Deer Lodge County, rare at Cable; Granite County, in all silver-gold fissure veins near Philipsburg; Jefferson County, with galena and pyrite and lesser quantities with tetrahedrite in galena ores of Basin, Boulder, Clancey, Elkhorn, Gregory, and Lump Gulch districts; Lewis and Clark County, with galena in Bald Butte, Helena, and Rimini; Lincoln County, Cullahan Creek and Troy; Missoula County, Iron Mountain; Powell County, Elliston; Silver Bow County, common in Butte mines.

Spinel (pleonaste). Madison County, between South Meadows and Moore creeks not mined.

Stephanite (brittle silver). Cascade County, rare in Neihart district.

Stibnite (sulphide of antimony). Granite County, abundant in primary ore of silver .veins near Philipsburg.

Tennantite. Granite County, in lower portions of Granite-Bimetallic mine, Philipsburg; Silver Bow County, occurs sparingly associated with enargite in copper veins at Butte.

Tetradymite. Broadwater County, with gold and silver in Keating mine, Radersburg.

Tetrahedrite (gray copper ore). Granite County, Flint Creek district, with galena and sphalerite, argentiferous, was formerly mined, abundant in lower levels, Granite-Bimetallic mine; Jefferson County, with sphalerite in Elkhorn mine, argentiferous; also at Basin and Clancey; Lewis and Clark County, formerly mined at Drumlummon mine, Marysville; Missoula County, Pleasant View and Slate Creek prospects, carries gold and silver; Silver Bow County, ore of minor importance in Butte mines in copper and silver veins.

Thorianite. Madison County, known at Norris, not mined.

Vanadinite. Beaverhead County, reported 27 miles northwest of Dillon in Rothschild mine.

Volcanic ash. Gallatin County, deposits suitable for use as polishing powder in vicinity of Bozeman, and in Meagher County, at Castle Mountain.

Wad. Jefferson County, with limonite in granite about 6 miles north of Wickes station, not mined; Silver Bow County, with silver ores of Butte district.

Wurtzite. Silver Bow County, Gagnon mine, Butte. $29123^{\circ}-$ Bull. $585-14-8$ 


\section{NEBRASKA.}

Abrasive. See Infusorial earth and Pumice.

Agate (moss). Agate, Keith, Scotts Bluff, and Sioux counties; cut for jewelry.

Cement material. Carboniferous limestone and shale, suitable for cement material, outcrop in southeastern part of State in Cass, Douglas, Gage, Johnson, Lancaster, Nemaha, Otoe, Pawnee, Richardson, and Sarpy counties; not utilized. Cement formerly made from Carboniferous rock at Beatrice, Gage County. Cretaceous chalk rock and underlying shales, suited to the manufacture of cement, outcrop extensively in northeastern Nebraska along Niobrara and Missouri rivers in the following counties: Eastern Boyd, Cedar, Dixon, Dakota, and northern Knox. Likewise, along the southern line of Nebraska in the Republican Valley, in the following counties: Franklin, Nuckolls, southern Harlan, and Webster. The cement material of the Cretaceous in Nebraska belongs essentially to the Niobrara formation, although a chalky layer (Inoceramus zone) about 20 feet thick constitutes the upper part of the Greenhorn limestone. A large plant is at Superior, Nuckolls County.

Chalcedony. Gage County, common vein filling in the Badlands.

Chalk rock. The Greenhorn limestone at Hebron, Thayer County, and the Niobrara formation of Knox County, notably at the town of Niobrara, furnish considerable quantities of building material. The chalk rock of these formations is soft enough to be sawed into blocks when "green" (fresh from the quarry); on drying, it becomes harder and has good lasting qualities. The chalky Greenhorn rock of Endicott, Jefferson County, and at Pleasant Hill, Saline County, used to be burned into lime for local consumption.

Clay (brick). Brick and tile made in the following counties: Adams, Antelope, Box Butte, Boyd, Buffalo, Burt, Butler, Cass, Cedar, Clay, Cuming, Dixon, Dodge, Douglas, Fillmore, Furnace, Gage, Greeley, Hall, Hamilton, Howard, Jefferson, Kearney, Knox, Lancaster, Loup, Madison, Nance, Nemaha, Nuckolls, Otoe, Pawnee, Phelps, Platte, Polk, Redwillow, Richardson, Saline, Saunders, Scotts Bluff, Seward, Sherman, Stanton, Thayer, Washington, Wayne, Webster, and York.

Clay (fire). Occurs in Pennsylvanian ("Coal Measures") in southeastern part of State.

Clay (loess). In many parts of the State large quantities of ordinary building and hollow brick are made from loess, which in many cases is very poor in clay.

Clay (pottery). Cass County, has been dug at Louisville; Jefferson County, coarse pottery clay at Endicott; Washington County and elsewhere in southeastern Nebraska.

Coal (bituminous). Cass, Johnson, and Otoe counties; Nuckolls bed 8 to 18 inches thick, worked for local use. Nemaha County, working mine at Honey Creek 4 miles south of Peru in bed 33 inches thick; Otoe County, bed 15 inches thick in a boring at Nebraska City; Pawnee County, beds at Du Bois, Friezes Mill, and Turners Branch worked intermittently; Richardson County, has been mined at Rulo, and a bed 18 to 30 inches thick has been opened and worked for local use in southwest corner of county.

Coal (lignite). Dakota County, mined for local use near Homer; and Dixon County, in bluffs near Ponca.

Flint. Gage County, quarried and crushed for ballast at Blue Springs and Wymore. Gold (placer). Occurs in sands of Platte River and in glacial drift; of no importance. Halite (common salt). Previous to development of Kansas salt beds salt was made in considerable quantity in southeastern Nebraska from water of salt springs and deep wells. No longer produced, but artesian flow of salt water is used at Lincoln in sulpho-saline baths. 
Infusorial earth. Greeley County, best beds in this county; Thomas County, deposit of several acres near Thedford; Wheeler County, number of beds on Cedar Creek; occurs in Blaine, Hooker, and other counties. Small quantity formerly sold for polishing powder.

Limestone (building). Cass County, quarries located at Nehawka, Cedar Creek, Louisville, and Weeping Water; Gage County, Wymore and: Blue Springs; Jefferson County, near Fairbury and Endicott; Johnson County, Graf and Tecumseh; Nemaha County, Auburn and Glen Rock; Otoe County, Syracuse and Nebraska City; Sarpy County, La Platte and Meadow; Cheyenne County, Sidney; small quarries at other localities.

Limestone (crushed stone). Cass County, quarried at Cedar Creek, Louisville, and elsewhere; Cheyenne County, Sidney; Gage County, Holmesville, Rockford, and Wymore; Nemaha County, Auburn, Brock, and Johnson.

Limestone (flux). Cass County, quarried at Nehawka.

Lithographic stone. Otoe County, occurs near Syracuse; has not proved of commercial quality.

Ocher. Known in many places in northeastern counties on Platte River and along Republican River; was mined at Indianola, Redwillow County.

Peat. Widely distributed. On Loups Rivers and on their tributaries; on the Logan; along tributaries at headwaters of Elkhorn, Blue, and Stinking rivers; not utilized.

Pumice. Produced in Furnas County; Harlan County, Orleans; Holt County, Atkinson; Jefferson County, Endicott; Lincoln County, Ingham; and in other counties; used as an abrasive.

Road metal. Cass County, gravel in Platte Valley and in glacial drifts; pits near Louisville; Gage County, large supply of flint, quarried in vicinity of Wymore and Blue Springs.

Sand (building). Principal pits are at the following places: Antelope County, Oakville; Buffalo County, Ravenna, Kearney; Burt County, Tehameh; Cass County, Cedar Creek, Louisville; Cedar County, Hartington; Colfax County, Schuyler; Custer County, Ansley, Mason City, Sargent; Douglas County, Omaha, Valley; Dodge County, Fremont; Fillmore County, Geneva; Gage County, Beatrice; Hall County, Grand Island; Platte County, Lindsay; Polk County, Atkinson; Richardson County, Falls City, Salem; Sarpy County, Meadow; Saunders County, Ashland. Many small pits widely scattered through State. Dredges taking sand from lower Platte at Ashland, Cedar Creek, Louisville, Fremont, Meadow, Valley, and Oreapolis. Forty sandshipping stations in State produced in one year 40,000 cars, equal to train over 300 miles long. Cass County is largest producer.

Sand (molding). Adams County, dug at Erickton.

Sand and gravel. Pits supplying local demand are widely distributed; Cass County, large production from Cedar Creek; Jefferson County, dug 2 miles west of Fairbury; shipped for cement, plastering, etc., also dug near Kesterson and elsewhere.

Sandstone. Cass County, quarried at Louisville; Cherry County, occurs at Valentine; Dawes County, Chadron; Nemaha County, Brownville.

Turquoise. Brown County, three stones, probably variety known as Odontolite, have been found.

\section{NEVADA.}

Alum (kalinite). Esmeralda County, prospected by roadside about 10 miles north of Silver Peak.

Alunite. Esmeralda and Nye counties, abundant in volcanic rocks and with ores in Goldfield district, not utilized, 
Anglesite (sulphate of lead). Eureka County, important mineral in oxidized ores at Ruby Hill and in Eureka district, silver bearing; Clark County, mined with oxidized zinc ores at Goodsprings.

Annabergite. Humboldt County, important constituent of ore at Lovelock nickel mine, Cottonwood Canyon, Pahute Range.

Antimony. See Jamesonite, Stibiconite, and Stibnite.

Argentite (silver glance). Elko County, at Columbia; Humboldt County; at Rosebud; Lander County, at Cortez; Nye County, important silver mineral of Tonopah district; White Pine County, Cherry Creek district.

Arsenic. Washoe County, native arsenic, in considerable quantity, occurs at a prospect a few miles south of Pyramid Lake.

Arsenopyrite. Elko County, silver ore at Tuscarora; Eureka County, Ruby Hill, Eureka district; Humboldt County, with pyrite and quartz at Auld Lang Syne mine near Chafey; Washoe County, with lead and zinc ore at Galena.

Asphalt. Eureka County, stringers and lenses up to 18 inches wide filling fractures in Carboniferous rocks 15 miles south of Palisade.

Azurite. Elko County, with silver ore in Mountain City; Esmeralda County, sparingly in Goldfield district, Montezuma and Cuprite mines; Eureka County, small quantity at Ruby Hill, Eureka district, and in Mineral Hill district; Humboldt County, small quantity in Red Butte copper district and Lovelocks cobaltnickel mine in Cottonwood Canyon, Pahute Range; Lyon County, in Mason Valley mine, Yerington copper district, and other localities.

Barite. Ormsby County, mined at Barium mine; Elko, Eureka, and Lander counties, gangue mineral in many veins; Esmeralda County, abundant with ore in Sandstorm and Kendall mines, Goldfield district; Humboldt County, a common gangue mineral in Humboldt Range.

Bindheimite. Esmeralda County, 15 miles east of Thorne.

Bismuth (native). Clark County, with bismutite near Sandv; Mineral County, with bismite near Candelaria.

Bismuthinite. Esmeralda County, with rich gold ore at Goldfield.

Borax. Deposits of the marsh type were formerly extensively worked in Churchill County, in Salt Wells Valley; Esmeralda County, at Teals, Rhodes, and Columbus marshes, and Fish Lake Valley. Borax was also made from hot spring waters in Churchill County, east of Wadsworth; Washoe County, at Gerlach.

Bornite. Elko County, secondary ore in Tuscarora mines; Humboldt County, with chalcopyrite at Mazuma Hills mine, Seven Troughs district; Lander County, mined for gold and silver at Tenabo.

Bromyrite. Elko County, silver ore in Mountain City, mined at Protection mine; Eureka County, Silver Hill and in quartz at Caribou Hill, Eureka district.

Brown iron ore (limonite). Not mined as an ore of iron, but occurs abundantly in the oxidized portions of deposits worked for other metals and may carry gold and silver, as in the following districts: Esmeralda County, Cuprite and Goldfield districts, Old Camp, Gold Mountains district; Eureka County, carries free gold, principal component of Ruby Hill ores; Humboldt County, with argentite at Brown Palace mine, Rosebud district; Lander County, Mud Springs 4 miles north of Lander; Lyon County, Mason Valley mine, Yerington district, also with hematite and magnetite near Dayton; Nye County, Bullfrog and Silverbow districts.

Calamine (zinc silicate). Clark County, mined with other zinc ores at Goodsprings; Eureka County, in fine crystals with limonite at Ruby Hill, Eureka district.

Cement material. Carboniferous limestone outcrops in east third of State; suitable for Portland cement; not used. Ormsby County, large bodies of limestone in shale several miles east of Carson City, analyses show that suitable mixture would make good cement. 
Cerargyrite (horn silver). Elko County, secondary mineral in Gold Circle district; Esmeralda County, abundant in quartz at Great Western mine, Hornsilver district; in oxidized ore near Diamondfield, Goldfield district; Humboldt County, Durango Girl mine, Rosebud district; Nye County, principal mineral of Bullfrog district, formerly mined at Montgomery-Shoshone mine; secondary mineral at Silverbow and Eden.

Cerusite (carbonate of lead). Clark County, mined at Potosi and other mines, Goodsprings district; Elko County, silver ore in Mountain City, mined at Protection mine; Esmeralda County, Redemption mine near Hornsilver; Lone Mountain mines, South Klondike, and Montezuma; mined for silver; Eureka County, Ruby Hill, Eureka district; worked for silver at Mineral Hill; Humboldt County, mined for silver at Fairmont and Beaconsfield mines, Winnemucca district; Lander County, Mud Springs 4 miles north of Lander; Lincoln County, Potosi mine; White Pine County, has been mined in Ely (Robinson) district.

Chalcanthite. Lyon County, Bluestone mine, Yerington copper district. Formerly mined for use in amalgamating Comstock ores.

Chalcedony. Occurs in Esmeralda County, at Aurora; Mineral County, 2 miles southeast of Redlich; Nye County, Gold Mountain district between Tonopah and Klondike.

Chalcocite (copper glance). Elko County, important ore in Bullion district, Standing Elk principal mine; Esmeralda County, argentiferous in mines of Cuprite and Montezuma districts; Humboldt County, in a vein in gabbro at Red Butte; Lander County, mined for gold in Tenabo district; Lyon County, Yerington mine, Yerington copper district in small quantity; Nye County, sparingly in Original Bullfrog mine in Bullfrog district, with free gold; Ormsby County, at numerous localities, carries gold and silver; White Pine County, important ore in Ely district.

Chalcopyrite (copper pyrite). Clark County, with platinum in Copper King district; Elko County, important gold and silver ore at Big Four, Columbia, Jack Pot, and other mines; Esmeralda County, mined at Montezuma, carries silver; Eureka County, important silver ore at Mineral Hill, and in small mines and prospects in Safford district; Humboldt County, Adelaide mine, Seven Troughs district; Lander County, principal silver ore at Cortez, Little Gem, Phoenix, and Gold Quartz mines; Lyon County, Bluestone and other mines in Yerington district; Nyo County, Silverbow district; small quantity at Tonopah mine, Tonopah; White Pine County, Nevada Consolidated, Cumberland, and other mines in Ely district.

Chrysocolla. Elko County, important ore in Bullion district, Standing Elk principal mine; Esmeralda County, occurs in various prospects, Oriental Wash district; Humboldt County, sparingly at Red Butte and Munroe Hill, Chafey district; Lyon County, in Ludwig mine, Yerington district; Nye County, Bullfrog district, carries gold; in veins at Oak Spring.

Cinnabar. Esmeralda County, near Black Butte, Goldfield district, not mined; Eureka County, Lynn mining district; Humboldt County, near Fitting in American Canyon, Piute Range, in prospect on edge of Black Rock desert few miles south of Red Butte; in Eldorado Canyon; in Winnemucca Mountain, and in gold ores at National: Nye County, mined near Ione and Bonita, prospected on Bear Mountain; in old Barcelona silver mine at Belmont; Washoe County, very small quantity taken years ago near western margin of sinter at Steamboat Springs.

Clay (brick). Esmeralda County, dug at Goldfield; Lyon County, 1 mile west of Yerington; Washoe County, Reno.

Clay (fire). Ormsby County, deposit in Alumina mine Delaware district, not used. 
Coal. Elko County, beds of shaly coal in Tertiary, Centennial Range, Bull Run Basin; Esmeralda County, extensive deposits of subbituminous coal in southern and western part of county; between Silver Peak and Candelaria, 4 beds, 6 to 8 feet; 4 miles south of Coaldale, 4 beds.

Cobalt. See Erythrite.

Copper. Ores of copper are of chief importance in following districts: Churchill County, Whitecloud (Coppereid); Clark County, Bunkerville (Copper King), Great Eastern, Logan (St. Thomas); Douglas County, Spruce Mountains, Wellington; Elko County, Contact, Dolly Varden, Elk Mountain; Humboldt County, Jackson Creek, Red Butte; Lander County, Kimberley (Hill Top); Lyon County, Yerington (Mașon); Mineral County, Sodaville (Pilot Mountain); White Pine County, Ely (Robinson).

Copper minerals. See Azurite, Bornite, Chalcanthite, Chalcocite, Chalcopyrite, Chrysocolla, Covellite, Cuprite, Enargite, Malachite, and Tetrahedrite.

Copper (native). Esmeralda County, reported in surface panning in Goldfield district; Humboldt County, near Red Butte district; Lyon County, Nevada Douglas, Mason Valley, and Bluestone mines, Yerington district.

Corundum. Esmeralda County, reported from near Silver Peak.

Covellite. Humboldt County, occurs sparingly in Red Butte district; White Pine County, with copper ores of Ely (Robinson) district.

Cuprite. Elko County, important ore in Bullion district, Standing Elk principal mine; Humboldt County, occurs with covellite, chrysocolla, and iron oxides at Red Butte, was mined in Bolivia district; Lyon County, Mason Valley mine, Yerington district.

Electrum. Humboldt County, principal mineral at National; Nye County, mined at Gibraltar mine, Bullfrog district.

Enargite. Elko County, in Tuscarora and Good Hope districts; Esmeralda County, Gold Bar and Victor mines, Goldfield district.

Erythrite (cobalt ore). Churchill County, rich mines in northeast part of county; Humboldt County, has been mined at Lovelock mine, Cottonwood Canyon, Pahute Range.

Famatinite. Esmeralda County, with native gold in Goldfield mines.

Freibergite. Elko County, silver ore in Good Hope district; was mined at Buckeye, Ohio, and other mines.

Galena. Clark County, Potosi and other mines in Goodsprings district, argentiferous; Elko County, has been mined for gold and silver at Big Four, Columbia, and other mines in Aura (Columbia) district; in Dolly Varden, Ruby Valley, Spruce Mountains, Tecoma, and other districts; Esmeralda County, sparingly with rich gold ores at Goldfield, argentiferous; at Redemption mine near Hornsilver, in Buena Vista, Hornsilver, Lida, Lone Mountains, Palmetto, and other districts; Eureka County, important silver ore at Cortez, Mineral Hill, Safford, and Schroeder districts; Eureka district, at Ruby Hill, Tip top, Richmond, and other mines; Humboldt County, Pfluger mine, Humboldt Range, and in Adar, Chafey, Seven Troughs, and other districts; Lander County, in Campbell, Cortez, Galena, Kimberley, and Reese River districts; worked for gold at Tenabo; Lincoln County, in Comet, Geyser, Highland Valley, Hiko, Jackrabbit, Lone Mountain, and Pioche districts; Lyon County, Pine Nut and Yerington districts; Washoe County, at Wedekind and other mines 1 mile north of Sparks; formerly mined at Galena; White Pine County, Bunker HillSullivan mine, Granite district, in Ward, Hunter, Hamilton, Ely, and Newark districts.

Gold (lode). Predominant in following districts: Churchill County, Bernice, Boyer, Eaglesville, Eastgate, Fairview, Jessup, White Plains; Clark County, Crescent, Eldorado Canyon, Gold Butte, Lyons, Searchlight, Vincent; Douglas County, 
Gardnerville, Red Canyon; Elko County, Aura, Carlin, Centennial, Cornucopia, Cornwall Basin, Gold Circle (Widas), Good Hope, Jarbidge, Tuscarora, Van Dusen; Esmeralda County, Buena Vista, Cuprite, Dyer, Goldfield, Gold Mountains, Hornsilver, Lida, Montezuma, Oriental Wash, Palmetto, Silver Peak, Southern Klondike, Windypah; Eureka County, Mill Canyon, Lynn; Humboldt County, Central, Disaster, Fitting, Gold Banks, Kennedy, National, Spring Creek, Rebel Creek, Seven Troughs, Vicksburg, Winnemucca; Lander County, Battle Mountain, Washington; Lincoln County, Chief, Eagle

Valley, Ferguson, Freiberg; Lyon County, Ramsey, Silver City, Tallapoosa; Mineral County, Aurora, Bovard, Granite, Pine Grove, Rawhide, Santa Fe, Silver Star; Nye County, Bare Mountain, Bellehelen, Berlin, Big Dune, Blakes Camp, Bullfrog, Cactus Spring, Cloverdale, Eden, Gold Bar, Gold Crater, Golden, Goldyke, Hannapah, Jefferson Canyon, Johnnie, Kawich, Manhattan, Millett, Monte Cristo, Oak Spring, Round Mountain, Silverbow, Stonewall Mountain, Wellington; Storey County, Comstock; Washoe County, Cottonwood, Deep Hole, Peavine, Sheepshead, White Horse; White Pine County, Black Horse, Gold Canyon, Osceola, Steptoe. Besides the districts named in which gold is the predominant metal produced, there are others, as Tonopah district, Nye County, in which there is a large annual production of gold.

Gold (placer). Produced in 1910 in following districts: Elko County, small production near Tuscarora; Esmeralda County, small production from Lida district; Eureka County, five placers operated in Lynn district; Humboldt County, five placers in Spring Valley district; Lander County, new camp at Bannock, 16 miles southwest of Battle Mountain; Nye County, 37 placers in Manhattan and Round Mountain districts.

Goldfieldite. Esmeralda County, with gold, marcasite, and famatinite in Goldfield district.

Graphite. Humboldt County, occurs in Sierra Mountains; Ormsby County, mined 3 miles from Carson for making paint.

Gypsum. Best-known deposits are in Clark County, in Spring Mountains near Las Vegas, Arden; Esmeralda County, large bodies near Hawthorne; Humboldt County, near Lovelocks; Lyon County, Moundhouse, and an extensive bed at Ludwig mine, Yerington district. Two plaster mills at Moundhouse, one at Reno and one at Arden.

Hematite. Clark County, low-grade oolitic near Las Vegas, not mined; Eureka County, mined at Borth, shipped; Humboldt County, mined near Lovelocks, reported 30 miles south (?) of Golconda; Lyon County, high-grade hematite abundant in surface outcrops 12 miles northeast and 2 miles southwest of Dayton; Ormsby County, Bessemer mine.

Hübnerite. Esmeralda County, occurs near State line west from Lida; Humboldt County, occurs 15 miles south of Golconda in Gold Run district, in Sonoma Mountains in silver ores; Mineral County, occurs in Redlich; Nye County, occurs with gold ore at Tonopah, mined at Round Mountain and Ellsworth; White Pine County, mined at Hub, 12 miles southeast of Osceola, on Mount Wheeler, at Regan.

Infusorial earth. Storey County, mined at Chalk Hills ranch 9 miles northeast of Virginia City, for polishing powder; Washoe County, occurs in great quantity on banks of Little Truckee River between Pyramid and Winnemucca lakes, and in a railroad cut 4 miles west of Reno; also near Verdi; Esmeralda County, forms lenticular beds in the Seibert formation near Goldfield. Reported also in Fossil Hills and along northeast edge of Kawich Hills. Common in various other parts of State. 
Jamesonite (antimonial lead ore). Esmeralda County, occurs 15 miles east of Thorne; Eureka County, in quartz at Hoosac mine, Eureka district, has been mined for silver; Humboldt County, abundant at Sheba and De Soto mines in Star Canyon, has been mined for silver at Sheba mine.

Kalinite. See Alum.

Kaolin. Humboldt County, deposit under development 24 miles southeast of Lovelocks; Ormsby County, large deposit 4 miles from Carson.

Lead minerals. Lead is the principal metal produced in following districts: Elko County, Ruby Valley, Spruce Mountains, and Tecoma districts; Eureka County, Cortez and Schroeder; Humboldt County, Cedar district; Lincoln County, Comet and Highland Valley; Mineral County, Lucky Boy; Washoe County, Leadville and Washoe (Galena); White Pine County, Hunter and White Pine; occurs less abundant in other districts. See also Anglesite, Cerusite, Galena, and Jamesonite.

Limestone (building). Humboldt County, abundant good building stone near Lovelocks. Some of the abundant limestones of the eastern half of the State might yield good building stone.

Limestone (lime). Ormsby County, formerly quarried several miles southeast of Carson City. Limestone suitable for lime is common in eastern half of State; scattered occurrences in western half of State.

Limonite. See Brown iron ore.

Magnetite. Clark County, with platinum in Copper King district; Eureka County, near Palisade; Humboldt County, in masses near Lovelocks, Pahute Range; Lyon County, with limonite and hematite near Dayton.

Malachite. Elko County, prominent ore of Bullion district, Standing Elk mine, carries silver and gold; Esmeralda County, Cuprite, Goldfield, and Montezuma districts; Eureka County, in oxidized ore at Ruby Hill, Eureka district; Humboldt County, small quantities in Red Butte district, has been mined in Bolivia; Lyon County, Mason Valley mine, Yerington copper district; Nye County, mined for gold at one mine in Bullfrog district, Silverbow district, carries gold and silver; Ormsby County, with copper ores 9 miles east of Carson City, carries gold and silver; White Pine County, Cumberland, Ely, Nevada Consolidated, Giroux, and other mines.

Manganese minerals. See Pyrolusite and Wad.

Marble. Elko County, La Neville Valley; Mineral County, near Luning; Nye County, occurs in Bullfrog district; White Pine County, abundant near Grandy.

Massicot. Esmeralda County, Redemption mine $1 \frac{1}{2}$ miles south of Hornsilver.

Mica. Lincoln County, 2 miles east of Gold Butte, has been mined and shipped.

Mimetite. Eureka County, in oxidized ore at Ruby Hill and in Eureka district.

Molybdenite. Reported near head of Death Valley. Otner localities are: Lyon County, in pegmatite in Yerington district; Mineral County, in quartz veins at Redlich; Nye County, prospected with powellite and scheelite at Oak Springs, 45 miles north of Johnnie Siding.

Monazite. Ormsby County, occurs in black sands at Carson City.

Nickel. Clark County, occurs with pyrrhotite and chalcopyrite in Copper King district, 16 miles south of Bunkerville; Churchill County, with silicates and sulphides 40 miles east of Lovelocks. See also Annabergite.

Obsidian. Occurs in regions of Tertiary volcanic rocks; small quantities cut for gems purposes.

Ocher. Humboldt County, replacement deposits in limestone near Golconda.

Opal. Lander County, prospected near Austin; Humboldt County, 20 miles south of Oregon and 40 miles east of California line; Nye County, reported in Ione district, and as milky opal with cinnabar on Bare Mountain. 
Platinum. Clark County, prospects with copper and nickel in Copper King district, 16 miles south of Bunkerville.

Polybasite. Esmeralda County, in Florence mine near Goldfield; Lander County, in Cortez silver deposits; Nye County, Tonopah mine, Tonopah.

Proustite. Elko County, silver ore at Protection mine in Mountain City; Esmeralda County, possibly in ore of Florence mine near Goldfield; Humboldt County, Dreamland mine, Rosebud district; Lincoln County, Rich Hill mine; Nye County, Silverbow.

Psilomelane. Warren County, large deposit at Happy Creek.

Pyrargyrite. Elko County, important silver ore in Humboldt mine at Columbia, also mined at National; Nye County, Tonopah district.

Pyrite. Common and widely distributed in many mining districts. A few places where it has been mined for gold or silver are the following: Elko County, mined for gold at Dexter, Tuscarora, and Columbia mines; Esmeralda County, mined for gold at Goldfield; Eureka County, carries gold at Ruby Hill in quartzite and unoxidized ore, important silver ore at Mineral Hill; Humboldt County, mined for silver at Sheba mine, Humboldt Range, also at Seven Troughs district and Chafey, Piute Range; Lander County, principal silver ore at Cortez, worked for gold at Tenabo; Lyon County, principal mineral at Yerington mine; Nye County, at Crappmans, Oak Spring, and elsewhere, carries gold and silver; Ormsby County, Ozark mine, mined for sulphur and gold; White Pine County, small quantity in gold veins, Osceola district, important ore in Ely district, in Robinson, Cumberland, Ely, Nevada Oonsolidated, and Giroux mines.

Pyrolusite (manganese oxide). Humboldt County, small deposit near Golconda on Humboldt River; Warren County, large deposit at Happy Creek.

Pyromorphite. Elko County, surface mineral of Cornucopia mines at Tuscarora; Eureka County, mined for silver at Mineral Hill.

Pyrrhotite. Clark County, in peridotite dikes with platinum in Copper King district, probably nickeliferous.

Quartzite. Eureka County, Ruby Hill, has been used as siliceous flux.

Quicksilver. See Cinnabar.

Salt. Churchill County, brine pumped at Leete and Parran; Clark County, extensive bed at St. Thomas, used locally; Esmeralda County, found in various places, shipped for table and dairy purposes; Eureka County, deposit in north part Diamond Valley, has been mined extensively; Washoe County, brine pumped at Sheepshead.

Sand and gravel. Dug in Clark County, at Rox; Humboldt County, at Perth.

Sand (glass). Ormsby County, in quantity 4 miles from Carson.

Sandstone. Eureka County, quarried along Prospect Mountain south of Eureka; Humboldt County, has been quarried near Winnemucca; Ormsby County, formerly at State Prison, Carson City.

Scheelite. Humboldt County, small grains through limestone; mined 4 miles from Browns; prospected in Paradise Mountains in New Goldfield district; Nye County, first discovery prospect with hübnerite at Ellsworth; with powellite near Oak Springs; White Pine County, small flakes with hübnerite at Hub, near Osceola.

Shale. Eureka County, has been quarried at New York Canyon, Eureka, for furnace brick.

Silver. Predominant metal in following districts: Churchill County, Alpine, I X L, West Gate, Wonder; Elko County, Bullion (Railroad); Esmeralda County, Lone Mountain; Eureka County, Eureka, Mineral Hill, Safford; Humboldt County, Humboldt, Lovelocks, Rosebud, Star; Lander County, Bullion, Campbell, Cortez, Dean, Galena, Reese River (Austin), Skookum; Lincoln 
County, Bristol, Geyser, Hiko, Jackrabbit, Lone Mountain, Patterson, Pioche; Mineral County, Columbus (Candelaria); Nye County, Belmont, Lodi Valley, Revielle, Tonopah, Trappmans, Tybo; Washoe County, Wedekind; White Pine County, Aurum (Silver Canyon), Newark, Ward. Of less importance in ores of many other districts.

Smithsonite (carbonate of zinc). Clark County, principal mineral of Goodsprings district, Potosi, Rover, Monte Cristo, and other mines, mined and shipped; Eareka County, in oxidized ore at Ruby Hill and Eureka districts.

Soda. Esmeralda County, near Hawthorne.

Sphalerite (zinc blende). Elko County, important silver ore at Columbia, has been mined; Esmeralda County, sparingly in principal mines of Goldfield district; Eureka County, important silver ore at Mineral Hill; Humboldt County, Pfluger mine, Humboldt Range, and Chafey mine, Piute Range, Adelaide mine, Sonoma Range; Lander County, principal silver ore at Cortez, also worked for gold at Tenabo; Nye County, small quantity in Tonopah mine and Oak Spring; Washoe County, Wedekind district, north of Sparks; formerly mined at Galena.

Stephanite. Elko County, silver ore mined at Protection mine in Mountain City; Humboldt County, Seven Troughs district; Lander County, in Cortez silver deposits; Lincoln County, Rich Hill mine, Eldorado Canyon; Nye County, Tonopah mine, Silverbow:

Stetefeldite. Esmeralda County, original sulphide ore of veins in Southern Klondike district, silver bearing; reported in other silver-producing districts.

Stibiconite. Humboldt County, Rosebud, Juniper Mountain.

Stibnite. Churchill County, has been mined in Star district, 15 miles east of Lovelocks, at Boyer, and in Bernice district; Elko County, has been mined for silver at Columbia; Eureka County, mined for silver in Stafford district; Humboldt County, deposits have been worked in Trinity Range, in Star Canyon, in Bloody Canyon 2 miles south of Star Canyon, in Jackson Canyon, 1 mile north of Unionville, Juniper Mountain, Rosebud district, and in Seven Troughs district; Lander County, has been mined in Battle Mountain district, 6 and 10 miles south of railroad, and in Big Creek Canyon in Toyabe Range 12 miles south of Austin.

Stromeyerite. Lander County, in Cortez silver deposits.

Sulphur. Esmeralda County, large deposits near Luning and Cuprite, prospected with alum 10 miles north of Silver Peak; Humboldt County, extensively mined formerly at Rabbit Hole, 5 miles northeast of Rosebud; Lyon County, small quantity native sulphur in quartz at Mountain View mine, Yerington district; Washoe County, large deposit north of Pyramid Lake.

Tetrahedrite. Elko County, important silver ore at Columbia; Esmeralda County, with gold in Combination mine, Goldfield; Eureka County, Mineral Hill, argentiferous, and Safford district; Humboldt County, occurs in most of silver-gold deposits of Humboldt and Piute ranges; Lander County, mined at Pfluger mine, Humboldt Range, secondary ore at Cortez silver deposits.

Trona (carbonate of soda). Abundant in Churchill and Mineral counties.

Tungsten minerals. See Hübnerite, Scheelite, and Wolframite.

Turquoise. Found in following places: Clark County, at Searchlight; Esmeralda County, Royal Blue mine near Millers, 9 miles northeast of Blair Junction, and at Candelaria; 4 miles northeast of Coaldale; Lyon County, $1 \frac{1}{2}$ and also 7 miles northwest of Yerington; Mineral County, $3 \frac{1}{2}$ miles south of Redlich; 8 miles southwest and 12 miles northeast of Sodaville.

Ulexite (borate of lime). See Borax.

Vanadinite. Clark County, with wulfenite, 4 miles east of Crescent.

Variscite. Esmeralda County, 9 miles east of Blair Junction, 4 miles northeast of Coaldale; Mineral County, 8 miles south of Sodaville. 
Volcanic ash. Ormsby County, unlimited quantity $5 \frac{1}{2}$ miles east of Carson City on Carson River, and in many other localities.

Wad. Eureka County, Phoenix mine and elsewhere in Eureka district; Humboldt County, small undeveloped deposit 2 miles east of Golconda; Nye County, common in some veins of Bullfrog district, mined for precious metals.

Wolframite. Humboldt County, with silver ore in Gold Run district, Sonoma Mountains, 15 miles south of Golconda.

Wulfenite. Clark County, with vanadinite 4 miles east of Crescent; Esmeralda County, Redemption mine, $1 \frac{1}{2}$ miles south of Hornsilver; Eureka County, through oxidized ore at Ruby Hill and Eureka district; very fine specimens have come from the Eureka district.

Zinc. See Calamine, Smithsonite, and Sphalerite.

\section{NEW HAMPSHIRE.}

Arsenopyrite (arsenical pyrite, mispickel). Belknap County, occurs at Alton; Carroll County, with cassiterite at Jackson; Grafton County, at Groton, Haverhill, Lebanon, Lyman, and elsewhere; Hillsborough County, at Francestown and Weare, not mined.

Beryl. Merrimack County, gem beryl found at Danbury, not mined; Sullivan County, good gem material in mica mine at Springfield, not mined.

Bornite. Carroll County, with chalcopyrite and cassiterite at Jackson; Coos County, with copper and zinc ores at Shelburne and at Milan, mined at latter place; Grafton County, with chalcopyrite in White Mountain mine at Littleton, was formerly mined.

Brown iron ore. See Limonite.

Cassiterite. Carroll County, at Jackson, mined in small way in 1843 and 1864.

Chalcocite (copper glance). Coos County, mined near Milan, with galena; carries gold and silver.

Chalcopyrite. Carroll County, has been mined with lead-silver ore near Ossipee; Coos County, near Gorham and Milan; Grafton County, at Warren and in mines at Bath, Monroe, Lyman, and Littleton (Gardners Mountain); Merrimack County, at Silverdale mine, near Pittsfield; Sullivan County, at Croydon and Unity.

Clay (brick). Brick'yards were operating at the following places in 1911; Belknap County, the Weirs; Cheshire County, Keene; Coos County, Lancaster; Grafton County, Bath, Lebanon, and Plymouth; Merrimack County, Concord and Hookset; Rockingham County, Epping, Kingston, Exeter, North Epping, and Plaistow; Strafford County, Dover, Dover Point, East Barrington, Gonic, Farmington, and Rochester.

Clay (pottery). Cheshire County, one pottery is operating at Keene.

Essonite. Grafton County, found at Warren.

Flagstone. Slates and schists quarried for local use at localities in the Connecticut Valley.

Fluorspar. Cheshire County, mined near Westmoreland.

Galena. Carroll County, has been mined near Ossipee and Madison; Coos County, near Shelburne, Gorham, and Milan; Grafton County, at Warren and Woodstock, and with copper ore at mines of Gardner Mountain; Merrimack County, at Loudon and at the Silverdale mine, Pittsfield.

Garnet. Merrimack County, deposit worked at North Wilmot for abrasive material.

Gold. Coos County, minute quantities in alluvial sands, headwater of Indian Creek; Grafton County, free gold formerly mined in upper levels of Dodge mine near Lyman and at Bath; occurs in small quantity in quartzose conglomerate rock at Lisbon and Landaff, Lyman, and North Haverhill. 
Granite. Quarried at the following places: Carroll County, Conway (3 quarries) and at Madison; Cheshire County, Fitzwilliam township (4 quarries), Marlboro, and Troy, formerly at Roxbury and Swanzey; Coos County, Kilkenney and Stark, formerly at Columbia; Grafton County, Caanan, Haverhill, and Lebanon; Hillsborough County, Brookline (2 quarries), Manchester (2 quarries), Milford (14 quarries), and Nashua, formerly at Pelham and Mason; Merrimack County, Allenstown, Concord (9 quarries), and Hookset; Rockingham County, Auburn, formerly at Salem; Strafford County, Rochester, formerly at Farmington; Sullivan County, Sunapee (3 quarries).

Graphite. Formerly mined in Cheshire County at Nelson, Merrimack County at Potter Place, and Sullivan County at Goshen.

Infusorial earth. In large quantities in north part of State: Belknap County, small deposit at Laconia; Carroll County, Bemis Lake, Stamp Act Island, Tanworth, and Wolfborough; Cheshire County, Fitzwilliam; Coos County, Lake Umbagog and Stark; Grafton County, small deposits at Livermore and Littleton were formerly used. None is now mined on a commercial scale.

Limestone (lime). Grafton County, was burned at Haverhill, Lisbon, and Littleton. Limonite. Small deposits in various parts of the State, not mined.

Magnetite. Formerly mined at Carroll County, Bartlett; Cheshire County, Winchester; Grafton County, Franconia, Piermont.

Malachite. Grafton County, occurs at Franconia, Hanover, Littleton, and Orford, with copper ores.

Marls. Coos County, Lime Pond, Columbia; Hillsborough County, Hollis, not used.

Mica (chiefly muscovite). Belknap County, has been mined at New Hampton; Cheshire County, was formerly mined at Alstead, Gilsum, Keene, and Marlboro; Coos County, has been mined at West Milan; Grafton County, is mined at Alexandria and Groton, was formerly mined at Hoyt Hill, Tugg Hill, Grafton Center, and Orange; Merrimack County, was formerly mined at Wilmot; and Sullivan County, at Acworth and Springfield.

Ocher. Numerous small deposits of ocherous bog iron ore, not mined.

Peat. Numerous localities, especially in northern part of State. A bog in Rochester, Strafford County, was worked during the Civil War for manufacture of fuel.

Pyrite. Coos County, mined with copper ores of Milan, formerly mined with leadsilver ore near Shelburne; Grafton County, mined for manufacture of sulphuric acid at Lyman; Merrimack County, has been mined with galena at Silverdale mine, Pittsfield; Sullivan County, cupriferous pyrite has been mined at Croydon and Unity.

Pyrrhotite. Grafton County, formerly mined with copper ores of Bath, Monroe, Littleton, and Lyman; Sullivan County, known at Croydon and Unity, not mined.

Quartz. Hillsborough County, formerly quarried at Lyndeborough for glass making.

Silver. Coos County, has been produced as by-product from pyrite ores at Milan mine, West Milan.

Slate. Grafton County, formerly quarried at Hanover, Lebanon, and Littleton; also Sullivan County, Croydon Mountain, Cornish.

Sand and gravel. Dug at several places for road material.

Soapstone. Cheshire County, occurs but not now quarried at Richmond and Keene; Coos County, Lancaster; Grafton County, slaty character at Orford, large bed at Haverhill; Hillsborough County, Francestown and Weare; Merrimack County, Canterbury and Warner.

Sphalerite (zinc blende). Carroll County, formerly mined with silver-lead ores at Madison; Coos County, mined at Warren mine, and Milan mine (rare), Milan, formerly mined near Shelburne and near Gorham; Grafton County, formerly mined at Woodstock and Warren, and with copper ores of Gardner Mountain. 
Tin. See Cassiterite.

Topaz. Carroll County, Baldface Mountain, near North Chatham, not mined.

Whetstone. Grafton County, mica schists or fine-grained micaceous sandstone quarried at Haverhill, Lisbon, Littleton, Piermont, and Pike.

Wolframite. Carroll County, small quantities in cassiterite veins at Jackson, not mined.

\section{NEW JERSEY.}

Agate. Hudson County, has been found at Hoboken; Somerset County, Boundbrook and Liberty Corner.

Amethyst. Fludson County, occurs in small quantity in Weehawken tunnel; Passaic County, at Little Falls; Somerset County, in geodes at Lyons Station; Sussex County, at Franklin Furnace.

Apatite. Morris County, large quantity mixed with magnetite at Ferromonte near Dover, also found at Hurdtown, Mount.Pleasant, and Hibernia mines.

Azurite. See Copper minerals.

Braunite. Hunterdon County, occurs near Clinton, in small deposits.

Brown iron ore (limonite). Many old limonite mines were formerly worked: Cumberland County, Beatyestown, Shiloh; Hunterdon County, Califon and Bird mines; Morris County, German Valley, Denmark mine, Copper and Chester mines, Hacklebarney; Sussex County, Andover mine, Edsall mine near Hamburg, Pochuck mine near McAfee; Warren County, Marble Mountain, Fittz, and Shoemaker mines.

Cement material (Portland). Three large producing plants, the Alpha, the Vulcanite, and the Edison in Warren County. Extensive deposits of limestone of suitable quality in several counties.

Chalcocite. Hudson County, occurs in Schuyler mine; Hunterdon County, Neshanic mine; Middlesex County, mines near New Brunswick; Somerset County, has been mined at American Copper mine, Somerville; Warren County, has been mined at Pahaquarry mine.

Chalcopyrite (copper pyrites). Occurs in Hudson County, Arlington mine; Hunterdon County, Flemington mine; Middlesex County, mines near New Brunswick; Somerset County, Griggstown and Somerville mines.

Chrysocolla. See Copper minerals.

Clay (brick). Dug in Atlantic County, at Bakersville, Mays Landing, and Egg Harbor; Bergen County, Hackensack, Carlstadt, and Little Ferry; Burlington County, Crosswicks Creek at Crosswicks, and near Bordentown and Kinkora; Camden County, Collingswood and Delair; Cape May County, Belle Plain; Cumberland County, Bridgeton, Clayville, and Rosenhayn; Gloucester County, Woodbury; Hudson County, Homestead; Hunterdon County, Flemington; Mercer County, Trenton; Middlesex County, Woodbridge, South River, and elsewhere; Monmouth County, Cliffwood, Keyport, Lorillard, Matawan Creek, and West Asbury; Morris County, Logansville, Morristown, and Whippany; Ocean County, Herbertsville and Toms River; Passaic County, Little Falls, Mountainview, and Singac; Salem County, Penton station and Yorktown; Somerset County, east of Rocky Hill and at Somerville; Sussex County, small quantity dug at Newton; Union County, Berkeley Heights and Plainfield; Warren County, Brass Castle and Phillipsburg.

Clay (fire). Dug in Burlington County, at Bridgeboro and Florence; Camden County, Morris Station and near West Palmyra; Gloucester County, Bridgeport and Billingsport; Mercer County, sagger clay at Mercer Station and Dogtown; Middlesex County, Woodbridge, Milltown, South Amboy, and elsewhere, pipe clay dug at Burt Creek; Ocean County, sagger clay dug at Waretown, Davenport; Warren County, Port Murray. 
Clay (pottery). Dug in Camden County, at Haddonfield; Essex County, Newark; Monmouth County, Matawan; Morris County, Logansport; Union County, in vicinity of Linden; Middlesex County, ball and slip clay dug at Woodbridge, Sayreville, and South Amboy.

Copper minerals. Azurite, chrysocolla, cuprite, and native copper occur wherever copper has been mined in the State but in very small quantity. See also Chalcocite, Chalcopyrite, and Malachite.

Cuprite. See Copper minerals.

Diasbase. See Road metal.

Flagstone. Formerly quarried in Mercer County, at Woodsville; Sussex County, Bearfort Mountain, Flagstone Hill, and Quarryville.

Fluorspar. Sussex County, occurs in minor quantity throughout the zinc ore at Franklin Furnace.

Franklinite. Sussex County, most abundant ore mineral at Franklin Furnace and Sterling Hill, mined chiefly for zinc oxide.

Garnet. Morris County, abundant at Nolands Point, Lake Hopatcong, also at Ironia; Passaic County, Hope mine, Ringwood; Warren County, Cummings iron mine.

Gneiss (crushed stone). Morris County, quarried at Montville, 2 miles northeast of Boonton and at Morristown; Passaic County, near Pompton, and at Haskell.

Granite (crushed stone). Morris County, quarried at Boonton near Dover, German Valley, Mount Arlington, and elsewhere; Passaic County, near Pompton, Haskell, and Charlotteburg; Sussex County, near Waterloo and Cranberry Lake.

Graphite. Hunterdon County, occurs at Califon and High Bridge; Morris County, occurs at Mendham and Morristown, has been mined at Bloomingdale; Passaic County, numerous places in Wanaque Valley; Somerset County, Pottersville and Peacock; Sussex County, Franklin and elsewhere.

Hematite (red iron ore). Sussex County, was formerly mined in Simpon and Cedar Hill mines near McAfee; Warren County, small quantity mined at Marble Mountain.

Infusorial earth (tripolite). Morris County, Drakeville; Sussex County, small quantities formerly used for manufacture of giant powder, near Andover. Not now mined.

Iron. See Brown iron ore, Hematite, and Magnetite.

Limestone (building). Hunterdon County, small quantities quarried at Clinton; Sussex County, near Deckertown, Franklin, and Newton, local use; Warren County, Blairstown, Carpenterville.

Limestone (crushed stone). Hunterdon County, quarried at Clinton, Califon, and Vernoy; Sussex County, Ogdensburg; Warren County, Finesville.

Limestone (flux). Hunterdon County, quarried at Annandale, Clinton, Califon, and elsewhere; Sussex County, at Hamburg, McAfee, Port Jervis, and elsewhere; Warren County, Bloomsburg, Carpenterville, Murry, and elsewhere.

Limonite. See Brown iron ore.

Magnesite (carbonate of magnesia). Hudson County, occurs near Hoboken, with serpentine.

Magnetite (magnetic iron oxide). Following is a list of mines formerly operated in Sussex County: Andover group, 4 miles south of Newton; Ford group, $3 \frac{1}{2}$ miles southeast of Sparta; Ogden group, at Edison; Sherman group, 1 mile southeast of Sparta; Sickles mine, 3 miles south of Sparta; Franklin Furnace, group extending southwest from the zinc mines at Franklin Furnace. Morris County, has been mined at Mount Hope, Richard, Hoff, Hurd, and Hibernia mines, at Rockaway Valley mines near Taylorville, mines near Splitrock Pond, Montville, and Riverdale; Passaic County, at Ringwood mines; Sussex County, the Stanhope and Ahles mines; Warren County, Oxford Furnace mine. 
Malachite (green copper carbonate). Essex County, occurs in sandstone at Belleville and Bloomfield, has been mined at Belleville; Hudson County, occurs at East Belleville; Somerset County, has been mined at Somerville; Union County, occurs in Triassic sandstone at Chimney Rock, near Plainfield; Warren County, has been mined at Pahaquarry.

Marble. Sussex County, small quantity formerly quarried near Andover and Roseville; Warren County, formerly quarried near Upper Harmony, Marble Mountain, and Jenny Jump Mountain near Danville.

Marl. Small quantities of greensand marls dug from Raritan Bay across Monmouth, Ocean, Burlington, Camden, Gloucester, and Salem counties, to Delaware River; recently dug in quantity at Sewell, Gloucester County. Calcareous marls at Shiloh, Cumberland County, dug for local use.

Menaccanite. Morris County, occurs in Dell and Fichtor mines.

Molybdenite. Sussex County, occurs in Hude, Stanhope, and Ogden mines.

Ocher. Camden County, occurs at Camden; Middlesex County, Lincoln; Warren County, mined recently near Phillipsburg.

Peat. Beds of peat in many swamps; was made into briquets near Lincoln Park in $1904-5$.

Pyrite. Morris County, occurs in Old Copperas, Hibernia, and Hurdtown mines; Sussex County, with magnetite near Vernon, Waterloo; Warren County, Jenny Jump Mountain, Marble Mountain, Washington, Swaze, and other mines.

Pyrrhotite (magnetic pyrites). Morris County, occurs in Hurdtown mine; Sussex County, Longcore's mine.

Road metal. Baltimore gneiss quarried at Holland. Mica gneiss quarried near Byberry, Ford, Montville, Morristown, and Pompton. Diabase or trap rock quarried at Brookville, Lambertville, Marshalls Corners, Milburn, Moore, Mount Rose, Paterson, Plainfield, Springfield, Upper Montclair, and formerly along Palisades. Gabbro quarried extensively at Wayne. See also Granite, Limestone, and Trap rock.

Sand (building). Dug in Bergen County, at Hackensack and Wortendyke; Burlington County, Bordentown, Burlington, Florence, Palmyra, and elsewhere; Camden County, Morris station, Grenloch and Wilton; Cumberland County, Millville; Essex County, South Orange; Gloucester County, Swedesboro; Middlesex County, Monmouth Junction, Metuchen, Sayreville, and Woodbridge; Morris County, Succasunna, Oreland, Ironia, and Montville; Passaic County, Hawthorne and Oak Ridge; Sussex County, Stanhope; Warren County, Phillipsburg; also in small quantity at many other points.

Sand (fire). Middlesex County, fire sand and underlying Woodbridge fire clay dug at number of points for manufacturing fire brick.

Sand (filter). Burlington County, dug extensively at Birmingham; Cape May County, large output from Cape May.

Sand (glass). Camden County, dug at Penbryn and Wilton; Cumberland County, Cedarville, Millville, and South Vineland; Gloucester County, Williamstown; Middlesex County, Jamesburg.

Sand (molding). Dug in Burlington County, at Bordentown, Brown Mills, Burlington, Lumberton, Palmyra, and elsewhere; Camden County, Blenhein, Grenloch, and Morris Station; Cape May County, Belle Plain; Cumberland County, Millville and Cedarville; Gloucester County, Downer, Radix, and elsewhere; Middlesex County, Perth Amboy, South Amboy, and elsewhere; Morris County, Flanders; Passaic County, Little Falls; Sussex County, Stanhope; Warren County, Phillipsburg and Great Meadows.

Sandstone. Quarries, many abandoned: Bergen County, Closter and Ridgefield; Essex County, Pleasantdale and West Orange; Hunterdon County, Stockton and Raven Rock; Mercer County, Wilburta, Princeton, and elsewhere; Passaic 
County, Passaic and Paterson; Somerset County, one-half mile northeast of Watchung and Martinsville.

Sandstone (brownstone). Quarries; many closed: Essex County, Pleasantdale; Hudson County, North Arlington; Passaic County, below Great Falls on east side of Passaic River, Paterson, and near Passaic; Somerset County, near Kingston.

Sandstone (conglomerate, puddling stone). Morris County, quarried at Green Pond; Passaic County, Bearfort and Kanouse mountains, attractive building stone.

Serpentine. Hudson County, projects out into Hudson at Stevens Point, and formerly quarried for local use; Morris County, scattered through limestone at Montville; Warren County, quarried at Phillipsburg, for decorative use.

Slate (roofing). Sussex County, quarried at Newton and Lafayette; Warren County, formerly quarried at Delaware Water Gap, and elsewhere.

Talc and soapstone. Sussex County, occur at Sparta, Lockwood, Andover, Franklin, and Newton; Warren County, quarried with serpentine near Phillipsburg.

Tephroite. Sussex County, occurs locally abundant at Franklin Furnace and Sterling Hill.

Trap rock. Quarried in Bergen County, at Cliffside Park and Bergen Hill; Essex County, Caldwell, Upper Montclair, Milburn, and elsewhere; Hudson County, Granton, New Durham, and elsewhere; Hunterdon County, Lambertville and vicinity; Mercer County, Hopewell, near Princeton and elsewhere; Middlesex County, Dunellen; Morris County, Millington; Passaic County, Paterson, Little Falls, and Great Notch; Somerset County, Bernardsville, Boundbrook, Somerville, and elsewhere; Union County, Summit, New Providence, Springfield.

Tripolite. See Infusorial earth.

Willemite (silicate of zinc). Sussex County, one of the abundant minerals at Franklin Furnace and Sterling Hill.

Zinc. See Franklinite, Willemite, and Zincite.

Zincite (red oxide of zinc). Sussex County, Franklin Furnace and Sterling Hill.

Zircon. Sussex County, abundant in magnetite at Williams mine.

\section{NEW MEXICO.}

Alum (alum rock). Grant County, large supply of aluminum sulphate 25 miles north of Silver City on both sides of Gila River; Union County, Ute Creek, not mined.

Alunogen. Grant County, both sides of Gila River, secs. 19, 20, 29, 30, T. 13 S., R. $13 \mathrm{~W}$.

Anglesite. Luna County, Cooks Peak and Victorio districts, mined at Desdemona, Graphic, and Summit mines; Socorro County, mined in Magdalena district.

Anthracite. Santa Fe County, mined at Madrid, south of Cerrillos.

Antimony minerals. See Cervantite and Stibnite.

Argentite (silver glance, silver sulphide). Has been mined in the following districts: Dona Ana County, Organ (rare); Grant County, Black Hawk, Chloride Flat, Georgetown, Granite Gap, Kimball, Lone Mountain, Steeplerock, and Pyramid districts; Sandoval County, Cochiti; Socorro County, Cooney (Mogollon) and Socorro; Sierra County, Kingston, Hermosa, Tierra Blanca, Lake Valley, Black Range, and A pache districts.

Azurite (blue carbonate of copper). Mined with other copper ores in the following districts: Grant County, Burro Mountain and Sylvanite; Luna County, Fremont (a little); Rio Arriba County, Bromide, not important; Sandoval County, Nacimiento (red beds); San Miguel County, Tecolote; Sierra County, Chloride (Phillipsburg) and Caballos; Socorro County, Magdadena: Valencia County, Copperton (Zuni Mountains), red beds. 
Barite. Valencia County, Zuni Mountains; 10-foot vein in Smelter Gulch prospected for silver.

Bismuth (native). Luna County, Fremont, with silver ores, rare; Socorro County, mined in 1911 and 1912 about 35 miles southwest of Tularosa.

Bismutite. Socorro County, mined 25 miles southwest of Tularosa.

Bornite. Mined in the following districts: Grant County, Kimball, small quantity, and Lordsburg, minor ore; Sandoval County, Nacimiento (red beds); San Miguel County, Rociada and Tecolote; Sierra County, Caballos, Chloride (silver bearing), Hermosa (silver bearing), Kingston (silver bearing); Socorro County, Cooney (Mogollon), important ore; Taos County, Twining. Occurs also in Santa Fe County with other copper ores; Lincoln County, Nogal Mountains; Rio Arriba County, Abiquiu district; Sierra County, Caballos Mountains.

Brochantite. Dona Ana County, Organ district; not mined.

Bromyrite. Sierra County, with gold and silver ores in Tierra Blanca district; was formerly mined.

Brown iron ore (limonite, brown hematite). Common in all oxidized ores. Grant County, small quantity mined with magnetite near Fierro, Union mines, formerly mined in Glorieta district; Valencia County, prospected at head of Smelter Gulch, Zuni Mountains.

Cement rock. Colfax County, Springer, natural cement formerly manưfactured; Socorro County, limestone and shale suitable for Portland cement, near.Carthage.

Cerargyrite (horn silver, silver chloride). Has been mined with oxidized ores in the following districts: Dona Ana County, Organ, rare; Grant County, Burro Mountains, Chloride Flat, Kimball, Hachita, Apache No. 2, Black Hawk, Georgetown, Lone Mountain, and Pyramid; Luna County, Fremont; Santa $\mathrm{Fe}$ County, San Ysidro Mountain; Sierra County, Lake Valley, formerly an important ore, Kingston, in placers, Hermosa, Hillsboro, Chloride (Phillipsburg), Black Range and Apache, and Tierra Blanca, rare; Socorro County, Cooney (Mogollon) and Socorro.

Cerusite (lead carbonate). Mined in the following districts: Dona Ana County, Organ; Grant County, Granite Gap, Hanover, with zinc ores, Hachita, and Lordsburg; Luna County, Cooks Peak and Fremont; Sierra County, Hillsboro, Lake Valley, very rich in silver, and Chloride (Phillipsburg); Socorro County, Magdalena.

Cervantite. Grant County, Central district; not mined.

Chalcocite (copper glance). Mined in the following districts: Grant County, Burro Mourtain, with cupriferous pyrite, Hachita, Kimball, small quantity, Santa Rita; Otero County, Tularosa; Sandoval County, Nacimiento, principal ore of red beds; San Miguel County, Rociada and Tecolote; Sierra County, Caballos; Socorro County, Cooney (Mogollon), important ore; Taos County, Picuris. Known, but not mined: Rio Arriba County, Hermosa prospects; Santa $\mathrm{Fe}$ County, Lunto Mountains, in small quantities; Socorro County, small quantities at Sierra Oscura; Valencia County, in "Red Beds" in Copper Hill district and Zuni Mountains.

Chalcophanite. Socorro County, Magdalena; mined with smithsonite.

Chalcopyrite (copper pyrites). Has been mined in the following districts: Colfax County, Cimarroncito and Elizabethtown, small quantity; Dona Ana County, Organ, in copper deposits only; Grant County, Burro Mountains, Central, with galena, Fierro, with iron ore, Hachita, rare, Kimball, small quantity, Lordsburg, Pinos Altos, Santa Rita, Steeple Rock, and Sylvanite; Lincoln County, Nogal; Luna County, Fremont; Otero County, Jarilla, Tularosa, very little; Rio Arriba County, Bromide, Hopewell, minor ore; San Miguel County, $29123^{\circ}-$ Bull. $585-14-9$ 
Cooper (Pecos), Rociada, Tecolote; Santa Fe County, Cerrillos, a little, argentiferous and auriferous, Lunto and Santa Fe Mountains, San Pedro, principal ore; Sierra County, Caballos, Chloride (Apache); Socorro County, not plentiful, Cooney (Mogollon), Mogollon Mountains, with chalcocite, bornite, and native silver, argentiferous; Taos County, Red River, not abundant, Twining.

Chrysocolla. Mined with other copper ores in the following districts: Dona Ana County, Organ; Grant County, Apache No. 2, not prominent, Burro Mountains, and Lordsburg, not common; Otero County, Jarilla; Sandoval County, Nacimiento, red beds; Santa Fe County, Santa Fe Mountains; Socorro County, Oscura Mountains, in large quantity; Taos County, Picuris.

Clay (brick). Dug, in Bernalillo County, at Albuquerque; Colfax County, Raton; Dona Ana County, Bickland; Grant County, Silver City; San Juan County, Farmington, Aztec, and Kirtland; San Miguel County, Las Vegas; Santa Fe County, Santa Fe.

Clay (fire). Mined in McKinley County, Clarkville and Gallup; Socorro County, at San Antonio.

Coal (bituminous and subbituminous). Bernalillo County, undeveloped bed along Rio Puerca near San Ygnacio; Colfax County, mined at Blasburg, Brilliant, Dawson, Koehler, Van Houten; Lincoln County, mined at Capitan and White Oaks; McKinley County, mined at Clarksville and Gallup, Hosta Butte, not mined, Raton Springs, local use, and near Zuni, local use, San Mateo; Rio Arriba County, Gallina, not mined, Monero mined, Stinking Lake, not mined; Sandoval County, Chico Arroya, 15 miles northwest of Cabezon, not mined, Hagan, local use, 15 miles east of Bernalillo, Sierra Nacimiento, local use; San Juan County, Fruitland, local use, La Plata, Pendleton, Putnam, local use; San Miguel County, Rio Pecos, not mined; Santa Fe County, Omara, 18 miles southeast of Cerrillos; Socorro County, Carthage, mined; small quantity of coking coal about 25 miles northwest of Magdalena. See Anthracite.

Coke (natural). Santa Fe County, found with anthracite at Cerrillos Hills.

Copper (native). Socorro County, rare; Grant County, Pinos Altos, rare, and Santa Rita district, east of Silver City, important.

Copper minerals. Copper is the predominant metal produced in the following districts: Bernalillo County, Tyeras Canyon, 18 miles northeast of Albuquerque; Dona Ana County, Hembrillo; Grant County, Apache No. 2, Burro Mountains, Central, Pinos Altos, Santa Rita; Lincoln County, Estey; Otero County, Highrolls and Tularosa; Rio Arriba County, Abiquin, Bromide, Gallina; Sandoval County, Cuba, Placitas, Cooper, Mineral Hill, Tecolote; Santa Fe County, San Pedro; Sierra County, Caballos Mountains; Socorro County, San Andreas, San Lorenzo, Hansonburg; Taos County, Picuris, Twining; Valencia County, Copperton, Manzano.

Cuprite (ruby copper). Grant County, mined in Santa Rita district, east of Silver City, Hanover, formerly, and Burro Mountain district; Sierra County, CabaIlos; Socorro County, in limestone with zinc and lead ores at Magdalena and Mill Canyon; Taos County, Picuris. See also Azurite, Bornite, Chalcocite, Chalcopyrite, Chrysocolla, Cuprite, Malachite, Tetrahedrite, and Tenorite.

Descloizite. Grant County, Commercial mine, Georgetown.

Embolite. Sierra County, mined to small extent in Grande, Bella, and Apache mines, Lake Valley.

Endlishite. Sierra County, Lake Valley district and Hillsboro.

Epsomite. Torrance County, obtained at Estancia Lakes.

Fluorspar. Luna County, mined near Deming; Grant County, formerly mined for flux in Burro Mountain district.

Galena (generally argentiferous). Mined in the following districts: Bernalillo County, Soda Springs; Colfax County, Moreno, small amount; Dona Ana 
County, Organ; Grant County, Burro Mountains, a little with gold ores, Central, principal ore, Granite Gap, with cerusite, Hachita, Hanover, very little with zinc ores, Kimball, small amount, Lordsburg, minor ore, Pinos Altos, with copper and gold ore, Steeple Rock, small amount, formerly mined; Lincoln County, Nogal, not plentiful; Luna County, Cooks Peak, Victorio, principal ore, Fremont, Tres Hermanas, with zinc ore; Rio Arriba County, Hopewell, sparingly; San Miguel County, Rociada, Cooper, rare; Sandoval County, Cochiti, rare; Santa Fe County, Cerrillos, prominent ore; Sierra County, Caballos, unimportant, Hermosa, principal ore, Kingston, principal ore, Lake Valley, very rich in silver, Tierra Blanca; Socorro County, Canyoncito, Magdalena; Taos County, Red River; Valencia County, Copperton, with copper ores.

Garnet (pyrope). San Juan and McKinley counties, found in Navajo Reservation, of value as gem but not mined.

Glauberite. Torrance County, with epsomite and salt at Estancia Lakes; not mined.

Gold (lode). Mined in the following districts, chiefly in oxidized zone: Colfax County, Elizabethtown, Moreno, Cimmaroncito, and Ute Creek; Dona Ana County, Black Mountain, Texas Creek; Grant County, Burro Mountains, Gold Hill, Kimball, Pinos Altos, Sylvanite, Steeplerock; Lincoln County, Jicarilla, Nogal, White Oaks; Sandoval County, Cochiti; Rio Arriba County, Bromide, Hopewell; Santa Fe County, Old Placers, San Pedro; Sierra County, Fremont, Chloride, Hillsboro; Socorro County, Cooney, Mogollon, Mill Canyon, Silver Mountain, Rosedale; Taos County, Anchor, Red River.

Gold (placer). Colfax County, Elizabethtown, Ponil, and Ute Creek; Grant County, Pinos Altos; Lincoln County, Jicarilla, Gallinas, and White Oaks; Otero County, formerly mined at Jarilla, dry placers, and elsewhere; Rio Arriba County, Hopewell; Santa Fe County, Old Placers, New Placers; Sierra County, Hillsboro, Pittsburg; Taos County, Red River.

Graphite. Colfax County, mined to small extent 8 miles southwest of Raton; Valencia County, occurs in Sandia Mountains, not mined.

Gypsum. Occurs in Bernalillo, Chaves, Dona Ana, Eddy, Guadalupe, McKinley, Otero, Quay, Rio Arriba, Roosevelt, Sandoval, San Juan, San Miguel, Santa Fe, Sierra, Socorro, Torrance, and Valencia counties. Used locally, but on a commercial scale only, in Chaves County at Acme, Lincoln County at Ancho, Otero County at Alamogordo, gypsum sands, and Rio Arriba County at El Rito.

Halite. See Salt.

Halotrichite. Grant County, both sides Gila River, secs. 19, 20, 29, 30, T. 13 S., R. $13 \mathrm{~W}$.

Hematite. Common in oxidized ores throughout the State; Grant County, mined at Fierro; Santa Fe County, formerly mined in Glorieta district. See also Specularite.

Huibnerite. Lincoln County, in quartz with gold ores in White Oaks district.

Hydrozincite. Luna County, Tres Hermanas district, with willemite and smithsonite; Socorro County, in limestone at Magdalena, with smithsonite.

Iodyrite. Sierra County, with vanadinite, at Lake Valley.

Iron minerals. See Brown iron ore, Hematite, Magnetite, Pyrrhotite, and Specularite.

Lead minerals. Lead is the predominant metal produced in the following districts: Dona Ana County, Modoc and Organ; Grant County, Carpenter, Granite Gap, Hachita, and Red Hill; Luna County, Cooks Peak, Fremont, and Victorio; Santa Fe County, Cerrillos; Socorro County, Canyoncito. See also Anglesite, Cerusite, Galena, and Plumbojarosite.

Limestone (building and crushed stone). Present in many parts of the State: Mora County, quarried at Watrous; Otero County, abundant, not used. 
Iimestone (lime). San Miguel County, quarried at Las Vegas.

Iimonite. See Brown iron ore.

Magnetite (magnetic iron ore). Colfax County, common in contact metamorphic deposits at Cimarron and Elizabethtown; Grant County, mined as iron ore at Fierro; Santa Fe County, at Old Placers, in gold quartz veins; Socorro County, mined as iron ore at Jones Camp.

Malachite. Mined with oxidized ores of the following districts: Grant County, Apache No. 2, Burro Mountains, Lordsburg, Pinos Altos, Santa Rita, Sylvanite; Luna County, Fremont; Otero County, Jarilla; Sandoval County, Nacimiento, red beds; San Miguel County, Tecolote; Sierra County, Caballos, Phillipsburg; Socorro County, Magdalena; Taos County, Picuris; Valencia County, Copperton, Zuni Mountains, red beds.

Manganese minerals. See Chalcophanite, Manganite, Psilomelane, Pyrolusite, and Wad.

Manganite. Sierra County, mined at Lake Valley, with silver ore.

Marble. Lincoln County, occurs in White Oaks district, white and black, not quarried; Otero County, quarried at Alamogordo.

Meerschaum. Grant County, small quantities shipped from prospects 12 miles northwest and 24 miles north of Silver City; Luna County, deposits at Gila River Canyon and Bear Creek, not mined.

Mica. Mined or prospected in following places: Rio Arriba County, Petaca; San Miguel County, Glorieta Mountains; Santa Fe County; Nambe, Santa Fe Mountains; Taos County, near Taos.

Molybdenite. Dona Ana County, occurs with other ores at Organ; Grant County, rare at Modoc mine, Fierro district, and with copper ores at Santa Rita; Rio Arriba County, Bromide, with copper ores; San Miguel County, Rociada, with copper ores.

Monazite. Sierra County, in black sands at Shandon, not mined.

Natural gas. Eddy County, two wells near Dayton; not used, 1909.

Onyx marble. Grant County, reported near Silver City; Lincoln County, reported near White Oaks; Otero County, deposits worked near Alamogordo.

Opal. Grant County, near Fort Bayard, has been prospected.

Petroleum. Chaves County, occurs near Artesia; Colfax County, has been found south of Raton; Eddy County, field at Dayton produces for local use; McKinley County, has been found in several wells in Seven Lakes field.

Plumbojarosite. Luna County, Cooks Peak, with lead ores.

Proustite (light ruby silver). Sierra County, with other silver ores in Kingston district.

Psilomelane. Sierra County, Lake Valley district, was mined for silver at Apache, Bella, and Grande mines.

Pyrargyrite. Grant County, Bullards Peak district, and Gold Hill near Silver City, formerly mined with sphalerite, argentite, and native silver; Sierra County, was formerly mined in Kingston and other districts; Socorro County, rare in Cooney (Mogollon) district.

Pyrite. Generally auriferous; mined in following districts; Colfax County, Elizabethtown (Moreno), Cimarron; Grant County, Burro Mountains, Fierro, with iron ore, Hachita, with silver ores, Hanover, with very little zinc ore, Kimball, Lordsburg, with chalcopyrite, Pinos Altos, Santa Rita, Steeplerock, Sylvanite; Lincoln County, Nogal, abundant, White Oaks, Jacarilla; Luna County, Cooks Peak with lead ores, Tres Hermanas, small quantity with zinc ores, Victorio, with galena; Otero County, Jarilla, Tularosa, very little, cupriferous; Rio Arriba County, Bromide, with copper ores, Hopewell; Sandoval County, Cochiti, plentiful; San Miguel County, Tecolote, small quantity with copper ores, Rociada; Santa Fe County, Cooper, with copper ore, San Pedro; Sierra 
County, Hermosa, silver-bearing; Socorro County, Cooney, with copper and silver ores, Magdalena, with zinc ores; Taos County, Ancho, Red River, Twining, cupriferous; Valencia County, Copperton, cupriferous.

Pyrolusite. Grant County, with hematite and limonite coating quartz at Wood mine, Sylvanite district; Luna County, formerly mined in Tres Hermanas district; Sierra County, with silver ores in Lake Valley district.

Pyrrhotite. Colfax County, Elizabethtown (Moreno), locally with pyrite; Grant County, Fierro and Hanover district, with magnetite; Santa Fe County, San Pedro, small quantity with chalcopyrite.

Salt. Socorro County, 80 miles south of Gallup in western part of county; Torrance County, brine evaporated at Estancia, for local use.

Sand (building). Common throughout the State. Is dug at Raton, Colfax County, and near other towns and cities.

Sandstone. Colfax County, quarried at Cimarron and near Raton, building, curbing, etc.

Scheelite. Grant County, small quantity mined in Anderson-Apache copper mine at Hachita, and Daisy mine; San Miguel County, small deposit near Hermit Peak, not mined; Socorro County, has been mined with bismuth and copper ores on east side of San Andreas range, 37 miles west of Tularosa.

Silver (native). In oxidized ores of the following districts: Grant County, Granite Gap; Luna County, Victorio; Sierra County, Hermosa, Hillsboro, Lake Valley, rare, Phillipsburg, Tierra Blanca, Black Range, and Apache; Socorro County, Cooney (Mogollon), here an original mineral; Valencia County, Copperton; also at Black Hawk, Chloride Flat, Georgetown, Lone Mountain, Pyramid, not common, Grant County; and Kingston, Sierra County.

Silver ores. Silver is the predominant metal produced in the following districts: Grant County, Black Hawk, Chloride Flat, Georgetown, Kimball, Lone Mountain, Pyramid, Telegraph, Virginia; Lincoln County, Cedar Creek; Luna County, Florida Mountains; Sierra County, Chloride, Hermosa, Kingston, Lake Valley, Tierra Blanca; Socorro County, Socorro. See also Anglesite, Argentite, Cerargyrite, Embolite, Proustite, Pyrargyrite, and Xanthoconite.

Smithsonite. Grant County, Hanover; Luna County, Cooks Peak and Tres Hermanas; Santa $\mathrm{Fe}$ County, Cerrillos; Socorro County, Kelly, Magdalena, stones from Kelly cut as a gem.

Specularite. Mined with other ores in the following districts: Colfax County, Cimarroncito and Elizabethtown (Moreno), in contact metamorphic deposits; Dona Ana County, Organ, in contact metamorphic deposits; Grant County, Fierro, with magnetite, Burro Mountains, Central, Kimball, with silver, Pinos Altos, with copper and gold ores, Santa Rita, with copper ore, sparingly, Santa Rosa, with copper ores, not abundant, Steeplerock, with auriferous pyrite, no longer mined; Luna County, Cooks Peak, Tres Hermanas; Otero County, Jarilla, in contact metamorphic deposits; Rio Arriba County, Bromide, rare, Hopewell, sparingly with gold ores; Sandoval County, Cochiti, plentiful; Santa Fe County, Cerrillos, Old Placers; Sierra County, Lake Valley, in gold quartz veins, rare; Socorro County, Cooney, with copper ores, occasional, Magdalena; Taos County, Red River.

Stibnite (sulphide of antimony). Grant County, small quantity mined with silver ores at American mine, Hachita district; Santa Fe County, Cerrillos district, not mined.

Sulphur (native). Sandoval County, James, mined on a small scale.

Tedradymite. Grant County, Golden Eagle and Hand Car mines, Sylvanite district, mined for gold.

Tetrahedrite (gray copper, fahlerz). Dona Ana County, Organ; Rio Arriba County, with calcite in schist at Bromide mine, carries silver; Socorro County, in silver 
veins at Cooney (Mogollon), near Pueblo Springs, in quartz veins with chalcopyrite, highly argentiferous; Sierra County, has been mined at Chloride, Hermosa, and Kingston.

Tenorite. Grant County, occurs in Santa Rita, not mined.

Tungsten ores. See Hübnerite, Scheelite, and Wolframite.

Turquoise. Grant County, has been mined in Little Burro Mountains and Little Hachita Mountains; Otero County, Jarilla Mountains, between Jarilla and Las Cruces; Santa Fe County, Los Cerrillos.

Vanadinite. Grant County, with silver ores at Mimbres and McGregor mines, also found on Red Horse and White Horn claims, Georgetown district, mined at Lucky Bill mine, Bayard station; Sierra County, has been mined in Caballos Mountains, and with lead ores in Hillsboro district, occurs also in Bella, Apache, and Grande mines, Lake Valley district; Socorro County, mined at Kelly mine and found on other claims, Magdalena district.

Vanadium minerals. See Descloizite, Endlichite, and Vanadinite.

Wad. Sierra County, Lake Valley and other districts, was formerly mined.

Willemite. Luna County, Tres Hermanas district.

Wolframite. Grant County, Hachita, with argentiferous galena; Lincoln County, Homestake claims, White Oaks, with gold and silver; Luna County, small quantity mined in Victorio district, near Gage.

Wulfenite. Dona Ana County, mined with silver ores in Organ district; Grant County, Lordsburg; Sierra County, mined at Fillsboro, and reported from Caballos district.

Xanthoconite. Santa Fe County, Cerrillos district, was formerly mined.

Zinc minerals. See Hydrozincite, Smithsonite, and Willemite.

\section{NEW YORK.}

Abrasive. See Corundum, Garnet, and Millstone.

Allanite. Essex County, abundant in Smith mine, Mineville; Westchester County, occurs sparingly at Bedford feldspar quarries.

Almandite. See Garnet.

Apatite (phosphate of lime). Essex County, abundant in Old Red magnetite ores at Mineville, and obtained as by-product in their concentration, botryoidal and fibrous variety (Eupyrchroite) near Crown Point; Jefferson County, Vrooman Lake; St. Lawrence County, with calcite at Hammond, also near Gouverneur; Saratoga County, Greenfield.

Arsenopyrite (mispickel). Orange County, occurs near Edenville; Putnam County, occurs near Boyds Corner, has been mined near Pine Pond.

Asbestos. Dutchess County, found near Pawling; Orange County, near Greenwood Furnace; Putnam County, Phillipstown and Patterson; Richmond County, near Tompkinsville, in Serpentine Hill, Staten Island; Rockland County, Stony Point; Warren County, Thurman.

Barite (heavy spar). Columbia County, occurs at Ancram; Herkimer County, near Little Falls and Fairfield; Jefferson County, has been mined at Pillar Point; Onondaga County, near Syracuse; St. Lawrence County, Hammond, De Kalb, and Richville; Schoharie County, with strontianite in limestone near Schoharie, alșo at Carlisle.

Bluestone. See Sandstone.

Brown iron ore (limonite, brown hematite). Dutchess County, Amenia mine, the only producer in 1910. Was formerly produced in Columbia County, at Ancram, Boston Corner, Copake, Hillsdale, and Millerton; Dutchess County, at the Dover, Sylvan Lake, and other mines; Orange County, Townsend mine, Cornwall; Richmond County, Castleton, Four Corners, Newdorp, and Todt Hill, Staten Island. 
Cement (natural). Natural cement mills are largely being supplanted by those producing Portland cement. Former important producers: Erie County, Akron; Onondaga County, Syracuse, Fayetteville, Manlius, and Jamesville; Schoharie County, Howe Cave; Ulster County, Rosendale and Lawrenceville.

Cement (Portland). Limestone and clays used: Columbia County, at Greenport and Hudson; Greene County, Cementon and Alsen; Schoharie County, Howe Cave; Tompkins County, Cayuga; Warren County, Glens Falls. Marls and clay used: Livingston County, near Caledonia; Onondaga County, Jamesville; Steuben County, Wayland.

Cerusite (lead carbonate). Lewis County, occurs at Martinsburg; St. Lawrence County, sparingly in Rossie lead mines; Westchester County, near Ossining.

Chalcopyrite (copper pyrites). Columbia County, occurs in Ancram lead mine; Orange County, near Edenville; St. Lawrence County, was mined in connection with lead near Rossie and Canton; Sullivan County, abundant with galena near Wurtsboro; Ulster County, Ellenville and Red Bridge lead mines.

Chromite. Orange County, occurs in Clove mine; Putnam County, in serpentine near Peekskill; Richmond County, disseminated in serpentine of Staten Island; Westchester County, disseminated in serpentine at Rye and New Rochelle.

Chrysoberyl. Saratoga County, formerly found abundantly in Greenfield; of gem quality.

Clay (brick). Widely distributed and utilized in nearly every county of the State. Extensively dug in counties bordering the Hudson River. Used for tile and terra-cotta ware by firms in Albany, Allegany, Erie, Kings, Monroe, New .York, Oneida, Queens, Steuben, and Rensselaer counties.

Clay (fire). Richmond County, dug and shipped on Staten Island; Suffolk County, from Long Island.

Clay (kaolin). Dutchess County, dug at Shenandoah.

Clay (pottery). Dug intermittently in Chemung County, at Elmira; Dutchess County, Amenia; Monroe County, Chili; Oneida County, Utica; Onondaga County, Syracuse, Warner, and Amboy Station; Richmond County, Staten Island; Suffolk County, Long Island.

Clay (slip). Albany County, mined and shipped near Albany.

Corundum (emery). Westchester County, mined with spinel near Peekskill, and used as abrasive.

Corundum. Orange County, blue and white varieties occur in limestone near Amity.

Cyrtolite. Westchester County, found at Bedford feldspar quarries, utilized.

Diabase. See Trap.

Feldspar. Essex County, crushed pegmatite quarried for use in the manufacture of roofing material, and as poultry grit, at Crown Point and Ticonderoga; Fulton County, orthoclase and microcline for use in pottery mined near Northville; Saratoga County, has been mined at Batchellerville and Corinth; and in Westchester County, at Bedford and North Castle.

Flagstone. See Limestone (building) and Sandstone.

Fluorspar. Cayuga County, occurs sparingly at Auburn; Clinton County, abundant in Palmer Hill mine and occurs at Finch ore bed; Essex County, Burton Hill mines, Mineville; Jefferson County, Muscalonge Lake, Alexandria; Lewis County, Lowville; Monroe County, Rochester; Niagara County, Lockport; Onondaga County, Fayetteville and Manlius; Orange County, Amity and Edenville; Putnam County, Tilly Foster iron mine, Brewster; St. Lawrence County, De Kalb, Fine, Gouverneur, Hammond, and Macomb; Warren County, Johnsburg.

Galena. Columbia County, has been mined at Ancram; Lewis County, occurs at Martinsburg; Orange County, has been mined at Phoenix lead-zinc mine near Otisville; St. Lawrence County, has been mined at Rossie and vicinity, and 
occurs in limestone at Balmat mine between Edwards and Gouverneur, at Donovan mine at Macomb; Sullivan County, has been mined at Wurtsboro; Ulster County, has been mined at Ellenville and Red Bridge; Washington County, occurs at White Creek; Westchester County, has been mined near Ossining.

Garnet (almandite). Essex County, mined at Mount Bigelow, near Keeseville; St. Lawrence County, is an abundant constituent of many Adirondack gneisses, has been mined near Gouverneur; Warren County, mined at Johnsburg, Riparius, and North River, used as abrasive material.

Granite. Clinton County, quarried at West Chazy; Essex County, quarried intermittently at Ausable Forks; Fulton County, Gloversville; Jefferson County, Grindstone Island, northwest of Clayton, Picton Island, and Wellesley Island; Orange County, north end of Mount Adam, Warwick; Putnam County, at Phillipstown, and at several places on southwest side of Breakneck Mountain north of Cold Spring; Rockland County, Piermont, Stony Point, Round Island; Warren County, Glens Falls; Westchester County, Yonkers, Glenville, Scarsdale, and elsewhere.

Granite gneiss. Herkimer County, quarried at Little Falls for local use in riprap, concrete, etc.; Orange County, Cornwall; Putnam County; Carmel, used for buildings and monuments.

Granite-syenite. Clinton and Essex counties, quarried near Ausable Forks; Herkimer County, quarried at Little Falls.

Graphite (plumbago). Clinton County, occurs near Saranac River; Dutchess County, occurs south of Fishkill Landing; Essex County, has been mined at Bear Pond, town of Ticonderoga, $7 \frac{1}{2}$ miles southwest of Crown Point Center, and at Lead Hill, near Ticonderoga; Orange County, occurs at Duck Cedar Pond; Putnam County, occurs near Carmel; Saratoga County, mined at Conklingville and at Porter Corners, town of Greenfield; Warren County, mined at Graphite; Washington County, has been mined on South Bay, town of Dresden; Westchester County, occurs near Peekskill.

Gypsum. Found throughout central and western parts of State, in the Salina formation of the Silurian. Used for calcined plasters, agricultural plaster, and for admixture in Portland cement. Quarries in Cayuga County, at Union Springs; Erie County, Akron; Genesee County, Oakfield; Madison County, Canastota; Monroe County, Wheatland, Garbutt, and Mumford; Onondaga County, Jamesville, Fayetteville, Manlius, and Camillus; Ontario County, Victor and Port Gibson. Small quarries for local use at other places.

Hematite (red iron ore). Hematite associated with schists and limestone has been mined; Jefferson County, near Philadelphia, and Antwerp; St. Lawrence County, near De Kalb, Rossie, Hermon, and Somerville. Iron ore of Clinton formation outcrops through Herkimer, Monroe, Niagara, Oneida, Orleans, Oswego, and Wayne counties; mined at Clinton, Oneida County, and at Ontario, Wayne County.

Infusorial earth. Herkimer County, dug at Wilmurt; Suffolk County, occurs at Cold Spring Harbor.

Iron. See Brown iron ore, Hematite, and Magnetite.

Labradorite. Essex County, quarried for ornamental purposes near Keeseville.

Lead. See Cerusite and Galena.

Limestone (building). Limestones locally used for building; producing quarries in Albany, Cayuga, Clinton, Erie, Genesee, Greene, Jefferson, Lewis, Madison, Monroe, Montgomery, Niagara, Onondaga, Rensselaer, St. Lawrence, Schoharie, Seneca, Ulster, and Warren counties.

Limestone (crushed stone). Quarried in Albany County, at Ravena; Cayuga County, Auburn; Clinton County, Chazy and Plattsburg; Columbia County, 
on east outskirts of Hudson; Dutchess County, New Hamburg and Stoneco; Erie County, Depew, Lancaster, and elsewhere; Essex County, Westport; Fulton County, Mayfield; Genesee County, North Le Roy; Greene County, Catskill; Herkimer County, Jacksonburg and Jordanville; Jefferson County, Chaumont, Watertown, and near Clayton; Lewis County, small quantity at Lyon Falls; Madison County, Perryville and Blakeslee; Monroe County, Rochester; Montgomery County, Amsterdam and vicinity, and Cranesville; Niagara County, Lewiston, Lockport; Oneida County, Higginsville and Sauquoit; Orange County, Cedar Cliff; Onondaga County, East Onondaga, near Syracuse, Jamesville, and elsewhere; Ontario County, Canandaigua; Orleans County, Medina; Rensselaer County, Troy; Rockland County, Tompkins Cove; Saratoga County, Stillwater Center and near Saratoga; Schenectady County, Pattersonville; Schoharie County, Cobleskill and Schoharie; Seneca County, Waterloo and Seneca Falls; Ulster County, Kingston; Warren County, Glens Falls; Washington County, Sandy Hill, Smiths Basin, and Whitehall; Westchester County, Verplanck.

Limestone (flux). Quarried for flux in Cayuga County, at Auburn; Clinton County, Chazy; Erie County, Buffalo, Clarence, and Williamsville; Essex County, Port Henry; Genesee County, Le Roy; Niagara County, Pekin; St. Lawrence County, Gouverneur; Suffolk County, Greenport.

Limestone (lime). Burned in Albany, Cayuga, Clinton, Dutchess, Erie, Fulton, Genesee, Herkimer, Jefferson, Lewis, Monroe, Niagara, Onondaga, St. Lawrence, Ulster, Warren, Washington, Westchester, and other counties.

Iimonite. See Brown iron ore.

Magnesite (carbonate of magnesia). Orange County, occurs at Warwick; Richmond County, Newdorp; Rockland County, Stony Point; Westchester County, near Rye and New Rochelle.

Magnetite (magnetic iron ore). Large deposits in Adirondack region. Principal producers are the Mineville, Port Henry, Lyon Mountain, Salisbury, and Benson mines. Workable bodies occur at many other places, as at Arnold mines, Clinton County. Lenticular ore bodies in gneiss mined in southeastern part of the State; Sterling Iron Co. and Lakeville \& Hudson Iron Co., of Fort Montgomery, are the producers.

Marble. Clinton County, fossiliferous limestone has been quarried for ornamental work at Plattsburg and Chazy; Dutchess County, white marble quarried at South Dover; New York County, was formerly quarried at Kingsbridge and Tremont; Orange County, formerly quarried at Warwick; Oswego County, old quarries at Hastings and Sparta; Putnam County, was quarried at Towners Four Corners; St. Lawrence County, white, gray, and mottled marble are quarried at Gouverneur; Warren County, black marble is quarried at Glens Falls; Westchester County, is quarried at Tuckahoe.

Marl. Large deposits in Onondaga and Madison counties. Deposits also found in Albany, Columbia, Dutchess, Greene, Orange, Ulster, and Wayne counties; used as fertilizer. Cayuga County, occurs at Montezuma; Onondaga County, Warner; Steuben County, used for Portland cement at Wayland.

Menaccanite (titanic iron). Associated with gabbro-anorthosite intrusions in Clinton, Essex, Franklin, and Warren counties. Some attempts at smelting these ores have been made.

Mica (muscovite). Generally present in pegmatites, of which several have been listed under Feldspar. Essex County, obtained as by-product of feldspar mines at Crown Point, used for roofing; Orange County, found at Edenville; Saratoga County, suitable for grinding at Batchellerville feldspar quarry, and found at Greenfield; St. Lawrence County, has been mined near Oswegatchie; Westchester County, found at Pleasantville. 
Millstone. Ulster County, Shawangunk conglomerate quarried at several localities.

Mineral paint. Manufactured from shales, iron ore, slate, and talc. Cattaraugus County at Randolph, from red shales of Chemung formation; Delaware County, red shales of Catskill formation at Roxbury; Oneida County, Clinton ore mined at Clinton; Otsego County, hematite at Oneonta; St. Lawrence County, hematite; Washington County, Cambrian red slate; Wayne County, Clinton hematite at Ontario.

Molybdenite. Clinton County, occurs at Lyon Mountain; Orange County, West Point and near Warwick; Putnam County, Tilly Foster mine; sparingly in granite.

Natural gas. Produced in 15 counties of the State. Principal fields in Allegany, Cattaraugus, Chautauqua, and Erie counties. The number of producing gas wells at the close of 1910 was 1,411 .

Peat. Occurs in bogs of various sizes throughout the State. Some of the larger bogs are the Montezuma Marshes and Cowaselon Swamp, in central New York, and the Drowned Lands of the Wallkill, in southeastern New York. Nowhere utilized.

Petroleum. Productive horizon in Upper Devonian sandstones. The principal producing fields are Allegany County, Andover, Bolivar, Wirt, and other towns; Cattaraugus County, Allegany, Carrollton, and Olean townships. Erie and Steuben counties are minor producers.

Pyrite. Erie County, occurs along Eighteenmile Creek; Essex County, associated with graphite in Ticonderoga mines; Franklin County, in large bed at Duane; Jefferson County, with hematite in serpentine at Philadelphia, and with schist at Oxbow, Antwerp, and Keene station; Lewis County, at Martinsburg; Putnam County, Phillipstown, Patterson, and near Ludington Mill ; St. Lawrence County, with crystalline limestones, and schist, is mined at Hermon and Gouverneur; Sullivan County, with galena in Wurtsboro lead mine.

Pyrolusite. Cattaraugus County, small deposits near Randolph; Essex County, as coating on feldspar near Crown Point and Ticonderoga; Fulton County, in pegmatite near Northville; Saratoga County, in pegmatite at Corinth and Edinburg; Westchester County, in dolomite near Ossining.

Pyrrhotite. Iarge deposits, Jefferson County, at Oxbow; St. Lawrence County, at High Falle mine near Canton, and at Edwards; Westchester County, at Anthonys Nose.

Quartz. Essex County, has been quarried near Port Henry. Abundantly distributed in veins in the Adirondack region. Herkimer County, double-ended clear quartz crystals found in dolomite at Little Falls, sold for jewelry and curios; Washington County, quarried at Fort Ann; Westchester County, Bedford, for wood filler, paint, etc.

Rhodonite. Essex County, occurs near Keeseville.

Road metal. Albany County, limestone of the Helderberg group quarried at South Bethlehem; Rockland County, magnesian limestone quarried at Tompkins Cove, limestone and granite at Piermont and Iona Island; Schenectady County, sandstone at Duanesburg; Wéstchester County, granite and gneiss at Port Chester. Limestone and granite used at many localities in State. See also Trap.

Salt (brine). Pumped in Genesee County, at Le Roy; Livingston County, Piffard; Onondaga County, Tully, piped to Syracuse; Schuyler County, Watkins; Tompkins County, Ithaca and Ludlowville; Wyoming County, Rock Glen, Saltvale, and Silver Springs.

Salt (rock). Livingston County, mined at Cuylerville and Retsof.

Sand (building). Dug in Albany County, at Albany; Cayuga County, Auburn; Chautauqua County, Dunkirk and Fredonia; Broome County, Deposit; Cattaraugus County, Gowanda; Erie County, Buffalo, Clarence, and Lancaster; 
Genesee County, Le Roy and Oakfield; Livingston County, near Mount Morris; Monroe County, Brighton, Pittsford, and Rochester; Nassau County, near Roslyn and at Port Washington; Onondaga County, Fairmont and Camillus; Ontario County, Fishers and Oaks Corners; Orange County, Otisville and Roseton; Oswego County, Fulton and Minetto; Rensselaer County, Rensselaer and Troy; Saratoga County, Cohoes and Waterford; Schenectady County, Rotterdam, Schenectady, and Scotia; Schuyler County, Watkins; Suffolk County, Northport; Ulster County, Marlboro; Washington County, Smiths Basin, and elsewhere; and in many other places.

Sand (glass). Dug in Oneida County, at Durhamville near Oneida Lake; Oswego County, Cleveland and Minetto; Schenectady County, Niskayuna; Ulster County, sandstone at Ellenville.

Sand (molding). Dug in Albany County at Cohoes, Delmar, Selkirk, and West Albany; Cayuga County, Auburn; Chautauqua County, Dunkirk; Dutchess County, Fishkill Landing; Erie County, North Collins; Greene County, Coxsackie; Oneida County, Boonville, Fish Creek, Forestport, and Rome; Oswego County, Fulton; Queens County, Rockaway Beach; Rensselaer County, Rensselaer; Saratoga County, Ballston, Burgoyne, Elnora, Jonesville, Round Lake, and Ushers; Schenectady County, South Schenectady; Wayne County, Sodus Point.

Sandstone. Quarried in Albany County, at Cohoes; Cayuga County, small quarries in Medina sandstone at Sterling; Chautauqua County, quarried at Jamestown; Dutchess county, Rhinebeck and Poughkeepsie; Essex County, Keeseville, on Ausable River, and Port Henry; Franklin County, near Burke; Greene County, New Baltimore and Catskill village; Herkimer County, sandstone of the Clinton formation quarried at Frankfort Hill; Madison County, quarried at Munnsville; Monroe County, Greece, and small quarries at Penfield and Brockport; Niagara County, Lewiston; Oneida County, New Hartford, Oriskany Falls, Washington Mills, and elsewhere; Orleans County, Albion, Fancher, Medina, and elsewhere; Oswego County, Granby and Oswego; Rensselaer County, intermittently quarried at Troy; Rockland County, Haverstraw and Nyack; St. Lawrence County, Hammond and Potsdam; Schenectady County, Craig, Duanesburg, and Schenectady; Washington County, Fort Ann; Wayne County, small quarries in Medina sandstone at Wolcott; Wyoming County, Arcade; Yates County, Himrod.

Sandstone (bluestone). Quarried in Albany County, at Voorheesville and South Berne; Allegany County, Belmont; Broome County, Cartersville, Deposit, and McClure; Cattaraugus County, Franklinville and South Olean; Cayuga County, King Ferry; Chautauqua County, Fredonia; Chenango County, Norwich and South Oxford; Delaware County, Deposit, Hancock, Lordville, and elsewhere; Greene County, Platt Clove and Tannersville; Otsego County, Cooperstown, Middlefield, Milford, and Oneonta; Sullivan County, Callicoon, Pond, Eddy, and Roscoe; Tioga County, Waverly; Ulster County, Allaku, Olive, number of quarries at Saugerties; Wyoming County, Warsaw, Rock Glen, and near Portageville; Yates County, Himrod, and elsewhere.

Serpentine. Occurs in Orange County, near Amity; Putnam County, Phillipstown; Richmond County, in large area on Staten Island; St. Lawrence County, Gouverneur, Fowler, Edwards, and Pitcairn Township; Warren County, Johnsburg and Warrensburg; Washington County, Shelving Rock, Lake George; Westchester County, near New Rochelle and Rye.

Siderite (spathic iron ore). Greene County, occurs near Catskill station; Columbia County, occurs at Linlithgo; Jefferson County, in hematite at Philadelphia and in crystals at Antwerp; Ulster County, Napanock, has been mined; St. Lawrence County, in serpentine rock northeast of Hermon. 
Slate (roofing). Columbia County, occurs at New Lebanon; Rensselaer County, has been quarried near Hoosick; Washington County, quarried at Granville, Hebron, West Pawlett, and near Whitehall.

Sphalerite (zinc blende). Columbia County, with galena at Ancram lead mines; Herkimer County, Salisbury; Lewis County, Martinsburg and Lewisburg; Montgomery County, Flat Creek; Orange County, Phoenix lead-zinc mine near Otisville; St. Lawrence County, mined at Edwards, occurs in serpentine limestone at Balmat mine between Edwards and Gouverneur; Saratoga County, Saratoga Springs; Sullivan County, with galena at Wurtsboro; Ulster County, with galena at Ellenville and Red Bridge.

Spinel. Orange County, is found at numerous places; Westchester County, mined with corundum near Peekskill. Used as abrasive.

Strontianite. Schoharie County, in limestone near Schoharie.

Sunstone. Essex County, Crown Point; Westchester County, Horace Greely farm at Chappaqua.

Talc. Fibrous talc mined in Lewis County, near Natural Bridge; Richmond County, occurs with serpentine on Staten Island; St. Lawrence County, in towns of Fowler and Edwards. Used by paper, paint, and plaster manufacturers.

Trap. Unlimited supply in Palisades on lower Hudson River; Rockland County, quarried near Haverstraw, Mount Ivy, Rockland Lake, and West Nyack; Saratoga County, Greenfield. Used for road material, etc. Trap dikes are very numerous in the northern and eastern Adirondack region.

Verde antique. Essex County, occurs at Moriah, Port Henry, and Minerva; Warren County, Thurman.

Wad (earthy manganese). Columbia County, occurs at Austerlitz, Hillsdale, and Canaan Center; Dutchess County, small deposits at Unionvale; Essex County, near Keeseville; Lewis County, small deposits at Tug Hill near Houseville; Orange County, with iron ores near Warwick; also in Albany, Allegany, New York, Rensselaer, and Warren counties.

Zircon. Clinton County, found at Lyon Mountain; Essex County, occurs in few places near Crown Point and abundantly in pegmatite at Old Red mines, Mineville; Orange and St. Lawrence counties, occurs at numerous places.

\section{NORTH CAROLINA.}

Abrasive. See Corundum, Garnet, Millstone, and Novaculite.

Agalmatolite (pyrophyllite). In Algonkian rocks in a range crossing Chatham and Moore counties. Worked for use in wall paper, soaps, foundry.

Agate. Cabarrus County, near Concord and Harrisburg; Mecklenburg County, in small quantity; Orange County, moss agate near Hillsboro.

Allanite. Occurs in Henderson County, at zircon mines, near Zirconia; Iredell County, abundant near Bethany Church; Madison County, at Democrat; Mitchell County, Wiseman mica mine.

Almandite. See Garnet.

Amethyst. Iredell County, at several localities southeast of Statesville; Lincoln County, at Lincolnton; Macon County, in veins cutting gneiss at several places in valley of Tessentee Creek, near Scaly Mountain, and south of Highlands; Wake County, near Raleigh; Warren County, near Warrenton.

Aquamarine. Alexander County, mined at Hiddenite and Ellis mines, near Hiddenite; Burke County, has been found in South Mountain; Jackson County, mined several miles south of Cashiers; Macon County, mined at head of Tessentee Creek; Mitchell County, mined at Wiseman and other mica mines: Yancey County, in Roy and other mica mines. 
Arsenopyrite (mispickel). Cleveland County, mined for gold at Kings Mountain mine; occurs also in gold mines in Cabarrus, Gaston, Union, and Watauga counties, but only sparingly with other ores.

Asbestos. Burke County, occurs near Brindletown and Warlicks Mills; Caldwell County, near Baker mine; Jackson County, southern part; fine and fibrous; Macon County, Nantahala River; Mitchell County, near Bakersville; Wilkes County, near Wilkesboro and Brushy Mountains; and in many other localities.

Auerlite. Henderson County, at zircon mine, in pegmatite 2 miles west of Zirconia.

Azurite (blue carbonate of copper). At copper mines in Cabarrus, Chatham, Gaston, Granville, Mecklenburg, and Moore counties, in small quantity.

Barite. Principal deposits are: Gaston County, about 5 miles south from Bessemer City and in a belt extending southwest parallel with Kings Mountain Ridge; and in Madison County, near Hot Springs, Marshall, Sandy Bottom, and Stackhouse. Has also been mined in Orange County, at Hillsboro.

Beryl. Alexander County, mined at hiddenite-emerald mine; Burke County, near Burkmont in South Mountains; in mica mines in Alexander, Iredell, Mitchell, and Yancey counties. See also Aquamarine.

Bornite (purple copper ore). Cabarrus, Rowan, and Stanley counties, with chalcocite in Gold Hill district; Granville and Person counties, important ore in quartz gangue in Virgilina district, mined for copper. Occurs also in Alleghany County, Peach Bottom mine; Ashe County, Gap Creek mine; Chatham County, Clegg's mine; Guilford County, Gardiner Hill mine.

Brown iron ore (limonite, bog iron ore). Many deposits in eastern part of State, in Duplin, Jones, Nash, New Hanover, Pender, and other counties.

Brown iron ore (brown hematite). Ashe County, has been mined in upper part of Ore Knob copper mines, accompanying copper lodes; Burke County, many beds in a northeasterly direction from Jacobi Fork of Catawba River to Brushy Mountains in Wilkes County; large beds in Chatham County, at Ore Hill; Cherokee County, at Nottla, and along Valley River; Gaston County, Highshoals; Johnston County, near Smithfield; in Lincoln and Catawba counties; McDowell County, has been mined in Linville Mountains. Many localities have been worked in Buncombe, Burke, Caldwell, Gaston, McDowell, Mitchell, Surry, Watauga, and other counties.

Cassiterite (tin ore). Tin belt extends from southeastern part of Cleveland County, through western part of Gaston County, to about 4 miles east of Lincolnton, Lincoln County. Cleveland County, has been mined at Jones, Foster, and Fairies mines near Kings Mountain; and in Lincoln County, near Lincolnton.

Cement material. Crystalline limestones in western part of State, and soft limestones in Eocene and Miocene in eastern part of State suitable for cement.

Cerusite (lead carbonate). Caldwell County, Baker mine; Cherokee County, Murphy; Davidson County, Silver Hill, with galena and silver ores; Rowan County.

Chalcanthite (blue vitriol, hydrous copper sulphate). Cleveland County, secondary mineral at Kings Mountain mine, mined for gold.

Chalcocite (copper glance). Cabarrus, Rowan, and Stanley counties, with bornite in Gold Hill district; Person and Granville counties, mined for copper in Virgilina district. Found also in Ashe County, at Ore Knob mine and Gap Creek mine; Cabarrus County, Pioneer Mills mine; Jackson County, Way Hutta and Wolf Creek mines; Swain County, Nichols.

Chalcopyrite. Ashe County, found in Ore Knob mine; Alleghany County, Peach Bottom mines; Chatham County, Clegg mine; in mines of Davidson, Gaston, Guilford, Mecklenburg, Rowan, and Union counties; Guilford County, Gardiner Hill mine; Haywood and Jackson counties, has been mined in Way Hutta, Cullowhee, Savannah, and other mines in copper belt; Lincoln County, 
Macpelah Church; Orange County, near Hillsboro and Chapel Hill; Wake County, near Raleigh; Watauga County, Elk Knob and Gap Creek mines.

Chalcopyrite (auriferous). Rowan County, Gold Hill district, principal copper ore. Chromite. Buncombe County, near Democrat and Stocksville; Jackson County, at many places in vicinity of Webster, between Willets and Balsam Gap; Yancey County, in vicinity of Burnsville, has been mined and shipped from Mine Hill.

Chrysocolla (silicate of copper). Found in many copper mines in western part of State.

Clay (brick). Bricks are made from local clay pits at one or more localities in 67 counties out of the 98 in the State. Product in 1910 valued at more than $\$ 1,000,000$.

Clay (fire). Semirefractory and siliceous clays mined for fire brick in Buncombe County at Emma; Cleveland County, Grover; and Guilford County, Pomona.

Clay (kaolin). Jackson County, dug near Webster; Macon County, near Franklin; Mitchell County, on Bear Creek near Penland; Swain County, at Almond and near Bryson City; occurs in decomposed pegmatite veins in Smoky Mountain region in western part of State.

Clay (pottery). Mined in Buncombe County, at Luthers; Burke County, at Morganton; Gaston County, Mount Holly; Lincoln County, Henry and Lincolnton; Randolph County at Whynot Academy; also mined in Chatham, Johnston, Moore, Union, and Wilkes counties.

Coal. Dan River area, in Triassic rocks: Carbonaceous shale outcrops from Germanton, Stokes County, to Leaksville, Rockingham County; semianthracite was mined near Leaksville; beds too thin, irregular, and small in extent to be of value. Deep River area: Chatham and Moore counties, in Triassic rocks; bituminous 3 feet thick, was formerly mined at Cumnocks.

Columbite. Occasional pieces found in Mitchell County, at Wiseman and other mines near Spruce Pine; Yancey County, at Ray mine and elsewhere.

Corundum. Alexander County, mined to limited extent at Acme mine, near Statesville; Clay County, in peridotite in Buck Creek, Herbert, and other mines; Jackson County, considerable quantity at Sapphire mine, abrasive; Macon County, in Corundum Hill mine near Franklin, and in Mincey mine 2 miles northwest of Corundum Hill; Madison County, at the Carter mine, near Democrat; Transylvania County, good quality in peridotite at Burnt Rock mine; Yancey County, with magnetite, menaccanite, and staurolite, near Burnsville.

Corundum (emerald, oriental). Found sparingly in Clay County, at Cullakeenee mine, Buck Creek near Elf; Macon County, Corundum Hill mine. Pink corundum in green amphibolite, decorative stone.

Corundum (emery). Guilford County, occurs at McChristian Place, 7 miles south of Friendship; Macon County, has been mined at Fairview mine near North Skeener Gap, for abrasive; mined sparingly at several places south of Franklin; Mitchell County, near Bakersville.

Corundum (ruby). Mined in Jackson County, Montvale; Macon County, at Corundum Hill mine, Cullasaja, Caler Fork of Cowee Creek.

Corundum (sapphire). Clay County, few found near Elf; Jackson County, Sapphire and Whitewater mines near Sapphire; Macon County, Corundum Hill mine.

Cuprite (red oxide of copper). Sparingly in copper mines of Alleghany, Ashe, Caldwell, Chatham, Guilford, Jackson, Swain, Lincoln, and Mecklenburg counties.

Cyanite. Mitchell County, summit of Yellow Mountain; Yancey County, green cyanite at north end of Black Mountains.

Cyrtolite. Henderson County, at Zirconia; Mitchell County, in pegmatites near Sprucepine. 
Diamond. Ten authentic diamonds have been found in the State: Burke County, 2 at and near Brindletown Creek ford; Franklin County, 2 from Portis mine; Lincoln County, Cottage Home; McDowell County, headwaters of Muddy Creek, and near Dysartville; Mecklenburg County, Todds Branch; Rutherford County, Twitty's mine.

Emerald (beryl). Alexander County, Hiddenite mine, near Hiddenite; Cleveland County, Turner mine 5 miles southwest of Shelby; Mitchell County, Crabtree Mountain. See also Corundum (emerald).

Feldspar. Mitchell County, quarried at Penland. Found in nearly all mica mines of Mitchell and Yancey counties.

Galena. Cabarrus County, McMakin and other mines; Cherokee County, with gold ores, Murphy; Cleveland County, mined for gold at Kings Mountain mine in southern part of county; Davidson County, has been found at Silver Hill, with blende, native silver, etc.; Gaston County, with blende in Causler, Shuford and Long Creek mines; Randolph County, Hoover and Boss mines; Rowan County, Gold Hill district, for gold and silver; Union mine and others; Union County, Long mine; Watauga County, Beech Mountain, several localities; Wilkes County, Flint Knob; other localities in Alleghany, Burke, Caldwell, Chatham, Macon, Montgomery, Surry, Swain, and Union counties.

Garnet. Burke County, abrasive and gem formerly mined 8 miles southeast of Morganton, along Laurel Creek; Jackson County, abrasive, mined at Sugar Loaf Mountain, near Willets; Madison County, abrasive, mined at Marshall.

Garnet (rhodolite and almandite). Macon County, obtained with corundum and ruby near In Situ Hill, on Cowee Creek, and on Mason Branch, 5 miles north of Franklin.

Gneiss. Alexander County, ornamental stone at Rocky Face Mountain; Watauga County, Blowing Rock; not quarried.

Gold. There were 22 placer mines and 9 deep mines operating in 1911; production . was valued at $\$ 70,282$. Burke County, principal production from placers near Bridgewater and Brindletown; Cabarrus County, from reworking dump of old Phoenix mine; also Gorman, Saunders, McMakin, and Reed mines; Catawba County, Catawba and England mines; Cherokee County, Middle branch of Tathams Creek, near Andrews; Cleveland County, has been recovered as by-product in mining for monazite; Davidson County, several mines in Cid mining district; no production; Franklin County, in 1910, small amount produced at Portis mine; Gaston County, Kings Mountain and BurrellWells mines; Granville County, Blue Wing and Copper King mines were idle in 1911; Jackson County, Cullowhee mine; no gold reported in 1911; Macon County, small amount from placer near Flats; McDowell County, small amount from placer near Marion, Dysartville, and Vein Mountain; Mecklenburg County, Catawba River dredge near Charlotte and Surface Hill hydraulic mines; Montgomery County, Iola mine near Candor, most important producer in State, 650-foot vertical shaft, and 450-foot incline shaft; small production from Old Coggin, Uwharra (old Montgomery), Martha Washington, and Golconda mines; Moore County, small prospects near old Cagle mine; Nash County, small output from Mann-Arrington mine; gold ore found in several prospects near Nashville; Orange County, small yield from North State placer; Polk County, Double Branch mine has five shafts; Randolph County, Scarlett, Talbert, Ashboro, Redding, and Southern Homestake mines; Rowan County, mines in Gold Hill district made small yield in 1911, mainly from old dumps; the Steele placer near Cleveland was a producer; Union County, Bonnie Doon and other mines near Indian Trail made considerable output in 1910. 
Granite. Thirty-five quarries operating in 1910 produced granite valued at $\$ 839,742$; located in the following places: Buncombe County, near Asheville; Davie County, Lexington; Henderson County, Balfour; Mecklenburg County, near Charlotte; Polk County, Rockliff; Rockingham County, Ruffin; Rowan County, at Faith; large quarry at Salisbury; Surry County, Mount Airy, very large quarry; Vance County, Greystone; Wake County, near Raleigh; Warren County, 1 mile northwest of Wise siding; Wilson County, Elm City; also in Anson, Gaston, and McDowell counties; and small quarries, to supply local demand, have been opened at many other places in western part of State.

Graphite. Amorphous; has been mined in Alexander County, at Taylorsville; Cleveland County, at Kings Mountain mine; Haywood County, Waynesville; McDowell County, Graphiteville; Wake County, Method; and in Yancey County. Impure beds in gneiss in Catawba, Cleveland, Gaston, Lincoln, and Rutherford counties; opened near Catawba station, Catawba County.

Gummite. Mitchell County, Penland, Sprucepine, and other places.

Halite. See Salt.

Hematite. Has been mined in Chatham County, Ore Hill; Gaston County, Ormond mine; Harnett County, Buckhorn mine.

Hiddenite (spodumene). Alexander County, gems mined in veins in biotite gneiss at Hiddenite; associated with aquamarine and emerald.

Lignite (brown coal). Common in marl beds in the eastern, counties; in Triassic rocks in Anson County, on Brown Creek; Granville County, on Tar River.

Limonite. See Brown iron ore.

Limestone. Produced mainly for burning into lime, and for road metal. Quarries, in 1910 in Craven County, at Newbern; Henderson County, at Fletcher and Hendersonville; Transylvania County, Brevard. Has been quarried in Beaufort, Buncombe, Jones, and New Hanover counties. Other localities known in Cleveland, Gaston, Lincoln, and Stokes counties.

Magnetite (magnetic iron ore). Occurs in pre-Cambrian formations in central and western parts of State, at many localities. Mined for iron at Cranberry, Mitchell County. Has been mined in Ashe, Caldwell, Cleveland, Gaston, Stokes, Surry, and other counties.

Malachite (green copper carbonate). Occurs in small quantity in copper mines in western part of State.

Manganese ore. Caldwell County, reported from west of Lenoir; Chatham County, manganiferous iron ore occurs at the Buckhorn iron mine; Cleveland County, small veins and replacements in schists in Kings Mountain region; belt extends northeast into Catawba and Lincoln counties; Surry County, north of Dobson, manganiferous garnet.

Marble. Cherokee County, quarried at Murphy. Occurs also in McDowell, Mitchell, and Swain counties.

Marl (calcareous). Occurs in limited patches in all the eastern counties throughout an area equal to one-fourth of State. Used locally in many places.

Marl (greensand or glauconitic). Occurs in southeastern counties, from Neuse River to Cape Fear River.

Melaconite (black oxide of copper). Occurs sparingly in copper mines in western part of State.

Menaccanite. Caldwell County, was prospected north of Lenoir.

Mica (muscovite). Deposits have been opened in 18 or more counties in the western part of State, where the production of mica is an important industry. Has been mined and prospected extensively; probably have been over 100 good producing mines. Ashe County, near Jefferson, Beaver Creek, and Elk Crossroads; Buncombe County, near Balsam Gap, Black Mountain, Montreat, along the North Fork of Swannanoa River; Burke County, near Burkemont, 
in South Mountains; Cleveland County, in Indian Town region and near Casar; several miles northwest of Shelby, near Belwood; Gaston County, in northwestern part of county; Haywood County, in Allen Creek basin south of Waynesville, and in Balsam Mountains, at head of Pigeon River; Jackson County, a large number of mines in a belt several miles wide, extending northeast across the county from Cowee Bald and Moss Knob, on the Cowee Mountain divide, to Balsam Gap and Richland Balsam Mountain; also near Sols Creek, along Tuckasegee River, near Pinhook Gap, Wolf Mountain, and at several places in southeastern corner of county; Lincoln County, in belt along west side of county; Macon County, in a belt several miles wide, extending northeast across county, from Nantahala River over Wayah Mountain to Cowee Bald and Moss Knob, on the Cowee Mountain divide; also near Higdonville, Scaly, and Highlands; Mitchell County, large number of mines in region between Bakersville, Crabtree Creek, Blue Ridge Mountain, Lineback, and Cranberry; Sprucepine central point to mica region; Rutherford County, Isinglass Hill, $3 \frac{1}{2}$ miles north of Rutherfordton, and other localities; Stokes County, near Sandy Ridge; Transylvania County, Bee Tree Fork region and near Sapphire; Watauga County, north of Boone and 2 miles northwest of Elk Crossroads; Yancey County, many mines along South Toe River and westward across Black Mountains, near Burnsville and Green Mountain.

Millstone. Anson County, sandstone used as grindstones during the Civil War; Madison County, quartzite on Laurel River, used for millstone; Moore County, Triassic conglomerates, used for millstone, McLennans Creek; Rowan County, made from granitic rock at Salisbury.

Monazite. Found in gravels in area of about 3,000 square miles. Produced from placers in Burke County, at Bridgewater, Brindletown, Connellys Springs, and Morganton; Cleveland County, Belwood, Casar, Lawndale, Carpenters Knob region, Mooresboro, and elsewhere; Gaston County, Cherryville; Iredell County, north of Statesville; Lincoln County, western part; Madison County, in masses up to 60 pounds in weight near Mars Hills; Rutherford County, Ellenboro, Oak Springs, Rutherfordton, and elsewhere; also in Alexander and Catawba counties.

Nagyagite. Cleveland County, mined for gold at Kings Mountain mine.

Novaculite (whetstone). Anson County, has been quarried near Wadesboro; Orange County, few miles west of Chapel Hill, quarried extensively; Person County, near Roxboro.

Peat. Abounds in the eastern part of State, particularly in the seaboard counties; not used.

Pitchblende. See Uraninite.

Platinum. A belt of platinum-bearing rock is reported extending from Cedar Falls, N. C., to Danville, Va.

Polycrase. Henderson County, in gold washings with zircon, magnetite, etc., near Zirconia.

Psilomelane. Caldwell County, in gneissic rocks near Lenoir; Chatham County, with iron ore at Buckhorn iron mine; Gaston County, in schist 1 mile southeast of Kings Creek.

Pyrite. Cleveland County, mined for gold at Kings Mountain mine; Gaston County has been mined as sulphur ore 5 miles north of Bessemer City; Rowan County, mined for gold in Gold Hill district; and Union County, Colossus.

Pyrolusite (black oxide of manganese). Chatham County, with iron ore at Buckhorn iron mine; Gaston County, in schist 1 mile southeast of Kings Creek; and elsewhere in small quantity.

Pyrophyllite. Moore County, produced by three mines at Glendon for use as talc.

$29123^{\circ}-$ Bull. $585-14-10$ 
Pyrrhotite (magnetic pyrites). Plentiful, generally with pyrite and chalcopyrite in copper deposits in Ashe, Jackson, Macon, and Swain counties. Cleveland County, mined for gold at Kings Mountain mine; Macon County, occurs in gravels of corundum mines.

Quartz (quartzite). Cherokee County, quarried near Ranger for flux in copper smelting, and in blocks as filler for acid towers; Gaston County, mined at Oliver mine.

Ruby. See Corundum.

Rutile. Clay County, in placer on Shooting Creek east of Hayesville; Macon County, abundant with corundum in gravels of Mason Branch and Caler Fork of Cowee Creek; fine specimens in Alexander and Iredell counties.

Rhodolite. See Garnet.

Salt (brine). Buckingham, Chatham, and Orange counties, formerly obtained from wells in Triassic beds.

Samarskite (yttria ore). Mitchell County, large masses have been found at Wiseman mica mine; sparingly at other mica mines.

Sand and gravel. Dug at following places: Anson County, Lilleville; Buncombe County, Asheville; Cleveland County, Shelby; Gaston County, Bessemer City; Guilford County, Greensboro; Henderson County, Balfour; Iredell County, Statesville; Mecklenburg County, Charlotte; Moore County, West End; Wilkes County, North Wilkesboro.

Sandstone. Only quarry operating is at Sanford, Lee County. Idle quarries in sandstone of Triassic period in Anson County, at Wadesboro; Chatham County Chatham, near Egypt; Orange County, near Durham; Rockingham and Stokes counties, quarries in the Dan River belt.

Sapphire. See Corundum.

Serpentine. Very fine, dark-colored, takes fine polish; Buncombe County, Asheville; Caldwell County, Baker quarry; Clay County, Buck Creek; also in Forsythe and Wake counties; yellowish-green variety occurs in Caldwell, Orange, Stokes, Surry, Wake, Wilkes, and Yancey counties.

Siderite (black band ore and ball ore). Chatham County, beds in Triassic rocks of Deep River opened at Egypt, Farmville, and Gulf; occurs also in Davidson, Granville, and Halifax counties; common as gangue material in gold mines, also at some copper mines.

Silver. Recovered in refining gold and copper, produced mainly in Person and Rowan counties. Native silver at Silver Hill and Silver Valley mine, Davidson County.

Soapstone. Many undeveloped masses in western part of State; Ashe County, probable valuable deposits 2 miles west of Beaver Creek, quarried for local use.

Sphalerite (zinc blende). Cabarrus County, in McMakin mine with galena and silver ores; Cleveland County, mined for gold in Kings Mountain mine in southeastern part of county; Davidson County, has been found at Silver Hill with galena and silver ores; McDowell County, in Dobson mine, Cedar Grove, in limestone; Rowan County, small quantity in Gold Hill district; Union County, Lemmon, Long, Moore, and Stewart gold mines; in small quantities in Alleghany, Gaston, Macon, Madison, and Montgomery counties.

Spinel. Macon County, found in gravels in Cowee Valley; Mitchell County, gahnite variety in Chalk Mountain and other mica mines.

Spodumene. See Hiddenite.

Staurolite. Good single and double crossed crystals, have some commercial value as curios; found in Ashe County; Burke County, South Mountains; Cherokee County; Haywood County, near Waynesville; Iredell County, Belts Bridge; 
Macon County, near Corundum Hill; northern part of Wake County; and in many places west of Blue Ridge.

Sunstone. Iredell County, near Statesville.

Talc. Six companies producing in 1911. Most of the product came from Swain County. Mined in Alleghany County, near Piney Creek; Cherokee County,

- was formerly mined at Tomotla; Jackson County, mined at Beta; Moore County, three mines at Glendon mining pyrophyllite; Swain County, mined at Hewitts.

Tedradymite. Burke, Cabarrus, Gasto, and McDowell counties, in minute scales at copper mines; Davidson County, occurs in Allen mine and in Beck's mine west of Silver Hill; Montgomery County, mined for gold at Asbury mine.

Tetrahedrite. Cabarrus County, has been found in McMakin mine with silver, zincblende, and galena, and in Sudwick mine with copper pyrites; Cleveland, mined for gold at Kings Mountain mine.

Tin. See Cassiterite.

Tourmaline. Alexander County, black crystals at Stony Point; Yancey County, at Ray mine; and at many other localities.

Uraninite (pitchblende). Mitchell County, in Flat Rock mine, in Deake mine, in a feldspar quarry near Penland, and in Wiseman mica mine.

Uranophane. Mitchell County, Penland, Sprucepine, and other places.

Xenotime (yttrium phosphate). Burke County, from gold washings at Brindletown.

Zircon. Burke, McDowell, and Rutherford counties, in gravels of monazite mines; Henderson County, mined near Zirconia; Iredell County, occurs near New Sterling.

\section{NORTH DAKOTA.}

Cement material. Cretaceous limestone used for natural cement in Cavalier County, about 10 miles north of Milton; Pcmbina County, quarried and mined along Tongue River. Niobrara chalk suitable for Portland cement occurs in State, but is almost ontirely concealed by glacial drift and Pierre shale.

Clay (brick). Dug in Bottineau County, at Halls Spur 3 miles north of Omemee and at Arnedo; Bowman County, Scranton; Burleigh County, Bismarck and Chapin; Cass County, south of Fargo; Cavalier County, Mayo; Grand Forks County, Grand Forks; McLean County, Wilton, and 6 miles west of Coal Harbor; Morton County, Mandan and Hebron; Pembina County, Drayton and Mayo, near Walhalla; Stark County, Dickinson and Richardton; Ward County, Burlington, Kenmare, and Minot; Traill County, half a mile north of Hillsboro; Williams County, Williston.

Clay (fire). Morton County, good quality, used near Hebron; and in Stark County, at Dickinson.

Clay (pottery). Clay suitable for stoneware occurs in Billings County, near Sandcreek post office; Burleigh County, along Missouri River at Bismarck; Cavalier County, near Olga; Dunn County, near Oakdale; Morton County, near Hebron; Stark County, near Dickinson and Gladstone; and at other localities.

Coal (lignite). Extensive beds in Cretaceous and Tertiary formations underly western half of State. Production in 1911 was 502,628 short tons. Principal mines and outcrops are in following counties: Adams County, four mines in vicinity of Haynes work a 12-foot bed; Billings county, vicinity of Yule, Great Bend, Medora, Sentinel Butte, East Rainy Buttes, and numerous other localities; mined at Medora, near Sentinel Butte, and elsewhere; Bowman County, outcrops along North Fork of Grand River, in southeastern part of county, also on Coyote Creek, mined 2 miles west of Haley and at Scranton; Burleigh County, McClelland mine, 7-foot bed, excellent quality; Washburn mine, near Wilton, 
largest in State; Emmons County, near Livona, $2 \frac{1}{2}$-foot bed, mined at Edick and Parkhurst mine; Hettinger County, outcrops at number of points on Coal Bank Creek, 8 miles south of New England, and in the southeastern corner of the county; small quantity mined for local use; McLean County, outcrops along banks of Missouri River, 30 miles above Bismarck; Satterlund mine, 6 miles northwest of Washburn, 9-10 foot bed, local use; Rose Hill mine, 5-foot. bed; Coal Harbor district, Marion, Joe Mann, and Eskes mines, bed 7 feet 9 inches; Dogden Buttes, 16-foot bed; near Turtle Lake, 7-9 foot bed; Mercer County, along Missouri River near Mannhaven, 7 -foot bed; also above and below Hazen, and in Big Bend district; Morton County, along valley from Sims to New Salem; mined at New Salem, 6-foot bed, also mined in vicinity of Sims (Feland mine), Glen Ullin, and Hebron, and at many localities south of railroad; Oliver County, abundant beds on east bank of Missouri River and at Square Butte Creek, and branches of Knife River, 6-7 foot bed; mined by stripping, 3 miles south of Hensler; also mined in southern part of county; Rolette County, on southern slope of hills near Dunseith, 3-4 foot bed, mines reopened; Stark County, extensively mined near Lehigh, 10-15 foot bed; abundant about Belfield, mined on south side of Heart, 6 -foot bed, excellent; Ward County, along edge of bluffs of Des Lacs River to prairie; mined near Burlington, 9-13 foot bed; near Kenmare, 6-foot bed, Smith-Kenmare, Diamond, and many other mines; Williams County, considerable deposit about Williston along Missouri River, mined for local supply; workable beds occur also in Adams, Burke, Divide, Dunn, McKenzie, Mountrail, and Renville counties.

Granite. Large drift bowlders are abundant in all the counties of North Dakota, except Adams, Billings, Bowman, and Hettinger counties; used locally for building material.

Natural gas. Bottineau County, 12 wells in sand underlying drift of Lake Souris; gas piped to Westhope and Lansford, for local use; Lamoure County, some gas produced from 7 artesian wells; Renville County, in blue clay and shale near Mohall, 2 wells, local use.

Road metal (sand and gravel). Dug in Grand Forks County, at Emerado Beach; Hettinger County, at Liberty; Pembina County, in Fremont Township and Walhalla; Walsh County, in "The Mountains" in Herman and Norcross beaches in vicinity of Edinburg; and in many other places; along ancient shore lines of Lake Agassiz in Cass, Grand Forks, Pembina, Walsh, and Traill counties.

Sand (building). Small quantity dug for local use.

Sandstone. Emmons County, quarried at Linton; McLean County, along Missouri River at Washburn; McHenry County, near Velva; Stark County, small quantities have been quarried at Dickinson.

\section{OHIO.}

Bromine. Meigs County, distilled from brines at Pomeroy and Minersville.

Brown iron ore (limonite). Occurs in form of concretions known as "kidney ore," in thin beds as "block ores," and as "limestone ores." The "Lower Coal Measures," "Barren Measures," and "Upper Coal Measures" contain the orebearing horizons. Carroll, Columbiana, Gallia, Hocking, Jackson, Lawrence, Licking, Mahoning, Muskingum, Perry, Scioto, Trumbull, and Vinton counties have produced ore from these horizons; of little economic importance at present time.

Celestite (strontium sulphate). Lucas County, with calcite, at Whitehouse, and with gypsum at West Sister Island; Ottawa County, Green or Strontian Island, Put-in-Bay, Lake Erie, in fine crystals and in large masses, filling fissures in the water-lime rock. 
Cement (natural). Columbiana County, at Lisbon; Defiance County, Devonian calcareous shale used at Defiance.

Cement material (Portland). Ferruginous limestone and shale used in Lawrence County, at Ironton and Superior; and Stark County, at Middlebranch. Marl and clay used in Erie County at Baybridge and Castalia; Logan County, at Rushsylvania.

Cement (puzzolan). Mahoning County, manufactured at Struthers.

Clay (brick). Widely distributed; used at one or more places in every county of the State.

Clay (fire). Abundant in State; mined in Athens County, at Nelsonville; Columbiana County, East Liverpool and Washingtonville; Hamilton County, Delhi; Hocking County, East Clayton; Jackson County, Oak Hill; Jefferson County, Empire and Irondale; Lawrence County, Ironton and Steece; Morrow County, near Sparta; Muskingum County, South Zanesville and small quantity at Ellis Station; Perry County, small quantity at Chalfants; Scioto County, Lilly and Sciotoville; Stark County, Beach City, Massillon, and $1 \frac{1}{1}$ miles south of Magnolia, very small quantity at Limaville, also sagger clay at North Industry; Vinton County, sagger clay mined at Richland; Washington County, Newport.

Clay (pottery and tile). Clays and shales extensively mined in.Columbiana County, at East Liverpool; Darke County, Palestine; Hamilton County, in Springfield Township; Hocking County, at Haydenville and in very small quantity near Logan; Jefferson County, Steubenville; Licking County, Hanover; Lorain County, Elyria; Muskingum County, Zanesville; Perry County, Crooksville and Roseville; Stark County, extensively mined at Canton and North Industry; Wayne County, very small quantity at Dalton.

Coal (bituminous). The Sharon, Wellston, Lower and Middle Kittanning, Upper Freeport, Pittsburg, Pomeroy, and Meigs Creek coal beds cxtensively mined in eastern part of the State in Athens, Belmont, Carroll, Columbiana, Coshocton, Gallia, Guernsey, Harrison, Hocking, Holmes, Jackson, Jefferson, Lawrence, Mahoning, Medina, Meigs, Morgan, Muskingum, Noble, Perry, Portage, Scioto, Stark, Summit, Trumbull, Tuscarawas, Vinton, and Wayne counties. Athens, Belmont, Guernsey, and Jefferson counties each produced more than $3,000,000$ tons in 1911; the total output of the State was 30,759,986 tons in 1911.

Flagstone. Allen County, quarried in Lima; Clarke and Greene counties; Cuyahoga County, formerly quarried at Berea; Geauga County, Thompson; Highland County, from "Helderberg" limestone at Greenfield; Logan County, Belle Center; Lorain County, Amherst and Lagrange; Preble County, Eaton; Trumbull County, magnesian limestone at Warren. Scioto valley, sandstones of the Waverly group.

Grindstone. Has been quarried in Cuyahoga County, at Berea, Chagrin Falls, Independence, South Park, and West View; Erie County, Berlin Heights; Harrison County, Tippecanoe; Jefferson County, Empire; Lorain County, North Amherst, Elyria, Oberlin, and elsewhere; Scioto County, Portsmouth; Stark County, Massillon; Summit County, Peninsula; Washington County, Belpre, Briggs, Constitution, Marietta, and vicinity.

Gypsum. Occurs in various places in the "Helderberg," encountered in most of deep wells in north and central Ohio; Ottawa County, quarried near Gypsum Station and Port Clinton.

Hematite (fossil ore, dyestone). Occurs in Clinton County, at Todds Ford, near Wilmington; Highland County, at Sinking Springs, most important deposit of this ore in State - Muskingum County, near Zanesville.

Iignite. See Coal. 
Limestone (building). Quarried in Allen County, at Bluffton, Delphos, Elida, and Lafayette; Butler County, near Hamilton; Clark County, Springfield; Clermont County, Williamsburg; Clinton County, Wilmington; Delaware County; Erie County, Castalia and Sandusky; Franklin County, Columbus and Marble Cliff; Greene County, Xenia and New Jasper; Hamilton County, Cincinnati and Glendale; Hancock County, Arlington and Findlay; Highland County, Highland; Huron County, Bellevue; Logan County, Belle Center and Bellefontaine; Lucas County, Whitehouse; Marion County, Marion; Miami County, Covington and Ludlow; Montgomery County, Brookville and Dayton; Preble County, Eaton and Lewisburg; Putnam County, Cloverdale, Ottoville, Pandora, and Rimer; Sandusky County, Fremont; Seneca County, Bloomville, Flat Rock, and Tiffin; Wood County, Lime City and Bowling Green.

Limestone (crushed stone). Carboniferous, Silurian, and Devonian limestones widely distributed except for barren area extending in a north-south direction in the central part of the State. Used extensively in Allen, Butler, Clark, Clay, Clermont, Clinton, Columbiana, Crawford, Delaware, Erie, Franklin, Greene, Hamilton, Hancock, Hardin, Highland, Lawrence, Logan, Lucas, Mahoning, Marion, Mercer, Miami, Montgomery, Ottawa, Paulding, Preble, Putnam, Ross, Sandusky, Seneca, Van Wert, Wood, and Wyandot counties.

Limestone (flux). Used as flux in iron and copper smelters and in the manufacture of glass. Quarried in Clark County at Cold Springs and Springfield; Crawford County, Bucyrus; Franklin County, Columbus and Marble Cliff; Lawrence County, Bartles Station, Blackford, Eifort and Ort; Lucas County, Silica; Mahoning County, Lowellville; Marion County, Marion; Miami County, Piqua; Ottawa County, Marblehead.

Limestone (lime). Burned in Belmont County, West Wheeling; Clark County, at Cold Springs and Springfield; Crawford County, Oceola; Delaware County, Delaware and Radner; Erie County, Kellys Island; Greene County, Cedarville; Hamilton County, Cincinnati; Hardin County, Patterson; Harrison County, Germane; Highland County, Greenfield and Hillsboro; Logan County, Middleburg; Marion County, Marion; Mercer County, Fort Recovery; Miami County, Covington; Montgomery County, near Dayton; Ottawa County, Clay Center, Genoa, and Marblehead; Preble County, New Paris; Sandusky County, Fremont and Woodville; Seneca County, Fostoria and Tiffin; Stark County, Marlboro and elsewhere; Wood County, Luckey and Sugar Ridge; Wyandot County, Casey.

Iimonite. See Brown iron ore.

Marl. Erie County, used for Portland cement in Baybridge and Castalia; Fulton and Williams counties, occurs in lakes and marshes; Highland County, a ma:ly magnesian limestone at Sinking Spring; Logan County, a marly magnesian limestone at Rushsylvania; Preble County, Camden; Summit County, Hudson; Sandusky County, dug in lakes and marshes.

Natural gas. The "Trenton," "Clinton," "Helderberg," and Berea are the producing horizons. Many wells are located in Ashland, Ashtabula, Athens, Auglaize, Belmont, Carroll, Columbiana, Cuyahoga, Darke, Fairfield, Guernsey, Hancock, Hardin, Harrison, Hocking, Holmes, Jefferson, Knox, Lake, Licking, Logan, Lorain, Lucas, Medina, Mercer, and Monroe counties.

Oilstones. Cuyahoga County, quarried at Chagrin Falls.

Peat. Lake County, near Painesville; Lorain County, Brighton and Camden; Summit County, large deposits; Trumbull County, Bloomfield township, several thousand acres; many smaller deposits in Fulton, Williams, and other northern counties; not utilized.

Petroleum. Three important fields, the Lima or northwestern, the central, and the southeastern. Large production from Allen, Auglaize, Hancock, Lucas, 
Mercer, Ottawa, Sandusky, Seneca, Van Wert, and Wyandot counties of the northwestern field. Athens, Coshocton, Fairfield, Holmes, Knox, Lorain, Muskingum, Perry, and Vinton counties of the central field contain producing wells. Large production from wells in the southeastern field in Belmont, Carroll, Columbiana, Guernsey, Harrison, Jackson, Jefferson, Monroe, Morgan, Noble, and Washington counties. There were about 31,000 producing wells in Ohio in 1910.

Pyrite. Obtained as by-product in coal mining. Tuscarawas County, mined at Canal Dover, Midvale, New Philadelphia, Roswell, and Wainwright.

Salt (brine). Produced in Cuyahoga County, near Cleveland; Medina County, Wadsworth; Meigs County, Pomeroy; Morgan County, Durant; Summit County, Akron and Barberton; Wayne County, Rittman.

Sand (building). Dug in Allen County, near Allentown; Ashtabula County, Ashtabula; Athens County, Broadwell; Butler County, Hamilton; Clark County, Springfield; Clermont County, Miamiville; Columbiana County, East Liverpool; Coshocton County, Coshocton; Cuyahoga County, Cleveland; Darke County, Greenville; Erie County, Sandusky; Fairfield County, Lancaster; Franklin County, dredged from Scioto River, Columbus; Gallia County, dug near Gallipolis and Vinton; Hamilton County, Cincinnati; Jackson County, Coalton; Jefferson County, Brilliant; Lawrence County, Ironton; Lorain County, Brownhelm station and Lorain; Lucas County, Toledo; Mahoning County, Austintown and Youngstown; Miami County, Pleasant Hill; Montgomery County, Dayton; Muskingum County, Gilbert, Philo, Trimway, and Zanesville; Pike County, Wakefield; Portage County, Garrettsville; Richland County, near Mansfield; Sandusky County, Fremont; Scioto County, Portsmouth; Stark County, Alliance and Canton; Summit County, Akron; Tuscarawas County, Canal Dover; Washington County, Marietta; Wood County, Perrysburg.

Sand (glass). Sandstones of Silurian or Carboniferous age quarried and crushed in Erie County, at Sandusky; Hocking County, Rockbridge; Knox County, Howard; Licking County, near Toboso; Lucas County, 4 miles southwest of Sylvana; Mahoning County, Austintown; Muskingum County, Zanesville; Perry County, Chalfants; Stark County, Massillon; Summit County, Warwick; Trumbull County, 4 miles southwest of Niles; Tuscarawas County, Dundee.

Sand (molding). Dug in Ashtabula County, at Conneaut and Kingsville; Belmont County, Bellaire; Butler County, Overpeck and Hamilton; Carroll County, Sherrodsville; Columbiana County, Leetonia; Coshocton County, Layland; Cuyahoga County, Cleveland and Collinwood; Erie County, Avery, Huron, Milan, Sandusky, and Shinrock; Fairfield County, Lancaster; Gallia County, Gallipolis; Hamilton County, Delhi; Jackson County, Coalton; Jefferson County, Steubenville; Knox County, Howard; Lucas County, Toledo; Mahoning County, Austintown; Muskingum County, Dresden, Ellis, Gilbert, and Zanesville; Perry County, New Lexington; Portage County, Garrettsville; Stark County, Alliance, Canton, Crystal Springs, and Massillon; Summit County, Akron, Cuyahoga Falls, Everett, and Warwick; Tuscarawas County, Barrs Mills, Dundee, New Cumberland, and Somerdale; Washington County, Vincent.

Sandstone (building, crushed stone). Quarried in Allen County, at Allentown; Ashland County, Ashland; Belmont County, Martins Ferry; Carroll County, Sherrodsville; Cuyahoga County, Berea, South Euclid, West View, and elsewhere; Erie County, Berlin Heights; Fairfield County, Lancaster and Sugar Grove; Franklin County, Reynoldsburg; Guernsey County, Cambridge; Harrison County, Freeport; Highland County, Hillsboro; Holmes County, Glenmont; Jefferson County, Empire and Steubenville; Licking County, Newark; Lorain County, Amherst, Columbia, Grafton, and Oberlin; Mahoning County, Youngstown; Morrow County, Fulton and Iberia; Muskingum County, Zanesville and 
vicinity; Noble County, Sharon; Pickaway County, Circleville; Pike County, Waverly; Richland County, Mansfield; Scioto County, McDermott and Portsmouth; Stark County, Massillon; Summit County, Peninsula and Twinsburg; Trumbull County, Mineral Ridge; Washington County, Marietta; Wayne County, Wooster; Wood County, Grand Rapids.

Siderite. Occurs in Carboniferous limestones. Was formerly mined in Gallia, Jackson, Lawrence, Scioto, and Vinton counties.

\section{OKIAHOMA.}

Asphalt (rock). Extensive deposits in southern part of State, in and south of Arbuckle Mountains. Quarried for paving in Carter County, at Ardmore; Comanche County, Lawton; Murray County, at Gilsonite, 3 miles south of Sulphur, and near Dougherty. Occurs in Atoka, Bryan, Craig, Garvin, Jefferson, Johnson, Le Flore, Love, McCurtain, Ottawa, Pontotoc, and Stephens counties.

Azurite. Occurs in small quantities in Arbuckle Mountains.

Calamine. Ottawa County, mined at Quapaw and at Peoria.

Cement material (Portland). Limestones and shales suitable for cement in northeastern Oklahoma and elsewhere; utilized in.Pittsburg County, at Hartshorne; Pontotoc County, Ada; and Washington County, Dewey. Shales underlying Caddo limestone in Red River region south of Arbuckle and Ouachita Mountain uplifts, suitable for Portland cement.

Cerusite. Ottawa County, occurs in Peoria mines.

Clay (brick). Dug in Beaver County, at Logan; Canadian County, 4 miles west of El Reno; Carter County, Ardmore; Choctaw County, Boswell; Craig County, Vinita; Creek County, Sapulpa; Garfield County, Enid; Grady County, Chickasha; Jefferson County, Addington and Hastings; Kay County, Blackwell; Kingfisher County, Hennessey and Kingfisher; Kiowa County, Gotebo; Le Flore County, Poteau; Logan County, Guthrie; Muskogee County, Muskogee; Nowata County, Nowata;' Oklahoma County, Oklahoma City; Okmulgee County, Gaither; Pawnee County, Cleveland; Pittsburg County, McAlester; Pontotoc County, Ada; Pottawatomie County, South Beard; Rogers County, Claremore; Tulsa County, Broken Arrow, Red Fork, and near Tulsa; Washington County, Bartlesville; Woods County, Alva.

Clay (fire). Large quantities occur in coal fields: Coal County, at Lehigh and Coalgate; Latimer County; Wilburton; Pittsburg County, Blocker, Hartshorne, and McAlester.

Clay (kaolin). Reported from Cherokee County, near Tahlequah, and from Wichita Mountains.

Coal (bituminous). Carter County, Ardmore coal mined south of Ardmore, of little importance; Coal County, Lehigh district: Lehigh coal 4-7 feet, mined at Coalgate, Phillips, and Lehigh, good quality; Atoka coal 4 feet, mining limited; Craig County, good quality west of Blue Jacket, west and northwest of Welch, at Centralia and Catale; Latimer County, Wilburton district: Upper Hartshorne coal $4 \frac{1}{4}$ feet, mined; Lower Hartshorne 4 feet, mined in vicinity of Howe; Le Flore County, Howe-Poteau district, contains Hartshorne and McAlester coals; Lower Hartshorne mined and coked in vicinity of Howe, $4 \frac{1}{2}$ feet, Witteville coal around Cavanal Mountains, at Witteville, mined at Sutter, 4 feet; Panama coal mined at Panama; Muskogee County, near Boynton, Muskogee, and elsewhere; mined in considerable quantity on Dog Creek; Okmulgee County, Henryetta coal mined at Henryetta, Schulter, and Morris; Pittsburg County, McAlester district: Hartshorne coal 3-6 feet, mined at Hartshorne and elsewhere, good quality; McAlester coal along southeast side of district, southwest from Savanna, mined at Krebs and McAlester mines, 3-4 $\frac{1}{2}$ feet; Rogers County, mined at Catoosa, Dawson coal mined at Collinsville; Tulsa 
County, Henryetta coal mined at Broken Arrow; Dawson coal outcrops from near Bird Creek to southwest of Beggs, Okmulgee County, mined at Dawson, Mohawk, Tulsa, and Red Fork.

Copper (native). Small nuggets scattered through clay shale in Blaine County, near Winnview; Cimarron County, near Kenton and along valley of Cimarron River; McClain County, vicinity of Byars; Noble County, near Perry.

Galena. Ottawa County, mined with zinc ore at Miami, Peoria, Quapaw, and other districts, 25 mines in operation in 1910. Occurs in Arbuckle Mountain region.

Grahamite. Atoka County, occurs in fissure veins in Stanley shale on branch of Tenmile Creek, west side of Impson Valley; Pushmataha County, in Carboniferous rock in Jackfork Valley 10 miles west of Tuskahoma; Stephens County, in sandstone and shale near Loco.

Granite. Greer County, quarried at Granite; Johnston County, near Mill Creek, Ravia, Tishomingo, Troy, and Wapanucka; Kiowa County, Cold Springs and Roosevelt; Mayes County, reddish granite dike occurs near Spavinaw.

Gypsum. In Permian rocks; Blaine County, mined at Homestead, Watonga, and elsewhere; Caddo County, Cement; Canadian County, Okarche; Grady County, Rush Springs; Jackson County, Eldorado; Kay County, Peckham; Woodward County, Quinlan. Workable be..s of gypsite occur in Blaine, Caddo, Custer, Grady, Harmon, Jackson, Stephens, and Washita counties.

Impsonite (bitumen). Pushmataha County, Moulton mine in Impson Valley and on McGee Creek.

Iimestone. Jackson County, Creta and Olustee; Johnston County, large plant quarrying oolitic limestone at Bromide; Kay County, gray or nearly white, fine grained, quarried at Newkirk, Ponca, and Uncas; Nowata County, Nowata; Osage County, Pawhuska; Ottawa County, Boone limestone quarried to some extent at Wyandotte; Pawnee County, Jennings, and 1 mile west of Pawnee; Tulsa County, Skiatook, Lost City, and near Tulsa; Washington County, Bartlesville; and Dewey.

Limestone (crushed stone). Quarried in Atoka County, at Chockie; Caddo County, Cement; Comanche County, along northeast side Wichita Mountain uplift 30 miles northwest of Fort Sill, also at Richards Spur; Jackson County, Creta and Olustee; Kay County, Newkirk, Ponca, and Uncas; Murray County, Arbuckle Mountain uplift, quarried at Crusher; Nowata County, $2 \frac{1}{2}$ miles north of Lenapah; Osage County, Avant; Pawnee County, I mile east of Pawnee; Pittsburg County, Hartshorne; Tulsa County, Lost City, near Garnett, and Tulsa.

Limestone (lime). Burned in Delaware County, at Grove and at other localities, for local use; Johnston County, at Bromide and Wapanucka.

Magnetite. Comanche County, considerable deposits occur in Wichita Mountains.

Malachite. Arbuckle Mountains in small quantities; Jackson County, in sandstone near Elmer.

Manganese ore. Coal County, has been mined near Lehigh and Hunton; and Johnston County, Mill Creek.

Marble. Sequoyah County, pure white to pink marble is quarried near Marble City.

Marcasite. Ottawa County, occurs with lead and zinc ores at Miami, Peoria, and Quapaw mines.

Natural gas. Producing wells at close of 1912 numbered 870. Most productive areas of northeastern Oklahoma are: Carter County, Ardmore; Kay County, Ponca; Marshall County, Madill; Nowata County, Alluwe, Coodys Bluff, California Creek, and Delaware; Okmulgee County, Baldhill, Morris, Okmulgee; Osage County, Hominy; Pawnee County, Cleveland; Rogers County, Collinsville; Tulsa County, Tulsa; Washington County, Bartlesville, Copan, and Hogshooter 
Creek. Gas occurs also in Comanche County, in small quantity at Lawton; Creek County, Cushing field; Greer County, at Granite; Kiowa County, at Gotebo; Kay County, Blackwell; Muskogee County, Muskogee; Stephens County, Duncan.

Novaculite. Atoka County, exposures near Atoka; Le Flore County, Talihina.

Petroleum. Most productive areas are in northeastern Oklahoma at or near Bartlesville, Copan, Dewey, Glenn Pool, Hamilton, Henryetta, Ramona, Red Fork, Skiatook, Tamaha, and Tulsa. Important producers at Coodys BluffAlluwe field; Carter County, Wheeler; Marshall County, Mahill; Osage County, Hominy; Muskogee County, Muskogee; Pawnee County, Cleveland. Small quantity found in Comanche County, at Lawton; Creek County, near Mounds; Greer County, Granite; Kiowa County, Gotebo; Mayes County, spring near Adair.

Porphyry. Suitable for fine building stone occurs near Cache, Fort Sill, Lugert, Mountain Park, Roosevelt, Snyder, Wichita Mountains; and in east and west Timbered Hills near Davis, Murray County.

Salt. Beckham County, small quantities obtained from springs near Carter; Blaine County, Ferguson and Salt Creek plain in northern part of county; Harmon County, Salton; Woods County, northeastern part.

Sand (glass). Arbuckle Mountains and in southern Oklahoma north of Red River; Cherokee County, occurs near Tahlequah.

Sand and gravel. Found in nearly every county of the State and utilized for local building.

Sandstone. Widely distributed in central and southern parts of the State, in Cleveland, Garvin, Kay, Lincoln, Logan, McClain, Noble, Oklahoma, Osage, Pawnee, Payne, Pontotoc, Pottawatomie, and other counties. Quarried mostly for local use.

Sandstone (bituminous). Carter County, quarried in Ardmore district; Johnston County, prospects 3 miles southeast of Emet; Love County, Love and Washington prospects near Marietta; Murray County, in Buckhorn and Brunswick districts; used for paving.

Smithsonite. Murray County, mined in Arbuckle Mountains near Davis.

Sphalerite (zinc blende). Murray County, mined in the Arbuckle Mountain district; Ottawa County, mined at Miami, Peoria, and Quapaw districts.

Tripoli. Ottawa County, mined near Seneca, Mo.

Volcanic ash. Occurs in beds in Beaver, Ellis, Harper, Woods, and Woodward counties.

Zinc. See Calamine, Smithsonite, and Sphalerite.

Almandite. See Garnet.

\section{OREGON.}

Argentite (silver glance). Baker County, mined in Cable Cove and Rye Valley districts.

Arsenopyrite (arsenical pyrite). Baker County, mined for gold in Elkhorn, Cable Cove, Granite, Sparta, and other districts; Grant County, Susanville district; Josephine County, Braden mine and Maid of the Mist, Grants Pass district, and Silent Friend mine.

Asbestos (chrysotile). Josephine County, reported 10 miles west of Kerby, and at other points not definitely located in the Klamath Mountains and Blue Mountains.

Azurite (blue carbonate of copper). Douglas County, occurs in Ball mine, on Cedar Springs Mountain; Josephine County, oxidized ore Queen of Bronze mine, Waldo district.

Barite. Lane County, occurs in Bohemia district. 
Basalt. Practically every county in the State has basalt or similar rock suitable for road metal. Quarried at or near Astoria, Corvallis, Dallas, Dayton, Eugene, Forest Grove, Hillsboro, Lafayette, Lebanon, Monroe, Newberry, Portland, St. Helen, Salem, and other places.

Borax. Curry County, a calcium borate mineral (priceite) has been mined at Chetco; Harney and Lake counties, deposits of borax of the marsh type have been worked.

Bornite. Baker County, mined in Copper Butte and lower Snake River regions; Josephine County, less important ore of mines near Waldo.

Brown iron ore (limonite). Clackamas County, has been mined at Oswego; and in Columbia County, at Scappoose.

Cement material. Baker County, a large deposit of limestone on Burnt River, 3 miles from Hutchinson, forms a possible source of Portland cement material; Clackamas County, a company building a cement plant at Oswego has bought quarry locations near Roseburg; Douglas County, 5 miles east of Monitor and 4 miles southwest of Dallas, Polk County.

Cerusite (carbonate of lead). Douglas and Lane counties, secondary mineral in Bohemia district, has been mined.

Chalcedony. Jackson County, great quantity of white chalcedony occurs in the vicinity of Eaglepoint.

Chalcocite (copper glance). Baker County, mined in Copper Butte and Lower Snake River regions; Douglas County, occurs in Ball mine near Cedar Springs Mountain.

Chalcopyrite (copper pyrites). Baker County, mined in Cable, Elkhorn, Greenhorn, Sparta, Sumpter, and other districts; Grant County, Susanville district, and Copperopolis claims, Quartzburg district; Jackson County, Corporal G mine; Josephine County, Braden and Opp mines, Grants Pass district, and Queen of Bronze mine, near Waldo; Lane and Douglas counties, Bohemia district, and many other localities.

Chromite (chromic iron ore). Baker County, heavy float at Winterville placers of upper Burnt River and Bonanza districts; Douglas County, Nickel Mountain, near Riddles; Grant County, small mass in serpentine 7 miles south of Prairie, Canyon district.

Chrysocolla (silicate of copper). Josephine County, oxidized ore in Queen of Bronze mine, Waldo district.

Cinnabar. Baker County, occurs in Sumpter district; Crook County, until recently mined at Howard; Douglas County, formerly mined at two places southeast of Oakland; and recently mined at Drew; Grant County, occurs in Granite and Susanville districts; Jackson County, small prospect on Palmer Creek, near Ashland; Lane County, recently mined at Blackbutte.

Clay (brick). Clay for making brick has been dug near almost every important town in the State.

Clay (fire). Lane County, occurs 3 miles west of Eugene; Multnomah County, used at Portland.

Coal (lignite). Baker County, lignite beds occur north of Goose Creek, along Powder River; Clackamas County, near Wilhoit Springs; Clatsop and Tillamook counties, lower Nehalem field; Columbia County, upper Nehalem field; Curry County, Eckley and Shasta Costa fields; Jackson County, Rogue River Valley field, Meford and Ashland prospects; Lincoln County, Yaquina field; Morrow County, Willow Creek prospects. Impure lignite is found at many places in Willamette Valley, and in the Coast Mountains.

Coal (subbituminous). Coos County, Coos Bay field, Newport bed, 6 feet, extensively mined at Newport; Beaver Hill bed, 6 feet, mined at Beaver Hill; coalbearing rocks of Eocene age. 
Cobaltite. Grant County, occurs with chalcopyrite and gold in Quartzburg district, near Prairie City.

Colemanite. Curry County, Chetco.

Copper. See Azurite; Bornite, Chalcocite, Chalcopyrite, Chrysocolla, Cuprite, Malachite, Tenorite, and Tetrahedrite.

Copper (native). Curry County, occurs on Iower Illinois River; Douglas County, occurs in Ball mine, near Cedar Springs Mountain.

Corundum. Josephine County, small ledge found at Grants Pass, little development; not worked at present.

Cuprite (red oxide of copper). Douglas County, occurs in Ball mine, Cedar Springs Mountain; Josephine County, oxidized ore of Queen of Bronze mine, Waldo district.

Galena. Baker County, mined in Cable Cove, Cornucopia, Elkhorn, Greenhorn, Sparta, and Sumpter districts; Grant County, Alamo, Susanville, and Quartzburg districts; and in mining districts in Cascade Mountains.

Garnet. Baker County, handsome garnets resembling rhodolite reported from near Pleasant Valley. No production during recent years. Almandine garnets found in Sulton Creek district south of Baker City.

Garnierite (nickel ore). Douglas County, occurs at Nickel Mountain, near Riddles.

Genthite (nickel ore). Douglas County, occurs at Nickel Mountain, near Riddles.

Gold (lode). Baker County, 6 producing mines at Baker City and Virtue; Bonanza district, 1 mine at Geiser; Cornucopia district, 4 deep mines operating; Cracker Creek district, 6 deep mines at Bourne and Sumpter; Mormon Basin, 4 deep mines near Rye Valley; Clackamas County, Chena Creek district; Douglas

- County, deep mines at Booth, Glendale, and Nugget; Grant County, in Alamo, Canyon, Crane Creek, Granite, Quartzburg, and Susanville districts; Jackson County, deep mines in Applegate, Ashland, Draper, Gold Hill, Jacksonville, and Pleasant Valley districts; Josephine County, 10 deep mines in Althouse, Davidson, Galice, Grave Creek, and Wolf Creek districts; Lane County, 4 deep mines in Blue River and Bohemia districts; Malheur County, 2 deep mines at Rye Valley and Malheur; Marion County, near Detroit, in Santiam district; Wheeler County, 1 small mine in Spanish Gulch district.

Gold (placer). Baker County, small amount sluicing in Baker, Buck Gulch, and Cracker Creek districts; Mormon Basin, Deep Creek, and Rye Valley hydraulics; Bridgeport district, 3 hydraulic, 2 drift, and 2 sluicing mines; also in Sanger, Stice, and Weatherby districts; Coos County, Eden, Myrtle Point, and Randolph districts; Crook County, in black sand at Howard; Curry County, at Chetco, Corbin, Selma, Eckley, Marial, Ophir, and Port Orford; Douglas County, hydraulics at Booth and Glendale; sluicing at.Dillard; Grant County, hydraulic at Austin, Poker Flat district, and 2 miles from Beach Creek Post Office; 4 hydraulics at Canyon City, 1 at Galena; dredge at Granite; hydraulic at Saw Mill Gulch, Quartzburg district; Harney County, 2 small sluicing properties at Harney City; Jackson County, 3 dredges at Gold Hill and Woodville, Foots Creek district; 9 hydraulic mines at Applegate, Draper, Rockpoint, Jacksonville, and Weimer; Josephine. County, 26 hydraulic mines, 2 dredges, 1 drift, and 7 sluicing mines, in following districts: Althouse, Galice, Grave Creek, Josephine, Picket Creek, Williams, Winona, and Wolf Creek; Lincoln County, Yaquina Bay and Toledo, in black sand; Malheur County, Quartz Gulch and Mormon Basin, hydraulic and a few sluicing mines; Multnomah County, Latourelle and Portland, found sparingly in black sand; Wheeler County, 2 hydraulic mines in Spanish Gulch district; placer gold found in many other places in small quantity.

Granite. Quarried in Baker County, at Haines and Pleasant Valley; Jackson County, Medford; Josephine County, Grants Pass; Union County, Elgin and La Grande. 
Gypsum. White and crystalline gypsum occurs on east border of State on ridge between Burnt River and Snake River; Baker County, mined and milled at Gypsum near Huntington; Crook County, deposit near Bend, undeveloped.

Hematite (red iron ore). Douglas and Lane counties, intermingled with sulphides in Bohemia district; mined for gold.

Hematite (specularite). Baker County, occurs in argillite on Burnt River divide near Sumpter.

Hessite. Baker County, occurs in Sumpter district.

Infusorial earth. Klamath County, found near Linkville; Wasco County, was mined at Mosier; occurs in Baker, Lane, Malheur, Union, and Wheeler counties.

Josephinite (nickel ore). Josephine County, occurs in placers of Josephine Creek.

Limestone (flux). Baker County, Lime; Jackson County, near Rock Point on Rogue River.

Limestone (lime). Baker County, burned near Huntington, Durkes, and Lime; Douglas County, Roseburg; Grant County, 4 miles east of Canyon City; Jackson County, on Rogue River near Rock Point, and on Kane Creek, south of Gold Hill; Wallowa County, at Lostine City.

Limonite. See Brown iron ore.

Malachite (green carbonate of copper). Baker County, considerable quantity at Copper Queen mine, Copper Butte district; Douglas County, small quantity in Ball mine; Grant County, Copperopolis claims, Quartzburg district; Josephine County, oxidized ore in Queen of Bronze mine, Waldo district.

Marble. Douglas County, has been quarried 9 miles southeast of Roseburg.

Marcasite. Baker County, Sumpter district; Grant County, in quartz-gold veins in Granite and Quartzburg districts.

Mineral paint. Iron ore for making paint has been dug in Columbia County, at Scappoose; Lane County, near Creswell.

Mirabilite (glauber salt). Lake County, in ponds and lakes.

Monazite. In black sands in Clatsop County, at Astoria, Warrenton, and elsewhere; Coos County, Randolph district; Curry County, Gold Beach; Josephine County, Holland, Sucker Creek, and Placer; Linn County, Foster; Multnomah County, Latourelle; Polk County, Fall City; Umatilla County, Weston; Wallowa County, Wallowa; Wasco County, Hood River; Wheeler County, Antone.

Natron. In Lake County, in lakes and ponds.

Natural gas. Malheur County, occurs in several wells near Vale and Ontario, not commercially developed.

Nickel. See Garnierite, Genthite, and Josephinite.

Niter (saltpeter). Lane County, ledge near Mount June; also in marsh deposits of southeastern Oregon.

Opal. Baker County, abundant in tuff, a few miles below Durkee, has been mined.

Platinum. Principal production from beach sands in Coos County, near Bullards; and Curry County, near Port Orford. Occurs in black sands in Baker County, at Durkee; Coos County, Randolph district; Curry County, Ophir; Douglas County, Drain, Glendale, and Riddles; Josephine County, Galice, Waldo, Greenback, and elsewhere; Linn County, Foster; Union County, La Grande; Wheeler County, Antone.

Pyrargyrite. Baker County, mined in Elkhorn, Sumpter, and Rye Valley districts; Grant County, Granite district.

Pyrite. Found in nearly all mining districts of Baker, Grant, and Union counties; mined for gold, Jackson County, Braden, Opp, and Tin Pan mines, Grants Pass district; Josephine County, Queen of Bronze mine near Waldo, Greenback, Baby, Silent Friend, and Orofino mines; Lane and Douglas counties, has been mined in Bohemia district. Occurs in all districts of the Cascade Muuntains north of Bohemia. 
Pyrolusite. Baker County, occurs in Sumpter district.

Pyrrhotite. Baker County, carries gold in Virtue district; Jackson County, Braden and Jewet mines, Grants Pass district, and Corporal G mine; Josephine County, Queen of Bronze mine near Waldo.

Quicksilver. See Cinnabar.

Salt. Reported abundant in numerous marshes and lakes in Lake County and elsewhere.

Sand and gravel. Dug at following places: Benton County, Corvallis; Klamath County, Klamath Falls; Lane County, Eugene; Lime County, Albany; Marion County, Salem; Multnomah County, Portland and St. Johns.

Sandstone. Has been quarried locally in Benton, Clackamas, Coos, Curry, Douglas, Lane, Lincoln, Polk, Union, Washington, and Yamhill counties. The use of cement has led to the suspension of operations in many places. The most important quarries are at Oakland, Douglas County, and at Pioneer, Lincoln County.

Silver. Baker County, predominant metal produced at Iron Dike (Homestead) district. Occurs in most lode gold districts. The principal producers of lode and placer silver are Baker, Grant, Jackson, Josephine, and Malheur counties. See also Argentite and Pyrargyrite.

Sphalerite (zinc blende). Baker County, Cable Cove, Elkhorn, Greenhorn, Sparta and Sumpter districts; Grant County, Alamo, Quartzburg and Susanville districts; Jackson County, mined for gold in Corporal $\mathrm{G}$ mine; Lane and Douglas counties, occurs in Bohemia district.

Stibnite. Baker County, occurs in Sumpter and Virtue districts; Jackson County, in fractures of greenstone 2 miles north of Watkins; Lane and Douglas counties, in Bohemia district.

Sylvanite. Baker County, occurs in quartz vein at Bryan mine, Cornucopia district.

Tenorite. Josephine County, oxidized ore in Queen of Bronze mine, Waldo district.

Tetrahedrite. Baker County, Cable Cove, Greenhorn, and Virtue districts; Grant County, Susanville district, small quantity in Badger mine.

Tetrahedrite (mercurial, schwatzite). Baker County, occurs in Sumpter district. Zinc. See Sphalerite.

Zircon. Baker County, found in black sands in upper Burnt River and Bonanza placer mines.

\section{PENNGYLVANIA.}

Amethyst. Bedford County, reported at East Bedford; Chester County, Pocopson, Sadsbury, and East Bradford townships; Delaware County, $1 \frac{1}{2}$ miles northeast of Media, at other localities in Upper Providence, Middletown, and Astor townships; Huntingdon County, Birmingham; Philadelphia County, fortysecond ward; occasionally stones suitable for gems.

Anthracite. See Coal.

Azurite (blue carbonate of copper). Berks County, Fritz Island, near Reading, sparingly with copper ores and magnetic iron ore; Lebanon County, Cornwall, with chalcopyrite and malachite in magnetic iron ore; Montgomery County; has been mined at Perkiomen mine, near Audubon (formerly Shannonville), Upper Salford Township, near Sumneytown, Eaton mine, Lower Providence Township.

Barite (heavy spar). Butler County, occurs west of New Hope; in several old mine holes; Chester County, at Phoenixville mines and found in small quantity in old Jug Hollow mine, Schuylkill Township; Franklin County, mined to a small extent near Chambersburg and Waynesboro; Fulton County, formerly mined at Fort Littleton; Montgomery County, at the Perkiomen copper mines. Barite is not mined on a commercial scale in Pennsylvania at present. 
Beryl. Delaware County, Deshong's quarry, Chester; Avondale quarry, near Media, Concord, Linwood; occasionally found.

Bluestone. See Sandstone.

Bromine. Allegheny County, concentrated from brine at Pittsburgh.

Brown iron ore (limonitel. Extensively developed in the Great Valley from Delaware River to the Maryland line. Many scattered ore banks have been worked out in Berks, Cumberland, Dauphin, Franklin, and Lebanon counties; occurs in Chester and Montgomery counties in a narrow belt crossing the Schuylkill at Spring Mill; Bedford, Huntingdon, and Mifflin counties, occurs in Juniata region; Blair County, in Yellow Creek district; Lancaster County, in the Chestnut Hill and other ore banks. Middle Pennsylvania, in Kishacoquillas, Nittany, Morrisons Cove, and Sinking Canoe valleys; Juniata and Perry counties on the affluents of the Juniata; York County, irregular masses scattered through clay near Dillsburg, mined at Heck mine. Western Pennsylvania: Armstrong County, formerly worked in West Franklin Township; also occurs in Beaver, Butler, Clarion, Center, Clearfield, Jefferson, Indiana and Lawrence counties. See also Mineral paint.

Calamine (zinc silicate). Columbia County, Espy; Lancaster County, Lancaster; Lehigh County, Friedensville, Saucon Valley, with blende in limestone; not mined.

Carnotite. Carbon County, on Mount Pisgah, three-fourths of a mile north of Mauch Chunk.

Cement material. Pennsylvania leads all the States in production of Portland cement, output in 1911 being $26,864,679$ barrels. There are 20 or more plants in the Lehigh district and single plants at York, Pittsburgh, Newcastle, and Wampum. Limestone and shale suitable for cement making are abundant throughout the State. Rock is quarried for cement in Berks County, at Evansville and Molltown; Lawrence County, at Newcastle and Wampum; Lehigh County, Allentown, Cementon, Coplay, and Egypt; Northampton County, Bath, Martins Creek, Nazareth, Northampton, Siegfried, and Stockertown. Blast furnace slag and limestone are used at Pittsburgh, Allegheny County, for Portland cement. Clay dug at Mount Holly Springs, Cumberland County, is used for white cement.

Cerusite (lead carbonate). Bradford County, in Carpenter mine, near New Albany; Chester County, in small quantities at Phoenixville lead mines, Schuylkill Township; Lancaster County, Lancaster; Montgomery County, Ecton iron and copper mines, Lower Providence Township.

Chalcocite (copper glance). Chester County, in small quantity at Phoenixville lead mines, Schuylkill Township, French Creek mines, Warwick Township; Lancaster County, Woods mine, Little Britain Township; Montgomery County, Perkiomen copper mines, Lower Providence Township.

Chalcopyrite (copper pyrites). Berks County, formerly mined at Jones's mine, and at Fritz Island mine near Reading; Chester County, Wheatley lead mine, Phoenixville, French Creek iron and copper mines, Warwick Township. Found only in small quantity in Delaware County, Arondale quarries; Lancaster County, Gap nickel mine; Lebanon County, occurs with other copper ores and is mined with magnetite at Cornwall, elsewhere unimportant as an ore; Montgomery County, near Lafayette Hill soapstone quarry; Philadelphia County, in gneiss at Frankford and on Wissahickon Creek.

Chromite (chromic iron ore). Delaware County, occurs in serpentine near Ox Run in Newton Township, near Palmers Mill, Marple Township, and elsewhere in the serpentine. Lancaster County, occurs in serpentine at Woods mine on Octoraro Creek and elsewhere in the "State line" serpentine, Lancaster and Chester counties. 
Clay (brick). Brick clay occurs in most counties of the State and is dug in at least 44 of them. The production of common brick in 1911 was valued at nearly $\$ 5,000,000$.

Clay (fire). Mined, often in connection with coal, in Allegheny, Armstrong, Beaver, Berks, Cambria, Carbon, Clarion, Center, Clearfield, Clinton, Cumberland, Elk, Fayette, Indiana, Jefferson, Juniata, Lackawanna, Lawrence, Lehigh, Luzerne, Lycoming, McKean, Montgomery, Perry, Snyder, Somerset, Union, and Westmoreland counties.

Clay (kaolin). Pits in Berks County, at Blandon and Mertztown; Chester County, at East Nottingham, Kennett, and New Garden; Cumberland County, Mount Holly Springs, Toland; Huntingdon County, Birmingham Township; Franklin County, Concord Township; Montgomery County, Plymouth Township.

Coal (anthracite). Anthracite region covers parts of Carbon, Columbia, Dauphin, Lackawanna, Luzerne, Northumberland, Schuylkill, Sullivan, Susquehanna, Wayne, and Wyoming (not mined) counties. Of these, the most important are Carbon, Lackawanna, Luzerne, Northumberland, and Schuylkill. Total production in 1911 was $80,771,488$ long tons.

Coal (bituminous). Coal-bearing rocks cover practically the whole of Allegheny, Armstrong, Blair, Butler, Beaver, Cambria, Clearfield, Cumberland, Greene, Indiana, Jefferson, Lawrence, Washington, and Westmoreland counties; the greater portions of Clarion, Elk, Fayette, Mercer, and Somerset counties; and parts of Bedford, Blair, Bradford, Cameron, Center, Clinton, Crawford (not mined), Forest (not mined), Fulton (not mined), Huntingdon, Lycoming, McKean (not mined), Tioga, and Venango (not mined) counties. Chief pro-

- ducers are Allegheny, Butler, Cambria, Clearfield, Fayette, Indiana, Jefferson, Somerset, Washington, and Westmoreland counties. Total production in 1911 was $144,754,163$ short tons.

Copper minerals. There are no valuable deposits of copper ore in eastern Pennsylvania; localities listed are well-known sources of museum specimens. See also Azurite, Chalcocite, Chalcopyrite, Cuprite, and Malachite.

Copper (native). Formerly mined in Bucks County, near Buckmanville, and Cumberland County, at South Mountain. Also found in small quantity in Adams County, Millerstown; Chester County, French Creek mines, and Phoenixville lead mines; Lebanon County, at Cornwall; Lancaster County, Jones's iron mine; Montgomery County, Perkiomen copper mine.

Corundum. With serpentine belt in Bucks, Chester, Delaware, Lancaster, and Montgomery counties; has been mined northeast of Unionville, Chester County. Not produced at present time in Pennsylvania.

Cuprite (red oxide of copper). Adams County, copper mines near Maryland line; Lebanon County, Cornwall; Montgomery County, sparingly at Perkiomen mine; Northampton County, Chestnut Hill near Easton.

Feldspar (orthoclase, microcline). Chester County, mined at Chatham, Toughkenanon, and Pomeroy; has been mined at Baker Station, Avondale, Embreeville, and Unionville; Delaware County, mined at Brandywine Summit, has been mined at Chester Heights, Glen Mills, and between Chelsea and Boothwyn in Middletown.

Feldspar (albite). Chester County, mined in town of West Nottingham, Pa., near Sylmar Station, Md.

Flagstone. See Sandstone.

Fluorspar. Chester County, Wheatley mine, Schuylkill Township; Columbia County, Newlin; Franklin County, Lancaster Station; Lebanon County, Cornwall; Monroe County, Delaware Water Gap; Philadelphia County, Frankford and Falls of Schuylkill. 
Galena. Blair County, Sinking Valley, accompanying zinc ores; Bucks County, New Britain; Chester County, Phoenixville lead mines; Lancaster County, Pequea mine, argentiferous; Schuylkill County, near Pottsville; Montgomery County, Perkiomen mines.

Ganister. Extends through mountain region of central Pennsylvania; mined for silica brick in Bedford County, at Pattonsville; Blair County, McKee Gap and Point View; Huntingdon County, Water Street Gap.

Garnet. Delaware County, formerly mined 1 mile southwest of Chelsea, abrasive. Found in small crystals in the Wissahickon mica gneiss of Chester, Delaware, and Montgomery counties along the serpentine contact.

Gold. Chester County, Phoenixville lead mines, in copper pyrites. Montgomery County, Franconia and Douglas townships, sparingly in quartz and pyrite.

Granite (including gneiss). Berks County, quarried at Seisholtzville; Bucks County, Rist Hill and Trevose; Chester County, St. Peters, West Chester, and West Grove; Delaware County, Cardington, Chester, Morton, Clifton Heights, Leiperville, and elsewhere; Montgomery County, Haverford, Ogontz, Spring Mill, and Wynnewood; Philadelphia County, Upper Dartz, Holmesburg, Philadelphia, Chestnut Hill, Overbrook, and Olney.

Graphite. Berks County, has been mined at Boyertown and at Mertztown; Chester County, mined at Byers (Uwchland Post Office) Coventryville and Chester Springs; has been mined at Anselma, Charlestown, and Kimberton.

Greenockite. Lehigh County, found at Friedensville.

Halite. See Salt.

Hematite (fossil iron ore, dyestone ore). In the Clinton formation, from Bloomburg, Columbia County, and Danville, Montour County, traceable through Center, Fulton, Juniata, Mifflin, Northumberland, Perry, Snyder, Union, and Huntingdon counties of middle Pennsylvania, and thence through Bedford County to the State line on the south. Fossil ores were also mined in the north, in Bradford, Lycoming, and Tioga counties.

Hematite (specular iron ore). Armstrong County, was formerly mined along outcrop for many miles in vicinity of Kittanning; Bucks County, occurs near Durham; Chester County, with magnetite at Warwick; Franklin County, micaceous Clinton ore in Catholic Valley, southeast ridge of South Mountain, near Chambersburg; Lebanon County, mined with magnetite at Cornwall; York County, near Hanover, at Dillsburg and Wellsville, the Codorus region.

Kaolin. See Clay.

Lead. See Cerusite, Galena, and Wulfenite.

Limestone. Extensively quarried over a large part of the State, for building stone, crushed stone, and flux.

Limonite. See Brown iron ore.

Magnetite. Berks County, formerly mined at Boyertown, Fritz Island, near Jacksonwald, near Joanna Station, near Reading and Wheatfield; Chester County, formerly mined at Falls of French Creek, and at Warwick; Dauphin County, formerly mined at Hummelstown; Lebanon County, mined at Cornwall, and formerly mined near Mount Pleasant; York County, mined at Dillsburg.

Malachite. Adams County, in copper mines near Maryland line; Berks County, Jones's mine near Morgantown and Fritz mine near Reading; Bradford County, formerly mined with other copper ores at Carpenter mines near New Albany; Chester County, found in small quantity, at the French Creek and Phoenixville mines; Lebanon County, Cornwall mines; Montgomery County, Perkiomen mine; Perry County, Millerstown.

Manganese ore. In Berks, Blair, Center, Huntingdon, and Northampton counties; Cumberland County at Mount Holly Springs; Dauphin County at several $29123^{\circ}-$ Bull. 585-14-11 
places on Broad Mountain; Lehigh County, in small quantities in iron-ore deposits at Ironton; has been mined to slight extent in connection with iron ores.

Marble. Chester County, quarried at Avondale, Bakers Station, and Westgrove; Montgomery County, at King of Prussia and other localities.

Melaconite. Bradford County, formerly mined with other copper ores at Carpenter mine, near New Albany; Chester County, found in small quantity at Phoenixville lead mines; Montgomery County, Perkiomen mines.

Millerite (capillary pyrites, nickel sulphide). Lancaster County, small quantity in Gap nickel mine, with copper-bearing pyrrhotite, copper pyrites, etc.

Millstones. Lancaster County, East Earl and Lincoln.

Mineral paint. Berks County, mined at Blandon, Fleetwood, Hancock, Reading, and Topton; Cambria County, at Johnstown; Carbon County, belt 7 miles southeast of Mauch Chunk extends in southwest direction 20 miles, mined at Hazard and Millport; Lawrence County, Pulaski; Lehigh County, mined at Breinigsville and Alburtis; Luzerne County, has been mined at Moosehead, 5 miles north of Whitehaven; Northampton County, has been mined at Camels Hump, $3 \frac{1}{2}$ miles northeast of Bethlehem, and near Easton. See also Shale.

Moonstone. Chester and Delaware counties, found in severa? localities.

Natural gas. Chiefly from Elk, Greene, McKean, Warren, and Washington counties, and to a less extent from Armstrong, Beaver, Butler, Fayette, Indiana, Lawrence, Venango, and Westmoreland counties. More than 10,000 producing wells at close of 1911.

Ocher. See Mineral paint.

Petroleum. Produced in Allegheny, Armstrong, Beaver, Bradford, Butler, Clarion, Crawford, Elk, Fayctte, Forest, Greene, Lawrence, McKean, Mercer, Tioga, Venango, Warren, and Washington counties. There were 52,545 producing wells at the close of 1911.

Pyrite. Lancaster County, has been mined at Gap mine, nickeliferous; Lebanon County, Cornwall, cupriferous and cobaltiferous; York County, with magnetite in James's iron mine, Dillsburg. The only commercial output of pyrite reported during the last few years is the small quantity obtained in connection with the mining of bituminous coal in Mercer County.

Pyrolusite (black oxide of manganese). Montgomery County, Edge Hill, and near Spring Mill; Lehigh County, commonly associated with limonite, especially in Saucona Township.

Pyrrhotite (magnetic pyrites). Berks County, in Alsace Township, near Reading; Lancaster County, at Gap mine, nickeliferous; in small quantities at several other localities.

Quartz. Adams County, mined at Bendersville; Chester County, mined at Cornog Station and on North Valley Hills, for pottery and abrasives; Monroe County, quartz suitable for gems found at Stroudsburg.

Salt (brine). Allegheny County, produced in Pittsburgh; Armstrong County, has been made at Bayard salt works, Long Run; Beaver County, New Brighton, Bellowsville, and Industry; Bradford County, oil district; Fayette County, on Youghiogheny River; and Indiana County, at Saltsburg. Bromine and calcium chloride are also obtained from the natural brine.

Sand (building). Local deposits utilized in majority of the counties.

Sand (glass). Dug in Clearfield County, at Falls Creek; Elk County, Daguscahonda; Fayette County, at Dunbar, and along Monongahela River near Belle Vernon; Huntingdon County, Mapleton; Mifflin County, Vineyard; Venango County, Kennerdell and Rockmere Station near Oil City.

Sand (molding). Dug in Allegheny County; at Pittsburgh; Beaver County, Koppel; Berks County, Berne and Hamburg; Blair County, Hollidaysburg; Bucks 
County, Tullytown; Butler County, Cabot; Carbon County, Ashfield and Bowmanstown; Clearfield County, Falls Creek; Columbia County, Catawissa, Miffinville, and Rupert; Dauphin County, Harrisburg; Elk County, Ridgway; Erie County, Erie and Fairview; Fayette County, Dunbar, West Masontown, Perryopolis, and Republic; Franklin County, Waynesboro; Huntingdon County, Mapleton Depot and Mill Creek; Lancaster County, Marietta, Beartown, and elsewhere; Lawrence County, Moravia and Newcastle; Lehigh County, Cementon; Lycoming County, Linden and Nisbet; Mercer County, Carlton; Mifflin County, Burnham and Lewistown; Montgomery County, Edge Hill and William Penn; Northampton County, South Bethlehem and Freemansburg; Northumberland County, Milton and Riverside; Philadelphia County, Philadelphia; Perry County, Newport; Somerset County, Rowena; Sullivan County, Lopez; Venango County, Utica and South Oil City; Westmoreland County, New Stanton; York County, near Weigelstown.

Sandstone. Quarried at various localities in majority of the counties of the State.

Sandstone (bluestone). Chiefly quarried in the northeastern part of the State: Allegheny County, Pittsburgh; Bradford County, Sugar Run, Towanda, and Wyalusing; Fayette County, Upper Middletown, Waltersburg; Luzerne County, Hunlock Creek; Lycoming County, Jersey Mills, Trout Run, and Waterville; McKean County, Port Allegheny; Mercer County, Greenville; Pike County, Lackawaxen, Pond Eddy, Millrift, Kimble, and elsewhere; Potter County, Burtville; Susquehanna County, Dimock, Hallstead, Lanesboro, and elsewhere; Venango County, Franklin; Westmoreland County, Hillside, Ligonier, and Penns Station; Wyoming County, Blackwalnut and Laceyville; York County, Hanover.

Sandstone (brownstone). Quarried in Berks County, at Birdsboro and Mohrsville; Bucks County, Grenoble Station, Lumberville, Neshaminy, Newton, and Yardley; Chester County, Phoenixville and Valley Forge; Dauphin County, Hummelstown; Lebanon County, Mount Gretna and Schaefferstown; Mercer County, near Jackson Center; Montgomery County, Morristown, Port Kennedy, and Fort Washington. Formerly quarried in Dauphin County, at Middletown, and York County, at Goldsboro (Etters).

Sandstone (flagstone). Bradford County, New Era; Monroe County; Pike County, near Delaware River and Lackawaxen Creek, numerous quarries in grits and sandstones in Shohola and Lackawaxen; Schuylkill County, Auburn; Sullivan County, Dushore; and Wyoming County, Nicholson. In northwestern and western counties, flagstone quarried for local use in many places.

Serpentine. Berks County, precious serpentine on Fritz Island, near Reading; Chester County, serpentine occurs in West Nottingham and West Town townships, and precious serpentine at Low's mine, Fulton Township; Delaware County, near Media, in Radnor Township; Northampton County, verdolite, an ornamental stone essentially serpentine, is quarried at Easton. Serpentine occurs but is not worked in Lancaster, Lebanon, Montgomery, and York counties.

Shale. Black shale.-Berks County, mined for pigment at Fritz Station; Clinton County, Rauchtown; Lycoming County, Muncy; Northampton County, Nazareth, formerly mined; Schuylkill County, Pottsville.

Yellow shale.-Berks County, occurs at Shoemakersville; Carbon County, formerly mined at Lehigh Gap and Slatington; Luzerne County, mined for pigment at Moosehead station.

Red shale.-Berks County, mined for pigment at Albany, formerly mined at Lenhartsville; Lawrence County, mined at Pulaski; Luzerne County, at Hudsondale; Tioga County, at East Charlestown; Westmoreland County, mined for pigment at Greenwald; Wyoming County, formerly mined at Factoryville. 
Siderite (iron carbonate). An important ore formerly mined in eastern Pennsylvania with limonite. Now mined only in Carbon County, at Lehigh Gap, for paint. Formerly mined in Bedford, Clearfield, Cambria, Fayette; Fulton, Huntingdon, Mifflin, and Somerset counties; in the Lackawanna Valley and at Scranton; in Lycoming County at Ralston.

Siderite (black band ore). Black band ores also occur throughout the northern coal field, but are not persistent, though occurring at the same horizon; not now mined.

Sienna. Berks County, 1 mile east of Reading.

Slate. Quarried in the following localities: Lehigh County, Slatington; Northampton County, Bangor, Berlinsville, Chapman, Danielsville, Heimbach, and Pen Argyl; York County, Delta and Peach Bottom.

Smithsonite (zinc carbonate). Blair County, Sinking Valley; Lancaster County, Lancaster zinc mines; Lehigh County, Friedensville zinc mines, with calamine and blende. Not worked alone as an ore.

Sphalerite (zinc blende). Blair County, Sinking Valley, with galena and smithsonite; Bucks County, New Britain, with galena; Chester County, Phoenixville mines, with lead ores and in considerable quantity; Columbia County, Espy, in limestone; Lancaster County, Lancaster zinc mines and Pequea mine, with galena; Lehigh County, Friedensville zinc mines, Saucona Valley, with blende and smithsonite in limestone; Montgomery County, Perkiomen and Eaton mines near Audubon. No longer worked.

Talc. Chester County, was formerly obtained in West Goshen Township, near Unionville; Montgomery County, formerly quarried at Gladwyne, and Lafayette Hill; Northampton County, quarried at Easton.

Trap rock (Triassic diabase and pre-Cambrian gabbro). Quarried in Adams County, at Gettysburg; Berks County, Birdsboro; Bucks County, Point Pleasant and Rushland; Dauphin County, Rockville (Fort Hunter); Delaware County, Glen Mills, Locksley, Radnor, and Wayne; Luzerne County, Wapwallopen; Montgomery County, Green Lane, Pottstown, and Sumneytown; Perry County, Marysville.

Umber. Berks County, Bethel; Bucks County, Doylestown; Northampton County, Quaker Hill.

Wad (bog manganese). Berks, Lehigh, Northampton, and other counties with limonite.

Wavellite. Chester County, has been found; Cumberland County, formerly mined in vicinity of Moores Mill, 4 miles west of Mount Holly Springs, and used in the reanufacture of phosphorus.

Wulfenite (molybdate of lead). Chester. County, Wheatley lead mines, Phoenixville; Lancaster County, Pequea mines; Montgomery County, Perkiomen and Eaton mines, near Audubon.

Zinc. See Calamine, Smithsonite, and Sphalerite.

\section{RHODE ISLAND.}

Agate. Providence County, occurs with chalcedony and quartz in southern portion of Diamond Hill, town of Cumberland.

Anthracite. See Coal.

Brown iron ore (limonite, brown hematite). Providence County, was mined at Cranston during Revolutionary times.

Brown iron ore (bog iron ore). 'Providence' County, occurs 3 miles west of Foster Center, near State line.

Chalcopyrite. Providence County, was prospected extensively probably over 100 years ago near Sneech Pond, town of Cumberland. 
Clay (brick). Bristol County, dug at Barrington and Nyatt; Providence County, old clay pits at Pawtuxet, town of Cranston, and west of Diamond Hill, town of Cumberland.

Clay (pottery). Newport County, reported on Block Island and at Newport Neck.

Coal (anthracite). Newport County, has been mined intermittently for a century at Portsmouth; three beds 1 to 3 feet thick, high percentage of ash, made impure by pyrite and quartz veinlets; hard to ignite, holds fire poorly; adapted for smelting but not successful steaming or domestic fuel. Has been mined also at Bristol, at Portsmouth Station on western side of northern part of Aquidneck Island, Cranston, and Pawtucket. Attempts have been made to briquet coal produced at Portsmouth in recent years. Was once mined at Cranston for graphite where most of this coal is graphitic.

Dolomite. Providence County, this "hard jointer" limerock was quarried from several small occurrences and burnt for lime in towns of Lincoln, Johnston, North Providence, and Providence.

Flagstone. Sandstone suitable for flagging has been quarred at Pawtucket.

Galena. Washington County, was once mined at Tower Hill, in Kingston, for molding dust for iron founders; 30 tons taken.

Granite. Newport County, has been quarried at Newport; Providence County, has been quarried at Ashton, near Providence, and Pascoag; Washington County, large quarries at Bradford and Westerly, for building and ornamental stone and paving blocks.

Graphite. Newport County, 200 tons mined about 4 miles south of Tiverton as basis for paint; Providence County, largest mine at Fenner Ledge, Cranston, near Providence, has produced several thousand tons; has been mined at Bridgeton, Pawtucket, and Valley Falls; several hundred feet of underground workings at latter place now full of water; Washington County, has been mined at Saunderstown.

Hematite. Providence County, occurs at Diamond Hill and Cranston.

Limestone. Providence County, is quarried and burned for lime at Limerock, town of Lincoln, and formerly near Centerdale.

Limonite. See Brown iron ore.

Magnetite. Providence County, occurs with copper ore in veins in ancient mine at Sneech Pond and in Iron Mine Hill, $2 \frac{1}{2}$ miles east of Woonsocket, as a prominent constituent of the gabbroid rock; beach sands on south shores.

Manganese ore. Providence County, resembles knebelite; occurs in bed 40 feet thick, near Sneech Pond, town of Cumberland.

Molybdenite. Providence County, occurs in manganese ore near Sneech Pond, town of Cumberland.

Peat. In fresh and salt swamps in many parts of State, including Block Island, where it was much used for fuel.

Quartz. Providence County, constitutes southern portion of Diamond Hill, town of Cumberland. Mainly milky quartz, but banded frequently; used for road material and for concreting.

Rhodonite. Providence County, occurs at Pawtucket and Sneech Pond.

Road metal. Glacial bowlders of quartzite conglomerate, quartzite, green schist, diorite, are most commonly hauled to crusher, or quarried direct from conglomerate occurrences. Scattered trap dikes from 1 foot to 10 feet wide along east slope of hills west of Smithfield station (not used), Snake Den, Woonsocket, north of Moosup Valley, Iron Mine Hill, Ironstone Reservoir. See also Quartz.

Sand and gravel. Large quantities utilized in concrete work in cities; abundant throughout State.

Sandstone. For building (dimension stone), several quarries near Providence. 
Serpentine. Newport County, occurs at Newport; Providence County, occurs at Smithfield, Johnston, and North Providence.

Talc. Providence County, quarried and ground at Manville.

Wad (bog manganese). Providence County, occurs at Sneech Pond, town of Cumberland.

Whetstones. Providence County, have been made in large quantities from mica slate at Smithfield and Woonsocket, and from quartz-mica schist in Smithfield.

\section{SOUTH CAROLINA.}

Amethyst. Fine crystals occur in Abbeville County, near Lowndesville; Anderson County, near Moffettsville.

Asbestos. Narrow veins occur in Anderson County, 8 miles southwest of Anderson; Cherokee, Newberry, and Pickens counties; Oconee County, near Seneca; Spartanburg County, near Spartanburg, not worked.

Aquamarine. Anderson County. See also Beryl.

Beryl. Anderson County, occasional clear crystals from McConnel place, 2 miles west of Anderson; occurs at numerous points along the Anderson-Spartanburg zone; cut for gems.

Barite. Cherokee County, mined at Kings Creek.

Cassiterite (tin ore). Cherokee County, occurs in pegmatite veins near Gaffney; Chesterfield County, Brewer mine. Many attempts have been made to mine the deposits of Cherokee County and neighboring counties in North Carolina.

Cement material (Portland). Many beds of marble in the western part of the State seem to be suitable for cement, but fuel, local market, and cheap transportation are lacking. Soft limestones, so-called "marls," abundant in Coastal Plain, might make satisfactory cement material.

Chalcopyrite (copper pyrites). Was formerly mined in Abbeville County, near Calhoun Falls; Saluda County, in Culbreath mine, 6 miles northeast of Saluda Courthouse; York County, Big Wilson mine near Yorkville, and Mary mine 4 miles northeast of Yorkville.

Clay (brick). Widely distributed. Dug in Abbeville County, at Abbeville; Aiken County, Hamburg and North Augusta; Anderson County, on Oconee side of Eighteen Mile Creek, near Pendleton; Beaufort County, Hardesville; Cherokee County, Gaffney; Chester County, Leeds; Chesterfield County, Cheraw and Chesterfield; Darlington County, Society Hill; Dorchester County, Badham and Summerville; Florence County, Florence; Greenville County, Greenville, Woods Crossing, and Greer; Greenwood County, Greenwood and Wareville; Horry County, Conway; Kershaw County, Camden; Lancaster County, Van Wyck; Laurens County, Laurens; Lee County, Bishopville; Lexington County, Casey; Marion County, Dillon and Mullins; Newberry County, near Newberry; Oconee County, Richland and near Westminster; Orangeburg County, Orangeburg; Pickens County, Pickens; Richland County, 1 mile west and 4 miles north of Columbia; Saluda County, Saluda; Spartanburg County, Cedar Spring and Spartanburg; Sumter County, Sumter; Williamsburg County, Greelyville and Kingstree; York County, Grallay station, Rock Hill, and Yorkville.

Clay (fire). Dug in Richland County, at Killian and near Columbia.

Clay (pottery and paper sizing). Common in Upper Cretaceous deposits; Aiken County, mined near Bath, Beach Island, Graniteville, and Langley; also in Kershaw, Lexington, and Richland counties. White Potomac clay dug in Aiken County, at Aiken and near Bath; Richland County, at Columbia.

Coal. See Lignite.

Cobalt. Aiken County, cobalt-bearing manganese exposed in placer bed at base of alluvial deposit at Silber Bluff, Savannah River. 
Copper. See Chalcopyrite, Covellite, and Enargite.

Corundum. Occurs more or less abundantly in Archean gneisses and later rocks in Anderson, Cherokee, Laurens, Oconee, Spartanburg, and York counties; Cherokee County, prospected 2 miles north of Gaston Shoals; York County, found in belt 200-300 feet wide in northeastern part of county, between Allison and Crowder creeks, mined 1 mile north of summit of Nannies Mountain.

Corundum. Cherokee County, valuable "oriental emerald" reported in Bowen River region, in Archean gneiss.

Corundum (sapphire). Cherokee County, some gem sapphires have been found in the Bowen River region.

Covellite. Chesterfield County, occurs in Brewer gold mine as a secondary mineral.

Enargite. Chesterfield County, small crystals occur in Brewer mine.

Feldspar. Abbeville County, large masses occur in pegmatites, near Iva; Anderson County, near Easley; Greenville County, in mica mine $8 \frac{1}{2}$ miles southeast of Greenville; Oconee County, near Central and Walhalla; Pickens County, highgrade feldspar, near Pickens.

Fuller's earth. The lower Eocene deposits consist largely of this material which is exposed along their marginal line extending across portions of Aiken, Calhoun, Clarendon, Lexington, Sumter, and Williamsburg counties. Mined near Salters, Williamsburg County.

Galena (argentiferous). Was formery mined in Cherokee County, at Cameron mine; and Oconee County, 15 miles north of Walhalla.

Gold (lode). Small production maintained or intermittent from numerous quartz mines in Abbeville, Anderson, Cherokee, Chesterfield, Edgefield, Greenville, Kershaw, Lancaster, Laurens, Newberry, Oconee, Saluda, Union, and York counties.

Gold (placer). Considerable placer gold has been obtained from mines in Cherokee, Chesterfield, Greenville, Pickens, York, and other counties, but is now of little economic importance.

Granite. Quarried: Chesterfield County, 9 miles west of Ruby; Edgefield County, Edgefield; Fairfield County, at Rockton and near Alston; Greenville County, near Greenville; Greenwood County, Ware Shoals and near Greenwood; Lancaster County, near Heath Springs; Laurens County, near High Point and at Gray Court; Lexington County, Casey, Lexington, and near Batesburg; Newberry County, near Newberry; Pickens County, Beverly Station; Richland County, Columbia. Was formerly quarried at various localities in Anderson, Kershaw, Oconee, Union, and York counties.

Graphite (plumbago). Occasional occurrences of graphite in slates of Anderson, Cherokee, Oconee, and other counties. One deposit worked to slight extent.

Hematite (specular iron ore). Occurs in highly metamorphosed Archean and later 10cks. Deposits have been worked to small extent but are not of immediate importance.

Ilmenite. Abbeville County, occurs near Calhoun Falls, and in gold-quartz veins. Infusorial earth. Williamsburg County, dug at Salters Depot.

Lignite (brown coal). Chesterfield County, Whortleberry Branch, north of Cheraw, and near Mount Croghan; Edgefield County, Savannah River; and in Pickens County.

Limestone (building and lime). Occurs at many points in State, especially in western part. Cherokee County, quarried regularly at Limestone Springs, near Gaffney, chiefly for lime, but in part for building stone; has. been quarried intermittently near Blacksburg and Grover; Greenwood County, has been quarried near Ware Shoals; Oconee County, 10 miles northwest of Fort Madison, and 4-9 miles northwest of Walhalla. 
Magnetite (magnetic iron ore). Occurs associated with hematite in metamorphosed Archean and later rocks. Of possible economic importance. Found also in gold-quartz veins.

Manganese ore. Deposits of economic importance occur in Abbeville County, near McCormick; Greenwood County, 2 miles west of Breezewood and 5 miles south of Greenwood. The McCormick deposit is nodular concretions of psilomelane and pyrolusite.

Marble. Laurens County, quarried for local use 4 miles east of Ware Shoals; Union County, small quantity quarried 12 miles southwest. of Union. Occurs also in Cherokee and Oconee counties.

Marl. Dug for local use in Aiken, Bamburg, Barnwell, Berkeley, Charleston, Clarendon; Colleton, Darlington, Dorchester, Florence, Georgetown, Hampton, Horry, Marlboro, Orangeburg, Sumter, and Williamsburg counties. Extensively quarried at Ingleside, Dorchester County, and calcined for the agricultural trade.

Mica (muscovite). Anderson County, occurs near Anderson, Barnes, Denver, and Iva; was formerly mined near Anderson; Greenville County, mined at Reedy River, also $8 \frac{1}{2}$ miles southeast of Greenville; Oconee County, occurs near Seneca.

Molybdenite. Lancaster County, occurs in Haile mine.

Monazite. Deposits of commercial value in Anderson, Cherokee, Greenville, Laurens, Oconee, Pickens, and Spartanburg counties. Mined near Gaffney, Cherokee County, and south of Greenville, Greenville County.

Nickel. Saluda County, occurs associated with chalcopyrite and gold at Culbreath mine.

Peat. Horry County, exposed at Myrtle Beach; Laurens County, exposed on Sharpe property, 3 miles northeast of Ware Shoals. Extensive beds along estuarine region of Combahee and Edisto rivers, and elsewhere. Not used.

Phosphate rock. Mined with dredges in Coosaw River tributaries; also mined extensively in the Ashley and Edisto River basins. Occurs in Wando and Cooper River basins; and at Johns Island, Charleston County.

Platinum. Cherokee and Laurens counties, occurs in Cambrian grit.

Polycrase. Greenville County, found 4 miles from Marietta.

Psilomelane (manganese ore). Abbeville County, in mica schists near McCormick; Greenwood County, 2 miles west of Breezewood and 5 miles south of Greenwood; Spartanburg County, 8 miles south of Glenn Springs.

Pyrite (iron pyrites). Mined for gold in Chesterfield County, Brewer mine; Lancaster County, at Haile and Blackburn mines; Spartanburg County, Thompson mine; Union County, West mine; York County, Big Wilson, Ferguson, Magnolia, and other mines.

Pyrolusite (oxide of manganese). Abbeville County, in mica schists near McCormick; Cherokee County, Smith Mountain; Edgefield County, Hard Labor Creek; Greenwood County, near Breezewood and 5 miles south of Greenwood.

Pyromorphite (phosphate of lead). Cherokee County, was found in Cameron mine, 3 miles southwest of Gaffney.

Pyrrhotite. York County, was mined on Nannies Mountain, 11 miles northeast of Yorkville, and is found at several gold mines.

Rutile. Occurs chiefly in Archean gneisses; Newberry County, crystal masses from vicinity of Prosperity.

Sand (building). Dug in Barnwell County at Blackville; Richland County, Columbia. The largest source of supply utilized is found in bed of Pon Pon River above Jehosse Island.

Sand (glass). Dug in Barnwell County at Blackville and Ulmers; Clarendon County, at Pee Dee area. 
Sand (molding). Dug in Charleston County, at Charleston; and Richland County, Columbia.

Siderite (spathic iron ore). Cherokee County, found at Cameron mine, 3 miles southwest of Gaffney.

Silver. Lancaster County, very small annual production, mostly from siliceous gold ores of Blackmon and Haile mines.

Soapstone. Formerly quarried to limited extent in Cherokee County, near Gaffney; Chester County, near Halsellville and Chester; Laurens County, near Laurens; Oconee County, Fair View Church, 6 miles northeast of Seneca, and Soapstone Hill, 4 miles northwest of Tomassee; Pickens County, near Central; Spartanburg County, Cedar Springs; Yórk County, at Nation Ford.

Tin. See Cassiterite.

Wad (bog manganese). Chester County, occurs in northeastern part of county; York County, 4 miles southeast of Catawba Junction; extensive exposure.

\section{SOUTH DAKOTA.}

Amblygonite. Pennington County, has been mined for lithium on the Peerless and other claims 1 mile south of Keystone, on the Tin Queen claim, $1 \frac{1}{2}$ miles east of Oreville; occurs in large masses in pegmatite.

Arsenopyrite. Custer County, of frequent occurrence, nearly always auriferous; Lawrence County, mined for gold at Lead, Central City, and Terraville. Large quantities go to waste in tailings from Homestake and other mines.

Autunite. Occurs in pegmatites of Black Hills, near Keystone.

Azurite. Occurs in copper prospects in Black Hills.

Beryl. Large crystals and masses occur in Custer County, in pegmatites with tin and mica; Pennington County, in pegmatites near Keystone.

Bornite (purple copper ore). Occurs in copper prospects in Black Hills.

Brown iron ore. See Limonite.

Cassiterite (tin ore). Lawrence County, has been mined in pegmatite at Tinton, and stream tin was mined and shipped from Bear Gulch and other streams near Nigger Hill; Pennington County, has been mined in pegmatites and quartz veins at Hill City and Keystone.

Cement material. Niobrara chalk in eastern and southeastern part of State furnishes excellent Portland cement material; used at Yankton, Yankton County.

Cerargyrite (horn silver). Lawrence County, in Cambrian quartzites and shales, mined at Carbonate and in Trojan and other mines near Portland (Trojan post office).

Cerusite (carbonate of lead). Lawrence County, in Paleozoic rocks at Carbonate; abundant at Galena; has been mined.

Chalcocite (copper glance). Custer, Lawrence, and Pennington counties, occurs in copper prospects in Black Hills.

Chalcopyrite. Lawrence County, occurs in Lead, Terraville, and Central City gold mines, prospects near Nemo and Deadwood; Pennington County, auriferous on Box Elder Creek, prospects near Sheridan and Rochford.

Cinnabar. Pennington County, reported on Victoria Creek a few miles above Rapid City, also was prospected near Pactola and Rochford.

Clay (brick). Loess abundant in extreme southeastern part of State; excellent brick material. Brick clay dug in Brown County, near Aberdeen; Clay County, Vermilion; Grant County, Bigstone; Hughes County, Pierre; Kingsbury County, De Smet; Lawrence County, Deadwood, Spearfish, Englewood, and Lead; Meade County, Sturgis; Pennington County, Hill City and near Rapid City.

Clay (fire). Pennington County, dug near Rapid City.

Clay (kaolin). Custer County, occurs near Custer, in close proximity to marble. 
Coal (bituminous). Fall River County, thin beds exposed in Coal Canyon and Bennett Canyon, north of Edgemont. Not of workable character.

Coal (lignite). Lignite beds having a thickness up to 10 feet underlie portions of the northern half of Harding and Perkins counties. Harding County, mined especially near Buffalo and Karinen in Cave Hills; Perkins County, in Slim Buttes, and at Strool.

Columbite. Custer County, has been mined near Laughing Water Creek north of Custer; Lawrence County, Tinton area, and abundant in gold placers in Nigger Hill district; Pennington County, in pegmatites near Hill City, Oreville, Keystone, and in gold placers in Black Hills.

Copper. See Azurite, Bornite, Chalcocite, Chalcopyrite, Cuprite, Enargite, and Malachite.

Cuprite (red oxide of copper). Custer, Lawrence, and Pennington counties, occurs in copper prospects in Black Hills.

Enargite. Occurs in copper prospects in Black Hills.

Ferberite. See Wolframite.

Fluorspar. Lawrence County, occurs in mines near Portland (Trojan post office), and in considerable quantity in Ulster mine.

Fuller's earth. Custer County, deposits have been worked near Fairburn. Common in the badland beds of Mellette, Pennington, Stanley, Washabaugh, and Washington counties.

Gabbro (black granite). Minnehaha County, quarried near Sioux Falls, takes high polish, and many excellent tombstones and pillars are made.

Galena. Custer County, occurs at Spokane, gold and silver bearing; Lawrence County, small quantity mined in Galena, Perry, and Carbonate districts; Pennington County, in limestone on Box Elder Creek, gold bearing, also in quartz veins near Hayward and Silver City.

Gold (lode). Custer County, free in quartz in Algonkian rocks in Chilkoot mining district near Custer; Lawrence County, mined at Lead, Central City, and Terraville, formerly mined in limestone near Ragged Top Mountain; Homestake mines at Lead produce three-fourths of the gold output of the State; Pennington County, mined in Holy Terror, Keystone, and other mines.

Gold (placer). Dredge at or near Rapid City and near Custer. Custer County, former workings in bed of French Creek, Custer; Lawrence County, Deadwood, Whitewood, Gold Run, and elsewhere in Deadwood district and in Nigger Hill district; Pennington County, Rockerville, Hill City, and Keystone.

Granite. Custer and Pennington counties, immense quantities exposed in Black Hills; Grant County, quarried extensively in Bigstone City.

Graphite. Custer, Lawrence, and Pennington counties, occurs with cassiterite in Black Hills; Custer County, small quantity ground and shipped from Custer; Pennington County, amorphous graphite on .Castle Creek and near Hill City, prospecting near Rochford.

Grindstone. Fall River County, excellent grindstones and burrstones quarried from Dakota sandstone near Edgemont.

Gypsum. Plaster mills in Fall River County, at Hot Springs; Lawrence County, Spearfish; Pennington County, Rapid City. Extensive deposits in Butte, Custer, Fall River, Lawrence, Meade, and Pennington counties.

Hematite (red iron ore). Custer County, occurs at Iron Mountain; Pennington County, mine 4 miles south of Keystone, contains gold and silver; abundant on Box Elder Creek, and in slates and quartzites near Rapid City, occurs at Iron Mountain.

Hubnerite. See Wolframite.

Infusorial earth. Custer County, extends from high slopes of hills west of Fairburn and Hermosa, east into bad lands; has been mined at Argyle and Fairburn. 
Jamesonite. Pennington County, occurs in lead-silver ores near Silver City and Rochford.

Jasper. Minnehaha County, a thick deposit susceptible of high polish; worked to a large extent, especially at Sioux Falls and Dell Rapids;.shipped to Omaha, St. Paul, Chicago, and other cities for buildings, pavements, and ornamento. Outcrops locally also in Hanson, McCook, and Turner counties.

Lead. See Cerusite and Galena.

Lepidolite (lithium mica). Pennington County, occurs in many pegmatite dikes near Keystone.

Lignite. See Coal.

Limestone (building, crushed stone). Quarried in Custer County, near Argyle, for railroad ballast; Lawrence County, at Spearfish; Meade County, Sturgis.

Limestone (chalkstone). Bonhomme County, has been used locally for building in Scotland and Springfield; Davison County, Mitchell; Minnehaha County, Brandon.

Iimestone (lime, flux). Excellent lime made from purple limestone in Black Hills region; quarried at Deadwood, Lawrence County, and near Rapid City, Pennington County.

Limonite (brown hematite). Occurs with gold-quartz veins in Black Hills, with other iron ores in Iron Mountain on Pennington-Custer county line; carries gold and silver.

Lithographic stone. Custer County, fine-grained limestone occurs 10 miles west of Custer, also in vicinity of Loring, not used.

Malachite (green carbonate of copper). Custer, Lawrence, and Pennington counties, occurs in copper prospects of Black Hills.

Manganese. See Pyrolusite.

Marble. Custer County, extensive deposit occurs in Algonkian schist 4 miles northeast of Custer, was formerly quarried; in Lawrence and Fall River counties; Pennington County, in schist at Box Elder.

Mica (muscovite). Custer County, mined at several places near Custer; Pennington County, formerly mined near Keystone.

Natural gas. Considerable quantities are found in boring artesian wells in Hand County, at Miller; Hughes County, at Pierre, used locally. Small quantity in artesian wells in Lyman County; Spink County, at Ashton; Stanley and Sully counties; Turner County, at Dolton; Walworth County, at Selby.

Ocher (mineral paint). Occurs with iron ores on Iron Mountain on PenningtonCuster county line, 4 miles south of Keystone.

Peat. Tripp County, reported at head of Cottonwood Creek.

Pumice. Occurs at Argyle, Custer County, and in Washington County.

Pyrite. Lawrence. County, principal gold-bearing mineral of Black Hills; mined at Lead, Central City, and Terraville; also used as flux in smelting siliceous ores. Large deposits carrying very small quantities of gold, silver, and copper occur on Whitewood Creek near Deadwood.

Pyrolusite. Custer County, disseminated in sandstone at Argyle, has been mined and shipped; Pennington County, occurs also in Algonkian rocks.

Pyrrhotite (magnetic iron pyrites). Lawrence County, in gold-quartz veins at Lead, Central City, and Terraville; contains gold; mined with pyrite for use as flux.

Quartz (rose). Custer County, occurs in Red Rose mine 61 miles south of Custer; Pennington County, many veins on Harney Peak, and in the vicinity.

Quartzite. Minnehaha County, quarried at Sioux Falls and Dell Rapids.

Sand (glass). Meade County, Unkapapa sandstone on Elm Creek suitable for making glass, but not utilized. 
Sand and gravel. Abundant along streams near Black Hills and in eastern part of State. Dug extensively in Beadle County, at Wessington; Brown County, near Aberdeen; Hanson County, near Mitchell; Lincoln County, near Hudson; Minnehaha County, Sioux Falls.

Sandstone. Quarried for local use in Butte County, near Bellefourche; Davison County, on Firesteel and Enemy creeks; Fall River County, near Hot Springs; Harding County, an excellent building sandstone occurs in North Cave Hills; Hutchinson County, 3 miles north of Milltown; Lawrence County, Spearfish; Meade County, near Doyle; Pennington County, near Rapid City.

Scheelite. Lawrence County, occurs with cassiterite and wolframite in Nigger Hill district; Pennington County, in small quantity with cassiterite and wolframite in quartz veins near Hill City.

Silver. Lawrence County, small quantities recovered from gold bullion; argentiferous lead ores at Galena and Carbonate Camp. See also Cerargyrite.

Sphalerite (zinc blende). Lawrence County, occurs with gold-quartz veins in Uncle Sam mine near Perry and with lead-silver ores at Galena.

Spodumene. Custer County, occurs in Tin Mountain claim 5 miles west of Custer; Hand County, in vicinity of Glendale; Pennington County, near Oreville, at the northwest base of Harney Peak, and in the Etta claim $1 \frac{1}{2}$ miles south of Keystone. A considerable quantity has been mined and shipped from the Etta claim for the manufacture of lithium salts. The crystals at this place are immense, attaining 42 feet in length.

Tantalite. Pennington County, in placers near Keystone.

Tetradymite. Custer County, occurs associated with quartz near Custer.

Tin. .See Cassiterite.

Torbernite. Pennington County, found near Keystone.

Tungsten. See Scheelite and Wolframite.

Uranocircite. Pennington County, found near Keystone.

Volcanic ash. Occurs in workable quantities in the upper badland beds in several counties, especially Mellette, Shannon, and Todd.

Wolframite (tungstate of iron and manganese). Lawrence County, in gold ores at Lead and on Yellow Creek, has been mined and shipped; Pennington County, occurs in quartz veins near Hill City and Keystone. In Pennington County part of the mineral is ferberite and part is hübnerite, but the largest part is probably wolframite.

Wood (petrified). Found in Custer, Fall River, Lawrence, Pennington, and other counties.

Zinc. See Sphalerite.

\section{TENNESSEE.}

Alum. Abundant in caverns (rock houses) in Cannon, Coffee, Dekalb, Franklin, Giles, Jackson, Lincoln, Overton, and Putnam counties; Sevier County, Alum Cave.

Asbestos. Johnson County, in small quantity.

Azurite. Polk County, Ducktown copper mines.

Barite. Cocke County, has been mined at Del Rio; Davidson County, gangue of lead mine near Haysborough; Green County, 12 miles from Greeneville in veins in dolomite. Monroe County, mined at Sweetwater; Smith County, has been mined near Trousdale, Ferry-Lebanon Road; has been mined also in Bradley, Jefferson, Loudon, McMinn, and Washington counties.

Bauxite. Carter County, mined at Elizabethton; Hamilton County, mined at Missionary Ridge, near Chattanooga, and used chiefly in the manufacture of aluminum salts and compounds.

Bitumen (asphalt). Hickman County, Perrys, on fork of Blue Buck Creek, in seams in limestone. 
Brown iron ore. Limonite.-Occurs in Benton, Decatur, Dickson, Hardin, Hickman, Houston, Humphreys, Lawrence, Lewis, Montgomery, Perry, Stewart, and Wayne counties; mines at Allens Creek, Ferro, Iron City, Pinkney, Riverside, and West Point.

Brown hematite.-Eastern iron ore region across State from Virginia to Georgia, in Blount, Carter, Cocke, Greene, Johnson, Monroe, Polk, Sevier, Sullivan, and Washington counties. The ores occur in matrix of clay, sand, chert, and débris of disintegrated rocks, mostly in Knox dolomite. Blount and Monroe counties, almost inaccessible; Carter County, Dove River Cove banks; Cocke County, Whitehall, Pecks Mountain, and elsewhere; Greene County, several banks of manganiferous ore near Unaka Furnace; Johnson County, Crockett's, Sharp's, and other banks, south foot of Holston Mountain, Laurel Creek Valley and Butler Furnace banks; McMinn County, Tellico Plains, several deposits; Polk County, in gossan at Ducktown copper mines; Sevier County; Sullivan County, at Crockett bank and other places in eastern part of county; Washington County, deposits in Bompass Cove and Greasy Cove.

Calamine. Claiborne County, overlying Knox dolomite near Tazewell; Hancock County, in many places, with Smithsonite. Jefferson County, associated with smithsonite and blende in Knox dolomite at Mossy Creek; Union County, near New Prospect, and at Stiner's zinc mine; Powell River, with smithsonite in irregular veins in Knox dolomite; occurs at other localities in Bradley, Cocke, Jefferson, Knox, Loudon, Monroe, and Moore counties in valley of east Tennessee.

Calcite. Polk County, Ducktown mines; Smith County, Foley mine 8 miles west of Carthage.

Cement (natural). Hardin County, argillaceous limestone mined at Clifton, good grade natural cement; Knox County, calcareous shales used for natural cement.

Cement (Portland). Limestone along east front Cumberland Plateau, in Sequatchie Valley, and on west front of plateau; mined at Richard City, Marion County. Limestone and shale suitable for Portland cement abundant in eastern and middle Tennessee.

Cerusite. Blount, Bradley, McMinn, Union, Washington, and other counties, secondary mineral of lead ore, not mined; occurs as accessory mineral with galena.

Chalcanthite (blue vitriol). Polk County, small quantity in ores of Ducktown district.

Chalcocite (copper glance). Polk County, small quantity in ores of Ducktown district.

Chalcopyrite (copper pyrites). Polk County, in massive pyrrhotite of Ducktown ore bodies, carries gold and silver.

Chert. Abundant in Knox dolomite in the valley of east Tennessee and in Fort Payne formation (Carboniferous) on edge of basin of middle Tennessee; mined for road metal at Centerville, Hickman County, and elsewhere.

Chert (Camden). Benton County, near Camden.

Chert (novaculite). Used for road making all over west Tennessee.

Clay (brick). Mined in Bedford County, at Shelbyville; Blount County, Maryville and Scottsville; Bradley County, Cleveland; Carroll County, McKenzie; Carter County, Elizabethtown; Cheatham County, Ashland City; Coffee County, Tullahoma; Crockett County, Gadsden; Davidson County, Nashville; DeKalb County, near Smithville; Dickson County, small quantity, Dickson; Dyer County, Dyersburg; Franklin County, Winchester; Gibson County, Brownsville, Eaton, Humboldt, Milan, and elsewhere; Giles County, Pulaski; Greene County, Greeneville and Mohawk; in Grundy County; Hamblen County, Morristown; Hamilton County, Chattanooga; Hardeman Cónty, Bolivar and Whiteville; Henderson County, Lexington; Henry County, Paris and Peryear; 
Jefferson County, Jefferson City; Knox County, Byington, Dedie, Edgewood, Knoxville, and elsewhere; Lauderdale County, Gates, Halls, and Ripley; Lawrence County, Lawrenceburg; Lewis County, Hohenwald; Lincoln County Fayetteville; McMinn County, Englewood; Madison County, Gilmore; Macon County, small quantity near Lafayette; Marshall County, Lewisburg; Maury County, Columbia; Monroe County, Sweetwater; Montgomery County, Clarksville; Obion County, Obion, Rives, and Union City; Polk County, Benton; Putnam County, Cookeville; Rhea County, Dayton; Rutherford County, Eagleville and Murfreesboro; Scott County, Robbins; Sevier County, Seviersville; Shelby County, Memphis and New South Memphis; Sullivan County, Bristol; Sumner County, Portland; Tipton County, Covington; in Van Buren County; Warren County, McMinnville; Weakley County, Gleason, Greenfield, and Martin; White County, Sparta; Wilson County, Lebanon.

Clay (fire). Has been mined in Bradley County, at Cleveland; Carroll County, at McKenzie; Hamilton County, St. Elmo; Henry County, Peryear; Houston and Stewart counties; in district between Central Basin and Tennessee River; Knox County, Powell Station; Madison County, Gilmore and Pinson; Putnam County; Rhea County, near Evansville; Roane County, Oliver Springs.

Clay (kaolin). ' Carroll and Carter counties, small quantities; Henry County, Sparta; Stewart County; has been mined at Tennessee kaolin mines.

Clay (pottery). Carroll County, near Hico and Hollow Rock; Fayette County, LaGrange; Hardeman County, Grand Junction; Henry County, Peryear (ball clay) and Henry; James County, Summit; Madison County, Pinson; Rhea County, Graysville.

Clay (stoneware). Cocke County, has been mined at Del Rio; Putnam County, small quantity formerly mined at Silver Point; Weakley County, formerly mined near Gleason.

Coal (bituminous). The State is divided into two districts, the northern and southern, by the Tennessee Central Railway. These are also known as the Jellico and Chattanooga districts. The Jellico coal district is divided into the northeastern and northwestern fields by the Queen \& Crescent Railway. Northeastern field, between Queen \& Crescent Railway and Cumberland Mountain escarpment. Coal is mined at the following places: Anderson County, Briceville, Coal Creek, and Windrock; Campbell County, Anthras, Block, Careyville, Chasca, Cotula, Cupp, Elk Valley, Jellico, Kimberley, Lafollette, Morley, Newcomb, Peabody, Remy, Rich Mountain, Red Ash, Turley, Westbourne, Wynn; Claiborne County, Clairfield, Egan, Fonde, Fork Ridge, Hartranft, Nicholson, and Pruden; Morgan County, Coalfield, Petros, and State mines; Roane County, Oliver Springs and Rockwood; Scott County, Almy, Glenmary, Helenwood, Laxton, and LeMoyne. Northwestern field, north of Tennessee Central and west of Queen \& Crescent Railway, includes parts of Cumberland, Fentress, Morgan, Overton, Pickett, Putnam, and Scott counties. Coal mined at the following places: Cumberland County, mined at Isoline, formerly mined at Fall, Millstone, and Mammys creeks, east side of Crab Orchard Mountain, and attempted at Crab Orchard but abandoned because too badly crushed; Fentress County, Wilder; Overton County, Crawford, Obey City, and old Murdock opening 1 mile south of Cook Place; Scott County, Bear Creek. Southernfield, south of Tennessee Central Railway, includes nearly all of Bledsoe, southern Cumberland, Grundy, Marion, Sequatchie, and Van Buren counties, eastern part of White County, and western Hamilton, Rhea, and Roane counties. Bledsoe County, mined at Atpontley and on Stephen Gap Road, and has been opened at numerous places along west boundary of the county; Cumberland County, coal worked only for local use at small banks; Franklin County, formerly mined at Sewanee, worked out; Grundy 
County, mined at Coalmont, Clouse Hill, and Tracy City; Hamilton County, mined at Montlake, Sales Creek, Soddy, and every few miles on Walden Ridge; Marion County, mined at Orme and Whitwell, large body of coal undeveloped by lack of transportation; Rhea County, mined at Dayton, Grand View, and Graysville; Sequatchie County, mined at Dunlap; Van Buren County, mined at Gillentine, Oleo, Roverton Springs, Spencer, and at many small banks for local use; White County, mined at Bon Air, Eastland, and Ravenscroft.

Cool (lignite). See Lignite.

Cobalt. Hickman County, in wad at numerous points near Centerville.

Copper. See Azurite, Chalcanthite, Chalcocite, Chalcopyrite, Cuprite, Malachite, Melaconite, and Tetrahedrite.

Cuprite. Polk County, small quantity in ores of Ducktown district.

Dolomite. Knox dolomite very abundant in east Tennessee, quarried and dressed for structural work.

Epsomite. At many places with alum and copperas; Sevier County, Alum Cave.

Flagstone. See Limestone and Sandstone.

Fluorspar. Carter County, Watauga Point; Smith County, Foley mine, about 8 miles west of Carthage; Trousdale and Wilson counties, small quantities mined.

Galena (lead ore). Bradley County, 20 miles east of Chattanooga and at Blue Springs 6 miles south of Cleveland, has been mined at latter place; Claiborne County, Straight Creek, 5 miles southwest of New Tazewell, has been mined with zinc; Davidson County, has been mined; Polk County, in minute quantities in ore bodies of Ducktown mines; Washington County, disseminated in grains in rock of Bompass Cove; Williamson County, has been mined near Nolansville; also found in Blount, McMinn, and Union counties.

Gold (placer). Blount County, has been mined in Montvale Springs and back of Chilhowee Mountain; Monroe County, Coker Creek; Polk County.

Gold (lode and placer). Monroe County, Whippoorwill Branch of Tellico River, has been mined.

Gold. By-product from copper ores.

Granite. Max Patch and Cranberry granites in Carter, Cooke, Greene, Johnson, and Unicoi counties; Carter County, Ripshin. Mountain on Doe River.

Graphite. Knox County, with zinc ores, in small quantities; Polk County, associated with copper ores, Ducktown.

Gypsum. In small quantities in many caves; Grays Cave, northern part of Sumner County.

Halite (common salt). Salt has been worked in White County, 3 miles from Sparta; Overton County, at Obey River. Brine has been found in most of borings for petroleum in middle Tennessee, in Anderson, Jackson, Overton, Van Buren, and Warren counties.

Hematite. Occurs in Bledsoe, Bradley, Campbell, Claiborne, Cocke, Grainger, Hamilton, Hancock, Henderson, James, Loudon, Marion, McMinn, Monroe, Rhea, Roane, Sequatchie, and Sullivan counties. Mined in Carter County, Stony Creek Valley; McMinn County, east of Athens.

Iron. See Brown iron ore, Hematite, Magnetite, and Pyrite.

Lead. See Cerusite and Galena.

Lignite. In Eocene deposits of west Tennessee; extensive in Dyer, Johnson, Lauderdale, Obion, Shelby, and Tipton counties.

Iimestone. Quarries: Bradley County, Charleston; Cumberland County, Crab Orchard; Davidson County, Newsom Station, Fuller's Siding, and Nashville; Decatur County, Perryville; Franklin County, Sherwood; Giles County, Aspen Hill; Hamilton County, East Chattanooga and Chickamauga; Houston County, Erin; Jefferson County, Straw Plains; Knox County, Knoxville; Lawrence County, very small quantity quarried at Lawrence; Marion County, Hales 
Bar Dam near Chattanooga; Marshall County, Chapel Hill; Maury County, Columbia; Overton County, Windle; Roane County, Rockwood; Robinson County, Adams; Rutherford County; Eagleville; Sullivan County, Bluff City; Sumner County, near Goodlettsville; White County, Doyle; Wilson County, Lebanon.

Limestone (flagging). Quarried: Knox County, near Knoxville, blue flags; Mprgan County, near Montgomery; Wilson County, Lebanon.

Limestone (flux). Quarried: Carter County, Milligan; Claiborne County, Cumberland Gap; Hickman County, Bon Aqua; James County, Ooltewah; Montgomery County, Clarksville; Rhea County, Dayton; Roane County, Rockwood; Washington County, Embreeville.

Limonite. See Brown iron ore.

Iithographic stone. Clay, Jefferson, McMinn, and Overton counties; Putnam County, at Algood.

Magnetite. Blount County, float found in eastern part of county; Carter County, in older rocks of mountain spurs near Crab Orchard Valley; Cocke and Unicoi counties.

Malachite. Monroe County, Buck Miller mine; Polk County, small quantities in ores of Ducktown district.

Manganese. Bradley County, 9 miles from Cleveland; Cocke County, in vicinity of Newport and Del Rio; Johnson County, Shady Valley; Unicoi County, Unicoi. Small deposits reported from Carter, Greene, and Sevier counties; Hamblen County, near Morristown; and Hickman County, has been mined at Whitefield. See also Psilomelane, Pyrolusite, and Wad.

Marble. Abundant in State; occurs in Blount, Claiborne, Grainger, Hamlen, Hancock, Hawkins, Knox, Loudon, McMinn, Monroe, Roane, Sevier, and Union counties. Quarried in Blount County, near Knoxville, Knox County, Caswell and Concord, and at confluence of French Broad and Holston rivers; Hawkins County, has been quarried at Rogersville; Union County, Luttrell. Marbles are also found in Franklin, Greene, Lincoln, Washington, and other counties.

Marble (onyx). Small quantity found in caves, especially in Anderson and Claiborne counties.

Marl. Greensand associated with Selma chalk in western part of State.

Melaconite (black copper). Polk County, mixed with chalcocite in Ducktown copper mines.

Mineral paint. Oxides and carbonates of iron, lead, and zinc ore are so used; supply from Bradley, Cheatham, and James counties.

Natural gas. Bedford, Cumberland, southwestern Davidson, Dickson, Franklin, Lincoln, Marshall, Maury, Sumner, and White counties; production small.

Niter (saltpeter). In caves in limestone region; large quantities mined during War of 1812 and Civil War.

Novaculite. See Chert.

Onyx maxble. See Marble (onyx).

Peat. Hardin, Henry, and Tipton counties; not used.

Petroleum. Dickson County, in black Chattanooga shale on Jones Creek; Overton County, Netherland, Spring Creek, and Eagle Creek; Putnam County, near Algood; Scott County, near Glenmary; no producing wells since 1908. Fentress and Pickett counties, in Spurrier-Riverton district; also in Clay, Franklin, and other counties.

Phosphate rock. Davidson County, near West Nashville; Decatur County, Parsons; Giles County, Wales; Hickman County, Centreville, Fogg, and Swan Bluff; Lewis County, Big Swan; Maury County, Mount Pleasant, near Columbia, Ewell Station, Kleburne, and elsewhere; Perry County, Lick Creek; 
Putnam County, Boma; Sumner County, Gallatin and Rogana; Williamson County, Brentwood, and near Franklin.

Potash. See Niter.

Psilomelane. Cocko County, Yellow Springs mine, ncar Nowport.

Pyrite. Carter County, in black shale on Stony Creek, 12 miles northeast of Elizabethtown, has been mined; Cheatham, Greene, and Moore counties, large quantities have been found; Polk County, as stringers and particles in ore bodies of Ducktown mines, bearing gold and silver.

Pyrolusite. Has been mined in Carter County, near Elizabethtown; Cocke County, near Newport and Del Rio; Johnson County, in iron and manganese ores at Shady Valley; Monroe County, irregular masses with iron ores near Sweetwater; Unicoi County, ncar Unicoi in limestone.

Pyrrhotite. Polk County, principal sulphide of Ducktown district, bears gold and silver.

Salt. See Halite.

Sand (building). Dug in Carter County, at Elizabethtown and Watauga; Davidson County, Mackie; Fayette County, LaGrange; Franklin County; Estell Springs; Hamilton County, Chattanooga and St. Elmo; Hardeman County, Saulsbury; Knox County, Knoxville; Lincoln County, near Fayetteville; Loudon County, Lenoir City; Roane County, Harriman and Rockwood; Shelby County, Memphis; Sullivan County, West Bristol.

Sand and gravel. From bottom of Mississippi, Tennessee, and Cumberland rivers, in Benton, Carter, Davidson, Decatur, Hamilton, Johnson, Knox, Rhea, Roane, and Shelby counties.

Sand (glass). Great quantities of sandstone suitable for crushing: Anderson County, Coal Creek; Benton County, saccharoidal sandstone; Blount County, Chilhowee; Hardeman County, Saulsbury; Knox County, Knoxville; Montgomery County; Sullivan County, 20 miles from Bristol.

Sand (molding). Davidson County, near Nashville; Franklin County, Estell Springs; Hamilton. County, Chattanoooga; Hardeman County, Saulsbury; Henry County, Paris; Knox County, Knoxville; Loudon County, Lenoir City; Madison County, 4 miles west of Jackson; Rhea County, Dayton.

Sandstone. Bledsoe County, near Pikesville; Blount County, Chilhowee; Franklin County, Sewanee and side of Lookout Mountain; Hawkins County, Clinch Mountain; White County, along west side of plateau.

Sandstone (flagging stone). Abundant in counties of eastern Highland Rim; Macon County, at Lafayette, sometimes used for buildings; used for foundations in western Tennessee.

Shale. For paving and other brick; has been mined in Anderson County, at Donovan; Roane County, Rockwood. For wood-fiber plaster, in Campbell County, at Jellico Plains.

Siderite (clay ironstone, carbonate of iron). Anderson County, below Wiley coal bed; Grundy County, Beersheba Springs, and other localities; Houston County, Coal Creek and Caryville, Wells Creek Basin.

Silver. By-product with copper and lead ores.

slate. Vast supply of metamorphosed slates in extreme eastern counties; quarries along Little Tennessee River, Knox County; Blount, Cocke, McMinn, Monroe, Polk, and Sevier counties.

Smithsonite (carbonate of zinc, "dry bone"). Claiborne County, overlying Knox dolomite near Tazewell; Hancock County, occurs with calamine, abundant; Jefferson County, Mossy Creek and New Market, mined extensively; Union County, near New Prospect; other localities in valley of east Tennessee.

$29123^{\circ}$-Bull. $585-14-12$ 
Sphalerite (zinc blende). Claiborne County, in Knox dolomite near Tazewell; Jefferson County, mined at New Market; Knox County, mined extensively near Mascot; Smith County, with calcite and fluorspar near Trousdale, FerryLebanon Road; Union County, in Knox dolomite, near New Prospect.

Sulphur. Polk County, obtained from reduction of copper, used for sulphuric acid. See also Pyrite and Pyrrhotite.

Tetrahedrite (gray copper ore). Monroe County, Buck Miller mine; mouth of Coco Creek, on Hiwassee River; argentiferous.

Wad. With manganese ore in Cocke County, near Newport and Del Rio; Johnson County, in Shady Valley; Unicoi County, near Unicoi.

Zinc. See Calamine, Smithsonite, and Sphalerite.

\section{TEXAS.}

Agate. Brewster County, at many localities north and south of Alpine, especially at Agate Hill, on the Terlingua road, 20 miles south of Alpine, and on the Kokernut .ranch, northeast of Alpine; Presidio County, on the Bogel ranch, 12 miles south of Marfa; many beautiful colors, blue, blue-gray, red, and white.

Allanite. Llano County, at Barringer Hill and near Kingsland; some specimens contain much occluded hydrogen.

Alum (native). Brewster County, northwest of the Chisos Mountains; Presidio County, Fresno Canyon, 80 miles south of Marfa.

Amethyst. In Burnet, El Paso, and Llano counties.

Asbestos. El Paso, Gillespie, and Llano counties; has not been found in commercial quantities.

Asphalt. Bituminous sandstones and limestones in the following counties: Anderson, Angelina, Brewster, Burnet, Coke, Cooke, Hardin, Hunt, Jack, Jasper, Martin, Montague, Nacogdoches, Panola, Pecos, San Augustine, Stephens, Travis, Uvalde. The bituminous limestone from Uvalde County has been used for paving in San Antonio, and also as a source of lithocarbon (a bitumen extracted from the rock with naphtha); the bituminous sandstone from Montague County also has been used for paving. The principal source of asphalt in Texas now is the residuum from the distillation of crude petroleum.

Barite. Llano County; also reported from Burkeville, Newton County.

Borax. Small quantity as incrustations in old shallow lakes in western Texas, El Paso County.

Brown iron ore (brown hematite, limonite). There are many localities in eastern and northeastern Texas which afford an excellent limonite for blast-furnace use. The principal counties are: Anderson, Cass, Cherokee, Gregg, Henderson, Marion, Morris, Nacogdoches, Panola, Rusk, Shelby, Smith, Upshur, and Wood. A special iron-ore dock was built at Port Bolivar, Galveston Bay, in 1912, for handling ocean shipments of iron ore and a good deal of active prospecting work is in progress.

Cassiterite. El Paso County, in Franklin Mountains 14-16 miles north of El Paso, where it is worked for tin, in aplite dikes cutting granite; Mason County, reported from Herman and Willow creeks.

Celestite. Burnet County, at Strickling; Lampasas County, 5 miles north of Lampasas, in large crystals filling pockets in Glen Rose limestone; San Saba County; Travis County, on Mount Bonnell, Colorado River, near Austin.

Cement material. Limestones and shales widely distributed over the State. Eagle Ford shale and Austin chalk used near Dallas and San Antonio; Cretaceous limestone and shale used at El Paso.

Chalcocite. Considerable quantities from the Permian in Archer, Foard, Haskell, Jones, Knox, and Stonewall counties, mostly in nodular form in these beds 
and carrying from 50 to 60 per cent of copper. Found also in El Paso and Llano counties.

Chalcopyrite. Burnet County; El Paso County, west side of Quitman Mountains, from which shipments have been made, and Sierra Diablo; also in Culberson and Llano counties. The most promising localities are in the Quitman Mountains and the Sierra Diablo, El Paso County.

Cinnabar. See Quicksilver.

Clay (brick). Many varieties widely diffused over the State. Used chiefly for common brick, sewer pipe, drain pipe, fire brick, also used for making ordinary pottery. The principal counties are: Anderson, Bastrop, Bexar, Bowie, Brewster, Brown, Cameron, Coleman, Collin, Cooke, Dallas, Denton, Ellis, El Paso, Erath, Falls, Fayette, Fort Bend, Gonzales, Grayson, Guadalupe, Hall, Hardin, Harris, Harrison, Henderson, Hidalgo, Hill, Hopkins, Hunt, Jefferson, Johnson, Jones, Lamar, Lee, Leon, Limestone, McLennan, McMullen, Marion, Maverick, Medina, Milam, Montague, Nacogdoches, Navarro, Orange, Panola, Parker, Polk, Potter, Rains, Red River, Robertson, San Augustine, Shelby, Smith, Tarrant, Taylor, Titus, Tom Green, Travis, Upshur, Valverde, Van Zandt, Walker, Washington, Webb, Wharton, Wichita, Williamson, Wilson, Wise, Wood, Young. The clay in Brewster County is used in a yard 130 miles from the railroad for making brick for the quicksilver furnaces in the Terlingua district.

Clay (kaolin). Edwards County, about 6 miles west of the little town of Leakey, a considerable deposit of high-grade kaolin from which excellent china and porcelain wares have been made. Kaolinite has been reported from Nueces County, but very little is known about the locality.

Coal. Bituminous coal is mined in the following counties: Erath, Jack, Palo Pinto, Parker, Wise, and Young in the North Central coal field, and in Maverick and Webb in the Rio Grande coal field. The coals of the North Central field are true Carboniferous coals (Pennsylvanian); the Rio Grande coals have been regarded as late Cretaceous or early Tertiary. Besides the counties enumerated as producing coal at the present time in the North Central field, workable beds also occur in Brown, Coleman, Comanche, Eastland, McCulloch, Montague, and Stephens counties. The total workable coal area is about 8,200 square miles, with an additional area of 5,300 square miles which may contain workable beds. See also Lignite.

Cyrtolite. Llano County, occurs sparingly in pegmatite at Baringer Hill, mined with other yttrium minerals.

Eglestonite. Brewster County, occurs sparingly, with other quicksilver minerals, in the Terlingua district.

Fergusonite. Llano County, occurs sparingly at Baringer Hill.

Fluorspar. Brewster County, sparingly, in association with quicksilver deposits; Burnet County, Spring Creek drainage basin; Gillespie County, near Enchanted Rock; Llano County, at Baringer Hill.

Fuller's earth. Extensive deposits of excellent fuller's earth are found in Burleson, Fayette, Smith, and Washington counties, and the deposits in Smith County extend also into Cherokee County; some of the deposits in Fayette County are worked.

Gadolinite. Burnet County, in small quantity, except in one instance; is found in red granite area; Llano County, at Baringer Hill. Used in making the glower in the Nernst electric lamp.

Galena. Brewster County, in the Solitario, excellent material; Burnet County, in calcareous sandstone on Silver Creek; Coleman County, in a conglomerate near Santa Ana; El Paso County, on both sides of the Quitman Mountains, associated with ores of copper and zinc;: Knox County, associated with ores of copper 
and zinc in the Permian; Presidio County, at Shafter, with silver ores in San Antonio Canyon and southwest of the Chinati Mountains, good material.

Gold. Occurs sparingly in Llano County.

Granite. Burnet County, red granite quarried extensively at Granite Mountain $2 \frac{1}{2}$ miles north of Marble Falls and gray granite at localities west of the town of Burnet; El Paso County; Llano County, near Kingsland and Llano; many excellent and beautiful varieties. Opaline granite (granite porphyry) occurs near Llano; it is a most beautiful and attractive stone, but has not been placed on the market.

Graphite. Burnet and Llano counties, prospected to some extent but not mined commercially; in schist at Lone Grove 7 miles east of Llano.

Gypsum. At many localities in the State, especially in the Permian rocks west of the Pennsylvanian area of rocks. Brewster County, curious forms of gypsum, curved and twisted like a ram's horn, occur in association with quicksilver deposits in the Terlingua district; Hardeman County, mined at Acme and Quanah; much Keenes plaster is made from the gypsite beds; Jones County, mined at Hamlin; Stonewall County, extensive deposits of good alabaster are reported from the northeastern corner of the county at Kiowa Peak in beds up to 4 feet thick; Nolan County, rose gypsum occurs near Sweetwater in beautiful forms and colors. The eastern border of the Permian area contains extensive beds of gypsum, and gypsum has been found in deep borings along the Gulf of Mexico.

Hematite. Llano and Mason counties, associated with the magnetite ores. See Magnetite.

Imenite. Llano County, at Baringer Hill and east of Cold Creek; Mason County, at Fly Gap and north of Pontotoc.

Jasper. Brewster and Presidio counties, occurs with agate, chalcedony; Jeff Davis County, near Fort Davis; Llano County, on Pennington and Sandy creeks; Uvalde County, near Montell.

Kleinite. Brewster County, occurs very sparingly in association with rare quicksilver minerals, montroydite, eglestonite, terlinguaite, in the Terlingua district.

Iignite. The lignite area in Texas is probably about 60,000 square miles. The lignite deposits are, for the most part, confined to the Tertiary and they occur on the Gulf slope, from the Red River to the Rio Grande, in an area 650 miles in length and 200 miles in width. In thickness the beds run to 15 feet and more. The counties in which workable beds of lignite occur are the following: Anderson, Angelina, Atascosa, Bastrop, Bowie, Brewster, Caldwell, Camp, Cass, Cherokee, Dimmit, Fayette, Freestone, Grimes, Harrison, Henderson, Hopkins, Houston, Jasper, Lee, Leon, Limestone, McMullen, Marion, Medina, Milam, Morris, Nacogdoches, Newton, Panola, Rains, Robertson, Rusk, Sabine, San Augustine, Shelby, Smith, Titus, Upshur, Van Zandt, Webb, Wood, and Zavala. The lignite producing counties are: Bastrop, Fayette, Henderson, Hopkins, Houston, Lee, Leon, Medina, Milam, Rains, Robertson, Van Zandt, and Wood. During the last few years there has been a marked increase in the use of lignite for making producer gas. The total engine horsepower thus generated is about 13,000 , one establishment alone having 4,400 horsepower obtained from lignite gas. There are no establishments in the State making briquets from lignite, but the matter is now under serious consideration. Some of the Texas lignites make a good briquet without a binder.

Limestone and lime. Limestones in great variety of texture and composition occur in many localities. The principal quarries are in the following counties: Bell, Bexar, Bosque, Brown, Coleman, Collin, Comal, Comanche, Coryell, Dallas, El Paso, Erath, Grayson, Guadalupe, Jack, Jones, Kaufman, Lampasas, McCulloch, Nolan, Palo Pinto, Runnels, San Saba, Smith, Tarrant, Travis, 
Williamson. These localities also afford lime, but the chief lime-producing counties are Bexar, Comal, El Paso, San.Saba, Williamson. The pure white limestones of Bexar and Williamson counties are much used for building and have the advantage of being easily sawed into shape by hand.

Limonite. See Brown iron ore.

Mackintoshite. Llano County, occurs sparingly at Baringer Hill, in association with other rare minerals, such as yttrialite, nivenite, fergusonite, gadolinite.

Magnetite. Llano and Mason counties, the iron ores are principally magnetite with some hematite. Some of these ores are of good quality but a commercial quantity has yet to be proved. The principal localities are Iron Mountain, the Boder tract, and the Olive mine, Llano County, and places between Iron Mountain and Llano River. At the old Olive mine there is a shaft $\mathbf{3 0 0}$ feet deep and some shipments were made many years ago to the Birmingham district, Ala., and to the State Furnace, Rusk, Cherokee County. High-grade magnetite is to be seen on the surface at Iron Mountain and some work has been done in prospecting the underground ore.

Marble. El Paso County, at Marble Canyon in the Eagle Mountains; Brewster County, south of the Southern Pacific Railroad and about 14 miles from Alpine, beds of white, faint bluish-white, black, and black and white marble of superior quality; this deposit has been prospected to some extent. Llano County, some work has been done on several ledges near the town of Llano, and recent reports indicate the existence of workable beds in other parts of this county. San Saba County, near the town of San Saba, some development work has been done on ledges of pale gray and reddish marble. In association with the gray and reddish marble of San Saba County there occurs a beautiful silver black and golden onyx; polished slabs of this material have been prepared. No commercial marble is now produced in Texas.

Mica. El Paso County, north of Dahlberg, there is a deposit of mica which has been developed to some extent; Mason County, reported from the eastern part of county.

Montroydite. Brewster County, occurs sparingly in association with other rare quicksilver minerals, eglestonite, terlinguaite, and kleinite, in the Terlingua district.

Natural gas. Clay County, chief supplies from Petrolia (Henrietta) field, from which it is piped to Fort Worth, Dallas, Wichita Falls and many other north Texas cities and towns, through distances of 25 to 125 miles: McMullen County, there is much gas near Crowther; Maverick County, gas has been prospected: Navarro County, gas at Corsicana is used locally; Shackelford County, wells at Moran supply local demand, and this gas will probably be piped to Cisco and Albany; Webb County, wells (Reiser) supply Laredo; Texarkana and Marshall are supplied from Caddo, La. The natural gas in association with petroleum is used locally in many of the oil-producing districts, Spindletop, Sour Lake, Saratoga, Humble, Markham, Goose Creek. An important feature of the natural-gas industry in Texas is its competition with producer gas made from lignite.

Nivenite. Llano County, occurs sparingly with other rare minerals at Barringer Hill. See also Fergusonite, Gadolinite, and Mackintoshite.

Onyx marble. San Saba County, silver, black and golden onyx occurs with gray and red marble.

Petroleum. Widely distributed in Texas, the producing counties being: Clay, Duval, Hardin, Harris, Jefferson, Matagorda, McCulloch, McMullen, Navarro, and Wichita. A producing well between Jefferson and the Louisiana line, may be in Texas in Marion County. Oil is known to exist in many other 
counties but producing wells have not yet been brought in; these counties are Brewster, Brown, Coleman, Gonzales, Reeves, Smith, Walker, Wood. The Coastal Plain oils in the counties of Hardin, Harris, Jefferson, and Matagorda are generally of heavier gravity than the interior oils, such as in Navarro and Wichita counties, although there is also a heavy oil in Navarro County (Powell field). Lubricating oil in small quantities is yielded by some wells in Bexar County, near San Antonio, also in Brown and McCulloch counties. The oil from the later fields (Wichita County) is much lighter than the oil from the Coastal Plain; it probably comes from an entirely different geologic horizon, the Pennsylvanian. The Coastal Plain oils are probably from Tertiary. It is likely that country south, southwest, and west of Wichita County, will be found to be oil bearing in localized anticlines. Texas produced $9,526,474$ barrels of petroleum in 1911.

Polycrase. Llano County, at Baringer Hill, in pegmatite.

Pyrite. 'In a great many localities, but so far as known not in commercial quantities. It is widely distributed in Cretaceous limestones and in claye associated with beds of lignite. An interesting occurrence of this mineral is with cinnabar, in the Terlingua district, Brewster County, where some of it carries a little gold. In the Cretaceous bituminous shales of that district pyrite sometimes forms the greater part of the ore carrying quicksilver, and this is particularly the case with the cinnabar in Maverick Mountain, where the veins are in trachyte and andesite. Llano County, prospected at the eastern base of Riley Mountain; also disseminated in pre-Cambrian schists and quartz in Llano and Burnet counties.

Pyrolusite. Dickens County, some high-grade material has been found, but the locality has not been developed; Mason County, Spiller mine, 15 miles northeast of Mason, not developed.

Quartz. Abundant all over the State. Fayette County, in fine but small crystals; Llano County, at Baringer Hill, a fairly well developed crystal weighing 700 pounds was found. Rose quartz has been used for ornament. See also Agate.

Quicksilver. Brewster County, Terlingua district, in Cretaceous limestones and shales, as cinnabar, terlinguaite, montroydite, eglestonite, kleinite, and native quicksilver. A single cavity in limestone yielded 150. pounds of native quicksilver; has also been observed as a sort of quicksilver sponge in hard limestone. With the exception of terlinguaite, none of the rare quicksilver minerals has been found outside of the limestone area. The bituminous shales have not been found to carry any of these minerals except terlinguaite, nor has any native quicksilver been found in them. The quicksilver localities are from 90 to 130 miles from rail, the Southern Pacific Railroad at Marathon, Alpine, and Marfa being the nearest. The Terlingua district has yielded about 47,000 flasks of quicksilver, valued at about $\$ 2,000,000$, and active operations are still carried on. In Presidio County, immediately west of Brewster County, quicksilver ores have also been found, and some prospecting was carried on for a while; but all of the production of this metal in Texas is to be credited to Brewster County.

Rowlandite. Llano County, occurs sparingly at Baringer Hill with nivenite, fergusonite, yttrialite, and gadolinite.

Salt. Produced from brines in Anderson, Mitchell, and Van Zandt counties. There are old lake beds in Crane, El Paso, and other counties which afford a certain amount of crude salt used for stock. A bed of coarse rock salt at the old Brooks Saline, southwestern part of Smith County, has been used as a source of brine for many years; no operationa there now. At this locality a water has been found which contained 1,275 grains of potassium chloride per gallon-a much 
larger proportion than has been found in any deep well water in the United States. Some of the oil wells in the Coastal Plain have shown the presence of salt deposits, but no salt is obtained in Texas from such localities. During the Civil War and previous thereto a good deal of salt was made at the old Brooks Saline, previously referred to, as also at the Steen Saline, 14 miles north of Tyler, Smith County. From the records of those days it has been ascertained that the Brooks saline water yielded a bushel of salt from 300 gallons, and that the yield from the Steen water was a bushel of salt from 190 gallons of water.

Sand and gravel. The producing counties are Bastrop, Bexar, Bowie, Coleman, Colorado, Dallas, Ellis, El Paso, Erath, Fayette, Galveston, Grayson, Gregg, Harris, Jefferson, McLennan, Milam, Navarro, Tarrant, Travis, Waller, Webb, and Wilson. Coleman County, at Santa Anna, there is a large deposit of pure sand under Cretaceous limestone. Walker County, 8 miles northwest of Huntsville, fine deposit of white quartz sand from disintegration of a ledge of coarse sandstone. The greater part of this deposit is composed of transparent and translucent particles of quartz, the grains varying in size from $\frac{1}{64}$ to $\frac{1}{6}$ inch.

Sand (glass). Grayson County, dug at Denison.

Sand (molding). Dug in Liberty County, at Liberty; Tarrant County, at Fort Worth.

Sandstone. The producing counties are Burleson, Burnet, Fayette, Grimes, Lampasas, Lavaca, Mills, Montague, Palo Pinto, Polk, Tom Green, Tyler, and Ward. Ward County, red sandstone near Barstow, has been used extensively for building. Lampasas County, one of the best undeveloped properties is a gray stone at Chadwicks Mill.

Serpentine. Gillespie County, in the northeastern part there is an excellent cerpentine, affording many varieties of color and texture; polished slabs, spheres, columns, lamp stands, have been prepared from this material, but it is not on the market.

Silver. Brewster County, argentiferous galena has been mined near Altuda. A piece of silver ore from the Chisos Mountains carried 1,100 ounces of silver per ton, but the locality from which it came has not been revealed by the finder. El Paso County, silver-bearing copper ores have been mined in the Sierra Diablo, and values up to 2,000 ounces of silver per ton have been recorded (old Hazel mine); also in galena, associated with ores of copper and zinc in the Quitman Mountains. Presidio County, The Presidio Mining Co. has been mining and milling silver ore for neariy 30 years; the ore carries silver chloride, and with it is associated a galena which carries silver and a little gold. A little native silver has been found at Shafter in thin sheets accompanying silver chloride. In a galena from the San Antonio Canyon, south of the Chinati Mountains, and from near Candelaria.

Smithsonite. El Paso County, near Eagle Flat, shipments have been made; Presidio County, in considerable quantities about 2 miles west of Shafter.

Sphalerite. Burnet County, occurs sparingly with fluorite; El Paso County, east side of the Quitman Mountains with galena and chalcopyrite in old Bonanza mine, has been mined and concentrated; Montague County, small but excellent pieces have been found near St. Jo, in calcite.

Strontianite. Travis County, on Mount Bonnell, Colorado River, near Austin.

Sulphur. From many of the deep borings in the Coastal Plain. Brazoria County, sulphur has been reported and extensive operations have been planned and are in progress (1913) near the mouth of the Brazos River; Culberson County, in the northeastern and eastern part (cut off from El Paso County) there are extensive deposits of native sulphur in gypsum and decomposed limestone; 2 carloads of this sulphur have been melted out of the containing rock by 
means of superheated water, and the quality is excellent. This area has been prospected by means of open cuts, pits, boreholes, and sulphur has been found to a depth of 40 feet; 30 feet of this material carries 25 per cent of sulphur. Pecos County, deep wells 15 miles northeast of Fort Stockton; Smith County, a sand containing 10 per cent of native sulphur was found at a depth of about 200 feet at the old Brooks Saline, southwestern part of county.

Talc. Llano County, an impure variety of talc (soapstone) occurs east of Valley Springs; it has been used locally but has not been marketed to any extent.

Tengerite. Llano County, occurs at Baringer Hill, with nivenite, yttrialite, fergusonite, and gadolinite.

Terlinguaite. Brewster County, with montroydite, eglestonite, kleinite, in the Terlingua quicksilver district. It is the only one of the rare mercury minerals found outside of the limestones.

Thorogummite. Llano County, occurs at Baringer Hill.

Tin. See Cassiterite.

Topaz. Mason County, with cassiterite and blue feldspar near Streeter; some fine crystals have been cut and polished.

Turquoise. El Paso County, a 4 to 6 inch seam near Van Horn, has been mined.

Wolframite. Culberson County, the most promising locality appears to be near the Figure 2 ranch, 32 miles north of Van Horn; prospecting work in progress in 1913; samples of the material have carried as much as 17 per cent of tungstic oxide. El Paso County, occurs with cassiterite 12 to 15 miles north of El Paso.

Yttrialite. Llano County, at Baringer Hill, with nivenite, fergusonite, gadolinite. Zinc. See Smithsonite and Sphalerite.

\section{UTAH.}

Alunite. Piute County, large deposit near Marysvale.

Anglesite. Juab County, occurs in mines of the Tintic district; Summit Ccunty, common in Park City mines.

Antimony. See Stibnite.

Argentite (silver glance). Juab County, some of the mines of the Tintic district; Piute County, occurs in small quantities in Annie Laurie vein.

Asphalt. Salt Lake County, occurs in Rozel Hills, northwestern part of Great Salt Lake; Uinta County, asphalt-saturated sandstone is exposed in Asphalt Ridge a few miles west and south of Vernal; prospected and some mined for use in paving the streets in Vernal. See Gilsonite, Nigrite, Ozokerite, Uintaite, and Wurtzilite.

Autunite. Kane County, 9 miles south of Pahreah.

Azurite (blue carbonate of copper). Occurs in Beaver County; Juab County, in mines of Tintic district; Summit County, in Park City mines.

Barite (heavy spar). Occurs in Juab County, as gangue mineral of Tintic district; Salt Lake County, Bingham and Alta.

Beaverite. Beaver County, Horn Silver mine, near Frisco.

Bentonite. Garfield County on the upper part of Crescent Creek, Henry Mountains.

Beryl. Tooele County, occurs about 35 miles southwest of Simpson Springs, Ibapah Mountain.

Bismuth. Beaver County, occurs sparingly as bismuthinite at Beaver; Boxelder County, near Lucin; Juab County, occurs in Tintic district with silver-lead ores; Salt Lake County, recovered from smelter bullion, Bingham Junction; Tooele County, has been found sparingly as bismuthinite and carbonate in Clifton district, in Deep Creek Mountains.

Bismutite. Generally occurs in the oxidized portions of bismuth deposits. 
Bornite. Salt Lake County, secondary ore mined in Bingham district.

Brown iron ore (limonite). Iron County, occurs near Modena, containing silver, lead, and gold. Extensive deposits in Iron, Juab, Morgan, and Uinta counties; used as flux in lead smelting.

Calciovolborthite. Grand County, mined with carnotite at Richardson.

Carnotite. Emery County, is mined on the east flank of San Rafael Swell, 18 miles west of Greenriver, in Upper Jurassic (P) sandstone; occurs in Temple Rock on the southeast side of the Swell and along San Rafael River; Garfield County, on the east and southwest flanks of the Henry Mountains, particularly on Crescent and Trachyte creeks; Grand County, is mined near Richardson in sandstone, with calciovolborthite and copper minerals, and 22 miles southeast of Thompsons with calcium vanadate; occurs in numerous places in the La Sal Mountains, particularly on Pack Creek, where it is mined; San Juan County, of mineralogic importance only, in White Canyon 8 miles from Hite; many deposits in Dry, Big Indian, and Lisburne Valleys north of Monticello; Uinta County, small deposits in pre-Cambrian quartzite, on Red Creek, Browns Park, with copper minerals; Wayne County, near the north end of the Henry Mountains, of mineralogic importance only.

Cement material. Producing plants in Boxelder County at Bakers Spur, and Morgan County at Devils Slide. Cement rock and limestone from quarry in Parleys Canyon, used for Portland cement at Salt Lake City.

Cerargyrite (horn silver). In the ore of various mines, especially those in Beaver, Juab, Salt Lake, and Summit counties.

Cerusite (lead carbonate). Juab County, important ore of Tintic district; Salt Lake, Summit, Tooele, and Utah counties, abundant in many of the mines.

Chalcocite (copper glance). Salt Lake County, secondary ore at Bingham.

Chalcopyrite (copper pyrites). Beaver County, principal ore in Cactus mine; Juab County, primary ore mineral of Tintic district, gold bearing; Salt Lake County, with pyrite at Bingham, mined for copper, gold, and silver.

Chrysocolla (copper silicate). Juab County, found in abundance in Tintic district. Cinnabar. Tooele County, occurs in ores in Mercur district; was formerly mined.

Clay (brick). Dug in Boxelder County, north of Brigham; Cache County, Logan, and Smithfield; Davis County, Bountiful, Kaysville, and Woods Cross; Emery County, Ferron; Iron County, Cedar City; Salt Lake County, Murray, Salt Lake, and West Jordan; San Juan County, Monticello; Sanpete County, 3 miles south of Manti; Sevier County, Richfield; Summit County, Coalville; Uinta County, Vernal; Utah County, Lehi Junction, Pleasant Grove, and elsewhere; Weber County, Harrisville and Roy.

Clay (fire). Dug in Salt Lake County, near Salt Lake and Fort Douglas; Utah County, Lehi Junction, and Pleasant Grove; Weber County, in small quantity at North Ogden.

Coal (bituminous and subbituminous). Blacktail Mountain field.-Wasatch County, occurs near Blacktail (Tabby) Mountain, in Mesaverde and Mancos formations; thoroughly prospected; very little mining done.

Book Cliffs field.-Includes portions of Carbon, Emery, Grand, and Sevier counties; Mesaverde formation; mined at Sunnyside, coked; Scofield, Castlegate, and Winterquarters, Carbon County.

Colob-Harmony field.-Garfield, Iron, Kane, and Washington counties; from Cedar City, Iron County, to Mount Carmel, Kane County, bituminous; mined neas Kanarra, Cedar City, Coal Creek Canyon; locally called black lignite; coal in Upper Cretaceous deposits.

Emery coal field.-Emery County, occurs in Mancos shale south and east of Emery in Coal Cliffs; prospected and some mined for local use. 
Henry Mountain coal field.-Garfield and Wayne counties, occurs west and northwest of Mount Ellen, Henry Mountains; prospected.

Sanpete County.-Wales mine, Wasatch bed (Eocene); Sterling coal (Upper Cretaceous) mined at Momson mine east of Sterling, bituminous.

Vernal field and Henrys Fork field.-Uinta County, bituminous coal mined in the Upper Cretaceous (Mancos shale) near Vernal.

Weber River or Coalville field.-Summit County, coal in Upper Cretaceous rocks of Benton age; mined at Wasatch and Dexter mines, Coalville, subbituminous.

Copper. See Azurite, Bornite, Chalcocite, Chalcopyrite, Chrysocolla, Covellite, Cuprite, Enargite, Malachite, Tenorite, and Tetrahedrite.

Covellite. Salt Lake County, in Bingham district.

Cosalite. Beaver County, Frisco district.

Cuprite (copper oxide). Juab County, occurs in mines of Tintic district.

Elaterite. See Wurtzilite.

Enargite. Juab County, abundant, original mineral of Tintic district.

Galena. Important ore of many mines in Beaver, Juab, Salt Lake, Summit, Tooele, and Utah counties; mined at Tintic, Bingham, Park City, and elsewhere.

Gilsonite. Uinta County, mined at Dragon and elsewhere. See also Uintaite.

Gold (lode). Predominant ore in Beaver County, Bradshaw and Newton districts; Box Elder County, Park Valley district; Grand County, Miners Basin; Iron County, Gold Springs and Stateline; Juab County, Spring Creek and Tintic; Piute County, Kimberley and Ohio; San Juan County, Blue Mountains; Tooele County, Mercur; Uinta County, Carbonate; Wasatch County, North Fork and Snake Creek.

Gold (placer). Small production from black sands in Garfield County, White Canyon district; Grand County, at Wilson Mesa; Iron County, at Sand Springs; Salt Lake County, in Bingham Canyon; San Juan County, Bluff; Uinta County, Green River.

Granite. Small quantities quarried in Box Elder County, at Willard; Salt Lake County, Draper; Utah County, Alpine City and Provo City; Weber County, Ogden.

Gypsum. Iron County, enormous deposits reported; Emery and Wayne counties, enormous deposits in Jurassic along margin of San Rafael Swell; Juab County, large deposits mined near Nephi and Levan; Millard County, vast deposits at White Mountains; Salt Lake County, in small quantities in fibrous and selenitic form; San Juan County, Monticello; Sevier County, Sigurd. Black gypsum found also in Grand County, between Grand River and La Sal Mountains; Kane County, near Kanab; Sanpete County, near Gunnison; Sevier County, near Richfield; Washington County, in eastern part of county; Wayne County, in South Washington.

Hematite (red iron ore). Iron and Washington counties, immense quantities in Iron Mountain district, has been mined at Iron City; Wasatch County, large deposits at the head of Duchesne River, in the Uinta Range, small quantity mined for flux.

Hübnerite. Tooele County, with scheelite in mines of Clifton district, Deep Creek, associated with copper, gold, silver, lead, and bismuth ores.

Infusorial earth. Beaver County, was formerly mined at Milford.

Iron. See Brown iron ore, Hematite, and Magnetite.

Lead. See Anglesite, Cerusite, Cosalite, and Galena.

Limestone (building). Quarried in Beaver County, at Beaver and Greenville; Carbon County, on Tie Fork of Soldier Creek, 7 miles northwest of Clearcreek; San Juan County, Grayson; Sanpete County, Ephriam; Utah County, Lehi and Provo.

Limestone (crushed stone). Quarried at Ogden and Salt Lake City. 
Iimestone (flux). Used in Salt Lake County, at Salt I Lake City; Tooele County, at Topliff; Weber County, Hot Springs.

Limestone (lime). Burned in Beaver County, at Beaver; Iron County, Cedar City; Salt Lake County, Salt Lake; Sevier County, Richfield; Utah County, near Provo.

Limonite. See Brown iron ore.

Magnetite. Iron and Washington counties, large deposits with hematite in Iron Mountain district.

Malachite (green carbonate of copper). Occurs in Beaver County, Cactus mine; Juab County, in many Tintic mines; Summit County, Park City mines.

Manganese ore. Juab County, Tintic district, chiefly manganiferous silver ores; also near Joy.

Marble. Beaver County, quarried at Beaver City; occurs also in Juab, Salt Lake, Sanpete, Summit, Utah, and several other counties.

Molybdenite. Salt Lake County, occurs in canyon on south side of Little Cottonwood Canyon and elsewhere.

Monazite. Uinta County, occurs in black sands in Green River, Jensen district.

Natural gas. Salt Lake County, small quantity found in valley of Jordan River and in vicinity of Salt Lake City; has been exploited.

Nigrite. Utah County, occurs at Soldier Summit and vicinity; small quantity has been mined.

Niter (saltpeter). Iron County, several small beds near Parowan; Millard County, occurs near Fillmore.

Obsidian. Occurs in regions of Tertiary volcanic rocks; small quantities cut for gem purposes.

Opal. Beaver County, occurs near Milford.

Orpiment (yellow sulphide of arsenic). Garfield County, occurs in irregular seams in shale in Coyote Creek Valley; Tooele County, in good crystals in Mercur district; Salt Lake County, limited quantity in one silver mine in Bingham Canyon.

Ozokerite (mineral wax). Utah County, occurs at Soldier Summit and near Colton; small quantities have been mined.

Petroleum. San Juan County, 9 producing wells in San Juan field at close of 1911; Washington County, 6 producing wells in Virgin field.

Phosphate rock. Morgan County, occurs in Carboniferous limestone in upper canyon Weber River between Morgan and Devils Slide Station, little prospecting; Rich County, in Crawford Mountains near Randolph, mined and shipped, also at other points in Rich County; Salt Lake County, in foothills east of Salt Lake City; Weber County, in limestone in Shepherd Valley, 6 miles southeast of Huntsville; east of Beaver Creek, and near Ogden Canyon.

Platinum. Occurs sparingly in black sands in Garfield County, at Hite; also in Salt Lake County.

Plumbojarosite. Beaver County, Horn Silver, Hub, Moscow, Red Warrior, Harrington-Hickory mines and prospects.

Pyrite. Beaver County, principal ore of Cactus mine, Frisco district; Juab County, original mineral of Tintic district; Salt Lake County, massive and in grains disseminated through monzonite in Bingham district, mined for gold and silver.

Quicksilver. Piute County, mercury ores, onofrite and tiemannite have been mined 5 miles southeast of Marysvale. See also Cinnabar.

Realgar. Garfield County, occurs in irregular seams in shale in Coyote Creek Valley; Salt Lake County, in some mines of the Bingham district. Tooele County, in Mercur district.

Salt (brine). Produced in Juab County, at Nephi City; Millard County, Clear Lake; Salt Lake County, Saltair; Sanpete County, near Gunnison; Sevier County, Redmond; Weber County, Ogden and Whithie Junction. 
Sand and gravel. Dug at Box Elder County, Brigham City and Pigeon; Salt Lake County, Salt Lake City and Sandy; Tooele County, Stockton; Utah County, Point Mountain.

Sandstone. Quarried in Grand County, at Moab; Iron County, Cedar City and near Buck Horn; Salt Lake County, Salt Lake City; Sanpete County, Manti; Summit County, Park City; Utah County, Colton and Thistle.

Scheelite. Tooele County, with hübnerite in mines of Clifton district, Deep Creek Mountains, associated with copper, gold, silver, lead, and bismuth ores.

Scorodite. Tooele County, occurs in Gold Hill mine, Clifton district.

Silver. Yield principally from lead-ore mines in following districts: Beaver County, Beaver Lake, North Star, Washington; Juab County, Fish Springs, West Tintic; Summit County, Park City; Tooele County, Ophir, Rush Valley, Willow Springs; Utah County, American Fork, Silver Lake, Santaquin. Predominant ore in several other districts. Little silver in copper ore of Cactus mine, Beaver County, and in copper at Bingham, Salt Lake County. See also Argentite and Cerargyrite.

Slate. Utah County, occurs 2 miles southeast of Provo.

Sphalerite (zinc blende). Mined with argentiferous lead ores of Summit County, in Park City district, and Salt Lake County, Bingham.

Stibnite (sulphide of antimony). Garfield County, occurs with antimony oxides at Coyote Creek; ore has been shipped.

Sulphur. Beaver County, mined at Sulphurdale; Emery County, occurs along San Rafael River in the San Rafael Swell, and on Cedar Mountain.

Tenorite. Salt Lake County, occurs as secondary ore at Bingham.

Tetrahedrite (gray copper ore). Salt Lake County, secondary ore at Bingham; Summit County, principal copper ore in silver mines at Park City.

Tiemmanite. Piute County, formerly mined near Marysvale.

Topaz. Juab County, occurs at Topaz Mountain, 8 miles northwest of Joy; has been cut for gems.

Travertine (Utah onyx). Deposits in Boxelder, Millard, and Utah counties; has been quarried and used in interior work.

Tufa. Beaver County, quarried near Beaver City.

Uintaite (gilsonite). Uinta County, Uinta Basin in eastern Utah, mined at Fort Duchesne, and in Bonanza and Cowboy claims, near Utah-Colorado line, on White River; many other small veins in Uinta County.

Uranium. Wayne County, uranium sulphate occurs in a fine-grained sandstone with copper carbonates near Fruita. See also Carnotite.

Uranospinite. Kane County, 9 miles south of Pahreah.

Vanadium. Emery County, calcium vanadate has been mined in a small way with carnotite in asphaltic sandstone in Wild Horse Canyon; Grand County, calcium vanadate has been mined with carnotite on claims 8 miles south of Thompson's, and 20 miles south of Cisco. See also Carnotite and Calciovolborthite.

Variscite (amatrice). Boxelder County, mined 5 miles north of Lucin; Tooele County, mined 14 miles south of Tooele, and occurs 2 miles from Mercur; Utah County, occurs in Clay Canyon, $1 \frac{1}{2}$ miles west of Fairfield.

Wood, silicifled. Very abundant on San Rafael Swell and Henry Mountains.

Wulfenite (molybdate of lead). Salt Lake County, occurs in limestone with lead ores in Alta district, small quantity.

Wurtzilite (elaterite). Wasatch County, found in an area embracing about 100 square miles in region of Indian, Lake, Avintequin, and Sams canyons, little northeast of Grey Head Mountain and about 50 miles southwest of Fort Duchesne; 3 or 4 promising veins; mined and shipped from Sams and Avintequin canyons.

Wurtzite. Beaver County, Horn Silver mine, near Frisco. 


\section{VERMONT.}

Arsenopyrite (mispickel). Brookfield, Stockbridge, Vershire, and Waterbury, with pyrite and chalcopyrite; not mined.

Asbestos. Mined in Lamoille County, at Eden; Orleans County, near Chrysotile and Lowell.

Braunite. Bennington, Brandon, Chittenden, and Plymouth, in small quantities; not mined.

Brown iron ore.(brown hematite, limonite). Bennington County, Bennington, formerly dug to some extent; $\cdot$ Rutland County, with manganese ores at Brandon and South Wallingford; Windsor County, Plymouth, was formerly mined in connection with ocher and kaolin.

Cement material. Limestone suitable for Portland cement in many counties; not used.

Chalcopyrite (copper pyrite). Orange County, has been mined at Corinth, in Ely mine at Copperfield, and Elizabeth mine at South Strafford.

Clay (brick). Pits in Caledonia County, at East Ryegate; Chittenden County, Champlain and Essex Junction; Rutland County, Rutland; Washington County, Waterbury; Windham County, Putney; Windsor County, Wilder.

Clay (fire). Rutland County, mined at Rutland.

Clay (kaolin). Addison County, deposit at Monkton, not mined; Bennington County, mined at Shaftsbury; Rutland County, mined at Forestdale.

Feldspar. Orange County, deposits at Corinth and Strafford, not worked; Windham County, deposits at Newfane and Saxtons River, not worked; Windsor County, quarried at Chester, deposit at Norwich not worked.

Flagstone. Windsor County, gneiss at Cavendish; small quarries in slate between Hartford and Rockingham, not working.

Galena. Lamoille County, in small vein in talcose slate at Morristown; Orange County, has been mined in quartz vein in talcose slate at Thetford; Rutland County, small occurrence at Chittenden; Windsor County, found at Bridgewater, Carter, and Plymouth; formerly mined at Carter.

Gold (placer). Windsor County, formerly mined to small extent at Plymouth. 'Found in very swall quantities in many places.

Gold (lode). Formerly mined in small way in Bennington County, at Readsboro; and Windsor County, Bridgewater Center.

Granite. Caledonia County, Groton, Hardwick, Kirby (3 quarries), Newark, and South Ryegate (6 quarries); Essex County, was formerly quarried at Brunswick and Victory; Orange County, Williamstown (3 quarries), formerly quarried at Topsham and Randolph; Washington County, Barre (34 quarries), Calais (3 quarries), Graniteville, Websterville, and Woodbury (12 quarries); Windham County, West Dummerston (3 quarries); Windsor County, Windsor (2 quarries), Rochester, and Bethel (2 quarries).

Graphite. Has been found in Addison County, at Hancock; Chittenden County, Huntington; Franklin County, Swanton; Orange County, Newbury; Rutland County, Brandon and Pittsford; Windham County, Halifax; and Windsor County, Norwich.

Hematite. Chittenden County, Milton near Lake Champlain, formerly worked to slight extent; Windsor County, small deposit at Weathersfield.

Infusorial earth. Caledonia County, Peacham, and many other places; not mined.

Limestone. Quarried for building stone; Grand Isle County, Isle La Motte; quarried chiefly for lime: Addison County, Leicester Junction and New Haven; Chittenden County, Colchester; Franklin County, Highgate, Highgate Springs, St. Albans, and Swanton; Rutland County Brandon; Windsor County, Amsden.

Iimonite. See Brown iron ore. 
Magnetite. Orleans County, Troy, a titaniferous ore in small beds, formerly mined; Windsor County, Bridgeport and at Rochester, sparingly in chlorite slate.

Malachite (green carbonate of copper). Orange County copper mines; not mined. Manganese ore. Reported in Addison County, Bristol and Monkton; Bennington County, from Bennington and Stamford; Chittenden County, Colchester; Orange County, Topsham; Orleans County, Irasburg and Coventry; Rutland County, Chittenden and Pittsford, near South Wallingford and Brandon, in Otter Creek Valley; Windsor County, Plymouth. Nowhere mined. See Psilomelane and Pyrolusite.

Marble. Quarried in Addison County, at Beldens Falls, Middlebury, Monkton, and Vergennes; Bennington County, Dorset and East Dorset; Chittenden County, Burlington; Franklin County, St. Albans and Swanton; Rutland County, Brandon, Danby, Fowler, Pittsford, Proctor, Rutland, and West Rutland; Washington County, Roxbury.

Marl. Caledonia County, deposits at Sutton, not worked. Abounds in most of towns bordering Lake Champlain, also in Orange and Windsor counties.

Mica (muscovite). Rutland County, at North Sherburne; Windsor County, at Chester, has not been mined.

Ocher. Bennington County, formerly mined at Bennington, occurs at North Dorset, not mined; Leicester County, formerly mined at Brandon.

Peat. Numerous localities, Champlain Valley and elsewhere; not utilized.

Psilomelane (black manganese). Rutland County, was formerly mined near South Wallingford and at Brandon.

Pyrite. Orange County, has been mined in Copperas Hill mine at Strafford, large deposit interstratified with mica schist, associated with chalcopyrite; also at Brookfield, Corinth, and Vershire; Rutland County, Cuttingsville.

Pyrolusite (manganese dioxide). Rutland County, was formerly mined near South Wallingford and at Brandon.

Pyrrhotite. Orange County, with copper ores of Ely mine, Copperfield, Elizabeth mine, South Strafford, and Union and Eureka mines.

Sand (building). Dug in Rutland County, Rutland, and at many other localities.

Sand (glass). Bennington County, East Dorset, disintegrated quartz rock once used for glass; Windsor County, Plymouth, associated with kaolin, not mined.

Sand (molding). Dug in Rutland County, Rutland; Windsor County, Springfield.

Sandstone. Quarried for building stone at Burlington, Chittenden County, and elsewhere.

Schist, mica. Formerly quarried at Halifax, Windham County. Abundant in many localities but quarried only as needed locally.

Serpentine (verde antique marble). Washington County, quarried at Roxbury. Deposits in Orleans County, at Troy, and Westfield; Windkam County, Marlboro; Windsor County, Cavendish and Windsor.

Siderite (spathic iron ore). Windsor County, Plymouth, in talcose slate, with magnetite and pyrite; not mined.

Slate. Principal quarries in Rutland County, at Blissville, Brandon, Castleton, Fair Haven, Granville, Hydeville, North Poultney, Pawlet, Poultney, Wells, West Castleton, and West Pawlet; Washington County, Montpelier and Northfield.

Soapstone and talc. Quarried: Addison County, at East Granville; Lamoille County, Johnson; Washington County, Moretown; Windham County, Hammondsville and Windham; Windsor County, Cluster, Perkinsville, Rochester, Stockbridge and Weatherfield. Deposits not utilized: Orleans County, at Lowell; Washington County, Roxbury; Windham County, Newfane; and Windsor County, Bridgewater. 
Sphalerite (zinc blende). Lamoille County, sparingly with galena; Orange County, small quantity mined with copper ores, occurs in lead mine, Thetford; Windsor County, at Norwich, sparingly with galena at Bridgewater, contains cadmium, not mined.

Talc. See Soapstone.

Trap rock. Occurs in dikes; scattered quarries only.

Umber. Rutland County, formerly obtained at Brandon.

Whetstone (scythestone). Orleans County, quartz-mica schist, quarried at Evansville; formerly quarried near Canada line, Lake Memphremagog, Fitchs Island quarry, honestones; Washington County, Northfield, talc schist, scythestones; Windsor County, Ludlow and Stockbridge, scythestones.

\section{VIRGINIA.}

Allanite. Amelia County, masses weighing several pounds in mica mines; Amherst County, iron allanite carrying nearly 17 per cent ceria in mica-free pegmatite with blue quartz, sipylite, and zircon at Massie mine on Little Friar Mountain; Bedford County, allanite with 33 per cent ceria near Thaxton; Page County, iron allanite, Owen prospect, 3 miles southeast of Marksville.

Alum. Small accumulations in caves or sheltered spots have been used.

Amethyst. See Quartz.

Apatite. Amelia County, with mica and beryl in mica mines; Nelson County, with nelsonite and rutile near Roseland.

Arsenic. Floyd County, refined from arsenopyrite mined at Brinton.

Arsenopyrite (arsenical pyrite). Buckingham County, associated with pyrite, in gold veins near Arvonia, Dillwyn, and elsewhere; Carroll County, southern copper lode; Culpeper County, 18 miles west of Fredericksburg, on Rapidan River; Fauquier County, near Morrisville; Floyd County, in mica-quartz schists 4 miles from Lick Fork, mined for arsenic at Brinton; Goochland County, associated with pyrite, in gold veins west of Caledonia and elsewhere; Grayson County, southern copper lode; Orange.County, near Rapidan River and along narrow-gage railroad between Fredericksburg and Orange; Rockbridge County, with cassiterite in quartz veins in Irish Creek area; Spotsylvania County, in northwest corner; Stafford County, in western part.

Asbestos (amphibole). Albemarle County, in thin platy masses in the soapstone at Alberene; Amelia County, has been mined near Appomattox River, 7 miles north of Mattox station; Bedford County, 12 miles south of Bedford City; an asbestos mill was built at Bedford City some years ago; small production reported in 1911; Buckingham County, Anaconda (formerly Eldridges Mill), $5 \frac{1}{2}$ miles northwest of Dillwyn; Fauquier County, Barnets Mill; Floyd County, Bartons and Singers; Franklin County, was mined 2 miles east of Rocky Mount; Grayson County, near northern copper lode; on Little River below Hampton mine; Wythe County, lead and zinc mines, Painters Branch; also in Goochland, Pittsylvania, and Powhatan counties. None produced in 1910.

Azurite (blue carbonate of copper). Madison County, small quantities in prospects near Fishers Gap; Mecklenburg County, fine crystals filling small cavities in quartz and epidote at Pontiac mine, 8 miles north of Virgilina; Page County, mines and prospects southeast of Luray near Ida; Rockingham County, mines and prospects near High Knob southeast of Elkton, small quantities; Warren County, near Bentonville, Front Royal, and Linden; has been mined at Bentonville.

Barite (heavy spar). Bedford County, near Thaxton, between Bedford and Roanoke, was mined and shipped; Campbell County, occurs east of Evington, near Otter River Station, and at Leesville: Louisa County, in schists near 
Mechanicsville, has been mined; Pittsylvania County, occurs at Toshes, near Motleys and Hurt; Prince William County, occurs with red shales 4 miles east of Catlett Station; Russell County, extensive deposits near Honaker and Lebanon, mined and shipped; Smyth County, near Marion, was extensively mined and shipped; Tazewell County, near North Tazewell and Richlands, not used; Washington County, near Glade Spring and Saltville Branch of Norfolk \& Western Railway, in clays; Wythe County, with metallic ores in zinc and iron mines near Ivanhoe and elsewhere in southern part of county.

Bauxite. Botetourt County, at Old Houston iron and manganese mines 2 miles east of Troutville.

Beryl. Amelia County, in mica mines near Amelia; Henry County, in pegmatite near Axton; Rockbridge County, with cassiterite in Irish Creek area.

Bornite (purple copper ore). Amherst County, with actinolite in old Folly mine, 4 miles south of Amherst; Charlotte County, in quartz near Keysville, has been mined; Grayson County, in schist in southwestern part of county, prospects; Greene County, near Elkton; Halifax County, in quartz at Virgilina copper mines; Loudoun County, has been mined near Leesburg; Madison County, one of primary copper minerals near Fishers Gap, prospects; Page County, near Ida, southeast of Luray, one of original copper minerals; Rappahannock County, Manassas Gap copper mine near Front Royal; Rockingham County, disseminated ore in mines and prospects near High Knob southeast of Elkton; Warren County, has been mined near Bentonville.

Brown iron ore. See Mountain brown ore, Oriskany brown ore, Valley brown ore. Calamine (silicate of zinc). Pulaski County, oxidized ore of Delton mines near Delton, has been mined; Russell County, principal ore of prospects on Copper Creek, 10 miles north of Castlewood; Wythe County, secondary ore of lead and zinc mines at Austinville.

Coke (natural). Chesterfield County, Chesterfield (Triassic) coal basin.

Cassiterite (tin ore). Reported in Clarke County, at Capon Springs; Nelson County, at Nellysford; Rockbridge County, in Irish Creek area.

Cement (natural). Rockbridge County, Cambrian limestone used in natural cement at Glasgow and near Balcony Falls; mills also in Botetourt County.

Cement (Portland). Augusta County, limestone and shale ábundant at several places; plant at Fordwich; Clarke County, limestone in vicinity of Wades. ville; Frederick County, limestone near Winchester and Middletown; Giles County, limestone and shale in Copper Creek area and near Lurich; Lee County, limestone and shale abundant near Wallen Ridge and Cumberland Mountain, also at Big Stone Gap and Pennington Gap; Norfolk County, plant at Norfolk using shell marl from Smithville and Chuckatuck; Rockingham County, limestone and shale exposed at several places in vicinity of Harrisonburg; Russell County, along west slope of Clinch Mountain; Scott County, Copper Creek, Clinchport, and Gate City; Shenandoah County, abundant in vicinity of Strasburg and near Woodstock; Smyth County, along western foothills of Walker Mountain; Tazewell County, between Cedar Bluff and Tiptop station, through Clinch River Valley and elsewhere; Warren County, shales and limestone at Riverton and vicinity, extensively quarried; Washington County, near Walker Mountain, Bristol, and Abingdon. Calcareous marls and clays of the Coastal Plain are used for the manufacture of Portland cement at Norfolk. ${ }^{\circ}$

Cerusite (lead carbonate). Wythe County, occurs in residual clays derived from limestone and on galena at Austinville.

Chalcocite (copper glance). Carroll County, copper lodes west and northwest of Hillsville; Charlotte County, in quartz near Keysville, has been mined; Floyd County, Toncray mine, with magnetite and pyrite; Halifax County, in quartz 
at Virgilina copper mines; Smyth County, Mount Airy; Wythe County, near Max Meadows.

Chalcopyrite (copper pyrite). Albemarle County, was mined for gold near Stony Point; Botetourt County, small quantity near Bonsack station; Buckingham County, near Dillwyn, Arvonia, and elsewhere; Carroll County, in Gardner and Goad mines in northeastern part of county; Culpeper County, has been mined for gold 18 miles west of Fredericksburg on Rapidan River; Fairfax County, has been mined near Herndon; Floyd County, large quantity with pyrrhotite near Floyd, has been mined; Franklin County, small quantities with pyrrhotite at Howell mine near Rocky Mount; Goochland County, mined for gold 2 miles west of Caledonia; Grayson County, near Troutdale; Greene County, small quantity near Stanardsville and Elkton; Loudoun County, has been mined at Guilford; Louisa County, has been mined, frequent in small quantities of pyrite in Mineral City mines; Madison County, one of the original copper minerals in prospects near Fishers Gap; Orange County, near Rapidan River and between Fredericksburg and Orange, carries gold; Page County, mines and prospects southeast of Luray near Ida; Patrick County, carrying small quantity of gold along western boundary in the Blue Ridge, in the vicinity of Vesta and elsewhere; Prince William County, mined with pyrite in considerable quantities at Cabin Branch mine near Dumfries, matte produced; Rockingham County, at mines and prospects near High Knob southeast of Elkton; Warren County, near Linden, has been mined.

Chromite (chromic iron ore). Fairfax County, Dranesville, in serpentine near the Potomac.

Chrysocolla. Warren County, has been mined near Front Royal, in epidote rock.

Clay (brick). Clay dug and brick made: Alexandria County, around Alexandria, Arlington, Addison, Riverside; Caroline County, near Milford; Charles City County, Sturgeon Point, Oldfield, about 4 miles south of Sturgeon Point; Chesterfield County, Bermuda Hundred, much clay exposed in this general vicinity, Manchester, Ettricks; Dinwiddie County, near Petersburg; Elizabeth City County, Hampton; Essex County, along Rappahannock River, near Layton, at Occupacia; Greenesville County, around Belfield, adjoining Emporia; Henrico County, Rocketts (suburb of Richmond), Fort Lee; Fulton, near Stagg's mill on Williamsburg road, near Curles Neck, near Cotman post office; King George County, along Rappahannock River near Wilmot; Nansemond County, general vicinity of Suffolk, along Nansemond River; Prince George County, Broadway area along Appomattox River below Petersburg, in bluff along James River near City Point; Princess Anne County, Princess Anne Road near Godfrey Avenue; Spotsylvania County, near Fredericksburg; Warwick County, Morrison. Brick is made from the residual clays at one or more principal towns in most of the Ṕiedmont counties.

Clay (fire). Mined and used in Botetourt County, at Catawba Furnace; in Appomattox, Buckingham, and Cumberland counties; Chesterfield County, at Bon Air; Montgomery County, near Christiansburg; Orange County, Madison Run; Powhatan County, Clayville; Rockbridge County, Buena Vista; Wythe County, under coal seams in southwest angle of State Lick Mountain.

Clay (kaolin). Henry County, mined at Oak Level; reported from Amelia, Amherst, Nelson, and Nottoway counties; Augusta County, Kaolin or Sherando station; from crystalline area of Cumberland and Prince Enward counties; Fauquier County, near Warrenton; Henrico County, at Bon Air, 9 miles from Richmond; Smyth County, near Rye Valley; Wythe County, near Wytheville.

Clay (pottery). Miocene clays suited for pottery occur in Hanover, Henrico, King William, and other counties.

$29123^{\circ}-$ Bull. $585-14-13$ 
Coal (anthracite). Frederick County, small field of semianthracite undeveloped; Montgomery and Pulaski counties, small basin developed.

Coal (bituminous). Produced more than $6 \frac{1}{2}$ million tons in 1911. Field in southwestern part of State includes Buchanan, Dickenson, Lee, Russell, Scott, Tazewell, and Wise counties; coal is of high quality, and there are several thick beds. Buchanan County, large quantity of bituminous coal, undeveloped for lack of railroad; Dickenson County, considerable area, several beds of fine bituminous coal, prospected, not mined for lack of railroad; Lee County, north of Pennington Gap, several mines; Russell County, Dante, Dumps Creek, large mines; Tazewell County, Pocahontas, Big Creek, large mines; Wise County, Toms Creek, Norton, and north of Bigstone Gap, several large mines. Farmville area, including Cumberland, Buckingham, and Prince Edward counties; thin seams. Richmond area, Chesterfield, Goochland, and Henrico counties; Triassic coal, mined at Midlothian and at Winterpock, Chesterfield County; Gayton, Henrico County, bed 4 feet 8 inches, shipped. Pocket coal district between Cumberland and Little Black Mountains north of Pennington Gap, of Pottsville (early Pennsylvanian) age; 12 workable beds; mined from small banks for local supply.

Columbite. Amelia County, with microlite in Amelia mica mines.

Copper (native). In small quantities at many localities along Blue Ridge region; Carroll County, native copper loae near Hillsville; Floyd County, Toncray mine; Greene County, near Stanardsville and Elkton; Halifax County, small quantity in Virgilina copper mines; Madison County, secondary ore at Fishers Gap, prospects; Page County, small quantities in mines and prospects southeast of Luray, near Ida; Rappahannock County, near Front Royal, has been mined; Rockingham County, at mines near High Knob, 7 miles southeast of Elkton; Warren County, near Linden, with cuprite and melaconite.

Copper minerals. See Azurite, Bornite, Chalcocite, Chalcopyrite, Cuprite, Malachite, and Melaconite.

Corundum. Patrick County, near Stuart, in mica schist on knob of Bull Mountain.

Cuprite (red oxide of copper). Greene County, near Stanardsville and Elkton; Halifax County, as alterations of original sulphides in Virgilina copper mines; Madison County, important ore of mines near Fishers Gap; Page County, at mines and prospects southeast of Luray near Ida; Rockingham County, near High Knob, 7 miles southeast of Elkton; Warren County, near Linden and Bentonville.

Diabase. Excellent quality widely distributed through the crystalline area and through several of the middle Valley counties west of the Blue Ridge; quarried in Fauquier County, near Catlett; Loudon County, near Goose Creek 3 miles from Leesburg.

Diamond. Chesterfield County, found at Manchester in 1855.

Diorite. Less abundant than diabase; occurs penetrating crystalline rocks east of Blue Ridge; quarried only near Annandale and Falls Church, Fairfax County.

Dufrenite (iron phosphate). Rockbridge County, South Mountain, 10 miles east of Lexington.

Emery. Pittsylvania County, with magnetite or hematite near Whittles.

Feldspar. Abundant, but few mines; Amelia County, was mined as accessory mineral to mica near Amelia Courthouse, and at Jetersville; Amazon stone variety found in Rutherford mine near Amelia Courthouse. Bedford County, was mined about 1 mile south of Bells on Otter River; Prince Edward County, mined near Prospect.

Fergusonite. Amelia County, in mica mines at Amelia Courthouse.

Flagstone. Buckingham County, slate was quarried on Hunts Creek. 
Fluorspar. Albemarle County, gangue mineral at Faber lead and zinc mine, near Fabers, Nelson County; Rockbridge County, Irish Creek; Russell County, with barite in mines near Gardner and Honaker; Shenandoah County, near Woodstock; Smyth County, with lead and zinc in prospects in Rye Valley.

Fluorspar (chlorophane). Amelia County, in pegmatite at Amelia mica mines.

Gabbro. Limited to crystalline area of Blue Ridge; found in Amherst County, near Lynchburg; and in northwest corner of Floyd County.

Galena. Albemarle County, principal mineral in fluorspar lenses near Faber, argentiferous; Bedford County, disseminated through barite near Thaxton; Bland County, has been mined near Sharon, also in Garden and Flat Top Mountains; Buckingham County, near Arvonia, Dillwyn, and elsewhere, has been mined for gold; with copper ore near New Canton; Culpeper County, 1.8 miles west of Fredericksburg on Rapidan River, has been mined for gold; Fauquier County, near Morrisville 8 miles east of Bealeton, has been mined for gold; Floyd County, on west side Blue Ridge along Brush and Laurel Creeks, mined for gold; Goochland County, mined for gold 2 miles west of Caledonia, and elsewhere; Halifax County, in Virgilina copper district; Louisa County, frequent in small quantities with pyrite near Mineral City; Montgomery County, on west side. Blue Ridge along Brush and Laurel creeks, mined for gold; Orange County, near Rapidan River and along railroad between Fredericksburg and Orange; Prince William County, occasionally in pyrite in Cabin Branch mine near Dumfries; Pulaski County, New River, near mouth of Reed Island Creek, with other lead and zinc minerals, Tract Mountain, and Big Walker Mountain; Russell County, on Copper Creek 7 miles south of Castlewood, has been mined; Smyth County, along south fork of Holston River in Rye valley, has been mined; Spotsylvania County in northwest corner of county, near Rappahannock River, and elsewhere, has been mined for gold; Wythe County, in association with sphalerite in zinc mines at Austinville.

Garnet (spessartite). Amelia County, gem hyacinth found in pegmatite in mica mines near Amelia.

Gneiss. Alexandria and Fairfax counties, extensively quarried along Potomac River; Amherst County, quarries on north side of James River; Bedford County, exposed along Norfolk \& Western Railway at Bellevue; Campbell County, along streams, local use; Fluvanna County, has been quarried at Columbia; Pittsylvania County, has been quarried near Chatham on Cherrystone Creek.

Gold. In an auriferous belt from Potomac River to Halifax County 200 miles long and 15 to 25 miles wide, gold-bearing quartz veins and lenses in crystalline rocks, many mines and prospects opened, principally in Buckingham, Culpeper, Fauquier, Fluvanna, Louisa, Orange, Spotsylvania, and Stafford counties; Culpeper County, several localities in eastern part, also Culpeper gold mine; Fauquier County, has been mined in Franklin, Liberty, and other mines; Fluvanna County, Snead mine; Goochland and Fluvanna counties, Tellurium gold mine; Halifax County, in Virgilina copper district; Louisa Ccunty mines; Orange County, Chicago and Virginia mine; Spotsylvania County, Rappahannock mine, Randolph mine, Whitehall mines, Pocahontas mine at Andrews; Stafford County, Eagle mine.

Gold (placer). Has been mined in Buckingham County, in vicinity of Turpins Creek; Floyd and Montgomery counties, along Brush and Laurel creeks on western side of Blue Ridge; Goochland County, near Lantana; Louisa County, Tinder Flats; Spotsylvania County, along Pigeon Run; Stafford County, western part near Rappahannock River.

Granite. Production valued at more than one-half million dollars in 1910, largely for ballast and concrete. Principal producing areas are Fredericksburg, Petersburg, and Richmond. Quarries in Alexandria County, on bank of 
Potomac River; Bedford County, Clevilas Tunnel; Campbell County, several quarries at Lynchburg; Chesterfield County, near Granite and Manchester; Fairfax County, quarried near Falls Church and Annandale; Goochland County, several quarries at Boscobel, Lee, and Lassiter; Greenville County, Emporia; Henrico County, several large quarries near Richmond; Lunenburg County, was quarried for crushed stone near Kenbridge; Nottoway County, for ballast near Jennings; Page County, near Luray; Prince Edward County, Farmville; Prince William County, Occoquan; Roanoke County, Roanoke; Spotsylvania County, large quarry 3 miles northwest of Fredericksburg. Granite is quarried in small way at other places, and occurs undeveloped and widely distributed in mountain district of Loudoun County, in Blue Ridge area and crystalline area eastward to the "fall line."

Graphite. Albemarle County, between Free Union and Boonsville, near Buck Mountain, blocks weighing several hundred pounds have been obtained; prospected but no production; occurs also at Charlottesville. Occurrences noted also in Amelia, Buckingham, Charlotte, Loudoun, Nelson, Orange, and Powhatan counties.

Gypsum. Mined in Smyth County, at Chatham Hill, North Holston, and Saltville; Washington County, Plasterco.

Halite. See Salt.

Hematite (specular). Occurs in workable quantity along Blue Ridge in Bedford, Botetourt, and Roanoke counties: Bedford County, Ironville and Dewey mines, near Montvale; Botetourt County, Arcadia and Wood mines, about 4 miles southeast of Buchanan; Lemon, Grubb-Specular, and Edith mines, about 3 miles northwest of Blue Ridge Springs; Roanoke County, GriffinSpecular mine 5 miles south of Roanoke.

Hematite (fossil ore). Occurs in workable quantity in Alleghany, Lee, and Wise counties; Alleghany County, has been mined on southeast slope of Horse Mountain, 3 miles southeast of Low Moor, and in bluff northeast of Jackson River at Iron Gate; Lee County, southwest of Pennington Gap along Poor Valley Ridge, includes Pennington, Lavine, Ben Hur, Truro, Noes Siding, Grabill, Boones Path, and Ewing mines; Wise County, south of Big Stone Gap, on Wallen Ridge, and in Powell Valley, fossil ore is mined at Yeary, Irondale, Keystone, and Oreton mines.

Ilmenite. Nelson County, with white apatite in dikelike masses (nelsonite) near Roseland; Roanoke County, with apatite near Roanoke.

Infusorial earth. Has been mined at Wilmont, King George County. An extensive deposit traceable from Herring Bay, Md., on the Chesapeake, to Petersburg, Va.; exposed along numerous streams near Richmond and Petersburg.

Kaolin. Amelia County, derived from decay of feldspar at Pinchback mine, shipped for pottery; Henry County, mined and shipped at Oaklevel; Nelson County, near Roseland; similar occurrences in other counties of the Piedmont province.

Lead. See Cerusite, Galena, and Massicot.

Limestone. Abundant west of the Blue Ridge; quarried in many localities from Frederick County to Wise County; also in Piedmont counties.

Iimestone (building). Quarried in Botetourt County, at Compton Bridge; Loudoun County, Leesburg; Roanoke County, Roanoke; Washington County, Abingdon; Wythe County, small quantity at Wytheville.

Limestone (crushed stone). Quarried: Botetourt County, at Eagle Rock, Indian Rock, and Springwood; Campbell County, Lynchburg; Loudoun County, Leesburg; Roanoke County, Roanoke; Washington County, Abingdon.

Limestone (flux). Quarried: Alleghany County, at Longdale, Low Moor, and Clifton Forge district; Botetourt County, Buchanan, Eagle Rock, and elsewhere; 
Pulaski County, Ardway; Rockbridge County, Bells Valley and Glasgow; Wise County, Big Stone Gap; Wythe County, Ivanhoe.

Limestone (hydraulic). Orange County, has been quarried at Madison Run; Rockbridge County, Balcony Falls on James River (a gray magnesian stone, noted "Balcony Falls cement").

Limestone (lime). Quarried: Augusta County, at Staunton; Botetourt County, Eagle Rock and Indian Rock; Frederick County, Stephen City and Winchester; Giles County, Ripplemead; Loudoun County, Lucketts and Leesburg; Montgomery County, Blacksburg and Christiansburg; Rockbridge County, Glasgow and Lexington; Rockingham County, Linville; Shenandoah County, Oranda and Strasburg; Warren County, Limeton and Riverton.

Limonite. See Mountain brown ore, Valley brown ore, Oriskany brown ore.

Magnetite. Principal deposits in Giles County, near Big Stony Junction; and Washington County, Abington; smaller deposits in Giles County, near Ripplemead; Louisa County, Mineral City; Wythe County, Wytheville; in many of the Piedmont counties, and has been mined in Franklin County, at Rocky Mount; and Pittsylvania County, at Pittsville.

Malachite. Buckingham County, with cupriferous pyrite in copper mine near Anaconda; Charlotte County, has been mined with chalcocite and bornite near Keysville; Halifax County, as alteration of original sulphides in Virgilina copper mines; Madison County, small quantity in Milans Gap prospects; Page County, has been mined southeast of Luray near Ida; Rappahannock County, has been mined near Front Royal; and Warren County, near Linden. Occurs in small quantity in many other places.

Manganese. See Psilomelane, Pyrolusite, and Wad.

Marble. Little or no marble has been produced in several years; quarried formerly to small extent in Rockingham County. Good quality of marble is reported, undeveloped in Albemarle County, west of Scottsville on Buck Island, and on Limestone and Meechum creeks; Botetourt County, about three-fourths mile eoutheast of Buchanan; Campbell County, a few miles from Lynchburg; Culpeper County, on Rapidan River near mouth of Summerduck Run and on Mountain Run; Fauquier County, on Rappahannock River, near Marsh Run; Giles County, near base of Angels Red Mountain and near Chapmans Ferry; Loudoun County, Taylortown and in vicinity of Goose Creek; Montgomery County, considerable quantity of black marble near Blacksburg; Nelson County, near mouth of Tye River; Orange County, between Gordonsville and Orange; Page County, on east side of Massanutten Mountain; Rockbridge County, 5 miles from Lexington; Scott County, near Gate City and in valley portion of county; Shenandoah County, near New Market and Woodstock.

Marble. See Onyx marble.

Marl (calcareous). Widely distributed in nearly all counties of tidewater region; also in many valley counties on west side of Blue Ridge; formerly of limited use as flux. Marl of the Coastal Plain has been used in manufacture of Portland cement.

Marl (greensand). Limited largely to inner margin of Coastal Plain region; exposed along Potomac, Rappahannock, Pamunkey, and James rivers and on interstream areas; used as fertilizer; has been worked at several places, especially on James and Pamunkey rivers; carries a small variable per cent of phosphoric acid; of little value as source of phosphate.

Massicot (lead ocher). Wythe County, Austin mines, in small quantities with galena and other lead ores.

Melaconite (black oxide of copper). Carroll County, in upper portions of copper lodes; also Floyd and Grayson counties; Warren County, has been mined at Iinden. 
Mica (muscovite). Has been prospected or mined: Amelia County, at Amelia and Jetersville; Bedford County, near New London; Goochland County, near Goochland; Hanover County, near Hewlett; Henry County, at Ridgeway; Pittsylvania County, south of Chatham; has been observed in several other counties; principal production from Amelia County.

Microlite. Amelia County, Amelia mica mines, fine brilliant yellow to red gem stone.

Millstone (burrstone). Montgomery County, Prices Fork, 5 miles southwest of Blacksburg, siliceous conglomerate quarried on Brush Mountain.

Monazite. Amelia County, fine specimens with microlite, in mica mines near Amelia; also found as sand in stream gravels.

Moonstone. Amelia County, occurs in mines at Amelia, some fine gems have been cut; Hanover County, found near Hewlett.

Mountain brown ore. Occurs in two belts, one extending along west slope of Blue Ridge from Front Royal, Warren County, to 10 miles south of Roanoke, Roanoke County; the other belt extends along the east side of the New RiverCripple Creek district, Pulaski County, and along and near to the WytheCarroll county boundary. Associated with Cambrian quartzite. Principal groups of mines: Page County, at Shenandoah; Rockingham County, Grottoes; Rockbridge County, Vesuvius and Buena Vista; Roanoke County, Roanoke; brown ore also mined near Pittsville, Pittsylvania County. Gossan ore of the sulphide deposits of crystalline area formed the basis of the first iron industry in the South.

Nelsonite. Prospected: Nelson County, near Roseland and Bryant; and Roanoke County, near Vinton.

Nickel. Reported in pyrrhotite from several localities in Piedmont region, especially in Floyd-Carroll-Grayson plateau in southwest Virginia and in Amherst County, near Lynchburg. Principal work done on Lick Fork, in Floyd County, 7 miles southeast of Shawsville.

Niter. In numerous caves in Shenandoah limestone in the valley on west side of Blue Ridge. Has been procured for local use.

Ocher. Has been mined: Bedford County, near Bedford City; Chesterfield County, near Bermuda Hundred, on Appomattox River; Loudoun County, in Little Catoctin Mountain, near Leesburg; Page County, Stanleyton, near Marksville; Rockingham County, near Keezletown and near west base of Massanutten Mountain, also along Naked Creek, 5 miles southeast of Shenandoah station; Warren County, excellent grade umber half mile east Shenandoah Railway, mined and shipped.

Onyx marble. Stalactitic and stalagmitic deposits on walls and floors of caves in Valley region; Luray, Page County, largest deposit.

Oriskany brown ore. Deposits occur locally in western portion of Appalachian belt from Maryland to southwestern Virginia. Principal mines in Alleghany County, near Longdale, Covington, Lowmoor, and Potts Creek. Other mines are: Augusta County, Buffalo Gap and Ferrol mines; Botetourt County, near Glen Wilton, Dagger Springs, and Oriskany; Pulaski County, Pulaski; and Wythe County, Max Meadows.

Phosphate. Alleghany County, phosphate nodules occur at base of Devonian black shale, near Clifton Forge, extent unknown. See also Marl and Nelsonite.

Psilomelane (manganese ore). Augusta County, Crimora, Lyndhurst, and Vesuvius mines; Botetourt County, Houston mines near Troutville; Campbell County, near Mount Athos and Evington; Nelson County, has been mined with pyrolusite near Warminster; Page County, Dry Run mine near Compton, also Eureka mine near Stanleyton, shipped; Rockingham County, several mines near Elkton; Smyth County, Umbarger mine near Sugar Grove and Currin Valley mine near Attoway. 
Pyrite. Botetourt County, prospects near Bonsack station; Buckingham County, near Arvonia, Dillwyn, and elsewhere, has been mined for gold; Culpeper County, 18 miles west of Fredericksburg on Rapidan River, has been mined for gold; Dinwiddie County, near Pools Siding; Fauquier County, has been mined for gold near Morrisville; Goochland County, mined for gold 2 miles west of Caledonia and elsewhere; Louisa County, mined extensively for sulphuric acid at Mineral City; Montgomery and Floyd counties, on west side of Blue Ridge along Brush and Laurel creeks, gold-bearing; Orange County, near Rapidan River and along and north of narrow-gage railroad between Fredericksburg and Orange, gold-bearing; Prince William County, large deposit near Dumfries; Rockbridge County, with cassiterite in quartz veins in Irish Creek area; Spotsylvania County, in northwest corner and elsewhere, near Rappahannock River, was mined for gold; Stafford County, in western part near Rappahannock River, was mined at Garrisonville for gold. About one-half the production of the United States comes from Louisa and Prince William counties.

Pyrolusite (black oxide of manganese). Amherst County, scattered through clay and as replacements in granite at Stapleton, has been mined; Augusta County, in Lower Cambrian quartzite at Crimora mine near Crimora Station; Botetourt County, in manganiferous clay at Houston mines near Troutville; Campbell County, high grade in nodular masses and as replacements in granite at Mount Athos, Evington, Otter River, and Clarion (Lynch), mined near Evington, Mount Athos, and Otter River; Frederick County, in limestone at Paddy Mills mine in southwest corner of county; Nelson County, has been mined at Warminster and Midway Mills; Page County, Eureka mine near Stanleyton; Rockbridge County, Midvale; Shenandoah County, in sandstone at Powells Fort, has been mined at Baltimore and Philadelphia mines; Smyth County, in psilomelane at Umbarger mine near Sugar Grove and filling cavities in limonite at Currin Valley mine; Warren County, in limonite deposits associated with quartzite at Happy Creek mine near Front Royal; Wythe County, has been mined near Wytheville.

Pyrrhotite (magnetic pyrites). Largest occurrence is a lode varying in width up to 100 feet and extending 20 miles from Floyd County, through Carroll Mountains, Grayson County. Carroll County, mined for sulphuric acid between Chestnut Creek and New River near Sylvatus; Grayson County, in Carroll Mountains; Fauquier County, occurs near Broad Run; Floyd County, in mica schist 8 miles southeast of Floyd, also has been mined on Lick Fork in northern part of county, nickeliferous; Franklin County, in mica schist at Howell mine near Rocky Mount; Louisa County, with pyrite in mines near Mineral City; Prince William County, small quantity with pyrite in Cabin Branch mine near Dumfries.

Quartz (amethyst). Amherst County, has been mined $2 \frac{1}{2}$ miles northeast of Lowesville; Campbell County, good specimens found near Brookneal; Charlotte County, good specimens 2 miles west and 4 miles south of Charlotte.

Quartz (gem). Fairfax County, milky-white chalcedony, greenish-colored, colorless, and smoky quartz, near Fairfax; gems cut.

Quartzite. Found at various points along James River between Scottsville and Lynchburg, in Albemarle, Appomattox, Bedford, Buckingham, Campbell, Fluvanna, and Nelson counties. Quarries at several places formerly worked for building stone.

Road metal. See Gabbro, Gneiss, Granite, Limestone, Syenite, and Trap rock.

Rutile. Goochland County, mined near Peers; Hanover County, mined at Gouldin, in pegmatite dikes, in residual soil, and in gravels; Nelson County, occurs in large deposits of excellent quality, 5 miles northwest of Arrington on the Southern Railway, and in pegmatite and nelsonite dikes near Roseland 
Salt (brine). Smyth County, pumped at Saltville, for manufacture of alkali and caustic soda. Formerly used for manufacture of salt; no salt made for some years.

Salt (rock). Occurs in large quantity with gypsum from Plasterco, Washington County, to within 3 miles of Chatham Hill, Smyth County; not mined.

Sand (building). Widely distributed, considerable quantity along streams; mined: Caroline County, at Massaponax; Pulaski County, Delton; Rockingham County, North River; Shenandoah County, Edinburg; Spotsylvania County, Fredericksburg; and other places.

Sand (glass). Fine white sand of suitable quality is found along eastern edge of Middle Valley region; Amherst County, Stapleton Mills; Augusta County, near Greenville; Rockbridge County, Balcony Falls, along west base of Blue Ridge; Roanoke County, Catawba Mountain, 9 miles northwest of Salem. Worked only at Salem locality.

Sand (molding). Has been found chiefly in vicinity of Fredericksburg, Petersburg, and Richmond. Is dug on Cowardin place at Richmond.

Sandstone. Lower Cambrian sandstone quarried along Chesapeake \& Ohio Railway, Augusta County, for crushed stone. Silurian sandstone extends along Great Valley, fine to coarse, suitable for constructional work. Mississippian sandstone found in Augusta, Bland, Botetourt, Craig, Frederick, Montgomery, Pulaski, Roanoke, Rockingham, Shenandoah, Smyth, and Wythe counties; quarried at Pulaski, Pulaski County, for building material. Pennsylvanian sandstone found in Buchanan, Dickenson, Lee, Russell, Scott, Tazewell, and Wise counties; quarried for local building stone. Sandstone of the Newark group distributed in seven areas east of Blue Ridge, few quarries, good stone; quarried near Warrenton, Fauquier County, and in vicinity of Manassas, Prince William County. Cretaceous sandstone found near Fredericksburg on Rappahannock River, Spotsylvania County, and at several points in Brunswick, Chesterfield, and Greensville counties; has been quarried in vicinity of Aquia Creek and on Rappahannock near Fredericksburg, Spotsylvania County.

Schist (mica). Common in Piedmont region; quarried: Campbell County, at Altavista, for ballast; Franklin County, near Rocky Mount, for flagging.

Siderite. Washington County, with magnetite in limestone near Abingdon.

Silver. Halifax County, in copper ores of the Virgilina district; Louisa County, in pyrite mines near Mineral City.

. Sipylite (niobate of erbium). Amherst County, adherent to magnetite occurs sparingly on northwest slope of Little Friar Mountain.

Slate. Quarried: Albemarle County, at Esmont; Amherst County, Snowden; Buckingham County, Arvonia; Fauquier County, has been quarried near White Sulphur Springs, 6 miles south of Warrenton; undeveloped beds in Craig, Prince William, and Stafford counties.

Smithsonite (zinc carbonate). Albemarle County, in lead-zinc mine near Faber; Pulaski County, oxidized ore of Delton mines near Delton, has been mined; Russell County, with calamine in prospects 10 miles north of Castlewood; Wythe County, secondary mineral of lead and zinc mines at Austinville.

Soapstone. Production much larger than that of any other State. Widely distributed in older crystalline rocks of Piedmont region east of Blue Ridge; Albemarle and Nelson counties, extensively quarried near Green, Hawkins, Findley, Ball, and Appleberry mountains. Has been quarried: Amelia County, at head of Walnut Creek; Campbell County, on Otter River; Charlotte County, near Cullen; Fairfax County, Annandale, near Clifton Station, Falls Church, and Tenley; Franklin County, Rocky Mount. Good stone undeveloped at many other localities. 
Spessartite (garnet). Amelia County, fine gems cut from mines at Amelia.

Sphalerite (zinc blende). Albemarle County, common in fluorspar-quartz lenses near Faber; Bedford County, occasionally found in barite near 'Thaxton; Botetourt County, has been mined near Bonsack station; Buckingham County, has been mined for gold near Arvonia, Dillwyn, and elsewhere; Culpeper County, has been mined for gold 18 miles west of Fredericksburg on Rapidan River; Fauquier County, has been mined for gold near Morrisville; Goochland County, mined for gold 2 miles west of Caledonia and elsewhere; Halifax County, in Virgilina copper district; Louisa County, frequent in small quantities of pyrite in mines near Mineral City; Orange County, near Rapidan River and along and north of narrow-gage railroad between Fredericksburg and Orange; Prince William County, occasionally with pyrite in Cabin Branch mine near Dumfries; Pulaski County, prospected in unaltered limestone in bed of New River; Russell County, has been mined in Copper Creek 7 miles south of Castlewood; Smyth County, has been mined with galena along South Fork of Holston River in Rye Valley; Spotsylvania County, has been mined for gold near Rappahannock River in northwest corner of county; Stafford County, has been mined for gold in western part of county, near Rappahannock River; Wythe County, with galena and pyrite at Austinville, Bertha, and Cedar Springs.

staurolite. Good crossed crystals (fairy stones), have some value as curios; found in Patrick County.

Sunstone. Amelia County, Amelia Courthouse.

Syenite. Suitable for building stone, undeveloped, occurs in Carroll County, northeastward from Sylvatus and on Big Reed Island Creek; Charlotte County, from Drakes Branch to near Charlotte Courthouse; Floyd County, in northwest corner; Greene County, near Elkton; Madison County, at Milams Gap; Warren County, along west side of Blue Ridge, near Front Royal.

Talc. Found in commercial quantity and mined in Fairfax County, at several places near Clifton station and Wiehle; Orange County, near Rhoadesville, a small quantity was mined and sawed for crayons and burners in 1911.

Tantalite. Amelia County, fine splendent crystals near Amelia.

Tetradymite. Goochland-Fluvanna counties, Tellurium mine; Spotsylvania County, Whitehall gold mines; Stafford County, Monroe mine.

Tin. See Cassiterite.

Tourmaline. Amelia County, in pegmatite dikes in Amelia district, and in some of the quartz veins in the gold belt.

Trap rock. Occurs in many counties in Piedmont region; used for road metal.

Tripolite. See Infusorial earth.

Umber. Grayson County, about $2 \frac{1}{2}$ miles south of Troutdale; Page County, Milams Gap near Luray; in Blue Ridge of north Virginia and in Blue Ridge of southwest Virginia.

Valley brown ore. Occurs in same general area as mountain brown ore. Associated with limestone. Mines: In Augusta County, Lofton; Page County, Luray; Pulaski County, Reed Island; Rockbridge County, Midvale; Wythe County, Foster Falls and Ivanhoe.

Verde antique. Loudoun County, occurs on Goose Creek, not used.

Wad. Augusta County, with other manganese ores at Crimora and in siliceous rock near Waynesboro; Rockingham County, interbedded with clay at Kendall and Flick mine near Elkton.

Wolframite. Rockbridge County, with cassiterite in Irish Creek area.

Zinc minerals. See Calamine, Sphalerite, and Smithsonite.

Zircon. Amelia County, in pegmatite dikes in Amelia district; Hanover County, as zirconiferous sandstone of Calvert age, 3 miles west of Ashland. 
Antimony. See Stibnite.

\section{WASHINGTON.}

Argentite. Okanogan County, Moses (Nespelem) district, in Apache and Little Chief mines; Stevens County, Deer Trail (Cedar Canyon) district, at Silver Queen and Orchid mines.

Arsenic (native). Snohomish County, Monte Cristo. See also Arsenopyrite, Realgar. Arsenopyrite (arsenical pyrite). King County, Mono claims near Berlin and Apex mine; Okanogan County, Twisp and Squaw Creek districts, mined for gold; Snohomish County, principal ore in Monte Cristo district; with chalcopyrite in Stilaguamish district, mined for gold and silver; mined also near Everett for gold, silver, and arsenic.

Asbestos. Chelan County, developed property near Leavenworth, occurs in Mount Stuart and Wenatchee Mountains but not mined; occurs in huge quantity along Columbia River and through Cascade Mountains.

Basalt. Most abundant surface rock in State. Quarried at following places: Clarke County, Fishers Landing, 10 miles above Vancouver; King County, Franklin and Riverton; Lewis County, Meskill; Spokane County, Marshall; Walla Walla County, Dixie; Yakima County, North Yakima.

Bismuth. See Cosalite.

Bornite (purple copper ore). King County, Climax claims southwest of Baring, carries silver; Pierce County, Surprise claims, Carbon River district; Snohomish County, important ore at Index prospects.

Brown iron ore (limonite). Snohomish County, Monte Cristo district, mined for gold and silver; Stevens County, prospects near Deep Creek Lake southeast of Northport.

Cassiterite (tin ore). Spokane County, in pegmatite cutting Archean gneiss, quartzites, and schists at Silver Hill 12 miles southeast of Spokane; has been prospected.

Cement material. See Limestone.

Cerargyrite (horn silver). Stevens County, occurs with lead ores in Cedar Canyon district; mined and shipped from Orchid.

Cerusite (lead carbonate). Stevens County, argentiferous, occurs in Cleveland, Colville, and Summit mining districts; has been mined.

Chalcocite (copper glance). Lewis and Skamania counties, St. Helena district, not mined; Snohomish County, Index district, mined at Ethel and Independent mines.

Chalcopyrite (copper pyrite). Chelan County, claims in Horseshoe Basin and Railroad Creek district, carries gold and silver; King County, chief mineral of Climax claims near Baring and Dutch-Miller, carries gold and silver; Lewis and Skamania counties, St. Helena district, auriferous; Okanogan County, Myers Creek, Palmer Mountain, Upper Methow, Twisp Creek, and Squaw Creek districts, carries gold and silver; Pierce County, a number of claims in Carbon River district; Snohomish County, one of chief ores of Monte Cristo district, mined for gold and silver; principal gold ore of Stilaguamish district; mined for gold and silver at Index district; Stevens County, Copper King mine, Chewelah.

Clay (brick). Bricks are made from local clay deposits at the principal towns in more than half of the counties. Pits at the following places: Chehalis County, at Aberdeen; Chelan County, Chelan and Wenatchee; Clarke County, Vancouver; Columbia County, Dayton; Cowlitz County, near Olequa; Ferry County, near Republic; King County, near Seattle, Taylor, Renton, Kummer, Van Asselt, Woodinville, and elsewhere; Kitsap County, Harper; Kittitas County, Clealum; Lewis County, Centralia, Chehalis, and Little Falls; Lincoln County, Irby; Okanogan County; Okanogan; Pierce County, Fox Island; Skagit County, 
Alger; Snohomish County, Everett; Spokane County, Deer Park, Freeman, Spokane, and elsewhere; Stevens County, Chewelah, Clayton, and Springdale; Walla Walla County, Walla Walla; Whatcom County, Bellingham; Whitman County, Colfax, Oakesdale, Palouse, and elsewhere; Yakima County, mined in valley of Yakima River near North Yakima and at Granger.

Clay (fire). Cowlitz County, occurs 2 miles east of Sopenah; Spokane County, small quantity mined at Mica; Stevens County, occurs at Northport.

Clay (kaolin). Pierce County, occurs at Eatonville.

Clay (pottery). Cowlitz County, occurs along Cowlitz Fiver a few miles above Olequa and 2 miles east of Sopenah; dug at Sopenah; King County, small quantity dug at Auburn; Whitman County, occurs along Palouse River near Palouse.

Coal (bituminous and subbituminous). King County, Green River district, highly bituminous; mined at Pocahontas mine; Kittitas County, Roslyn-Clealum district, excellent quality; mined at Roslyn and Clealum mines, 4-5: feet thick; shipped; Pierce County, Wilkeson-Carbonado district, lying midway between Tacoma and Mount Rainier; 6 beds worked at Wilkeson mine; 4 beds worked at Carbonado mine, 4-7 feet; coking and steam; Whatcom County, Blue Canyon mine on southeast shore of Lake Whatcom, 7 feet.

Coal (subbituminous and lignite). Cowlitz County, Kelso-Castle Rock district, mined on Coal Creek, 8 miles west of Kelso; shipped; King County, Newcastle-Issaquah district, 7 beds worked at Issaquah mine; 4 beds at Coal Creek mine, 3-14 feet; Renton-Cedar district, mined at Cedar Mountain mine near Renton, 8 feet; Green River district, mined at Gem mine near Franklin, and Lawson mine near Black Diamond; Lewis County, Chehalis-Centralia district, mined near Centralia, bed $5 \frac{1}{2}$ feet; small mine near Chehalis, bed 4 feet; Thurston County, mined 4 miles from Tenino.

Coal (semianthracite). Whatcom County, number of coal beds in coal measures on Glacier Creek; prospects.

Cobalt. Ferry County, occurs near Keller.

Copper minerals. Copper is the predominant metal produced in the following districts: Ferry County, Belcher, Lone Star, Sanpoil; Okanogan County, Csoyoos Lake (Oroville); Pierce County, Carbon River (Fairfax station); Skagit County, Bald Mountains, 10 miles south of Lymon; Snokomish County, Index, Silver Creek, Stilaguamish; Stevens County, Chewelah; of minor importance in many other districts. See also Bornite, Chalcocite, Chalcopyrite, Malachite, Melaconite, and Tetrahedrite.

Copper (native). Pierce County, rare; found at Eatonville.

Cosalite (argentiferous). Stevens County, with wolframite at Cedar Canyon and with hübnerite at Loon Lake; not saved.

Galena. Chelan County, claims in Horseshoe Basin district, gold and silver; Lewis and Skamania counties, claims in St. Helens district; Lincoln County, has been mined for silver at Crystal mine, $1 \frac{1}{2}$ miles east of mouth of Spokane River; Okanogan County, mined for gold and silver at Monterey and Yakima mines, Myers Creek district, and Golden Zone and Gold Hill mines, Palmer Mountain district; Snohomish County, principal gold and silver ore in Monte Cristo and Stilaguamish districts; Stevens County, chief silver-bearing mineral at Colville; mined for gold and silver at Deer Trail mines and Silver Queen, Cedar Canyon district; Spokane County, in siliceous veins at Silver Hill; carries silver.

Gold (lode). Gold is the predominant metal produced in the following districts: Chelan County, Bridge Creek, Entiat, Horseshoe Basin, Lakeside, Leavenworth, Peshastin, Railroad Creek, and Wenatchee; Ferry County, Danville and Republic; King County, Money Creek, 6 miles from Berlin; Kittitas County, Fish Lake, Swauk; Okanogan County, Myers Creek, Nighthawk, Palmer 
Mountains, Squaw Creek, Twisp, Wauconda; Snohomish County, Darrington, Granite Falls, Monte Cristo; Stevens County, Meyers Falls, Orient; Whatcom County, Mount Baker, Slate Creek. Gold occurs in other mining districts but is of less importance than some other metal.

Gold (placer): Asotin County, occurs in black sands of Snake River and at Clarkston, small production; Chehalis County, at Oyhut; Clallam County, at Shishi Beach, Ozette River, and Yellow Bank; Clark County, at Camas and Brush Prairie; Douglas County, in sands of Columbia River. Ferry County, has been mined in sands and gravels of Columbia River at many points between mouths of Kettle and Nespelem rivers; and along Granite Creek near Republic; is mined in small way on Strawberry Creek, a tributary of west fork of Sanpoil River; Kittitas County, Swauk district, 12 placers; Lincoln County, at Davenport and at Hell Gate Bar few miles above Sanpoil and at Peach Bar; Okanogan County, has been mined along Mary Ann Creek, tributary of Myers Creek; Snohomish County, occurs near Silverton; Stevens County, at Wilmot Bar and Marcus; Thurston County, on Wahkiakum Island and Sand Island and along Columbia River; Uinta County, along Snake River and in vicinity of Horse Creek; in the latter prospecting; Whatcom County, in Slate Creek and Mount Baker districts; Yakima County, at Mabton.

Granite. Snohomish County, unlimited supply near Index; Spokane County, quarried at Medical Lake and Spokane; Whitman County, quarried on Snake River, 20 miles below Lewiston and at mouth of Grand Ronde River.

Hematite (red iron ore). Kittitas County, occurs 20 miles north and little west of Clealum; Skagit County, along south bank of Skagit River near Hamilton; Snohomish County, mined for gold and silver in Monte Cristo district; Stevens County, in prospects near Deep Creek Lake, southeast of Northport.

Hübnerite. Stevens County, mined near Loon Lake and Deer Park; occurs with argentiferous cosalite in quartz veins and pegmatite cutting mud stones and granite.

Infusorial earth. Yakima County, formerly mined at North Yakima.

Iron minerals. Iron is the principal metal produced in Kings County, at Snoqua1mie Pass; Skagit County, Hamilton; Stevens County, Deep Creek Lake. See also Brown iron ore, Hematite, Magnetite, Pyrite, and Pyrrhotite.

Iridosmine. Clallam County, small quantity with gold at Shishi Beach, 2 miles northwest from Point of Arches.

Limestone (building). Snohomish County, quarried 3 miles east of Granite Falls; shipped to Seattle and elsewhere.

Limestone (cement material). Counties of Ferry, King, Okanogan, San Juan, Skagit, Snohomish, Stevens, and Whatcom; limestone suitable for cement making, associated with shale.

Limestone (flux). San Juan County, worked on East Sound, Orcas Island; San Juan Island, deposit extending from Roche Harbor to Westcott Bay, extensively worked; Stevens County, Evans and Northport.

Limestone (lime). Chelan County, burned at Lake Chelan; Ferry County, burned between Republic and Wauconda; King County, near Olga and at Seattle; San Juan County, Orcas Island, Deer Harbor, and Roche Harbor; San Juan Island, deposit extending from Roche Harbor to Westcott Bay, extensively worked; Snohomish County, 3 miles east of Granite Falls; Stevens County, Springdale.

Limonite. See Brown iron ore.

Magnetite (magnetic iron ore). In sands of Columbia River placers, northeast Washington, not recovered; King County, in Cascade Mountains, $2 \frac{1}{2}$ miles north and west of Snoqualmie Pass: Kittitas County, 20 miles north and a little 
west of Clealum on Clealum River; Skagit County, deposits along south bank of Skagit River, from Hamilton to Marble Mountain.

Malachite. Snohomish County, Monte Cristo district; mined for gold and silver.

Marble. Stevens County, large supply at Colville, several quarries; also quarried near Valley and Chewelah; counties of Cowlitz, Okanogan, and Skagit; several kinds of good marble reported.

Melaconite. Snohomish County, Monte Cristo district; mined for gold and silver.

Mineral paint. Lead paint is made at Spokane and Tacoma from Idaho and Washington ores. Pierce County, metallic paint mined at Eatonville. See also Ocher.

Molybdenite (sulphide of molybdenum). Chelan County, in quartz at Crown Point, Railroad Creek district; small quantity has been mined; Ferry County, Sanpoil district, occurs in many prospects; Okanogan County, Golden Zone mine, Palmer Mountain district, with calcite near Conconully; Snohomish County, rare in Monte Cristo district; Stevens County, Metalline district, has been prospected.

Monazite. Chehalis County, in black sands at Moclips and Grays Harbor, not recovered; Douglas County, occurs in sands of Columbia River; Stevens County, occurs at Wilmot Bar, Columbia River.

Nickel. Ferry County, Congress mine near Keller; Okanogan County, Stepstone prospect, 12 miles north of Nespelem.

Ocher. Stevens County, reported at Valley.

Opal. Whitman Creek near Oregon line, 5 miles northwest of Moscow, has been mined.

Petroleum. Clallam County, wells were drilled near Lapush at mouth of Solduck River; Okanogan County, Moses (Nespelem) district, Little Chief mine; Thurston County, between Tenino and Grand Mound; Whatcom County, wells drilled at Happy Valley near Fairhaven. No production reported for the State.

Platinum. Clallam County, occurs with gold at Shishi Beach; Pacific County, occurs in black sands at Beards Hollows; not recovered.

Pyrargyrite (ruby silver). Okanogan County, Moses district, Little Chief mine; Snohomish County, in gold and silver ores of Forty-Five mine, Stilaguamish district.

Pyrite. Common in many mining districts, as follows: Chelan County, in granite in Holden claims, Railroad Creek district, carriea gold and silver; Ferry County, Chesaw mines, northwest of Republic; Lewis and Skamania counties, with copper ores in St. Helens district; Okanogan County, mined for gold and silver at Yakima and Review mines, Myers Creek district, and at Goldon Zone and Gold Hill mines, Palmer Mountain district; Snohomish County, goldbearing in Monte Cristo district, and with galena in Stilaguamish district; Stevens County, scattered through quartz 5 miles northeast of Loon Lake; Whatcom County, large masses of ore exposed in Mount Baker district, carry gold and silver.

Pyrrhotite. Snohomish County, one of chief ores of Monte Cristo district, carries gold and silver. Occurs with chalcopyrite at Silverton, Stilaguamish district, mined for gold.

Realgar. Lewis County, has been mined for arsenic at Mineral; Snohomish County, has been mined in Monte Cristo district.

Road metal. Chehalis and Thurston counties, basalt between Gate City and Aberdeen; Kitsap County, basalt quarried at Orchard; King County, volcanic rock quarried between South Seattle and Black River Junction. Sce also Basalt.

Sand (building). Common along entire course of Columbia and other large rivers, in Puget Sound region, and near many large towns; has been dug at following 
places: Chehalis County, Chehalis River'at Aberdeen; King County, Richmond Beach and Vashon Island; Pierce County, Steilacoom and Tacoma.

Sand (molding). King County, dug at Cedar Mountain and Richmond Beach.

Sandstone. Has been quarried at following places: King County, Cumberland; Kitsap County, Bremerton; Pierce County, Wilkeson and Fairfax; San Juan County, East Sound, Provost post office, Steward Island, and Waldron Island; Thurston County, Tenino; Whatcom County, Bellingham district.

Scheelite. Spokane County, associated with quartz at Silver Hill, not mined.

Scorodite. Snohomish County, oxidized ore of Monte Cristo district, mined for gold and silver.

Serpentine. Stevens County, quarried on Green Mountain near Valley.

Silver. Chelan County, with gold ore in Pole Pick mine and in Ivanhoe mine, Peshastin district, and in minor quantity in several other districts; Ferry County, in gold quartz veins at Tom Thumb, Quilp, Lone Pine, Surprise, and other mines near Republic, predominant metal in Meteor district; Lincoln County, principal metal at Crystal district, 15 miles north of Davenport; Okanogan County, in gold-quartz veins in Palmer district, mined at Gold Hill, Black Bear, and War Eagle mines, in Moses (Nespelem) district and in Upper Meteor district; Stevens County, in Chewelah, Deer Trail, Colville, Silver Queen, and other districts; Skagit County, number of claims in Thunder Creek district. See also Cerargyrite, Pyrargyrite, and Sylvanite.

Silver (native). Okanogan County, in Apache mine, Moses (Nespelem) district.

Sphalerite (zinc blende). Okanogan County, mined at Yakima mine, Myers Creek district, for gold and silver; Snohomish County, one of chief ores of Monte Cristo district, mined for gold and silver with galena in Stilaguamish district, mined at Forty-Five mine for gold and silver; Stevens County, with galena in Deer Trail (Cedar Canyon) district.

Stibnite. Ferry County, occurs in Enterprise (Covada) district, considerable quantity in Longstreet and other mines and prospects of district; King County, Great Republic mine; Okanogan County, mined near Methon.

Sylvanite. Okanogan County, Squaw Creek district.

Talc. Skagit County, 7 miles above Marblemount, was mined.

Tetrahedrite. Okanogan County, many claims in Squaw Creek districi; Snohomish County, Stilaguamish district, mined at Forty-Five mine for gold and silver.

Tin. See Cassiterite.

Tufa. Mason County, outcrops along beach $2 \frac{1}{2}$ miles on west side of Hoods Canal, has been quarried 2 miles northeast of Hoodsport; Stevens County, extensive deposits on China Bend on Columbia River near Northport; has been quarried.

Tungsten. See Hübnerite, Scheelite, and Wolframite.

Wolframite. Okanogan County, occurs 35 miles northwest of Loomis near Cathedral Peak, development in progress; Spokane County, associated with quartz at Silver Hill; Stevens County, mined at Germania mine, Deer Trail (Cedar Canyon district.

\section{WEST VIRGINIA.}

Barite (heavy spar). Mercer County, on north slope of East River Mountain; not mined.

Bromine. Manufactured from brine in Kanawha County, at Malden; Mason County, Hartford and Mason.

Brown iron ore (brown hematite, limonite). Berkeley County, south of Martinsburg, pits were opened and ore shipped; Grant County, Greenland Gap, has been mined; Greenbrier County, prospects near Anthony Creek Gap; Hampshire County, near Capon Springs, on ridges north of Capon Springs; Hardy 
County, has been mined at number of places near Wardensville; Jefferson County, ore bank 4 miles above Harpers Ferry, has been mined; Mineral County, has been mined near Keyser; Monroe County, considerable quantity in Zenith area, in flint and lime at Crimson Spring; prospects on Peters Mountain and elsewhere, has been mined at Crimson Spring; Morgan County, Sandy Ridge; Pendleton County, at many places along North Fork Mountain; prospects on sides of Little Mountain, 2 miles east of Franklin; Pocahontas County, prospects on Beaver Lick Mountain; Raleigh County, has been mined near Beckley.

Cement material. Jefferson County, Cambrian limestone used for natural cement near Shepherdstown; Mineral County, Lewistown limestone quarried at Cedar Cliff; Preston County, Greenbrier limestone used at Manheim on Cheat River, for Portland cement. Occurs, but not used for cement in Berkeley County, near Martinsburg; Jefferson County, Charlestown, and Millville; Mineral County, near Keyser; Monongalia County, along Cheat River, 6 miles east of Morgantown, and on Deckers Creek; Tucker County, in vicinity of Hendricks.

Cement material (calcareous tufa, travertine, calcareous marl). Grant County, Patterson Creek; in Hardy, Hampshire, Jefferson, and other counties, in large deposits; not mined.

Clay (brick). Dug and used at following places: Barbour County, Philippi; Berkeley County, near Martinsburg; Cabell County, Barboursville, Central City, Culloden, Huntington, and Milton; Greenbrier County, Caldwell; Hancock County, New Cumberland and Zalia; Harrison County, Clarksburg, and Glen View; Jackson County, Ripley and Ravenswood; Jefferson County, Shepherdstown; Kanawha County, Charleston and South Ruffner; Lewis County, Janelew and Weston; Marion County, Colfax, Fairmont, and Hammond; Marshall County, Moundsville; Mason County, Huntington, Point Pleasant, and Spilman; Mineral County, Ridgeley; Mingo County, Williamson; Monongalia County, Morgantown and Randall; Preston County, Kingwood; Putnam County, Bancroft; Randolph County, Elkins; Ritchie County, Pennsboro; Roane County, Spencer; Taylor County, Colfax and Thornton; Tyler County, Middlebourne; Upshur County, Buckhannon; Wetzel County, Brooklin and New Martinsville; Wood County, Parkersburg.

Clay (fire). Barbour County, flint clay 1 mile east of Junior; Braxton County, near Savageville, has been mined; Hancock County, occurs in vicinity of New Cumberland; Harrison County, occurs 1 mile east of Clarksburg; Kanawha County, near Charleston, has been mined; Marion County flint and plastic clay worked at Hammond; Mineral County, occurs 1 mile east of Piedmont; Monongalia County, occurs near Morgantown; Preston County, occurs along Cheat River; Taylor County, occurs near Lost Run, Thornton; Tucker County, North Fork of Blackwater; Wayne County, occurs near Cassville.

Clay (stoneware). Has been dug and used at following piaces: Harrison County, Bridgeport; Jackson County, Ravenswood; Monongalia County, Morgantown; Wood County, Parkersburg; occurs in Randolph County, at Elkins.

Coal (bituminous and semibituminous). Over 20 workable coal beds in State; hundreds of mines; coal all of Carboniferous age; mined in Barbour, Boone, Braxton, Brooke, Cabell, Clay, Doddridge, Fayette, Gilmer, Grant, Greenbrier, Hancock, Harrison, Kanawha, Lewis, Lincoln, McDowell, Marion, Marshall, Mason, Mineral, Mingo, Monongalia, Nicholas, Ohio, Pleasant, Preston, Putnam, Raleigh, Randolph, Ritchie, Roane, Taylor, Tucker, Upshur, Wayne, Webster, Wetzel, and Wyoming counties. Bituminous coal in all these counties except Fayette, McDowell, Mercer, Raleigh, and Wyoming, where the coal is mostly the semibituminous and high-grade bituminous, smokeless coal, of the New River and Pocahontas fields, 
- Fluorspar. Jefferson County, Shepherdstown, not mined.

Grahamite (asphalt). Ritchie County, was once extensively mined 25 miles southeast of Parkersburg, and is still mined there in a small way.

Grindstone. Has been quarried: Jackson County, at Lone Cedar, 21 miles south of Parkersburg; Kanawha County, on north side of Kanawha River, at Sattes; Upshur County, Buckhannon; .Wood County, north of Parkersburg.

IIalite. See Salt.

Hematite (red iron ore). Grant County, prospects in southeastern part, South Fork Mountain; Hardy County, has been mined near Wardensville and Perry; Mineral County, has been mined 1 mile southeast of Keyser; Monongalia County, location of several early furnaces which used local ore.

Hematite (fossil ore). Grant County, vicinity of Greenland Gap, parallel seam 5 feet thick, has been mined; Greenbrier County, Anthonys Creek and Howard Creek, prospected, both fossil and black ore; Hardy County, middle and also on north mountain ranges, large bodies developed; Mercer County, north slope of East River Mountain, Bluestone River, on Black Oak Mountains, and Flat Top Mountains, prospected; Monroe County, Little Mountain, prospected; Pendleton County, South Fork Mountains, prospected.

Iron ore. See Brown iron ore, Hematite, Ocher, and Siderite.

Limestone (building). Quarried: Greenbrier County, at Lewisburg; Jefferson County, near Charlestown, at Millville, and Shepherdstown; Preston County, small quantity quarried at Orr, also 1 mile west of Corinth.

Limestone (crushed stone). Quarried: Greenbrier County, at Fort Spring; Jefferson County, Keller and three-fourths mile west of Engles Siding; Mineral County, Keyser; Monongalia County, Sturgisson; Monroe County, near Frazier; Ohio County, near Wheeling; Preston County, Afton.

Iimestone (flux). Berkeley County, has been quarried for flux at Bunker Hill and Martinsburg.

Limestone (lime). Burned for lime: Berkeley County, at Bunker Hill; Greenbrier County, Fort Spring; Jefferson County, Millville; Monroe County, Snowflake; Preston County, Afton, Cranesville, and elsewhere.

Limonite. See Brown iron ore.

Manganese ore. Greenbrier County, in Oriskany iron ores at Glenmore; not mined.

Mica (muscovite). Berkeley County, large muscovite scales in Slate district, 13 miles west of Blue Ridge; not mined.

Natural gas. Produced in 1910 to 1912 more than any other State; from wells in Boone, Braxton, Brooke, Cabell, Calhoun, Clay, Doddridge, Gilmer, Hancock, Harrison, Kanawha, Lewis, Lincoln, Marion, Marshall, Monongalia, Ohio, Pleasants, Putnam, Ritchie, Roane, Taylor, Tyler, Upshur, Wayne, Wetzel, Wirt, and Wood counties. Wells range in depth to 4,000 feet.

Niter (saltpeter). Found in caves in Greenbrier, Monroe, and Pocahontas counties; has been used.

Ocher. Cabell County, on Guyandotte River; Hardy County, South Branch Valley; Jefferson County, Lost River, near Harpers Ferry and near Shepherdstown; Lewis County, yellow ocher near Weston; Pendleton County, Clines Crossroads; Wayne County, near Ceredo; not mined.

Petroleum. Produced in Brooke, Cabell, Calhoun, Doddridge, Gilmer, Hancock, Harrison, Kanawha, Lewis, Lincoln, Marion, Marshall, Monongalia, Ohio, Pleasants, Putnam, Ritchie, Roane, Tyler, Wayne, Wetzel, Wirt, and Wood counties; Harrison and Lincoln counties produced over 1,000,000 barrels each in 1909. Producing wells numbering about 13,000 and ranging in depth from 215 to 3,580 feet, yielded more than 12,000,000 barrels in 1912 .

Pyrite. Berkeley County, in Slate district, 13 miles west of Blue Ridge, not mined. 
Quartz (sand). Hampshire County, Blue Gap, Short Mountain, cliffs of white sand rock; Monongalia County, near Morgantown, very soft sandstone; Morgan County, Sir Johns Run, not used.

Salt (brine). Obtained: Kanawha County, near Malden; Mason County, at Hartford and Mason; Wood County, Kanawha. Production over 180,000 barrels of salt in 1911. Salt has been made from brine wells at following places: Braxton County, Bulltown, on Little Kanawha; Clay County, at mouth of Otter Creek, on Elk River; Mercer County, New River; Monongalia County, along Cheat River, Deckers Creek, and Scotts Run, in borings for oil; and at other localities.

Sand (building). Dug and used at following places: Cabell County, at Huntington; Kanawha County, Charleston and on Elk River; Marshall County, Moundsville; Mason County, Hogsett; Monongalia County, Star City; Morgan County, Berkeley Springs; Ohio County, Wheeling; Preston County, Holmes station; Taylor County, Grafton; Upshur County, Buckhannon and Ivanhoe; Wood County, near Parkersburg.

Sand (glass). Monongalia County, Homewood sandstone member of the Pottsville formation, quarried on Deckers Creek at Sturgisson, 9 miles southeast of Morgantown; Morgan County, large quarries in Oriskany sandstone near Berkeley Springs, large deposits of white sand are worked and shipped for glass manufacturing; Preston County, Holmes station and near Independence, Homewood sandstone member of Pottsville formation; Randolph County, has been quarried at Silica; Taylor County, has been quarried near Grafton; Upshur County, early Pennsylvanian sandstone was quarried at Craddock.

Sand (molding). Dug in Cabell County, at Huntington; Monongalia County, at Star City; and other places.

Sandstone. Barbour County, quarried at Philippi and vicinity, and near Laurel; Braxton County, near Gassaway, and small quarry at Frametown; Brooke County, near Wellsburg, local use; Cabell County, small quarry 2 miles southwest of Huntington; Hancock County, Kings Creek and below New Cumberland; Harrison County, Clarksburg; Jackson County, Sherman and Murrayville; Kanawha County, Charleston and Sattes; Lewis County, Weston; McDowell County, Gary; Marion County, Farmington and near Fairmont; Mineral County, Bloomington; Monongalia County, quarried at Morgantown and Sturgisson; Monroe County, has been quarried near Alderson; Pleasant County, quarried on small scale at St. Marys; Preston County, Bowlesburg, Albright and Zevely; Randolph County, Kingsville; Ritchie County, Cornwallis and Harrisville; Summers County, has been quarried near Hinton; Taylor County, quarried at Grafton, Yates, and Fetterman; Tyler County, Sisterville; Wetzel County, Littleton, New Martinsville; Upshur County, Buckhannon; Wood County, near Parkersburg.

Siderite (carbonate of iron). Has been prospected or mined in small way at following places: Barbour County, near Philippi; Braxton County, mouth of Strange Creek; Clay County, has been worked by Elk River Iron Co., Standing Rock Run; Grant County, thin seams at several localities; Kanawha County, near Charleston; Marion County, Fairmont; Mineral County, thin seams at several localities; Monongalia County, Deckers Creek, Scott Run, Booth Creek, and Cheat River, eastern part; Preston County, Three Forks Creek, Reedsville, Tunnelton, and Muddy Creek; Taylor County, near mouth of Lost Run; Wayne County, eight seams 1 to 3 feet thick on Big Sandy River at Cassville.

Siderite (black band ore). Has been mined: Clay County, on Little Sycamore Creek of Elk River; Fayette County, Bell Creek; Kanawha County, Davis $29123^{\circ}-$ Bull. $585-14-14$ 
and Briar creeks; Nicholas County, Little Elk Run; Wayne County, near Big Sandy River.

Slate. Berkeley County, rather inferior quality quarried 3 miles northeast of Martinsburg.

\section{WISCONSIN.}

Arsenopyrite. Oconto County, found in vein in granite quarry south of Mountain. Asbestos (actinolite). Portage County, has been mined near Stevens Point.

Azurite (blue carbonate of copper). Grant, Iowa, and Lafayette counties, found at several points in lead and zinc district.

Barite (heavy spar). Grant, Iowa, and Lafayette counties, deleterious gangue mineral, abundant in certain of the lead and zinc mines.

Brown iron ore (bog iron ore). Juneau County, near Necedah; Wood County, Grand Rapids; in many other localities in marshes of central and northern Wisconsin; not mined.

Brown iron ore (brown hematite, limonite). Florence County, accompanies hard hematite ore at Commonwealth and Florence mines; Grant, Iowa, and Lafayette counties, in minor quantities in ore-bearing crevices and in pockets of rock of the lead and zinc region; Pierce County, mined and smelted at Spring Valley; Sauk County, Ironton, Westfield, and elsewhere; not mined.

Cement (natural). Milwaukee County, Devonian limestone used for natural cement north of Milwaukee on Lake Michigan, and at Berthelet.

Cerusite (lead carbonate). Grant, Iowa, and Lafayette counties, secondary mineral of lead and zinc mines, mined with galena, which it coats.

Chalcocite (copper glance). Iowa County, Mineral Point copper mines, with chalcopyrite and carbonate.

Chalcopyrite (copper pyrites). Florence County, found in quantities sufficient to encourage exploration in green schists south of Homestead settlement, in south eastern part of county; Grant, Iowa, and Lafayette counties, has been mined at several points in lead and zinc region; Oconto County, in vein in granite near Mountain; Richland and Vernon counties, occurs sparingly in Cambrian ("Potsdam") sandstone.

Clay (brick). Dug and worked near almost every large town in the State. Production of common brick in 1911 valued at $\$ 985,824$.

Clay (kaolin). Barron County, occurs at Rice Lake, sec. 19, T. 35 N., R. 9 W.; St. Croix County, Hersey, washed and sold to paper manufacturers; excellent kaolin in vicinity of Glenwood; not used.

Clay (pottery). Rock County, terra-cotta ware made at Edgerton, from mixture of Edgerton white burning and Springfield red burning clay.

Clay (shale). Eau Claire County, large supply of pre-Cambrian shales suitable for brick, near Eau Claire; not used.

Copper (native). Ashland County, occurs in veins, amygdules, and scattered through epidotized trap, and in sandstone, on Montreal and Bad rivers; Bayfield County, in southwestern part of county; Douglas County, in Annicon, Brule, and Black rivers; Iowa County, has been mined at Mineral Point. Float bowlders common in eastern Wisconsin. Found at many points in upper Mississippi lead region.

Copper ores. See Azurite, Chalcocite, Chalcopyrite, and Malachite.

Feldspar. Marathon County, in pegmatite at Stettin, about 5 miles northwest of Wausau, not mined.

Flint. Abundant in certain parts of Galena dolomite in Grant, Iowa, and Lafayette counties, and in Niagara dolomite in eastern part of State; not used.

Galena. Original lead ore of upper Mississippi Valley; Grant County, mined at Platteville, Cuba City, and Hazel Green; Iowa County, occurs at Mifflin, 
Highland, Montfort, Livingston, Linden, Mineral Point district, and Dodgeville; Lafayette County, Benton and Shullsburg; Green County, has been mined near Monroe.

Granite. Quarried: Marathon County, at Granite Heights and Wausau; Marinette County, Athelstane and Amberg; Marquette County, Montello; Waupaca County, Waupaca; Waushara County, Lohrville, Neshkoro, Red Granite, and Warren. Occurs: Jackson County, at Black River Falls; Lincoln County, Irma; Wood County, abundant at Jenny Bull Falls; and at many other places.

Granite (porphyry). Wood County, has been quarried near Dexterville, on Yellow River.

Graphite. Portage County, amorphous graphite mined at Junction City.

Hematite (red hematite). Menominee Range.-Western extension is worked extensively at Commonwealth and Florence mines, in T. 40 N., R. 18 E., in Florence County. Beds of great thickness in Huronian rocks. Hard red ore accompanied by some limonite.

Penokee-Gogebic Range.-Large deposits, upon which a number of mines are working in eastern side of Iron County. The deposits occur in pitching troughs formed by the intersection of "greenstone" dikes and the footwall quartzite. Ore is mostly a soft red or brownish-red hematite with a little hard, steely, specular hematite.

Baraboo Range.-Deposits of red hematite ore in Huronian iron-bearing rocks in Sauk County; several mines being developed.

Iron Ridge.- "Clinton" or "fossil" ore near Mayville, Dodge County, in a lensshaped bed.

Iron minerals. See Brown iron ore, Hematite, Magnetite, Marcasite, Ocher, and Pyrite.

Kaolin (porcelain clay and fire clay). Jackson and Wood counties, along junction of Laurentian and Cambrian rocks; Wood County, well exposed at Grand Rapids, and worked for fire brick.

Lead minerals. See Cerusite and Galena.

Limestone (building). Quarried in following places: Brown County, at De Pere and Duckcreek; Buffalo County, Fountain City, Marshland, and Bluff Siding; Calumet County, Chilton; Crawford County, Bridgeport; Dodge County, near Foxlake and at Knowles; Door County, Sturgeon Bay; Fond du Lac County, small quantity quarried at Waupun and in vicinity of Marblehead; Grant County, Boscobel and Cassville; Iowa County, Mineral Point and Spring Green; Jefferson County, Watertown; Kewaunee County, small quantity quarried at Kewaunee; La Crosse County, Holmes, La Crosse, Mindora, and West Salem; Lafayette County, Darlington; Manitowoc County, Cooperstown; Milwaukee County, Wauwatosa and Milwaukee; Oconto County, very small quantity quarried at Little Suamico; Outagamie County, Appleton, Dale, Hortonville, Kaukauna, Seymour, and elsewhere; Ozaukee County, Cedarburg; Pepin County, Pepin; Pierce County, Elmwood and Maiden Rock; Polk County, in vicinity of Osceola; Racine County, small quantity quarried at Burlington; Rock County, Beloit and Edgerton; St. Croix County, small quantity quarried at River Falls; Sheboygan County, Sheboygan; Trempealeau County, very small quantity quarried at Trempealeau; Vernon County, Stoddard and Viroqua; Walworth County, small quantity quarried at Whitewater; Waukesha County, Lannon, Genesee, and Waukesha; Winnebago County, Neenah, Nenasha, Oshkosh, Omro, and Winneconne; Wood County, small quantity quarried at Grand Rapids.

Limestone (crushed stone). Quarried at following places: Brown County, at Green Bay, De Pere, Duckcreek, and Greenleaf; Buffalo County, Alma and Fountain City; Calumet County, Brillion and Chilton; Dane County, Madison; 
Dodge County, near Foxlake, Knowles; and Richwood; Door County, Sebastopol, Sturgeon Bay, and Sawyer; Fond du Lac County, Hamilton, Marblehead, Oakfield, and Waupun; Grant County, Boscobel, Cassville, and Lancaster; Iowa County, Mineral Point; Jefferson County, Watertown; Kewaunee County, Kewaunee; La Crosse County, La Crosse and Onalaska; Lafayette County, Burlington; Manitowoc County, Quarry and Valders; Milwaukee County, Wauwatosa and Milwaukee; Monroe County, Sparta; Outagamie County, Appleton, Black Creek, Hortonville, Kaukauna, and elsewhere; Ozaukee County, Cedarburg, Druecker, and Grafton; Racine County, Burlington and Racine; Rock County, Janesville; Sheboygan County, Sheboygan and Sheboygan Falls; Trempealeau County, Galesville; Vernon County, Stoddard and Viroqua; Waukesha County, Lannon and Waukesha; Winnebago County, Neenah, Omro, and Oshkosh.

Limestone (flux). Quarried: Dodge County, at Knowles and Mayville; Fond du Lac County, Hamilton.

Limestone (hydraulic, water lime, cement rock). Fond du Lac County, quarried at Ripon; Milwaukee County, has been quarried at Milwaukee; Winnebago County, has been quarried at Poygan.

Limestone (lime). Quarried in following places: Buffalo County, at Alma; Calumet County, Brillion, Clifton, and elsewhere; Dodge County, Knowles and Mayville; Door County, Baileys Harbor, Fish Creek, and elsewhere; Fond du Lac County, Hamilton and Marblehead; Green County, Martintown; Kewaunee County, Kewaunee; Lafayette County, Darlington; Manitowoc County, Grimms, Manitowoc, and Quarry; Oconto County, Chase and Gillette; Outagamie County, Black Creek; Ozaukee County, Cedarburg, Druecker, and

- Grafton; Pierce County, Elmwood; Racine County, in vicinity of Racine; Trempealeau County, Aroadia; Vernon County, Stoddard; Washington County, Rockfield and South Germantown; Waukesha County, Templeton.

Limonite. See Brown iron ore.

Magnetite. Ashland and Bayfield counties, in quartzites and slates of the Huronian in Penokee range; Chippewa County, Penokee Gap, along Chippewa River, mixed magnetic and hematite ores, ferruginous schists; Florence County, found in small quantities in Commonwealth iron ores, and in slates and schists, associated with ores and lean iron-bearing rocks; not mined; Jackson County, Black River Falls.

Malachite (green carbonate of copper). Iowa and Lafayette counties, found at several points in lead and zinc region, not mined.

Manganese. See Wad.

Marcasite (white iron pyrites). Iowa County, accompanies sphalerite near Dodgeville; Lafayette County, common with lead and zinc ores in mines near Hazel Green, Meekers Grove, Strawbridge, and Sullsburg; mined.

Ocher. Juneau County, brown ocher has been mined; Waupaca County, red and yellow ocher at Clintonville.

Peat. Underlying many bogs and swamps; attempted use not yet successful.

Porphyry (quartz porphyry). Columbia County, Marcellon; Marquette County, Moundsville; Green Lake County, Berlin and Utley, has been quarried. See also Rhyolite.

Pyrite (iron pyrites). Grant County, mined at Platteville. Abundant in some lead and zinc mines associated with galena and sphalerite, as in Iowa and Lafayette counties.

Quartzite. Quarried: Dodge County, near Portland; Jefferson County, at Waterloo; Juneau County, occurs in large quantities near Necedah; Marathon County, Albeman, Baraboo, and Wausau, for sandpaper. 
Rhyolite. Green Lake County, quarried at Berlin and Utley. See also Porphyry.

Sand (building). Dug at following places: Ashland County, on Oak Island; Fond du Lac County, at Ripon; Kenosha County, Kenosha and Wilmot; Marathon County, Wausau and Rib River; Marinette County, Marinette; Milwaukee County, Milwaukee; Monroe County, Tomah; Racine County, Burlington; Rock County, Janesville and Beloit; Walworth County, Fontana; Waukesha County, Waukesha.

Sand (glass). Dug in Columbia County, at Portage; Monroe County, Tomah; Rock County, Beloit. St. Peter sandstone in many localities, as at Waukau, Winnebago County; not used.

Sand (molding). Dug in following places: Columbia County, Portage; Fond du Lac County, Fairwater; Green Lake County, Berlin; Racine County, Burlington and Racine; Rock County, Beloit.

Sand and gravel. Occur all over eastern and northern portions of State, used locally as road material and for concrete work. Principal deposits, Kenosha County, along Fox River, near Camp Lake and Wilmot; Rock County, near Janesville; and Walworth County, Fontana.

Sandstone. Keweenawan sandstone outcrops on shore of Lake Superior, from Ashland to Superior; Bayfield County, quarried at Houghton, Port Wing, and Siskiwit Point. Cambrian ("Potsdam") sandstone is quarried at Chippewa County, Chippewa Falls; Clark County, abundant in vicinity of Neillsville; small quantity quarried in Crawford County, at Prairie du Chien; Dane County, Madison; Dodge County, near Portland; Dunn County, Colfax and Dunnville; Jackson County, near Black River Falls and at Alma; Juneau County, Mauston; LaCrosse County, Holman, small quantity; Lafayette County, Argyle and Darlington; Monroe County, small quantity quarried at Sparta; Outagamie County, Black Creek; Pepin County, Durand; Portage County, Stevens Point, harder beds used for paving blocks; St. Croix County, small quantity quarried; Sauk County, Ableman, Baraboo, and North Freedom; Trempealeau County, Arcadia, Galesville, and Independence; Waupaca County, near New London; Wood County, small quantity quarried at Grand Rapids and near Centralia.

Smithsonite (carbonate of zinc). Important ore of lead and zinc mines; mined in Grant County; Iowa County, Dodgeville and Fighland; and in Lafayette County.

Specularite. Found with hematite. See Hematite.

Sphalerite (zinc blende). Most important ore of lead and zinc region: Grant County, mined at Platteville, Cuba City, and Hazel Green; Iowa County, near Dodgeville, Highland, Linden, Mineral Point, Mifflin, Rewey, Montfort, and Livingston; Lafayette County, near Benton, Buncombe, Shullsburg, and Meekers Grove.

Trap rock. Douglas County, quarried at South Range.

Wad. Iowa, Grant, and Lafayette counties, widely distributed in small quantities in lead and zinc mines; St. Croix County, occurs near Wilson and other localities in northern Wisconsin; not used.

Zinc ore. See Smithsonite and Sphalerite.

\section{WYOMING.}

Agate (moss). Carbon County, has been mined near Sweetwater River; common in other localities; Laramie County, Wilde and Deercorn mine, 2 miles northwest of Guernsey, moss agate, also red and banded; mined intermittently.

Allanite. Albany County, near Albany station; occurs near line between secs. 3 and 10, T. 14 N., R. 78 W., in pegmatite.

Anglesite (lead sulphate). Carbon County, at Ferris, with galena, cerusite, and quartz. 
Argentite (silver sulphide). Laramie County, with other ores, Laramie Peak.

Asbestos (chiefly chrysotile). Albany County, Laramie Range; Carbon County, in Seminole Mountains; Converse County, occurs 10 miles south of Glenrock; Crook County, Black Hills; Natrona County, mined on Casper Mountain, 8 miles south of Casper, and on Smith Creek, 20 miles southeast of Casper; fair quality; associated with serpentine; 2 mills erected in 1910; small production in 1911.

Asphalt. Fremont County, occurs 4 miles northeast of Fort Washakie at a depth of 1,500 feet in wells drilled for oil, and in nearly all of the oil districts as maltha or brea, west slope of Bighorn Mountains in secs. 28, 29, 32, 33, T. 52 N., R. $89 \mathrm{~W}$.

Azurite (blue carbonate of copper). Albany County, Rambler and Blanche mines at Holmes, Grand Encampment district; Carbon County, occurs but not mined in Seminole district; Crook County, Warrens Peak; Johnson County, Bighorn Mountains; Laramie County, in Hartville Uplift in many prospects; mined in mines of Copper Belt Co.

Barite (heavy spar). Albany County, Medicine Bow Mountains; not mined; Crook County, Black Hills.

Bentonite. Occurs in Albany, Crook, Johnson, Natrona, and Weston counties; used for weighting paper and as adulterant; has been shipped from Rock Creek, Albany County, and Clay Spur, Weston County; Bighorn County, thick deposits in northern part of Bighorn Basin.

Bismuthinite. Albany County, occurs near Cummings City; not mined.

Bismutite. Albany County, has been mined on Jelm Mountain.

Bornite (purple copper ore). Carbon County, mined at Encampment district; Laramie County, formerly mined about Hartville.

Brown iron ore (limonite). Albany County, occurs at Jelm mines; Converse County, near Douglas; Fremont County, on Little Popo Agie Creek; not mined.

Cassiterite. Crook Gounty. Stream tin has been found sparingly at various times in the gulches around Nigger Hill, S. Dak., on State line.

Cement (Portland). Albany County, 15 feet of pure marl in Niobrara formation, 8 miles southwest of Laramie; Laramie County, Niobrara and Minnekahta limestones and Graneros shale member of the Benton, near Cheyenne; Weston County, near Newcastle; not used.

Cerargyrite (horn silver). Crook County, Black Butte mines, Warrens Peak; Fremont County, associated with other ores in Wind River Mountain mines.

Cerusite (carbonate of lead). Albany County,-in schists and diorite at Esterbrook; has been mined and shipped; Carbon County, with galena and quartz at Ferris; Crook County, Black Butte mines, hard and soft carbonates; argentiferous; has been mined.

Chalcocite (copper glance). Albany County, in gneiss and schist at Jelm; gold and silver values; Doane-Rambler and other mines; Carbon County, important ore of Encampment district; Laramie County; important ore in Hartville Uplift; carries gold and silver at some mines.

Chalcopyrite (copper pyrites). Albany County, in granite and schist at Jelm mines; gold values; Carbon County, important ore of Encampment district; Seminole Mountains; Fremont County, South Pass City, with other ores; Laramie County, with iron ores in quartz at Ulcahoma mine, near Hecla; gold and silver values; important ore of Hartville Uplift.

Chromite (chromic iron ore). Converse County, mined at Deer Creek Canyon, 15 miles southwest of Glenrock; Natrona County, similar deposit occurs on Casper Mountain.

Chrysocolla (copper silicate). Laramie County, Hartville iron range; mined at Green Hope, Silver Cliff, and Copper Belt mines. 
Clay (brick). Abundant throughout the State. Brick made in the following localities: Albany County, Laramie; Bighorn County, Basin, Cody, Park, and Worland; Carbon County, Encampment; Converse County, Douglas; Crook County, Gillette; Fremont County, Lander and Thermopolis; Laramie County, Wheatland; Natrona County, Casper; Sheridan County, Sheridan; Sweetwater County, Green River.

Coal. Estimated tonnage of coal in the ground second largest in the United States; about 50 per cent of the area of the State is underlain by coal-bearing formations.

Coal (subbituminous). Bighorn Basin.-Bighorn and Park counties; mines near Basin, Cody, Gebo, Meeteetse, and Thermopolis.

Powder River field.-Largest in the State; lies between Black Hills and Bighorn Mountains; extends from Montana line south to North Platte River; Upper Cretaceous and Eocene; beds up to 45 feet thick; 11,000 square miles underlain by workable beds; mined at Glenrock, Big Muddy, and Inez station, Converse County; Buffalo, Johnson County; and Carney, Dietz, Monarch, and Sheridan, Sheridan County; small quantity for local use taken at many places.

Wind River Basin.-Fremont-Natrona counties; mined in Popo Agie Valley, 8 miles northeast of Lander; 8 feet.

Coal (bituminous coking). Cambria field.-Weston County; large mine at Cambria; about 12 square miles of workable coal; has been coked.

Coal (bituminous and subbituminous). Green River field.-Carbon, Fremont, Sweetwater, and Uinta counties; contains 4,800 square miles of available coal, and 20,000 square miles of coal deeply buried. Bituminous coal mined at Hanna and Rawlins, Carbon County; Rock Springs, Sweetwater County; and Cumberland, Diamondville, Kemmerer, and Spring Valley, Uinta County.

Coal (bituminous). Laramie Basin.-Albany County, mined for local use at Rock Creek, Dutton Creek, and Mill Creek.

Henrys Fork field.- Uinta County, coal widely distributed; little developed.

Cobalt. Albany County, with gold-copper ores in Medicine Bow mines at Holmes; Laramie County, with copper ores in Silver Crown district.

Copper (native). Albany County, in granite at Rambler mine, Grand Encampment district; Fremont County, Copper Mountain district; Laramie County, Hartville Uplift; mined in Iron Belt mines.

Copper minerals. Copper is the predominant metal produced in the following districts: Albany County, Douglas Creek, Horse Creek, Jelm Mountains, and Laramie Peak; Carbon County, Encampment, French Creek, Rankin, and Seminole; Converse County, Warbonnet; Fremont County, Copper Mountain, De Pass, and Owl Creek; Johnson County, Bull Camp; Laramie County, Rawhide Butte, and Hecla; Natrona County, Casper Mountain; Park County, Sunlight; Uinta County, Cockscomb. See also Azurite, Bornite, Chalcocite, Chalcopyrite, Chrysocolla, Covellite, Cuprite, Malachite, and Melaconite.

Corundum (emery). Fremont County, Wind River Range; not mined.

Covellite. Albany County, mined at Rambler mine at Holmes, Grand Encampment district; Laramie County, Hartville Uplift.

Cuprite (red copper oxide). Albany County, Rambler mine at Holmes, Grand Encampment district; Bighorn County, prospects in Bull Creek, Walker Prairie, in Bighorn Mountains; Crook County, associated with hard carbonate ores at Black Buttes and Inyankara Peak; has been mined; Laramie County, mined at Hartville Uplift; prospects in Whalen Canyon, Muskrat Canyon, and Rawhide Buttes.

Epsomite (epsom salt, magnesium sulphate). Long, needle-shaped crystals in soda lakes in Albany, Carbon, and Natrona counties. Brooklyn Lake, area 90 acres, covered with nearly pure deposit, near Wilcox station, Albany County.

Flagstone. Common in same localities as marble, limestone, and sandstones; has been quarried for local use. 
Galena (argentiferous). Albany County, mined for gold and silver in gneiss and schist at Jelm; Carbon County, at Ferris in fissure veins with quartz, cerusite, anglesite; Crook County, has been mined at Black Buttes.

Gold (placer). Albany County, Douglas Creek and Keystone; Bighorn County, Shoshone River and Bald Mountain; Carbon County, on the South French Creek; Crook County, Sand Creek and Nigger Hill; Fremont County, Atlantic and Lewiston; South Pass City, hydraulicking in 1912; Wind River near Riverton, dredge being erected; Johnson County, in Kelley Creek near Buffalo, and in Bighorn Mountains; Park County, Shoshone River and Clark Fork at Crandall; Sweetwater County, Green River; Uinta County, in sands of Snake River, mined intermittently, and on Snake Creek.

Gold (lode). Produced in following districts, in most cases as predominant metal: Albany County, Centennial, Holmes, and Jelm Mountains; Crook County, Bear Lodge and Black Buttes; Fremont County, Atlantic, Owl Creek, and South Pass; Laramie County, Rawhide Buttes and Hecla; Uinta County, Horse Creek, 114 miles north of Kemmerer.

Granite. Abundant in Bighorn Mountains, Hartville Uplift, Laramie Range, and Medicine Bow Range; production small.

Graphite (plumbago). Albany County, near Ironton, has been mined; Fremont County, near Miners Delight; Laramie County, Haystack Hills:

Grindstone. Carbon County, quarried near Rawlins; small production.

Gypsum. Albany County, rock gypsum is mined at Red Butte, and used by one mill for making plaster; mined also west of Sheridan; occurs abundantly in Bighorn, Carbon, Converse, Crook, Fremont, Johnson, Laramie, Natrona, Sweetwater, Uinta, and Weston counties. Gypsite, or earthy gypsum, is dug near Laramie, Albany County, and used by two mills for making plaster.

Halite (common salt). In soda lakes in Albany, Carbon, and Natrona counties; salt springs numerous in several counties; Crook County, at Cambria, salt was made by evaporating water of Salt Creek.

Hematite (red iron ore). Carbon County, extensive deposit north of Rawlins was mined for flux; also on south side of the Seminole Mountains, 35 miles north of Rawlins, and at Jelm mines; Laramie County, chief ore of Hartville iron range; mined at Sunrise, Lone Jack, and Good Fortune mines.

Ilmenite (titanic iron ore). Albany County, Iron Mountain; immense dike; not mined.

Iron. Iron is the chief metal produced in Albany County, at Iron Mountain, and Laramie County, Hartville; and chromic iron ore in Converse County, Deer Creek district. See also Brown iron ore, Chromite, Hematite, Ilmenite, Magnetite, Pyrite, and Pyrrhotite.

Kaolin. Carbon County, occurs near the soda lakes, pure and in quantity.

Lead. See Anglesite, Cerusite, and Galena.

Limestone. Albany County, 3 miles northeast of Laramie City, used for lime in beet-sugar refining. Limestones of Carboniferous and Jurassic age in many counties afford an abundance of good lime suitable for plaster; some of these limestones are hydraulic.

Limestone (building). Quarried: Albany County, at Laramie; Carbon County, Rawlins; Fremont County, Thermopolis; Sweetwater County, Green River.

Limestone (flux). Quarried: Carbon County, at Rawlins; Laramie County, Guernsey.

Limonite (brown hematite). See Brown iron ore.

Magnetite (magnetic iron ore). Albany County, in diorite near Fox Park; Carbon County, with hematite, near Rawlins.

Malachite (green carbonate of copper). Albany County, abundant in Rambler mine, and found in Blanche mine at Holmes, Grand Encampment district; 
Carbon and Crook counties, prospects at Bull Camp and Walker Prairie in Bighorn Mountains, with other ores; Laramie County, important ore of Hartville Uplift; mined at Green Hope, Silver Cliff, and Copper Belt mines.

Manganese ore. Albany County, west side of Laramie Peak.

Marble. Albany County, west flank Laramie Range; east flank Medicine Bow Range; 100-foot ledge of good quality, Cooper Lake station; Converse County, Douglas, red, good quality; Crook County, west flank Black Hills; Fremont County, Rattlesnake Mountains; Johnson County, Bighorn Mountains; Laramie County, east flank Laramie Range, abundant in the Carboniferous; pure white marble occurs 20 miles west of Wheatland.

Marl. Albany County, 15 feet pure marl, 8 miles southwest of Laramie.

Melaconite (black oxide of copper). Albany County, quantity in Rambler mine, Holmes; Laramie County, Michigan mine.

Mica (muscovite). Albany County, in Medicine Bow Range; Converse County, occurs in sizable plates at Glenrock; Fremont County, 60 miles west of Lander; Laramie County, near Ironton and in Haystack Mountains near Hartville.

Mineral paint. Carbon County, made from soft iron ore at Rawlins; suitable material at Hartville, and other iron localities.

Mirabilite (sodium sulphate; glauber salt). In soda lakes in Albany, Carbon, and Natrona counties; has been mined in Albany County near Laramie, and in Natrona County, Sweetwater Valley.

Monazite. Carbon County, in black sands in Bald Mountain district; Sheridan County, reported from Bighorn Mountains.

Natron (carbonate of soda). Common in soda lakes of Albany, Carbon, Natrona, and Sweetwater counties; not marketed.

Natural gas. Bighorn County, Bighorn gas field on slopes of anticline of Bighorn Mountains; gas used at Basin and Greybull; Converse County, small field at Douglas.

Nickel ore. Converse County, in pyrrhotite, Esterbrook district; Laramie County, in ores of Ulcahoma mine, and associated with copper ores, Little London mine, near Hecla.

Niter. Sweetwater County, soda niter in Leucite Hills.

Ozokerite (mineral wax). Fremont County, occurs 20 miles southeast of Lander; Sweetwater and Uinta Counties, near Colorado line, in Tertiary and Cretaceous; shipped east for use in manufacture of ointments and insulating material.

Palladium. Albany County, in copper ores with platinum in Rambler mine at Holmes.

Petroleum. Bighorn County, Byron field, 22 wells, paraffin base; portion shipped to refinery at Crowley; Converse County, Douglas field, 6 wells, heavy black asphaltum oil; local use; Crook County, Belle Fourche field, 20 miles north of Moorcroft, 9 wells, local use for fuel and lubrication; Fremont County, Dallas field, 39 wells, pipe line 9 miles to Wyopo; Wind River Reservation, 2 wells, pipe line 6 miles to railroad; new field begun at Lander; many wells and two kinds of oil; Natrona County, Salt Creek field, 52 producing wells in 1912; 2 pipe lines 50 miles to Casper; 2 refineries at Casper; Powder River field not producing; Uinta County, Labarge field, along east base of Labarge Range, from Labarge Creek to South Piney, 20 wells; Spring Valley field; numerous small wells from Spring Valley, north, 5 miles; Weston County, several wells near Newcastle got small quantity of oil.

Phosphate rock. Uinta County. Mined and shipped at Cokeville; large area 140 miles long; beds 10 feet thick.

Platinum. Albany County, in copper ores of the Rambler mine, at Holmes; Uinta County, in concentrates from Snake River placers. See also Sperrylite.

Potash. Sweetwater County, large quantity in rocks of Leucite Hills; no methods known for making it commercially available 
Pumice (volcanic ash). Albany County, beds 4 to 6 feet thick near Sportsmans Lake. Pyrite (iron pyrites). Albany County, with copper ores, Encampment district, in Jelm and Ulcahoma mines; mined for gold and silver content; Sweetwater and other counties, with gold and quartz veins; little worked.

Pyrrhotite. Albany and Converse counties, underlying iron oxides at Cooney Hill and with copper ores in prospects in North Laramie district.

Salt. Uinta County, mined at Auburn; salt produced from brine south of Star Valley on Salt Creek. See also Halite.

Sand (building). Dug in small quantity for local use at many places.

Sand (glass). Albany County, from soft sandstone of Casper formation; has been quarried 3 miles east of Laramie.

Sandstone. Albany County, quarried at Laramie, small quantity; Carbon County, Rawlins; Fremont County, Lander and Thermopolis; Laramie County, Iron Mountain; Uinta County, Cumberland, Evanston, Oakley, Frontier, and Glencoe, and at many other towns and villages.

Shale. Used for brickmaking at Laramie, Albany County.

Silver (native). Laramie County, Silver Cliff mine in Hartville Uplift, and in other copper mines and prospects. See also Cerargyrite.

Sperrylite. Albany County, has been found at Rambler mine, Holmes.

Sphalerite. Laramie County, mined with hematite in Hartville mines.

Sulphur. Fremont County, massive and in small crystals in travertine near Thermopolis; mined and shipped; in local deposits on south side of Shoshone River; at lower end of Shoshone Canyon, and on west side of Sulphur Creek; Park County, occurs in the Sunlight Basin, 52 miles northwest of Cody; has been mined near Cody.

Sylvanite. Crook County, recently discovered in Bear Lodge Mountains.

Tennantite. Laramie County, has been mined north of Guernsey in Copper Bottom prospect, SE. $\frac{1}{1}$ sec. 23, T. 29 N., R. $65 \mathrm{~W}$.

Tenorite. Albany County, quantity at Rambler mine, Holmes.

Tin. See Cassiterite.

Trona (sodium carbonate). Sweetwater County, number of wells at Greenwater; produce good soda; shipped.

Wolframite. Albany County, small stringer in copper mine near Holmes.

Wood, silicified. Abundant in Yellowstone National Park.

Zinc. See Sphalerite.

\section{GLOSSARY AND INDEX.}

The definitions in this glossary are not intended to be sufficiently full and detailed for the determination of unknown minerals. They are expected only to show definitely what is meant by the terms used in the text of the paper. The aim has been to make the definitions as clear as possible for the reader not used to technical terms. However, the intricacies of the subject do not allow that all definitions shall be made perfectly clear to those wholly unfamiliar with minerals or with chemical terms and symbols.

In the hope of adding to the usefulness of the definitions the percentage of those constituents which ordinarily make the mineral of value, and items that may make the relations of the minerals clearer, have generally been given.

Free use has been made of Dana's monumental "System of mineralogy" (6th ed.), Kemp's "Handbook of rocks" (5th ed.), and publications of the United States Geological Survey. The Standard and 
Century dictionaries and other standard works have also been consulted.

It is thought that a table of atomic weights will be of use in connection with formulas of the minerals, and therefore the list given by the International Committee on Atomic Weights, 1913, is printed below.

International atomic weights, $19.13 .^{1}$

\begin{tabular}{|c|c|c|c|}
\hline & $\begin{array}{l}\text { A tomic } \\
\text { weight. }\end{array}$ & & Atomic \\
\hline Aluminum. & 27.1 & Molybdenum....... & 96.0 \\
\hline . $\mathrm{Sb}$ & 120.2 & Neodymium......... & 144.3 \\
\hline$\ldots \mathrm{A}$ & 39.88 & Neon........ & 20.2 \\
\hline ..As & 74. 96 & Nickel................Ni & 58.68 \\
\hline$\ldots \ldots \ldots$ Ba & 137. 37 & Niton (radium emanation)...Nt & 222.4 \\
\hline$\ldots \ldots \ldots \ldots . . \mathrm{Bi}$ & 208.0 & Nitrogen.................. & 14.01 \\
\hline$\ldots \ldots \ldots \ldots$ & 11.0 & Osmium... & 190.9 \\
\hline$\ldots \ldots \ldots \ldots \mathrm{Br}$ & 79.92 & Oxygen.... & 16. 0 \\
\hline$\ldots \ldots \ldots \ldots \mathrm{Cd}$ & 112.40 & Palladium............ & 106.7 \\
\hline$\ldots \ldots \ldots \ldots . \mathrm{Cs}$ & 132.81 & Phosphorus............. & 31.04 \\
\hline ..........Ca & 40.07 & a & 195.2 \\
\hline$\ldots \ldots \ldots \ldots, \ldots$ & 12.0 & Potassium............. & 39.10 \\
\hline$\ldots \ldots \ldots \ldots . \mathrm{Ce}$ & 140.25 & Praseodymium.......... & 140.6 \\
\hline$\ldots \ldots \ldots \ldots \mathrm{Cl}$ & 35.46 & Radium............... & 226.4 \\
\hline Chromium.............. Cr & 52.0 & Rnodrum.................. & 102.9 \\
\hline Cobalt.................. Co & 58.97 & $\ldots R b$ & 85.45 \\
\hline$\ldots \ldots \ldots \ldots \ldots \mathrm{Cb}$ & 93.5 & $1 \ldots \ldots \ldots \ldots$ & 101.7 \\
\hline$\ldots \ldots \ldots \ldots \ldots \ldots . \mathrm{Cu}$ & & $\ldots \ldots \ldots \ldots \ldots$ & 150.4 \\
\hline Dysprosium.............. Dy & 162.5 & m.............. & 44. 1 \\
\hline Erbium................. & 167.7 & $\ldots$ Se & 79.2 \\
\hline Europium............... & 152.0 & , & 28.3 \\
\hline Fluor & 19.0 & ...Ag & 107.88 \\
\hline Gadolinium............Gd & 157.3 &. $\mathrm{Na}$ & 23.00 \\
\hline (n.............. & 69.9 & Strontium.... & 87.63 \\
\hline Germanium...........Ge & 72.5 & & 32.07 \\
\hline$\ldots \ldots \ldots \ldots \ldots$ Gl & 9. & $\ldots \mathrm{Ta}$ & 181.5 \\
\hline$\ldots \ldots \ldots \ldots \ldots \ldots \ldots$ Au & 197.2 & $\ldots \mathrm{Te}$ & 127.5 \\
\hline Helium................. He & 3.99 & a................ & 159.2 \\
\hline Holmium............... & 163.5 & $\ldots \mathrm{Tl}$ & 204.0 \\
\hline Hydrogen............... & 1.008 & ..Th & 232.4 \\
\hline Indium................ & 114.8 & Thulium....... & 168.5 \\
\hline Todine.................. & 126. 92 & Tin.................. & 119.0 \\
\hline Iridium................. & 193.1 & itanium. . . . . . . . . & 48. 1 \\
\hline Iron...$\ldots \ldots \ldots \ldots \ldots$ & 55.84 & $n \ldots \ldots \ldots \ldots$. & 184.0 \\
\hline Krypton.............. & 82.92 & $1 \ldots \ldots \ldots \ldots . .$. & 238.5 \\
\hline Lanthanum............La & 139.0 & Vanadium............. & 51.0 \\
\hline Lead...................Pb & 207.10 & ......Xe & 130.2 \\
\hline$\ldots \ldots \ldots \ldots \ldots \ldots \operatorname{Li}$ & 6.94 & m (Neoytterbium). Yb & 172.0 \\
\hline ................Lu & 174.0 & $\ldots \ldots \ldots \ldots \ldots \ldots$ Yt & 89.0 \\
\hline$u m \ldots \ldots \ldots \ldots \ldots . . \ldots g$ & 24. & $\ldots \mathrm{Zn}$ & 65.37 \\
\hline ese..............Mn & 54.93 & Zirconium... & 90.6 \\
\hline Mercury............. & 200.6 & & \\
\hline
\end{tabular}

1 Clarke, F. W., Thorpe, T. E., Ostwald, W., and Urbain, G., Annual report of the International Committee on Atomic Weights, 1913: Am. Chem. Soc. Jour., vol. 34, p. 1439, Nov., 1912. 
Abrasives. See Burrstone, Corundum, Emery, Garnet, Grindstone, Infusorial earth, Millstone, Novaculite, Oilstone, Pumice, Scythestone, Tripoli, Volcanic ash, Whetstone.

Acanthite. A silver sulphide, $\mathrm{Ag}_{2} \mathrm{~S}$. It contains 87 per cent silver.

Colorado.

Actinolite. A light-green calcium-magnesium-iron amphibole, $3 \mathrm{Mg}(\mathrm{Fe}) \mathrm{O} . \mathrm{CaO}$. $4 \mathrm{SiO}_{2}$. See Asbestos.

Eggerite. See Wurtzilite.

Egirite. A monoclinic pyroxene having the general composition, $\mathrm{Na}_{2} \mathrm{O} \cdot \mathrm{Fe}_{2} \mathrm{O}_{3}$. $4 \mathrm{SiO}_{2}$. Vanadiferous ægirite near Libby, Mont., contains 4 per cent of $\mathrm{V}_{2} \mathrm{O}_{3}$, which replaces a part of the $\mathrm{Fe}_{2} \mathrm{O}_{3}$.

Montana.

Eonite. See Wurtzilite.

Agalmatolite. See Pyrophyllite.

California, North Carolina.

Agate. A variegated chalcedony, $\mathrm{SiO}_{2}$.

Arkansas, California, Colorado, Connecticut, Michigan, Montana, Nebraska, New Jersey, North Carolina, Rhode Island, Texas, Wyoming.

Alabandite. Manganese sulphide, MnS.

Colorado.

Alabaster. Compact fine-grained gypsum, white or delicately shaded. See Gypsum.

Arizona, California.

Albertite. A jet-black pitchlike, brittle hydrocarbon with conchoidal fracture, differing from ordinary asphalt in being only partly (about 30 per cent) soluble in turpentine and in very imperfect fusion when heated. Specific gravity about 1.1 .

Albite, Soda feldspar. A silicate of aluminum and sodium, $\mathrm{Na}_{2} \mathrm{O} \cdot \mathrm{Al}_{2} \mathrm{O}_{3} \cdot 6 \mathrm{SiO}_{2}$. See Feldspar.

Allanite, Orthite. A complex variable silicate of aluminum, iron, the cerium metals (cerium, didymium, lanthanum), and in smaller quantity those of the yttrium group.

New York, North Carolina, Texas, Virginia, Wyoming.

Almandite. An iron-aluminum garnet, $3 \mathrm{FeO} \cdot \mathrm{Al}_{2} \mathrm{O}_{3} \cdot 3 \mathrm{SiO}_{2}$. Used as a gem (precious garnet).

Colorado, New York, North Carolina, Oregon.

Altaite. A lead telluride, $\mathrm{PbTe}$.

Colorado.

Aluminum. A metallic element, Al. Not found native. See Bauxite, Halloysicie.

Alum salts. Natural salts from which alum can be made. See also Halloysite, Kalinite.

Alabama, California, Massachusetts, Nevada, New Mexico, Tennessee, Texas, Virginia.

Alunite. A hydrous sulphate of aluminum and potassium, $\mathrm{K}_{2} \mathrm{O} .3 \mathrm{Al}_{2} \mathrm{O}_{3} \cdot 4 \mathrm{SO}_{3} \cdot 6 \mathrm{H}_{2} \mathrm{O}$. It contains 11.4 per cent potash, $\mathrm{K}_{2} \mathrm{O}$.

California, Colorado, Nevada, Utah.

Alunogen. A hydrous aluminum sulphate, $\mathrm{Al}_{2} \mathrm{O}_{3} \cdot 3 \mathrm{SO}_{3} \cdot 18 \mathrm{H}_{2} \mathrm{O}$.

New Mexico.

Amalgam. A native compound of silver and mercury, in which the percentage of silver ranges from 27.5 to 95.8 . Native gold amalgam carrying 39 to 42.6 per cent gold has also been found.

California, Colorado.

Amazon stone. A green microcline, a variety of potash feldspar. Used as a gem. Colorado, Virginia. 
Amblygonite. A fluo-phosphate of aluminum and lithium, $\mathrm{Li}(\mathrm{AlF}) \mathrm{PO}_{4}$.

California, South Dakota.

Amethyst. A purple or bluish-violet quartz, $\mathrm{SiO}_{2}$. Used as a gem.

Connecticut, Colorado, Georgia, Maine, Michigan, New Jersey, North Carolina,

Pennsylvania, South Carolina, Texas, Virginia.

Amianthus. See Asbestos.

Amphibole. A group name for a series of minerals which, although crystallizing in different systems, are closely related in form, as shown by the common prismatic cleavage of $54^{\circ}$ to $56^{\circ}$, also in optical characters and chemical composition; they consist essentially of silicates of lime, iron, magnesia, alumina, and in some cases soda. Hornblende is the commonest variety. See Asbestos.

Andalusite. An aluminum silicate, $\mathrm{Al}_{2} \mathrm{O}_{3} \cdot \mathrm{SiO}_{2}$. Sometimes used as a semiprecious stone. See Chiastolite.

California, Massachusetts.

Andradite. The common calcium-iron garnet, $3 \mathrm{CaO} \cdot \mathrm{Fe}_{2} \mathrm{O}_{3} \cdot 3 \mathrm{SiO} \mathrm{O}_{2}$. Arizona.

Anglesite. Lead sulphate, $\mathrm{PbSO}_{4}$. Contains 68 per cent lead.

Arizona, California, Colorado, Idaho, Missouri, Nevada, New Mexico, Utah, Wyoming.

Anhydrite. Calcium sulphate, $\mathrm{CaSO}_{4}$ or $\mathrm{CaO} . \mathrm{SO}_{3}$. Contains 41.2 per cent lime and 58.8 per cent sulphur trioxide. Usually associated with gypsum, to which it alters. Differs from it in being harder and in lacking water of crystallization. California, Michigan.

Annabergite. A hydrous nickel arsenate, $\mathrm{Ni}_{3} \mathrm{As}_{2} \mathrm{O}_{8} \cdot 8 \mathrm{H}_{2} \mathrm{O}$. Nevada.

Anthracite, Hard coal. A hard black lustrous coal containing 85 to 95 per cent carbon as against 70 to 85 per cent in bituminous or "soft" coal. Sec Coal.

Colorado, Massachusetts, New Mexico, Pennsylvania, Rhode Island.

Antimony. An element, Sb. Sometimes found native. See also Cervantite, Dyscrasite, Jamesonite, Nagyagite, Polybasite, Stibiconite, Stibnite.

Arizona, Arkansas, California, Colorado, Idaho, Montana, Nevada, New Mexico, Utah, Washington.

Antimony glance. See Stibnite.

Antimony ocher. See Stibiconite.

Apatite. A calcium phosphate containing a little fluorine or chlorine, $\mathrm{Ca}_{4}(\mathrm{CaF})$ $\left(\mathrm{PO}_{4}\right)_{3}$ or $\mathrm{Ca}_{4}(\mathrm{CaCl})\left(\mathrm{PO}_{4}\right)_{3}$. The fluor-apatite contains 42.3 per cent $\mathrm{P}_{2} \mathrm{O}_{5}$ and the chlor-apatite 41 per cent $\mathrm{P}_{2} \mathrm{O}_{5}$.

California, Maine, New Jersey, New York, Virginia.

Apophyllite. A calcium-hydrogen silicate sometimes containing potassium and fluorine, $\mathrm{K}_{2} \mathrm{O} .8 \mathrm{CaO} \cdot 16 \mathrm{SiO}_{2} \cdot 16 \mathrm{H}_{2} \mathrm{O}$. Occasionally used as a gem.

California.

Aquamarine. A transparent light bluish-green beryl. Used as a gem.

Colorado, Connecticut, Massachusetts, North Carolina, South Carolina.

Argentite, Silver glance. A silver sulphide, $\mathrm{Ag}_{2} \mathrm{~S}$. Contains 87 per cent silver. Arizona, Colorado, Idaho, Maine, Montana, Nevada, New Mexico, Oregon, Utah, Washington, Wyoming.

Arsenic. An element, As. Sometimes found native. See also Arsenopyrite, Mimetite, Niccolite, Orpiment, Realgar, Scorodite, Smaltite, Sperrylite.

California, Montana, Nevada, Virginia, Washington.

Arsenical nickel. See Niccolite.

Arsenopyrite, Mispickel. A sulpharsenide of iron, FeAsS. Contains 46 per cent arsenic, equivalent to 57.7 per cent white arsenic, $\mathrm{As}_{2} \mathrm{O}_{3}$.

Arizona, California, Colorado, Connecticut, Georgia, Idaho, Maine, Montana, Nevada, New Hampshire, New York, North Carolina, Oregon, South Dakota, Vermont, Virginia, Washington, Wisconsin. 
Asbestos. A fibrous variety of amphibole. In commerce it includes also fibrous serpentine (chrysotile). Amianthus is a fine silky amphibole asbestos.

Alabama, Arizona, California, Colorado, Connecticut, Delaware, Georgia, Idaho, Maryland, Massachusetts, New York, North Carolina, Oregon, South Carolina, Tennessee, Texas, Vermont, Virginia, Washington, Wisconsin, Wyoming.

Asphalt, Mineral pitch. A complex compound of various hydrocarbons, part of which are oxygenated. Related in origin to petroleum. Is brown or brownish black in color, melts at $90^{\circ}$ to $100^{\circ} \mathrm{F}$., and is mostly or wholly soluble in turpentine. See also Albertite, Elaterite, Gilsonite, Grahamite, Impsonite, Nigrite, -Wurtzilite.

Alabama, Arkansas, California, Indiana, Kentucky, Missouri, Nevada, Oklahoma, Texas, Utah, Wyoming.

Auerlite. A silico-phosphate of thorium containing about 70 per cent of thorium. Like zircon in form.

North Carolina.

Autunite. A hydrous phosphate of uranium and calcium; $\mathrm{CaO} .2 \mathrm{UO}_{3} \cdot \mathrm{P}_{2} \mathrm{O}_{5} \cdot 8 \mathrm{H}_{2} \mathrm{O}$. Contains 62.7 per cent $\mathrm{UO}_{3}$, equivalent to 61.6 per cent $\mathrm{U}_{3} \mathrm{O}_{8}$, and is radioactive. South Dakota, Utah.

Axinite. A boro-silicate of aluminum and calcium with varying quantities of iron and manganese. Exact composition doubtful.

California.

Azurite. Blue copper carbonate, $\mathrm{CuCO}_{3} \cdot \mathrm{Cu}(\mathrm{OH})_{2}$. Contains 46 per cent copper.

Arizona, Arkansas, California, Colorado, Connecticut, Idaho, Missouri, Montana, Nevada, New Jersey, New Mexico, North Carolina, Oklahoma, Oregon, Pennsylvania, South Dakota, Tennessee, Utah, Virginia, Wisconsin, Wyoming.

Azurmalachite. A mixture of blue and green copper carbonates.

Arizona.

Barite, Heavy spar. Barium sulphate, $\mathrm{BaSO}_{4}$.

Alabama, Arrkansas, Colorado, Connecticut, Georgia, Kentucky, Maryland, Missouri, Nevada, New-Mexico, New York, North Carolina, Oregon, Pennsylvania, South Carolina, Tennessee, Texas, Utah, Virginia, West Virginia, Wisconsin, Wyoming.

Basalt. A dense to glassy dark-colored basic volcanic rock, composed essentially of soda-lime feldspar and pyroxene, with or without olivine, and with accessory magnetite or ilmenite and apatite. The glassy varieties are composed of the uncrystallized constituents of these minerals and are called obsidian.

California (see Road metal), Connecticut (see Trap rock), Massachusetts (see Trap rock), New Jersey (see Trap rock), Oregon, Washington.

Bauxite. Hydrated alumina, essentially $\mathrm{Al}_{2} \mathrm{O}_{3}, 2 \mathrm{H}_{2} \mathrm{O}$.

Alabama, Arkansas, California, Colorado, Georgia, Tennessee, Virginia.

Beaverite. A hydrous sulphate of copper, lead, and ferric iron, CuO.PbO. $\mathrm{Fe}_{2} \mathrm{O}_{3}$. $2 \mathrm{SO}_{3} .4 \mathrm{H}_{2} \mathrm{O}$.

Utah.

Benitoite. A blue barium-titanium silicate, so far found only in California, $\mathrm{BaTiSi}_{3} \mathrm{O}_{9}$. Used as a gem.

California.

Bentonite. A bedded plastic clay which swells immensely upon wetting.

California, Montana, Utah, Wyoming.

Beryl. A glucinum-aluminum silicate, $3 \mathrm{GlO} \cdot \mathrm{Al}_{2} \mathrm{O}_{3} \cdot 6 \mathrm{SiO}_{2}$. Used as gem when clear and well colored. The grass-green variety is known as emerald; light-green, beryl; blue-green, aquamarine. Contains 14 per cent glucina (glucinum oxide).

Alabama, California, Colorado, Connecticut, Georgia, Maine; Massachusetts, New Hampshire, North Carolina, Pennsylvania, South Carolina, South Dakota, Utah, Virginia. 
Bindheimite. A hydrous antimonate of lead; an oxidation product of jamesonite. Nevada.

Biotite. A black or brown mica. See Mica.

Bismuth. An element, Bi. Found as a native metal. See also Bismuthinite, Bismutite, Cosalite, and Tetradymite. .

Arizona, California, Connecticut, Nevada, New Mexico, Utah, Washingtoin.

Bismuthinite. Bismuth sulphide, $\mathrm{Bi}_{2} \mathrm{~S}_{3}$. Contains 81.2 per cent bismuth.

Colorado, Connecticut, Nevada, Wyoming.

Bismutite. A basic bismuth carbonate of doubtful composition, perhaps $\mathrm{Bi}_{2} \mathrm{O}_{3}$. $\mathrm{CO}_{2} \cdot \mathrm{H}_{2} \mathrm{O}$. Contains about 80 per cent bismuth.

California, New Mexico, Utah, Wyoming.

Bitumen. See Asphalt. A general name for various solid and semisolid hydrocarbons. In 1912 the term was used by the American Society for Testing Materials to include all those hydrocarbons which are soluble in carbon bisulphide, whether gases, easily mobile liquids, viscous liquids, or solids.

California, Tennessee.

Blackjack. See Sphalerite.

Black oxide of manganese. See Pyrolusite.

Blende. See Sphalerite.

Bloodstone. A variety of chalcedony or jasper, dark green in color, interspersed with small red spots. Used as a gem.

California.

Bluestone. The commercial name for a dark bluish-gray feldspathic sandstone or arkose. The color is due to the presence of fine grains of black and dark-green minerals, chiefly hornblende and chlorite. The rock is extensively quarried in New York. Its toughness, due to slight metamorphism, and the ease with. which it may be split into thin slabs especially adapt it for use as flagstone. The term has been locally applied to other rocks, among which are dark-blue slate and blue limestone.

New York, Pennsylvania.

Blue vitriol. See Chalcanthite.

Bog iron ore. See Brown iron ore.

Bog manganese. See Wad.

Borax, Tincal. Sodium biborate, $\mathrm{Na}_{2} \mathrm{~B}_{4} \mathrm{O}_{7} \cdot 10 \mathrm{H}_{2} \mathrm{O}$, or $\mathrm{Na}_{2} \mathrm{O} \cdot 2 \mathrm{~B}_{2} \mathrm{O}_{3} \cdot 10 \mathrm{H}_{2} \mathrm{O}$.

California, Nevada, Oregon, Texas.

Bormite, Erubescite, Peacock copper ore. A sulphide of copper and iron, $\mathrm{Cu}_{3} \mathrm{FeS}_{3}$. Contains 62 per cent copper.

Arizona, California, Colorado, Connecticut, Idaho, Maine, Maryland, Montana, Nevada, New Hampshire, New Mexico, North Carolina, Oregon, South Dakota, Utah, Virginia, Washington, Wyoming.

Braunite. A somewhat variable manganese silicate, approximately $3 \mathrm{Mn}_{2} \mathrm{O}_{3} \cdot \mathrm{MnO}$. $\mathrm{SiO}_{2}$.

Arkansas, Georgia, New Jersey, Vermont.

Brittle silver ore. See Stephanite.

Brochantite. A basic sulphate of copper, $\mathrm{CuSO}_{4} \cdot 3 \mathrm{Cu}(\mathrm{OH})_{2}$.

Arizona, Colorado, New Mexico.

Brongniardite. A lead-silver sulphantimonide, $\mathrm{PbAg}_{2} \mathrm{Sb}_{2} \mathrm{~S}_{5}$. Contains 26.2 per cent silver.

Arizona.

Bromine. An element, Br. It does not occur native but is derived in large quantities from brines. Its form of occurrence in the brines is unknown.

Michigan, Ohio, Pennsylvania, West Virginia.

Bromyrite. A silver bromide, AgBr. Contains 57 per cent silver.

Nevada, New Mexico. 
Brown iron ore, Iimonite, Brown hematite, Bog iron ore. Its approximate formula is $2 \mathrm{Fe}_{2} \mathrm{O}_{3} \cdot 3 \mathrm{H}_{2} \mathrm{O}$, equivalent to about 59.8 per cent iron. Probably a mixture of hydrous iron oxides.

Alabama, Arizona, Arkansas, California, Colorado, Connecticut, Delaware, Florida, Georgia, Idaho, Indiana, Iowa, Kentucky, Louisiana, Maine, Maryland, Massachusetts, Minnesota, Mississippi, Missouri, Montana, Nevada, New Hampshire, New Jersey, New Mexico, New York, North Carolina, Ohio, Oregon, Pennsylvania, Rhode Island, South Dakota, Tennessee, Texas, Utah, Vermont, Virginia, Washington, West Virginia, Wisconsin, Wyoming.

Brownstone. See Sandstone.

Burrstone. A tough siliceous rock used for millstones. See Millstone.

Calamine. A hydrous zinc silicate, $\mathrm{H}_{2} \mathrm{O} .2 \mathrm{ZnO}$. $\mathrm{SiO}_{2}$. Contains 54 per cent zinc. Arkansas, Connecticut, Kansas, Maryland, Missouri, Nevada, Oklahoma, Pennsylvania, Tennessee, Virginia.

Calaverite. A telluride of gold and silver, (Au.Ag) $\mathrm{Te}_{2}$. Variable in composition, but contains about 39.5 per cent gold and 3.1 per cent silver.

California, Colorado.

Calciovolborthite. A vanadate of copper and calcium. Contains about 38 per cent $\mathrm{V}_{2} \mathrm{O}_{5}$.

California, Colorado, Utah

Calcite. Hexagonal (rhombohedral) calcium carbonate, the more common form of $\mathrm{CaO} . \mathrm{CO}_{2}$. Contains 56 per cent lime, $\mathrm{CaO}$.

Kentucky, Minnesota, Missouri, Tennessee.

Caledonite. A green basic sulphate of lead and copper of uncertain composition. California.

Californite. A compact, massive vesuvianite, used as an ornamental stone. California.

Carnotite. A canary-yellow mineral, somewhat variable in composition, containing uranium and vanadium, with either or both lime and potash. Is ordinarily a mixture of true carnotite, $2 \mathrm{UO}_{3} \cdot \mathrm{V}_{2} \mathrm{O}_{5} \cdot \mathrm{K}_{2} \mathrm{O}+\mathrm{xH}_{2} \mathrm{O}$, and tyuyamunite, $2 \mathrm{UO}_{3}$. $\mathrm{V}_{2} \mathrm{O}_{5} \cdot \mathrm{CaO}+\mathrm{xH}_{2} \mathrm{O} .{ }^{1}$ Is radioactive and is used as a source of radium.

Arizona, Colorado, Pennsylvania, Utah.

Cassiterite. Tin oxide, $\mathrm{SnO}_{2}$. Contains 79 per cent tin. The mineral from which practically all tin is obtained.

California, Colorado, Connecticut, Georgia, Idaho, Maine, New Hampshire, North Carolina, South Carolina, South Dakota, Texas, Virginia, Washington, Wyoming.

Catlinite, Indian pipestone. A red clay found in southwestern Minnesota and formerly used by the Indians for making pipes.

Minnesota.

Celestite. Strontium sulphate, $\mathrm{SrO} \cdot \mathrm{SO}_{3}$.

Arizona, Arkansas, California, Ohio, Texas.

Cement rock. An argillaceous limestone used in the manufacture of natural hydraulic cement. Contains lime, silica, and alumina in varying proportions, and usually more or less magnesia.

Alabama, Arizona, Arkansas, California, Colorado, Connecticut, Delaware, Florida, Georgia, Illinois, Indiana, Iowa, Kansas, Kentucky, Maine, Maryland, Michigan, Minnesota, Mississippi, Missouri, Montana; Nebraska, Nevada, New Jersey, New Mexico, New York, North Carolina, North Dakota, Ohio, Oklahoma, Oregon, Pennsylvania, South Carolina, South Dakota, Tennessee, Texas, Utah, Vermont, Virginia, Washington, West Virginia, Wisconsin, Wyoming. 
Cerargyrite, Horn silver. Silver chloride, $\mathrm{AgCl}$. Contains 75 per cent silver.

Arizona, California, Colorado, Idaho, Maine, Montana, Nevada, New Mexico, South Dakota, Utah, Washington, Wyoming.

Cerusite. Lead carbonate, $\mathrm{PbO} \cdot \mathrm{CO}_{2}$. Contains 77.5 per cent lead.

Arizona, Arkansas, Colorado, Connecticut, Idaho, Illinois, Iowa, Kansas, Missouri, Montana, Nevada, New Mexico, New York, North Carolina, Oklahoma, Oregon, Pennsylvania, South Dakota, Tennessee, Utah, Virginia, Washington, Wisconsin, Wyoming.

Cervantite. An orthorhombic antimony oxide, $\mathrm{Sb}_{2} \mathrm{O}_{4}$. Infusible before the blowpipe.

Jdaho, New Mexico.

Chalcanthite, Blue vitriol, Copper sulphate. A hydrous copper sulphate, $\mathrm{CuO} . \mathrm{SO}_{3}+5 \mathrm{H}_{2} \mathrm{O}$.

Arizona, California, Colorado, Idaho, Montana, Nevada, North Carolina, Tennessee.

Chalcedony. A transparent or more generally translucent cryptocrystalline quartz. Lines or fills cavities in rocks.

Arizona, California, Colorado, Idaho, Iowa, Nebraska, Nevada, Oregon.

Chalcocite, Copper glance. A copper sulphide, $\mathrm{Cu}_{2} \mathrm{~S}$. Contains 79.8 per cent copper.

Arizona, California, Colorado, Connecticut, Georgia, Idaho, Maine, Maryland, Minnesota, Missouri, Montana, Nevada, New Hampshire, New Jersey, New Mexico, North Carolina, Oregon, Pennsylvania, South Dakota, Tennessee, Texas, Utah, Virginia, Washington, Wisconsin, Wyoming.

Chalcophanite, Hydrofranklinite. A hydrous manganese-zinc oxide (Mn, Zn)O. $2 \mathrm{MnO}_{2} .2 \mathrm{H}_{2} \mathrm{O}$.

New Mexico.

Chalcopyrite, Copper pyrites, Yellow copper ore. A sulphide of copper and iron, $\mathrm{CuFeS}_{2}$. Contains 34.5 per cent copper.

Alabama, Arizona, California, Colorado, Connecticut, Georgia, Idaho, Maine, Massachusetts, Minnesota, Missouri, Montana, Nevada, New Hampshire, New Jersey, New Mexico, New York, North Carolina, Oregon, Pennsylvania, Rhode Island, South Carolina, South Dakota, Tennessee, Texas, Utah, Vermont, Virginia, Washington, Wisconsin, Wyoming.

Chalk. A soft, compact, light-colored limestone composed of the delicate skeletons of rhizopods and other marine organisms.

Alabama, Iowa, Nebraska.

Chert, Hornstone. An impure flint or chalcedony with splintery fracture. More brittle than flint.

Alabama, Iowa, Tennessee.

Chiastolite, Macle. A variety of andalusite, aluminum silicate, $\mathrm{Al}_{2} \mathrm{O}_{3} \cdot \mathrm{SiO}_{2}$, in which carbonaceous impurities are arranged in a regular manner along the longer axis of the crystal, in some varieties like the $X$ (Greek "chi"), whence the name.

Massachusetts. (Found in many other States but not utilized.)

China clay. See Kaolin.

Chlorastrolite. Not a definite mineral but probably a mixture of zeolites. Found as small, light bluish-green pebbles, with finely radiated structure, on Isle Royale, Lake Superior. Used as a gem.

Michigan.

Chromite. A chromate of iron, $\mathrm{FeO} \cdot \mathrm{Cr}_{2} \mathrm{O}_{3}$. Contains 68 per cent chromic oxide.

California, Georgia, Maryland, Massachusetts, New York, North Carolina, Oregon, Pennsylvania, Virginia, W.yoming.

$29123^{\circ}-14-$ Bull. $585-15$ 
Chrysoberyl. A glucinum-aluminum oxide, $\mathrm{GlO}_{2} \cdot \mathrm{Al}_{2} \mathrm{O}_{3}$, known as cat's-eye when it has a chatoyant effect.

Connecticut, New York.

Chrysocolla. A hydrous copper silicate. Contains theoretically about 36 per cent of copper.

Arizona, California, Colorado, Maryland, Michigan, Montana, Nevada, New Jersey, New Mexico, North Carolina, Oregon, Utah, Virginia, Wyoming.

Chrysolite. See Olivine.

Arizona.

Chrysoprase. An apple-green chalcedony, the color of which is due to nickel. Arizona, California.

Chrysotile. Fibrous serpentine. See Asbestos.

Arizona, Maryland, Vermont, Wyoming.

Cinnabar. A vermilion mercury sulphide, $\mathrm{HgS}, 86$ per cent mercury. It is the common ore of mercury and forms hexagonal crystals. See Metacinnabarite.

Arizona, California, Colorado, Idaho, Nevada, New Mexico, Oregon, South Dakota, Texas, Utah.

Clay. A natural substance or rock which, when finely ground and mixed with water, forms a pasty, moldable mass that preserves its shape when air dried; the particles soften and coalesce upon being highly heated and form a stony mass upon cooling. Clays vary greatly mineralogically and chemically and consequently in their physical properties. Most of them contain many impurities, but their base is hydrous aluminum silicate.

Every State.

Coal. A carbonaceous substance formed from the remains of vegetation by partial decomposition.

Alabama, Arizona, Arkansas, California, Colorado, Georgia, Idaho, Illinois, Indiana, Iowa, Kansas, Kentucky, Maryland, Massachusetts, Michigan, Missouri, Montana, Nebraska, Nevada, New Mexico, North Carolina, North Dakota, Ohio, Oklahoma, Oregon, Pennsylvania, Rhode Island, South Carolina, South Dakota, Tennessee, Texas, Utah, Virginia, Washington, West Virginia, Wyoming.

Cobalt. A metallic element, Co, not found native. See Cobaltite, Erythrite, Lin- ' næite, Smaltite.

- Colorado, Idaho, Missouri, Nevada, South Carolina, Tennessee, Washington, Wyoming.

Cobalt bloom. See Erythrite.

Cobalt pyrites. See Linnæite.

Cobaltite, Cobalt glance. A sulpharsenide of cobalt, CoAsS. Contains 35.5 per cent of cobalt.

Oregon.

Coke. Coal from which the volatile constituents have been driven off by heat, so that the fixed carbon and the ash are fused together. Commonly artificial, but natural coke is also known.

New Mexico, Virginia.

Colemanite. A hydrous borate of calcium, $2 \mathrm{CaO} .3 \mathrm{~B}_{2} \mathrm{O}_{3} .5 \mathrm{H}_{2} \mathrm{O}$. The commonest source of borax in the United States.

California, Oregon.

Columbite. A variable columbate and tantalate of iron and manganese containing preponderant columbium and grading into tantalite, in which tantalum preponderates.

Colorado, Connecticut, Maine, North Carolina, South Dakota, Virginia. 
Copper. An element, Cu. Sometimes found as a native metal. See also Azurite, Azurmalachite, Beaverite, Bornite, Brochantite, Chalcanthite, Chalcocite, Chalcopyrite, Chrysocolla, Covellite, Cuprite, Enargite, Famatinite, Freibergite, Goldfieldite, Linarite, Malachite, Melaconite, Stromeyerite, Tennantite, Tenorite, Tetrahedrite.

Alabama, Arizona, Arkansas, California, Colorado, Connecticut, Georgia, Idaho, Maine, Michigan, Minnesota, Missouri, Montana, Nevada, New Jersey, New Mexico, New York, Oklahoma, Oregon, Pennsylvania, South Carolina, South Dakota, Tennessee, Utah, Virginia, Washington, Wyoming.

Copper glance. See Chalcocite.

Copper pyrites. See Chalcopyrite.

Copper sulphate. See Chalcanthite.

Coquina. A porous limestone composed of fragments of marine shells. Florida.

Cordierite, Iolite, Water sapphire. A magnesium-iron-aluminum silicate. Sometimes used as a gem.

Colorado, Connecticut.

Coronadite. A manganate of lead and manganese, $(\mathrm{Mn}, \mathrm{Pb}) \mathrm{Mn}_{3} \mathrm{O}_{7}$. Resembles psilomelane in general aspect.

Arizona.

Corundum. Aluminum oxide, $\mathrm{Al}_{2} \mathrm{O}_{3}$. The colored and the clear varieties form the gems, sapphire, ruby, oriental emerald, and oriental topaz; the granular impure variety is known as emery.

Alabama, California, Colorado, Connecticut, Delaware, Georgia, Idaho, Massachusetts, Montana, Nevada, New York, North Carolina, Oregon, Pennsylvania, South Carolina, Virginia, Wyoming.

Cosalite. A sulphide of lead and bismuth, $\mathrm{Pb}_{2} \mathrm{Bi}_{2} \mathrm{~S}_{5}$. Contains 42 per cent bismuth.

Colorado, Utah, Washington.

Cotton ball. See Ulexite.

Covellite. An indigo-blue copper sulphide, CuS. Contains 66.4 per cent copper. Alabama, Arizona, Colorado, Georgia, Idaho, Montana, Nevada, South Carolina, Utah, Wyoming.

Crocoite. Lead chromate, $\mathrm{PbO} . \mathrm{CrO}_{3}$. Contains 68.9 per cent $\mathrm{PbO}$ and 31.1 per cent $\mathrm{CrO}_{3}$. Arizona.

Cryolite. A fluoride of sodium and aluminum, $3 \mathrm{NaF} \cdot \mathrm{AlF}_{3}$. Colorado.

Cuprite. Native red copper oxide, $\mathrm{Cu}_{2} \mathrm{O}$. Contains 88.8 per cent copper.

Arizona, California, Colorado, Connecticut, Idaho, Missouri, Montana, Nevada, New Jersey, New Mexico, North Carolina, Oregon, Pennsylvania, Tennessee, South Dakota, Utah, Virginia, Wyoming.

Cyanite, Disthene. Identical in chemical composition with andalusite and sillimanite, $\mathrm{Al}_{2} \mathrm{O}_{3} . \mathrm{SiO}_{2}$, but differing in crystal form. Generally in flat-bladed pieces. Sometimes used as a gem.

Delaware, Massachusetts, North Carolina.

Cyrtolite. A yellowish to brownish mineral containing zirconia, yttria, ceria, and other rare earths. Found in pegmatites.

New York, North Carolina, Texas.

Dark ruby silver. See Pyrargyrite.

Datolite. A hydrous silicate of boron and calcium, $\mathrm{H}_{2} \mathrm{O} .2 \mathrm{CaO} . \mathrm{B}_{2} \mathrm{O}_{3} \cdot 2 \mathrm{SiO}_{2}$. Used as a gem.

Michigan. 
Descloizite. A vanadate of lead and zinc, found only in the oxidized parts of veins. Arizona, New Mexico.

Diabase. A basic igneous rock usually occurring in dikes or intrusive sheets, and composed essentially of plagioclase feldspar and augite with small quantities of magnetite and apatite. The plagioclase forms lath-shaped crystals lying in all directions among the dark irregular augite grains, giving rise to the peculiar diabasic or ophitic texture, which is a distinctive feature in the coarser-grained occurrences.

Connecticut, Maryland, Massachusetts, New Jersey, New York, Virginia.

Diamond. A very hard, native, crystallized form of carbon, C. When pure and clear it is used as a gem.

Arkansas, California, Georgia, Indiana, Michigan, North Carolina, Virginia.

Diatomaceous earth. See Infusorial earth.

Diopside. A calcium-magnesium silicate, $\mathrm{CaMg}\left(\mathrm{SiO}_{3}\right)_{2}$. California, Georgia.

Diorite. A granitoid rock composed essentially of hornblende and feldspar which is mostly or wholly plagioclase, with accessory biotite and (or) augite. Minute grains of magnetite and titanite may be visible. Quartz may be present in considerable amount, in which case the rock is called quartz diorite.

Quarried for crushed rock in the District of Columbia, Virginia, and many other States.

Disthene.' See Cyanite.

Dolomite. (a) A carbonate of calcium and magnesium, $(\mathrm{Ca}, \mathrm{Mg}) \mathrm{CO}_{3}$. (b) A rock composed mainly of the mineral dolomite.

Alabama, Connecticut, Indiana, Iowa, Kentucky, Maryland, Rhode Island, Tennessee, Virginia.

Dufrenite. A hydrous iron phosphate. Contains approximately 27.5 per cent $\mathrm{P}_{2} \mathrm{O}_{5}, 62$ per cent $\mathrm{Fe}_{2} \mathrm{O}_{3}$, and 10.5 per cent $\mathrm{H}_{2} \mathrm{O}$. Exact composition doubtful. Virginia.

Dufrenoysite. A sulpharsenide of lead, $\mathrm{Pb}_{2} \mathrm{As}_{2} \mathrm{~S}_{5}$.

Arizona, Idaho.

Dyscrasite. A variable silver antimonide including $\mathrm{Ag}_{3} \mathrm{Sb}$. Arizona.

Eglestonite. A mercury oxychloride, $\mathrm{Hg}_{4} \mathrm{Cl}_{2} \mathrm{O}$. Texas.

Elaterite. A massive amorphous dark-brown hydrocarbon ranging from soft and elastic to hard and brittle. It melts in a candle flame without decrepitation, has a conchoidal fracture and gives a brown streak. See also Wurtzilite.

Utah.

Electrum. A natural alloy of gold and silver containing approximately 40 per cent of silver.

California, Nevada.

Embolite. A chlorobromide of silver, $\mathrm{Ag}(\mathrm{Cl}, \mathrm{Br})$.

Arizona, Colorado, New Mexico.

Emerald. A variety of beryl (which see). Used as a gem.

North Carolina.

Emery. An impure form of corundum $\left(\mathrm{Al}_{2} \mathrm{O}_{3}\right)$ used as an abrasive. See Corundum. Massachusetts, New York, Virginia.

Enargite. A copper sulpharsenide, $\mathrm{Cu}_{3} \mathrm{AsS}_{4}$. Contains 48.4 per cent copper. Colorado, Montana, Nevada, South Carolina, South Dakota, Utah.

Endlichite. See Vanadinite.

New Mexico. 
Epidote. A basic orthosilicate of calcium, aluminum, and iron, $\mathrm{H}_{2} \mathrm{O} .4 \mathrm{CaO}$. $3(\mathrm{Al}, \mathrm{Fe})_{2} \mathrm{O}_{3} \cdot 6 \mathrm{SiO}_{2}$.

Colorado, Maine.

Epsomite. A hydrous magnesium sulphate, $\mathrm{MgSO}_{4}+7 \mathrm{H}_{2} \mathrm{O}$.

New Mexico, Tennessee, Wyoming.

Erubescite. See Bornite.

Erythrite, Cobalt bloom. A hydrous cobalt arsenate, $\mathrm{Co}_{3} \mathrm{As}_{2} \mathrm{O}_{8} \cdot 8 \mathrm{H}_{2} \mathrm{O}$. Found in the oxidized parts of cobalt and arsenic-bearing veins.

California, Colorado, Idaho, Nevada.

Essonite. A cinnamon-colored variety of garnet; called hyacinth when used as a gem, though the term more properly belongs to zircon.

Maine, New Hampshire.

Famatinite. A copper-antimony sulphide, $3 \mathrm{Cu}_{2} \mathrm{~S} \cdot \mathrm{Sb}_{2} \mathrm{~S}_{5}$. Contains 43.3 per cent copper.

- Nevada.

Feather ore. See Jamesonite.

Feldspar. A general name for a group of abundant rock-forming minerals, the names and compositions of which are as follows:

Orthoclase, a monoclinic potassium-aluminum silicate, $\mathrm{K}_{2} \mathrm{O} . \mathrm{Al}_{2} \mathrm{O}_{3} .6 \mathrm{SiO}_{2}$; varieties are known as adularia and sanidine.

Microcline, a triclinic variety of the same composition as orthoclase.

Anorthoclase, a triclinic feldspar containing both sodium and potassium.

Plagioclase feldspars are a subgroup of triclinic minerals at one end of which is albite, a sodium-aluminum silicate, $\mathrm{Na}_{2} \mathrm{O} \cdot \mathrm{Al}_{2} \mathrm{O}_{3} \cdot 6 \mathrm{SiO}_{2}$; and at the other end anorthite, a calcium-aluminum silicate, $\mathrm{CaO} \cdot \mathrm{Al}_{2} \mathrm{O}_{3} \cdot 2 \mathrm{SiO}_{2}$. Mixtures of these two molecules, which may be represented by $\mathrm{Ab}$ and $\mathrm{An}$, respectively, form:

Oligoclase, $A b_{6} A n_{1}$ to $A b_{3} A n_{1}$.

Andesine, $A b_{3} A n_{1}$ to $A b_{1} A n_{1}$.

Labradorite, $A b_{1} A n_{1}$ to $A b_{1} A n_{3}$.

Bytownite, $A b_{1} A n_{3}$ to $A b_{1} A n_{6}$.

Celsian is similar to anorthite, but contains barium in place of calcium, $\mathrm{BaO} . \mathrm{Al}_{2} \mathrm{O}_{3} .2 \mathrm{SiO}_{2}$.

Hyalophane is a monoclinic form containing barium and calcium.

Feldspar is found in practically all igneous rocks.

Alabama, California, Connecticut, Delaware, Maine, Maryland, Massachusetts, Minnesota, Missouri, New York, North Carolina, Pennsylvania, South Carolina, Vermont, Virginia, Wisconsin.

Ferberite. An iron tungstate, $\mathrm{FeWO}_{4}$. Applied to the wolframites which carry little or no manganese. Ferberite contains 76.3 per cent tungsten trioxide, $\mathrm{WO}_{3}$. Colorado, South Dakota.

Fergusonite. A metacolumbate and tantalate of yttrium, with erbium, cerium, uranium, etc. Found in pegmatites.

Texas, Virginia.

Flagstone. A rock which may be cleft into large slabs suitable for sidewalks.

Alabama, Connecticut, Illinois, Indiana, Maine, Maryland, Massachusetts, Michigan, Minnesota, New Hampshire, New Jersey, New York, Ohio, Pennsylvania, Rhode Island, Tennessee, Vermont, Virginia, Wyoming.

Flexible sandstone. See Itacolumite.

Flint. A rather loose term, used in the United States for a dense fine-grained form of silica which is very tough and breaks with a conchoidal fracture and cutting edges. Of various colors, white, yellow, gray, and black. See Chert.

Maryland, Nebraska, Wisconsin. 
Fluorspar, Fluorite. A calcium fluoride, $\mathrm{CaF}_{2}$. Color commonly purple, green, or white.

Arizona, California, Colorado, Connecticut, Illinois, Kentucky, Maryland, Massachusetts, Missouri, New Hampshire, New Jersey, New Mexico, New York, Pennsylvania, South Dakota, Tennessee, Texas, Utah, Virginia, Washington, West Virginia.

Fool's gold. See Pyrite.

Fossil wax. See Ozokerite.

Franklinite. An iron-manganese-zinc oxide ( $\mathrm{Fe}, \mathrm{Zn}, \mathrm{Mn}) \mathrm{O} .(\mathrm{Fe}, \mathrm{Mn})_{2} \mathrm{O}_{3}$. New Jersey.

Freestone. See Sandstone.

Freibergite. A silver-rich tetrahedrite. See Tetrahedrite. Idaho, Nevada.

Freieslebenite. A lead-silver sulphantimonide, approximately $5\left(\mathrm{~Pb}, \mathrm{Ag}_{2}\right) \mathrm{S} .2 \mathrm{Sb}_{2} \mathrm{~S}_{3}$. Contains 24.5 per cent silver.

Arizona, Colorado.

French chalk. See Talc.

Fuller's earth. An imperfectly understood clay relatively high in magnesia and possessing the property of decolorizing oils and fats by retaining the coloring matter. It may or may not be plastic.

Arkansas, Colorado, Florida, Georgia, Massachusetts, South Carolina, South Dakota, Texas.

Gabbro. A finely to coarsely crystalline igneous rock composed mainly of lime-soda feldspar (labradorite or anorthite), pyroxene, and frequently olivine. Magnetite or ilmenite, or both, and apatite are accessory minerals. It is generally dark colored.

California, Maryland, South Dakota, Virginia.

Gadolinite. A complex silicate of glucinum, iron, and the yttrium and cerium rare-earth metals. Occurs in pegmatites.

Arizona, Colorado, Texas.

Galena. Lead sulphide, PbS. Contains 86.6 per cent lead.

Alabama, Arizona, Arkansas, California, Colorado, Connecticut, Georgia, Idaho, Illinois, Iowa, Kansas, Kentucky, Maine, Maryland, Massachusetts, Minnesota, Missouri, Montana, Nevada, New Hampshire, New Mexico, New York, North Carolina, Oklahoma, Oregon, Pennsylvania, Rhode Island, South Carolina, South Dakota, Tennessee, Texas, Utah, Vermont, Virginia, Washington, Wisconsin, Wyoming.

Ganister. A highly refractory siliceous sedimentary rock used for furnace linings. Pennsylvania.

Garnet. A group of silicate minerals including several species with related chemical structure commonly crystallized in dodecahedrons or trapezohedrons of the isometric (cubic) system. Garnets are not always pure but may contain the molecules of two species giving rise to intermediate types, as the gem rhodolite. Common varieties are:

Almandite, iron-aluminum garnet (abrasive and gem, precious garnet).

Andradite, lime-iron garnet.

Essonite, gem variety of grossularite.

Grossularite, lime-aluminum garnet.

Pyrope, magnesia-aluminum garnet; gems-“Arizona ruby," "Cape ruby," etc. Rhodolite, isomorphous mixture of 2 molecules of pyrope and 1 molecule of almandite.

hyacinth.

Spessartite, manganese-aluminum garnet; used as a gem, sometimes called 
Arizona, California, Colorado, Connecticut, Georgia, Idaho, Kentucky, Massachusetts, Montana, New Hampshire, New Jersey, New Mexico, New York, North Carolina, Oregon, Pennsylvania, Virginia.

Garnierite. A hydrous nickel-magnesium silicate allied to genthite. Oregon.

Genthite. A hydrous nickel-magnesium silicate, theoretically $2 \mathrm{NiO} .2 \mathrm{MgO}^{2} 3 \mathrm{SiO}_{2}$. $6 \mathrm{H}_{2} \mathrm{O}$, but the nickel content is variable.

Georgia, Oregon.

Geode. A hollow nodule or concretion, the cavity of which is lined with crystals. Illinois, Iowa.

Giant granite. See Pegmatite.

Gilsonite, Uintaite. A brilliant black, very brittle variety of asphalt having a marked conchoidal fracture and a brown streak. Upon exposure to air readily breaks down into a brown powder. Decrepitates but fuses easily in a candle flame, and is soluble in carbon disulphide $\left(\mathrm{CS}_{2}\right)$, alcohol, and turpentine.

Utah.

Glauber salt. See Mirabilite.

Glauberite. Sodium-calcium sulphate, $\mathrm{Na}_{2} \mathrm{SO}_{4} \cdot \mathrm{CaSO}_{4}$. Arizona, New Mexico.

Glauconite, Greensand. Essentially a hydrous silicate of iron and potassium, but the material is usually a mixture and consequently varies much in composition. The potash ranges from 2.2 to 7.9 per cent. See Marl.

Gneiss. A banded metamorphic rock with a more or less well developed cleavage, but without the fissility of schist.

Connecticut, Delaware, District of Columbia, Georgia, Maryland, Massachusetts, Minnesota, New Jersey, North Carolina, Virginia.

Gold. An element, Au. Generally found as native metal. See also Amalgam, Calaverite, Electrum, Krennerite, Nagyagite, Petzite, Sylvanite.

Alabama, Arizona, California, Colorado, Georgia, Idaho, Indiana, Iowa, Maine, Maryland, Michigan, Minnesota, Montana, Nebraska, Nevada, New Hampshire, New Mexico, North Carolina, Oregon, Pennsylvania, South Carolina, South Dakota, Tennessee, Texas, Utah, Vermont, Virginia, Washington, Wyoming.

Goldfleldite. A sulphantimonide of copper in which part of the antimony is replaced by arsenic and bismuth and part of the sulphur by tellurium.

Nevada.

Grahamite. A hydrocarbon resembling albertite in its jet-black luster. Is soluble in carbon disulphide and chloroform but not in alcohol, and is fusible. Occurs in veinlike masses. Specific gravity 1.145. Has conchoidal fracture and is brittle. Colorado, Oklahoma, West Virginia.

Granite. A granular igneous rock composed essentially of quartz, orthoclase or microcline, and mica. Commonly a part of the feldspar is plagioclase. The mica may be either biotite or muscovite or both. Hornblende is a common, and augite an uncommon, component. Apatite, zircon, and magnetite are always present, generally as very small individuals. Commercially, almost all compact igneous rocks are called granite as distinguished from slate, sandstone, and marble.

Alabama, Arizona, California, Colorado, Connecticut, Delaware, District of Columbia, Georgia, Idaho, Iowa, Maine, Maryland, Massachusetts, Michigan, Minnesota, Missouri, Montana, New Hampshire, New Jersey, New York, North Carolina, North Dakota, Oklahoma, Oregon, Pennsylvania, Rhode Island, South Carolina, South Dakota, Tennessee, Texas, Utah, Vermont, Virginia, Washington, Wisconsin, Wyoming.

Granodiorite. An igneous rock intermediate between granite and quartz diorite. Found in the Pacific coast, Rocky Mountain, and Eastern States. 
Graphite. A soft, steel-gray to black, more or less impure, native form of carbon. Alabama, Arizona, California, Colorado, Connecticut, Georgia, Maine, Massachusetts, Michigan, Montana, Nevada, New Hampshire, New Jersey, New Mexico, New York, North Carolina, Pennsylvania, Rhode Island, South Carolina, South Dakota, Tennessee, Texas, Vermont, Virginia, Wisconsin, Wyoming.

Gravel. Small stones and pebbles or a mixture of sand and small stones; more specifically, fragments of rock worn by the action of air and water, larger and coarser than sand: Gravel occurs and is used in every State.

See Gravel in Iowa, Kentucky, and Louisiana, and Sand and gravel in other States.

Gray antimony. See Stibnite.

Gray copper ore. See Tennantite, Tetrahedrite.

Gray manganese ore. See Manganite.

Green lead ore. See Pyromorphite.

Greenockite. Cadmium sulphide, CdS. Contains 77.7 per cent cadmium. Greenockite occurs as a secondary mineral in zinc deposits in various parts of the United States, but not as a commercial deposit at any place. The majority of sphalerite deposits are cadmiferous, and cadmium in commercial quantity is obtained as a by-product in smelting these ores at certain plants.

Arkansas, Colorado, Missouri, Pennsylvania.

Greensand. See Glauconite.

Greensand marl. Sands or marl containing glauconite. See Marl.

Grindstone. A tough sandstone of fine and even grain, composed almost entirely of quartz, mostly in angular grains. It must have sufficient cementing material to hold the grains together but not enough to fill the pores and cause the surface to wear smooth.

Colorado, Connecticut, Indiana, Massachusetts, Michigan, Missouri, Montana, Ohio, South Dakota, West Virginia, Wyoming.

Gypsite. See Gypsum.

Gypsum. Hydrous calcium sulphate, $\mathrm{CaSO}_{4}+2 \mathrm{H}_{2} \mathrm{O}$. Contains 32.5 per cent lime, 46.6 per cent sulphur trioxide, and 20.9 per cent water. Alabaster is a finegrained compact variety, white, shaded, or tinted.

Gypsite is an incoherent mass of very small gypsum crystals or particles, and has a soft, earthy appearance; contains various impurities, generally silica and clay.

Satin spar is a fine fibrous variety which has a pearly, opalescent appearance.

Selenite is a variety which occurs in distinct crystals or in broad folia. Some crystals are 3 or 4 feet long and clear throughout.

Alabama, Arizona, Arkansas, California, Colorado, Florida, Iowa, Kansas, Louisiana, Michigan, Mississippi, Montana, Nevada, New Mexico, New York, Ohio, Oklahoma, Oregon, South Dakota, Tennessee, Texas, Utah, Virginia, Wyoming.

Halite; Rock salt. Sodium chloride, NaCl. See Salt.

Halloysite. A claylike aluminum silicate resembling kaolinite but amorphous and containing a larger but uncertain quantity of water, $2 \mathrm{H}_{2} \mathrm{O} \cdot \mathrm{Al}_{2} \mathrm{O}_{3} \cdot 2 \mathrm{SiO}_{2}+\mathrm{Aq}$.

Alabama, Georgia.

Halotrichite. Hydrous sulphate of iron and aluminum, $\mathrm{FeSO}_{4} \cdot \mathrm{Al}_{2}\left(\mathrm{SO}_{4}\right)_{3}+24 \mathrm{H}_{2} \mathrm{O}$. New Mexico.

Hard coal. See Anthracite.

Heavy spar. See Barite.

Hematite, Specular iron, Red iron ore. Oxide of iron, $\mathrm{Fe}_{2} \mathrm{O}_{3}$. Contains 70 per cent iron.

Alabama, Arizona, California, Colorado, Georgia, Idaho, Indiana, Iowa, Kentucky, Louisiana, Maine, Maryland, Massachusetts, Michigan, Minnesota, Missouri, Montana, Nevada, New Jersey, New Mexico, New York, North Carolina, 
Ohio, Oregon, Pennsylvania, Rhode Island, South Carolina, South Dakota, Tennessee, Texas, Utah, Vermont, Virginia, Washington, West Virginia, Wisconsin, Wyoming.

Hessite. Silver telluride, $\mathrm{Ag}_{2}$ Te. Contains 63.3 per cent silver. Colorado, Oregon.

Hiddenite. An emerald-green spodumene. Used as a gem. See Spodumene. North Carolina.

Hinsdalite. A mineral related to alunite, but with replacements as indicated in the following formula: $2 \mathrm{PbO} \cdot 3 \mathrm{Al}_{2} \mathrm{O}_{3} \cdot 2 \mathrm{SO}_{3} \cdot \mathrm{P}_{2} \mathrm{O}_{5} \cdot 6 \mathrm{H}_{2} \mathrm{O}$.

Colorado.

Horn silver. See Cerargyrite.

Hornstone. See Chert.

Huibnerite. Nearly pure manganese tungstate, $\mathrm{MnWO}_{4}$. When pure it contains 76.6 per cent tungsten trioxide, $\mathrm{WO}_{3}$.

Arizona, California, Colorado, Idaho, Montana, Nevada, New Mexico, South Dakota, Utah, Washington.

Hyalite. A variety of opal (hydrous silica) which occurs in clear globular or botryoidal forms resembling drops of melted glass.

Georgia, Kansas.

Hydrofranklinite. See Chalcophanite.

Hydrozincite, Zinc bloom. A basic zinc carbonate, exact composition uncertain, perhaps $3 \mathrm{ZnO} \cdot \mathrm{CO}_{2} \cdot 2 \mathrm{H}_{2} \mathrm{O}$.

Arkansas, Kansas, New Mexico.

Imenite, Menaccanite. Iron-titanium oxide, $\mathrm{FeTiO}_{3}$. Contains 36.8 per cent iron and 31.6 per cent titanium (52.7 per cent $\mathrm{TiO}_{2}$ ).

South Carolina, Texas, Virginia, Wyoming.

Impsonite. An asphalt much like albertite but almost insoluble in turpentine. Oklahoma.

Indian pipestone. See Catlinite.

Infusorial earth, Diatomaceous earth, Tripolite. An earthy substance or soft rock composed of the siliceous skeletons of small aquatic plants called diatoms.

Alabama, California, Colorado, Delaware, Florida, Maryland, Maine, Massachusetts, Nebraska, Nevada, New Hampshire, New York, Oregon, South Carolina, South Dakota, Utah, Vermont, Virginia, Washington.

Iodyrite. Silver iodide, AgI. Contains 46 per cent silver.

New Mexico.

Iolite. See Cordierite.

Iridosmine. A natural alloy of iridium and osmium. Analyses show 43 to 77 per cent of iridium, 17 to 49 per cent osmium, and a little rhodium, ruthenium, platinum, iron, and copper.

Washington.

Iron. An element, Fe. Rarely found native. See Brown iron ore, Hematite, Ilmenite, Limonite, Magnetite, Marcasite, Pisanite, Pyrite, Pyrrhotite, Siderite, Specularite.

Iron pyrites. See Pyrite.

Itacolumite, Flexible sandstone. A variety of metamorphosed sandstone, slabs of which will bend noticeably without breaking.

Georgia.

Jack. See Sphalerite.

Jade, Jadeite, Nephrite. A hard and extremely tough material of varying composition, greenish white to deep green in color, used in making carved ornaments. Part of the so-called jade is jadeite, a variety of pyroxene, essentially a metasilicate of sodium and aluminum. Part is nephrite, a variety of amphibole, and essentially a metasilicate of iron, lime, and magnesium; and part is a variety 
of saussurite, which is commonly a complex alteration product of plagioclase feldspar. Williamsite, a variety of serpentine, is sometimes mistaken for jade. Massachusetts.

Jamesonite, Feather ore. A sulphide of lead and antimony, $\mathrm{Pb}_{2} \mathrm{Sb}_{2} \mathrm{~S}_{5}$. Arizona, Nevada, South Dakota.

Jasper. Red, brown, yellow, green, impure, slightly translucent cryptocrystalline quartz with a dull fracture.

Arizona, California, Massachusetts, South Dakota, Texas.

Jaspilite. A term used around Lake Superior for the jasper associated with the iron ores. It is made up of bands of bright red jasper alternating with bands of black, commonly specular hematite.

Michigan.

Jet. A dense black lignite, taking a good polish. Sometimes used for jewelry.

Colorado.

Josephinite. A natural iron-nickel alloy, $\mathrm{Fe}_{2} \mathrm{Ni}_{5}$.

Oregon.

Kalinite, Potash alum. Hydrous aluminum-potassium sulphate, $\mathrm{K}_{2} \mathrm{SO}_{4} \cdot \mathrm{Al}_{2}\left(\mathrm{SO}_{4}\right)_{3}+$ $24 \mathrm{H}_{2} \mathrm{O}$.

Ca'ifornia, Nevada.

Kaolin, China clay, Porcelain clay. A clay, mainly hydrous aluminum silicate, from which porcelain may be made.

Alabama, Arizona, Arkansas, California, Colorado, Delaware, Georgia, Indiana, Minnesota, Missouri, Nevada, Pennsylvania, Virginia, Wisconsin, Wyoming.

kleinite. Mercury ammonium chloride. Formula uncertain.

Texas.

Krennerite. Orthorhombic telluride of gold and silver. Composition variable, $(\mathrm{Au}, \mathrm{Ag}) \mathrm{Te}_{2}$. At Cripple Creek analysis gives gold 43.86 per cent, silver $0.46 \mathrm{per}$ cent, tellurium 55.68 per cent.

Colorado.

Kunzite. A lilac-colored or pink spodumene. Used as a gem.

California, Maine.

Labradorite. A lime-soda feldspar. See Feldspar and Moonstone.

New York.

Lapis lazuli. A translucent, rich berlin-blue, azure-blue, violet-blue, or greenishblue stone used for ornament. It is a mixture of lazurite, haüynite, and other blue minerals.

California.

Lazulite. A hydrous aluminum phosphate with varying proportions of iron and magnesium, $(\mathrm{Fe}, \mathrm{Mg}) \mathrm{O} \cdot \mathrm{Al}_{2} \mathrm{O}_{3} \cdot \mathrm{P}_{2} \mathrm{O}_{5} \cdot \mathrm{H}_{2} \mathrm{O}$. Azure blue in color, usually in pyramidal crystals; also massive. Used as an ornamental stone.

California, Georgia, Neyada.

Lava. A rock that has reached the surface of the earth while molten.

Lead. A heavy metallic element, $\mathrm{Pb}$. Rarely found native. See also Altaite, Anglesite, Brongniardite, Cerusite, Crocoite, Dufrenoysite, Galena, Jamesonite, Leadhillite, Linarite, Massicot, Mimetite, Minium, Plumbojarosite, Pyromorphite. Alabama, Arizona, California, Colorado, Connecticut, Georgia, Idaho, Illinois, Iowa, Kansas, Maine, Massachusetts, Missouri, Montana, Nevada, New Mexico, New York, Pennsylvania, South Dakota, Tennessee, Utah, Virginia, Wisconsin, Wyoming.

Leadhillite. Sulphato-carbonate of lead, perhaps $4 \mathrm{PbO} \cdot \mathrm{SO}_{3} \cdot 2 \mathrm{CO}_{2} \cdot \mathrm{H}_{2} \mathrm{O}$.

Arizona. 
Lepidolite. A light-colored (pearly, rose-red, violet-gray, lilac, yellowish) lithiumbearing mica. Contains from 3.9 to 5.9 per cent lithia, $\mathrm{Li}_{2} \mathrm{O}$.

California, Connecticut, Maine, South Dakota.

Light ruby silver. Șee Proustite.

Iignite. A brownish-black coal in which the alteration of vegetable material has proceeded farther than in peat but not 80 far as in subbituminous coal.

Arkansas, Florida, Idaho, Kansas, Kentucky, Louisiana, Massachusetts, Mississippi, Minnesota, Montana, North Carolina, North Dakota, South Carolina, South Dakota, Tennessee, Texas.

Limestone. A rock composed mainly of calcium carbonate.

All parts of the United States except District of Columbia and North Dakota.

Limonite. See Brown iron ore.

Iinarite. A basic sulphate of lead and copper, $\mathrm{PbO} \cdot \mathrm{CuO} \cdot \mathrm{SO}_{3} \cdot \mathrm{H}_{2} \mathrm{O}$.

California.

Linnæite, Cobalt pyrites. A sulphide of cobalt, $\mathrm{Co}_{3} \mathrm{~S}_{4}$. A part of the cobalt is nearly always replaced by nickel and to a less extent by iron and copper.

Maryland, Missouri.

Iithographic stone. A fine-grained homogeneous limestone suitable for etching. Alabama, Iowa, Kentucky, Nebraska, South Dakota, Tennessee.

Mackintoshite. A hydrous uranium-thorium silicate.

Texas.

Macle. Sec Chiastolite.

Magnesite. Magnesium carbonate, $\mathrm{MgO}^{-\mathrm{CO}_{2}}$.

California, New Jersey, New York.

Magnetite, Magnetic iron ore. The magnetic iron oxide, $\mathrm{FeO}_{2} \mathrm{Fe}_{2} \mathrm{O}_{3}$. Contains 72.4 per cent iron.

Alabama, Arizona, Arkansas, California, Colorado, Connecticut, Georgia, Idaho, Maine, Maryland, Massachusetts, Michigan, Minnesota, Montana, Nevada, New Hampshire, New Jersey, New Mexico, New York, North Carolina, Oklahoma, Pennsylvania, Rhode Island, South Carolina, Tennessee, Texas, Utah, Vermont, Virginia, Wisconsin, Wyoming.

Magnetic pyrites. See Pyrrhotite.

Malachite. Green basic copper carbonate, $2 \mathrm{CuO} \cdot \mathrm{CO}_{2} \cdot \mathrm{H}_{2} \mathrm{O}$. Contains 40.3 per cent copper.

Arizona, California, Colorado, Connecticut, Florida, Georgia, Idaho, Maryland, Missouri, Montana, Nevada, New Hampshire, New Jersey, New Mexico, North Carolina, Oklahoma, Oregon, Pennsylvania, South Dakota, Tennessee, Utah, Vermont, Virginia, Washington, Wisconsin, Wyoming.

Manganese. A metallic element, Mn. Occurs abundantly in nature, chiefly as oxides. See Alabandite, Braunite, Chalcophanite, Coronadite, Manganite, Psilomelane, Pyrolusite, Rhodochrosite, Rhodonite, Tephroite, Wad.

Arizona, Arkansas, California, Colorado, Georgia, Maryland, Michigan, Missouri, Montana, Nevada, New Mexico, North Carolina, Oklahoma, Pennsylvania, Rhode Island, South Carolina, Utah, Vermont, Virginia, West Virginia, Wisconsin, Wyoming.

Manganese hydrate. See Psilomelane.

Manganite, Gray manganese ore. A hydrated manganese oxide, $\mathrm{Mn}_{2} \mathrm{O}_{3} \cdot \mathrm{H}_{2} \mathrm{O}$.

Alabama, Georgia, New Mexico.

Marble. Crystalline granular limestone or dolomite, generally susceptible of a high polish.

Alabama, Arizona, Arkansas, California, Colorado, Connecticut, Delaware, Georgia, Idaho, Iowa, Kentucky, Maryland, Massachusetts, Michigan, Missouri, Nevada, New Jersey, New. Mexico, New York, North Carolina, Oklahoma, 
Oregon, Pennsylvania, South Carolina, South Dakota, Tennessee, Texas, Utah, Vermont, Virginia, Washington, Wyoming.

Marcasite, White iron pyrite. Orthorhombic iron disulphide, $\mathrm{FeS}_{2}$. Contains 46.6 per cent iron.

Colorado, Idaho, Iowa, Kansas, Michigan, Missouri, Montana, Oklahoma, - Oregon, Wisconsin.

Marl. A soft earthy deposit of calcium carbonate, containing more or less clay and sand.

Alabama, Arkansas, Delaware, Florida, Georgia, Indiana, Iowa, Kentucky, Louisiana, Maryland, Massachusetts, Michigan, Mississippi, Minnesota, New Hampshire, New Jersey, New York, North Carolina, Ohio, Tennessee, South Carolina, Vermont, Virginia, Wyoming.

Massicot. Lead monoxide, $\mathrm{PbO}$. Contains 92.8 per cent lead.

Colorado, Idaho, Nevada, Virginia.

Meerschaum, Sepiolite. A tough, compact hydrous magnesium silicate.

California, New Mexico.

Melaconite. Black copper oxide, CuO. Contains 79.8 per cent copper. The name given to an earthy, black, massive variety of tenorite.

Alabama, Arizona, Colorado, Idaho, North Carolina, Pennsylvania, Tennessee, Virginia, Washington, Wyoming.

Menaccanite. See Ilmenite.

New Jersey, New York, North Carolina.

Mercury, Quicksilver. An element sometimes found native, Hg. See also Amalgam, Cinnabar, Eglestonite, Kleinite, Metacinnabarite, Montroydite, Terlinguaite, Tiemmanite.

California.

Metacinnabarite. Composition same as cinnabar, but black in color, and crystallizing in isometric forms (tetrahedral).. See Cinnabar.

California.

Mexican onyx. See Onyx marble.

Mica. A hydrous silicate having a very fine basal cleavage which renders it capable of being split into thin tough transparent plates. The most common varieties are muscovite and biotite. Phlogopite and lepidolite are prominent locally.

Alabama, Arizona, Arkansas, California, Colorado, Connecticut, Georgia, Idaho, Maine, Maryland, Massachusetts, Minnesota, Nevada, New Hampshire, New Mexico, New York, North Carolina, South Carolina, South Dakota, Texas, Vermont, Virginia, West Virginia, Wyoming.

Microlite. Essentially a calcium pyrotantalate. Contains also small quantities of columbium, fluorine, tungsten, and other bases. Used as a gem.

Virginia.

Millerite. Nickel sulphide, NiS. Contains 64.1 per cent nickel.

California, Pennsylvania.

Millstone. A hard tough stone used for grinding cereals, cement rocks, and other materials. Usually a coarse-grained sandstone or fine quartz conglomerate.

Alabama, Georgia, Mississippi, New York, North Carolina, Pennsylvania, Virginia.

Mimetite. Lead chlorarsenate, $3 \mathrm{~Pb}_{3} \mathrm{As}_{2} \mathrm{O}_{8} \cdot \mathrm{PbCl}_{2}$. California, Colorado, Nevada.

Mineral oil. See Petroleum.

Mineral paint. Minerals used as pigment, including the ochers, iron oxides, barite, etc. See also Ocher, Sienna, Umber.

Alabama, Arizona, California, Connecticut, Florida, Georgia, Indiana, Iowa, Kentucky, Massachusetts, Minnesota, Missouri, New York, Oregon, Pennsylvania, Tennessee, Washington, Wyoming. 
Mineral pitch. See Asphalt.

Mineral wax. See Ozokerite.

Minium. Red oxide of lead, $2 \mathrm{PbO} \cdot \mathrm{PbO}_{2}$. Contains 90.6 per cent lead. Colorado.

Mirabilite, Glauber salt. Hydrous sodium sulphate, $\mathrm{Na}_{2} \mathrm{SO}_{4}+10 \mathrm{H}_{2} \mathrm{O}$. Arizona, Oregon, Wyoming.

Mispickel. See Arsenopyrite.

Molybdenite. Sulphide of molybdenum, $\mathrm{MoS}_{2}$. Contains 60 per cent molybdenum. Arizona, California, Colorado, Connecticut, Maine, Montana, Nevada, New Jersey, New Mexico, New York, Rhode Island, South Carolina, Utah, Washington.

Molybdenum. A metallic element, Mo, of wide but not abundant distribution. See Molybdenite and Wulfenite.

Monazite. Phosphate of the cerium metals (cerium, didymium, lanthanum) and other rare-earth metals, including thorium, which alone gives it commercial value. Some varieties carry no thorium, but others carry as much as 18 per cent thorium oxide.

Colorado, Connecticut, Idaho, Montana, Nevada, New Mexico, North Carolina, Oregon, South Carolina, Utah, Virginia, Washington, Wyoming.

Montroydite. Oxide of mercury, $\mathrm{HgO}$.

Texas.

Moonstone. A variety of feldspar, commonly transparent or translucent orthoclase, albite, or labradorite, which exhibits a delicate pearly opalescent play of colors. Pennsylvania, Virginia.

Mountain brown ore. A local name for limonite or brown iron ore. Applied in Virginia to the low-grade siliceous variety, which commonly occurs in hard lumps and which is found on the mountain slopes at or near the contact of the Cambrian shale and sandstone with the Cambro-Ordovician limestone. Sce Valley brown ore.

Virginia.

Muscovite. Potash-bearing white mica, $\mathrm{H}_{2} \mathrm{KAl}_{3}\left(\mathrm{SiO}_{4}\right)_{3}$. See Mica.

Alabama, Arizona, Arkansas, New York, Wyoming.

Nagyagite. A sulphotelluride of lead, gold, and antimony, possibly $\mathrm{Au}_{2} \mathrm{~Pb}_{14} \mathrm{Sb}_{3}$ $\mathrm{Te}_{7} \mathrm{~S}_{17}$. The gold content ranges from 5.8 to 12.8 per cent, the silver from 8.1 to, 10.8 per cent.

North Carolina.

Native paraffin. See Ozokerite.

Natron. Hydrous sodium carbonate, $\mathrm{Na}_{2} \mathrm{CO}_{3}+10 \mathrm{H}_{2} \mathrm{O}$.

Oregon, Wyoming.

Natural gas. A mixture of gaseous hydrocarbons found in nature; in many places connected with deposits of petroleum, to which the gaseous compounds are closely related.

Alabama, Arkansas, California, Colorado, Illinois, Indiana, Iowa, Kansas, Kentucky, Louisiana, Michigan, Missouri, New Mexico, New York, North Dakota, Ohio, Oklahoma, Oregon, Pennsylvania, South Dakota, Tennessee, Texas, Utah, West Virginia, Wyoming.

Nelsonite. A dike rock composed essentially of ilmenite or rutile and apatite. Virginia.

Nephrite. See Jade.

Niccolite, Arsenical nickel. Arsenide of nickel, NiAs. Contains 43.9 per cent nickel.

Colorado.

Nicholsonite. A variety of aragonite (the orthorhombic carbonate of $\lim \theta, \mathrm{CaCO}_{3}$ ) containing from less than 1 per cent up to 10 per cent of zinc.

Colorado. 
Nickel. A metallic element, Ni. See also Annabergite, Garnierite, Genthite, Josephinite, Millerite, Niccolite, Pyrrhotite, Zaratite.

California, Georgia, Idaho, Minnesota, Missouri, Nevada, Oregon, South Carolina, Virginia, Washington, Wyoming.

Nigrite. A name given to a variety of asphalt mined at Soldier Summit, Utah, but whose composition is imperfectly understood.

Utah.

Niter, Saltpeter. Potassium nitrate, $\mathrm{KNO}_{3}$.

Alabama, Arkansas, California, Indiana, Oregon, Tennessee, Utah, Virginia, West Virginia, Wyoming.

Nivenite. A variety of uraninite high in uranium and carrying 10 per cent or more of the yttrium earths and 6.7 to 7.6 per cent thoria. It is wholly soluble in dilute sulphuric acid. See Uraninite.

Texas.

Novaculite. An extremely fine grained quartzose sedimentary rock.

Arkansas, Georgia, Massachusetts, North Carolina, Oklahoma, Tennessee.

Obsidian, Volcanic glass. Extrusive igneous rocks which have cooled either without crystallization or with only partial crystallization.

Arizona, California, Nevada, Utah.

Ocher. A metallic oxide occurring in an earthy or pulverulent form. Commercially ocher is used to mean the yellow, red, and brown earthy iron oxides.

Alabama, California, Delaware, Georgia, Indiana, Iowa, Kentucky, Maine, Maryland, Mississippi, Missouri, Nebraska, Nevada, New Hampshire, New Jersey, Pennsylvania, South Dakota, Vermont, Virginia, Washington, West Virginia, Wisconsin.

Oilstone. A fine-grained whetstone on which oil is used.

Arkansas, Georgia, Indiana, Ohio.

Olivine, Chrysolite, Peridot. An orthosilicate of iron and magnesium, 2(Mg.Fe)O. $\mathrm{SiO}_{2}$. Used as a gem.

Arizona.

Onofrite. Sulpho-selenide of mercury, $\mathrm{Hg}(\mathrm{S}, \mathrm{Se})$. Contains 81 to 82 per cent of mercury.

Onyx. A cryptocrystalline variety of quartz, made up of different colored layers, chiefly white, yellow, black, or red. Not found in commercial quantity in United States.

"Onyx marble" (including Mexican onyx). Calcite somewhat resembling true onyx in appearance and used as an ornamental stone. Is usually formed as stalactites, stalagmites, vein filling, or spring deposits.

Arizona, California, Kentucky, Missouri, New Mexico, Tennessee, Texas, Virginia.

Opal. Hydrous silica, $\mathrm{SiO}_{2} \cdot \mathrm{xH}_{2} \mathrm{O}$. When it shows a play of colors, or "opalescence," it becomes the gem stone or precious opal of commerce, known as "fire opal."

Arizona, California, Colorado, Georgia, Nevada, New Mexico, Oregon, Utah, Washington.

Orpiment. Arsenic trisulphide, $\mathrm{As}_{2} \mathrm{~S}_{3}$. Contains 61 per cent arsenic (the element). Utah.

Orthite. See Allanite.

Orthoclase. The monoclinic potash feldspar, $\mathrm{K}_{2} \mathrm{O} . \mathrm{Al}_{2} \mathrm{O}_{3} \cdot 6 \mathrm{SiO}_{2}$. Contains $16.9 \mathrm{per}$ cent potash, $\mathrm{K}_{2} \mathrm{O}$. See Feldspar.

Ozokerite, Mineral wax, Fossil wax, Native paraffln. Waxlike hydrocarbon, yellow-brown to green in color; translucent when pure; feels greasy. Streak is light to brown, and specific gravity is slightly less than 1 . Soluble in carbon disulphide.

Utah, Wyoming. 
Palladium. An element, $\mathrm{Pd}$, one of the platinum metals. Occurs in minute quantities in copper ores and is recovered in electrolytic refineries.

Wyoming.

Peacock copper ore. See Bornite, Erubescite.

Peat. Partly decayed vegetable matter which has accumulated in marshes and wet places.

Florida, Illinois, Indiana, Massachusetts, Michigan, Minnesota, Nebraska, New Hampshire, New Jersey, New York, North Carolina, Ohio, Rhode Island, South Carolina, South Dakota, Tennessee, Vermont, Wisconsin.

Pegmatite, Giant granite. An igneous rock, generally coarse grained but usually irregular in texture and composition, composed mainly of silicate minerals of large size, including quartz, feldspar, muscovite, biotite, tourmaline, beryl, lithia minerals, zircon, etc. Some pegmatites carry minerals containing rare earth metals, tin, tungsten, tantalum, uranium, and others.

Pencil stone. See Pyrophyllite.

Peridot. See Olivine.

Peridotite. A granular rock composed chiefly of olivine and pyroxene with little or no feldspar.

Petroleum, Mineral oil. An oily, inflammable, liquid mixture of numerous hydrocarbons, chiefly of the paraffin series, found in the earth. The petroleums found in different areas vary widely in composition and appearance.

Alabama, California, Colorado, Illinois, Indiana, Iowa, Kansas, Kentucky, Louisiana, Michigan, Missouri, Montana, New Mexico, New York, Ohio, Oklahoma, Pennsylvania, Tennessee, Texas, Utah, Washington, West Virginia, Wyoming.

Petzite. Telluride of silver and gold, $(\mathrm{Ag}, \mathrm{Au})_{2} \mathrm{Te}$. The gold content ranges from 18.2 to 25.6 per cent and the silver from 40.7 to 46.8 per cent.

California, Colorado.

Phenacite. Glucinum orthosilicate, $\mathrm{Gl}_{2} \mathrm{SiO}_{4}$.

Colorado.

Phosphate rock. A sedimentary rock containing phosphate of lime. The form in which the phosphate of lime occurs is obscure.

Alabama, Arkansas, Florida, Idaho, Kentucky, Montana, South Carolina, Tennessee, Utah, Virginia, Wyoming.

Pisanite. An iron sulphate in which part of the iron is replaced by copper, $(\mathrm{FeCu}) \mathrm{SO}_{4}+7 \mathrm{H}_{2} \mathrm{O}$.

Montana.

Pitchblende. See Uraninite.

Colorado, Connecticut, North Carolina.

Platinum. An element, $\mathrm{Pt}$, occurring as a native metal. Practically all platinum is found in the metallic state, though small quantities are obtained from sperrylite (which see) and in the electrolytic refining of coppet ores.

Arizona, California, Colorado, Idaho, Maine, Montana, Nevada, North Carolina, Oregon, South Carolina, Utah, Washington, Wyoming.

Plumbojarosite. A hydrous sulphate of lead and iron, $\mathrm{PbFe}_{6}(\mathrm{OH})_{12}\left(\mathrm{SO}_{4}\right)_{4}$. New Mexico, Utah.

Pollucite. Hydrous cæsium-sodium-aluminum silicate, $\mathrm{H}_{2} \mathrm{O} \cdot(\mathrm{Cs}, \mathrm{Na})_{2} \mathrm{O} \cdot \mathrm{Al}_{2} \mathrm{O}_{3} \cdot 5 \mathrm{SiO}_{2}$. Found in pegmatite.

Maine.

Polybasite. Sulphide of silver and antimony, $\mathrm{Ag}_{9} \mathrm{SbS}_{6}$. If pure, it would contain 75.6 per cent silver, but copper replaces part of the silver; also arsenic replaces antimony.

Arizona, Colorado, Idaho, Montana, Nevada. 
Polycrase. A columbate and titanate of yttrium, erbium, cerium, and uranium, with some iron and water.

North Carolina, South Carolina, Texas.

Porcelain clay. See Kaolin.

Porphyry. An igneous rock in which relatively large conspicuous crystals (phenocrysts) are set in a finer-grained or glassy groundmass. Porphyries are generally named in accordance with their rock composition (e. g., granite porphyry, trachyte porphyry) or with the character of the phenocrysts, as quartz porphyry. Colloquially the word "porphyry" is used to mean almost any igneous rock, particularly one that is spotted, soft, or light colored.

Oklahoma, Wisconsin. Occurs in many States but is little used.

Potash. The oxide of potassium, $\mathrm{K}_{2} \mathrm{O}$. Not an independent compound, but used as a basis of comparison for all potash minerals and artificial salts. The potash of commerce is derived from the minerals carnallite, kainite, sylvite (not found in the United States), and niter, and also from certain seaweeds and wood ashes. See also Alunite, Alunogen, Kalinite, Niter.

Alabama, California, Tennessee, Virginia, West Virginia, Wyoming.

Potash alum. See Kalinite.

Priceite. A friable, chalky boron mineral similar to colemanite. See Colemanite.

Proustite, Light ruby silver. Silver-arsenic sulphide, $3 \mathrm{Ag}_{2} \mathrm{~S} \cdot \mathrm{As}_{2} \mathrm{~S}_{3}$. Contains 65.4 per cent silver.

Arizona, Colorado, Idaho, Montana, Nevada, New Mexico.

Psilomelane, Manganese hydrate. A common ore of manganese. Perhaps $\mathrm{H}_{4} \mathrm{MnO}_{5}$.

Alabama, Arizona, Arkansas, California, Colorado, Georgia, Massachusetts, Montana, Nevada, New Mexico, North Carolina, South Carolina, Tennessee, Vermont, Virginia.

Pumice. Highly vesicular lava.

California, Idaho, Kansas, Nebraska, South Dakota, Wyoming.

Pyrargyrite, Dark ruby silver. Silver-antimony sulphide, $3 \mathrm{Ag}_{2} \mathrm{~S}_{2} \mathrm{Sb}_{2} \mathrm{~S}_{3}$. Contains 59.9 per cent silver when pure, but analyses show from 57 to 60.9 per cent.

Arizona, California, Colorado, Idaho, Maine, Montana, Nevada, New Mexico, Oregon, Washington.

Pyrite, Iron pyrites, Fool's gold. Isometrically crystallized iron disulphide, $\mathrm{FeS}_{2}$. Contains 46.6 per cent iron.

Alabama, Arizona, California, Colorado, Connecticut, Georgia, Idaho, Illinois, Indiana, Iowa, Kansas, Maine, Maryland, Massachusetts, Minnesota, Missouri, Montana, Nevada, New Hampshire, New Jersey, New Mexico, New York, North Carolina, Ohio, Oregon, Pennsylvania, South Carolina, South Dakota, Tennessee, Texas, Utah, Vermont, Virginia, Washington, West Virginia, Wisconsin, Wyoming.

Pyrolusite, Black oxide of manganese. Manganese dioxide, $\mathrm{MnO}_{2}$. Contains 63.2 per cent manganese.

Alabama, Arizona, Arkansas, California, Colorado, Georgia, Maryland, Massachusetts, Montana, Nevada, New Mexico, New York, North Carolina, Oregon, Pennsylvania, South Carolina, South Dakota, Tennessee, Texas, Vermont, Virginia.

Pyromorphite, Green lead ore. Chlorophosphate of lead, $3 \mathrm{~Pb}_{3} \mathrm{P}_{2} \mathrm{O}_{8}: \mathrm{PbCl}_{2}$.

Arizona, Colorado, Oonnecticut, Georgia, Idaho, Montana, Nevada, South Carolina.

Pyrope. Magnesium-aluminum garnet, $3 \mathrm{MgO} . \mathrm{Al}_{2} \mathrm{O}_{3} \cdot 3 \mathrm{SiO}_{2}$. Color deep red to nearly black. Used as a gem when transparent.

Arizona. 
Pyrophyllite, Pencil stone. A hydrous aluminum silicate, $\mathrm{H}_{2} \mathrm{O} \cdot \mathrm{Al}_{2} \mathrm{O}_{3} \cdot 4 \mathrm{SiO}_{2}$. Resembles talc in color, feel, luster, and structure. Used for slate pencils and for the "talc" or "talcum" of commerce.

California, North Carolina.

Pyrrhotite, Magnetic pyrites. A variable iron sulphide, $\mathrm{Fe}_{\mathrm{n}} \mathrm{S}_{\mathrm{n}+1}$. Many pyrrhotites contain nickel and are mined as nickel ores.

Alabama, Arizona, California, Colorado, Connecticut, Idaho, Maine, Maryland, Massachusetts, Montana, Nevada, New Hampshire, New Jersey, New Mexico, New York, North Carolina, Oregon, Pennsylvania, South Carolina, South Dakota, Tennessee, Vermont, Virginia, Washington, Wyoming.

Quartz, Silica. Crystallized silicon dioxide, $\mathrm{SiO}_{2}$.

Amethyst is a variety of the well-known amethystine color.

Aventurine is a quartz spangled with scales of mica, hematite, or other minerals.

False topaz or citrine is a yellow quartz.

Rock crystal is a watery clear variety.

Rose quartz is a pink variety.

Rutilated quartz contains needles of rutile.

Smoky quartz is a brownish variety sometimes called cairngorm.

Tiger-eye is crocidolite (an asbestos-like mineral) replaced by quartz and iron oxide, and having a chatoyant effect.

Alabama, Arizona, Arkansas, California, Colorado, Connecticut, District of Columbia, Delaware, Georgia, Iowa, Maine, Maryland, Massachusetts, Michigan, New Hampshire, New York, North Carolina, Pennsylvania, Rhode Island, South Dakota, Texas, Virginia, West Virginia.

Quartzite. A sandstone in which the grains are so cemented by silica that they break across when the rock is fractured.

Arizona, Iowa, Michigan, Minnesota, Nevada, South Dakota, Virginia, Wisconsin.

Quicksilver. See Mercury and Cinnabar.

California, Colorado, Nevada, Oregon, Texas, Utah.

Radium. A metallic element, $\mathrm{Ra}$, derived through a series of intermediate elements from uranium. It gives off helium (the $\alpha$ rays) and alters to emanation. Successive alterations give other elements, part of which radiate $\beta$ and $\gamma$ rays. Radium is never found in sufficient quantity to be visible, but occurs with and only with uranium minerals. From these it is separated to obtain the radium salts of commerce. See Uranium.

Realgar. Arsenic monosulphide, AsS. Contains 70.1 per cent elemental arsenic. Utah, Washington.

Red iron ore. See Hematite.

Red oxide of zinc. See Zincite.

Reddle. Ocherous red clay.

Arkansas.

Rhodochrosite. Manganese carbonate, $\mathrm{MnCO}_{3}$.

Colorado, Georgia.

Rhodolite. A variety of garnet characterized by its roselike color and brilliant luster. Composition corresponds to 2 molecules of pyrope and 1 of almandite. North Carolina.

Rhodonite. Manganese silicate, $\mathrm{MnSiO}_{3}$.

California, Maine, Massachusetts, Montana, New York, Rhode Island.

Rhyolite. A highly siliceous compact or porphyritic variously colored volcanic rock. An extrusive form of granite.

Wisconsin. Found in many other States, but little utilized.

Road material. See Road metal.

$29123^{\circ}-$ Bull. 585-14-16 
Road metal. Rock suitable for surfacing macadamized roads and for foundations for asphalt and concrete roadways.

Alabama, California, Connecticut, District of Columbia, Delaware, Georgia, Indiana, Iowa, Maryland, Massachusetts, Michigan, Mississippi, Missouri, Nebraska, New Jersey, New York, North Dakota, Rhode Island, Virginia, Washington.

Rock salt. See Halite.

Roscoelite. A vanadium-bearing muscovite mica in which $\mathrm{Al}_{2} \mathrm{O}_{3}$ is partly replaced by $\mathrm{V}_{2} \mathrm{O}_{3}$. The content of $\mathrm{V}_{2} \mathrm{O}_{3}$ may reach an equivalent of 28.85 per cent $\mathrm{V}_{2} \mathrm{O}_{5}$, though generally much less.

Colorado.

Rose quartz. Crystalline quartz with a rose-pink color. Used as a gem or as an ornamental stone. See Quartz.

Rosinjack. See Sphalerite.

Rowlandite. Yttrium silicate, $2 \mathrm{Yt}_{2} \mathrm{O}_{3} \cdot 3 \mathrm{SiO}_{2}$.

Texas.

Rubellite. Dark-pink or red tourmaline. See Tourmaline.

California.

Ruby. Clear red corundum, $\mathrm{Al}_{2} \mathrm{O}_{3}$. A well-known gem.

Georgia, North Carolina.

Ruby silver. See Proustite and Pyrargyrite.

Rutile. Tetragonally crystallized titanium oxide, $\mathrm{TiO}_{2}$. Octahedrite is another tetragonal form with different facial angles. When crystallized in orthorhombic form titanium oxide is known as brookite.

Arkansas, Colorado, Connecticut, North Carolina, South Carolina, Virginia.

Salt, Halite, Common salt. Sodium chloride, $\mathrm{NaCl}$.

Alabama, Arizona, California, Idaho, Indiana, Kansas, Kentucky, Louisiana, Michigan, Nevada, New Mexico, New York, North Carolina, Ohio, Oklahoma, Oregon, Pennsylvania, Tennessee, Texas, Utah, Virginia, West Virginia, Wyoming.

Saltpeter. See Niter.

Samarskite. A columbate and tantalate of uranium, the cerium metals, the yttrium metals, and minor quantities of other metals.

North Carolina.

Sand, building. Any hard, granular rock material finer than gravel and coarser than dust. As used in this work the term indicates material comminuted by natural means. Quartz grains generally predominate in natural deposits, although such deposits commonly contain many other minerals.

All States.

Sand, glass. Sand of medium grain consisting of 98 to 100 per cent of silica $\left(\mathrm{SiO}_{2}\right)$, used in glass making. Iron oxides should form less than 1 per cent of the mass.

Alabama, Arkansas, California, Delaware, Florida, Georgia, Illinois, Indiana, Iowa, Kansas, Kentucky, Maine, Maryland, Massachusetts, Michigan, Mississippi, Missouri, Nevada, New Jersey, New York, Ohio, Oklahoma, Pennsylvania, South Carolina, South Dakota, Tennessee, Texas, Vermont, Virginia, West Virginia, Wisconsin, Wyoming.

Sand, molding. A sand used in making molds for casting metal.

Alabama, Arkansas, California, Colorado, Connecticut, Delaware, Georgia, Illinois, Indiana, Iowa, Kentucky, Maryland, Massachusetts, Michigan, Mississippi, Minnesota, Missouri, Nebraska, New Jersey, New York, Ohio, Pennsylvania, South Carolina, Tennessee, Texas, Vermont, Virginia, Washington, West Virginia, Wisconsin.

Sandstone, asphaltic. A loose-textured sandstone containing asphalt.

Sandstone, bituminous. See Sandstone, asphaltic.

Sandstone, bluestone, A tough bluish sandstone used for flagging. 
'Sandstone, brownstone. A sandstone of brown or reddish-brown color. Used for building.

Sandstone, building. A sandstone suitable for building.

Alabama, Arizona, Arkansas, California, Colorado, Connecticut, Georgia, Idaho, Illinois, Indiana, Iowa, Kansas, Kentucky, Louisiana, Maine, Maryland, Massachusetts, Michigan, Mississippi, Minnesota, Missouri, Montana, Nebraska, Nevada, New Jersey, New Mexico, New York, North Carolina, North Dakota, Ohio, Oklahoma, Oregon, Pennsylvania, Rhode Island, South Dakota, Tennessee, Texas, Utah, Vermont, Virginia, Washington, West Virginia, Wisconsin, Wyoming.

Sandstone, flagstone. A sandstone which cleaves into flags suitable for sidewalks and areaways. Includes most bluestone.

Sandstone, freestone. A sandstone which cuts with equal ease in any direction. Used for building.

Sapphire. Clear blue corundum, $\mathrm{Al}_{2} \mathrm{O}_{3}$. A well-known blue gem. There are also white, pink, and yellow sapphires.

California, Connecticut, Georgia, Indiana, Montana, North Carolina.

Satelite. The gem trade name for a fibrous serpentine having a chatoyant effect. California.

Scheelite. Calcium tungstate, $\mathrm{CaWO}_{4}$. Contains 80.6 per cent tungsten trioxide, $\mathrm{WO}_{3}$.

Arizona, California, Colorado, Connecticut, Idaho, Montana, Nevada, New Mexico, South Dakota, Utah, Washington.

Schist. A thinly laminated or foliated metamorphic rock which splits more or less easily along closely spaced, nearly parallel planes.

Massachusetts, Vermont, Virginia.

Scorodite. Hydrous ferric arsenate, $\mathrm{Fe}_{2} \mathrm{O}_{3} \cdot \mathrm{As}_{2} \mathrm{O}_{5} \cdot 4 \mathrm{H}_{2} \mathrm{O}$.

Utah, Washington.

Scythestone. A whetstone suitable for sharpening scythes.

Selenite. Gypsum in distinct crystals or broad folia, $\mathrm{CaSO}_{4} \cdot 2 \mathrm{H}_{2} \mathrm{O}$. See Gypsum.

Selenium. An element, Se. Not found native in visible quantity. Is obtained as a by-product in the electrolytic refining of copper. See Onofrite and Tiemmanite.

Sepiolite. See Meerschaum.

Serpentine. (a) Hydrous magnesium silicate, $3 \mathrm{MgO} \cdot 2 \mathrm{SiO}_{2} \cdot 2 \mathrm{H}_{2} \mathrm{O}$. (b) A rock composed mostly of the mineral serpentine.

Arizona, California, Colorado, Connecticut, Delaware, Georgia, Maryland, Massachusetts, New Jersey, New York, North Carolina, Pennsylvania, Rhode Island, Texas, Vermont, Washington.

Shale. A fine-grained rock formed by the consolidation of silt or clay, and fissile along bedding planes.

Alabama, Georgia, Iowa, Michigan, Nevada, Pennsylvania, Tennessee, Wyoming.

Siderite, Spathic iron ore. Iron carbonate, $\mathrm{FeCO}_{3}$. Contains 48.2 per cent iron.

Colorado, Connecticut, Illinois, Indiana, Kansas, Kentucky, Maryland, Massachusetts, Mississippi, New York, North Carolina, Ohio, Pennsylvania, South Carolina, Tennessee, Vermont, Virginia, West Virginia.

Sienna. A brownish orange-yellow clay colored by iron and manganese oxides. Used as a pigment.

Alabama, California, Pennsylvania.

Silica. An oxide of silicon, $\mathrm{SiO}_{2}$. Occurs in nature as a mineral of economic importance in quartz, chalcedony, chert, flint, opal, infusorial earth, and shale (which see), also as a constituent of all the silicate minerals. The most abundant constituent of the earth's crust. See also Agate, Quartz, Sand, glass, and in Illinois (p. 7.1) Silica, amorphous. 
Silver. An element, Ag. Sometimes found native. See Acanthite, Amalgam, Argentite, Brongniardite, Bromyrite, Calaverite, Cerargyrite, Dyscrasite, Electrum, Embolite, Freibergite, Freieslebenite, Hessite, Iodyrite, Krennerite, Nagyagite, Petzite, Polybasite, Proustite, Pyrargyrite, Stephanite, Stetefeldite, Stromeyerite, Sylvanite, Xanthoconite.

Arizona, Arkansas, California, Colorado, Georgia, Idaho, Iowa, Illinois, Kentucky, Maine, Maryland, Michigan, Minnesota, Missouri, Montana, Nevada, New Hampshire, New Mexico, North Carolina, Oregon, South Carolina, South Dakota, Tennessee, Texas, Utah, Virginia, Washington, Wyoming.

Silver glance. See Argentite.

Sipylite. A columbate of erbium chiefly, also of the cerium metals and other metals. Virginia.

Slate. A dense, fine-textured metamorphic rock whose separate minerals are indistinguishable to the unaided eye, and which has an excellent parallel cleavage, so that it breaks into thin plates or pencil-like shapes.

Alabama, Arizona, Arkansas, California, Connecticut, Georgia, Maine, Maryland, Massachusetts, Michigan, Minnesota, New Hampshire, New Jersey, New York, Pennsylvania, Tennessee, Utah, Vermont, Virginia, West Virginia.

Smaltite. Cobalt diarsenide, $\mathrm{CoAs}_{2}$. Contains, when pure, 28.2 per cent cobalt. Through replacement of the cobalt by nickel it grades into chloanthite, the nickel arsenide, $\mathrm{NiAs}_{2}$.

Colorado.

Smithsonite. Carbonate of zinc, $\mathrm{ZnCO}_{8}$. Contains 52 per cent zinc.

Arizona, Arkansas, California, Illinois, Iowa, Kansas, Kentucky, Maryland, Missouri, Nevada, New Mexico, Oklahoma, Pennsylvania, Tennessee, Texas, Virginia, Wisconsin.

Soapstone. See Talc.

Alabama, Arkansas, California, Georgia, Maryland, Massachusetta, New Hampshire, New Jersey; North Carolina, South Carolina, Vermont, Virginia.

Soda. See Natron, Salt, Thenardite, Urao (Trona).

California, Nevada.

Soda feldspar. See Albite.

Spathic iron ore. See Siderite.

Specularite, Specular hematite, Specular iron, Gray hematite. An iron oxide, $\mathrm{Fe}_{2} \mathrm{O}_{3}$, occurring in tabular or disklike crystals of gray color and splendent metallic luster. Also called "micaceous hematite" if occurring in foliated or micaceous masses. Contains 70 per cent iron. See Hematite.

Arizona, Idaho, Michigan, Minnesota, Missouri, New Mexico, Wisconsin.

Sperrylite. Platinum arsenide, $\mathrm{PtAs}_{2}$. The theoretically pure mineral would contain 56.5 per cent platinum, but antimony and rhodium are also present in small quantities.

Wyoming.

Spessartite. A variety of garnet. See Garnet.

Virginia.

Sphalerite, Blende, Blackjack, Jack, Rosinjack, Zinc blende. A sulphide of zinc, $\mathrm{ZnS}$, crystallizing in isometric forms. Contains 67 per cent zinc. See Wurtzite. Alabama, Arizona, Arkansas, California, Colorado, Connecticut, Georgia, Idaho, Illinois, Iowa, Kansas, Kentucky, Maine, Maryland, Massachusetts, Minnesota, Missouri, Montana, Nevada, New Hampshire, New York, North Carolina, Oklahoma, Oregon, Pennsylvania, South Dakota, Tennessee, Texas, Utah, Vermont, Virginia, Washington, Wisconsin, Wyoming.

Spinel. An isometric mineral, typically magnesium aluminate, $\mathrm{MgO}_{2} \mathrm{Al}_{2} \mathrm{O}_{3}$. The magnesium may be in part replaced by ferrous iron, or manganese, and the alumi- 
num by ferric iron and chromium. Spinel is red, yellow, green, black, and other colors, and is used as a gem.

California, Colorado, Massachusetts, Montana, New York, North Carolina.

Spodumene. Lithium-aluminum silicate, $\mathrm{Li}_{2} \mathrm{O} \cdot \mathrm{Al}_{2} \mathrm{O}_{3} \cdot 4 \mathrm{SiO}_{2}$. Used as a source of lithia, of which it contains as a maximum 8.4 per cent. The clear green variety, known as hiddenite, and the clear pink or lilac, known as kunzite, are used as gems.

California, Connecticut, North Carolina, South Dakota.

Staurolite. Iron-aluminum silicate, $\mathrm{Fe}(\mathrm{AlO})_{4}(\mathrm{Al}, \mathrm{OH})\left(\mathrm{SiO}_{4}\right)_{2}$. Sometimes used as a gem.

North Carolina, Virginia.

Stephanite, Brittle silver ore. Silver-antimony sulphide, $5 \mathrm{AgS} \mathrm{Sb}_{2} \mathrm{~S}_{3}$. Contains 68.5 per cent silver.

Colorado, Maine, Montana, Nevada.

Stetefeldite. A somewhat uncertain compound containing silver, copper, iron, antimony, sulphur, and water.

Nevada.

Stibiconite, Antimony ocher. Hydrous oxide of antimony, $\mathrm{Sb}_{2} \mathrm{O}_{4} \cdot \mathrm{H}_{2} \mathrm{O}$. Contains 74.5 per cent antimony.

Nevada.

Stibnite, Antimony glance, Gray antimony, Sulphuret of antimony. Antimony sulphide, $\mathrm{Sb}_{2} \mathrm{~S}_{3}$. Contains 71.4 per cent antimony.

Arizona, Arkansas, California, Colorado, Idaho, Maryland, Montana, Nevada, New Mexico, Oregon, Utah, Washington.

Stromeyerite. A somewhat variable sulphide of silver and copper, $(\mathrm{Ag}, \mathrm{Cu})_{2} \mathrm{Ss}$ Contains 50.2 to 52.7 per cent silver and 30.5 to 33.7 per cent copper.

Arizona, California, Colorado, Nevada.

Strontianite. Strontium carbonate, $\mathrm{SrCO}_{3}$.

New York, Texas.

Sulphur. An element, S. Frequently found native.

Alabama, California, Colorado, Georgia, Idaho, Kentucky, Louisiana, Nevada, New Mexico, Tennessee, Texas, Utah, Wyoming.

Sulphuret of antimony. See Stibnite.

Sunstone. A variety of oligoclase feldspar containing numerous small inclusions which cause a delicate play of colors. Used as a gem.

Arkansas, North Carolina, New York, Virginia.

Syenite. A granular igneous rock composed typically of orthoclase or microcline, and hornblende. In mica syenites hornblende is replaced by biotite, and in augite syenites it is replaced by augite. If a small quantity of quartz is present it is called quartz syenite. In nepheline syenite the feldspar is partly replaced by nepheline.

Arkansas, Virginia.

Sylvanite. A gold-silver telluride, ( $\mathrm{Au}, \mathrm{Ag}) \mathrm{Te}_{2}$, containing gold and silver in the atomic ratio of 1 to 1 . This requires 24.5 per cent of gold and 13.4 per cent silver.

Colorado, Oregon, Washington, Wyoming.

Tabbyite. See Wurtzilite.

Talc. A hydrous magnesium silicate, $\mathrm{H}_{2} \mathrm{O} .3 \mathrm{MgO} .4 \mathrm{SiO}_{2}$. Has a greasy or soapy feel and is soft and easily cut. Occurs in beds more or less impure and is then known as stearite or soapstone. Also called potstone because it has been used for pots owing to the ease with which it is worked and to its resistance to ordinary heats. French chalk is a variety used for crayons. See Soapstone.

Arkansas, California, Georgia, Maine, Maryland, Massachusette, New Jersey, New York, North Carolina, Pennsylvania, Rhode Island, Texas, Vermont, Virginia, Washington. 
Tantalite. The member of the tantalite-columbite group of minerals which is composed of nearly or quite pure tantalate of iron and manganese. Nearly all tantalite contains some columbium. The members of the group containing more columbium are known as columbite. Tantalite is very rare. Pure tantalite, $(\mathrm{Fe}, \mathrm{Mn}) \mathrm{Ta}_{2} \mathrm{O}_{6}$, would contain about 86 per cent $\mathrm{Ta}_{2} \mathrm{O}_{5}$, or 70.4 per cent tantalum, but the percentage in actual minerals is generally much lower.

South Dakota, Virginia.

Tengerite. Of doubtful composition, said to be yttrium carbonate.

Texas.

Tennantite, Gray copper ore. Copper-arsenic sulphide, $3 \mathrm{Cu}_{2} \mathrm{~S} \cdot \mathrm{As}_{2} \mathrm{~S}_{3}$. Contains 57.5 per cent copper. Composition varies as in tetrahedrite, into which it grades. Colorado, Montana, Wyoming.

Tenorite. Black oxide of copper in minute black scales, CuO. Contains 79.8 per cent copper.

Arizona, New Mexico, Oregon, Utah, Wyoming.

Tephroite. Manganese orthosilicate, $2 \mathrm{MnO}^{\mathrm{S}} \mathrm{SiO}_{2}$. Contains 70 per cent $\mathrm{MnO}$, and commonly also small quantities of magnesium, iron, and zinc.

New Jersey.

Terlinguaite. Oxychloride of mercury, $\mathrm{Hg}_{2} \mathrm{ClO}$. Contains 88.65 per cent mercury. Texas.

Tetradymite. Bismuth telluride, $\mathrm{Bi}_{2}(\mathrm{Te}, \mathrm{S})_{3}$. Contains theoretically 51.9 per cent. bismuth, but the actual content ranges from 50.4 to 52.8 per cent. Sulphur generally replaces part of the tellurium, and the mineral sometimes contains a trace of selenium. The sulphurous variety contains from 57.7 to 62.2 per cent bismuth, and may be represented by the formula $2 \mathrm{Bi}_{2} \mathrm{Te}_{3} \cdot \mathrm{Bi}_{2} \mathrm{~S}_{3}$. Gold, copper, and iron are present in some tetradymites.

Arizona, California, Colorado, Maryland, Montana, New Mexico, North Carolina, South Dakota, Virginia.

Tetrahedrite, Gray copper ore. Copper-antimony sulphide, essentially $3 \mathrm{Cu}_{2} \mathrm{~S}$. $\mathrm{Sb}_{2} \mathrm{~S}_{3}$. Contains 52.1 per cent copper. In many tetrahedrites the copper is partly replaced by iron, lead, zinc, mercury, and silver, and the antimony by arsenic. Through the last replacement tetrahedrite grades into tennantite.

Arizona, California, Colorado, Idaho, Massachusetts, Montana, Nevada, New Mexico, North Carolina, Oregon, Tennessee, Utah, Washington.

Thenardite. Sodium sulphate, $\mathrm{Na}_{2} \mathrm{O} \cdot \mathrm{SO}_{3}$.

Arizona.

Thomsonite. Hydrous sodium-calcium-aluminum silicate, $\left(\mathrm{Na}_{2}, \mathrm{Ca}\right) \mathrm{O} . \mathrm{Al}_{2} \mathrm{O}_{3}$. $2 \mathrm{SiO}_{2} \cdot 2 \frac{1}{2} \mathrm{H}_{2} \mathrm{O}$. One of the zeolites, sometimes used as a gem.

Michigan:

Thorianite. A mineral of complex and uncertain composition but consisting chiefly of thorium and uranium oxides with minor quantities of many other bases. Contains about 12.1 per cent $\mathrm{U}_{3} \mathrm{O}_{8}$ and 71 per cent $\mathrm{ThO}_{2}$.

Montana.

Thorium. An element, Th. One of the rare-earth metals. Not found native. See Auerlite, Monazite, Thorianite, Thorogummite, Yttrialite.

Thorogummite. A hydrous silicate of uranium and thorium, $\mathrm{UO}_{3} \cdot 3 \mathrm{ThO}_{2} \cdot 3 \mathrm{SiO}_{2}$. $6 \mathrm{H}_{2} \mathrm{O}$. Contains 22 per cent $\mathrm{UO}_{3}$ and 41 per cent $\mathrm{ThO}_{2}$.

Texas.

Tiemmanite. Mercuric selenide, HgSe. Contains 71.7 per cent mercury and 28.3 per cent selenium:

Utah.

Tin. A white malleable metallic element, Sn. Found in nature probably only in combination, principally as tin oxide, cassiterite. See Cassiterite.

Tincal. See Bornite. 
Topaz. An aluminum fluosilicate, simplest formula $\mathrm{Al}_{2} \mathrm{SiO}_{4} \mathrm{~F}_{2}$, but with part of the fluorine commonly replaced by HO. Used as a gem, especially when yellow.

California, Colorado, Connecticut, Maine, New Hampshire, Texas, Utah.

Torbernite. A hydrous phosphate of uranium and copper, $\mathrm{CuO} .2 \mathrm{UO}_{3} \cdot \mathrm{P}_{2} \mathrm{O}_{5} .8 \mathrm{H}_{2} \mathrm{O}$. South Dakota.

Tourmaline. A complex aluminum silicate of hexagonal crystallization containing boron and in some varieties lithium and other elements. Of various colors; the clear pink, blue, and green varieties are used as gems.

California, Colorado, Connecticut, Georgia, Maine, Maryland, Massachusetts, North Carolina, Virginia.

Trap, Trap rock. A general name for dark fine-grained igneous rocks, particularly lavas or dikes. See also Basalt and Diabase.

California, Connecticut, Delaware, Massachusetts, Michigan, Minnesota, New Jersey, New York, Pennsylvania, Vermont, Virginia, Wisconsin.

Travertine. Carbonate of lime, $\mathrm{CaCO}_{3}$, deposited from solution in ground and surface waters. The cellular deposits are known as tufa, calcareous sinter, spring deposit, or cave deposit. When solid, banded, and susceptible of a good polish, it is known as Mexican onyx, or onyx marble. True onyx, however, is banded silica or agate. Travertine forms the stalactites and stalagmites of caves, and the filling of some veins and spring conduits.

Utah.

Tremolite. White fibrous amphibole, $\mathrm{CaMg}_{3} \mathrm{Si}_{4} \mathrm{O}_{12}$.

Connecticut, Georgia.

Tripoli. A porous siliceous rock resulting from the decomposition of siliceous limestone. Used for polishing powder and filters.

Alabama, Arkansas, Georgia, Illinois, Indiana, Iowa, Kentucky, Maine, Maryland, Minnesota, Missouri, Oklahoma.

Tripolite. See Infusorial earth.

Trona. An impure form of urao. See Urao.

California, Colorado, Nevada, Wyoming.

Tufa. See Travertine.

California, Utah, Washington.

Tuff. Fragmental rock ejected from a volcano. It ranges from very fine, powdery material to coarse, heavy fragments. See Volcanic ash. California.

Tungsten. A metallic element, W. Not found native. See also Ferberite, Hübnerite, Scheelite, Wolframite.

Arizona, California, Colorado, Idaho, Nevada, New Mexico, South Dakota, Washington.

Turquoise. Hydrous phosphate of aluminum and copper, $\mathrm{CuO} .3 \mathrm{Al}_{2} \mathrm{O}_{3} .2 \mathrm{P}_{2} \mathrm{O}_{6} .9 \mathrm{H}_{2} \mathrm{O}$. Used for the well-known gem of the same name.

Arizona, California, Colorado, Nebraska, Nevada, New Mexico, Texas.

Uintaite. See Gilsonite.

Utah.

Ulexite, Cotton ball. Hydrous borate of sodium and calcium, probably $\mathrm{Na}_{2} \mathrm{O}$. $2 \mathrm{CaO} .5 \mathrm{~B}_{2} \mathrm{O}_{3} \cdot 16 \mathrm{H}_{2} \mathrm{O}$. Contains theoretically 43 per cent $\mathrm{B}_{2} \mathrm{O}_{3}$. Analyses of the natural mineral show from 42 to 45.3 per cent $\mathrm{B}_{2} \mathrm{O}_{2}$.

California, Nevada.

Umber. A chestnut-brown to liver-colored hydrated ferric oxide containing manganese oxide and clay. As found in nature it is called raw umber, and when heated so as to produce a reddish brown it is called burnt umber.

Pennsylvania, Vermont, Virginia. 
Uraninite. A complex uranium mineral containing also rare earths, radium, lead, helium, nitrogen, and other elements. Uraninite in the stricter sense is applied to crystallized forms found in pegmatites. It contains $\mathrm{Th}, \mathrm{Ce}, \mathrm{La}$, and $\mathrm{Yt}$. The mineral found in Connecticut and North Carolina is of this variety. Pitchblende is the massive form, probably amorphous, and contains no thoria, but a specimen from Gilpin County, Colo., contained 7.6 per cent zirconia. Pitchblende is found in metalliferous veins with sulphides. Both varieties contain radium. Contains from 65 to 90.7 per cent of the combined oxides $\mathrm{UO}_{3}$ and $\mathrm{UO}_{2}$. See also Nivenite.

Colorado, Connecticut, North Carolina.

Uranium. A heavy metallic element, U. Not found native. All uranium minerals contain radium. See Autunite, Carnotite, Fergusonite, Mackintoshite, Nivenite, Polycrase, Samarskite, Thorianite, Thorogummite, Torbernite, Uraninite (including Pitchblende), Uranocircite, Uranophane, Uranospinite, Yttrialite.

Uranocircite. A hydrous phosphate of uranium and barium, $\mathrm{BaO} .2 \mathrm{UO}_{3} \cdot \mathrm{P}_{2} \mathrm{O}_{5} \cdot 8 \mathrm{H}_{2} \mathrm{O}$. South Dakcta.

Uranophane. A hydrous silicate of uranium and calcium, $\mathrm{CaO} .2 \mathrm{UO}_{3} \cdot 2 \mathrm{SiO}_{2}+6 \mathrm{H}_{2} \mathrm{O}$. North Carolina.

Uranospinite. Probably an arsenate of uranium and calcium corresponding to autunite, $\mathrm{CaO} .2 \mathrm{UO}_{3} \cdot \mathrm{As}_{2} \mathrm{O}_{5} \cdot 8 \mathrm{H}_{2} \mathrm{O}$. Contains about 47.6 per cent uranium, equivalent to 56.1 per cent calculated as $\mathrm{U}_{3} \mathrm{O}_{8}$.

Utah.

Urao. Hydrous sodium carbonate, $3 \mathrm{Na}_{2} \mathrm{O} \cdot 4 \mathrm{\cup O}_{2} \cdot 5 \mathrm{H}_{2} \mathrm{O}$. Trona is an impure form of urao.

Utahlite. See Variscite.

Valley brown ore. A local name for limonite or brown iron ore. Applied in Virginia to the comparatively pure high-grade ore found in the Cambro-Ordovician limestone which forms the Valley of Virginia. See Mountain brown ore.

Virginia.

Vanadinite. Lead chlorvanadate, $9 \mathrm{PbO} .3 \mathrm{~V}_{2} \mathrm{O}_{5} \cdot \mathrm{PbCl}_{2}$. Contains when pure 19.4 per cent $\mathrm{V}_{2} \mathrm{O}_{5}$, but arsenic and phosphorus both replace vanadium, so that the mineral grades into mimetite, $3 \mathrm{~Pb}_{3} \mathrm{As}_{2} \mathrm{O}_{8} \cdot \mathrm{PbCl}_{2}$, and into pyromorphite, $3 \mathrm{~Pb}_{3} \mathrm{P}_{2} \mathrm{O}_{8} \cdot \mathrm{PbCl}_{2}$. Endlichite is a variety of vanadinite containing considerable arsenic.

Arizona, Montana, Nevada, New Mexico.

Vanadium. An element, V. It does not occur native but is found in the United States in the minerals carnotite, roscoelite, vanadinite, descloizite, volborthite, calciovolborthite, and ægirite.

Arizona, Colorado, Montana, New Mexico, Utah.

Variscite, Utahlite. Green hydrous phosphate of aluminum, $\mathrm{Al}_{2} \mathrm{O}_{3} \cdot \mathrm{P}_{2} \mathrm{O}_{5} \cdot 4 \mathrm{H}_{2} \mathrm{O}$. Used as a gem.

Arkansas, Nevada, Utah.

Verde antique. A dark-green rock composed essentially of serpentine (hydrous magnesium silicate). Usually crisscrossed with white veinlets of magnesium and calcium. Used as an ornamental stone. In commerce often classed as a marble.

California, Georgia, Maryland, Massachusetts, New York, Virginia.

Verde salt. See Thenardite.

Vesuvianite. A complex calcium-aluminum silicate of uncertain formula. A massive light-green variety is known as californite.

Arkansas, California.

Volborthite. A hydrous vanadate of copper, barium, and calcium.

Arizona, Colorado. 
Volcanic ash, Volcanic tuff. A material made up of either loose or solidified small fragments and dust of lava, commonly glassy in character, blown from a volcano and deposited either on land or under water. If numerous large fragments are embedded in the ash, the deposit is called volcanic agglomerate or volcanic breccia.

Colorado, Montana, Nevada, Oklahoma, South Dakota.

Volcanic glass. See Obsidian.

Volcanic tuff. See Volcanic ash.

Wad, Bog manganese. An impure mixture of manganese and other oxides. It contains 10 to 20 per cent of water, and is generally soft, soiling the hand. A variety known as asbolite carries as much as 32 per cent cobalt.

Arizona, Arkansas, California, Georgia, Maine, Massachusetts, Missouri, Montana, Nevada, New Mexico, New York, Pennsylvania, Rhode Island, South Carolina, Tennessee, Virginia, Wisconsin.

Water sapphire. See Cordierite.

Wavellite. Hydrous aluminum phosphate, $3 \mathrm{Al}_{2} \mathrm{O}_{3} \cdot 2 \mathrm{P}_{2} \mathrm{O}_{5} \cdot 12 \mathrm{H}_{2} \mathrm{O}$. Fluorine is present in some specimens up to 2 per cent.

Alabama, Pennsylvania.

Whetstone. A stone suitable for sharpening tools.

Arkansas, Connecticut, Indiana, Massachusetts, Michigan, New Hampshire, Rhode Island, Vermont.

White iron pyrite. See Marcasite.

Williamsite. An apple-green impure variety of serpentine. See Jade.

Willemite. Zinc silicate, $2 \mathrm{ZnO} \cdot \mathrm{SiO}_{2}$. Contains 58.6 per cent zinc. The zinc is commonly replaced in part by manganese.

Arizona, New Jersey, New Mexico.

Wolframite. A series of minerals composed of tungstate of iron and manganese $(\mathrm{Fe}, \mathrm{Mn}) \mathrm{WO}_{4}$, containing, when the iron and manganese are in a ratio of 1 to 1 , 76.4 per cent $\mathrm{WO}_{3}$. As the iron increases and the manganese decreases wolframite grades into ferberite, the pure iron tungstate, $\mathrm{FeWO}_{4}$, with 76.3 per cent $\mathrm{WO}_{3}$. At the other end of the series is hübnerite, the pure manganese tungstate, containing 76.6 per cent $\mathrm{WO}_{3}$.

Arizona, California, Connecticut, Nevada, New Hampshire, New Mexico, South Dakota, Texas, Virginia, Washington, Wyoming.

Wood, silicifled, Petrifled wood, Opalized wood, Agatized wood. A material composed of opal or chalcedony (agate) and formed by the replacement of wood by silica. The replacement of the woody matter by the silica takes place in such a way that the original form and structure of the wood is preserved.

Arizona, California, Colorado, South Dakota, Utah, Wyoming.

Wulfenite. Lead molybdate, $\mathrm{PbMoO}_{4}$. Contains 39.3 per cent $\mathrm{MoO}_{3}$. Calcium, chromium, copper, and vanadium are sometimes constituents.

Arizona, Massachusetts, Nevada, New Mexico, Pennsylvania, Utah.

Wurtzilite, Elaterite, Tabbyite, Eonite, Egerite. An asphaltic mineral which is jet-black by reflected light and deep red in thin plates. It softens in hot water, toughens, and becomes more elastic. In a candle flame it softens and burns with a bright flame. It is practically insoluble in gasoline of $76^{\circ} \mathrm{B}$., partly soluble in ether, carbon disulphide, and turpentine, and less so in carbon tetrachloride.

Utah.

Wurtzite. A zinc sulphide of the same composition as sphalerite, $\mathrm{ZnS}$, but hexagonal in its crystallization.

Montana, Utah. 
Xanthoconite. Silver-arsenic sulphide, $3 \mathrm{Ag}_{2} \mathrm{~S} . \mathrm{As}_{2} \mathrm{~S}_{5}$. Contains 61.4 per cent silver.

New Mexico.

Xenotimè. Essentially yttrium phosphate, $\mathrm{YtPO}_{4}$. Contains phosphorus pentoxide 38.6, yttria 61.4.

North Carolina.

Yellow copper. See Chalcopyrite.

Yttrialite. Silicate of thorium and the yttrium metals chiefly, but it contains also uranium and other elements in small quantity.

Texas.

Zaratite. A massive, vitreous emerald-green hydrous nickel carbonate, $\mathrm{H}_{12} \mathrm{Ni}_{3} \mathrm{CO}_{11}$. Occurs usually as an incrustation.

Maryland.

Zeolites. A group of minerals occurring in cracks and cavities of igneous rocks, especially the more basic lavas. Zeolites are hydrous silicates of aluminum with either sodium or calcium or both, and rarely barium or strontium. Before the blowpipe most of the zeolites fuse readily and with strong intumescence, whence their name, derived from the Greek, of "boiling stone." They have little economic importance.

Zinc. An element, $\mathrm{Zn}$. Not found native. See Calamine, Franklinite, Hydrozincite, Nicholsonite, Smithsonite, Sphalerite, Willemite, Wurtzite, Zincite.

Zinc blende. See Sphaleritè.

Zinc bloom. See Hydrozincite.

Zincite, Red oxide of zinc. Zinc oxide, $\mathrm{ZnO}$. Contains 80.3 per cent zinc. New Jersey.

Zircon. Zirconium silicate, $\mathrm{ZrSiO}_{4}$. When clear and orange-colored it is used for the gem known as hyacinth.

New Jersey, New York, North Carolina, Oregon, Texas, Virginia.

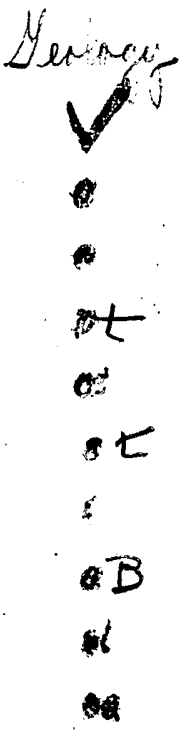

